\title{
RECLAMAR OU INTERVIR? AS OBRIGAÇÕES POSITIVAS DO ESTADO EM SITUAÇÕES DE DESASTRE AMBIENTAL
}

\author{
José Roberto Gioia Alfaia Júnior
}

Tese de Doutorado

Orientadora: Prof ${ }^{a}$ Dra. Ana Flávia Barros-Platiau

\author{
Brasília - DF \\ Dezembro/2014
}


Ficha catalográfica elaborada pela Biblioteca Central da Universidade de Brasília. Acervo 1019216.

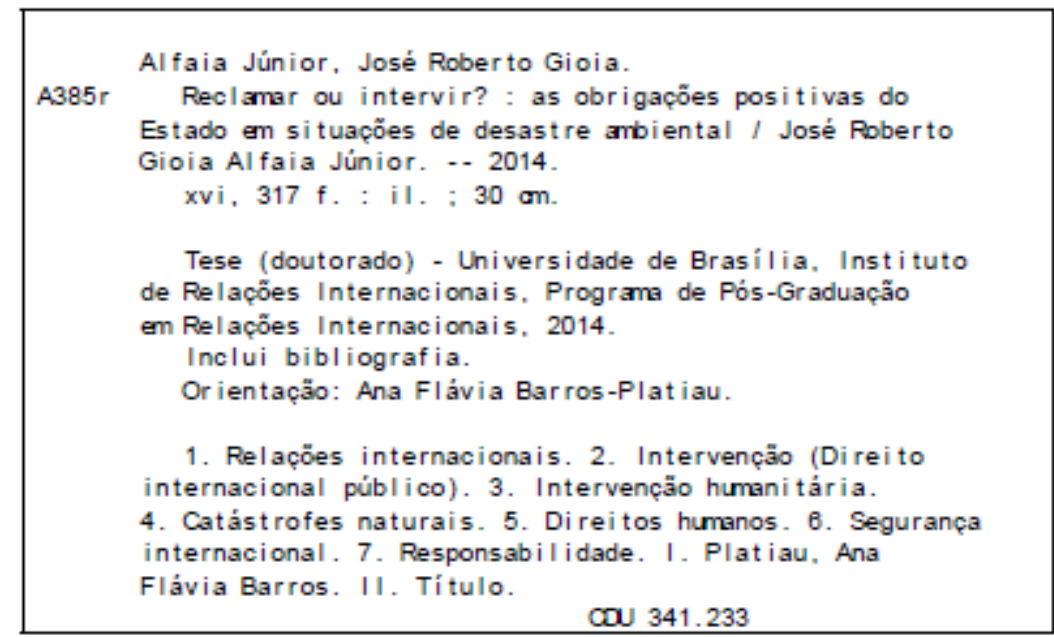

É concedida à Universidade de Brasília permissão para reproduzir cópias desta tese e emprestar ou vender tais cópias somente para propósitos acadêmicos e científicos. $\mathrm{O}$ autor reserva outros direitos de publicação e nenhuma parte desta tese de doutorado pode ser reproduzida sem a autorização por escrito do autor.

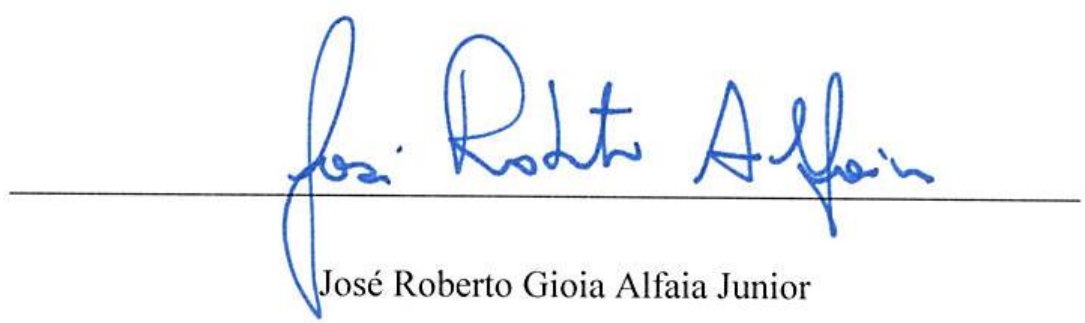




\title{
RECLAMAR OU INTERVIR? AS OBRIGAÇÕES POSITIVAS DO ESTADO EM SITUAÇÕES DE DESASTRE AMBIENTAL
}

\author{
José Roberto Gioia Alfaia Júnior
}

Tese de Doutorado submetida ao Instituto de Relações Internacionais da Universidade de Brasília, como parte dos requisitos necessários para obtenção do Grau de Doutor em Relações Internacionais, na área de concentração em Política Internacional e Comparada.

\section{Banca Examinadora:}

Dra. Ana Flávia Barros-Platiau (IREL/UnB) - Orientadora

Dr. Eiiti Sato (IREL/UnB) - Examinador Interno

Dra. Danielly Ramos Becard - (IREL/UnB) - Examinadora Interna

Dr. Wagner Costa Ribeiro (USP) - Examinador Externo

Dra. Carina Costa de Oliveira (FD/UnB) - Examinadora Externa

Dr. Fúlvio Eduardo Fonseca (CGU) - Suplente 


\section{A Máquina do Mundo}

E como eu palmilhasse vagamente uma estrada de Minas, pedregosa, e no fecho da tarde um sino rouco

se misturasse ao som de meus sapatos que era pausado e seco; e aves pairassem no céu de chumbo, e suas formas pretas

lentamente se fossem diluindo na escuridão maior, vinda dos montes e de meu próprio ser desenganado,

a máquina do mundo se entreabriu para quem de a romper já se esquivava e só de o ter pensado se carpia.

Abriu-se majestosa e circunspecta, sem emitir um som que fosse impuro nem um clarão maior que o tolerável

pelas pupilas gastas na inspeção contínua e dolorosa do deserto, e pela mente exausta de mentar

toda uma realidade que transcende a própria imagem sua debuxada no rosto do mistério, nos abismos.

Abriu-se em calma pura, e convidando quantos sentidos e intuições restavam a quem de os ter usado os já perdera

e nem desejaria recobrá-los, se em vão e para sempre repetimos os mesmos sem roteiro tristes périplos,

convidando-os a todos, em coorte, a se aplicarem sobre o pasto inédito da natureza mítica das coisas (...)

Carlos Drummond de Andrade (1902-1987) in Claro Enigma (1951) 
"Mensura omnium rerum optima"1

(provérbio latino/autoria desconhecida)

\footnotetext{
${ }^{1}$ Tradução livre: "tudo na vida requer tempo e medida".
} 


\section{AGRADECIMENTOS}

Honoré de Balzac (1799-1850) dizia que a gratidão é uma dívida que nem sempre os filhos aceitam no inventário. Não é o meu caso. A elaboração de um trabalho científico é solitária, mas resultado de um esforço coletivo, compassado, contínuo e desinteressado. A conclusão desta Tese de Doutorado reveste-se de caráter peculiar, por encerrar um ciclo acadêmico de dez anos nas bancadas da Universidade de Brasília, no Instituto de Relações Internacionais (PPGRI), ainda como egresso em um curso de especialização nos idos de 2005.

Ao longo desses anos, o Instituto acolheu-me como filho e, "no meio do caminho da nossa vida, onde a confusão é tão grande que a alma não se acha capaz de reencontrar-se", guiou-me os passos e iluminou o espírito. Agradeço, assim, aos que fizeram parte do desafio: professores universitários, funcionários administrativos e colegas discentes. Há de se incorrer em injustiça se tentarmos elaborar uma lista exaustiva. No entanto, alguns nomes não poderiam ser desmerecidos, sob pena agravada de desrespeito. São eles: Prof. Dr. Antônio Augusto Cançado Trindade, Prof. Dr. Antônio Carlos Lessa, Prof. Dr. Carlos Pio, Profa. Dra Cristina Inoue, Prof. Dr. Eduardo Viola, Prof. Dr. José Flávio Sombra Saraiva e Profa. Dra Norma Breda dos Santos. Dos funcionários da Secretaria Administrativa e da Pós-Graduação do IREL, agradeço: Anderson Xavier, Celi Rodrigues, Telma Alves, Odalva Costa e Vanderlei Valverde.

Em destaque, assinalo a paciência e dedicação, sentimentos nobres que denotam profissionalismo e seriedade, de minha orientadora, Profa. Dra . Ana Flavia Barros-Platiau, pela condução do delineamento da pesquisa e sistematização do trabalho. Estendo um agradecimento especial também aos integrantes da Banca de Defesa, pela leitura acurada do texto e pelos comentários pertinentes, nas figuras dos Profs. Dr. Eiiti Sato (IREL/UnB), Dr ${ }^{\mathrm{a}}$. Danielly Ramos Becard (IREL/UnB), Dr. Wagner Costa Ribeiro (USP), Dra ${ }^{\mathrm{a}}$. Carina Costa de Oliveira (FD/UnB) e Dr. Fúlvio Eduardo Fonseca (CGU).

Last but not least, agradeço a meus pais, José Roberto Gioia Alfaia e Maria das Graças Alfaia, pela existência e educação; irmãos, Allan Franklin e Eduardo Alfaia, pelo companheirismo; e esposa, Ana Cláudia Leocádio, pela compreensão e ânimo durante todo o percurso, bem como pela revisão atenta e crítica dos escritos - não traduzida em isenção de minha integral responsabilidade por eventuais falhas. Não posso deixar de mencionar, ainda, o Ministério das Relações Exteriores, a Casa, pelo apoio financeiro e logístico e pela formação de minha identidade. 


\section{$\underline{\text { RESUMO }}$}

Em um cenário internacional composto pela dicotomia entre as sociedades pluralistaminimalista, de viés soberanista, e a consensualista-maximalista, mais aberta aos fenômenos transnacionais e mais propensa à cooperação, é discutida a obrigação do Estado de intervir ou não no país vizinho em caso de danos oriundos de desastres ambientais. O desafio ambiental é privilegiado como unidade analítica, consoante a expansão de temas securitários no cenário internacional, e pelos estudos críticos sobre segurança tradicional realizados pelo Círculo de Copenhague. A Ordem Ambiental Internacional (OAI), que serve de arcabouço jurídico-político e pauta a agenda multilateral da pesquisa, vem sendo posta à prova pelas alterações sistêmicas globais nas últimas quatro décadas. Em consequência, os instrumentos político-legais tradicionais parecem não vir acompanhando questões mais prementes das relações interestatais, de que são exemplos casos de desastres naturais e tecnológicos graves de efeitos transfronteiriços. Quando se adiciona o componente das intervenções, como mecanismo de defesa da "soberania como responsabilidade", baseada na construção discursiva dos conceitos de Segurança Humana e de Responsabilidade de Proteger, chega-se a um debate polêmico e controverso, cuja aceitação passa pela relutância de diversos atores estatais, com capacidades de agir absolutamente díspares. Diante da inadequação dos mecanismos legais clássicos em situações de desastres ambientais transfronteiriços e de eventual necessidade de defesa territorial pelo instrumento interventivo, percebe-se uma lacuna acadêmica, política e jurídica presciente dos desafios que deverão ser enfrentados no futuro. Assim, para além dos componentes e características dessa ordem ambiental, a pesquisa discute a obrigação dos Estados na salvaguarda da própria população e território, com fundamento em princípios basilares de Direitos Humanos. A ordem ambiental é revisitada, sua evolução histórico-política investigada e os fundamentos dos institutos intervencionistas levados ao escrutínio, de modo a cumprir uma reavaliação cautelosa do tema das "intervenções verdes" no Direito e nas Relações Internacionais.

PALAVRAS-CHAVE: Obrigações Positivas, Ordem Ambiental Internacional; Desastres Ambientais; Intervenções; Segurança Humana, R2P. 


\begin{abstract}
$\underline{\text { ABSTRACT }}$
In an international scenario framed by the dichotomy between the minimalist-pluralist and the consensualist-maximalist societies, the first with a sovereignty bias and the latter more opened to cooperation, the obligation of the State to intervene in neighboring countries in case of disasters is overtly discussed. The environmental challenge is privileged as an analytical unit by the expansion of security issues in the international arena and through critical studies on traditional security by the Copenhagen Circle. The International Environmental Order (IEO), which serves as a legal and political framework of the multilateral agenda in this research, has been contested by global systemic changes in the last four decades. Consequently, the traditional political-legal tools do not seem to be following more pressing issues of interstate relations, as in cases of serious environmental disasters with transboundary effects. When the component of interventions as a defense tool is added along with the idea of "sovereignty as responsibility", based on the discursive construction of the concepts of Human Security and Responsibility to Protect, one is taken to a controversial and contentious debate. The acceptance of this debate faces the reluctance of various state actors. Given the inadequacy of traditional legal tools to deal with "interventions", serious situations of transboundary environmental disasters change into a prescient academic, political and legal loophole of the new challenges to be addressed in this new century. With this in view, in addition to the components and characteristics of environmental politics, this research discusses the obligation of sovereign state actors in safeguarding its own population and territory, based on fundamental principles of human rights. In this sense, the environmental order is revisited, its historical and political progress investigated, and the basis of interventions taken to scrutiny in order to fulfill a cautious reassessment of the "green intervention" in International Relations and Law.
\end{abstract}

KEY-WORDS: Positive Duties, International Environmental Order; Disasters; Interventions; Human Security, R2P. 


\section{RÉSUMÉ}

Dans un contexte international composé de la dichotomie entre la société minimalistepluraliste, de biais souverainiste, et la consensualiste-maximaliste, plus ouverte et plus enclinée aux processus de coopération, l'obligation de l'État d'intervenir dans le pays voisin en cas de catastrophes est discuté. Le défi environnemental est privilégié comme une unité d'analyse, en fonction de l'expansion des questions relatives à la sécurité internationale et les études critiques sur la sécurité traditionnelle menées par le Cercle de Copenhague. L'ordre international de l'environnement (OIE), qui sert de cadre juridique et politique et d'ordre du jour de l'agenda multilatéral dans cette recherche, a été mis à l'épreuve par des changements systémiques dans ces quatre dernières décennies. Par conséquent, les instruments politiques-juridiques traditionnels ne semblent pas suivre des questions plus pressantes des relations interétatiques, dont des exemples sont les cas de catastrophes environnementales graves ayant d'effets transfrontaliers. Lorsque l'on ajoute la composante des interventions comme un instrument de défense de la «souveraineté responsable», basée sur la construction discursive des concepts de sécurité humaine et de la responsabilité de protéger, l'on arrive à un débat controversé, dont l'acceptation passe certainement par la réticence de différents acteurs étatiques avec des capacités d'agir. Compte tenu de l'insuffisance des mécanismes juridiques traditionnels dans les situations de catastrophes environnementales transfrontalières et de la nécessité éventuelle de l'instrument d'intervention on perçoit un vide académique, politique et juridique, prémonitoire des défis à relever dans l'avenir. Ainsi, en plus des composants et des caractéristiques de la politique environnementale, la recherche examine la capacité des acteurs étatiques souverains d'agir dans la sauvegarde de sa propre population et du territoire, fondée sur les principes fondamentaux des droits de l'homme. De cette façon, l'ordre environnementale est revisité, son évolution historique et politique fait l'objet d'une enquête, et les bases des instituts d'intervention sont examinées, afin d'accomplir une réévaluation prudente du thème de «l'intervention verte» dans le droit et les relations internationales.

MOTS-CLÉS: obligations positives, ordre international de l'environnement; catastrophes écologiques; interventions; sécurité humaine, la R2P. 


\section{$\underline{\text { Lista de Tabelas }}$}

TABELA 6.1: EXCLUDENTES DE ILICITUDE - MODELO COMPARATIVO 213

TABELA 6.2: LIBERAÇÃO TOTAL DE MATERIAL RADIOATIVO DO ACIDENTE DE CHERNOBYL (1986)....227 TABELA (ANEXO) - DEZ MAIS IMPORTANTES ACIDENTES NATURAIS POR CATEGORIA (1985-2014)...303 TABELA (ANEXO) - ACIDENTES INDUSTRIAIS (TECNOLÓGICOS) POR CONTINENTE (1985-2014). 305

\section{$\underline{\text { Lista de Figuras }}$}

FIG. 2.1: RELAÇÃO ENTRE GOVERNO E SOCIEDADE ....................................................................58

FIG. 3.1: REGIME COMPLEXO DE MUDANÇA CLIMÁTICA.............................................................80

FIG. 4.1: NOVAS DIMENSÕES DA SEGURANÇA HUMANA ........................................................124

FIG. 5.1: NORM CICLE LIFE - CICLO DE VIDA NORMATIVO.........................................................173

FIG. 6.1: NÚMERO DE DESASTRES AMBIENTAIS POR PAÍS (1976-2005) ............................................191

FIG. 6.2: NÚMERO DE VÍTIMAS NO MUNDO DE DESASTRES TECNOLÓGICOS (1975-2012) ..................192

FIG. 6.3: OCORRÊNCIAS DE DESASTRES POR INUNDAÇÕES (HIDROLÓGICOS) POR PAÍS (1974-2003) .193

FIG. 6.4: OCORRÊNCIAS DE DESASTRES POR EPIDEMIAS (BIOLÓGICOS) NO MUNDO: 1974-2003.......194

FIG. 6.5: OCORRÊNCIAS DE DESASTRES VULCÂNICOS (GEOFÍSICOS) POR PAÍS (1974-2003) ...............195

FIG. 6.6: OCORRÊNCIAS DE DESASTRES POR FURACÕES (METEOROLÓGICOS) POR PAÍS (1974-2003) 196

FIG. 6.7: OCORRÊNCIAS DE DESASTRES POR TERREMOTOS (GEOFÍSICOS) POR PAÍS (1974-2003) ......197

FIG. 6.8: DISPÊNDIO TOTAL EM RAZÃO DE ACIDENTES NATURAIS (1990-2012).................................199

FIG. 6.9: DISPÊNDIO TOTAL EM RAZÃO DE ACIDENTES TECNOLÓGICOS (1990-2011) .........................200

FIG. 6.10: ÁREA DO ENTORNO DA CENTRAL NUCLEAR DE CHERNOBYL .........................................221

FIG. 6.11: MODELO DE REATOR NA USINA DE CHERNOBYL....................................................222

FIG. 6.12: IMAGEM DE SATÉLITE DA ÁREA ATINGIDA PELO ACIDENTE ...........................................224

FIG. 6.13: EFEITOS DO ACIDENTE NA CENTRAL NUCLEAR DE CHERNOBYL ....................................225

FIG. 6.14: MAPA DE DEPOSIÇÃO DE RADIONUCLÍDEOS................................................................229

FIG. 6.15: MAPEAMENTO DO TSUNAMI DE MARÇO DE 2011 - JAPÃO.............................................2237

FIG. 6.16: MAPA DA NUCLEARIZAÇÃO DO TERRITÓRIO JAPONÊS...................................................2238

FIG. 6.17: MAPEAMENTO DA OCORRÊNCIA DE DESASTRES NATURAIS NA ÁSIA ...............................2241 


\section{Lista de Abreviaturas e Siglas}

\begin{tabular}{|c|c|}
\hline AGNU & Assembleia Geral das Nações Unidas \\
\hline AIEA & Agência Internacional de Energia Atômica \\
\hline Art. & Artigo \\
\hline ASEAN & Association of Southeast Asian Nations \\
\hline ASIL & American Society of International Law \\
\hline Cap. & Capítulo \\
\hline $\mathrm{CDB}$ & Convenção sobre Diversidade Biológica \\
\hline CDI & Comissão de Direito Internacional \\
\hline CDS & Comissão de Desenvolvimento Sustentável \\
\hline $\mathrm{CEDH}$ & Corte Europeia dos Direitos Humanos \\
\hline CEA & Comissariado de Energia Atômica \\
\hline $\mathrm{CF}$ & Constituição Federal \\
\hline $\mathrm{Cf}$. & Conferir \\
\hline $\mathrm{CICV}$ & Comitê Internacional da Cruz Vermelha \\
\hline CIJ & Corte Internacional de Justiça \\
\hline CMDS & Cúpula Mundial sobre Desenvolvimento Sustentável \\
\hline CMMAD & Comissão sobre Meio Ambiente e Desenvolvimento/ONU \\
\hline CNUMAD & Conferência da ONU sobre Meio Ambiente e Desenvolvimento \\
\hline CNUMAH & Conferência das Nações Unidas sobre Meio Ambiente Humano \\
\hline CNUDS & Conferência da ONU sobre Desenvolvimento Sustentável \\
\hline CMNUDS & Cúpula Mundial da ONU sobre Desenvolvimento Social \\
\hline $\mathrm{COP}$ & Conferência das Partes \\
\hline COPRI & Copenhague Peace Research Institute \\
\hline CRED & Centre for Research on the Epidemiology of Disasters \\
\hline CSNU & Conselho de Segurança das Nações Unidas \\
\hline DIA & Direito Internacional Ambiental \\
\hline DI & Direito Internacional \\
\hline DIDH & Direito Internacional dos Direitos Humanos \\
\hline $\mathrm{DIH}$ & Direito Internacional Humanitário \\
\hline DIMA & Direito Internacional do Meio Ambiente \\
\hline DIP & Direito Internacional Público \\
\hline EM-DAT & Banco de Dados Internacional de Desastres \\
\hline EU & European Union \\
\hline EUA & Estados Unidos da América \\
\hline FAO & Food and Agriculture Organization of the United Nations \\
\hline Fig. & Figura \\
\hline $\mathrm{HS}$ & Human Security \\
\hline ICISS & International Commission on Intervention and State Sovereignty \\
\hline IDP & Internally Displaced People/Deslocados Internos \\
\hline IDRL & International Disaster Response Law \\
\hline IDRC & International Development Research Centre \\
\hline IFRC & $\begin{array}{l}\text { Federação Internacional das Sociedades da Cruz Vermelha e do } \\
\text { Crescente Vermelho }\end{array}$ \\
\hline ILC & International Law Commission \\
\hline ILA & International Law Association \\
\hline
\end{tabular}




\begin{tabular}{|c|c|}
\hline IPCC & Intergovernmental Panel on Climate Change \\
\hline IR & International Regime \\
\hline ISIL & Islamic State of Iraq and the Levant \\
\hline LD & Legítima Defesa \\
\hline MRE & Ministério das Relações Exteriores \\
\hline MIT & Massachusetts Institute of Technology \\
\hline NAFTA & North American Free Trade Agreement \\
\hline NISA & Agência de Segurança Industrial e Nuclear do Japão \\
\hline PIMA & Proteção Internacional do Meio Ambiente \\
\hline OAI & Ordem Ambiental Internacional \\
\hline $\mathrm{OAG}$ & Ordem Ambiental Global \\
\hline ODS & Objetivos de Desenvolvimento Sustentável \\
\hline OECD & $\begin{array}{l}\text { Organização Europeia para a Cooperação Econômica e } \\
\text { Desenvolvimento }\end{array}$ \\
\hline OI & Organização Internacional \\
\hline ONG & Organização Não-Governamental \\
\hline OMS & Organização Mundial de Saúde \\
\hline ONU & Organização das Nações Unidas \\
\hline OTAN & Organização do Tratado do Atlântico Norte \\
\hline PIPH & Proteção Internacional da Pessoa Humana \\
\hline PIMA & Proteção Internacional do Meio Ambiente \\
\hline PM & Primeiro-Ministro \\
\hline PNUD & Programa da ONU para o Desenvolvimento (ver UNDP) \\
\hline PNUMA & Programa da ONU para o Meio Ambiente (ver UNEP) \\
\hline pp. & Páginas \\
\hline RI & Relações Internacionais \\
\hline RIMA & Relatório de Impacto Ambiental \\
\hline R2P/RtoP & Responsibility to Protect/Responsabilidade de Proteger \\
\hline RwP & Responsibility while Protecting/Responsabilidade ao Proteger \\
\hline $\mathrm{S} / \mathrm{D}$ ou s/d & sem data \\
\hline SGNU & Secretaria-Geral das Nações Unidas \\
\hline SH & Segurança Humana \\
\hline SA & Segurança Ambiental \\
\hline SI & Sistema Internacional \\
\hline TEPCO & Tokyo Eletric Power \\
\hline TPI & Tribunal Penal Internacional \\
\hline TRI & Teoria das Relações Internacionais \\
\hline UNCCC & United Nations Climate Change Conference/2009 \\
\hline UNFCCC & Convenção Quadro da ONU sobre Mudança Climática \\
\hline UE & União Europeia \\
\hline UNDP & United Nations Development Program (ver PNUD) \\
\hline UNEP & United Nations Environment Program (ver PNUMA) \\
\hline UNSCEAR & Comitê Científico da ONU sobre os Efeitos da Radiação Atômica \\
\hline UNESCO & United Nations Educational, Scientific and Cultural Organization \\
\hline URSS & União das Repúblicas Socialistas Soviéticas \\
\hline USNRC & Comissão Regulatória Nuclear dos Estados Unidos \\
\hline
\end{tabular}




\section{SUMÁRIO}

Parte I - Metodologia e marco teórico para uma reflexão das Obrigações Positivas relativas ao Meio Ambiente

\section{INTRODUÇÃO: OBJETIVOS DO ESTUDO E PERSPECTIVAS GERAIS}

1.1 CONSIDERAÇð̃ES INICIAIS ..................................................................................... 1

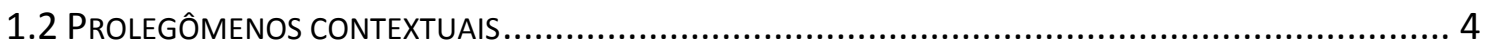

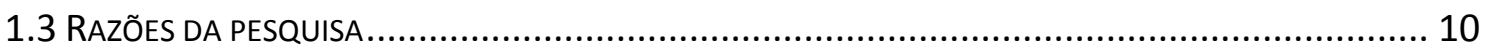

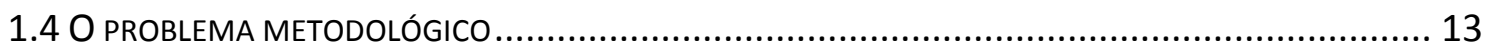

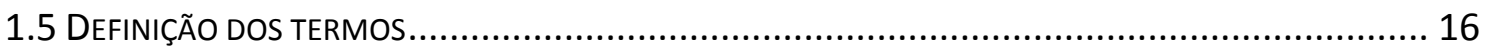

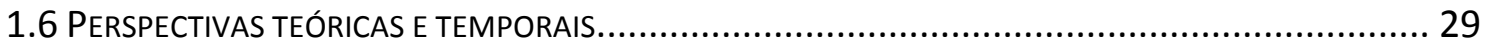

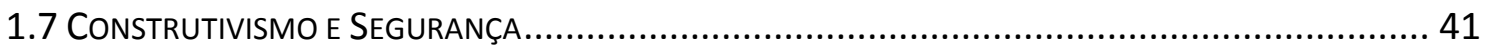

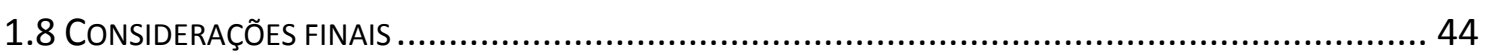

II. A ORDEM GLOBAL CONTEMPORÂNEA: NOVOS DESAFIOS DE SEGURANÇA GLOBAL

2.1 CONSIDERAÇð̃ES INICIAIS ................................................................................... 48

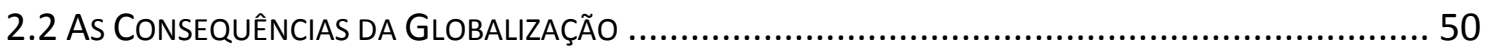

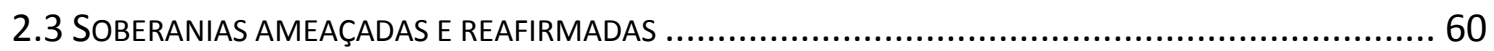

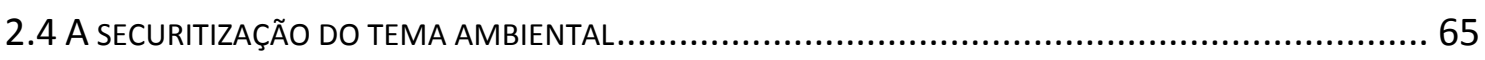

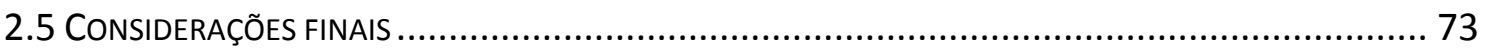

III. A ORDEM AMBIENTAL INTERNACIONAL: ASPECTOS E DIMENSÕES

3.1 CONSIDERAÇð̃ES INICIAIS ..................................................................................... 77

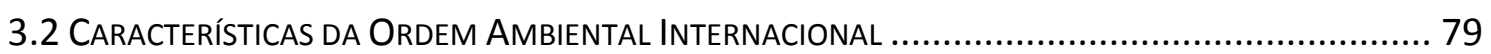

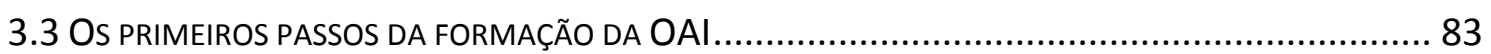

3.4 DE ESTOCOLMO À RIO+20: QUATRO DÉCADAS DE TRANSFORMAÇÃO ..................................... 91

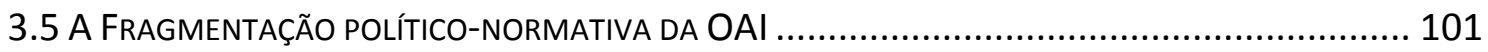

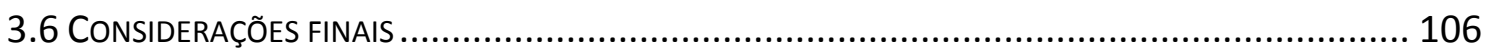

Parte II - Entre a Segurança Humana e a Responsabilidade de Proteção: as Obrigações Positivas do Estado como inovação conceitual

\section{A INTERVENÇÃO: EVOLUÇÃO DO CONCEITO NAS RELAÇÕES INTERNACIONAIS}

4.1 CONSIDERAÇÕES INICIAIS

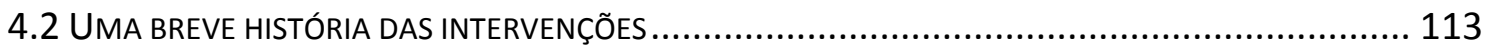

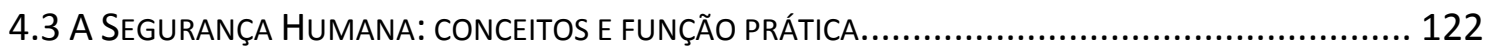

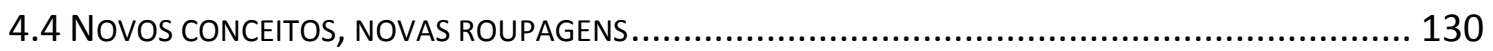

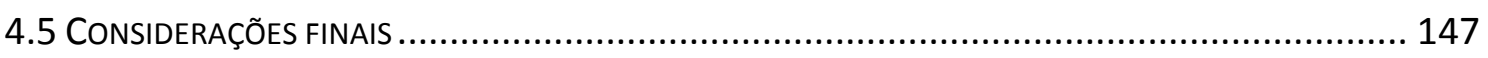




\section{A RESPONSABILIDADE DE PROTEGER: CONCEITOS E LIMITES}

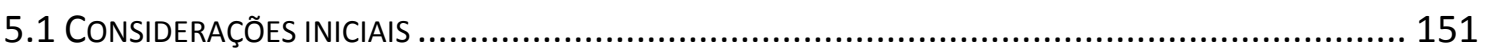

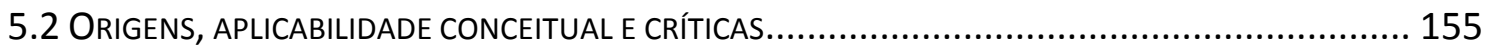

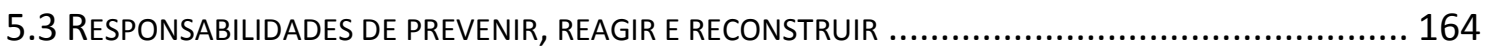

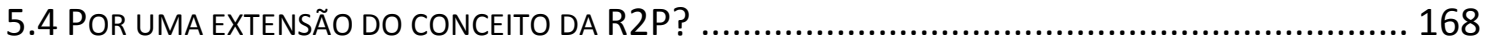

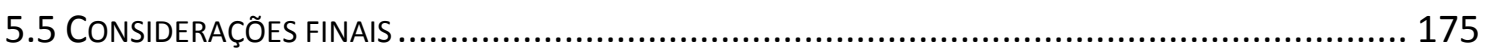

\section{AS INTERVENÇÕES VERDES EM DESASTRE AMBIENTAL}

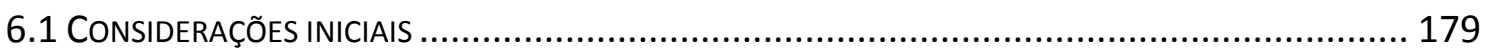

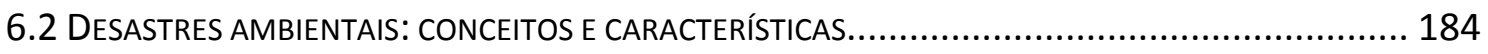

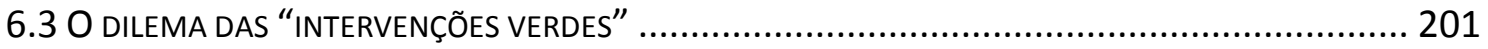

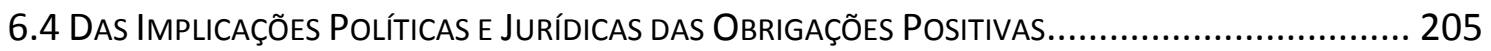

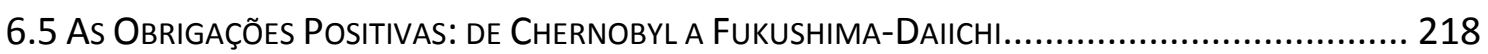

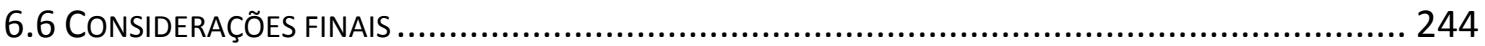

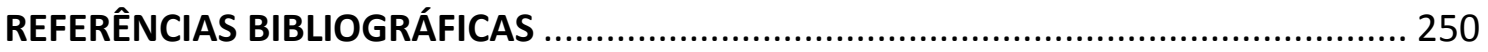

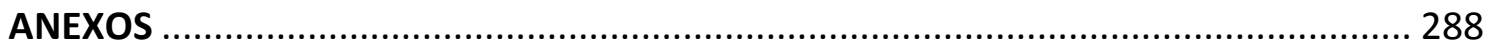


CAPÍTULO I

INTRODUÇÃO: OBJETIVOS DO ESTUDO E

PERSPECTIVAS GERAIS 


\title{
I. Introdução: Objetivos do Estudo e Perspectivas Gerais
}

\author{
"Moral choices are not simply made; they are also judged, and so \\ there must be criteria for judgment"
}

Michael Walzer, in Spheres of Justice (1983)

\subsection{Considerações iniciais}

Enquanto escrevíamos os últimos traços desta pesquisa, o periódico francês $L e$ Monde informava que dois drones não-identificados sobrevoavam instalações nucleares no sudeste do país (em Saint-Alban, na Província de Val d'Isère, e em Marcoule, no Gard), somando-se a uma dezena de outros voos suspeitos realizados dias antes, que as autoridades francesas buscavam, sem sucesso, identificar a autoria. ${ }^{1} \mathrm{O}$ local onde se encontra a central nuclear de Marcoule abriga um estabelecimento de pesquisas do Comissariado de Energia Atômica (CEA) do país e uma usina de processamento de combustível. Cinco mil pessoas, entre técnicos e operários, ali trabalham diariamente.

Em Saint-Alban, a direção da planta nuclear buscava tranquilizar a população contígua de que não haveria "aucune conséquence sur la sûreté et le fonctionnement des installations" ("qualquer consequência sobre a segurança e o funcionamento das instalações"). Em outro tom, a ministra de Energia e Meio Ambiente Ségolène Royal informava dos desdobramentos das investigações e esclarecia não haver, até aquele momento, quaisquer indícios dos responsáveis pela utilização indevida dos veículos aéreos em áreas de máxima segurança nuclear. Em um país que possui 19 plantas nucleares e 58 reatores em atividade, suprindo cerca de $75 \%$ de sua eletricidade, a preocupação da sociedade francesa é legítima. ${ }^{2}$

Após três anos da ocorrência de um dos desastres mais dramáticos da história, em Fukushima-Daiichi, na costa do Japão (2011), não para menos indagações a respeito da segurança nuclear em solo francês foram reavivadas na sociedade. Enquanto as

\footnotetext{
${ }^{1}$ Cf. http://www.lemonde.fr/planete/article/2014/11/07/le-site-nucleaire-de-marcoule-survole-par-undrone_4520207_3244.html (acesso em 07/11/2014).

${ }^{2}$ Cf. http://energie.edf.com/nucleaire/carte-des-centrales-nucleaires-45738.html (acesso em 07/11/2014)
} 
autoridades diziam que a segurança das instalações nucleares, ainda que sobrevoadas por drones, seguiam todos os padrões de seguridade, ONGs antinucleares apressavamse em denunciar a "incapacidade" do Estado francês em lidar de forma adequada com a situação. O Greenpeace exprimia sua "inquietude crescente" com a inércia estatal e exortava as autoridades a revelarem elementos mais críveis que permitissem à sociedade civil uma avaliação mais efetiva de que o material radioativo presente nos tanques de armazenamento não se encontrava vulnerável a um potencial ataque terrorista de dimensão inimaginável.

Do outro lado do Atlântico, no mesmo dia do noticiário francês, as Nações Unidas (ONU) pareciam confirmar, por meio de estudos do Programa para o Meio Ambiente (PNUMA), que pelo menos $40 \%$ dos conflitos intraestatais nos últimos 60 anos estariam diretamente associados a problemas ambientais. ${ }^{3}$ O Secretário-Geral Ban Ki-moon ponderava que os conflitos armados “(...) estão se tornando cada vez mais complexos e exigem soluções que abordem a raiz das causas". Referia-se, entre outros, ao conflito interno somali e ao uso de reservas de carvão vegetal do país para fins de financiamento da insurgência e de grupos terroristas lá atuantes. Ao final, conclamava a comunidade internacional a "reafirmar" o compromisso assumido com a proteção ambiental e a prevenção do uso de recursos naturais que contribua para a insegurança global.

O discurso do Chefe da Diplomacia Multilateral, feito no "Dia Internacional para a Prevenção da Exploração do Meio Ambiente em Tempos de Guerra e Conflito Armado" (06/11), sintetizava três décadas de iniciativas rumo à "construção de um conhecimento coletivo para trazer avanços na gestão efetiva do meio ambiente, como parte integrante da construção da paz e do desenvolvimento sustentável”. Desvelava, ainda, o reconhecimento da variável ambiental como causa "profunda" da insegurança internacional, pela qual nações de todo o planeta buscavam mitigar seu efeito e influência. Diante disso, surgem questionamentos eloquentes, cujas respostas envolvem pensar as relações internacionais sob outros paradigmas e lentes analíticas que não apenas os atuais existentes: qual a relação entre os drones no território francês e a

3 Cf. http://www.onu.org.br/40-de-todos-os-conflitos-internos-dos-ultimos-60-anos-estao-associados-arecursos-naturais-diz-onu/ (acesso em 07/11/2014). 
utilização de recursos naturais para o financiamento de conflitos na Somália? Seriam os dois eventos paralelos e inter-relacionados? Com a incapacidade das autoridades francesas de descobrir a responsabilidade sobre a utilização dos drones, do risco nuclear ao território, como deveriam reagir seus vizinhos, em caso potencial de ataque terrorista? E se a França fosse atacada, o que poderiam fazer os vizinhos? Em vista da situação política no Oriente Médio e das constantes ameaças de grupos terroristas (militantes da ala mais extremista do Estado Islâmico ${ }^{4}$, por exemplo) a países europeus por interferência indevida em assuntos internos da região, a comunidade internacional deveria, igualmente, imiscuir-se no caso francês? Melhor ainda: em um provável ataque por drones de excepcional gravidade contra as instalações nucleares na França, com efeitos transfronteiriços irreparáveis, quais deveriam ser as reações dos Estados fronteiriços e da comunidade internacional a um novo acidente nuclear comparável às proporções de Chernobyl, em pleno solo europeu e em um mundo multipolar completamente diferente daquele dos anos 1980? Todas essas inquietações são prementes, válidas e desafiadoras e não podem ser desconsideradas em razão das novas ameaças que a realidade do século XXI nos revela.

Os casos francês e somali representam desafios nem tão novos que, desde a edificação da atual Ordem Ambiental Internacional $(\mathrm{OAI})^{5}$, com a derrocada do universo bipolar prevalecente até os anos 1990, a sociedade internacional tem buscado enfrentar na construção de um mundo mais seguro e distante das guerras e conflitos. Uma das mudanças paradigmáticas mais relevantes nesse processo foi a crescente consciência global contraditória de que o meio ambiente é um atributo essencial para o bem-estar da coletividade e também motivo das agruras mais severas que afetam a

\footnotetext{
${ }^{4}$ O Estado Islâmico do Iraque e do Levante (conhecido pela sigla, em inglês, ISIL) constitui uma aliança jihadista do Oriente Médio, com ramificações externas em vários países, cuja finalidade proclamada seria constituir um califado na região, para afirmar sua autoridade sobre os religiosos muçulmanos em todo o globo. O ISIL passou a ser conhecido por suas atividades consideradas radicais, ainda durante a conflagração interna na Síria, a partir de 2011. A crise regional levou, recentemente, os Estados Unidos e parceiros europeus a empreenderem uma nova intervenção armada no Iraque para conter o avanço do grupo. A questão das sistemáticas violações aos direitos humanos pelo ISIL no Iraque, contra grupos minoritários cristãos e curdos e outras atividades consideradas terroristas, foi tema de Resolução do CSNU (Resolution 2170 (2014), sob os auspícios do Capítulo VII, da Carta das Nações Unidas. (cf. http://www.un.org/press/en/2014/sc11520.doc.htm, acessado em 15/10/2014)

${ }^{5} \mathrm{O}$ conceito de Ordem Ambiental Internacional (OAI), que será visto mais adiante no tópico "definição dos termos", surgiu dos estudos de Geografia Humana do geógrafo da Universidade de São Paulo (USP) Wagner Costa Ribeiro. Foi resultado de sua tese de Doutoramento, sob o mesmo título (RIBEIRO, 2001). Suas características e definições analíticas, bem como os desdobramentos históricos de sua formação, serão analisadas apropriadamente no Cap. III.
} 
modernidade. Seus atores se multiplicaram e seus protagonistas se tornaram difusos. Os Estados, antes primordiais e ordenadores da agenda internacional, passam paulatinamente a adequar-se a uma estrutura mais plural e a compartilhar valores e normas menos uniformes, com prejuízos a serem perscrutados para prerrogativas, como a soberania, que por séculos pautaram sua atuação no cenário global.

Estamos diante de um enigma ainda a ser decifrado, com desdobramentos que poderão influenciar de forma efetiva a dinâmica dos conflitos futuros de viés ambiental. Esse processo incluirá o debate das intervenções, que desenvolve no mesmo compasso das transformações por que passa a comunidade de Estados, com seus desígnios e idiossincrasias, em um espaço mais humanista e limitante sem precedentes, com tendências de prevalência do indivíduo em detrimento de tradicionais formas de coletividade estatais mais centralizadoras. É o cenário acima, seus componentes e transformações que pretendemos explorar neste trabalho. Esse campo tão vasto desafia o pesquisador, e também lhe serve de alento, ao contribuir de modo genuíno e apaixonante para o avanço das reflexões sobre o tema nas Relações Internacionais. Esperamos poder cumprir esse objetivo.

\subsection{Prolegômenos contextuais}

Durante algum tempo a evolução do tema ambiental foi vista com desconfiança por parte da comunidade de nações, sobretudo em foros multilaterais. A constatação devia-se, em parte de forma correta, às inúmeras controvérsias e diferenças de opiniões dos seus protagonistas com relação aos mais variados interesses que compõem a extensa agenda internacional no tema do meio ambiente. ${ }^{6}$ Para os países em desenvolvimento

\footnotetext{
${ }^{6}$ A temática ambiental usualmente alheia à high politics durante décadas ganhou proeminência como campo de estudos, não somente pelo acréscimo das variáveis econômico-desenvolvimentistas, mas também pela maior securitização do discurso sobre o meio ambiente em foros internacionais, como as Nações Unidas. A literatura acadêmica a respeito deste último aspecto tem sido profícua. Vale mencionar: LUCILE, Maertens. Environmental Securitization within the United Nations: a Political Ecology Perspective. Institut de Recherche Stratégique de l'École Militaire, 2013; BARNETT, Jon et al. Global Environmental Change and Human Security. Cambridge: MIT, 2010; DALBY, Simon. Security and Environmental Change. Cambridge: Polity, 2009; FLOYD, Rita. Security and the environment: Securitization theory and US environmental security policy. Cambridge: Cambridge University Press, 2010; IMBER, Mark. Environment, Security and UN Reform. New York: St. Martin's Press,1994; WEISS, Thomas \& THAKUR, Ramesh. Global governance and the UN: an unfinished journey. Bloomington: Indiana University Press. 2010; SCHWARTZ, Peter; RANDALL, Doug. An Abrupt Climate Change Scenario and Its Implications for United States National Security, 2003; Climate Change Adaptation Roadmap, US Department of Defense (DoD), 2014.
} 
e/ou emergentes ${ }^{7}$, a questão suscitava desconfiança porque a agenda ambiental exercida por nações mais afluentes era transposta ao plano internacional considerando interesses por vezes obscuros. O ritmo acelerado do processo de internacionalização dos problemas ambientais reproduzia a rapidez com que evoluía a agenda doméstica dos países desenvolvidos nessa área. Assim, o que começou com pequenos ecos de grupos restritos do Estado, do mercado e da sociedade civil transformou-se progressivamente em tema de relevância política, econômica e securitária para os Estados (LAGO, 2004:8-12).

Não poderia ser diferente. A partir da década de 1960, o movimento ecologista ganhou cada vez mais espaço nos foros internacionais. Com a emergência do Estado de bem-estar social nos países europeus, a sociedade civil parecia mais engajada em cobrar das lideranças políticas a solução de problemas relacionados ao meio ambiente e que preocupavam, principalmente, a manutenção do estilo de vida saudável nas grandes metrópoles, assoladas com problemas de degradação ambiental e visível poluição atmosférica e dos rios, oriunda da industrialização desenfreada. Outros temas mais recentes como a crescente competição pelo acesso aos recursos naturais, o empobrecimento da diversidade biológica e a mudança climática também foram incluídos na agenda multilateral à medida que os mais diversos atores internacionais se davam conta da efetiva e profunda interdependência ecológica a que estavam fadados ${ }^{8}$. É nesse contexto que a comunidade internacional se volta cada vez mais para questões ambientais e se edifica uma verdadeira OAI.

\footnotetext{
${ }^{7} \mathrm{O}$ conceito de países em desenvolvimento ou "emergentes", para efeito deste estudo de tese, refere-se às economias que, nas últimas décadas, vem aprimorando seus padrões de vida, de sustentabilidade e economia comparáveis aos padrões dos países “desenvolvidos”. O conceito não é aleatório, tendo em vista os critério objetivos hoje existentes com relação aos cálculos para definição dessa comparação, em especial os índices definidos por agências das Nações Unidas, como o Programa da ONU para o Desenvolvimento (UNDP), com seu Relatório do Desenvolvimento Humano (HDR), ou às estatísticas de instituições multilaterais como o Fundo Monetário Internacional (FMI) e o Banco Mundial. Cf. www.imf.org/ ; www.worldbank.org e www.unep.org/.

${ }^{8}$ A interdependência ecológica aqui entendida, aproxima-se do significado filosófico dado pelo físico Fritjof Capra, em A Teia da Vida: uma nova compreensão científica dos sistemas vivos (1996), quando afirma que: “(...) Todos os membros de uma comunidade ecológica estão interligados numa vasta e intrincada rede de relações, a teia da vida. Eles derivam suas propriedades essenciais, e, na verdade, sua própria existência, de suas relações com outras coisas. A interdependência - a dependência mútua de todos os processos vitais dos organismos - é a natureza de todas as relações ecológicas. $O$ comportamento de cada membro vivo do ecossistema depende do comportamento de muitos outros (...) '”.
} 
Com sua evolução, em paralelo ao desenvolvimento conceitual de temas voltados à Segurança Humana $(\mathrm{SH})$ e, consequentemente, à Responsabilidade de Proteger $(\mathrm{R} 2 \mathrm{P} / \mathrm{R} \text { toP })^{9}$, além de variados institutos jurídico-políticos, relativos à Proteção Internacional da Pessoa Humana (PIPH) e do Meio Ambiente (PIMA) ${ }^{10}$, surgiram os fundamentos para o arcabouço analítico da presente tese de Doutorado. A ótica pluridisciplinar deste trabalho deverá permitir a fixação de diretrizes maiores para a conclusão da pesquisa. Ao estudar as disciplinas Relações Internacionais (RI) e Direito Internacional (DI), a perspectiva de analisar a ordem global contemporânea póshegemônica de difícil definição (PRANTL, 2014) ${ }^{11}$, em seus múltiplos aspectos ainda em formação, torna-se para o pesquisador um desafio.

Andrew Hurrell (1999: 62-3) esforça-se para superar essa dificuldade de definição da ordem global, e avalia que um de seus mais relevantes aspectos refere-se à "retração" do princípio da não-intervenção, característico do sistema político pluralista minimalista e tradicional, que privilegia a soberania como elemento basilar de manutenção da ordem global. Durante o século XX, esse princípio foi continuamente contestado por abordagens mais "solidaristas" e "maximalistas", de tendências humanistas e em favor de uma governança global complexa, com a diminuição progressiva da prerrogativa soberana estatal. Iniciativas da ONU e de organismos regionais, como a aplicação de sanções econômicas, não-reconhecimento de faits acomplis e o emprego de operações de paz ao estilo peace enforcement, em casos extremos de desrespeitos aos direitos humanos, têm contribuído para esse processo e expandido a noção usual de ameaças à paz, ao incluir novas variáveis que auxiliam na

\footnotetext{
${ }^{9}$ Utilizaremos nesta pesquisa, indistintamente, as siglas "R2P" e "RtoP", como largamente empregadas na literatura a respeito e reconhecidas pelo SGNU Ban Ki-moon, no Relatório "Implementing the Responsibility to Protect” (2009/A/63/677).

${ }^{10} \mathrm{O}$ conceito de Proteção Internacional do Meio Ambiente (PIMA) faz paralelo aqui com a Proteção Internacional dos Direitos Humanos, porém com ele não se confundindo. A PIMA refere-se ao arcabouço jurídico basilar da OAI, representado pelo Direito Internacional do Meio Ambiente (DIMA). Varella (2009) chega a considerar que o Direito Ambiental representa verdadeiro ramo autônomo do DI, por sua lógica própria, passando por uma célere expansão nos últimos anos.

${ }^{11}$ Como bem analisou Prantl (2014), em seu artigo "Taming Hegemony: Informal Institutions and the Challenge to Western Liberal Order”, as instituições informais, compostas pelos diversos mecanismos intra-estatais, principalmente de países emergentes, apresentam um "espaço vital" para a renegociação das condições hegemônicas antes determinadas pelos EUA como potência na ordem unilateral do imediato pós-Guerra Fria. Segundo Prantl. Com a crescente alteração da balança de poder global contemporâneo, a hegemonia norte-americana não mais é vista com exclusividade para a solução de problemas que exigem uma ação coletiva urgente. Conjugamos dessa ideia de "taming hegemony" de desenvolvida pelo autor. A OAI caracteriza-se pela multiplicidade dos atores em formação temática multi-fragmentada e temática.
} 
edificação de um framework compatível com as exigências dos desafios (ecológicos e humanitários) mais prementes do mundo contemporâneo.

Nossa pesquisa, assim, trata dessas mudanças na ordem contemporânea, da redefinição do papel do Estado, em busca de uma nova identidade, em ambiente plural de novos atores, mas também do fortalecimento de velhas prerrogativas e manutenção de outras. Nesse ambiente anárquico, os Estados ainda mantêm a prevalência do poder legítimo de uso da força contra as mais variadas ameaças. Ainda com a evolução histórico-conceitual das últimas décadas, voltamos novamente, no século XXI, a fazer as mesmas perguntas que inquietaram nossos antepassados, e que parecem repetir-se continuadamente através dos anos: um Estado tem o direito de intervir no território de outro? A evolução dos direitos humanos e ambiental poderá um dia levar a maior legitimidade e quiçá legalidade de intervenções nos territórios de vizinhos? Impossível responder, mas a tese traz pistas de reflexão (elementos de resposta), demonstrando que há 30 anos o que era impensável, a noção de Responsabilidade de Proteger (R2P), foi estabelecido sob a égide da ONU.

Diante dessa mudança de perspectiva na ordem global, faz-se relevante adaptarmos nossos quadros analíticos para incorporar instrumentos renovados de análise, que possam acompanhar a sintonia com uma realidade focada crescentemente na prevalência de princípios voltados para a segurança humana, em seus diversos âmbitos, como o meio ambiente. É de suma importância, nesse processo, que nossas percepções interajam com a contemporaneidade, de modo a reconhecer que nossos valores são histórico, social e politicamente construídos.

A proteção ambiental tende a tornar-se mais efetiva quando os princípios que regem a OAI começam a fazer parte de arcabouço jurídico e político maior que crie um sistema de valores, princípios, normas e sanções coibindo determinadas ações ou estimulando iniciativas positivas. Quando grupos de interesse exigem das autoridades estatais que se proteja determinada espécie, ou então busquem aperfeiçoar o sistema de tratamento sanitário, as autoridades públicas aplicam regras jurídicas vigentes ou criam novas, exercendo seu poder normativo de polícia por meio de inúmeras agências e instituições responsáveis pelos mais diversos temas dentro da administração pública. 
Em todas as situações, no entanto, há demandas formais de recurso a instrumentos jurídicos já existentes.

Nas últimas décadas, a formação do Direito Internacional do Meio Ambiente (DIMA) passou por avanços consideráveis e desilusões momentâneas, desde a euforia dos anos 1970, quando as regulamentações contra a poluição ambiental e a destruição da fauna e da flora, ora em implementação pelos mais diversos países, representavam o apanágio do ecologismo global, até as percepções mais realistas uma década depois quanto à eficácia dos instrumentos então postos em prática. Foram anos cruciais para o avanço do direito ambiental. Na década de 1990, com a volta do tema à esfera internacional com mais intensidade, após o colapso das forças do mundo bipolar da Guerra Fria, esperava-se o retorno do otimismo inicial, que nos arriscamos a considerar ainda não ocorreu.

É nesse ambiente político e de evolução normativa que a presente pesquisa ganhará seu rumo, para discutir a conformação da Ordem Global e da OAI que lhe sustenta, buscando compreender os novos desafios que lhe são postos e propor soluções para situações ainda pouco situadas na literatura acadêmica e nos diversos compêndios do sistema político e jurídico de áreas tão vastas como RI, PIPH e PIMA. Propomos um estudo exploratório em torno dos temas da intervenção, segurança humana, meio ambiente e obrigações positivas, de maneira a situá-los nessa realidade tão vasta das relações internacionais, o "estado da arte" das discussões acadêmicas e políticas mais contemporâneas, sem olvidar do processo histórico que lhe acompanhou. Reconhecemos que as obrigações positivas relativas ao meio ambiente, em específico em situações de desastres, vetor deste trabalho, é tema dos mais polêmicos e ainda por ser efetivamente perscrutado diante da realidade concreta e pelos esforços intelectuais dos acadêmicos e prática política nas mais diversas instâncias multilaterais do cenário internacional.

No primeiro capítulo da Tese, pretendemos expor os fundamentos do trabalho, analisar minuciosamente questões metodológicas, esclarecer seus objetivos e o método a ser adotado, apresentar o problema que nos desafia. Uma análise do nível de conhecimento que se tem a respeito do tema, das motivações intelectuais da pesquisa, 
de seu âmbito de pertinência, das diversas dimensões do problema, do corte temporal do estudo, dos limites a ela impostos e do quadro teórico de referência encontra-se entre os tópicos que seguem.

Dividimos o vetor do estudo em duplo aspecto. Propôs-se inicialmente, além dessa parte introdutória metodológica, uma análise teórico-histórica e descritiva da Ordem Global e da OAI, no intuito de discutir os desafios impostos aos Estados pela globalização, com todas as suas múltiplas consequências para a formação da ordem contemporânea. Nesta fase, pretendemos avaliar e revisitar o debate teórico sobre a soberania, não apenas no Direito Internacional, mas também na área das RI. Será dada relevância especial aos velhos e novos paradigmas do princípio da soberania no cenário internacional. Descobrir em que ponto se passou a ser avaliada a possibilidade de se "securitizar" o tema do meio ambiente, para incorporar variáveis explicativas inovadoras do mundo contemporâneo, será igualmente objeto de análise. Os fatos que marcaram as últimas décadas, como as crises nos Bálcãs, na África e no Oriente Médio, que ensejaram intervenções ainda hoje discutíveis em foros multilaterais e em instituições públicas e de proteção aos direitos humanos deverão ser, ainda que marginalmente, consideradas.

$\mathrm{Na}$ segunda parte, assaz analítica, trataremos das abordagens teóricas sobre intervenções e sua relação com o plano interno estatal. A essa fase da pesquisa correspondem os Cap. IV ("Segurança Humana"), Cap. V ("Responsabilidade de Proteger”) e Cap. VI (“Obrigações Positivas”). Iniciamos aí uma análise da evolução histórica da noção de SH na prática política e na literatura das RI, com a finalidade de conhecer sua influência conceitual na conformação terminológica do fundamento teórico dos temas dos direitos humanos e ambiental e seus naturais reflexos em torno da controvérsia sobre as intervenções. Após uma apresentação de seus conceitos e função prática, debruçamo-nos em avaliar as novas "roupagens" adquiridas pelas práticas intervencionistas, que partiram do âmbito das intervenções humanitárias para contornos mais nuançados. $\mathrm{O}$ capítulo sobre $\mathrm{SH}$ avança conceitualmente ao tópico da $\mathrm{R} 2 \mathrm{P}$, onde revisitaremos a literatura político-jurídica e acadêmica já produzida sobre o instituto. Discutiremos ainda a pretensa dicotomia dos conceitos de intervenção e soberania, 
apontando para eventuais correlações, incongruências e viabilidade da extensão do mecanismo para além do consenso político alcançado sobre o tema.

No Capítulo VI, fase mais empírica do estudo, analisamos dois fatos que permitem uma reflexão maior à luz da teoria das obrigações positivas relativas à área ambiental: os desastres nas plantas nucleares de Chernobyl (1986) ${ }^{12}$, ocorrido na Ucrânia, e, mais recentemente, de Fukushima-Daiichi (2011), no Japão. Os dois acidentes propostos, embora não exaustivos, servem de baliza, em nosso entender, para a aplicação prático-conceitual do tema, por representarem desastres ambientais de grave risco para as populações envolvidas, transfronteiriças ou não. É relevante notar que a discussão em torno das obrigações positivas aplicadas ao meio ambiente é um exercício reflexivo-acadêmico, não positivado na ordem jurídica internacional e limitado aos foros políticos multilaterais ou regionais.

Nesse último tópico, desenvolvemos também os pormenores do conceito de desastres ambientais. O dilema das "intervenções verdes" adquire aqui contornos especiais e substantivos, dada sua relevância para a contextualização do objeto da pesquisa. A seguir, analisamos as Obrigações Positivas, em estudo comparativo com outros mecanismos jurídico-normativos, como os institutos da Legítima Defesa e do Estado de Necessidade, na busca de apreender suas implicações políticas e jurídicas quando aplicadas na área ambiental. Ao final da jornada, em razão do estudo exploratório, por meio de vasto levantamento bibliográfico, apresentamos um vasto referencial teórico que pretendemos seja útil no auxílio de pesquisas afins.

\subsection{Razões da pesquisa}

O presente trabalho trata do tema da intervenção e de seus pressupostos conceituais, como soberania, conflitos, SH e R2P, que vem alcançando crescente

\footnotetext{
12 A título de recordação, o caso mais emblemático de poluição transfronteiriça e sua relação com questões de segurança nacional refere-se decerto ao acidente de Chernobyl (1986). O acidente demonstrou a vulnerabilidade dos Estados diante da inadequação das tecnologias existentes na época e a ausência de densidade normativa internacional para lidar com situações daquela natureza. A catástrofe levou a Agência Internacional de Energia Atômica (AIEA) a promover projetos de acordos que antes haviam enfrentado forte oposição das potências nucleares na época (LE PRESTRE, 2005).
} 
relevância nas discussões de áreas tão amplas como RI, DI e DIMA. ${ }^{13}$ Nesta mesma linha, propõe uma reflexão sobre a extensão conceitual-principiológica dos Direitos Humanos (quanto ao tema das obrigações positivas) ${ }^{14}$ às disciplinas relativas ao meio ambiente. A ideia de que os Estados têm obrigação de imiscuir-se em assuntos internos de seus congêneres também soberanos para a proteção da pessoa humana não é novidade, sendo há décadas discutida sob a perspectiva da doutrina intervencionista. Durante a ordem bipolar da segunda metade do século XX, discutir o tema da intervenção chegou mesmo a ser tabu em rodadas de negociações relativas a questões que envolvessem minimamente qualquer interferência na qualidade inerente soberana dos Estados, tendo em vista sua centralidade na ordem internacional e em questões relativas à segurança e estratégia militar, pauta dos mais variados foros multilaterais.

Discutir o tema das intervenções representa um dos maiores desafios nos estudos securitários das relações internacionais contemporâneas. A polêmica em torno do conceito e de sua aplicabilidade tem gerado uma dinâmica produção acadêmica nos mais diversos círculos e estimulado discussões político-diplomáticas acerca da efetividade de sua prática para além da tradicional proteção do ser humano. Ao deparamo-nos com estudos relacionados à segurança e à intervenção sob uma perspectiva ambiental, a situação muda, em razão da existência de uma ampla lacuna na produção intelectual-científica e das escassas abordagens em foros políticos e jurídicos, apesar de sua crescente relevância como desafio a ser enfrentado no contexto internacional hodierno.

\footnotetext{
${ }^{13}$ Nos últimos anos, a ideia de intervenção humanitária, extraída atualmente de sua fonte potencialmente legitimadora de R2P, parece estar passando por um momento de teste quanto à sua aplicabilidade e eficácia (Cap. V), parte em razão das discussões sobre seu correto uso em crises as mais diversas, a exemplo dos conflitos no âmbito da "Primavera Árabe". A extrapolação da competência conferida pelo CSNU na Resolução 1973 (que autorizava os estados-membros da ONU "a tomar todas as medidas necessárias, sem prejuízo do disposto no $§ 9$ da Resolução 1970 de 2011, para proteger os civis e áreas civis densamente povoadas sob ameaça de ataque na Líbia), que levou à deposição do líder Muammar Kadafi, contribuíram para tanto, bem como o fracasso do CSNU em alcançar consenso para nova aplicação do mecanismo, na conflagração interna síria. Em quase quatro anos de conflito (dez/2014), o conflito sírio já contabiliza ao menos 200 mil vítimas fatais e mais de 3,2 milhões de refugiados, além de 6,4 milhões de deslocados internos.

${ }^{14}$ O conceito de "Obrigações Positivas" não é novo, nem faz parte somente do ordenamento jurídico internacional. É encontrado também nas searas jurídicas domésticas, no Direito Civil (Teoria Geral das Obrigações), geralmente de tendência francesa-germânica. Às "obrigações positivas" (de fazer determinada "coisa"), contrapõem-se as "obrigações negativas" (de "não-fazer"). (AZEVEDO, 2011; CARVALHO, 2009; GAGLIANO; 2014; MONTEIRO, 2014). Nesta tese, o conceito será pautado, no entanto, no sentido que adquiriu nos estudos da área dos Direitos Humanos.
} 
A OAI confronta-se crescentemente com desafios que exigem uma reformulação conceitual e análises não distantes da estrutura político-normativa conformadora da PIPH, base da SH e da R2P. Analistas mais tradicionais, puristas e céticos quanto à extensão do conceito ao tema ambiental afirmam que eventual alargamento do horizonte securitário para além dos direitos humanos deverá fragilizar o consenso já alcançado naquela seara. Dessa controvérsia, surge a motivação intelectual do autor desta pesquisa de tentar ultrapassar as fronteiras teórico-conceituais tradicionais e analisar eventos que dariam novo estímulo ao preenchimento daqueles hiatos quanto à aplicabilidade da PIMA.

O objetivo principal da tese é analisar as obrigações positivas nos estudos sobre meio ambiente em situações específicas de desastres ambientais (naturais e tecnológicos) ${ }^{15}$, de modo a suprir lacuna no conhecimento da área, portanto, um estudo exploratório. ${ }^{16}$ Como objetivos secundários, pretendemos revisitar a dicotomia entre soberania e intervenção, com foco nas RI e nos estudos de Segurança Ambiental (SA); perscrutar a evolução histórica dos fenômenos que conformaram a OAI e o sistema internacional (SI), assim como os desdobramentos criativos conceituais decorrentes, nas subáreas Segurança, Meio Ambiente e Direitos Humanos. Analisaremos também a possibilidade de extensão dos princípios da R2P à OAI, principalmente no tocante ao preceito de "soberania como responsabilidade". Pretendemos, ainda, pesquisar o nível de densidade normativa relacionado às situações de desastres ambientais e eventual regularidade da transformação da OAI, com a inclusão de novos padrões de segurança e o surgimento de novos temas nas últimas décadas, como SH e R2P.

\footnotetext{
${ }^{15}$ Utilizo-me aqui de empréstimo conceitual da taxonomia de desastres constante do Banco de Dados Internacional de Desastres (EM-DAT), do Centro para Pesquisa sobre Epidemiologia de Desastres (CRED) da Organização Mundial de Saúde (OMS/ONU), que os classifica, quanto à origem, em "naturais" e "tecnológicos". O tema de desastres será objeto do capítulo VI, quando será analisado apropriadamente. Para maiores informações, cf. os endereços eletrônicos: www.emdat.be - EM-DATInternational Disaster Database e www.cred.be - Centre for Research on the Epidemiology of Disasters.

${ }^{16}$ Estudo exploratório no sentido de que consiste em uma pesquisa preliminar onde o maior objetivo é tornar-se familiar com o fenômeno a ser investigado, de modo que o estudo principal a seguir será planejado com grande entendimento e precisão (THEODORSON, 1970).
} 


\section{$1.4 \mathrm{O}$ problema metodológico}

Basicamente, a pergunta central do trabalho de tese e o problema metodológico proposto referem-se à análise da questão de se um Estado tem a responsabilidade de intervir no território soberano de outro com o qual compartilha áreas limítrofes ou não, em situações excepcionais de perigo efetivo ao seu território ou população, no intuito de protegê-los de danos ambientais. Em outros termos: Há uma “obrigação positiva” do Estado de intervir em outro em situações de efetivo e irreparável dano ambiental à própria população em áreas fronteiriças ou não, diante da inação ou impossibilidade imediata de resposta curativa do país causador do dano?

No caso de prestação de auxílio humanitário a um país afetado por desastre ambiental, embora haja crescente entendimento de que a comunidade internacional ${ }^{17}$ tenha um "direito" de intervir no ente afetado por considerações de ordem de responsabilidade de proteção da pessoa humana, não há, todavia, uma "obrigação" formal (hard), mas apenas moral e ética (soft), por parte daquela comunidade para tanto, segundo as normas jurídicas existentes e costumeiras do DIMA contemporâneo.

Em situações de desastres ambientais em áreas fronteiriças, caso haja uma inação do Estado afetado - ou originador - e da comunidade internacional em sanar seus danos, poderá haver sérios riscos e consequências irreparáveis ao território e à população de um Estado contíguo. Diante de tal quadro, a existência de uma lacuna conceitual na área das RI e do DI com relação a uma eventual responsabilidade de proteger ambiental, que preveja mecanismos político-jurídicos adequados para lidar com situações excepcionais de desastres, para além de institutos tradicionais já previstos na ordem jurídica, como a legítima defesa e a necessidade, ainda é uma realidade. Tendemos a considerar, portanto, haver uma obrigação positiva (ação-dever) do Estado de proteger a própria população, de modo a sanar os efeitos nocivos daquela catástrofe.

\footnotetext{
${ }^{17}$ O termo "comunidade internacional" neste trabalho de tese refere-se ao conjunto de Estados no âmbito internacional, sem excluir a participação de indivíduos e dos diversos setores que os compõem. Fazemos essa observação para distingui-la do conceito utilizado por Paul Wapner (1997) e Clark Ann (1998) de "Global Civil Society”. Usaremos os dois termos indistintamente, muito embora de preferência semântica para "comunidade internacional" quando referir-nos aos Estados, e "sociedade civil global" quando em análise centrada mais ao espectro da área ambiental, tendo em vista sua transnacionalidade, corroborando entendimento de autores como Barros-Platiau (2000), que consideram mais apropriada a utilização de "sociedade civil global", pela clareza de que outros atores além dos Estados influenciam sobremaneira as decisões multilaterais contemporâneas.
} 
O trabalho proposto foi realizado sob as lentes das disciplinas Direito Internacional e Relações Internacionais. Na primeira, por meio do levantamento e da reavaliação do quadro normativo-institucional já existente sobre os temas da $\mathrm{SH}$ e da R2P. Na segunda, pela revisitação da dicotomia entre soberania e intervenção e dos diversos aspectos que envolvem o conceito de SA, buscando-se uma análise criteriosa do problema apresentado e oferecendo uma proposta conceitual-analítica que ultrapasse as discussões já realizadas na área ao inserir o conteúdo ambiental. Ressalte-se que, malgrado a longevidade dos debates, o tema das intervenções na área ambiental (“intervenções verdes”) ainda não é ponto pacífico na política internacional e nem na estrutura normativa internacional contemporânea, por isso polêmico e controverso. Ainda que as duas áreas do conhecimento constituam disciplinas diversas, propõe-se neste trabalho uma transversalidade temática, como é o caso dos estudos voltados para a análise da soberania, subjacentes às duas áreas do conhecimento, de conceitos como os mecanismos de recurso à força, pautados na noção de legítima defesa e do estado de necessidade, vistos oportunamente ao final deste trabalho.

O arcabouço teórico de referência, assim, será extraído tanto da literatura do DI quanto das RI, no que se refere ao conjunto teórico geral dos conceitos de Soberania, SH, Intervenção, R2P, e Meio Ambiente. O método a ser empregado será o exploratório, buscando-se revelar aspectos do problema, sua classificação e definição dos conceitos. Em seguida, ensejamos teorizar o problema, com o objetivo de reavaliar generalizações, estruturas sistêmicas e modelos teóricos, e relacionar e enfeixar hipóteses. Em uma terceira fase, aplicaremos o conhecimento gerado em situações efetivas e potenciais para investigar, comprovar ou rejeitar hipóteses sugeridas por aqueles modelos.

No decorrer da tese, propomos também uma atualização e revisão do tema das intervenções, a fim de explorar lacunas e a ineficiência empírica da extensão de conceitos para situações que não as originalmente concebidas, a exemplo da extensão de mecanismos como legítima defesa e necessidade para casos de desastres ambientais. Tais tarefas baseiam-se em bibliografia recente, que exige uma interpretação acurada dos novos fenômenos de um campo em rápida transformação, como a concepção analítica securitária da área ambiental. 
A pesquisa tem natureza qualitativa, pela existência de uma relação dinâmica entre o mundo real (objetivo) e o sujeito (subjetivo), não traduzível em números (método quantitativo-positivista). Os métodos qualitativos enfatizam as especificidades de um fenômeno "em termos de suas origens e razão de ser" (HAGETTE, 1987). Não houve neste trabalho, portanto, a utilização de métodos e técnicas estatísticas. A literatura acadêmica e o ambiente político institucional-normativo foram as principais fontes do levantamento bibliográfico e da coleta dos dados. As análises tomaram escopo indutivamente, sendo o processo e seu significado os focos principais de abordagem. Foi uma pesquisa bibliográfica e documental, graças à elaboração da tese a partir de material já publicado, constituído principalmente de fontes primárias, como livros, artigos de periódicos e outros documentos disponíveis no mundo digital, além de material não tratado ainda analiticamente.

A complexidade inerente ao tema da intervenção e as incipientes pesquisas empíricas até então realizadas sobre o objeto da tese limitam, de certo modo, as discussões sobre a relação entre soberania e intervenção, de um lado, e sobre os conceitos de R2P e Obrigações Positivas, de outro. O estado atual do conhecimento da área, em especial das análises conceituais de R2P, está em grande parte voltado para a área dos Direitos Humanos, e não para o Meio Ambiente, em vazio que dificultou inicialmente expressivo levantamento bibliográfico e documental tratando especificamente de sua transposição para o âmbito da PIMA. Essa lacuna, porém, permitiu uma liberdade construtiva sem amarras teórico-conceituais características das Ciências Sociais.

É de se observar que os temas voltados aos conceitos de soberania e intervenção recebem uma profícua atenção acadêmica, em análises por vezes ofuscadas por discussões enviesadas e de rigor analítico duvidoso, daí a necessidade de critérios bem direcionados pelo pesquisador na escolha do material utilizado, por meio do equilíbrio intelectual e da escorreita análise de suas fontes.

Quanto às condições materiais da pesquisa, percebemos que as análises que buscam estabelecer um marco teórico mais definido ainda resultam de produção intelectual dos tradicionais centros acadêmicos anglo-saxônicos, que geralmente pautam 
a agenda dos estudos ora em andamento nas universidades mais prestigiadas, em think tanks, e em institutos de relações internacionais mundo afora. Elaborar um estudo de tese sob uma perspectiva brasileira, influenciado a priori pelos trabalhos produzidos por aqueles centros, e deles partindo para buscar rumo próprio, representa desafio adicional ao pesquisador, que buscou ousar e valorizar, igualmente, fontes locais de qualidade inigualável e avançada precisão intelectual.

\subsection{Definição dos termos}

Apresentaremos pontualmente o significado de alguns conceitos-chave da pesquisa, para melhor compreensão do leitor, em razão da multiplicidade de significados que algumas ideias adquirem nas mais diversas áreas do conhecimento científico. Tomando-se em esforço inicial o conceito de "Soberania", percebemos que tal palavra remete à ideia tradicional de que o Estado não reconhece qualquer autoridade superior em seu território, tendo o monopólio da violência legítima para poder autorizar e/ou exercer o recurso à força (BOBBIO, 1986, 1997). O Estado possui também o monopólio da edição de leis que impõe à população e que devem ser respeitadas, sob pena de aplicação de sanções contra seus "súditos". A soberania é a expressão do poder coletivo da nação, cujo depositário e garantidor supremo é o Estado. Ela apresenta-se como um limite à ação de outros entes, na medida em que o detentor exerce sobre seu território competências gerais e exclusivas (BENEVIDES, 1999). A competência é geral porque ele organiza o conjunto de poderes sobre seu território. O Estado é responsável por todos que nele se encontram (LEFEBVRE, 2000). O tema da soberania perpassa diretamente este estudo de tese e seu significado tem tido impacto profundo na dinâmica das relações internacionais por vários séculos.

Se a soberania, ou o monopólio da força, é o poder de garantir, em última instância, a eficácia de um dado ordenamento jurídico, sendo por isso a garantia da manutenção de relações pacíficas dentro do Estado, ela é também a causa de conflitos e agressões mútuas nas relações intraestatais. Ser soberano significa que o Estado não se sujeita a leis que lhe sejam impostas por uma autoridade supra-estabelecida, dotada do monopólio daquela força. Significa a existência de uma situação anárquica (BULL, 1977). Quando se analisa os conceitos de "Soberania" e "Intervenção", surgem diversas 
interpretações em consonância aos interesses e percepções dos observadores. A literatura que trata do tema pauta-se por inúmeras abordagens, geralmente divergentes. Para os tradicionalistas, a soberania refere-se àquela noção tradicional geralmente encontrada nos compêndios de DI, baseada na Carta da ONU, no artigo $2^{\circ}$, parágrafo $1^{\circ}$, que versa "a Organização das Nações Unidas é baseada no princípio da igualdade soberana de todos os seus membros" "18, vertente defendida pela corrente realista da Teoria das Relações Internacionais (TRI), para quem a própria noção de Estado caminha pari-passu ao desenvolvimento do conceito de soberania. ${ }^{19}$

As mudanças por que passou o conceito, da lógica estadocentrista até sua fragmentação (transnacionalismo), ${ }^{20}$ com a aparição de novos centros de poder, têm alterado seu sentido tradicional (HINSLEY, 1986; KRASNER, 2001; HAMMER \& NAGAN, 2003; HELD, 2003; LAKE, 2003). Com a intensidade da globalização nas últimas décadas e a evolução conceitual de áreas como Direitos Humanos e Meio Ambiente, torna-se difícil defender a concepção de uma soberania absoluta hobbesiana que impeça a solidariedade internacional (na concepção kantiana) e a resposta individual das nações em defesa de seus nacionais, sobretudo em casos de catástrofes

${ }^{18}$ Cf. BRASIL. Decreto n 19.841, de 22 de outubro de 1945. Presidência da República. Casa Civil. Subchefia para Assuntos Jurídicos: Promulga a Carta das Nações Unidas, da qual faz parte integrante o anexo Estatuto da Corte Internacional de Justiça, assinada em São Francisco, a 26 de junho de 1945, por ocasião da Conferência de Organização Internacional das Nações Unidas.

${ }^{19}$ É notável na TRI a tendência de se valorizar nos estudos da disciplina as prerrogativas do paradigma realista, preconizado pelo Estado como um ator unitário racional no cenário internacional, em busca de maximizar ganhos e minimizar perdas, em razão do ambiente anárquico e sem cooperação, segundo os defensores da corrente. Para eles, a anarquia internacional direciona o sistema para um estado de natureza hobbesiano, em que cada um torna-se responsável por sua sobrevivência. Entre as premissas comuns ao Realismo encontra-se a primazia estatal que, em busca da manutenção da própria existência, preconiza a soberania como elemento basilar da anarquia no SI. Valoriza-se, ainda, a relevância do sistema, no entendimento de que a natureza das relações internacionais define os acontecimentos. Essa concepção realista clássica reducionista, ao apontar a figura do Estado como principal propulsor dos fatos na política internacional, engendrou reflexões as mais diversas que reavaliaram as premissas básicas para agregar novos paradigmas explicativos mais amplos e menos reducionistas, como o pensamento realista estrutural. Mais aspectos da teoria realista serão analisados adiante, ao tratarmos dos fundamentos metodológico-teóricos da pesquisa. Cf. HERZ (1951); BULL(1977); WIGHT (1979); GILPIN (1981); ARON (1986); MORGENTHAU (1993); MERLE (1995); WOODS (1996); CARR (2001); MEARSHEIMER (2001); WALTZ (2001, 2002); NOGUEIRA \& MESSARI (2005).

20 O conceito de "transnacional" impacta a política internacional ambiental e contribui para a fragmentação da OAI (cf. Cap.III). Risse-Kappen (1999:2) considera o transnacional como "regular interactions across national boundaries when at least one actor is a non-state agent or does not operate on behalf of a national government or an intergovernmental organization [...]. "É interessante notar que Kappen modifica o foco do debate quanto à necessidade de se confrontar os paradigmas "state-centered" ao "society-dominated". Para o autor, a questão não seria se as relações internacionais são dominadas por Estados ou por sociedades, por não haver conexão lógica entre o argumento de que Estados permanecerem atores dominantes e de que atores transnacionais seriam irrelevantes. 
humanitárias e desastres ambientais. Anthony Mcgrew (apud BAYLIS, 2004) argumenta que, enquanto a ideia de um "governo mundial" apresenta-se longínqua, uma governança global complexa - com soberanias desafiadas - evolui. ${ }^{21} \mathrm{O}$ autor acredita que essa governança apresenta uma variedade de estruturas formais e informais entre governos, instituições intergovernamentais e agências transnacionais, designadas para a busca de metas comuns.

A ampliação dos temas na agenda internacional e a multiplicidade dos participantes na conformação dessa nova ordem não implicam afirmar, no entender de Mcgrew (idem), que o papel do Estado esteja em declínio. Muito embora venha-se tornando um tópico comum a noção de "erosão de fronteiras", como apontou Bertrand Badie, em La fin de territoires: essai sur le désordre international et sur l'utilité sociale $d u$ respect (1995), o poder soberano e a autoridade governamental transformam-se, em vez de erodir. Neste sentido, tanto na política como no direito internacional, há um entendimento crescente de que o Estado soberano construiu um sistema internacional que lhe garantia inicialmente direitos (não-agressão, reconhecimento de fronteiras, nãoingerência). Porém, com o passar dos séculos, foram impostos aos Estados alguns limites à soberania (dever de não poluir territórios fora de sua jurisdição, prestar contas, dever de participar das organizações internacionais - OI) e também deveres, colocando em questão o princípio basilar do pacta sunt servanda. ${ }^{22}$ É nessa perspectiva de soberanias limitadas e desafiadas que se discutirá nesta pesquisa as Obrigações Positivas.

\footnotetext{
${ }^{21}$ Em uma conceituação que acompanhamos, Rosenau (1992: 6) considera "governança" como um conjunto de mecanismos de regulação existente em uma esfera de dada atividade e que funciona mesmo não emanada de uma autoridade oficial. O conceito remeteria, no entender do autor, à diversidade de atores emergentes na cena internacional ("sovereignty-free actors"), cuja real autoridade tem potenciais chances de encontrar sua tradução no plano internacional. Sua relevância vai no sentido de que, na medida em que algumas instituições reforçam a contestação da autoridade e da soberania estatal, contribuem para o surgimento de novos critérios de legitimidade política. A contestação do "nacional" feita por esses novos atores representa uma esfera poderosa que se relaciona com os Estados, constituindo assim a chamada "esfera transnacional", que consistiria na inexistência do espaço territorial, determinante para o reconhecimento das nacionalidades.

${ }^{22} \mathrm{Em}$ outros termos, mesmo que um Estado soberano não ratifique acordos multilaterais, outros meios podem ser usados pela comunidade internacional no esforço de mudar seu comportamento. Neste sentido, mais adiante será evocado o conceito de "soft intervention". Isto serve para a não-proliferação nuclear, crimes ambientais e até para a proteção de populações específicas, como minorias, mulheres, crianças. Ou seja, o século XXI é o século da responsabilidade do Estado.
} 
Tratar do tema da soberania nesse contexto "uni-multipolar", descortinado com o término da bipolaridade pré-1990 e com a emergência de novos atores, leva o pesquisador a delimitar a perspectiva analítica daquilo que se entende como "ordem global" e suas complexas concepções, como "sociedade internacional" e "governança mundial". Ambas variáveis analíticas vêm merecendo especial atenção da tradição teórica da Escola Inglesa das RI, corrente à qual nos solidarizamos no caminho de melhor entender as transformações por que passou o SI nas últimas décadas. Os conceitos utilizados no decorrer da tese terão influência direta do quadro teóricohistórico da literatura anglo-saxônica e francesa da disciplina das RI, no que tange à formação da ordem global, em sentido amplo, e em paradigmas explicativos mais específicos da formação do tema ambiental, como a OAI e seus atributos inerentes, além da literatura sobre intervenções.

A Escola Inglesa caracteriza-se por uma concepção "racionalista" da sociedade internacional, no entender de Martin Wight (1991), um dos seus mais proeminentes representantes. O racionalismo atribuído por Wight ao pensamento inglês baseia-se na tradição de Grotius e Vattel, uma espécie de limiar entre as correntes "realistas" (hobbesiana) e "revolucionistas" (kantiana). Segundo o autor, a tendência racionalista busca ultrapassar ambas as visões realistas e revolucionistas, embora reconheça sua importância histórica (LINKLATER, 2010: 2). Na concepção de "sociedade internacional" da Escola Inglesa, os Estados não estariam fadados a uma eterna competição no ambiente anárquico, como preconizam os realistas. Em suas relações interestatais, formam uma sociedade capaz de controlar o uso indevido da força e mitigar, por meio da cooperação e do compartilhamento de normas e valores comuns, a anarquia existente (e inerente) do sistema internacional (BULL, 1977). Linklater (2010: idem) sintetiza da seguinte forma o paradigma racionalista:

“(...) States are not condemned to compete for power and security; indeed, they form a society that preserves a remarkably high level of order in the context of anarchy (understood not as chaos but as the absence of government). Political communities have mitigated the effects of that struggle by agreeing on principles that provide some measure of security for the parties involved. But achievements in that domain are always precarious and they are unlikely to survive indefinitely. For that reason, rationalism rejects the optimism of 
revolutionist approaches and the pessimism of realist standpoints. It occupies the middle ground between them."

O paradigma racionalista, como equilíbrio de duas visões de mundo (realista vs. idealista), serve de fundamento teórico para as análises desenvolvidas sobre a ordem global por Andrew Hurrell, que, na obra "On Global Order: Power, Values, and the Constitution of International Society” (2007), revisita a sociedade anárquica e apresenta uma proposta teórica interessante para se pensar o papel do Estado em um sistema caracterizado pela complexa governança e pluralidade de atores e desafios. Em sua busca por entender os problemas que se apresentam na modernidade, decorrentes do processo atual de globalização (Cap. II), avalia que há questões políticas difíceis sobre como o mundo encontra-se politicamente organizado e de como deveria estar, e questiona quais formas de organização política seriam as mais viáveis para fazer face àqueles desafios enfrentados pela humanidade. Para realizar esse exercício de reflexão, pondera Hurrell (idem), devemos primeiramente entender a natureza "sem precedentes" dos desafios políticos que estão postos. Para isso, propõe que consideremos as perspectivas estatais em direção a uma sociedade solidarista.

A política contemporânea da "governança global" pode ser apreendida, no entender de Hurrell (1999), pela convergência de dois desenvolvimentos peculiares no sistema internacional. Um deles passa pela ideia de avanço de uma sociedade pluralista e limitada de estados soberanos ("pluralistic and limited society of sovereignty states"), de característica minimalista e hobbesiana (realista) prevalecente no século XX, para a concepção mais alargada de natureza maximalista (ou solidarista), envolvendo atributos mais extensos de cooperação para "salvaguardar a paz e a segurança internacional, promover o desenvolvimento econômico, solucionar problemas comuns e garantir valores comuns" (idem: 59). Essa concepção solidarista, de característica consensual e maximalista, que pautou parte das iniciativas dos Estados na ordem internacional do pós-Guerra Fria, vem sendo crescentemente exigida, no intuito de redefinir suas bases epistemológicas para o advento de um solidarismo coercitivo, concorrente com a maior ambição normativa da sociedade internacional por formas mais assertivas de aplicação e cumprimento das normas internacionais. 
Para além de um avanço conceitual e de práticas em torno da "governança global" centrífuga, os dois paradigmas parecem, em síntese, conviver. De um lado, a concepção pluralista-minimalista, que preza por uma ordem fundamentada no respeito aos princípios da não-intervenção, de defesa da soberania e na criação de regras e instituições "minimalistas" de modo a evitar o esperado conflito inerente da anarquia internacional, em um sistema pluralista e fragmentado em seus diversos atores. De outro, a concepção consensualista-maximalista, que aceita os preceitos da ordem internacional oriunda do processo globalizatório e que tem no respeito às instituições e no reconhecimento da natureza dos desafios mais difusos, como meio ambiente, e da proliferação do transnacionalismo, sua fonte de inspiração, existência e prática. Ao distanciar-se do paradigma realista tradicional, característico da concepção pluralistaminimalista, o consensualismo-maximalista (coercitivo ou não) valoriza os indivíduos como sujeito ativo na ordem global contemporânea, daí sua maior adequação aos ditames do mundo moderno.

Ao analisarmos os conceitos oferecidos por Hurrell e reconhecermos a relevância dos dois paradigmas para a concepção da ordem contemporânea, com todas as suas idiossincrasias e diferenças, notamos que as discussões são similares a outras esferas dos estudos sobre o SI e partem dos desafios que a ordem pós-Guerra Fria nos apresentou, entre eles essa constante dicotomia entre o realismo político (hobbesiano) e o liberalismo-institucional (kantiano), fonte de tensão nas formas de agir das unidades políticas estatais. Parece-nos que a OAI gira em torno dessas duas forças, ao se exigir dos Estados maiores considerações de ordens práticas ou realistas, em determinadas áreas como em casos de desastres ambientais, enquanto se permite orientar-se pela concepção maximalista em outras abordagens mais transversais. Essa "tensão" foi percebida por Hurrell (idem), que aponta, em lacuna explorada por este trabalho, a inadequação dos preceitos normativos (déficit regulatório) e da instrumentalização dos mecanismos para efetivo cumprimento das normas internacionais:

"Pode-se dizer, entretanto, sem recorrer a um estadocentrismo nem negligenciar as fragilidades manifestas dos estados e os horrores impostos por muitos destes aos seus cidadãos, que as estruturas alternativas mais óbvias para a ordem permanecem, ou relativamente frágeis (como no caso da sociedade civil transnacional), ou normativamente falhas (como é o caso dos mercados nada ou só 
frouxamente regulamentados, que parecem incapazes de lidar com os problemas da desigualdade e da estabilidade econômica globais). É isso que cria a tensão central. De uma parte, houve um enorme aumento daquilo que entendemos que seja legítimo, e talvez mesmo necessário, esperar da política internacional. De outra, a capacidade desse sistema de sustentar as crescentes demandas materiais, políticas e morais que lhe são impostas não está, de forma alguma, bem delineada. Uma das mais importantes áreas em que essa tensão se manifesta diz respeito ao cumprimento obrigatório de normas internacionais." (in: LUA NOVA, 1999: 58)

Nesse contexto de nova ordem global e reavaliação dos fundamentos tradicionais que basearam durante séculos a atuação dos Estados e legitimaram suas ações, é que se torna útil revisitar conceitos relacionados à intervenção e seus atributos inerentes.

Desde as origens, relacionado diretamente ao campo do direito humanitário, o conceito de intervenção penetrou nas esferas da Diplomacia e do Político, atingindo plenamente os debates internacionais sobre o tema de auxílio e intervenção humanitários. Com o forte apoio dos meios de comunicação e das ações de seus apoiadores, como Estados e entidades governamentais, o "direito/dever de ingerência" 23 adquiriu acentuada relevância como pauta de discussões - positiva e negativa - nas mais variadas instâncias das relações internacionais. A "intervenção humanitária” (na época sinônimo de "direito/dever de ingerência") aduzia à concepção hoje inovadora que não era - e alguns acreditam ainda não ser - coerente com os princípios em uso (costumeiros) no direito internacional.

Especificamente quanto ao seu conceito, basilar nas análises teleológicas à pesquisa, partiremos de uma definição mais ampla, contida no relatório da Comissão Internacional sobre Intervenção e Soberania Estatal, o ICISS $(2001)^{24}$, para uma noção

\footnotetext{
${ }^{23}$ Os termos direito e dever de ingerência possuem uma diferença sutil, de causa mais epistemológica do que conceitual. A expressão "dever de ingerência" (destaque nosso) apareceu inicialmente nos escritos do filósofo Jean-François Revel, no final da década de 1970, no sentido de reconhecimento de intervenções estrangeiras em congêneres, sob a supervisão de uma autoridade supranacional. Na esteira do conflito cambojano, foi retomado por Bernard Henri-Lévy. A transposição de um "dever" para um "direito" foi operada nos estudos do jurista Mario Bettati e do médico-político Bernard Kouchner, que buscaram imprimir um conteúdo mais político ao termo, distante do sentido jurídico inicial empregado à expressão. (ZORGBIBE, 1994). Desse modo, Bettati e Kouchner passaram a conceber um "direito de ingerência humanitário" como a tradução jurídica de um dever moral. Esse "droit de regard" tende a pôr em discussão, em última análise, o princípio da não intervenção e a soberania estatal (BETTATI, 1996).

${ }^{24}$ A Comissão Internacional sobre Intervenção e Soberania Estatal (ICISS) será vista em detalhes em capítulo específico, quando tratarmos do temas da intervenção. A título de informação preliminar, o
} 
mais limitada, proposta por Holzgrefe \& Keohane (2003), ao tratarem das intervenções humanitárias. Buscaremos um equilíbrio nos dois espectros e um avanço conceitual mais apropriado e específico, consubstanciados na proposta das "intervenções verdes", definidas a seguir. Seu foco ultrapassa o sujeito, para também motivar-se nas origens e causas do evento interventivo: a variável ambiental.

O ICISS propôs o escopo das intervenções como (idem: 8):

"1.38 The kind of intervention with which we are concerned in this report is action taken against a state or its leaders, without its or their consent, for purposes which are claimed to be humanitarian or protective. By far the most controversial form of such intervention is military, and a great part of our report necessarily focuses on that. But we are also very much concerned with alternatives to military action, including all forms of preventive measures, and coercive intervention measures - sanctions and criminal prosecutions - falling short of military intervention."'(destaque nosso)

A conceituação proposta pelo ICISS considerou o ser humano, sem as amarras ideológicas soberanistas ou jurídico-normativas da nacionalidade. Holzgrefe \& Keohane, por sua vez, em Humanitarian Intervention: Ethical, Legal, and Political Dilemmas (2003:18), partiram de premissa humanista similar, mas limitaram o conceito a nacionais outros exceto do Estado-interventor. Retiraram, ainda, o elemento de permissibilidade do Estado a sofrer a intervenção:

“(...) the threat or use of force across state borders by a state (or group of states) aimed at preventing or ending widespread and grave violations of the fundamental human rights of individuals other than its own citizens, without the permission of the state within whose territory force is applied." (destaque nosso)

A síntese dos dois conceitos nos leva a propor uma definição alternativa do conceito de "intervenção", para critério específico da pesquisa. Uma proposta que

ICISS foi uma Comissão plurinacional, sob o incentivo do Governo do Canadá, com o objetivo de realizar estudos para buscar meios de conciliar o debate entre o invervencionismo unilateral e as novas exigências da instrumentalização da proteção aos direitos humanos. O ICISS foi presidido pelo exChanceler australiano Gareth Evans e as conclusões de seu trabalho, consubstanciadas no Relatório "Responsibility to Protect", tornaram-se uma referência para os debates posteriores no âmbito das Nações Unidas e outros foros multilaterais. Foram louváveis os esforços do ICISS na tentativa de "mitigar" a clivagem política Norte-Sul em torno da questão da intervenção, principalmente pela formação heterogênea da ICISS. O documento almejou congregar as aspirações de representantes de todo o globo, não apenas por sua composição, mas também pela discussão in loco das diretrizes dos trabalhos realizados. 
endosse não apenas os sujeitos interventivos e sua temporalidade e instrumentalidade ("threat or use of force"), mas também seu elemento causal: os desastres ambientais. Sendo assim, por "intervenções verdes" entendemos a coerção individual contra o território de um Estado, com o qual se divide fronteiras (imaginárias), no intuito de conter graves danos e real ameaça transfronteiriços advindos de desastres ambientais (naturais e tecnológicos), para salvaguardar a vida da própria população - nacionais ou estrangeiros - e a integridade territorial.

Feitas tais considerações e partindo para o conceito de R2P, corolário da doutrina intervencionista, notamos que sua noção encontra guarida no princípio básico de que a soberania estatal implica uma "responsabilidade" (sobre a população em determinado território, sejam nacionais ou não). A primazia dessa responsabilidade na proteção humana reside no próprio Estado. Onde a população venha a sofrer sérios riscos como resultado de conflagrações internas, insurgências e repressões, os Estados têm, coletivamente, obrigação direta e de forma excepcional de valer-se da intervenção para buscar conter as ameaças e danos advindos da ação, inação ou negligência de outro Estado com relação ao povo. Neste estudo, partimos, na análise histórica, do conceito tradicional de R2P, elaborado a partir do Relatório do ICISS (2001) ${ }^{25}$, que envolve as catástrofes ambientais entre suas aplicabilidades. ${ }^{26}$ Para uma análise mais políticonormativa, seguimos o disposto na Resolução 60/1(2005) - World Summit Outcome Document $^{27}$, aprovada em Assembleia pelos Estados-membros da ONU, que delimita a atuação do conceito a alguns crimes específicos (§ 138-139), conforme veremos adiante (Cap. V).

Já a noção de obrigações positivas, da mesma forma que a de R2P, resguarda-se na concepção de "soberania como responsabilidade". Ultrapassando o dever da comunidade de nações de agir coletivamente sob os auspícios da ONU, a zona cinzenta

${ }^{25}$ Cf. supra nota ${ }^{0} 24$ e o Relatório da Comissão, em ICISS: The Responsibility to Protect. Publicado pelo International Development Research Centre. Gareth Evans, co-Chair; Mohamed Sahnoun, co-Chair. Dezembro, 2001

${ }^{26}$ Segundo se depreende do Relatório/ICISS, no ponto "4.20": "It is important to make clear both what these two conditions include and what they exclude. In the Commission's view, these conditions would typically include the following types of conscience-shocking situation: overwhelming natural or environmental catastrophes, where the state concerned is either unwilling or unable to cope, or call for assistance, and significant loss of life is occurring or threatened." (destaque nosso)

${ }^{27}$ Cf. UNITED NATIONS. UN General Assembly. 2005 - World Summit Outcome Document (UN A/RES/60/L.1) 
da discussão sobre os aspectos intervencionistas expõe aos internacionalistas lacunas e um campo propício de estudo, na busca de teorizar sobre casos potenciais. Com a evolução do tema da R2P, é provável que analistas busquem ampliar ou estender conceitos já existentes diante dos inúmeros desafios que se apresentam à ordem global.

As obrigações recebem tratamento peculiar no Direito Internacional. Conceituam-se a partir de sua adjetivação (positivas ou negativas), caracterizada por uma "ação" ou "inação" diante de uma realidade concreta. Enquanto as obrigações negativas referem-se à abstenção do Estado em dada atividade, ou seja, uma obrigação de "não-fazer" algo, de que é exemplo não causar danos a territórios fora de sua jurisdição, as obrigações positivas definem-se por seu oposto, ou seja, agir. Há uma responsabilidade do Estado, uma atribuição da qual não se deve esquivar. Importar esse sistema político e jurídico-conceitual para as RI não é tarefa simples. Além de polêmico, o tema vem sendo crescentemente contestado por analistas de tendência mais conservadora e realista, embora aceito em círculos acadêmicos do espectro mais construtivista.

Diferentemente da R2P, avaliamos que as obrigações positivas não envolvem uma ação coletiva contra outros Estados por eventos ou ações danosas às populações e territórios de outros países. A obrigação "de fazer" do Estado apresenta-se diante de uma real ameaça às populações de áreas afetadas por desastres dentro de seu território. Tal limitação analítica é necessária para que a pesquisa não se distancie de seu escopo: analisar casos potenciais de intervenção sob a ótica da possibilidade de legitimação de ações que envolvam uma "justa causa" intervencionista, pela impossibilidade de se exigir ação diversa do ente interventor diante de ameaça efetiva à sua população e território. $^{28}$

As obrigações positivas merecem também algumas considerações acerca de sua origem epistemológica. Trataremos desse assunto de forma mais detalhada no Cap. VI, razão pela qual faremos aqui tão somente uma breve diferenciação conceitual. Para

\footnotetext{
${ }^{28}$ Valioso instrumento de análise das excludentes de ilicitude encontra-se no texto adotado pela Comissão de Direito Internacional (CDI) em sua quinquagésima terceira sessão, de 2001, submetida à Assembleia Geral como parte do relatório da Comissão, denominado, em inglês, "draft article on Responsibility of States for Internationally Wrongful Acts, with commentaries (2001).
} 
além do tema específico das obrigações de fazer existente nos mais diversos compêndios de códigos civis em vários sistemas jurídicos nacionais pelo mundo, ${ }^{29} \mathrm{o}$ conceito sempre teve relevância na estrutura jurídica da área dos Direitos Humanos, em especial na jurisprudência exaurida da Corte Europeia dos Direitos Humanos (CEDH), no âmbito do Conselho Europeu (MOWBRAY, 2004; XENOS, 2012; RHARADE, 2014). ${ }^{30}$

A OAI, por sua vez, é entendida como a arena político-institucional tradicional de participação dos Estados, de que fazem parte também atores não-estatais, cada vez mais numerosos e influentes nos temas voltados para o meio ambiente. Essa atuação estatal, embora influenciada por uma série de iniciativas de outros atores inter- e transnacionais, ainda reflete, em certos âmbitos da vida societária internacional, uma política voltada à defesa dos interesses e da proteção da soberania. O conceito de OAI a ser utilizado no decorrer da tese, por excelência, será aquele introduzido por Wagner Ribeiro (2001) como um processo ainda em construção, expressa pela miríade de tratados e acordos no intuito de gerir o tema ambiental, que guarda características do sistema internacional de que é tributário como um subsistema heterogêneo e multipolar (ARON, 1986: 162-63, apud RIBEIRO, idem).

${ }^{29}$ O conceito de "Obrigações Positivas" na legislação doméstica estatal não é novo e faz paralelo com a noção, utilizada nesta pesquisa, oriunda dos Direitos Humanos, pela similaridade de fundamento epistemológico. A teoria das Obrigações é das mais balizadas variáveis principiológicas do ramo do Direito Civil, de compêndios jurídicos os mais variados em diversas legislações pátrias de tendência francesa-germânica, de longa data empregada também e nossa doutrina nacional. Cf. AZEVEDO (2011); CARVALHO (2009); GAGLIANO (2014); MONTEIRO (2014). Apenas à título de informação, as "obrigações positivas" se contrapõem, no Direito das Obrigações, ao conceito de "obrigações negativas" (em consonância com os Direitos Humanos). Correspondem a obrigações de fazer ou entregar determinada "coisa", em contraposição à obrigação de não-fazer, também gerador de fatos jurídicos, decorrentes da inação. Nos Direitos Humanos, no entanto, o debate é mais simples. Antes, baseava-se no respeito do Estado pelos direitos adquiridos. Os governos não podiam ou não deveriam violar direitos dos cidadãos: a não-interferência seria uma obrigação negativa. $O$ entendimento com base na segunda geração dos direitos humanos alterou os termos do debate. A partir de então, o Estado não deveria se contentar em simplesmente não interferir. Como obrigação primária, deveria fomentar e ampliar os direitos da população, principalmente na área social e no respeito aos direitos humanos (FREDMAN, 2006).

30 Akandji-Kombe (2006:10) distingue duas vertentes das obrigações (positivas e negativas): “(...) as primeiras exigem uma intervenção positiva do Estado, enquanto a segunda uma abstenção de cometer ingerências. A violação da Convenção resultará no primeiro caso de que as autoridades nacionais não tenham agido, permanecem passivos e, no segundo, do fato que eles impediram ou limitaram o exercício de um direito por meio de um ato positivo. Na prática, esta diferença é às vezes evidente (...)” (tradução livre do autor) No original: "Ce qui distingue les obligations positives des obligations négatives, c'est que les premières exigent une intervention positive de l'Etat tandis que les secondes requièrent de lui qu'il s'abstienne de commettre des ingérences. La violation de la Convention résultera dans le premier cas de ce que les autorités nationales n'ont pas agit, sont restées passives et, dans le deuxième, du fait qu'elles ont empêché ou limité l'exercice du droit par le moyen d'un acte positif. Dans la pratique, cette différence est parfois evidente (...). 
Ribeiro aplica uma transversalidade temática interessante, ao aliar de modo equilibrado a concepção realista-política tradicional de Hans Morgenthau (1993) ${ }^{31}$ ao conceito de subsistema proposto por Raymond Aron (1986) $)^{32}$ e à teoria da interdependência $^{33}$, no tocante à transnacionalidade e proliferação dos atores não-

${ }^{31}$ Na obra Politics among Nations, publicada em 1948, ainda nas cinzas deixadas pelo término da Segunda Grande Guerra, o cientista político Hans Morgenthau, precursor do pensamento realista político nas RI e dos estudos sobre as causas da desordem e dos conflitos, apresenta os princípios norteadores do que se convencionaria pautar o debate sobre o "Realismo". O autor contrapõe à doutrina realista o idealismo clássico do liberalismo norte-americano. Da tendência realista é derivada uma "contravisão" do mundo, cujo ponto de partida pode-se encontrar no pensamento filosófico de Thomas Hobbes e Maquiavel. Para Morgenthau, a percepção de que os Estados e seus líderes são as unidades básicas para se entender o funcionamento da política internacional é uma premissa básica. Os Estados, portanto, são os atores fundamentais da arena internacional, relegando-se a segundo plano outros entes no que se refere à capacidade de influência na ordem global. São duas as conclusões que direcionam a dimensão prescritiva de sua teoria: a racionalidade da política exterior ditada pelo interesse nacional e a necessidade de equilíbrio de poder como mecanismo de estabilidade para o sistema de Estados (KEOHANE, 1986; MORGENTHAU, 1993; KNUTSEN, 1997; BOUCHER, 1998; DEUTSCH; 2002; WALTZ, 2002; NOGUEIRA \& MESSARI, 2005; CARLSNAES, 2007; BAYLIS, 2011) .

${ }^{32}$ Raymond Aron foi um dos principais expoentes franceses das RI, representante da tradição realista que predominou entre as décadas de 1930 a 1960, influenciada inicialmente pelos estudos de política internacional norte-americanos, mas com forte viés sociológico. Nessa linha de pensamento francesa, preconizada por Aron, a política internacional baseia-se em relações sociais de interação e de interdependência. As primeiras referem-se ao comportamento estatal na vida internacional e seus efeitos no conjunto das interações sociais, ou seja, adotar uma ação de defesa gera uma contramedida em processo. A observação dessa característica do SI levou Aron (1986:103) a classificar as relações internacionais como um conjunto competitivo "constituído por unidades políticas que se relacionam entre si e que são suscetíveis de entrar em guerra total" (tradução nossa). As relações de interdependência, ao contrário, produzem efeitos de agregação. Nesse contexto ideal, os atores operariam escolhas individuais marginais, que acumuladas modificam o conjunto de relações. O crescimento dos fluxos transnacionais ou transfronteiriços provoca efeitos não explicitamente desejados pelos atores, porém resultado intrínseco desse contexto de interdependência (DEVIN, 2002: 5-6). Na concepção da sociologia francesa das RI, de que Aron fez parte, o conjunto dessas relações aplicadas ao espaço mundial conduz a se apreender "internacional" como um sistema. Como realista, Aron propusera ler a história das relações internacionais por meio de duas configurações ideais, uma que denominou "multipolar", composta de unidades políticas comparáveis em tamanho, poder econômico e militar, outra uma repartição de forças apresentada sob a forma de duas coalizões antagônicas, em razão da Guerra Fria existente naquele período. Aron considerava que as relações interestatais seriam "condenadas" ad eternum ao estado de natureza hobbesiano. Essa perspectiva levou-o a escrever em Paix et Guerre entre les Nations (1962) que "[...] dans l'étude des relations internationales, il me paraissait et il me paraît encore aujourd'hui inévitable de mettre au premier rang le système interétatique. Cette primauté du système interétatique excluait a priori la prédominance causale du système économique. [no original : “(...) no estudo das relações internacionais, parece-me ainda hoje inevitável de por em primeiro lugar o sistema interestatal. Essa primazia de tal sistema excluiria a priori a predominância causal do sistema econômico"].

${ }^{33}$ Novas teorias a partir dos anos 1970 buscam contrapor ou complementar diretrizes do pensamento realista das RI, sobretudo pela observância do funcionamento e da lógica de instituições, que passam a angariar influência renovada no cenário internacional. Entram em cena, a partir daquele período, analistas que buscam compreender o fenômeno econômico na ordem global e a natureza de outros atores que emergiam no SI. Por meio do conceito de "Interdependência", destacaram-se trabalhos os mais variados de autores como Robert Keohane e Joseph Nye, com "Transnational Relations and World Politics" (1971) e "Power and Interdependence: World Politics in Transition (1977)"; Stephen Krasner, com "International Regimes (1982)", marcos do pensamento liberal-institucionalista. Para a escola liberal, uma das características do sistema global reside na emergência de atores para além do unitarismo analítico estatal. Keohane e Nye (idem), por exemplo, preconizam que o estudo das RI não deveria considerar exclusivamente as ações estatais. A agenda do relacionamento interestatal, não hierarquizada, 
estatais, característicos da Global Civil Society ${ }^{34}$. O argumento central de sua análise passa pela percepção de que a teoria da interdependência, embora tomada como das mais relevantes abordagens explicativas a pautar a ação das unidades políticas na OAI, não é capaz de explicar integralmente as relações sociais estatais em suas diversas instâncias, como em foros multilaterais. Para o autor, o paradigma realista-político, que preconiza a defesa dos interesses nacionais e a salvaguarda da soberania, ainda subjaz na atuação dos Estados, apesar da natureza dos problemas ambientais, que geralmente repercutem em uma escala mais ampla e transnacional (idem: 48-49).

Em nosso entender, a OAI concebida por Wagner Ribeiro complementa, como instrumento analítico eficaz, a "Ordem Global" preconizada por Andrew Hurrell (supra), no ponto em que a inadequação de uma sociedade consensualista-maximalista a desafios contemporâneos, como os ambientais, ainda carece de uma reassunção parcial de valores realistas tradicionais que consigam alcançar temas mais prementes na ordem ambiental, como os desastres transfronteiriços. Ao se valorizar o compartilhamento de normas e valores sem o devido reconhecimento da qualidade inerente, ainda minimalista, prevalecente na arena internacional, em temas que dizem respeito à segurança estatal, tende-se a desconsiderar a atualidade das perspectivas realistas em prol de um consensualismo-idealista não efetivo na prática das relações internacionais, sobretudo em aspectos que envolvam situações de risco em que os Estados tendem a valer-se de suas prerrogativas securitárias mais prementes. A complementação dessas duas ordens, uma mais ampla ("Ordem Global”) e uma mais específica (“OAI”), deverá pautar este trabalho de tese, como lentes analíticas com as quais buscaremos visualizar de forma mais nítida a natureza do cenário internacional, em especial da ordem ambiental contemporânea.

exporia a porosidade da fronteira doméstica e transnacional. Os liberais-institucionalistas mantinham expectativa de que forças militares deixassem gradualmente de ser utilizadas em um ambiente cooperativo de "interdependência complexa". Embora fizessem uma crítica à perspectiva realista e percebessem as diferenças fundamentais nas relações interestatais (com o contato crescente proporcionado pelo avanço material dos meios de comunicação e dos transportes), os "interdependentistas" continuaram a conceber a interdependência como fonte de possíveis conflitos, que seriam inerentes ao SI. Tema relevante que se colocaria para autores liberais seria descobrir os meios de se alcançar uma administração viável dos conflitos, de modo a que a comunidade internacional usufruísse de um ambiente pautado na resolução pacífica das controvérsias e na maior integração do comércio e de temas de interesses de seus atores. Surge assim o debate teórico que permearia as relações internacionais durante a década de 1980: os regimes internacionais (KEOHANE \& NYE, 1977: 24-25).

${ }^{34}$ Sobre o conceito de "global civil society", Cf. nota 17 supra. 
Ribeiro (idem, 2001b), que se utiliza de uma abordagem mais política que geoeconômica, para entender o SI, afirma que o objetivo da OAI seria "regular as ações humanas em escala internacional para evitar que as condições de habitabilidade humana no planeta sejam perdidas elou regular as relações hegemônicas do capitalismo internacional entre as partes envolvidas em cada questão que é trazida à discussão. Os temas da escassez de recursos naturais necessários à reprodução da vida (Desenvolvimento Sustentável) e a ameaça à segurança ambiental internacional integram a pauta dos trabalhos (SA Global)".

Aos dois conceitos de "Desenvolvimento Sustentável” e "Segurança Ambiental Global" 35 , propomos uma extensão analítica que nos permita avaliar a adequação da Segurança Ambiental sob as lentes ampliadas da Segurança Humana, para além da relação homem-natureza de reprodução/regulação dos recursos naturais. Uma extensão que nos conduza à inclusão de novas variáveis de análise, como os desastres ambientais e sua correlação com a PIMA, para que fatores que influenciem na relação interestatal, em tais situações específicas, possam servir de suporte para maior compreensão de problemas transfronteiriços correntes no âmbito da ordem ambiental.

\subsection{Perspectivas teóricas e temporais}

As investigações científicas partem de pressupostos sobre como o mundo "é" e "como" podemos conhecê-lo. O primeiro remete à natureza da realidade ontológica; a segunda valoriza o método, a epistemologia (EASTON, 2002). Com a TRI não é diferente e por meio de tais pressupostos a disciplina desenvolveu-se. Das teorias que se formaram no decorrer do século $\mathrm{XX}$ e que buscaram apreender o significado epistemológico da realidade que se apresenta ao pesquisador, afinamo-nos com o "construtivismo", por sua abertura programática e ausência de limitações teóricas mais assertivas.

A atualização do debate e o reconhecimento da existência de novos temas nas RI, dando vazão à compreensão da realidade por meio dos atos de fala - que

\footnotetext{
${ }^{35}$ Centrais para o estabelecimento da OAI, no entender do autor (2001: 109), por nos fazer "refletir sobre a necessidade de manter as condições da reprodução da vida humana na Terra" e procurar "regular o uso dos recursos naturais por meio do emprego de técnicas de manejo ambiental, de combate ao desperdício e à poluição”.
} 
proporcionaram uma virada linguística ao reconhecer a co-constituição sujeito-estrutura -, eliminou os entraves à securitização do tema do meio ambiente. Essas limitações eram antes preconizadas por teorias realistas mais tradicionais, que valorizavam abordagens explicativas baseadas em uma segurança estratégica estatal centralizada ou uma cooperação entre atores únicos nas relações internacionais. Apontaremos brevemente a abordagem explicativa do sistema internacional (SI) a ser desenvolvida e o corte temporal, para em seguida avançarmos em uma digressão histórica, com o fim de delimitarmos o campo explicativo construtivista e fundamentarmos a escolha do método.

Privilegiou-se na pesquisa uma abordagem explicativa transdisciplinar do SI, com as lentes teóricas das Relações Internacionais (política) e do Direito Internacional (jurídica), que envolve evoluções doutrinárias relativas ao tema, compondo uma agenda de pesquisa ampla em TRI. Partiremos da premissa realista do Estado como ator central $^{36}$, mas com um viés construtivista para melhor explicar as evoluções recentes na política internacional, em especial na área de segurança. ${ }^{37}$ Nossos principais conceitos, portanto, circulam no campo semântico das RI e do DI, tais como Ordem Global, OAI, Intervenções (verdes), Segurança Humana e Ambiental, RtoP, Legítima Defesa,

\footnotetext{
${ }^{36}$ Muito embora reconheçamos, pautado no paradigma maximalista-consensualista da Ordem Global de Hurrell (2007), a existência da multiplicidade de atores no cenário internacional. Entendemos, no entanto, que esses entes intra- e transnacionais não influenciam diretamente, como variável independente, a análise desta pesquisa.

${ }^{37}$ Autores como Samuel Barkin (2003), Patrick Jackson, Daniel Nexon, Jennifer Sterling-Folker, Janice Bially et al. (2004) fazem parte de uma corrente mais progressiva que busca contruir uma ponte para aproximar ("bridge the gap") o realismo do construtivismo, distante da imcompatibilidade e do antagonismo apregoado desde sua origem na TRI, de ambas as direções. É Barkin que nos recorda que os construtivistas apontam para a controvérsia epitemológica dos realistas, por sua associação com o racionalismo e o materialismo, enquanto inversamente os construtivistas são considerados pelos realistas como utópicos, por buscarem-se distanciar do poder como unidade de análise básica no SI, para além de aspectos discursivos de linguagem e que remeteriam, em última analise, a explicações voltadas para questões linguísticas e sociais. Os construtivistas criticam também o método positivista-empiricista dos realistas políticos como incompatível com o construtivismo. Os autores discutem uma abordagem "intricada" entre o realismo e o liberalismo, de modo a indicar os pontos de convergências entre as tês correntes e favorecer um diálogo que permita se falar em um construtivismo-realista. Uma discussão mais profunda dessa tendência não nos cabe aqui, por distanciar-se dos propósitos da pesquisa. Vale notar, no entanto, que avaliamos positivamente a epistemologia construtivista e em compasso com tendências realistas, no que tange a aspectos de poder e anarquia. A Escola Inglesa, conforme visto, não é realista ao extremo de considerar a anarquia um ambiente voltado somente à luta pelo poder, como asseveram os realistas-racionalistas, tampouco o poder é absoluto, dando ênfase para uma maior abertura das relações internaionais para a cooperação e expansão da arena de contatos no meio internacional, por meio de outras instituições e entes que não somente os Estados. O construtivismo-realista busca esse equilíbrio, razão pelo qual creditamos ao mesmo fundamento de uma proposta de pensamento viável e necessária ao TRI.
} 
Necessidade e Obrigações Positivas, que serão tomados de forma holística no decorrer da pesquisa, mas cada um com peculiaridade própria.

Com relação ao corte temporal, partiremos do recorte cronológico apresentado por le Prestre (idem: 131-166), que distingue três fases na evolução da política ambiental contemporânea, mas propomos um quarto período. Em sua periodização, o autor aponta para um período que se inicia no final do século XIX até 1968, ano da “Conferência da Biosfera", organizada pela UNESCO (Paris/1968). Nessa época, as iniciativas ambientais chegaram a ser variadas, porém limitadas. Um segundo período, que inicia no ano de 1968 até 1986, consiste na internacionalização do tema ambiental, em parte devido à eclosão das questões sobre meio ambiente, que ultrapassavam as decisões internas estatais. Foi um período de ativismo intenso, com a elevação de novos atores na discussão dos temas ambientais, como as OIs e as ONGs. Um terceiro período, que le Prestre indica a partir de 1987, e que persistiria ainda nos dias atuais, assiste ao ressurgimento e presença de novas questões, caracterizadas pela "multiplicação, aceleração e complexificação progressiva de interações internacionais e de questões tratadas após 1987”.

Adotaremos para fins desse estudo uma adaptação da periodização de le Prestre pós-1987, mas com a proposta de subdivisão em um quarto período, no intuito de atualizar seu recorte histórico. Acreditamos que a ordem ambiental pós-1987 esgotou-se em 2009, com os impasses pós-Conferência do Clima das Nações Unidas (UNCCC), em Copenhague, caracterizada pela percepção da complexidade dos atores, que travam soluções para graves problemas que nos afetam; da proliferação inadequada dos regimes para lidar com o meio ambiente (complexo de regimes) ${ }^{38}$; e da consequente fragmentação da área, com impactos negativos no otimismo e na confiança da comunidade internacional quanto a temas afins, como Mudança Climática, Biodiversidade e Florestas.

38 A literatura sobre os "complexos de regimes", largamente produzida por adeptos das teorias funcionalistas, entre eles Keohane \& Victor (2010), refere-se ao novo aspecto de fragmentação político institucional da ordem global pós-anos 1990, resultante da proliferação de estruturas e regimes para lidar com temas transversais e conectados, mas sem uma hierarquia definida. O "complexo de regimes" se forma em função da evolução desgovernada de acordos ambientais sobre temas conexos, ou os mesmos temas em diferentes negociações, como no caso das florestas e mudanças climáticas (RAUSTIALA \& VICTOR, 2004; KEOHANE \& VICTOR, 2010). 
O corte temporal proposto pela pesquisa, portanto, tem início no biênio 19861987, percorre as últimas duas décadas (1990-2000), para esgotar-se em 2009 e depois prosseguir aos dias atuais. O marco temporal foi escolhido em razão de dois fatos que, a nosso ver, representam um divisor de águas na política internacional ambiental e que deram alento renovado para uma reformulação substantiva - política e conceitual - das diretrizes da OAI até o presente: o acidente na central nuclear de Chernobyl (Ucrânia/1986) e a publicação do Relatório Brundtland (“Our Common Future”), pela Comissão Mundial sobre Meio Ambiente e Desenvolvimento da ONU (CMMAD), em 1987.

Os dois eventos elevaram, sem dúvidas, o tema do meio ambiente ao centro da agenda internacional ("la mondialisation et l'institutionnalisation de la protection de l'environnement") com relação às discussões sobre segurança. À época do acidente, o Presidente Mikhail Gorbachev chegou a afirmar que Chernobyl teria sido um dos mais relevantes fatores da queda do Império Soviético, muito mais que seu programa reformador liberal, a Perestroika. Podemos arriscar que Chernobyl respondeu por preocupações globais acerca das consequências nefastas da utilização inadequada de recursos tecnológicos por ação antrópica, pautando sobremaneira a inclusão do tema ambiental nas discussões sobre segurança em todo o mundo, a partir de então, com reflexos diretos na conformação da ordem global pós-Guerra Fria.

O Relatório Brundtland ${ }^{39}$, publicado pela CMMAD, presidida pela entãoPrimeira-Ministra da Noruega, Gro Harlem Brundtland, buscava estabelecer uma ponte entre os países do Norte (desenvolvido) e do Sul (em desenvolvimento), identificando os desafios que dificultavam o desenvolvimento pleno destes países, e apresentar uma alternativa para minimizar a clivagem Norte-Sul (RIBEIRO, 2001: 73-91; BURSZTYN \& PERSEGONA, 2008: 2008-209), oriunda ainda dos embates entre os dois lados na Conferência da ONU sobre Meio Ambiente Humano (CNUMAH), a "Conferência de Estocolmo", de 1972. A relevância do Relatório transparece na sua definição de Desenvolvimento Sustentável como “(...) aquele que atende às necessidades do presente sem comprometer a possibilidade de as gerações futuras atenderem as suas próprias necessidades" (CMMAD, 1988: 46), constituindo uma evolução conceitual

${ }^{39}$ Cf. Cap. III, para maiores detalhes. 
sem precedentes, a influenciar ainda nos dias atuais as discussões sobre a utilização sustentável dos recursos naturais pelos seres humanos e sobre segurança ambiental global, no tocante à busca por mitigar os efeitos negativos da degradação ambiental e do uso inadequado daqueles recursos e de sua relação com os conflitos modernos de causas ambientais. $^{40}$

Quanto às bases do marco teórico da pesquisa, a TRI pautou-se no que se convencionou denominar os "Grandes Debates", que mesclaram no decorrer dos estudos da disciplina aquela busca ontológica, em certo momento, para conhecer sua epistemologia, reformulada pelos pressupostos empíricos que conformavam as preferências e ações dos diversos atores na arena (ou cena) internacional. Em linhas gerais, o primeiro daqueles debates, de aspecto ontológico, contrapunha duas correntes de pensamento que buscavam conhecer a natureza das relações internacionais, o realismo, corrente dominante, e o idealismo, de inspiração kantiana. Em 1939, o diplomata britânico Edward Carr, na obra Vinte Anos de Crise, percebeu que as preocupações dos primeiros acadêmicos das RI centravam-se em entender as causas da guerra e buscar formas de evitar a repetição de tragédias que assolavam a humanidade há séculos. Para Carr, as iniciativas normativas empreendidas pelos acadêmicos e

40 É crescente a literatura debruçada em tentar responder sobre um possível nexo entre ameaças ambientais e conflitos. Pode-se falar em velhos e novos desafios securitários nas últimas décadas, com as mudanças nos paradigmas de segurança tradicionais advindos de ameaças crescentes do terrorismo, com raízes eminentemente culturais, e ameaças como a proliferação nuclear, que chamam a atenção dos principais organismos multilaterais regionais (a exemplo da Organização do Tratado do Atlântico Norte OTAN). Niloy Biswas (2011) faz um interessante esforço de analisar o que denomina "environmentthreat-vulnerability nexus". O autor acredita que essa fórmula possui um papel vital no sentido de comprovar a relação entre o meio ambiente e as reais ameaças securitárias. Biswas aponta dois significativos aspectos do nexo. Um deles relaciona-se à "integridade ecossistêmica", crucial para a qualidade de vida sustentável das populações. Diante dessa variável, certas condições ambientais que resultem em intensas mudanças, como degradação ambiental, poluição e desastres naturais, podem representar séria ameaça à segurança, aumentando a vulnerabilidade individual. O meio ambiente torna-se mais relacionado à segurança internacional à medida que soluções nacionais para problemas ambientais parecem não ser sustentáveis no longo prazo sem a presença da cooperação internacional. Um segundo aspecto referir-se-ia à relação direta entre meio ambiente e conflitos de caráter transnacional. $\mathrm{O}$ autor considera a tese de que inúmeros fatores ambientais podem levar à eclosão de conflitos. Assim, cada vez mais comum e defendida entre os adeptos do tema da segurança, o meio ambiente como variável para se pensar as relações internacionais contemporâneas encontra defensores nas mais diversas escolas que tratam da questão sobre as novas ameaças à ordem contemporânea. Gunther Baechler (1998, apud Niloy Biswas, idem) defende que os conflitos internacionais ambientais são inevitáveis em razão da superexploração dos recursos renováveis, do esgotamento da capacidade de resiliência ambiental e do empobrecimento dos espaços de convivência. Baechler entende que a relação entre meio ambiente e segurança advém do fato de que conflitos violentos que eclodem devido à degradação dos recursos renováveis geralmente se manifestam em crises regionais de sociedades em desenvolvimento ou em transição, quando "fendas sociais" referentes ao poder internacional, político e étnico são manipuladas por atores em conflito. 
tomadores de decisão de seu tempo no cenário internacional eram por demais utópicas para responder ao questionamento fundamental sobre como o mundo realmente funcionava. ${ }^{41}$ Essa corrente, em que se incluía, definiu de "realistas", por defenderem uma visão menos utópica e "mais sintonizada com as dimensões do poder e do interesse que permeiam a política internacional”. (NOGUEIRA \& MESSARI, 2005: 38)

Foi na magistral obra Politics among Nations ${ }^{42}$, de 1948, que o cientista político Hans Morgenthau (1993) nos brindou com os princípios básicos do Realismo clássico ou tradicional, contrapondo o idealismo liberal norte-americano das primeiras décadas do século XX nas relações internacionais com os eventos de high politics que assolaram o globo do entre e do pós-guerra. Morgenthau faz de suas ideias sobre o "realismo" uma "contravisão" política, inspirado no pensamento filosófico de Thomas Hobbes e Maquiavel. O paradigma realista considera os Estados e seus líderes as unidades básicas de compreensão das relações internacionais e do jogo político. Para Morgenthau, deve haver nítida diferença entre os dois planos da soberania, o doméstico e o exterior, pois nesta última reina a anarquia.

$\mathrm{Na}$ política internacional há uma disputa contínua e indelével pelo poder, propulsor das decisões dos entes soberanos e característica contumaz do jogo realista da busca da proeminência estatal no cenário mundial. A racionalidade da política exterior seria ditada pelo interesse nacional, de um lado, e a necessidade de equilíbrio de poder como mecanismo de estabilidade para o sistema de Estados, de outro. Assim, o “interesse nacional" e o "sistema de Estados" representam conceitos-chave no pensamento realista e excluem qualquer outra ideia que não considere o Estado um ator central das relações internacionais. Em esforço de síntese, pode-se apontar a principal característica do pensamento realista a centralidade do Estado, que para manter sua sobrevivência se utiliza do poder inerente à soberania.

\footnotetext{
${ }^{41} \mathrm{O}$ foco dos primeiros homens de Estado liberais, presente nos primórdios da TRI pelas ações de Wilson na paz versalhiana, em seus quatorze pontos, propusera já no final da segunda década do século XX a Liga das Nações, instituição que seria responsável pelo equilíbrio do pós-Grande Guerra, arauto das relações pacíficas que deveriam conduzir a atuação dos Estados. Conquanto não tenha logrado êxito na realização de seus objetivos propostos, como a manutenção da paz, a Liga representou experiência singular tanto para a conformação posterior da ONU quanto para o processo de integração europeu e a edificação das organizações estatais e não-estatais.

${ }^{42}$ Cf. nota $\mathrm{n}^{\circ} 31$ supra.
} 
Tal concepção realista clássica, embora tenha servido para justificar ações estatais diante de conflitos que afligiram o cenário internacional durante décadas de Guerra Fria, passou a ser considerada reducionista e levou a reflexões diversas que se pretendiam menos inadequadas. Um grupo de acadêmicos de tendências neorrealistas ou realista-estruturais defenderam maior "rigor científico" sob bases positivistas, que fundamentavam uma "revolução" epistemológica behaviorista nas ciências sociais. Assim, o "segundo debate" na disciplina não preconizava o que estudar, mas como estudá-la (NOGUEIRA \& MESSARI, idem; WIGHT, 1991). Nos anos 1970, o realismo clássico conheceu uma crise paradigmática, devido às dificuldades de atualização do pensamento ao contexto internacional que então se descortinava, com o início da distensão americano-soviética e sino-norte-americana. Essa transformação nos níveis analíticos da Ciência e da Sociologia das RI implicou a inclusão, no seu quadro teórico, de temas mais econômicos e, porque não já falar à época, ambientais, pondo em dúvida a centralidade estatal como influência primordial do sistema SI.

Foi no contexto acima que se buscou revisitar o pensamento realista tradicionalclássico. Kenneth Waltz, em Theory of International Politics (1979) resgatou a tradição realista sob novas roupagens e reafirmou a relevância do realismo na explicação dos fenômenos interestatais. Sem desconsiderar as premissas básicas de seus antecessores, considerou o surgimento de novas diretrizes analíticas - o componente econômico e o surgimento dos novos atores - e atualizou a análise realista, incorporando a "anarquia" como elemento explicativo da perene existência das guerras nas relações internacionais. Na obra Man, the State and War (1959), o autor elaborou a teoria das três matrizes (ou imagens), que apresentam a perspectiva neo-realista das relações internacionais e aparecem como os primórdios do pensamento "realista-estruturalista".

Em razão do contexto belicoso que prevalecia no pós-guerra, parece não havia espaço suficiente para a prevalência de outras perspectivas além daquela realista tradicional. Com os movimentos integracionistas (funcionalistas) do período, no entanto, a exemplo da formação do bloco europeu e das inúmeras iniciativas em diversas regiões do globo, a visão liberal parecia transparecer lentamente no debate acadêmico, trazendo consigo a estruturação de um debate elevado e renovado de ideias entre os então chamados neo-realistas estruturalistas e os liberais-institucionalistas. Esta 
última, caracterizada pelo caráter utópico-idealista, atributo inerente do paradigma liberal, foi marcada não apenas pela valorização da "paz perpétua" ao estilo kantiano, como também por iniciativas mais pragmáticas no campo da cooperação e da configuração de instituições que lhe dessem materialidade. Os liberais tendem a concordar com os pensadores realistas quanto à existência da "anarquia" nas relações internacionais, porém não aceitam a imutabilidade preconizada no sistema por tal escola de pensamento. ${ }^{43}$

O terceiro debate retoma os pressupostos ontológicos da disciplina e revisita a epistemologia realista e liberal positivista, ao ponto de Yossef Lapid (1989) considerálo um retorno aos pressupostos do primeiro grande debate (ontológico), agora entre positivistas e pós-positivistas. ${ }^{44}$ Foi nesse debate "paradigmático" que a teoria construtivista chegaria para contestar os pressupostos até então existentes nas relações internacionais de centralidade dos Estados e relevância de temas a eles afetos, sem uma percepção crítica da formação dos discursos que pautaram até então a "realidade" do cenário internacional.

O construtivismo apresenta os primeiros passos como teoria no campo das Ciências Sociais, com o estudo de autores da Sociologia, entre eles Michel Foucault e Anthony Giddens, cujas obras Power/Knowledge: Selected Interviews and Other Writings (1980) e The Constitution of Society: Outline of the Theory of Structuralism (1984), respectivamente, são referências ainda hoje. Foucault e Giddens analisam o papel das ideias na composição dos agentes e das estruturas na conformação da linguagem, influenciando nos anos 1980 um movimento intelectual-acadêmico epistemológico denominado de virada linguística.

\footnotetext{
43 Segundo Joseph Nye (2007), teórico do liberalismo-institucionalista, os conflitos são usualmente explicados em termos de sistema internacional que, para o autor, refere-se a um "padrão de relacionamentos" entre Estados. Nye afirma que a distribuição de poder em um dado sistema internacional contribui para criar predileções a respeito de certos aspectos do comportamento deles. A tradição da geopolítica põe em tela a localidade e a proximidade entre as nações para jogar luz ao padrão de comportamento dos Estados. Para o autor, uma certa linha comportamental geralmente é encontrado em sistemas anárquicos.

44 Autores como Weaver (2004, apud Vieira, 2010) e Halliday (1999) citam a existência de um "quarto debate" no seio da corrente pós-positivista, representadas por teorias reflexivistas (KEOHANE, 1988), incluídas aí as feministas, a teoria crítica, os pós-modernos e os pós-estruturalistas.
} 
Nas RI, a influência construtivista sociológica teve como marco as obras de Nicholas Onuf, com World of Our Making - Rules and Rule in Social Theory and International Relations (1989), e de Alexander Wendt, com o artigo Anarchy Is What States Make of It (1992), cujas premissas básicas de inspiração pós-positivista consistiam em afirmar que vivemos uma realidade (estrutura) construída pelos agentes, como produto das próprias escolhas. Desloca-se, assim, o debate das relações internacionais não mais para o campo metodológico, mas para a dimensão ontológica da disciplina. Essa diferença apresenta-se como pedra angular para as correntes de pensamento que surgem a partir de então e contribui para a abertura das ideias e a multipolarização dos temas de estudo (entre eles o ambiental), em razão do reconhecimento dos pressupostos teóricos permissivos de se conhecer a securitização temática para além do tradicional militar e estratégico.

Na década de 1990, a teoria construtivista tornou-se definitivamente central no debate da RI, levando Stephen Walt (1998) a apresentar o construtivismo pari passu ao realismo e ao liberalismo como abordagens dominantes da disciplina. A elevação das ideias construtivistas a corrente de pensamento não representou, no entanto, ponto pacífico. Diversos foram os desafios ao reconhecimento de sua validade enquanto método, em razão de sua busca inerente por desconstruir a estrutura metodológica da revolução quantitativa edificada há décadas, propondo a centralidade de valores e questionando os pilares sobre os quais tradicionalmente se assentava a "verdade científica dos positivistas". 45

Apesar de todas as aversões testemunhadas pela teoria em suas origens, 0 construtivismo logrou desenvolver-se em diversas áreas, compartilhando o pensamento sociológico em debate multidisciplinar e contribuindo para a edificação de um verdadeiro quadro analítico nas RI. Para Risse-Kappen (1997: 255-298) e Friedrich von Kratochwil (1997: 13-35), a premissa geral da teoria passa pelo reconhecimento da nãopredeterminação do mundo e dos fatos políticos e sociais, co-construídos na interação com seus agentes. Essa percepção preconiza que o agente e a estrutura são coconstituídos, em simbiose que torna indistinguível uma precedência sistêmica de

\footnotetext{
${ }^{45}$ Entre os críticos da corrente construtivista, Erik Jörgensen (2001) considerou a teoria então nascente uma "metateoria", ao afirmar que os construtivistas não desenvolviam teorias, nem traziam conceitos novos, mas apenas desconstruíam o paradigma cientificista.
} 
qualquer das duas variáveis, negando-se uma antecedência ontológica. Vieira (idem: 30) resume bem a teoria, ao tratar de seus aspectos discursivos:

\begin{abstract}
"Do ponto de vista construtivista, há de se averiguar não somente as lógicas dos processos de sistematização, mas também sua extensão, no tempo e no espaço. Os valores condicionam os agentes envolvidos no processo de forma diferente, redefinindo constantemente os lugares e os papéis de cada um dos atores. Segundo essa forma de pensamento, estruturas e agentes não existem de forma autônoma e independente. As estruturas são historicamente constituídas, positivadas pela regularidade do uso e das práticas, os agentes constituem-se mutuamente, $e$, ao interagirem, podem ou não reproduzir o modelo oferecido pela tradição. Assim, cabe aos analistas compreenderem como os agentes $e$ as estruturas se transformam, na dinâmica da história, ou seja, como esses processos mudam o mundo. Não se trata de explicar fenômenos, mas de entender suas lógicas múltiplas."
\end{abstract}

Somando-se a tais considerações, é notável que a teoria construtivista apresentase como um elemento divergente das premissas não apenas do realismo clássico e estrutural, mas também do liberalismo-institucionalista. Se o construtivismo desconsidera a divisibilidade entre agente e estrutura (leia-se "sistema"), desconstrói, logo, tanto o realismo clássico (com ênfase na natureza do indivíduo) e waltziano (com ênfase no sistema), quanto o liberalismo, no ponto em que reconhece a existência da anarquia. Ao negar importância definidora para a natureza do SI, os construtivistas reconhecem a possibilidade da existência de conflitos e cooperação nas relações internacionais, definidas como voláteis quanto à identidade do Estado no tempo e no espaço. Enquanto os liberais-institucionalistas presumem que os Estados agem no cenário internacional com regras predeterminadas de atuação, os construtivistas tendem a considerá-los adquirindo identidades e interesses durante a participação na estrutura social do regime ou do organismo internacional. ${ }^{46}$

Para além das premissas do construtivismo, e buscando uma ponte entre as teorias pós-positivistas e o reconhecimento do valor epistemológico para se compreender as relações internacionais e a formação dos conceitos que contribuam para

\footnotetext{
${ }^{46}$ Para Kyle Danish (in BODANSKY et alli: 2007), o construtivismo não corresponde a uma teoria única, porém a um padrão de diferentes teorias e perspectivas que compartilham a ênfase dos aspectos sociais da cooperação estatal nas instituições, valendo dizer que o autor considera de fundamental relevância o papel dos regimes internacionais para a visibilidade da corrente teórica. Ou seja, podemos falar de "agendas de pesquisa construtivista e outra realista".
} 
"reescrever" a normatividade hoje predominante, em constante transformação, retomamos nesse recorte metodológico o pensamento de Kratochwil, por sua contribuição singular para a pesquisa. Concordamos com o autor, ao afirmar que a natureza metodológica do construtivismo representa um dos seus principais desafios. Segundo Nogueira \& Messari (idem: 168):

\begin{abstract}
“(...) a questão que se impõe aos construtivistas é relativa à correspondência entre o mundo que se observa e o conhecimento que se constrói em torno dele. Para Kratochwil, essa questão não deveria impedir a elaboração de pesquisas empíricas, incluindo nisso pesquisas baseadas em programas de pesquisa e nos padrões do positivismo lógico. Kratochwil admite a possibilidade de a metodologia para elaborar esse programa poder ficar em aberto, com diferentes construtivistas seguindo caminhos diferentes. Isso significa que Kratochwil não descarta a possibilidade de existência de pesquisas construtivistas que sejam científicas."
\end{abstract}

Dos estudos de Kratochwil, interessa-nos o referente à sua percepção construtivista da linguagem, que abriu possibilidade para, por meio da própria ciência, reconhecer que o poder dos "atos de fala" adquire uma proeminência como variável explicativa válida e viável para a realidade do contexto internacional. A "virada linguística" atribuída aos construtivistas, por centrar-se na análise do discurso, traz o interesse dos teóricos da disciplina na análise das regras e normas que conformam a realidade empírica internacional, facilitando o entendimento do comportamento que certos agentes têm em determinadas situações (VIEIRA, 2010).

Em Rules, Norms and Decisions (1999), Kratochwil amplia sua percepção sobre o papel das normas no processo decisório dos atos internacionais, em estudo transversal, utilizando-se de conceitos da Filosofia da Linguagem, da Linguística e do Direito, e vai buscar em Ludwig Wittgenstein (1889-1951), filósofo da Fenomenologia e adepto das teorias da linguagem, os conceitos de "ato de fala", a fim de justificar a ação como reflexo do próprio discurso. Esse pensamento torna-se central nas discussões ontológicas da percepção empírica da realidade, tão cara aos adeptos das teorias realistas e liberais positivistas. Kratochwil reafirma a co-constituição agente-estrutura, sem oferecer a precedência ontológica a quaisquer dos dois, permitindo assim, junto a outros teóricos construtivistas, uma verdadeira revisão epistemológica das bases que por 
décadas justificavam o positivismo obrigatório das pesquisas empreendidas nas mais diversas áreas das Ciências Sociais, daí incluída as RI.

Essa reformulação ontológica da disciplina permitiu que temas antes centrais em outras abordagens teóricas, como segurança, cooperação e militar, aceitassem novas contribuições transdisciplinares, com a extensão dos estudos antes considerados específicos de determinadas áreas e delimitados por um grau excessivo de base teórica e lexical. O construtivismo representou uma revolução no debate paradigmático, a ponto de não poder mais ser ignorado hoje nos diversos estudos não apenas da área das RI, mas também das Ciências Jurídicas, da Filosofia da Linguagem, da Sociologia, dentre outras.

Nosso trabalho de tese insere-se nessa discussão ontológica e epistemológica, ao reconhecer a "circulação de normas"47 e conceitos em diversas disciplinas que compõem o conhecimento científico. Se hoje podemos intercambiar noções como Obrigações Positivas e Segurança Humana, de outras áreas constituídas das Ciências Sociais e Humanas, isso se deve em parte a estudos até aqui realizados e largamente discutidos nas mais distintas searas acadêmicas. Ao analisarmos o tema da segurança e do construtivismo, com a contribuição singular dos estudos do Círculo de Copenhague (Copenhagen Peace Research Institute - COPRI), estender o tema securitário para a área ambiental, nos dias atuais, antes um tabu para os adeptos das teorias realistas, torna-se um imperativo para qualquer discussão sobre conflitos e recursos naturais na OAI.

O tema das obrigações positivas relativas ao meio ambiente, objeto desta pesquisa, privilegiou-se das contribuições analíticas da Escola de Copenhague, em razão dos avanços teórico-conceituais securitários, ampliados sob as lentes construtivistas a outras áreas que não somente as estratégicas e militares, como tradicionalmente considerado. A Escola reconheceu os desafios impostos pela contemporaneidade,

\footnotetext{
${ }^{47}$ A ideia de "circulação de normas" vem ganhando densidade nos estudos do projeto de pesquisa pluridisciplinar denominado "Circulex", financiado pela Agência Nacional de Pesquisa (ANR) francesa e composto de acadêmicos de nível internacional (UnB/UniCEUB/Université Aix-de-Province/Université de Genève, Sciences Po Bordeaux, entre outras instituições). O projeto busca analisar o fluxo (circulação) de normas e a dinâmica de redes de atores a influenciar a governança ambiental global. Para maiores informações, acessar: http://circulex.wix.com/projet.
} 
consubstanciada na globalização dos problemas que assolam a comunidade internacional. No próximo tópico, contextualizamos os estudos de segurança desenvolvidos por aquele Círculo, de modo a buscar revisitar sua contribuição nos estudos securitários ambientais.

\subsection{Construtivismo e Segurança}

A Escola de Copenhague (COPRI), criada em 1985, como centro de estudos sobre segurança, de que fazem parte eminentes autores como Barry Buzan, Ole Waever e Jaap de Wilde, passou a ser conhecida pelo êxito em desenvolver conceitos amplamente utilizados na área das RI, no tocante aos estudos de segurança internacional. Ao introduzir uma perspectiva socioconstrutivista que busca a linhagem de como os problemas no cenário internacional transformam-se em questões de segurança, passou por diversas abordagens com o desdobramento dos estudos e a caracterização do agente de segurança. No início de suas pesquisas, o COPRI encontrava-se ainda atrelada à lógica realista-estatocêntrica, como indicam os textos de Barry Buzan, entre eles People, States and Fear: The National Security Problem in International Relations, publicado em 1983, com o sentido tradicional do aspecto militar nas questões de segurança nacional (TANNA, 2003).

Com a virada conceitual linguística e teórico-empírica dos estudos do COPRI, em razão do novo contexto internacional do pós-Guerra Fria e das novas variáveis de observação daí resultantes, como a incorporação de teorias pós-modernas e a aceitação de outros atores como agentes de segurança para além da centralidade estatal, sobretudo após os conflitos étnicos à margem dos Estados que assolaram a década de $1990^{48}$, os estudos do COPRI adquirem um novo status. São exemplos dessa nova tendência as publicações de duas obras, em um intervalo de cinco anos, que revolucionariam as

\footnotetext{
48 A análise dos construtivistas com relação às guerras étnicas, inversamente diferentes dos conflitos ambientais, com natureza palpável e distante do conteúdo cultural é interessante, segundo Nye (2007: 158): "Constructivistis point out that ethnicity is not an immutable fact that inevitably leads to war. It is socially constructed in the sense that symbols, myths, and memories can be altered over time. For example, in Rwanda, which suffered a genocide in 1994, people spoke the same language and had the same skin of color, but there were economic class differences between the Tutsi people who had migrated into the area with a cattle-based culture centuries earlier and the larger number of agricultural Hutu people. Over time, intermarriage and social change had blurred some of the distinctions, but they were reinforced during colonial rule. In the 1994 genocide in which 750,000 Tutsis were killed, many Hutus who urged moderation or who appeared to be Tutsi were also murdered."
} 
análises da segurança internacional: Identity, Migration and the New Security Agenda in Europe (WÆVER et alli, 1993) e Security: a New Framework for Analysis (WÆVER et alli, 1998).

O conceito de "securitização", formado a partir da hipótese de que a segurança pode ser entendida como o resultado de um "ato de fala", passou a ser utilizado, juntamente com suas variantes, em diversas análises, como em temas acerca do comportamento estatal com relação à política externa (SMITH, 2005), dos crimes transnacionais (EMMERS, 2003), além de meio ambiente e saúde pública. Biswas (2011) sintetizou o pensamento da Escola de Copenhague como "securitization labels an issue as its prime concern and transforms the way the issue is dealt with the concerned stakeholders."

De acordo com o conceito de "securitização" preconizado pelo COPRI, qualquer problema relacionado à segurança pode ser visto como uma "ameaça" que requer medidas excepcionais. Agiria a partir daí uma "manipulação política" de convencimento de que certos temas, a exemplo do meio ambiente, seria uma questão irrefutável de segurança. A inovação da Escola de Copenhague foi projetar à teoria das RI a lógica de que a própria segurança seria um conceito socialmente construído. Buzan e Waever chegaram a propor uma pesquisa metodológica, um framework diferente das tradicionais abordagens teóricas (de cunho realista) que antes empreendiam para estudar o conceito de segurança. Os estudos sobre "securitização", como ficou conhecida a teoria predominante da Escola, foram desenvolvidos no contexto das pesquisas sobre a dinâmica da segurança em âmbito europeu, mas sem os enlaces limitadores para que se expandissem a outras regiões.

Ao definir segurança como um "ato de fala", Waever et alli (1998) passaram a enfatizar o papel de outros atores, além dos Estados, no cenário internacional. Determinado ato de fala torna-se um tema de segurança, ao ser aceito assim por seus interlocutores. Relevante notar que, em razão do processo de "securitização" de um dado empírico por meio de tais "atos" (da construção social do conceito de segurança), uma potencial questão passa a existir como uma ameaça real não porque se relacione diretamente com segurança, mas por ser apresentada de tal forma que cria uma 
percepção coletiva de que constitui uma ameaça securitária. São exemplo dos interlocutores os líderes políticos, funcionários governamentais, membros da imprensa e de ONGs.

Biswas (2011), no entanto, aponta que nenhum simples ator leva o crédito por "securitizar" um tema. Em razão disso, argumenta, uma vez securitizado, o tema reflete estruturas institucionais e estruturais existentes na sociedade. Waever et alli (idem) afirmam que a natureza socialmente construída da sociedade reflete diretamente no processo de securitização. De acordo com os autores, o securitizing move será exitoso somente se aceito pela "audiência" como uma ameaça existencial a ser compartilhada.

$\mathrm{Na}$ análise construtivista daqueles autores subjaz, ainda que bem menos do que antes da virada epistemológica, a relevância dos Estados como agentes capazes de constituírem as agendas de segurança. Buzan e Waever não desconsideram o papel tradicional das nações como a driving force por trás de processos de securitização, em que os governos usualmente exercem o papel de promotor e porta-voz da segurança para uma determinada sociedade ou Estado. A razão para tanto residiria na qualidade inerente dos governos de possuírem uma responsabilidade nacional, que os incentivaria a exercer um "mandato" sobre o assunto.

Em Security: a New Framework for Analysis, como recordou Tanna (2003), há a defesa de que cabe ao pesquisador identificar uma questão como pertencente ao âmbito da segurança, sendo dada a possibilidade de, "politicamente de forma mais explícita", denunciar tentativas ilegítimas de "securitização", em cujo processo os atores tentarão conferir a uma "questão política um caráter emergencial", que exige meios "extraordinários" para a solução do problema. Essa percepção de que as agendas são socialmente construídas e uma dada questão "securitizada" ou "dessecuritizada", conforme a atribuição que lhe é conferida pelos agentes, permitiu a conformação de agendas de segurança diversas, em áreas específicas que Waever et alli propuseram como os setores político, econômico, societal, ambiental e militar, que não nos cabe aqui expor minuciosamente, por desviar sobremaneira do escopo deste trabalho.

O círculo acadêmico da Escola de Copenhague dialoga com o construtivismo de Kratochwil (1989), certamente influenciado por seus estudos de atos de fala na 
constituição das normas e decisões. Quando Kratochwil nos convida a entender as regras que regem o discurso, para que possamos apreender a realidade, ou seja, possamos compreender que "o mundo ao qual nos referimos é produto dos discursos que nos permitem nos referir a ele" (NOGUEIRA \& MESSARI, idem: 170), oferecenos um quadro analítico em que novos conceitos buscam expressar o significado de uma dada realidade, sem as amarras das teorias positivistas tradicionais. ${ }^{49}$

Todo esse aparato teórico-construtivista ajudou a expansão dos conceitos em diversas áreas do conhecimento, bem como permitiu uma justificativa mais sólida para a transversalidade e para a "circulação de normas" entre os variados regimes ${ }^{50}$ no cenário internacional. Entender a subjetividade dos padrões analíticos tradicionais deverá auxiliar este trabalho de tese e facilitar a compreensão da possibilidade de se ampliar conceitos nas áreas aqui propostas. As obrigações positivas não restaram alheias a essa lógica conceitual e adquiriram escopo para serem transpostas a outras instâncias científicas e políticas e perscrutadas em diferentes eixos temático-analíticos, estendidos em seu significado original, para enfim tornar-se instrumento de transformação prática da realidade.

\subsection{Considerações finais}

Chegando ao final deste capítulo introdutório, em que buscamos apresentar de forma coerente as razões da pesquisa, os aspectos metodológicos e o marco teórico, sem

\footnotetext{
${ }^{49}$ No tema da segurança internacional, esse entendimento permitiu um debate profícuo entre as teorias tradicionais e as novas perspectivas críticas que foram surgindo no âmbito das concepções pós-modernas e construtivistas, conhecidas pela "vertente abrangente" ( "wideners"), que defendiam o estudo dos temas de segurança para além das premissas teóricas realistas (TANNO, 2003). A vertente abrangente contribuiu sobremaneira para a ampliação dos pressupostos teóricos do discurso da segurança, ultrapassando as fronteiras do estatocentrismo e das questões miltares-estratégicas. Nesse contexto de eventual "securitização" e "dessecuritização" temática, Ullman (1983) já buscava expandir o tradicional conceito de segurança para as ameaças não-militares, como o meio ambiente, incluindo aí ameaças à qualidade de vida dos cidadãos na sociedade (BISWAS, 2011: 5).

${ }^{50}$ Toma-se aqui a conceituação de regimes elaborada por Krasner (1982): “(...) international regimes are defined as principles, norms, rules, and decision-making procedures around which actor expectations converge in a given issue-area". No entender do autor, deve-se considerar como ponto de partida que os regimes têm sido conceituados como uma variável interveniente entre os fatores causais básicos e os resultados e comportamentos. Young (1994) considera-os como instituições sociais que dirigem as ações daqueles interessados em atividades específicas (ou conjunto de atividades). Para o autor, os regimes são estruturas sociais e não devem ser confundidos com funções, embora as atividades dos regimes contribuam para o exercício de certas funções. Já "regimes internacionais" seriam aqueles que pertencem a atividades de interesse dos membros do sistema internacional, que na maior parte se realizam além das fronteiras jurisdicionais de Estados soberanos.
} 
descurar de uma breve apresentação dos principais conceitos a pautar o texto elaborado, não poderia deixar de citar o percurso pessoal que originou a pesquisa.

A ideia deste trabalho de tese surgiu de uma inquietação do pesquisador quanto à validade e efetividade das premissas teórico-conceituais que pautam os principais preceitos da área das RI, do DIP e do DIMA a respeito do tema da intervenção. As mudanças no SI, nas últimas décadas, e a expansão conceitual das análises no discurso de segurança, pela virada linguística proporcionada pela inovação construtivista, parecem ter dado renovado alento para se revisitar alguns elementos tradicionais usualmente aceitos dos fundamentos analíticos daquelas disciplinas.

Esse reconhecimento da crescente interconexão entre os sistemas social e natural, a desafiar as estruturas convencionais e as "predisposições políticas" por elas informadas, tem contribuído para a descoberta de crescentes incongruências entre o mundo político, delineada pelas fronteiras territoriais, e o mundo natural, com seus “ecossistemas interconectados". Esse mundo complexo, caracterizado pela proliferação dos novos atores e das regras por eles estabelecidas, com discursos diariamente sendo elaborados, enquanto outros convenientemente esquecidos, para dar vazão a interesses geralmente imediatistas, vem sendo paulatinamente "esverdeado" (LIFTIN, 1999) com os desdobramentos da política internacional e o surgimento de novas realidades que põem em discussão a prevalência do Estado-nação e seu tradicional atributo soberano.

Os capítulos que seguem buscam revisitar essa nova ordem internacional, dinâmica e controversa, que se apresenta ao pesquisador. A proliferação dos atores e a circulação normativa tornaram a dualidade do século passado anacrônica e os pressupostos analíticos mais complexos. A epistemologia positivista parece não mais responder com a mesma facilidade aos questionamentos de um ambiente anárquico realista, em que os Estados se padronizavam às teorias comportamentalistas psicológico-subjetivistas, para explicar com modelos teóricos simplificados a realidade que os sustentava.

Com relação aos desastres ambientais (nosso objeto de estudo), a busca por análises explicativas de novos fenômenos que justifiquem o emprego das obrigações positivas resulta em dificuldade mais peculiar, em razão da lacuna bibliográfica e da 
"securitização" ainda limitada do tema, na concepção da Escola de Copenhague, a respeito de sua prática na área ambiental pela natureza esporádica e emprego ainda idealizado (não positivado). Muito embora sua securitização caminhe em paralelo às políticas globais de proteção do meio ambiente, a questão das "intervenções verdes" carece, todavia, de maior atenção acadêmica e política, para não mencionar normativa.

Em busca da relação entre segurança e meio ambiente, e em que momento passa a ser "securitizado" no cenário internacional, Biswas (idem) questiona retoricamente: “seria, então, o meio ambiente uma ameaça à segurança?”. Constitui essa uma das indagações mais prementes que buscaremos responder no decorrer da tese, a começar pela compreensão da ordem internacional contemporânea e de seu subsistema, a OAI, que nos serve de cenário e campo analítico. Boa leitura! 
CAPÍTULO II

A ORDEM GLOBAL CONTEMPORÂNEA:

NOVOS DESAFIOS DE SEGURANÇA GLOBAL 


\title{
II. A Ordem Global Contemporânea: novos desafios de segurança global
}

\begin{abstract}
"Globalism and nationalism need not be viewed as opposing trends, doomed to spur each other on to extremes of reaction. The healthy globalization of contemporary life requires in the first instance solid identities and fundamental freedoms. The sovereignty, territorial integrity and independence of States within the established international system, and the principle of self-determination for peoples, both of great value and importance, must not be permitted to work against each other in the period ahead. Respect for democratic principles at all levels of social existence is crucial: in communities, within States and within the community of States. Our constant duty should be to maintain the integrity of each while finding a balanced design for all."
\end{abstract}

"An Agenda for Peace: Preventive diplomacy, peacemaking and peacekeeping”(A/47/277 - S/24111, 17 June 1992)

\subsection{Considerações iniciais}

Assumindo-se o protagonismo do Estado com suas diversas faces ao longo da história, não há como iniciar o presente trabalho sem que se busque avaliar a evolução da ordem internacional e as transformações por que passou o globo nas últimas décadas. Essas mudanças levaram a diferentes perspectivas com relação ao Estado nas Ciências Sociais, revisitando o conceito de soberania, e aos aspectos materiais e humanos que conformam os diversos níveis de análise nas RI. Essa discussão, no nível do sistema, relaciona-se diretamente com o que se convencionou chamar de "globalização". 51

Muito embora partamos na pesquisa de uma perspectiva realista interestatal para buscar auferir a compreensão da OAI, em situações específicas de desastres ambientais,

\footnotetext{
${ }^{51}$ É interessante notar a influência do tema do transnacionalismo no pensamento de autores da escola francesa nessa onda globalizatória, dentre os quais Bertrand Badie. Parte de sua obra trata de assuntos relacionados com a construção artificial dos Estados e as implicações quanto aos aspectos sociais e culturais, o que o aproxima das tendências construtivistas. Para Badie (1999), a crise de legitimidade dos Estados não-Ocidentais é o resultado de uma contradição entre a prática de "importação" dos Estados e da imposição e da prática de uma vida política de acordo com outra lógica e racionalidade. A legitimidade desse Estado "importado", em crise, afetaria diretamente o sistema internacional. É aqui que o "internacional" adquire importância, pois se incorpora à análise política do transnacional elementos tradicionalmente integrantes, agentes novos e níveis de análise.
} 
reconhecemos que a realidade da globalização somente pode ser apreendida em sua plenitude pela análise da interação de variados atores na composição do SI contemporâneo, para além da figura do Estado como único ator a influenciar a política global hodierna (em consonância com a perspectiva de sociedade maximalistaconsesualista). Sendo assim, percebe-se que a estrutura do SI contemporâneo redefine também o papel do Estado, em uma "via de mão dupla", por uma co-constituição social. Da interação entre os sujeitos das relações internacionais emerge a pluralidade de interesses que conformam a política mundial. Os dois níveis de análise - doméstico e internacional - vêm sendo revistos em razão da emergência desses novos atores, como as redes transnacionais, as comunidades epistêmicas ${ }^{52}$, os regimes, as ONGs, entre outros. Novas perspectivas entram em cena, essenciais para entender e explicar as transformações materiais e discursivas da evolução de conceitos em diversas áreas do contexto internacional, como Segurança e Meio Ambiente.

Neste capítulo, avaliaremos inicialmente as consequências desse processo globalizatório para a formação do quadro teórico securitário que se seguiu ao final da Guerra Fria, de modo a conhecer a causalidade histórica que proporcionou a proliferação dos agentes nas relações internacionais e a diversidade temática nos estudos acadêmicos e na prática diplomática diária dos Estados-nações. Neste breve percurso descritivo, propomos uma avaliação histórica centrada no espectro sociológico francês e na perspectiva brasileira (BADIE, 1992, 1995, 1999; SALAME, 1996; VIOLA, 1996; LAROCHE, 2000; DEVIN, 2002; BARROS-PLATIAU, 2004, 2004b; SMOUTS, 1998; DURAND et al, 2007; FONSECA, 2006; CERVO, 2007), em consonância com uma abordagem teórico-conceitual da Escola Inglesa, com relação ao paradigma consensualista co-constituído na sociedade global contemporânea. Uma análise desse ponto de vista preocupa-se mais com o SI e com os efeitos das alterações sistêmicas na estrutura da ordem global, como a intensificação do transnacionalismo com o surgimento de novos atores, do que com as lentes tradicionais explicativas que

52 Haas (1992:3) caracteriza a comunidade epistêmica como composta por profissionais (cientistas, políticos, empresários, entre outros) que trabalham para avançar determinada área de conhecimento, como instrumento de implementação de políticas, além de compartilharem valores e princípios normativos comuns. Compartilham, ainda, maneiras de conhecer, padrões de raciocínio e compromissos com a produção e aplicação do conhecimento. 
pautam os aspectos centrais dos níveis de análises somente no doméstico e internacional.

Entre os novos desafios da segurança global, que alteram o papel do Estado nas relações internacionais, apresentam-se as crescentes ameaças à soberania como elemento basilar da conformação dos Estados como atores da OAI. Não se pode desconsiderar que a ordem pós-Guerra Fria, edificada nos últimos quase trinta anos por um movimento simultâneo de ameaças e reafirmações dos princípios que pautaram a formação soberana estatal, passu por mudanças significativas na temática sobre segurança, antes uma prerrogativa estatal. Conforme visto anteriormente, a securitização preconizada pelos adeptos do grupo de Copenhague adaptou-se para estimular um debate renovado, em áreas mais amplas que perpassassem o tema político e estratégico, para incluir a sociedade e o meio ambiente.

A securitização do tema ambiental será tratada em tópico específico (2.4), devido à relevância que atribuímos à questão. Um recorte histórico será oferecido, de modo a revisitar a literatura sobre o assunto nas diversas escolas de pensamento. Atenção especial será dada também à sua evolução no âmbito multilateral e nas relações interestatais, sem desmerecer, todavia, análise mais prática de como o discurso da extensão do tema da segurança para envolver a variável ambiental vem sendo concebida por seus defensores.

\subsection{As Consequências da Globalização}

A globalização como processo histórico vem sendo estudada nas últimas décadas de modo fecundo em diversas áreas das Ciências Sociais, com suas múltiplas variáveis conceituais, que buscam entender o significado histórico-factual e diretrizes do fenômeno na constituição dos agentes e da estrutura do cenário internacional. Preconizado pela escola francesa de pensamento sociológico sob o epíteto de mondialisation, seus fenômenos, características, e busca de como o instrumento analítico pode explicar a realidade internacional é alvo de variadas interpretações. $\mathrm{O}$ conceito muitas das vezes é utilizado de forma enviesada para explicar as agruras econômicas e políticas por que passa de tempos em tempos a humanidade. Não pretendemos discutir nos próximos parágrafos os benefícios e malefícios político- 
econômicos deste processo ainda em andamento, e sim centrar-nos em suas consequências para o tema da segurança internacional.

Tratar da questão da mudança climática, do manuseio da energia atômica, da poluição das águas, dos conflitos transfronteiriços, do terrorismo, das finanças exige certa cautela, pois os resultados não se circunscrevem mais a parcelas reduzidas do globo. Os conflitos e crises que assolavam regiões, a exemplo das humanitárias de natureza étnica no Leste europeu e as econômico-financeiras na Ásia, nos anos 1990, e a euro-atlântica de 2008, afetaram de modo simultâneo a segurança internacional, por seus aspectos transfronteiriços oriundas das consequências migratórias e pela falência sucessiva de economias. ${ }^{53}$ Todos esses fenômenos parecem alterar a percepção de como os agentes na ordem global consideram as ameaças a serem "securitizadas", em um processo paralelo de "dessecuritização" de outros temas menos prementes. Nenhum processo exige uma análise mais complexa envolvendo a rapidez com que questões de segurança são postas em discussão do que a globalização.

Dessas mudanças se descortinariam um processo complexo e de natureza multidimensional (VIOLA, 1996), contraditório, por manifestar-se pela difusão planetária de modos de produção e de consumo capitalista. Citando Anthony Giddens (1993), para quem a globalização deve ser compreendida como uma "reorganização tempo-espacial" nas relações sociais, Senarclens (1998) afirma que o fenômeno implica o avanço da modernidade que se passa no conjunto da sociedade internacional. Na ideia da expansão econômica, vai além e elenca como características do processo globalizatório atual o crescimento das trocas internacionais, o aumento do fluxo dos investimentos externos, a evolução dos mercados financeiros e a expansão das empresas transnacionais.

Alguns tópicos são comuns em qualquer discussão sobre o alcance deste fenômeno. Das diversas faces desse processo "multidimensional", pretendemos nos limitar a investigar três, por suas consequências práticas no plano da realidade, ao alterar concepções de ordem sócio-securitárias relacionadas ao avanço conceitual das Obrigações Positivas no plano internacional: (1) as origens do fenômeno, a fím de

${ }^{53}$ Cf. Alfaia, Roberto (2008), dissertação de mestrado do autor, de cujo Cap. I foram extraídas algumas considerações utilizadas neste tópico. 
conhecermos seus reflexos sobre a "virada" conceitual em curso; (2) o fortalecimento ou diminuição do papel do Estado diante da globalização; (3) e as relações entre os governos e a sociedade civil, que têm sido responsáveis pela dinâmica social que envolve a busca de novas diretrizes e parâmetros para inclusão de novos atores no processo decisório internacional. Buscar conhecer esse processo e seus aspectos auxiliará na compreensão do objeto de estudo da tese, uma vez que as mudanças sociais e securitárias, com seus efeitos jurídico-normativos, políticos e econômicos, não se encontram ao largo dessa evolução conceitual por que passamos atualmente.

Quanto ao primeiro dos questionamentos (origens), é constante discutir se a globalização é tão somente uma simples continuação de um processo já existente ou uma "novidade" resultante da derrocada da ordem bipolar anterior. O processo de alterações substanciais na dinâmica das relações na ordem mundial, oriundas do avanço da ciência, das formas de se pensar a sociedade, do contato maior entre os indivíduos de diversas nações, como consequência daquelas tecnologias nos sistemas de comunicação e transporte, ocorreu com maior intensidade a partir da década de 1990. Ainda por serem desmiuçados, os anos daquele período são de relevância crucial para se entender o mundo contemporâneo, diante do que se convencionou ter sido criada uma "nova ordem global" (FUKUYAMA; 1992; HUNTINGTON, 1997; HELD \& MCGREW, 2001; BAYLIS, 2004; HURRELL, 2007; HIRST \& THOMPSON, 2009), conceito polêmico que, ainda hoje, desperta debates os mais variados em que se busca descobrir a dimensão daquelas mudanças.

O fim da ordem bipolar no início dos anos 1990 representou uma verdadeira euforia político-diplomática e econômico-cultural. A natureza multipolar e "multidimensional", que passou a dar o tom do novo cenário internacional, incentivou um debate fecundo sobre os rumos da política entre as nações e da economia mundial, muito embora já houvesse alguma indicação de que um processo do gênero aconteceria em breve, em razão do avanço das telecomunicações e dos transportes, que viria a “comprimir” a relação espaço-temporal (LAÏDI, 1994; HARVEY, 2003).

No mundo globalizado, a integração político-comercial resultou de um avanço na infraestrutura das comunicações, proporcionando maior conexão entre redes 
financeiras globais de forma instantânea (CASTELLS, 1996; ANDREFF, 1996). A revolução tecnológica nas telecomunicações e nos transportes pós-1970 implicou a possibilidade de intensificar-se a interação entre atores de diferentes nacionalidades com objetivos comuns. Surgiram também, com o aumento do fluxo de ideias e de pessoas, a intensificação das forças transnacionais e os problemas do gênero, que Estados-nações pareciam incapazes de solucionar sozinhos devido aos amplos (e de longo alcance) efeitos sobre diversas partes do globo.

Esse processo de redefinição das estruturas globais econômicas, sociais e securitárias, multidimensional e que apresenta tendências de reformulação da atuação dos Estados não é recente e suas origens são fontes de ávida discussão acadêmica. Pierre de Senarcles (1998), crítico da globalização, avalia que o processo originou-se antes mesmo da Guerra Fria, com as transformações econômicas "de grande amplitude" que marcaram as estruturas das relações internacionais. Keohane \& Nye (1972; 1989), de seu turno, consideram que a globalização tomou forma com a "interdependência complexa" interestatal e a natureza multifacetada do processo a afetar as tendências que se descortinavam na década de 1970, em um mundo bipolar cujas diretrizes eram ainda bem definidas pelas duas potências em jogo. Cervo (2007) e Barros-Platiau \& Góis (2004) entendem que o fenômeno seria bem mais antigo, remontando a séculos, com origem nas inovações tecnológicas e na revolução industrial, embora se associe a transformações econômico-financeiras recentes.

Ainda que aceita como processo histórico, a globalização apresenta, no conceito compartilhado entre parte das teorias que a definiram, características sobre as quais analistas e acadêmicos divergem, em especial quando confrontados com a realidade empírica dos fatos que convergem para desconstituírem as premissas dos adeptos da ideia do transnacional e do fortalecimento do fator estatocêntrico soberano. Eventos como as diversas crises humanitárias das últimas décadas e as intervenções daí advindas, somadas às crises econômicas globais e aos ataques terroristas como o $11 \mathrm{de}$ setembro, fundamentados em um suposto "choque entre civilizações" (HUNTINGTON, 1997), servem de apoio aos argumentos dos refratários da globalização, que proclamam o fortalecimento contínuo do papel dos Estados na dinâmica do poder político mundial. 
Diante desse fenômeno, analistas passaram a refletir sobre a natureza do papel do Estado nessa nova ordem, sobre o processo muitas vezes dicotômico da globalização sobre as soberanias e as estratégias estatais. Acreditava-se, de um lado, que o Estado estava perdendo força como ente soberano, diante de todos os desafios que agora enfrentava a respeito de eventual perda de autoridade nas áreas política, militar e econômica. De outro, pensava-se que a integração - regional e global - constituiria uma resposta dos Estados - no comando na ordem mundial - para direcionar ao seu critério os rumos da globalização (na concepção de uma sociedade pluralista-minimalista). Em vez de enfraquecidos, lideravam o processo em detrimento de organismos subestatais e entidades não-governamentais (HOFFMANN, 1987).

Amado Cervo (2007) apontou essa dicotomia em uma análise sobre o fenômeno da globalização e seus tributários, a integração e o papel do Estado nacional. O autor recorda que os internacionalistas buscaram entender a transição da ordem global da Guerra Fria às "linhas de força" das relações internacionais, insistindo, de certa forma, sobre o processo ora em discussão, que teria atingido com força os anos 1990. Tendiam a aproximar a globalização de outro processo que alcançava, na mesma intensidade, a ordem mundial: a integração. Cervo avalia que os dois fenômenos eram vistos como "tendências de fundo das relações internacionais, contribuindo para colocar em xeque o Estado Nacional como 'força profunda' de mesma envergadura'. Contrariando, no entanto, a convicção de que os Estado-nações estivessem em xeque, afirma que os governos desempenharam funções anteriores à transição pré-1990, agregando-as em outras.

Para Francis Fukuyama (1992), o ocaso da Guerra Fria representou o fim da História, pois os conflitos oriundos da bipolaridade que caracterizou a ordem mundial até então deixariam de existir. As divisões ideológicas teriam sido substituídas pela cooperação pacífica entre os atores no cenário internacional. A abertura política que caracterizou o final dos anos 1980 fez-se acompanhar de uma nova onda de liberalidades econômicas pela expansão do comércio global e dos investimentos. A interdependência política e econômica poderiam criar interesses compartilhados cuja finalidade seria evitar novos conflitos e incentivar valores comuns. Essa visão 
idealizada de uma paz perpétua finalmente alcançável, como desejou Kant, não foi bem aceita por todos.

Os céticos da globalização apressaram-se em desafiar os paradigmas da nova ordem que se estabelecia e a apontar para as contradições nela existentes, oriunda do capitalismo inconsequente e da reformulação das "forças profundas" que dariam o tom dos novos conflitos da década. Hirst \& Thompson (2009), por exemplo, buscam desmitificar a globalização no tocante à expansão dos fluxos financeiros e das ideias, voltando a dar relevância para o papel dos Estados. Na mesma linha de Cervo, argumentam que o mundo contemporâneo se caracterizaria pela regionalização e pela internacionalização e tentam desmerecer a globalização como processo histórico. As duas dinâmicas seriam criadas pelos Estados, e não pela estrutura em que estão inseridos. Analistas mais céticos ultrapassam esse entendimento e afirmam que, comparados ao período de 1870 a 1914 (HOBSBAWM, 1989), o mundo atual seria muito menos globalizado - econômico, político e culturalmente - e caracterizado mais pela crescente regionalização e internacionalização que pela globalização (HAY, 2000; HOOGVELT, 2001; GILPIN, 2001). ${ }^{54}$

Lechner \& Boli (2004) buscam explicar esse aspecto em termos de uma "globalização política" em andamento. Os autores atentam para o fato de que, por ser o globo organizado sob um único tipo de unidade política, com exceção de algumas áreas como poucas colônias ainda existentes de soberania limitada, já demonstra um sinal da globalização. Sustentam que jamais na história da humanidade o mundo teria sido composto por um mesmo tipo de unidade política, o que indica ter-se tornado o princípio da soberania um aspecto nuclear da sociedade global, em que um modelo

\footnotetext{
${ }^{54}$ Outro interessante ponto de vista a respeito da globalização refere-se ao de Andrew Linklater (1998), que trata da natureza da mudança do que denomina de "political community". O autor aponta o paradoxo dos tempos modernos sob bases da globalização econômica e política, que não vem se fazendo acompanhar da diminuição da fragmentação nacional. Linklater considera que a fragmentação de muitos entes políticos e a diversidade de crenças religiosas seriam os propulsores das transformações das comunidades políticas. Ressalta a ocorrência da fragmentação estatal principalmente em regiões subdesenvolvidas (Third World regions), responsável por crescente número de catástrofes humanitárias e, por que não, ambientais, vem levando muitos analistas a avaliar se as "democracias liberais" teriam efetivamente o dever de auxílio aos "failed states", aí incluídas as intervenções humanitárias com o objetivo de sanar constantes denúncias de desrespeito aos direitos humanos. Indo além, o autor aponta os desafios da interconexão global, em que formas inovadoras de comunidades políticas mais respeitadoras das diferenças culturais internas e mais cosmopolitas que seus predecessores estariam mais presentes na próxima fase da globalização.
} 
particular de organização política alcançara um status como a mais "viável, desejável e legítima" forma de estrutura política. ${ }^{55}$

Contrapondo a uniformidade política do Estado, mas não desmerecendo sua relevância político-institucional, outro aspecto bastante debatido do processo de globalização diz respeito à multiplicidade de atores no campo sociopolítico e cultural. ${ }^{56}$ Com diversificados polos de poder que emergem na política mundial, essa noção obscurece de forma relativa o pensamento realista tradicional, que tem no aspecto estatocêntrico um ator com força de alterar ou manter a composição do cenário internacional. Os espaços de poder destacam-se cada vez mais pela criação de organizações internacionais (SEITENFUS, 2003; HERZ \& HOFFMANN, 2004), redes transnacionais, fóruns multilaterais abertos à participação das ONGs, think tanks, associações, entre outros (cf. KECK \& SIKKINK, 1992; PRINCEN, 1994; RANJEVA, 1994; ARTS, 1998; CLARK, 1998; RISSE-KAPPEN, 1999; VILLA, 1999; NEIVA, 1999; BARROS-PLATIAU \& GÓIS, 2004; FONSECA, 2006). Os valores e normas que pautam as atividades dos atores transnacionais em busca de objetivos comuns em temas que afetam os cidadãos em todas as partes do globo parecem conjugar para conformar uma sociedade civil transnacional.

A multiplicação dos atores nas relações internacionais ocorreu por conjugação de forças, uma centrípeta outra centrífuga. Com relação à primeira, destaca-se a criação de organismos de caráter multilateral como a ONU e a Organização Mundial do Comércio (OMC), além dos diversos mecanismos interestatais que contribuem para diversificar a atuação dos Estados. Em caráter centrífugo, mais ao espectro dos movimentos sociais voluntários, nota-se a infinidade de organizações internacionais compostas por indivíduos da sociedade civil, como a World Wildlife Fund (WWF), o

55 A globalização seria caracterizada também por considerável uniformidade extraída dos estados soberanos em termos de objetivos, estruturas, programas, e operações internas, com responsabilidades internacionais em temas como educação, saúde, economia, entre outros, em paralelo às preocupações clássicas dos Estados quanto a questões de segurança, defesa, e política externa. Uma terceira característica da globalização política refere-se à emergência, nos últimos cem anos, das organizações intergovernamentais, criadas para lidar com problemas os mais diversos e que envolvem um alto nível de interdependência entre as nações. (LECHNER \& BOLI, idem)

56 Seitenfus (2002) argumenta que a "multiplicação de atores" e a "complexidade da agenda internacional" apresentam novos desafios para tornar eficaz o que chamou de "solidariedade internacional". O autor aduz à tendência da crescente fragilidade do princípio da soberania, no novo contexto internacional, e à necessidade de se reformular as instâncias decisórias para enfrentar tal fenômeno, de modo a evitar o perigo de intervenção do "mais forte sobre o mais fraco". 
Greenpeace e a Human Rights Watch, amplamente reconhecidas, inclusive pelos Estados. ${ }^{57}$ A figura (2.1) a seguir, adaptado de Nye (2007), apresenta-nos uma noção da nova configuração entre governos e sociedade. Tal característica traz à discussão um conceito muito caro para as relações internacionais e para a fragmentação da sociedade internacional, antes de cunho estatocêntrica: o transnacionalismo. Esse aspecto é explorado por autores como Bertrand Badie (1999), cujos escritos tratam de assuntos relativos à construção artificial dos Estados e suas implicações sociais e culturais, em verdadeiro esforço construtivista. Badie reconhece que a crise de legitimidade dos Estados não-Ocidentais resulta de contradição entre a prática de "importação" dos Estados e da imposição e da prática de uma vida política de acordo com outra lógica e racionalidade. A legitimidade desse Estado "importado", em crise, afetaria o SI.

\footnotetext{
${ }^{57}$ Barros-Platiau \& Góis (2004) avaliam que uma das principais consequências da globalização vem a ser o "conflito entre normas e sujeitos de direito internacional público", o que levaria a indagações a respeito da operacionalidade dos "referenciais de regulação". Os autores põem em evidência, juntamente com Varella (2013), a efetividade da continuação de um direito internacional eminentemente estatocêntrico em um mundo cada vez mais aberto à participação civil global. Barros-Platiau \& Góis consideram que os entes estatais crescentemente são chamados a "prestar contas" a outros atores da sociedade civil global com identidades múltiplas, em um "espaço público internacional."
} 
Fig. 2.1: Relação entre Governo e Sociedade

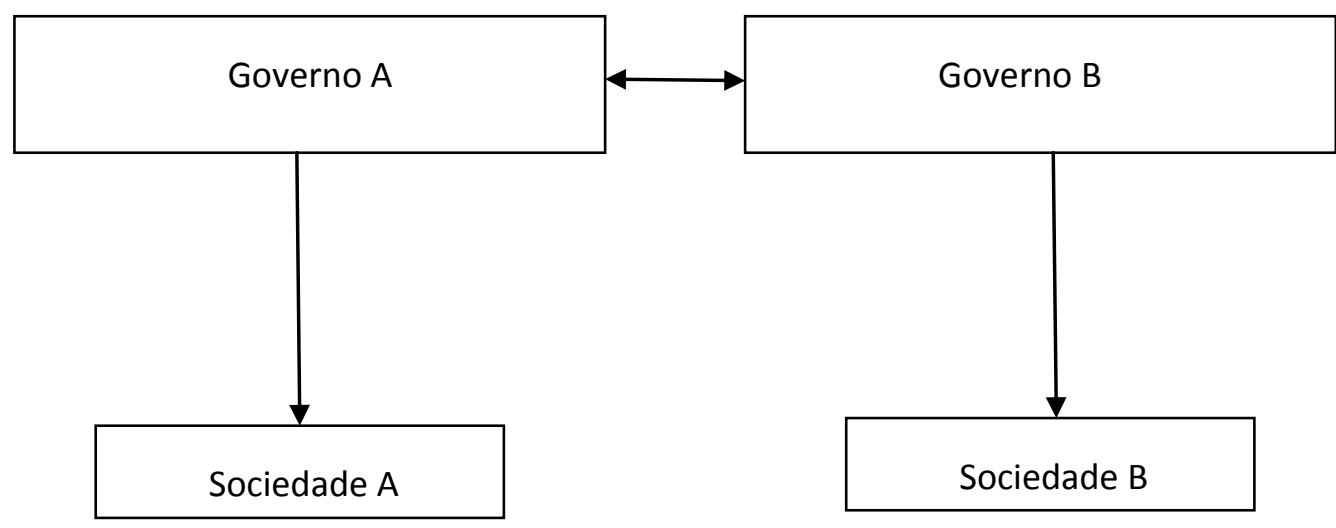

Tradicional vs Transnacional

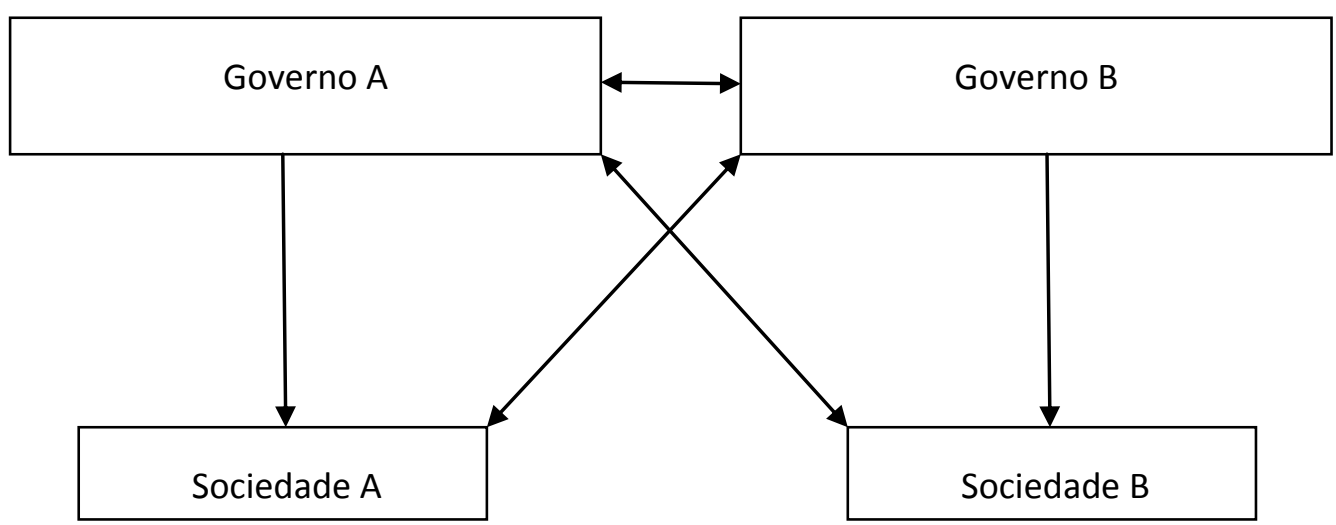

FONTE: Adaptado de Nye (2007)

Esse aspecto da multiplicidade dos atores vem para reavaliar, ainda que não deliberadamente, a relação entre os governos e a sociedade. A construção discursiva da ideia de um mundo global interfere naquilo que se entende empiricamente como um sistema internacional fragmentado. $\mathrm{O}$ esforço de teorizar esse sistema passa pelo arcabouço teórico dos estudos sobre a globalização e dos fatos internacionais, em razão da reelaboração contínua dos conceitos. O realismo clássico, por exemplo, ao desconhecer o papel da multiplicidade de agentes na cena internacional, não poderia alcançar uma análise mais promissora da atualidade das transformações ocorridas e que culminaram no reconhecimento da legitimidade, ainda que parcial, da sociedade internacional. 
Toda a doutrina sobre o cenário internacional contemporâneo, suas características, incertezas, evoluções, decadências e falências da noção um dia predominante dos Estados busca responder, na maior parte das vezes, ao verdadeiro significado do processo globalizatório e suas diversas vertentes sobre um dos elementos centrais da existência do ente estatal, a situação de sua "soberania" na ordem internacional. Os conceitos que surgiram como resposta às diversas crises humanitárias, como "direito de ingerência", "intervenção humanitária", "segurança humana", "responsabilidade de proteger", "ingerência ecológica" e "verde", além de diversos outros, remetem à necessidade de se redefinir - enquanto se rediscute - o conceito de soberania e o perene paradoxo que envolve o tema da globalização e seus princípios ontológicos de dissolução do Estado e de decomposição da ordem internacional.

São esses parâmetros que propomos rediscutir no próximo tópico. Entendemos que a soberania se dilui com a multiplicidade dos foros de decisão e com o compartilhamento das regras e normas que por tanto tempo fundamentaram uma ordem estatocêntrica nas relações internacionais, mas a figura do Estado ainda permanece basilar para a configuração de uma ordem global. O tema das intervenções ambientais comprova que, ainda com todas as alterações sistêmicas em sua relação com as sociedades, os governos permanecem na vanguarda da ideia de que deles emanam as fontes de segurança. $\mathrm{O}$ construtivismo securitário, embora inclua elementos adicionais de análise à parte do centralismo estatal, confere aos governos a "audiência" para determinar as potenciais "ameaças" do ponto de vista da securitização.

Inexiste tendência de que, ao menos na área ambiental, onde o transnacionalismo surge com força nas últimas décadas, os Estados deixem de conformar normas que regulamentem o trato societário entre governos e sociedades. Porém a construção de consenso parece muito mais árdua, e agendas importantes como a do clima e de florestas estão travadas há anos, com fraca expectativa de uma ação coletiva eficaz para o curto prazo. A redefinição das regras do SI, atributo das fontes de direito tradicionais, pautadas nas legislações e nos preceitos consuetudinários, são predominantemente estatais, apesar da influência de outros atores no processo. A globalização, com todos os aspectos naturais de alteração dessa ordem, tem decerto contribuído para a reformulação do conceito de soberania, em um processo dicotômico de ameaças e reafirmações. 


\subsection{Soberanias ameaçadas e reafirmadas}

Norberto Bobbio, em seu "Dicionário de Política" (1986), define soberania em seu sentido mais clássico como o monopólio internacional da força; o poder de garantir, em última instância, a eficácia de dado ordenamento jurídico. Sendo a garantia das relações pacíficas dentro do Estado, a soberania é, segundo Bobbio, também causa da guerra nas relações interestatais. $\mathrm{O}$ autor argumenta que, na arena internacional, a soberania estatal significa, em realidade, que o Estado não se sujeita a quaisquer leis que lhe sejam impostas por uma autoridade supra-estabelecida. Essa característica da soberania resulta em que, na ausência dessa autoridade (como ocorre no âmbito doméstico estatal) que imponha um ordenamento jurídico para regular as relações entre seus congêneres, os Estados recorrem ao uso da força, como uma "raiz profunda da política de potência, da guerra, do imperialismo" (idem: 1089).

A soberania constitui, assim, o apanágio do Estado. Sua posse gera automaticamente para o titular consequências diretas, conferindo-lhe uma "identidade corporativa" no interior de uma ordem jurídica internacional. A soberania é quem dita, no direito internacional, a personalidade jurídica estatal. Sendo um atributo da soberania, pode-se então afirmar que inexiste Estado sem uma personalidade jurídica nela pautada. Uma vez soberano, o ente adquire uma série de competências e capacidades, regulamentadas juridicamente, que fazem parte da própria identidade, entre elas a de produzir atos jurídicos internacionais, de ter imputado contra si fatos ilícitos, acesso aos procedimentos contenciosos internacionais, de tornar-se membro de instituições multilaterais e de estabelecer relações diplomáticas e consulares com outros entes soberanos (MAZZUOLI, 2006; DUPUY, 2008).

O termo "soberania" pode ser encontrado nas mais diversas disciplinas acadêmicas e no vocabulário de áreas tão vastas como Política e Direito, Diplomacia e RI, constituindo sempre relevante tópico de interesse que estimula discussões e controvérsias as mais diversas. ${ }^{58}$ A ideia de soberania é indissociável daquela de

\footnotetext{
${ }^{58}$ Nagan et alli (2003) apontam as dificuldades intelectuais de se decifrarem as "gradações sutis" típicas do termo "soberania" em cada uma daquelas disciplinas e elenca diferentes significados para o conceito, entre eles: 1. Soberania como um monarca personalizado; 2. Soberania como um símbolo para poder absoluto e ilimitado; 3. Soberania como um símbolo de legitimidade política; 4. Soberania como um símbolo de autoridade política; 5. Soberania como um símbolo de auto-determinação e independência
} 
desenvolvimento das estruturas do Estado moderno. Em seus primórdios, relacionava-se diretamente ao direito divino ilimitado dos soberanos sobre seus súditos. Jean Bodin (1530-1596) a denominava “La puissance absolue et perpétuelle d'une République”. O "príncipe" era, então, o garantidor da ordem política, pelo livre direito de criar leis, interpretá-las e executá-las (SENARCLENS, idem: 7).

Em sentido moderno, o rei detinha os três poderes necessários para a existência da soberania interna do Estado. A doutrina da soberania também foi estudo central na obra de Thomas Hobbes (1588-1679). À semelhança de Bodin, as duas características da soberania - face interna e externa - adquirem relevância como objeto de análise marcada pelas dissensões internas e as guerras de religião europeias do pós-medievo. $\mathrm{Na}$ obra maior do escritor e filósofo do absolutismo, "Leviatã", o homem torna-se o lobo do homem quando se encontra à margem de uma sociedade dominada pela figura do soberano.

Séculos depois dos adeptos da "teoria divina" da soberania, filósofos iluministas, como Jean-Jacques Rousseau e Alexis de Tocqueville, ou mesmo John Locke e o Barão de Montesquieu, darão o novo tom da soberania fundadora do Estado moderno, no momento em que o homem se torna paulatinamente protagonista como objeto de análise na Ciência Política. Segundo Senarclens (idem: 10) "a transferência da soberania ao povo é precedida e acompanhada de uma relevante reflexão doutrinária sobre os mecanismos constitucionais e os procedimentos necessários à realização da liberdade política, notadamente sobre os arranjos institucionais que dão consistência ao poder dos cidadãos e à sua representação no âmbito das instituições que encarnam a ideia de nação." (tradução livre do autor) ${ }^{59}$ Nas doutrinas de John Locke e do Barão de Montesquieu, o exercício da soberania será subdividida na tripartição do poder político (Executivo, Legislativo e Judiciário). Assim, na Constituição do Estado soberano,

nacional; 6. Soberania como um símbolo de governança e ordem constitucional; 7. Soberania como critério de validação jurisprudencial dos sistemas jurídicos; 8. Soberania como um símbolo da personalidade jurídica da igualdade soberana; 9. Soberania como um símbolo de "reconhecimento"; 10. Soberania como uma unidade forma de um sistema legal; 11. Soberania como um símbolo de poderes, privilégios e imunidades; 12. Soberania como um símbolo de competência jurisdicional; 13. Soberania como um símbolo de competências básicas de governança.

${ }^{59}$ No original: “(...) le transfer de la souveraineté au peuple est pourtant précédé et accompagné d'une importante réflexion doctrinale sur les mécanismes constitutionnels et les procédures nécessaires à la réalisation de la liberté politique, notamment sur les arrangements institutionnels donnant consistance au pouvoir des citoyens et à leur représentation au sein des corps constitués qui incarnent la nation. " 
idealmente oriunda do clamor popular e da participação dos cidadãos, subjaz a ideia moderna de soberania.

O conceito clássico de soberania vem sendo crescentemente contestado, não tanto em seus atributos, mas no significado para o sentido, também tradicional, de Estado. As transformações econômicas e políticas oriundas do processo globalizatório podem ser apontadas como fonte da eventual erosão parcial da ideia clássica de Estado. David Lake (2003: 303-323) acredita que esse processo vem influenciando, nos círculos acadêmicos, o estudo da soberania a ponto de o conceito vir a passar por uma "minirenascença". 60

Essa crise atinge diretamente a perspectiva da soberania encontrada nos escritos dos autores realistas e neorrealistas das RI e também os conceitos tradicionais de segurança. Para os realistas clássicos, a soberania é entendida como um atributo prático da existência estatal, idealizada ainda no Tratado de Westphalia (1648), "denotando a existência de uma autoridade suprema sobre um certo território, cuja ideia-chave seria a de que a soberania requer uma hierarquia política única". ${ }^{61}$ Essa teoria inicial unitária da soberania foi transposta, já nos tempos atuais, para a teoria dos níveis do sistema nas RI, onde a noção de "anarquia" ganharia novos adeptos (cf. BULL, 1977; WIGHT, 1979).

Em Problematic Sovereignty: contested rules and political possibilities (2001), Stephen Krasner levanta a questão sobre em qual extensão os atuais arranjos institucionais, regras e princípios associados à soberania inibem a solução de algumas das questões mais prementes na ordem global contemporânea. Questiona se essas regras podem ser desviadas ou ignoradas ou se elas se apresentam como uma insuperável barreira para soluções estáveis, reconhecendo a dificuldade de se analisar o conceito de soberania em razão da variedade de acepções nas diversas áreas do conhecimento, que implicam desdobrá-lo em facetas diferenciadas. Muito embora o poder e preferências de atores estrangeiros eventualmente limitem as opões disponíveis de um Estado qualquer, soberanias não são limitadas (constrained), no entender do autor, em razão de atores

\footnotetext{
${ }^{60}$ Lake (idem) considera que a crise com o conceito da soberania advém de seu principal aspecto, a hierarquia, que constituiria um verdadeiro dead horse no estudo e na prática da política internacional.

61 Idem, ibidem.
} 
externos que tenham controlado suas estruturas de autoridade doméstica. Na evolução de um ambiente anárquico, o sistema internacional contemporâneo criou suas próprias regras e atores, em que Estados soberanos seriam os "blocos formadores", as unidades básicas do moderno sistema estatal. Nesse sistema de soberanias plenas, os Estados são unidades territoriais com independência jurídica, não se sujeitando a quaisquer autoridades externas. $^{62}$

Um dos desafios modernos à soberania no cenário internacional contemporâneo refere-se à diversidade de atores que buscam sobrepor as regras convencionais do jogo. ${ }^{63}$ Alguns autores são refratários à ideia de uma soberania absoluta, como Gardner (2011), que aponta para o retorno à discussão primária do conceito de soberania na OAI, a fim de fazer frente às novas ameaças securitárias no âmbito do meio ambiente.

Deve-se considerar que aqueles desafios ao conceito de soberania são inerentes ao atual estágio das relações internacionais, como vimos anteriormente ao analisar a influência da globalização sobre a figura do Estado. Tomando como ponto de partida a natureza das novas ameaças, securitizadas ou não, percebemos que os entraves impostos aos Estados de pensarem estrategicamente em questões militares-defensivas não mais parecem assemelhar-se com as tradicionais percepções do que representava um perigo ao seu território. A razão para tanto encontra-se nas características dessas novas ameaças, que levam os tomadores de decisão a reavaliarem seus cálculos diante de uma

\footnotetext{
${ }^{62}$ Em esforço de limitar a quantidade de formas como o termo "soberania" tem sido utilizado, Krasner oferece uma tipologia de quatro significados da noção de soberania: "interdependente", como a habilidade de os Estados controlarem movimentos transfronteiriços; a "doméstica", relacionada às estruturas de autoridade dentro dos Estados; a "westphaliana", no tocante à exclusão de fontes externas de autoridade tanto de direito quanto de fato; e a "legal internacional", referente ao reconhecimento mútuo dos Estados.

${ }^{63}$ Como desafios anteriores, Krasner (idem) sustenta não haver possibilidade de superar a ordem soberana. $\mathrm{O}$ autor cita entre os atores a própria União Europeia, que, enquanto coexistindo "confortavelmente" com instituições no cenário internacional, sobrepõe as soberanias Westphaliana e a "international legal sovereignty", bem como altera as estruturas domésticas de autoridade de seus membros, incluindo o abandono de seus direitos de controlar os fluxos transnacionais em diversas áreas. Aponta, ainda, as organizações internacionais, como as Nações Unidas, o Fundo Monetário Internacional, o Banco Mundial, entre outros. Krasner reconhece o caráter voluntário da adesão às normas de muitas das instituições financeiras internacionais, e que tais atos comprometem a autonomia doméstica dos Estados, mas como ele mesmo afirma "better to get the money and acknowledge external involvement in domestic authority structures than to reject such involvement and be impoverished." As organizações nãogovernamentais, nas últimas décadas, têm sido vistas igualmente como um desafio à soberania estatal. A propagação do ideário da democracia e as mudanças tecnológicas fazem com que as atividades daquelas organizações operem nos e entre os Estados de modo "saliente" (idem: 246).
} 
nova variável analítica, a ambiental. Como funcionaria essa reordenação das ameaças ambientais na prática?

Os efeitos de problemas ambientais raramente estão confinados ao território de um Estado, por serem transnacionais. Do ponto de vista jurídico, para a maioria dos casos de danos ambientais transfronteiriços é prevista reparação e responsabilidade estatal, haja vista que a um ente não é dada a permissão de realizar atividades na “jurisdição doméstica” (KRASNER, 2001) que prejudique o território de um outro (KISS \& SHELTON, 1997). David Held (2003) vai além nas considerações acima sobre soberania e considera que o sistema de Estados soberanos tornou-se um "emaranhado" complexo de regras que evoluíram para assegurar a concepção de uma ordem estatal como uma sociedade internacional de governos soberanos, em ideia comparável à de Hedley Bull (1977).

Andrew Hurrell (2007) já avaliava que a crescente "seriedade" dos problemas ambientais faz acreditar que as formas tradicionais de sociedade internacional são inadequadas e que o sistema de Estados poderia estar caminhando para uma crise. Hurrell argumenta que o Estado adquire cada vez mais uma natureza bifacetária, quando confrontado com tais problemas, sendo ao mesmo tempo grande e pequeno: "too big for the task of devising viable strategies of sustainable development which can only be developed from the bottom up; and too small for the effective management of global problems such as combating global climate change or protecting biodiversity which by their nature demand increasingly wide-ranging forms of international cooperation.' (idem)

$\mathrm{O}$ autor apontou três argumentos no que tange à inabilidade da comunidade internacional em solucionar "desafios ecológicos". O primeiro referir-se-ia ao sistema de Estados como um todo. Dessa perspectiva, tal sistema estaria em crise ou “disfuncional" por não prover mais um quadro político viável que proporcione o gerenciamento coletivo do meio ambiente global. Um segundo argumento aponta para o fato de que um número crescente de Estados (individualmente) não é mais capaz de prover uma ordem local e um grau adequado de gerenciamento ambiental dentro das próprias fronteiras. O último, sinalizou como além da capacidade prática da figura 
estatal em lidar efetivamente com esses novos desafios. Hurrell, assim, avalia que os problemas ambientais estão "erodindo" o apelo normativo estatal e sua ideia como o foco primário das "lealdades humanas".

Para o sociólogo John Boli (2004), a soberania seria um "script" em que a mais importante linha é a de que o Estado tem o direito legítimo de exercer sua autoridade, podendo rejeitar alegações de autoridades oriundas de entes externos, ainda que com consequências que remetam à ideia primária de poder nas relações internacionais. Ao comentar a problemática da intervenção e sua relação com a soberania, Boli assevera que a prática das intervenções tende a tornar-se crescentemente legítimas. No entanto, os Estados concordariam em compartilhar autoridade para preservar seu controle em face do processo de globalização econômica, de clamores pela universalidade dos direitos humanos e cidadania e da crescente saliência das normas transnacionais que tendem a "sobrepor" o controle doméstico estatal.

O conceito de soberania, pela mutação por que vem passando, oferece perspectiva renovada para uma discussão mais profícua de seus atributos, entre eles o tema da segurança. Se antes a segurança se referia naturalmente aos aspectos militares e estratégicos de defesa do território ou ao fortalecimento da economia, nas relações internacionais contemporâneas assiste-se hoje à paulatina e irreversível extensão do conceito para incluir variáveis ambientais e sociais. A securitização do meio ambiente relaciona-se diretamente com essa evolução do significado do conceito de soberania e será assunto do próximo tópico. Pensar o tema das obrigações positivas no cenário internacional, para além da reafirmação do conceito da soberania e do papel central dos Estados na ordem ambiental, passa pelo reconhecimento de que o meio ambiente adquiriu forma mais ampla, ao incluir a segurança como atributo inerente de sua análise.

\subsection{A securitização do tema ambiental}

Propomos aqui explorar a literatura da evolução do tema securitário à luz da inclusão da variável ambiental. Buscaremos demonstrar como foi construída socialmente a relação entre as duas variáveis e como as influências políticas e 
científicas trabalham conjuntamente para conformar a ideia de que o meio ambiente cada vez mais se torna um tema imprescindível nas relações internacionais. ${ }^{64}$

Para além dos efeitos dos desastres ambientais sobre a economia dos países, devemos analisar até que ponto as crises envolvendo a variável ambiental são causas primárias de conflitos. Dupont (1998) avalia que não. O autor reconhece que questões ambientais interagem diretamente com causas mais diretas do conflito de forma a estender ou "complicá-lo", mas sem ser a causa primária. Em contraposição, Biswas (2011) aponta para a natureza avançada de alguns Estados, cujas instituições de segurança atuais estão modernizadas e adaptadas a situações de gerenciamento de crises advindas de desastres naturais ou programas de recuperação. O autor utiliza-se de sofisticada linha argumentativa e considera salutarmente o crescente apoio que países como Estados Unidos, Alemanha, França, China, entre outros, tem dado a temas como mudança climática, de que são exemplos as variadas fontes de pesquisa fundadas sobre documentos estratégicos de suas Forças Armadas.

Com o final da Guerra Fria não somente novas diretrizes para as políticas externas dos países estavam postas, como também uma reavaliação dos conceitos que baseavam suas estratégias de segurança, por estarem convenientemente envolvidos ao lado de um dos contendores (GADDIS, 1998). Muito embora já na década de 1970 a revolução tecnológica já anunciava mudanças no contexto internacional (KEOHANE \& NYE, 1989), somente com o fim daquela ordem pôde-se construir um verdadeiro arcabouço conceitual nos foros internacionais. O globo, a partir de então, passou a

\footnotetext{
${ }^{64}$ Revisitando brevemente a literatura, nota-se a perspectiva interdisciplinar sobre estudos de segurança e meio ambiente, que realça nos dias atuais a necessidade de simbiose entre os conceitos. A evolução temática não foi simples e acompanhou pari passu o reordenamento discursivo das RI, no que concerne aos desdobramentos teóricos das principais linhas do pensamento. A análise realista sobre segurança desconsidera o meio ambiente como um problema de interesse a ser debatido na teoria, tendo em vista a centralidade do Estado na ordem global, dotado de personalidade que lhe garante exercer premissas de força em prol da sobrevivência. Assim, o tema ambiental passou a ser considerado nas discussões acadêmicas com autores pós-realistas e construtivistas, como em Hassan (1991), que discutiu a importância da variável ambiental para a economia dos Estados, quando analisou as consequências dos desastres ambientais para o crescimento econômico, ou le Prestre (2000, 2005), quando analisa o meio ambiente com as lentes políticas (Ecopolítica Internacional), buscando estabelecer uma relação entre a degradação de recursos naturais e conflitos. Não devemos desmerecer que mudanças ambientais reduzem as oportunidades econômicas de um determinado ator, em razão de deslocamentos demográficos internos transnacionais, causadores de tensões transfronteiriças, daí o interesse crescente igualmente da teoria econômica em explorar essa relação entre temas, como Mudança Climática e Biodiversidade, nas estruturas produtivas e nas relações interestatais.
} 
enfrentar problemas antes já existentes e cruciais, mas relegados a um dos polos de poder global e dificilmente solucionados no âmbito multilateral. ${ }^{65}$ As discussões sobre o conceito de segurança ganharam novos contornos e concepções, como Segurança Humana, passaram a dar o tom da literatura e a serem aceitas pelos acadêmicos, políticos, diplomatas e outros setores da sociedade, ainda que sob variadas e convergentes perspectivas (UNDP. Human Development Report, 1994).

O conceito de segurança usualmente esteve atrelado às concepções realistas de poder e interesse nacional. Há algumas décadas, dizer que o impacto ambiental da degradação - ou as consequências da mudança climática - pudesse entrar na análise dos decision makers seria algo inusitado. Hoje, ao contrário, não é possível discutir segurança internacional sem que se considerem questões como desmatamento, mudança climática e desastres ambientais. A mudança de paradigma e das dimensões daquele conceito fez-se acompanhar de reformulações epistemológicas nos estudos dos temas internacionais, que a definiam até então pautadas no tradicional realismo político, no qual o termo se fundamentava quase que exclusivamente em relações de poder. Com o advento das concepções pós-realistas e o desafio ao estatocentrismo e ao interesse nacional, como as razões da lógica existencial das relações internacionais, um esforço de redefinição da segurança, em parte para ampliá-la e incluir novos temas, foi realizado. Nesse contexto de redefinição dos pressupostos do conceito, para torná-lo mais próximo da pessoa humana, o meio ambiente esteve entre os tópicos cuja "securitização" foi largamente aplicada.

Ullman (1983) foi um dos pioneiros na busca desse "alargamento" conceitual das ameaças tradicionais para compreender as ameaças não-militares. Ao incluir novos componentes às ameaças, em especial estudos relativos à qualidade de vida dos cidadãos em sociedade, revolucionaria as pesquisas sobre segurança internacional. No âmbito multilateral, a Conferência Internacional sobre a Relação entre Desarmamento e Desenvolvimento, organizada pela AGNU, no final da década de 1980, inaugurou a elevação do tema das ameaças não-militares à segurança nas mesas de negociações

\footnotetext{
65 Naquele período, o foco do multilateral passou para o Oriente Médio, em razão da nova ordem unilateral norte-americana, e também para o continente asiático, pela emergência da China e da Índia. A América Latina e a África, nesse contexto, restaram relegadas ao esquecimento. Como resultado, países como o Brasil investiram no âmbito regional, de modo a alavancar sua política externa.
} 
globais (BISWAS, idem: 5). Anos depois, a questão das crises econômicas seria considerada uma ameaça à Segurança Humana, pelo Relatório das Nações Unidas sobre o Desenvolvimento Humano (ALVES, 2010).

A securitização do tema ambiental não ocorreu como um processo simples e envolveu uma miríade de opiniões polarizadoras quanto à extensão do conceito. Cada ponto de vista seria defensável a partir das diferentes escolas de RI, do realismo tradicional aos pós-positivistas e construtivistas. Ao retomar os ensinamentos do círculo de Copenhague a respeito das problemáticas apontadas no setor ambiental, pretendemos debruçar-nos sobre a incerteza quanto às políticas produzidas por aquelas questões. Discordamos do ponto de vista de Waever et allli (1998) de que os temas ambientais, ao serem "securitizados" pela heterogeneidade dos atores existentes na área ambiental, são limitadamente politizados.

Quando analisamos questões envolvendo os desastres ambientais, percebemos no plano empírico que as ameaças se tornam crescentemente emergenciais e distantes das opiniões de que os problemas ambientais possuiriam um prazo mais longo a serem solucionados. Desastres ambientais como os ocorridos na central de Chernobyl (1986/Ucrânia) e Fukushima-Daiichi (2011/Japão) requerem soluções imediatas e genuinamente céleres, sem paralelo aparente a outros temas da seara ambiental, negociados nos foros multilaterais em outros ritmos, como a mudança climática, a biodiversidade e proteção de florestas, para citar alguns. Um dos questionamentos que surge ao pesquisador, ao tratar de questões relacionadas às obrigações positivas relativas ao meio ambiente, passa pela busca de se conhecer o nível a que alguns temas são mais "securitizados" que outros. A transnacionalidade da temática ambiental, no sentido de que diversos outros atores buscam "securitizar" o meio ambiente de forma exagerada, torna falho o argumento quando se trata de questões ambientais cuja intervenção seja o único meio de salvaguardar o território e a população de um determinado Estado-vítima.

Diante de tais contestações, não há como concordar com autores que admitem que o meio ambiente não constitua causa primária de conflitos interestatais, como defende Dupont (1998). Questões ambientais, embora interajam com causas mais diretas de conflito, de modo a prolongar ou complicar disputas existentes, também 
podem ser fontes de conflitos. O argumento de Waever \& Brock (1997), que presumivelmente identificaram uma relação entre militarismo e meio ambiente como “contraproducente", parece não corresponder à realidade, por acreditarem que as instituições tradicionais de defesa controladas pelo Estado não possuem instrumentos de cooperação ou auxílio para lidar com acidentes naturais. $\mathrm{O}$ entendimento dos autores, portanto, desatualizou-se diante das configurações multilaterais e regionais cada vez mais atentas para a securitização ambiental.

Instituições do sistema securitário internacional como a OTAN passaram a atribuir maior relevância aos desafios que emanam da temática ambiental. Fundamentada em uma definição alargada do conceito de segurança, reconhecem que fatores políticos, econômicos, sociais e ambientais, para além dos tradicionais parâmetros, são também causas dos conflitos. Nessa perspectiva, a Aliança Atlântica passou a incluir nos cálculos de segurança variáveis que partem de condições extremas de meteorologia e esgotamento de recursos naturais, até a poluição atmosférica e outros fatores com probabilidade de tornarem-se fontes de desastres, violência e tensões regionais. A organização, desse modo, busca correntemente maneiras de direcionar e gerenciar riscos ambientais à segurança em geral, bem como àqueles que influenciam diretamente suas atividades militares. ${ }^{66}$

Em tal situação, encontram-se os fatores ambientais que podem afetar o suprimento de insumos energéticos para as populações de áreas afetadas e para seu contingente militar, o que torna o tema energético um tópico de imediata preocupação. Dentre as atividades inovadoras da OTAN, pode-se citar o apoio aos países-membros e parceiros de auxílio à limpeza de estoque de armamentos defasados que representam riscos para o meio ambiente e de remanescentes de armamentos utilizados em conflitos presentes na natureza, responsáveis anualmente por elevado número de vítimas em todo o mundo. ${ }^{67}$

Se a percepção de que a variável ambiental pode ser realmente concebida como uma verdadeira ameaça, com importância em paralelo a outros temas securitários considerados "tradicionais", quais as expectativas no campo regulatório e normativo

${ }^{66}$ Cf. www.nato.int/ (acesso em 15/06/2014).

${ }^{67}$ Idem (acesso em 15/06/2014). 
para a conformação de conceitos que, em uma análise centrada no construtivismo, podem ser viáveis? A análise do tema da segurança internacional relacionado ao meio ambiente passa certamente pelos "atos de fala", que transformam o discurso em ação. Nos últimos anos, é inegável que a variável ambiental tenha pautado a agenda de segurança de diversos países, a exemplo das discussões no âmbito multilateral sobre a possibilidade de eventuais intervenções "verdes" em países assolados por tsunamis no Leste asiático. Tal assunto merece capítulo específico. Por ora, vale retomar o conceito de segurança ambiental (SA), no intuito de perscrutar seus aspectos mais prementes.

O campo de estudos que se convencionou denominar SA emerge da interseção de duas preocupações políticas: segurança e meio ambiente. Ambas as áreas são fortemente contestáveis e tornam passíveis de ambiguidades também os conceitos a si aplicáveis. O tema a que este trabalho se aventura é resguardado por inúmeras interpretações dos reais significados do que a SA pode representar. Para Barnett et alli (apud Lopes, 2010), o conceito de segurança refere-se geralmente à liberdade do risco à perda ou dano de algo relevante para a sobrevivência. Segundo o autor, o conceito poderá ter aplicação estreita ou ampla a um limitado conjunto de objetos a serem assegurados, ou a uma mais profunda série de elementos interconectados em um dado sistema social.

Como o conceito de segurança, em seu sentido mais amplo abarcando a variável humana para além dos aspectos estratégicos, implica um meio ambiente equilibrado e sadio para as populações envolvidas, precisamos rever o conceito de SA, de modo a transformá-lo em um discurso mais inclusivo com relação aos danos ambientais. Também provê-lo de terminologias mais apropriadas que corresponda às aspirações dos entes estatais como agentes da proteção ambiental e de sua população em situações de emergência. A relação entre meio ambiente e segurança dos seres humanos tem sido objeto de pesquisa há décadas, muito embora somente na atualidade tenha-se tornado foco de mais atenção nas relações internacionais (em especial depois da década de 1990).

Quando se avalia o tema do meio ambiente, alguns pontos curiosos que nos auxiliam a pautar e direcionar as discussões sobre a SA vêm à tona. Um deles indica 
que as questões ambientais seriam as mais transnacionais, no sentido de maior envolvimento da "sociedade civil global". 68 Esse fato resulta em que a segurança ambiental torna-se uma relevante dimensão a ser levada em consideração na busca da paz e da proteção dos direitos humanos. A humanidade terá de enfrentar variadas escolhas entre as formas atuais de consumo, de conservação e manejo do meio natural, além de rever os padrões civilizatórios atualmente existentes, os meios produtivos e a internalização das externalidades.

A SA torna-se central, nesse contexto, para a segurança dos Estados no cenário internacional e envolve uma dinâmica entre os recursos naturais, o tecido social estatal e a engrenagem econômica com vistas à estabilidade regional e local em diversas partes do planeta. Enquanto os efeitos precisos das questões ambientais sobre os processos de paz, conflito, e segurança humana podem diferenciar em cada situação, há crescente indicação de que o meio ambiente é cada vez mais causa de instabilidades e conflitos. ${ }^{69}$ Uma das razões passa pelo crescimento populacional, que exerce maior pressão sobre os recursos ambientais. Mesmo admitindo que a tecnologia permitirá um uso mais eficiente daqueles recursos, não há garantias de que o acesso à tecnologia de forma ampla esteja disponível, tendo em vista a lógica atual dos padrões capitalistas de sua transferência.

No âmbito multilateral, muito embora o discurso da SA tenha adquirido certa proeminência na "Década das Conferências" (ALVES, 2001), a aliança dos dois temas segurança e meio ambiente - já dava mostras de aparecer na transformação discursiva há pelo menos três décadas, tributária dos trabalhos das primeiras conferências internacionais sobre o tema. O trabalho seminal que inaugura, no âmbito multilateral, a noção de que a segurança deveria ir além da tradicional visão militar, pode ser associada ao supra citado "Relatório Brundtland" (1987), ao preconizar que o impacto das armas de destruição em massa constituiria um grave perigo ambiental, sugerindo a existência

\footnotetext{
${ }^{68} \mathrm{Cf}$. Nota $\mathrm{n}^{\circ} 11$ supra, que trata do conceito de "Sociedade Civil Global".

69 O tema da segurança ambiental em Le Prestre (2005) adquire contornos interessantes. O autor desenvolve um framework visando racionalizar a questão, ao afirmar que o conceito assume ao menos quatro acepções principais: a segurança ambiental; dos indivíduos; dos Estados; e da ordem internacional. Le Prestre considera que uma evolução clara da noção de "segurança ambiental" está em operação, ao levar em conta que a ideia de "tradicional" referia-se tão somente ao pensamento sobre a segurança ambiental em termos de acesso aos recursos naturais, com alguma relevância na área militar.
} 
de uma relação causal entre environmental stress, tensões políticas e conflitos militares. Aponta, ainda, provável recrudescimento de conflitos por acesso e controle a recursos naturais em razão da escassez de alguns deles.

Atualmente, associa-se também a SA ao impacto das mudanças ambientais sobre a coesão social nacional e sobre a estabilidade internacional. Os trabalhos recentes nesse campo pautam-se sobre a existência de uma relação positiva - potencial ou real - entre cooperação internacional na área do meio ambiente e a diminuição de conflitos. Le Prestre (idem) considera que a SA faz referência a conceitos e interrogações diversas, de acordo com as "preocupações" de cada ente. Pode conter os germes de nova dimensão importante das relações internacionais, definir opções de governos, influenciar relações de cooperação e conflitos entre Estados e servir para mobilizar populações.

Em análise mais acurada, le Prestre avalia que relacionar o meio ambiente aos conflitos armados tende a servir tanto para a promoção dos interesses de certos Estados, grupos ou organizações, quanto para o anúncio da dinâmica dos conflitos futuros. O autor aponta para como a Guerra do Golfo (1991) mostrou que valores ambientais podem servir a fins políticos em tempos de guerra, em análise aproximada do pensamento de Waever (1997). Nesse caso, um dos beligerantes pode ameaçar causar danos ao meio ambiente ou acusar um outro de tê-los feito, de forma a utilizar-se da variável ambiental como meio de propaganda (uma espécie de "instrumentalização" do tema para fins políticos, após a tentativa de transformá-lo em objeto de segurança). ${ }^{70}$

A acepção da SA com foco no ser humano, segundo le Prestre (idem, ibidem) reveste-se de múltiplos aspectos, entre eles (1) os atentados diretos à saúde dos indivíduos, por meio da intoxicação, das pandemias ou da poluição radioativa, fenômeno que se internacionaliza facilmente por causa da mobilidade transfronteiriça de

\footnotetext{
${ }^{70}$ No Golfo, os meios de comunicação, assim como as organizações internacionais e ONGs, exerceram um papel decisivo de "instrumentalização" do meio ambiente, ao fornecer uma "legitimidade ambiental" a algumas iniciativas militares, como ocorreu no início das operações militares dos marines norteamericanos de missão de reconhecimento do território iraquiano com a finalidade de avaliar a amplitude dos danos causados pelo incêndio dos poços de petróleo no norte do Golfo por forças de Saddam Hussein. A missão objetivou documentar crimes de guerras cometidos pelo governo iraquiano com vistas a responsabilização internacional do país após o conflito. Na época, o Presidente George Bush chegou a classificar as ações iraquianas de "terrorismo ambiental" - um conceito polêmico que demonstra bem os desvios a que podem ser submetidas as análises securitárias do grupo de Copenhague, pela simples aceitação do discurso dos "atos de fala" sem uma análise mais crítica do conteúdo.
} 
poluentes; (2) o NIMBY (do inglês "not in my backyard”), que tem causa direta com o aspecto precedente, e faz as populações locais recusarem a implementação de instalações as mais diversas que tornam suscetíveis de ameaçar sua qualidade de vida e saúde; (3) os desastres ambientais, nas suas mais variadas vertentes, como inundações, secas, furações, tormentas e epidemias, que representam um risco físico ou material imediato com efeitos negativos de longo prazo sobre a capacidade das populações de evitá-las; (4) a poluição transfronteiriça, que representa uma fonte de tensões internacionais ligadas a vários fatores, como a gravidade da poluição, o grau a que a fonte e o alvo são afetados, e a diferença entre as normas nacionais, elas mesmas em parte relacionadas à natureza do sistema político e à capacidade de um governo de fazer com que as regulamentações existentes sejam respeitadas.

A segurança dos Estados representa outro aspecto da relação entre segurança e meio ambiente, podendo-se considerá-la uma extensão da abordagem anterior, ao conceber a SA a respeito da proteção das instituições sociais, políticas e econômicas nacionais em face das mudanças ecológicas externas. Ullman (1983) acredita que os perigos enfrentados pela segurança nacional dizem respeito a toda influência ambiental que conduza a uma ameaça de redução significativa da autonomia de ação dos governos. Para le Prestre (idem: 390), do ponto de vista nacional, os governos tendem a se preocupar com mudanças globais suscetíveis de gerar impactos sociais e econômicos em seu território e no dos quais mantém alguma relação especial. $\mathrm{O}$ autor aponta dois tipos de ameaças: uma que se relaciona diretamente à sociedade nacional e aos seus valores fundamentais; outra que influencia indiretamente conflitos nos quais o Estado se encontre envolvido. $^{71}$

\subsection{Considerações finais}

O capítulo buscou oferecer uma visão panorâmica dos novos desafios por que passou a ordem global contemporânea nas últimas duas décadas e meia. O processo de

\footnotetext{
${ }^{71}$ Quanto à segurança do sistema internacional, um escopo mais amplo, le Prestre considera que ela diz respeito às ameaças diretas e indiretas das profundas modificações ambientais como fontes de novos conflitos interestatais. Essa forma de segurança está mais relacionada aos eventuais conflitos oriundos da gestão dos recursos naturais comuns, como o uso da água e gestão das bacias hidrográficas e florestas, com efeitos nocivos para toda a humanidade ou regiões do globo (QUEIROZ, 2011). Mesmo que um Estado não se sinta diretamente ameaçado, pode ser que profundas modificações do meio ambiente ou que a raridade dos recursos criem novas fontes de conflitos interestatais.
} 
globalização atingiu de forma inexorável o entendimento que antes se mantinha dos principais temas na política internacional. $\mathrm{O}$ avanço dos transportes $\mathrm{e}$ das telecomunicações tornou o mundo mais integrado e o conhecimento científico privilegiou-se dessas novas perspectivas.

Não foi somente o contato entre os governos que facilitou o compartilhamento de políticas públicas e de estratégias de combate a problemas transnacionais, mas também a maior interação entre diversas sociedades com interesses comuns nos mais variados temas, como meio ambiente, direitos humanos, cultura, dentre outros, a compor uma sociedade transnacional ou, como preferem alguns autores, uma "sociedade civil global”. A proliferação das ONGs, principalmente no Norte, trouxe novo alento a temas como os ambientais e às estratégias de preservação, e consigo a desconfiança crescente de alguns países do Sul com relação às suas reais intenções.

Essa proliferação dos atores, também incluídos os regimes internacionais, as comunidades epistêmicas e as estruturas societárias paraestatais, com seus valores e normas e inovadoras formas de se pensar temas os mais diversos - em uma rede transnacional de contato e iniciativas a influenciar temas antes afetos prioritariamente aos Estados - parece desafiar crescentemente a estabilidade político-global. Nesse contexto de fragmentação da OAI, as soberanias são cada vez mais ameaçadas e reafirmadas, em um fluxo constante e ambíguo de iniciativas centrípetas (uma governança global?) e centrífugas (ou uma sociedade plenamente pluralistaminimalista?) por parte dos Estados na sua relação com essa nova variedade de atores que figuram a ordem global.

Se, para alguns, a ameaça à soberania surge da multipolarização das relações entre governos, sociedade civil e OIs; para outros, a densidade normativa internacional influencia a perda de independência dos Estados diante do transnacionalismo dos problemas contemporâneos, proporcionando uma maior securitização de áreas colaterais em paralelo aos tradicionais preceitos de defesa e estratégia. A securitização ambiental insere-se nesse quadro analítico, e certamente trouxe desafios inovadores aos Estados, por terem de repensar na modernidade aqueles tradicionais conceitos de segurança e de 
enfrentar temas não antes afetos diretamente às suas preocupações, como as intervenções verdes.

Esta abordagem não poderia ser apresentada mais adiante sem uma análise dessas características da ordem global contemporânea, de suas vertentes e de seus aspectos a influenciar a interação entre os mais diversos agentes, tanto públicos quanto privados. Um esforço de reflexão sobre essa nova ordem que emergiu no pós-Guerra Fria e que vem mantendo uma desigual cadência foi certamente necessário. Os anos 1990 testemunharam a unipolarização da política global e, em sentido contrário, a proliferação dos temas sociais e ambientais mais voltados para uma multipolarização subjetiva. Na década passada, o combate ao terrorismo traria novamente à tona os fantasmas da exacerbação da lógica securitária tradicional militar interventiva, resguardadas por alegada defesa dos princípios universais de combate ao terrorismo. Essa dinâmica levaria ao centro da arena internacional uma clivagem multipolar, não somente Norte-Sul, nas discussões e negociações sobre conceitos, como a R2P, em paralelo à continuidade de temas ainda candentes. A atual década parece reservar um ponto de inflexão nessa mudança, ainda a ser avaliada em seus múltiplos fatores.

Partindo dessa análise ampliada da ordem global contemporânea, parece prevalecer cada vez mais uma sociedade consensualista-maximalista, não ainda consensualista-coercitiva, como almejou idealmente Andrew Hurrell (2007), mas um equilíbrio (ou uma contraposição?) de forças entre as tendências realistas-pluralistas e maximalistas. Trataremos no próximo capítulo da OAI, com suas peculiaridades, com características reflexivas daquele ambiente anárquico, que adquiriu uma dinâmica própria em razão da natureza específica dos problemas ambientais. Conhecer os instrumentos analíticos e o terreno em que vamos adentrar, na busca de conhecer a natureza das intervenções verdes, é esforço primordial nesta primeira parte da pesquisa. 
CAPÍTULO III

A ORDEM AMBIENTAL INTERNACIONAL:

ASPECTOS E DIMENSÕES 


\title{
III. A Ordem Ambiental Internacional: aspectos e dimensões
}

\begin{abstract}
"As our perspective changes, it is important to adapt our policy framework to meet this change. One alternative is to focus on human security, recognizing the inter linkages of environment and society, and acknowledging that our perceptions of our environment and the way we interact with our environment are historically, socially, and politically constructed."

\section{Global Environmental Change and Human Security Project Steven Lonergan, Kent Gustavson, and Brian Carter}

\subsection{Considerações iniciais}

A crescente preocupação com o meio ambiente fez, nas últimas décadas, os temas ambientais surgirem com força na arena internacional. Os países considerados "desenvolvidos" foram os arautos dessa nova fase de transposição do tema, antes resguardado sob o manto do princípio da soberania absoluta e do pensamento realista nas relações internacionais. A maior atenção aos problemas relacionados ao meio ambiente deveu-se por diversos motivos, entre os quais as diferentes constantes catástrofes que ocorriam e que não poderiam ficar em segundo plano nas discussões internacionais sobre o futuro da humanidade nos foros multilaterais. São exemplos acidentes de proporções antes inimagináveis, como o desastre de Minamata, no Japão, em 1956, causado por contaminação de mercúrio por uma indústria local, o naufrágio do petroleiro "Torry Canyon", em 1967, na costa britânica, o desastre de Seveso, na Itália, em 1976, também por contaminação química, além de constantes denúncias das comunidades científica e acadêmica dos abusos contra a natureza cometidos em diversas regiões do globo. ${ }^{72}$

O início das discussões ambientais em foros como as Nações Unidas ou, de forma incipiente, na então Comunidade Europeia, não foi fácil, mas constituiu relevante passo para a afirmação de uma ordem ambiental (KISS \& SHELTON, 1997). Nos anos 1960, o tema do Meio Ambiente, ainda que incipiente, começou a adquirir uma maior

\footnotetext{
${ }^{72}$ Cf. Alfaia Jr, R. (2008) e Anexos II e III.
} 
relevância na agenda internacional, em decorrência dos desastres ambientais supra citados e da pressão ocidental para fomentar a regulação internacional de questões ambientais, aliada a uma tomada de consciência generalizada que foi ouvida pelos decision makers progressivamente e, coincidentemente, com o final da Guerra Fria. $\mathrm{O}$ tema do desenvolvimento apresenta-se como crucial nos fóruns multilaterais naquela década, a exemplo da CNUMAH (Conferência de Estocolmo/1972), onde transparecia de forma clara a clivagem Norte-Sul. Desenvolver era a palavra de ordem, para diminuir a pobreza por meio da industrialização, ainda que não se considerasse eventual degradação do meio ambiente, vistos como efeitos colaterais.

A distância temporal entre a Conferência de Estocolmo e a Conferência das Nações Unidas sobre Meio Ambiente e Desenvolvimento (CNUMAD), a Rio-92, conduz à reflexão sobre quais os motivos do aparente "esfriamento" do tema ambiental na agenda internacional do período da Guerra Fria. Embora provocativo e instigante, buscar tais variáveis a fundo ultrapassa o escopo deste trabalho de tese, razão pela qual avançaremos tão somente para avaliar os desdobramentos daquelas conferências na OAI.

A proliferação das instituições e o recrudescimento da densidade normativa a partir de então, consubstanciada na expansão do número de acordos entre os atores da OAI, levaram a uma notável fragmentação do DIMA, sentida atualmente pelo "travamento" de decisões em foros relevantes como nos regimes de florestas e mudança climática, sem olvidar da questão sobre produção e transporte de organismos vivos modificados (OVM), tratados pelos inócuos protocolos de Cartagena. Este capítulo pretende explorar o significado dessa ordem internacional que se formou nas últimas décadas. O tema das intervenções caminhou em paralelo ao desenvolvimento da OAI. Se hoje cogitamos o "transbordamento" de práticas intervencionistas para além da temática dos direitos humanos, a razão em parte passa pela extensão dos princípios de outros ramos do direito e da política para o ambiental. 


\subsection{Características da Ordem Ambiental Internacional}

A OAI caracteriza-se pela fragmentação ${ }^{73}$ e pelo realismo político ${ }^{74}$, onde os Estados pautam suas ações e iniciativas pela salvaguarda da soberania e dos interesses nacionais, expressa em uma gama diversificada de instrumentos jurídicos no intuito de melhor gerir o meio ambiente (RIBEIRO, 2001). Partindo da premissa do realismo político, de maximização dos ganhos e da defesa de interesses para sobrevivência, a redefinição dos conceitos direciona as posições dos Estados que, cada um a sua maneira, interpretam as questões sobre meio ambiente em vista de interesses particulares (BODANSKY, 2007).

As características da OAI, resultantes de um modelo centrado na busca pelo poder e minimização de perdas, passam por sua fragmentação político-institucional e jurídico-normativa e por uma governança regional ainda limitada, composta de rede intricada de regimes também complexa, que busca dar alguma organicidade ao sistema de proteção internacional do meio ambiente. Observando a figura (3.1) abaixo, relativa à questão da mudança climática, pode-se perceber o complexo de regimes ${ }^{75}$, resultante da fragmentação acima mencionada.

\footnotetext{
${ }^{73}$ Fragmentação pode ser conceituada a partir de uma concepção biológica, significando no campo da genética uma "fragmentação cromossômica" resultante de uma "ação externa". Igualmente o conceito relaciona-se à complexidade das questões (DELMAS-MARTY,1998) e dos atores (VARELLA, 2014). Daillier e Pellet consideram o DIMA uma "colcha de retalhos". A fragmentação, em nosso entender, refere-se a um processo relacionado aos discursos ou "atos de fala" que compõem a diversidade temática própria da área ambiental. As incertezas científicas inerentes ao meio ambiente induzem os atores a, cada um a sua maneira, interpretar a realidade de acordo com suas experiências e práticas, fragmentando os discursos securitários e buscando legitimar - de forma unilateral - o que entendem por ameaças na área ambiental. Esse processo geralmente ocorre dentro de um nível mais elevado da unidade de análise estatal, os regimes e comunidades epistêmicas, que, por sua vez, influenciam o âmbito multilateral, mas sem uma hierarquia totalmente definida e mais porosa. Resulta daí uma série de iniciativas multilaterais, pouco coordenadas, cada uma com foco específico para um problema ambiental, o que conduz à atual superposição de normas e aprofunda a fragmentação.

${ }^{74}$ Cf. notas n 31 e 32 supra.

${ }^{75}$ Cf. nota $\mathrm{n}^{\mathrm{o}} 38$ supra.
} 


\section{Fig. 3.1: Regime complexo de mudança climática}

\section{Figure 1}

The regime complex for managing climate change.

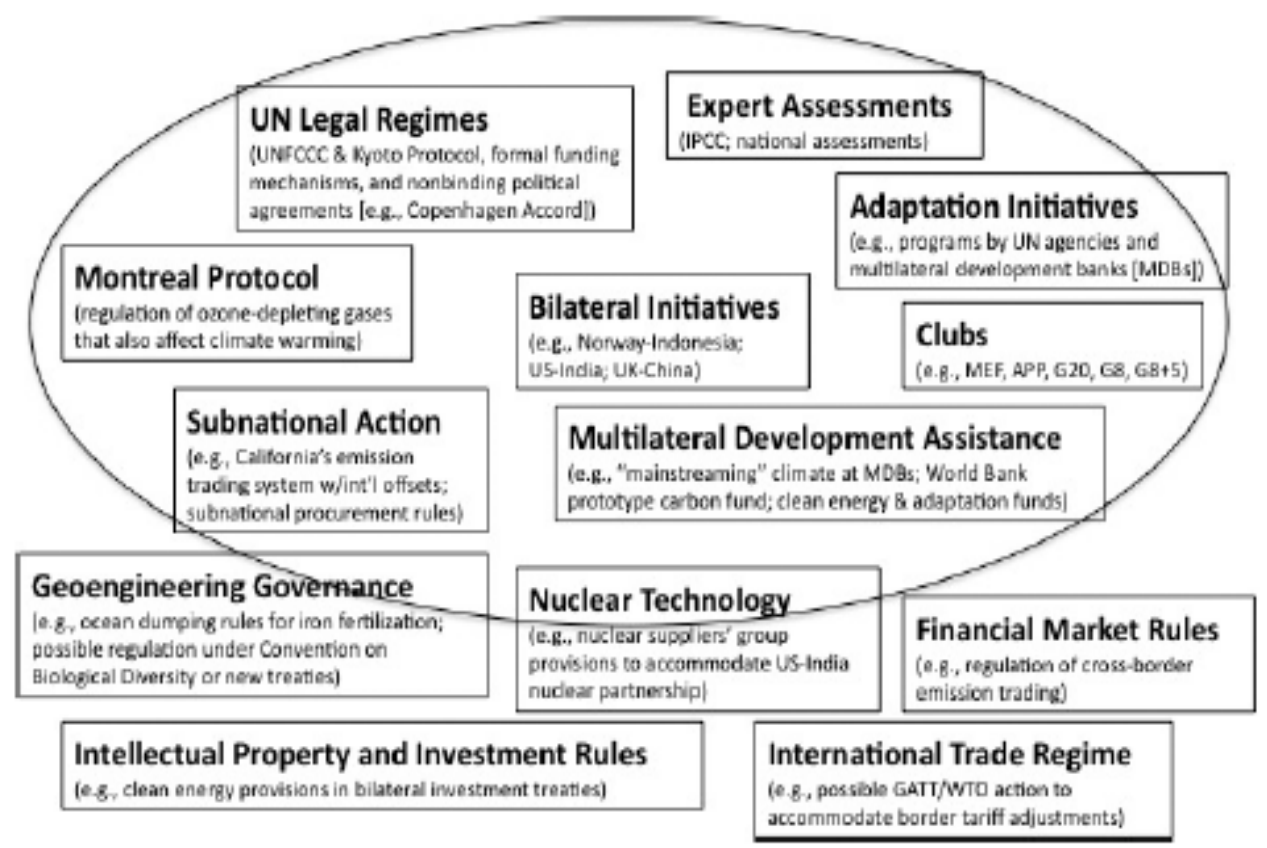

Fonte: Keohane \&Victor (2010)

Parte da fragmentação da OAI é reflexo dos próprios traços que caracterizam os problemas da área ambiental e os desafios a eles inerentes. Bodansky (2007: 6-8) enumera alguns aspectos desses problemas, enquanto Hurrell (2007) discute o fundamento daqueles "desafios ecológicos". Tal problemática e desafios, embora não alterem as premissas realistas conformadoras da ordem ambiental preconizada por Ribeiro (2001), conduzem o pesquisador a revisitar a OAI à luz das teorias securitárias mais recentes aplicadas à área ambiental, no tocante à aplicabilidade dos pressupostos construtivistas, sobretudo no tema das "intervenções verdes".

Retornando ao tema dos aspectos oferecidos por Bodansky (idem: 6-8), podemos reconhecer uma primeira característica dos problemas relacionados à OAI, a de que resultam tanto de condutas privadas - primordialmente - quanto de ações do Estado, sob uma base física e tecnológica. Um segundo aspecto refere-se à natureza dos temas ambientais, que seguem uma lógica peculiar, em virtude de sua dependência dos avanços tecnológicos e do conhecimento científico. Deve-se considerar que a agenda 
internacional caracteriza-se em essência por questões mais ao espectro político, como segurança, direitos humanos e comércio, enquanto a temática ambiental envolve uma dimensão política e também outros níveis de análise, que dependem do auxílio da Ciência (OST, 1996; BARROS-PLATIAU, 2004), como questões relacionadas à biodiversidade e mudança climática, que tem nas comunidades epistêmicas sua fonte de instrumentalização (INOUE, 2007). Essa característica torna o tema ambiental demasiado dinâmico e com alvos de atuação imprecisos, tendo em vista a dependência dos tomadores de decisão no progresso científico. ${ }^{76}$

Andrew Hurrell (2007), por sua vez, considera relevante discutir os fundamentos dos "desafios ecológicos", um componente da ordem global contemporânea, em seu entender, a pautar o arcabouço temático das sociedades que dela fazem parte. Esse desafio põe em questão a viabilidade prática e a adequação moral da concepção pluralista da ordem global estatocêntrica e faz os Estados responderem com inovadoras de produção das leis internacionais e novas regras de governança global. Segundo o autor, são quatro os aspectos do desafio ecológico da modernidade. Um deles refere-se à crescente consciência dos limites materiais do progresso e do desenvolvimento sob bases ocidentais. Formas dominantes de organização política contemporânea seriam inadequadas para lidar com a relação entre humanidade e meio ambiente em bases sustentáveis e duradouras. O autor avalia que a relevância política internacional de questões ambientais tem crescido enormemente como resultado da acelerada degradação ambiental, do crescente conhecimento científico, e do peso da consciência popular sobre a seriedade dos desafios ecológicos hoje enfrentados pela humanidade.

Um segundo aspecto aponta para o crescente caráter global das questões ambientais contemporâneas. A humanidade enfrenta cada vez mais problemas cujos

\footnotetext{
${ }^{76}$ Em paralelo, Oran Young (1994) oferece outra interpretação, complementar, mais centrada nas origens dos problemas, dividindo em quatro grupos: os bens comuns; os recursos naturais compartilhados; as externalidades transfronteiriças; e as "linked issues". Os bens comuns referem-se aos recursos naturais que pertencem a toda a humanidade, como a Antártica, o alto-mar, a camada de ozônio, etc. Os recursos naturais compartilhados são os sistemas físicos e biológicos que "se estendem à jurisdição de um ou mais estados". As externalidades transfronteiriças são os problemas com origem no território de um determinado Estado que afetem a população de um outro, a exemplo do objeto deste estudo, como os acidentes nucleares em Chernobyl e Fukushima. As "linked issues" referem-se a situações onde os esforços para resolcomunidasver determinada questão tem efeitos em regimes diversos, como nas áreas de meio ambiente e economia. Os problemas apresentados por Young aproximam-se da descrição apresentada por Owen Greene (in BAYLIS: 2004), no tocante à transnacionalidade.
} 
efeitos só podem ser efetivamente geridos de forma cooperativa, a exemplo daqueles de escalas regional ou local, como desmatamentos, desertificação e escassez de águas. Outro desafio deriva da complexa relação entre a geração de problemas ambientais e os efeitos da economia global. O quarto desafio diz respeito ao crescente número de Estados-nações que deixaram de ser capazes de prover uma ordem local/nacional e um gerenciamento ambiental adequado dentro das próprias fronteiras, como os failed states. Muitos dos mais sérios obstáculos de sustentabilidade teriam relação com certa "fragilidade" de alguns Estados e suas estruturas.

Os desafios ecológicos aventados por Hurrell - e que afrontam a sociedade pluralista minimalista - não poderiam deixar de se relacionar com os conceitos centrais atribuídos por Ribeiro (2001) à OAI: a segurança ambiental e o desenvolvimento sustentável. O primeiro reflete a necessidade da manutenção das condições de reprodução da vida humana no planeta, enquanto o segundo procura "regular o uso dos recursos naturais através do emprego de técnicas de manejo ambiental, de combate ao desperdício e à poluição. Ribeiro argumenta que se fôssemos empregar uma expressão para tal conceito, o desenvolvimento sustentável definiria que as ações humanas dirigidas para a produção de coisas necessárias à reprodução da vida devem evitar a destruição do planeta. Os dois conceitos certamente influenciaram as discussões internacionais nos anos 1990 e serviram para legitimar a OAI, buscando dar-lhe uma base científica.

Quanto à segurança ambiental global, Ribeiro (idem) recorda que, diferentemente do que ocorreu com o conceito de desenvolvimento sustentável (que serviu como fundamento para a implementação de políticas voltadas para a área ambiental), ela não se mostrou como um conceito que levaria à ação, e sim à implementação de estratégias por uma unidade política. A SA evoluiu como tema de maneira mais lenta e enfrentando muito mais resistência para firmar-se. Lorraine Elliot (1998) vai além e aponta que muitos autores refutam tal concepção, por associarem ao pensamento estratégico militar, e complementa, ainda, que deveria haver uma outra interpretação associando o militarismo à questão ambiental e à segurança. 
Diante de tais considerações, onde buscamos conhecer as características da OAI, seus aspectos e desafios mais prementes, qualidades inerentes de sua identidade como ordem ainda em construção, apresentaremos brevemente os passos de sua formação, no intuito de conhecer a influência de seus atores e de que modo a transformação da ordem global, com o fenômenos da globalização, definiu sua pauta ou foi pela OAI definida, em um processo de co-construção temática. A política internacional contemporânea segue uma lógica definida por seus atores em determinado plano de seu "meio", mas também uma ordem compartilhada de valores e regras pré-definidas pelos Estados e que priorizam a convivência no ambiente anárquico, onde o uso da força latente permanece inerte. A OAI reflete tal realidade. A governança ambiental global centrípeta se torna um ideal crescentemente distante e a realidade conforma a arena em que os Estados se confrontam, na defesa de seus interesses em detrimento da comunidade de nações, ou do interesse geral da humanidade, nas palavras de Alexandre Kiss (2006).

\subsection{Os primeiros passos da formação da OAI}

As preocupações com o meio ambiente nem sempre foram parte da história da humanidade, muito embora desde tempos imemoriais já se registrassem variadas expressões de condenação ao uso inapropriado da natureza e à proteção de espécies "úteis". O desconhecimento da vulnerabilidade e da limitação dos recursos naturais, bem como as justificativas para as catástrofes naturais que assolavam diferentes partes do globo, era uma realidade que não afetava cotidianamente a vida das pessoas, como se a gestão ambiental fosse algo inviável, ou pior, que a degradação ambiental fosse algo inelutável. À guisa de ilustração, o ritmo desenfreado de poluição atmosférica é um fenômeno aparentemente recente que surgiu com a Revolução Industrial, a partir do século XVIII, com o advento das máquinas a vapor e a transformação de uma sociedade eminentemente agrária para uma capitalista, pautada na utilização crescente de maquinário, impulsionada pelo desenvolvimento das técnicas e pelo avanço tecnológico (DOBB, 1983; HUBERMAN, 1985; BEAUD, 1989).

Não se devem desmerecer, ademais, os inúmeros deslocamentos populacionais e as catástrofes demográficas que facilitaram o advento de impérios e remodelaram a vida em sociedade, contribuindo para a compreensão da diversidade geográfica e a 
composição do mundo contemporâneo. Já em 1700 a.C., cidades sumérias foram abandonadas em razão da degradação precoce de áreas agriculturáveis. Séculos depois, o império romano iniciou a extração de chumbo (para a fabricação de utensílios), onde hoje se encontra a Espanha. A erosão do solo e o crescimento populacional causaram o colapso da civilização Maia, nas cidades-Estados da América Central, por volta do século X. Distante daquela região, o Império Bizantino destruía florestas costeiras no intuito de construir embarcações para suas frotas e de Veneza e Gênova (BURSZTYN \& PERSEGONA, 2008).

Isso não impedia que algumas vozes se debelassem contra a degradação da natureza, apesar da aparente abundância de recursos existentes. O filósofo grego Platão era conhecido por condenar o desmatamento e a erosão do solo nas colinas da Ática, pelo excesso de pastagem e corte de árvores para calefação. Seu contemporâneo Teofrasto (372-287 a.C.), discípulo de Aristóteles, vinha desenvolvendo os primeiros estudos de Botânica, em tratados que chegaram até nossos dias: De causis plantarum e De historia plantarum. Nas Arábias, Al-Damiri escrevia A Vida dos Animais (Kitab hayat al-Hayawan), cuja prosa mescla a descrição da natureza com elementos místicos, um verdadeiro estudo zoológico da fauna daquela região do planeta. No Novo Mundo, José de Anchieta, entre 1533 e 1597, trocava missivas com monarcas europeus descrevendo a fauna e a flora dos que em regiões brasílicas se encontravam antes da chegada dos navegadores portugueses e espanhóis, ao passo que Francisco de Orellana (1490-1546) desbravava a região amazônica. ${ }^{77}$

Para além das primeiras legislações produzidas pelo Senado romano, como leis de proteção a mananciais e de racionamento de alguns recursos naturais, registrava-se na França, nos idos de 1300, a promulgação de um Código Florestal para regular a produção de madeira para uso naval. Do outro lado do Canal da Mancha, Edward I já

\footnotetext{
${ }^{77}$ A parte histórica apresentada neste tópico sobre os passos da OAI é tributária direta de três obras, que merecem destaque aqui, em razão de seu auxílio para desenvolvê-lo, a fim de evitar excessivas citações bibliográficas no corpo do texto: RIBEIRO, Wagner Costa. A Ordem Ambiental internacional. São Paulo: Contexto, 2001; LE PRESTRE, Philippe. Protection de l'environnement et relations internationales. Paris: Armand Colin, 2005; e, BURSZTYN, Marcel; PERSEGONA, Marcelo. A grande transformação ambiental: uma cronologia da dialética do homem-natureza. Rio de Janeiro: Garamond, 2008. As citações serão utilizadas quando extraídas com excessiva similaridade. Para mais informações, cf. também A Green History of the World: The Environment and the Collapse of Great Civilizations (PONTING, Clive. Penguing Books, 1993)
} 
proibia a queima de pedra de carvão, embora com efeito limitado. No direito português, a Carta Régia de 1442, conhecida como a primeira disposição governamental para proteção às árvores daquele país, era expedida. No mesmo período, Portugal partia para o além-mar e, no reinado de Dom João I, já havia conquistado Celta e descoberto as ilhas de Madeira e Santa Maria, incorporadas ao reinado (BURSZTYN \& PERSEGONA, idem: 26). No que hoje são terras brasílicas, surge uma legislação especial, em forma de ordenação outorgada a Tomé de Souza, em 1548, para regular a extração de Pau-Brasil “com o menor prejuízo possível (HOLANDA, 1985; FAUSTO, 1995; SARAIVA; 2005, LE PRESTRE, 2000).

Os primeiros passos para a transformação do meio ambiente em tema de discussão política e acadêmica podem ser encontrados também nas diversas obras históricas de naturalistas dos séculos XVI ao XVIII, que inspiraram iniciativas de criação de jardins botânicos e as primeiras ações no sentido de conservação da fauna e das florestas em diversas partes do planeta, como nas colônias do além-mar das potências europeias da época. Podemos citar entre elas o livro "Historia Plantorum e Animalum”, do suíço Konrad von Gesner (1516-1565), uma enciclopédia botânica, ou ainda a "Enciclopédia de História Natural", do naturalista renascentista Ulisse Aldrovandi (1522-1605). Dos outros diversos autores do período, destacam-se também, já no século XVIII, o livro do naturalista francês René Réaumur (1683-1757), intitulado "Mémoires pour servir à l'histoire des insects", um marco da história da entomologia, e o livro "Systema Naturae", do naturalista e botânico sueco Carls von Lineu. Não se deve esquecer, todavia, livros pouco conhecidos, a maioria publicados por academias de ciências europeias, como a "Memória sobre a pesca das baleias e a extração do seu azeite, com algumas reflexões a respeito de nossas pescarias”, de 1790, escrito por José Bonifácio de Andrada e Silva, e um dos marcos da ecologia moderna, como "As leis da vida orgânica”, com ideias sobre a evolução, de Charles Darwin (1731-1802). (BURSZTYN \& PERSEGONA, idem)

No século XIX, na França, Jean-Baptiste Furier foi o primeiro a "perceber" um fenômeno em que gases atmosféricos prenderiam a energia solar e elevariam assim a temperatura da superfície terrestre, fenômeno hoje conhecido como "efeito estufa". (BURSZTYN \& PERSEGONA, idem; COWIE, 2007:3). Surgem, no país, as primeiras 
manifestações ecológicas, como as organizadas pelos escritores Georg Sand e Victor Hugo, com vistas à proteção das florestas de Fontainebleau, resultando na criação de uma reserva de 624 hectares. Nos Estados Unidos, George Perkins fez um discurso para a "Agricultural Society of Rutland County", em que chamava a atenção ao impacto destrutivo de atividades humanas sobre a terra. $\mathrm{Na}$ ocasião, Perkins defendeu a abordagem conservacionista na gestão de áreas florestais.

Anos mais tarde, sairia a publicação mais famosa do naturalista Charles Darwin, consagrada como um dos livros mais importantes da história da Biologia: "Sobre a origem das espécies através da seleção natural ou a preservação de raças favorecidas na luta pela vida” (1859). Ainda no século XIX, utiliza-se pela primeira vez o termo “ecologia”, pelo biólogo alemão Ernest Haeckel (1834-1919), em Generelle Morphologie der Organismen. Adepto das teses de Charles Darwin, o filósofo-biólogo inspirou-se nas palavras gregas oikis (casa) e logos (significado) para determinar as relações dos seres com o meio ambiente e as condições da existência (McCORMICK, 1992; BURSZTYN \& PERSEGONA, idem).

Além disso, vale mencionar o surgimento das primeiras ONGs de proteção da natureza, em especial em países europeus, como França e Inglaterra, de que são destaques a "Society for the protection of animals" (França, 1824), com o objetivo de intervir contra a crueldade em animais domésticos, e a "Manchester Association for the Prevention of Smoke" (Inglaterra), destinada a lutar pela qualidade de vida nas cidades e contra a poluição pela utilização excessiva de carvão mineral (BURSZTYN \& PERSEGONA, idem: 50). Na França, também foi criada a "Sociedade Zoológica de Aclimatação”, em 1854. As iniciativas dos governos são igualmente notáveis. Em 1815, a título de exemplo, foi criada a Comissão do Reno, considerada a mais antiga organização internacional de que se tem notícia. No Brasil, a Carta da Lei, de 1827, criou o termo "madeira de lei" e regulamentou o corte de certas árvores, mesmo em terras particulares. Nos Estados Unidos, George Catlin, renomado artista, propõe a criação de parques nacionais para preservação da paisagem selvagem e do habitat dos 
índios da região. Na África, são criadas as primeiras reservas estatais de caça, em Knysa e Tsisikama, entre outras iniciativas globo afora (WORSTER, 1993). ${ }^{78}$

No final do século XIX, percebe-se uma intensa atividade no sentido de conservação de espécies animais, seguida de uma relativa passividade no tema ambiental durante as duas grandes guerras mundiais, para então retomarem-se novamente as ações ambientais. Tal fase distinguiu-se pelo reduzido número de acordos internacionais negociados, em maioria com finalidades tão somente de assegurar a proteção de espécies úteis à agricultura, à gestão racional de recursos naturais para proteger a qualidade econômica de certos grupos (LE PRESTRE, idem: 131-4). Nesse período, os Estados eram os protagonistas, apesar do aumento significativo de instituições internacionais e de ONGs no pós-Primeira Guerra. Após os anos 1940, no entanto, testemunha-se uma "explosão" institucional de que é arauto a própria ONU, em uma verdadeira transformação da ordem sistêmica internacional, com profundos reflexos positivos nos temas do cenário global, entre eles o meio ambiente.

A preocupação com a natureza como concebemos hoje emerge nas relações internacionais ainda no século XIX, precisamente em sua segunda metade, no contexto de elaboração de acordos bilaterais e regionais de utilização de recursos, a exemplo da Comissão para o Reno e o Danúbio, cuja finalidade facilitaria o aproveitamento econômico dos rios, e da realização em Londres, a convite da Coroa Britânica, em 1900, de uma reunião internacional para se discutir a caça indiscriminada nas colônias da África (RIBEIRO, 2001: 54). Em países como França e Inglaterra surgem as primeiras associações de conservação da natureza, como a Sociedade Nacional Francesa de Proteção da Natureza (1854), a Associação de Proteção dos Pássaros (1870), a Sociedade Real para Proteção dos Pássaros (1899) e a Sociedade Real para Conservação da Natureza (1912). Paralelamente, em outros países, vale destacar a fundação do Sierra Club $(1892)^{79}$ e da Audubon Society (1905), nos Estados Unidos, da Bund für

\footnotetext{
${ }^{78}$ Ressalte-se que a grande maioria das iniciativas acima preocupava-se mais com a gestão de um recurso finito ou com os danos causados, no caso do carvão e da queima de florestas, do que com o direito à vida das espécies vivas. Uma abordagem mais antropocêntrica predominou ao longo dos séculos.

${ }^{79}$ O Sierra Club foi criado nos EUA para proteger a fauna de Serra Nevada. No início, contava com cerca de 180 membros, sendo presidido pelo naturalista e escritor John Muir (1838-1914). Dentre as primeiras iniciativas daquela organização não-governamental estava a luta contra a proposta de redução das fronteiras do Parque Nacional de Yosemite. Hoje, sua área de atividades abrange temas como
} 
Vogelschutz (1899), na Alemanha, da Dansk Ornitologisk Forening (1906), da Danmarks Naturfednings Forening (1911), dos Amigos das Árvores, na Grécia (1902), e da Liga Suíça para Proteção da Natureza (1909).

Já nesse período também se observa uma crescente densidade de formulação de acordos bilaterais e multilaterais, bem como a consciência da necessidade de se criar santuários de conservação da natureza, como os parques nacionais. No início, a criação de áreas de preservação da natureza não era vista como economicamente interessante, pois os países hesitavam levar adiante iniciativas com essa finalidade. Os primeiros acordos, no plano internacional, além de mais numerosos na área bilateral, referiam-se, no mais das vezes, a questões de conflitos de jurisdição e de problemas transfronteiriços. No plano multilateral-econômico, encontram-se acordos para proteção às focas marinhas (1911), pesca (1949), urso polar (1973), entre outras espécies. Com relação aos parques nacionais, destaca-se a criação do primeiro parque nacional dos Estados Unidos, em Yellowstone (1892), do Royal National Park (1879) e do Parque Nacional Tongariro (1894), na Austrália, e dos parques nacionais de Banff (1885) e de Glacier (1886), no Canadá. Na mesma tendência, ainda que de forma tímida em razão da forte densidade demográfica, a Europa conhece seu primeiro parque nacional somente em 1909, na Suécia, ${ }^{80}$ seguida por países como a Suíça (1914) e a Espanha (1918)..$^{81}$

A partir de 1945, nota-se uma maior atividade de organizações no sentido de buscar a conservação da natureza sem aqueles laços diretos com as limitações econômicas impostas pelo tema ambiental. As Nações Unidas, recém-criada com finalidades mais securitárias do que preservacionistas, engajou-se em trabalhos de conservação cujo testemunho foi a notável convocação, em 1949, da Conferência Internacional Técnica sobre Conservação. No âmbito setorial, a FAO, fundada em 1945,

biodiversidade, camada de ozônio e degradação ambiental por agentes químicos, entre outros. Fonte: Bursztyn, Marcel, et alli. (idem). E website da organização: www.sierraclub.org (24/07/2014)

${ }^{80}$ O Parlamento sueco autorizou, em 1909, a criação de dez parques nacionais, a saber, Abisko, Stora, Sjöfallet, Sarek, Pieljekaise, Sanfjället, Hamra, Garphyttan, Ängsöm e Gotska Sandön. Segundo o Riksdag, a legislação que cria os parques insere-se em conjunto de medidas inovadoras de proteção da natureza. Anos mais tarde, foram também criados os parques nacionais de Dalby Söderskog (1918), Vadvetjakka (1919), Norra Kvill e Bla Jungfrun (1926) e Töfsingdalen (1930). Fonte: Bursztyn, Marcel, et al. (idem: 74).

${ }^{81}$ Cf. Le Prestre, idem: 134-5. 
em Quebéc, no Canadá, posteriormente transferida para Roma (1951), passou a desenvolver projetos na área ambiental, agricultura e alimentícia; a OMS realizou estudos sobre a relação entre meio ambiente e doenças; e a UNESCO focou em programas de apoio a pesquisas científicas, culminando na convocação da Conferência da Biosfera (1968).

Na década de 1960, o meio ambiente adquire relevância crescente na agenda internacional, em decorrência dos graves desastres e experimentos militares-científicos com impacto imensurável, como as explosões nucleares na Argélia, em Raggane (1960), no Cazaquistão (1961), no Atol de Fangataufa, no Pacífico Sul (1968). Mencione-se também a degradação ambiental causada pela Guerra do Vietnã (1964) e os danos em decorrência do derramamento de petróleo com o naufrágio do Torrey Canyon, anteriormente mencionado.

Nesse período, buscava-se resolver problemas relacionados ao desenvolvimento descontrolado e com intensos impactos ambientais advindos da industrialização. Os responsáveis vinham tanto dos países desenvolvidos quanto dos países do então "Terceiro Mundo", aos poluírem e extraírem recursos sem quaisquer padrões de sustentabilidade. "Desenvolver" apresentava-se como uma questão central nas discussões dos poucos foros multilaterais existentes naquela década. Nações como China, Índia, Brasil, antiga Iugoslávia, entre outros, figuravam como contestadoras da ordem bipolar e do "congelamento" das estruturas político-econômicas do poder mundial, era o advento de uma clivagem Norte-Sul que iria prevalecer até os dias atuais na área do meio ambiente. ${ }^{82}$

A década de 1960 também se caracterizava pelas transformações dos valores sociais. A geração que nasceria no pós-Guerra, sobretudo nos centros políticos da Europa e dos EUA, sob a afluência dos "anos de ouro" do capitalismo, segundo

\footnotetext{
${ }^{82}$ Tal ordem sustentava-se sob os alicerces do pensamento não-alinhado, em que Sukharno, Nasser, Tito, Nehru lideravam movimento de contestação ao enquadramento das Nações aos blocos de poder à época. Desenvolver era o conceito e o objetivo daqueles países no momento. (HOBSBAWM, 2001; MAGNOLI, 2013). O progresso, a diminuição da pobreza, a riqueza implicavam, segundo o pensamento do período, "industrializar", independentemente da consequente degradação da natureza. A bipolaridade ideológica quanto ao sistema político a prevalecer, se capitalismo ou socialismo, entre EUA e URSS, marginalizouse diante das certezas dos países menos desenvolvidos de que teriam de alterar seus modos de produção a fim de alcançarem posição privilegiada na ordem internacional que então se apresentava.
} 
Hobsbawm (2001), passa a questionar crescentemente as bases pelas quais os Estados pautavam suas decisões: segurança e economia. Os episódios em Paris e Praga, de 1968, acenavam para a necessidade de transformações estruturais no sistema internacional, cujos reflexos seriam visíveis na reformulação dos temas da agenda global e na redefinição dos princípios que justificavam a atuação dos Estados.

Assiste-se também à emergência e rápida consolidação da sociedade civil dos países ricos do Ocidente, com pretensões de participarem de modo mais ativo nas questões que envolviam ideias e valores humanistas. Aqueles anos presenciaram uma gradual e crescente tomada de consciência das ameaças relacionadas ao meio ambiente pelos diversos atores que conformavam até então a OAI, principalmente da comunidade científica e da sociedade civil. A nuvem de poluentes que cobriu a cidade de Londres, em 1952, os acidentes ambientais, as denúncias de membros da comunidade científica e acadêmica sobre as consequências da industrialização e do uso inadequado dos recursos naturais contribuíram para o desvio da atenção de governos e sociedades de outros temas para o ambiental e para a percepção de que algo realmente estava errado e saindo do controle.

Obras como Silent Spring (1962), de Rachel Carson, com denúncias sobre uso de agrotóxicos e pesticidas na agricultura; The Tragedy of Commons $(1968)^{83}$, de Garret Hardin; Blueprint for Survival (1972), pelo magazine inglês The Ecologist, com apoio ao controle demográfico na contenção de problemas ambientais, ou o livro The Shallow and Deep (1973), do norueguês Arne Naess, apontando as divergências entre os ambientalistas, ganharam destaque e influenciariam o debate sobre as questões ambientais, com impactos positivos que estimularam o avanço das ideias sobre questões relacionadas à utilização sustentável dos recursos naturais e o crescimento demográfico.

\footnotetext{
83 "Tragedy of Commons", de Garrett Hardin, surge como artigo publicado na revista Science, em 1968, tornando-se uma referência no pensamento sobre questões ambientais. Representa um alerta quanto aos riscos da limitação de recursos naturais e crescimento populacional, em ideias aproximadas à do economista clássico David Ricardo. Hardin defendia a tese de que o progresso científico e tecnológico levaria ao uso intenso dos recursos, produzindo assim seu esgotamento e rendimentos decrescentes. Conforme apontou Bursztyn \& Persegona (idem: 134-35), o diagnóstico de Hardin levaria à prescrição de fórmulas de caráter neomalthusiano. Com a impossibilidade de alteração, no curto prazo, de modos de produção existentes, surgiram propostas de redução do crescimento populacional. Tais estudos sobre a relação entre as duas variáveis ficaram conhecidos como "bomba populacional", tema explorado por autores como Paul e Anne Erhlich (The Population Bomb).
} 
Também nesse período, revela-se o "Clube de Roma", com encontros patrocinados por grandes empresas, e responsável pela publicação do relatório The Limits to Growth. O "Clube" congregava cientistas, acadêmicos e empresários. Diferentemente das obras de Rachel Carson e Garret Hardin, o documento obteve impacto político internacional mais amplo e nortearia a discussão sobre o meio ambiente a partir de então, pautado pelo surgimento de duas teses apresentadas à sociedade. Em conjunto com a Associação Potomac e o Massachusets Institute of Technology (MIT), a publicação de The Limits to Growth dividiu a opinião pública entre os adeptos do crescimento zero (os zeristas) e os desenvolvimentistas, em razão das teses catastróficas quanto aos efeitos do crescimento demográfico. ${ }^{84}$

\subsection{De Estocolmo à Rio+20: quatro décadas de transformação}

Philippe le Prestre (idem, ibidem) considera que as duas décadas que se seguiram à Conferência da Biosfera em Paris (1968) foram os anos de emergência da chamada "Ecopolítica" (écopolitique). A década de 1960 é chave para o tema ambiental e para a evolução da OAI. Foram anos de maior engajamento da sociedade civil, em especial das democracias ocidentais e industrializadas, no sentido de mobilizarem-se com vistas à proteção da natureza. Pouco interessada pela política tradicional de resolver problemas, a sociedade civil passou a buscar resolvê-los localmente, sob um novo jogo político. Para le Prestre, isso significou que o meio ambiente tornou-se objeto de política pública, pela multiplicação de instrumentos jurídicos e instituições. ${ }^{85}$ Nas duas décadas que se seguiram, das 11 agências para proteção do meio ambiente em nações em desenvolvimento, em 1985, podiam-se contar agora mais de 130. Os

\footnotetext{
${ }^{84}$ Defendiam as teses neomalthusianas de limite do crescimento demográfico, por um lado, os que pretendiam esbarrar o acelerado desenvolvimento industrial, relacionado com a poluição atmosférica e com a degradação ambiental. Por outro lado, seus defensores apoiavam o progresso proporcionado pelas indústrias e era preconizado pelos países que ainda não haviam desenvolvido seus parques industriais, considerados essenciais segundo a ideologia desenvolvimentista do período, para entrar no clube das nações do "Primeiro Mundo". O debate ultrapassaria a sociedade para direcionar as políticas externas no âmbito dos fóruns internacionais.

85 Para além das organizações não-governamentais que surgem com força no período e desafiam crescentemente a primazia dos governos na discussão de temas e na execução das atividades voltadas ao meio ambiente, multiplicam-se também instituições (trans) governamentais, com a finalidade de colaborar sobre temas comuns, mas apoiadas pelos governos de que fazem parte ou são financiadas, como o Programa das Nações Unidas para o Meio Ambiente (PNUMA) e os comitês criados em outros organismos multilaterais, como o Comitê do Meio Ambiente, no âmbito da Organização para a Cooperação e Desenvolvimento da Europa (OCDE), em 1970, e do Banco Mundial, como o Escritório de Assuntos Científicos e Ambientais, em 1971, apenas para citar alguns.
} 
números são eloquentes, vê-se que o surgimento de novos atores trouxe uma dinâmica renovada para os debates ambientais, cujos impactos são percebidos ainda hoje pela consequente fragmentação da ordem ambiental. ${ }^{86}$

Durante o período, algumas questões relevantes se impõem. Le Prestre (2005:138) afirma que “(...) l'environnement surgit brusquement sur les scènes politiques nationales sur la vague d'une médiatistion croissante. Il ne s'agit plus seulement de préserver une espèce, un site ou une ressource, mais de protéger l'Humanité d'elle-même." 87 O autor aponta que a mudança do termo "natureza" para "meio ambiente" representou uma evolução e o alargamento dessa perspectiva ("l'environnement englobe la protection ou l'amélioration du cadre de vie”). Segundo le Prestre, assistiu-se naquele período à aparição de certos fenômenos acelerados, em razão do (1) engajamento das organizações intergovernamentais, que conduzem à institucionalização crescente da política internacional para o meio ambiente, de que foi exemplo a formação do Conselho da Europa, da UNESCO, da Organização Marítima Internacional e do PNUMA; (2) da fundação de ONGs de caráter militante, que buscam influenciar o jogo político e mobilizar a sociedade; (3) do desenvolvimento de arcabouço jurídico ambiental, com a maior frequência de acordos internacionais assinados desde então, ${ }^{88}$ (4) da criação de instituições nacionais voltadas

\footnotetext{
${ }^{86}$ Uma atenção especial nos atores durante o período demonstra uma gama diversificada de agentes crescentemente engajados a exercer papel relevante nas discussões sobre o meio ambiente. Cada vez mais militantes, as ONGs buscam desde aí maior proatividade. Nesse contexto, aponta-se o surgimento do Environmental Defense Fund (EUA, 1967), da Federação Francesa das Sociedades de Proteção à Natureza (1968), dos Friends of Earth (EUA, 1971), do Conselho de Defesa dos Recursos Naturais (EUA, 1970), do Greenpeace (Canada, 1971), da Federação Canadense da Natureza (1971), do Escritório Europeu da Natureza (Bélgica, 1974), entre outras. Com relação às organizações já existentes, há uma ampliação de suas atividades e reformulação de suas práticas. Le Prestre (2005, idem: 137) avalia que essa diversificação de movimentos voltada para a proteção ambiental acentuou algumas contradições tradicionais entre as ONGs científicas e as de conservação ambiental, resultando na edificação de novas organizações do seio daquelas e outras mais jovens de caráter eminentemente político, que buscam questionar os arranjos econômicos, sociais e institucionais já existentes que se apoiam tradicionalmente na exploração dos ecossistemas e na degradação ambiental.

${ }^{87}$ Tradução livre: “(...) o meio ambiente surge bruscamente sobre o cenário político doméstico na onda de uma 'midiatização' crescente. Não se trata mais somente de preservar uma espécie, um local ou um recurso, mas de proteger toda a Humanidade dela mesma."

${ }^{88}$ Haas \& Sundgen (1993), apud le Prestre (2005), apontam que de 132 tratados compilados pelo PNUMA, 65 foram assinados entre 1920 e 1973, outros 67 assinados entre 1974 e 1990 . Os novos instrumentos jurídicos, vale notar, evoluem para edificar novos princípios, como o do "poluidor-pagador" (PPP), cuja ideia surgiu no âmbito da OCDE, por meio da "Recomendação sobre os princípios diretores relativos aos aspectos das políticas ambientais no plano internacional”, em 1972, e para tratar de temas como cooperação internacional relativa ao meio ambiente, prevenção de desastres e utilização de tecnologias ambientais.
} 
exclusivamente para a área ambiental, com ritmos diferentes em diversas regiões do planeta, porém com tendência global. ${ }^{89}$

Foi em clima de novidade e preocupação com o destino do meio ambiente e de profusão de entidades ligadas à área ambiental, apoiadas crescentemente pela sociedade civil, que o canadense Maurice Strong convocou, em 1972, a CNUMAH, ou “Conferência de Estocolmo" (McCORMICK, 1995; KISS \& SHELTON, 2004; LAGO: 2004; BODANSKY, 2007). O evento sinalizou uma etapa histórica decisiva na evolução do tratamento dos assuntos ligados ao meio ambiente na agenda internacional e doméstica da maioria dos países e contribuiu significativamente para chamar a atenção da comunidade internacional a respeito do momento por que passava o planeta. ${ }^{90}$

Além do conflito bipolar característico da Guerra Fria ${ }^{91}$, duas frentes encontraram-se por ocasião da Conferência, com perspectivas diametralmente opostas relativas à condução das relações internacionais no que interessa ao meio ambiente. De um lado os países desenvolvidos, preocupados com os efeitos da devastação ambiental e propondo um programa de conservação dos recursos naturais e genéticos do planeta. De outro, os países em desenvolvimento, com graves problemas econômicos e em busca do pleno desenvolvimento espelhado nas nações mais ricas. Os países ditos "subdesenvolvidos", para usar o linguajar da época, duvidavam da legitimidade das recomendações dos países ricos e os acusavam de tentar impor complexas exigências de

\footnotetext{
${ }^{89}$ No Brasil, por exemplo, após a CNUMAH, é criada a Secretaria Especial do Meio Ambiente (SEMA), por meio do decreto n 73.030 (outubro/1973), ligada à Presidência da República.

${ }^{90}$ Para le Prestre (2005), as razões que motivaram a decisão dos países-membros das Nações Unidas a convocarem a conferência mundial passam pelo (1) crescimento da cooperação científica na década precedente, nos níveis internacional e não-governamental; (2) pela "midiatização" cada vez mais intensa dos problemas ambientais, em particular dos efeitos de catástrofes ambientais, como a degradação ambiental e modificação de paisagens; (3) pelo crescimento econômico acelerado que resultou em uma profunda transformação das sociedades e dos estilos de vida tradicionais, como o êxodo rural e as regulamentações com reflexos na dinâmica social; (4) e pela consciência, sobretudo no meio científico, de que alguns problemas ambientais não poderiam ser resolvidos sem o aprofundamento da cooperação internacional, como a chuva ácida, a poluição dos mares, o acúmulo de materiais tóxicos na atmosfera, entre outros elementos nocivos ao meio ambiente.

91 A Conferência de Estocolmo ocorreu de 5 a 16 de junho de 1972 e foi marcada pelas divisões existentes na política internacional da época entre os Estados Unidos e a ex-União Soviética, que boicotou o evento, juntamente com os países do Leste europeu, em razão da ausência da Alemanha Oriental, que não era membro das Nações Unidas. Os EUA, de seu turno, não foram proativos como se esperava, parte devido aos contratempos a que estava envolvido na Guerra do Vietnã e às constantes denúncias de desmandos dos direitos humanos e da degradação ambiental das florestas do país asiático. Apesar disso, houve a participação ativa de cerca de 115 países, constituindo-se até então a maior conferência internacional já realizada. (LE PRESTRE, 2005: 145).
} 
controle ambiental com probabilidade de retardar a industrialização. Consolidou-se então a clivagem Norte-Sul, que persiste forte até os dias atuais, apesar dos chamados "países emergentes". A polêmica em torno do assunto foi consubstanciada pela "Declaração sobre o Meio Ambiente Humano", uma espécie de carta de princípios que deveriam pautar as decisões governamentais com relação às questões ambientais. A ideia de "moratória do crescimento", como ficou conhecido o debate, tornou-se o background de complexas negociações internacionais. ${ }^{92}$

Embora relevante para a inclusão do tema ambiental na agenda internacional, a Conferência de Estocolmo sofreu críticas contundentes ao desviar o foco original do evento para a inclusão do debate sobre desenvolvimento, momento em que o tema ambiental passou a ser discutido menos do ponto de vista científico e mais do políticoeconômico. Le Prestre (idem: 146) aponta que as dificuldades inerentes à Conferência diziam respeito à própria extensão das medidas de proteção e cooperação internacional em matéria de meio ambiente, de difícil previsão. ${ }^{93}$ Concluída a Conferência, o tema ambiental se incorporaria em definitivo na agenda doméstica dos países e nos foros internacionais, em diversos níveis, no âmbito dos governos e da sociedade civil organizada. A polêmica entre desenvolvimento e preservação ambiental tornou-se assunto central nas discussões multilaterais, desencadeando novos estudos na área e o início de negociações de tratados internacionais com finalidades de regular iniciativas

92 Em análise mais centrada no indivíduo, le Prestre (idem, ibidem) avalia que, apesar de todos os componentes para se acreditar, a Conferência de Estocolmo não foi um fracasso em parte devido ao papel exercido por seu Secretário-Geral, o canadense Maurice Strong, que se dedicou a forjar um consenso prévio entre os participantes do evento, por meio de reuniões técnicas e políticas preparatórias, como a realizada em Founex, na Suíça (1971). Pode-se dizer que a CNUMAH foi eficaz em razão da entrada definitiva do tema ambiental na agenda internacional e da determinação de prioridades para as futuras negociações sobre o tema ambiental. Desenvolveu-se a partir dela uma nova dinâmica nas discussões ambientais com variáveis múltiplas e resultados promissores. Com a Conferência de Estocolmo, as nações de ambos os espectros da política ambiental passaram a reconhecer a existência dos problemas sobre desenvolvimento-preservação e sentiram-se compelidos de passar das discussões à prática. Adotou-se, além da "Declaração de Estocolmo", também um "Plano de Ação", composto de 109 recomendações em torno de três formas de iniciativas, a avaliação e a gestão do meio ambiente, bem como medida de apoio às atividades nacionais. Desenvolveu-se igualmente um mecanismo institucional para financiar e coordenar atividades ambientais das Nações Unidas, de forma a apoiar o recém-criado Programa das Nações Unidas para o Meio Ambiente (PNUMA). Deve-se considerar, ainda, o estímulo à criação de órgãos nacionais dedicados à área do meio ambiente, prontamente efetivado por diversas países.

93 Kay \& Jacobson (1983) enumeram três tipos de problemas a serem avaliados: (1) a natureza dos conhecimentos sobre os problemas do meio ambiente e sobre as políticas concernentes provaram-se mais incertos do que se pensava; (2) os custos relevantes da proteção ao meio ambiente, que "desacelera" o ímpeto inicial de cooperação, principalmente pelas nações do sul em desenvolvimento; e (3) oriundo dos problemas precedentes, as organizações internacionais governamentais tendem a fixar objetivos irrealistas, sob a forma de programas grandiosos. 
públicas potencialmente danosas para o meio ambiente e atividades que ameaçassem o território dos países (RIBEIRO, 2001). Nos anos que se seguiram à Conferência, uma verdadeira ofensiva ambiental tomou conta do cenário internacional, ${ }^{94}$ ofuscada somente pela própria natureza bipolar e crítica do sistema internacional do período. ${ }^{95}$

Vinte anos depois da Conferência de Estocolmo, por dez dias no mês de junho de 1992 a cidade do Rio de Janeiro sediaria o maior encontro de líderes do pós-Guerra Fria. Prevista para ser o primeiro evento em importância do início da década de um mundo transformado pelo fim do longo período de bipolarização ideológica, a Conferência foi marcada do início ao fim por tendências e divergências relacionadas aos interesses os mais diversos das nações, trazendo à tona novamente à interseção de temas ambientais e desenvolvimentistas. ${ }^{96}$ As desavenças resultavam da estrutura do sistema internacional que se transformava com força com o término do mundo bipolar. Com apenas $20 \%$ da população mundial, os países industrializados consumiam cerca de $2 / 3$ da energia gerada no mundo e eram responsáveis por lançar na atmosfera metade de todos os gases poluentes. As nações mais pobres e outras em desenvolvimento não se

\footnotetext{
${ }^{94}$ Durante as duas décadas que se seguiram à CNUMAH, algumas conquistas marcaram em definitivo a entrada do tema ambiental na agenda dos países e a determinação das prioridades das futuras negociações sobre o meio ambiente. É de se notar a criação do PNUMA (cf. nota 86), com o fim de coordenar as atividades relacionadas ao meio ambiente de outras agências do sistema ONU. Destacam-se também os trabalhos realizados pela CMMAD, criada em 1983 pela ONU, citada anteriormente, que resultaram no Relatório "Our Common Future", de 1987, um marco divisor na História do Meio Ambiente, ao introduzir o conceito de Desenvolvimento Sustentável, referência para as bases sob as quais se discutiriam o tema do meio ambiente até os dias atuais. Imprescindível na elaboração de posteriores estudos e trabalhos, o documento estabeleceu o conceito sob uma visão holística no tratamento das questões ambientais. Deve-se levar em consideração também que, durante os vinte anos pós-Estocolmo, houve avanços nos processos negociadores de tratados multilaterais em diversos temas ambientais. Vale notar a influência da comunidade científica nas formulações teóricas que justificaram as negociações da Convenção de Viena para a Proteção da Camada de Ozônio (1985) e do Protocolo de Montreal sobre Substâncias que Destroem a Camada de Ozônio (1987). Outros dois relevantes processos negociadores, como a Convenção das Nações Unidas sobre o Direito do Mar (1982) e a Convenção de Basiléia sobre o Controle do Movimento Transfronteiriço de Resíduos Perigosos e seu Depósito (1989) foram negociados à época (RIBEIRO, idem: 93-106; LAGO, 2007: 65).

${ }^{95}$ Apesar da atenção descontínua dos Estados com relação ao meio ambiente, não foram anos de completa letargia política e intelectual, pois se pôde verificar um dinamismo próprio no âmbito das instituições civis e sociais. A criação de diversos órgãos e agências ambientais, de legislações domésticas, de partidos políticos (a onda "verde"), os protestos crescentes contra testes nucleares, o desenvolvimento de projetos de cunho ambiental por organizações de variadas naturezas jurídicas, o estabelecimento de maior número de parques nacionais, a educação ambiental presente nos currículos escolares, entre outras atividades, davam o tom do período que precedeu a Conferência das Nações Unidas para o Meio Ambiente e Desenvolvimento (CNUMAD), em 1992.

${ }^{96}$ Ribeiro (2001: 129), no entanto, considera não haver sido verificada na CNUMAD a polaridade NorteSul, mas sim uma "ação geopolítica" em que os países configuravam variadas estruturas de negociação, com posições diversas no interior de cada bloco de países e temas.
} 
sentiam compelidas a pagar por problemas ambientais que não ajudaram a criar. A "Cúpula da Terra" surgiu nesse contexto e buscava minimizar o abismo crescente que separava pobres e ricos no mundo e seu acesso aos recursos naturais. Além dos temas da segurança ambiental, que dava seus primeiros passos na década de 1990, e do desenvolvimento, recorrente nas mesas de negociações, o que estava em jogo na CNUMAD era o acesso dos países mais pobres à tecnologia usada pelos países mais ricos para proteger o meio ambiente. ${ }^{97}$

A CNUMAD reuniu delegações de 172 países e 108 Chefes de Estado e de Governo. Foram credenciados cerca de 9.000 jornalistas e 1.400 ONGs. De acordo com a convocação oficial, o evento visava "to elaborate strategies and measures to halt and reverse the effects of environmental degradation in the context of increased national and international efforts to promote sustainable and environmentally sound development in all countries” (KISS, 2004; LAGO, 2007). Segundo Lago (2007), um dos motivos pelos quais a "sustentabilidade" ganhava adeptos era a dificuldade em defini-la. A definição do Relatório Brundtland de que o desenvolvimento sustentável seria aquele que atende às necessidades do presente sem comprometer a capacidade das gerações futuras de atender suas próprias necessidades recebera ampla aceitação. ${ }^{98}$

A CNUMAD, embora não tenha sido o começo, tampouco significou o fim da OAI, segundo Ribeiro (2002: 130). Foi responsável por sua renovação, dentro de um contexto maior de redefinição dos parâmetros globais de participação civil, com a multiplicação dos atores (recorde-se que a CNUMAD permitiu a participação das ONGs) e da retomada de consciência da necessidade de se estabelecer critérios mais objetivos para o efetivo cumprimento de acordos ambientais (ainda que timidamente), uma sobrevida ao consensualismo-coercitivo, no paradigma de Hurrell (idem). Até esse período, o sistema internacional carecia de mecanismos de regulação mais sólidos na área ambiental e em outras áreas antes consideradas soft das relações internacionais, como direitos humanos, direitos sociais, e novos desafios temáticos que surgiam com a nova ordem global. A partir da CNUMAD, um novo marco legal passou a ser

${ }^{97}$ Cf. Alfaia Jr, Roberto (2008).

${ }^{98}$ Essa ideia de "desenvolvimento sustentável", que buscou conciliar a ideia de desenvolvimento e preservação de recursos naturais e os interesses mais diversos da dicotomia desenvolvimentosustentabilidade, que estava no cerne das divergências entre países desenvolvidos e em desenvolvimento, facilitou, sem dúvida, a convocação da Conferência do Rio. 
consolidado, com base em inúmeros acordos multilaterais que visavam o estabelecimento de normas, ${ }^{99}$ no intuito de limitar e reverter os impactos da economia e da tecnologia sobre o meio ambiente. ${ }^{100}$

Os vinte anos que seguiram a Rio-92 foram de relativo otimismo para o tema ambiental, mesmo com dificuldades em se alcançar consensos em diversas áreas, como negociações de floresta, degradação ambiental e energia, e se convencer países produtores de petróleo e países consumidores de carvão em assumir compromissos que limitassem suas produções. O consenso político adquirido na Conferência do Rio em torno do conceito de "Desenvolvimento Sustentável" parecia fundamentar a partir de então a prática das recomendações contidas na Agenda 21 (LAGO, idem). Apesar dos avanços inegáveis em diversas áreas do conhecimento científico e da legislação ambiental em diversos países, além da maior participação da sociedade civil no processo de proteção ambiental, o progresso no tema ambiental desde a Rio-92 parecia ser cada vez mais lento e não condizia com o otimismo inicialmente demonstrado pelos protagonistas, levando Kofi Annan, então-Secretário-Geral da ONU, a afirmar "the record in the decade since the Earth Summit is largely one of painfully slow progress and a deepening global environmental crisis."

Seja como for, o pessimismo político no início do novo milênio, com todas as suas peculiaridades e diferenças culturais, que culminariam nos ataques terroristas contra o World Trade Center, em 2001, e as consequentes intervenções norteamericanas no Oriente Médio, sinalizaram o estágio em que se encontrava o tema ambiental, ofuscado novamente por questões securitárias mais prementes naquele

\footnotetext{
${ }^{99}$ Nesse sentido podem ser citados diversos documentos elaborados e avaliados pelos Estados durante aquela Conferência, tais como a Agenda 21; a Convenção da Biodiversidade; a Convenção da Desertificação; a Convenção das Mudanças Climáticas, Declaração de princípios sobre florestas; a Declaração do Rio sobre Ambiente e Desenvolvimento; e a Carta da Terra.

100 Apesar das difíceis negociações entre países ricos e em desenvolvimento, houve alguns resultados positivos do encontro, em razão da possibilidade de se encontrar pontos de convergência. No tema do financiamento, os países ricos se comprometeram a destinar $0,7 \%$ do PIB para a limpeza do planeta, ao Brasil, por exemplo, foram destinados cerca de 2,6 bilhões de dólares para a execução de projetos ecológicos. Quanto ao clima, cada nação comprometeu-se a reduzir suas emissões de gás carbônico aos níveis de 1990, muito embora nenhum prazo nesse sentido tivesse sido acordado. A respeito do tema da diminuição das queimadas, aprovou-se somente uma declaração de princípios, sem força normativa. Quanto à biodiversidade, as empresas dos países ricos deveriam transferir tecnologia e pagar royalties para as empresas dos países mais pobres em negociações conjuntas (Veja, de 17/06/92, "O Rio já é História", p. 39).

${ }^{101}$ Revista TIME. World Summit Special Report. 26/08/2002, 22 (apud LAGO, idem)
} 
momento. A Cúpula de Johanesburgo, em 2002, uma década após a CNUMAD, foi realizada sob esse contexto, e as promessas não cumpridas em acordos-chave da área ambiental, como em negociações sobre clima e florestas, pareciam dar o tom de que OAI estava travada.

A CMDS, também conhecida como Rio+10, realizou-se na África do Sul. O evento representou a terceira conferência mundial promovida pela ONU no tema ambiental. De modo similar à Rio-92, contou com elevada representação governamental (193 países) e da sociedade civil. Estima-se que mais de vinte mil credenciamentos foram feitos. A Conferência teve como objetivo "reafirmar o comprometimento aos princípios da CNUMAD” (soluções propostas na Agenda 21) e fazer com que os Estados assumissem maior responsabilidade coletiva para avançar os pilares da ideia de desenvolvimento sustentável em todos os níveis (KISS, 2006; LAGO, 2007). O conceito do Desenvolvimento Sustentável apresenta-se como a pedra angular da agenda a ser discutida. A Cúpula de Johanesburgo não preconizava a adoção de novos compromissos, mas a avaliação de eventuais avanços e dificuldades quanto ao comprometimento internacional dos acordos negociados na década anterior, no intuito de se identificar os motivos do parco avanço em temas centrais da área ambiental. A baixa mobilização popular no evento deu o tom do desencanto que o tema ambiental agora apresentava, diferentemente do entusiasmo da década de 1990, pautado pelo sentimento de urgência quanto ao futuro do planeta.

Apesar disso, resultaram da Conferência uma Declaração Política e um Plano de Implementação, cujos conteúdos refletem os limites das decisões baseadas no consenso e as divergências com relação a medidas mais eficazes para a solução de necessidades imediatas para questões ambientais. A exemplo dos documentos resultantes das Cúpulas anteriores, a imprevisibilidade de sanções quanto ao descumprimento de seus preceitos pautou-se na concepção pluralista-minimalista de defesa da soberania, o que na prática representou um conjunto de diretrizes e princípios, distante da mandatoriedade normativa exigível para a eficácia dos acordos dessa natureza.

A Cúpula de Johanesburgo refletiu a necessidade de instrumentos jurídicos mais centralizados e sólidos, para conter a fragmentação normativa oriunda da multiplicação 
dos acordos e dos regimes na ordem ambiental, que passaram a pautar o desafio de se equilibrar os mecanismos de compliance com as aspirações estatais de manutenção de suas prerrogativas soberanas, no dilema inerente da área ambiental de tratar coletivamente questões globais em uma estrutura multipolar descentralizada. Esse desafio fez-se premente na Conferência das Nações Unidas sobre as Mudanças Climáticas (COP-15), realizada em Copenhague, em 2009, e, mais ainda, na Cúpula sobre Desenvolvimento Sustentável (CNUDS), em junho de 2012.

A CNUDS reuniu-se na cidade do Rio de Janeiro, como 20 anos antes, seguida de uma proposta da Comissão sobre Desenvolvimento Sustentável, criada para assegurar um efetivo "follow-up" das iniciativas da CNUMAD. O objetivo da Rio+20 foi discutir, em última instância, o status dos compromissos políticos assumidos pelos países com relação ao tema do desenvolvimento sustentável. ${ }^{102} \mathrm{O}$ evento contou, como nas cúpulas anteriores, com elevada participação governamental e da sociedade civil, embora tenha sido feito sentir a ausência de Chefes de Estado e Governo, como as do Presidente Barack Obama, do Premier britânico David Cameron e da Chanceler alemã Angela Merkel.

O contexto em que ocorreu a Conferência não foi dos mais promissores, assolado pelas crises que atingiram os centros financeiros internacionais, entre eles os Estados Unidos e a União Europeia. Permanecem as desconfianças na cisão Norte-Sul, a respeito das diretrizes a serem seguidas por países desenvolvidos e em desenvolvimento direcionadas pela "economia verde" (OLIVEIRA \& SAMPAIO, 2011). Nesse sentido, é notável a dificuldade de adaptação dos mercados nacionais para "embarcar" no caminho do desenvolvimento sustentável e desacelerar a superexploração dos recursos naturais e a degradação do meio ambiente característico do atual sistema capitalista de mercado. Enquanto isso, a comunidade científica e acadêmica mantém seus alertas sobre o uso desregrado dos recursos naturais, principalmente para os efeitos de médio e longo prazo em questões como biodiversidade e mudança climática (HEYWOOD \& WATSON, 1995; GILPIN, 2006; HENSON, 2006; COWIE, 2007; CHALECKI, 2009; BARROSPLATIAU, 2011; INOUE, 2012; VIOLA, 2014).

${ }^{102}$ Cf. http://sustainabledevelopment.un.org/rio20.html (acesso em 15/07/2013) 
Apesar de avanços nas negociações, lideradas pelo Brasil, alguns impasses surgiram em questões como financiamentos de ações voltadas para o fomento do desenvolvimento sustentável, no tocante ao tema dos Objetivos de Desenvolvimento Sustentável (ODS). As divergências vinham tanto da interpretação de conceitos introduzidos na Conferência, relacionados à economia verde, tecnologias, instituições, quanto de questões mais práticas a respeito de execução de programas voltados à implementação da agenda do evento e das diretrizes do desenvolvimento sustentável.

Um dos temas destaques na CNUDS e que se relaciona diretamente com este trabalho diz respeito à complexa rede de atores atuando na área de desenvolvimento sustentável e que convida à discussão novamente a questão da governança global em um sistema político pluralista e fragmentado, com traços maximalistas limitados, assentado em preceitos tradicionais de limites à violência, ao respeito pelos tratados e a proibição do uso da força (HURRELL, 2007). A OAI acompanha essa tendência porque é parte indissociável do sistema internacional. Um sólido governo mundial, de “administração racional" do tema do meio ambiente (OLPHUS, 1992) continua um sonho distante, assim como a proposta de Held (1995) com relação a um modelo cosmopolita de democracia. Os Estados permanecem na ordem internacional ainda pautados por interesses mais imediatistas e de minimização de seus custos, em tendência realista, embora reconhecendo a necessidade de cooperação.

Quando voltamos ao tema dos desastres ambientais, a situação é mais peculiar. Apesar de estarem sendo desafiadas por componentes "maximalistas" consensuais, parece-nos que em situações de emergência a soberania estatal ainda é o garante, em última instância, da salvaguarda de seu território e população, tendo em vista a inadequação dos instrumentos de governança global incipientes para fazer frente à emergência e peculiaridade de caos daquela dimensão. Devemos, portanto, reconhecer a incapacidade da atual ordem global em lidar com situações de crise que envolvam uma resposta efetiva a acidentes transfronteiriços e mais urgentes, seja por sua débil estrutura de segurança coletiva ainda em construção, seja pela inexorável fragmentação política e institucional. 


\subsection{A Fragmentação político-normativa da OAI}

A década de 1990 foi um período de relevantes mudanças no cenário internacional. A iminência do final da Guerra Fria anunciava novo horizonte para as democracias e a abertura de diálogo mais promissor nos fóruns internacionais. Para os países desenvolvidos, surgia a oportunidade de se alcançar a estabilidade econômica, propiciando ao mercado global maior fluxo financeiro e comercial, que encontraria eco nas economias em desenvolvimento. Para estes, anunciava-se uma onda democratizante, em especial na América Latina, onde anos de regimes militares de exceção impediam adesões mais concertadas nos foros multilaterais, em razão dos projetos nacionalistas de industrialização desenvolvidos por burocracias estatais (CERVO, 2011).

O fim da Guerra Fria propiciou, ainda, a unipolaridade e depois a multipolarização do poder global. As antigas bases pelas quais se assentava a bipolarização ideológico-militar do período anterior cederam lugar à reflexão sobre o reordenamento das decisões sobre os temas da agenda internacional, que afetariam interesses de maior número de países nas instâncias internacionais (LAÏDI, 1994; SENARCLENS, 1998; SMOUTS, 1998; GADDIS, 1998). As convocações das conferências a partir de 1990 são ilustrativas: Cúpula Mundial sobre a Criança (Nova Iorque, 1990); Conferência das Nações Unidas sobre Meio Ambiente e Desenvolvimento (Rio, 1992); Conferência Internacional sobre População e Desenvolvimento (Cairo, 1994); Cúpula Mundial sobre o Desenvolvimento Social (Copenhague, 1995); IV Conferência Mundial sobre a Mulher (Pequim, 1995); Conferência das Nações Unidas sobre Assentamentos Humanos (Istambul, 1996). ${ }^{103}$

Mas o que todas as cúpulas da década de 1990 teriam em comum e quais as consequências e continuidades para o desenvolvimento da OAI? O liame elementar das características dessa nova ordem internacional que surgia no período pós-Guerra Fria, ausente a bipolaridade que caracterizou a segunda metade do século XX, dividido entre duas superpotências cercadas de nações subestacionárias, foi justamente a proliferação dos atores e de instituições globais no núcleo do SI, que alterava de alguma forma as

\footnotetext{
${ }^{103}$ Para uma análise mais completa das iniciativas das Nações Unidas de promoção de conferências sobre variados temas nos anos 1990, a chamada "Década das Conferências", Cf. ALVES (2001), LAGO (2004); LE PRESTRE (2005).
} 
regras do jogo da política mundial, e as características inovadoras dos conflitos interestatais, para além da busca de estratégias de poder e manutenção de estruturas tradicionais periféricas.

Se, de um lado, as entidades intergovernamentais pareciam dar o tom das propostas nos foros internacionais, de outro, alguns atores marginalizados submergem para ditar valores e buscar defender seus interesses, como ONGs e empresas transnacionais. Outros adquirem maior relevância e buscam tornar-se sujeitos plenos das relações internacionais, como os indivíduos em foros internacionais. A busca por uma governança ambiental eficiente e eficaz não poderia ficar alheia a essa realidade. Surge dessa nova compreensão política, paulatinamente, uma fragmentação políticoinstitucional e jurídico-normativa exacerbada ainda por ser organizada e que vem tornando ineficazes unidades mais centralizadoras de solução dos conflitos e controvérsias no âmbito do SI.

A complexidade de regimes e o crescimento desenfreado de instituições e atores operando no sistema têm sido constante fonte de preocupação, relacionando-se diretamente à fragmentação jurídico-institucional. Não menos preocupante é o papel da governança ambiental na fragmentação da ordem global contemporânea, com sua proliferação demasiada de mecanismos jurídicos e de proliferação daquelas instituições, resultando na imobilidade de seus atores e no "travamento" de seus temas. Tal conceito, que remete a inúmeras definições que ultrapassam o escopo do trabalho, crescentemente faz parte de conteúdos programáticos de foros multilaterais e de instituições do escopo do PNUMA, por exemplo. Em seu "Relatório sobre a Governança Ambiental Internacional”, aquela instituição já afirmava que “(...) the increasing complexity and fragmentation in international environmental governance is partly the consequence of the growing number of actors, both governmental and nongovernmental, in the environmental field. In addition, the proliferation of United Nations and other international bodies that incorporate elements of the environmental agenda adds to the complexity. ",104

${ }^{104}$ Cf. http://www.unep.org/ (acesso em 13/05/2014) 
A profusão dos atores certamente tem levado a ordem global a problemas como a ausência da centralidade dos produtores de normas e os questionamentos por parte da sociedade internacional sobre a aplicabilidade das decisões e do conteúdo regulamentar de acordos definidos nas principais instâncias do regime ambiental, como convenções e foros multilaterais. É complexo reconhecer as consequências dessa proliferação de atores; uma delas é a crescente e paulatina diminuição de seu dinamismo, em razão da fragmentação político-institucional que prejudica uma governança de médio prazo mais efetiva e com resultados concretos para a organização da ordem mundial. Esse pessimismo poderá impactar a área ambiental irreversivelmente, dada a limitação dos recursos naturais e os aspectos inerentes de questões como mudança climática e biodiversidade, quando confrontadas com a necessidade de soluções mais urgentes.

A fragmentação política tem-se feito acompanhar, como esperado, de um processo paralelo e de nuances similares de fragmentação jurídica, pelo incontrolável número de acordos colaterais negociados sem uma centralidade específica (DELMASMARTY, 1998; KOSKENIEMI, 2002; COMTOIS-DINEL, 2006). Uma das consequências mais imediatas poderá vir a ser a dificuldade de implementação de normas gerais a serem aceitas prontamente pelos atores no cenário internacional (CLARK, 1997; HURRELL, 2007). ${ }^{105}$ A fragmentação da OAI apresenta, assim, duplo aspecto: a desordem institucional e a ineficiência legislativa. Cada um deles com características específicas. Se, por um lado, há expectativa de que o regime ambiental consiga recuperar-se da proliferação das instituições e de seus efeitos negativos para a composição do regime ambiental; por outro, a expansão dos mecanismos internacionais de forma desregulada e de contínua especialização temática tem sido considerada um problema para o DIMA.

Sobre o tema, Maljean-Dubois (2014) entende que as últimas décadas de diálogo ambiental entre os Estados, pautadas por divergências recíprocas com relação à industrialização-desenvolvimento, resultaram em um crescimento exponencial de

105 São exemplos dessas "convenções" um também sem número de memorandos de entendimento assinados entre ministérios de Meio Ambiente e iniciativas de agências intergovernamentais, além da comunidade acadêmica e científica. Embora esse fato aparentemente demonstre a crescente vontade política de colaboração em grupos de trabalho e de avanços rumo a um esboço jurídico-institucional positivo, coerente e mais efetivo da governança ambiental, pode-se argumentar que essa centralização resulta na marginalização de alguns atores e questões ambientais. 
acordos ambientais no âmbito multilateral, com vistas a controlar um considerável espectro de questões, desde recursos naturais à preservação da fauna e da flora. A facilidade de negociação desses acordos, para além da efetividade prática e da tentativa de aprimoramento do sistema de compliance, remete à questão problemática da existência hoje de uma verdadeira "congestão de tratados". Tal fato levaria a uma "ineficiência operacional" do regime, causada pelo tempo e recursos despendidos pelos Estados para participarem dos foros negociadores, pelas inconsistências entre diversos mecanismos legislativos e pelas dificuldades de implementação dos acordos em âmbito local. ${ }^{106}$

Diante da situação, algumas tendências se impõem ao DIMA, com reflexos além das questões tradicionais apontadas pelos doutrinadores, de que são exemplos a necessidade de codificação efetiva deste ramo do direito e o estímulo à implementação e ao cumprimento das normas e das diretrizes para a resolução de conflitos, distantes dos princípios clássicos de centralidade estatal e mais próximas da valorização do ser humano. Nas últimas décadas, com a expansão temática das relações internacionais e da evolução conceitual do direito das gentes, uma tendência de se criar um direito social mais inclusivo e afirmativo, em direção à sociedade dos povos, em paralelo - para não dizer detrimento - de uma sociedade de nações, vem tornando-se predominante, como destacaram Armstrong (1999) e Cançado Trindade (2002).

$\mathrm{O}$ regime da responsabilidade estatal certamente faz parte desse movimento e insere-se no contexto de criação de novos preceitos a pautar a atuação do DIP e dos Estados, com o desenvolvimento das normas de jus cogens e das obrigações erga omnes, na medida em que aqueles preceitos caminham na contramão do positivismo clássico de supremacia do pacta sunt servanda, em detrimento de princípios básicos de defesa dos direitos humanos em geral e ambientais em menor medida. ${ }^{107}$ Franck (2003)

\footnotetext{
106 Maljean-Dubois exemplifica essa congestão de acordos com o regime de florestas, tema tratado exaustivamente na Convenção da Biodiversidade, no Foro das Nações Unidas sobre Florestas, no sistema ONU de Mudanças Climáticas e no próprio Protocolo de Kyoto. O acúmulo de tratados, sob essa ótica, chega a causar um peso administrativo cada vez maior aos Estados.

${ }^{107} \mathrm{O}$ regime da responsabilidade civil dos Estados não se confunde com a noção a ser tratada adiante de "soberania como responsabilidade". Enquanto o primeiro refere-se à responsabilidade estatal diante de atos ilícitos, assim definidos pelo Direito Internacional, como um princípio já longamente estabelecido, o segundo diz respeito à recente transformação por que passa o princípio da soberania, da antes afirmação absoluta à sua extensão como uma responsabilidade do Estado (vide cap. II). De acordo com a Comissão
} 
avalia que os Estados não mais são os únicos determinadores da justiça ou razão de suas ações no plano internacional. A comunidade internacional vem crescentemente exercendo um papel relevante por meio dessa representação difusa (embora também fragmentada) nos mais diversos foros internacionais e regimes. ${ }^{108}$

A fragmentação político-normativa da OAI contemporânea, assim, relaciona-se com o tema da necessidade ou não de uma governança ambiental global mais assertiva e de caráter centrípeto. Tendo em vista as dificuldades de se pensar em uma governança global mais eficiente nesse contexto de incertezas, em que os valores e as normas são recriados para servir aos interesses das nações mais bem equipadas para enfrentar esse complexo normativo e mitigar o aspecto pernicioso de todo o processo fragmentativo, os Estados recriam seus paradigmas e atuação na OAI. Ainda que a sociedade consensualista pareça concretizar-se em alguns aspectos temáticos socioambientais, como no compartilhamento de valores e princípios voltados à sustentabilidade do planeta e à crescente consciência dos Estados em prover maior qualidade de vida às populações, há tendência na atuação estatal de retorno gradual aos paradigmas mais ao espectro realistas-minimalistas, como demonstrou o pessimismo da última década no cenário internacional a respeito do cumprimento de normas que limitem a soberania estatal.

Essa tendência (ou inerência?) dos Estados na OAI, aventada por Ribeiro (2001), parece mais presente na atualidade e deverá transbordar para subtemas mais prementes

de Direito Internacional (ILC), há um ato ilícito internacional quando a conduta estatal consiste de uma ação ou omissão atribuída ao Estado que represente uma "quebra" da obrigação estatal. Já a "soberania como responsabilidade" prescreve que o ente soberano tem um dever de proteger a própria população, atributo inerente da soberania pautada nos princípios contemporâneos de proteção da pessoa humana. Tal princípio vem sendo continuamente reafirmado no âmbito multilateral em organismos como as Nações Unidas. A responsabilidade civil estatal, de sua vez, pode ser visualizada em situações de desastres nucleares que envolvam danos materiais a serem compensados. Baseia-se em princípios como os da responsabilidade exclusiva e estrita do operador pelos danos resultantes a terceiros, bem como jurisdição das cortes onde se encontram as instalações nucleares. São exemplos não exaustivos de legislação nesse sentido, se citarmos a área nuclear, a Convenção sobre Responsabilidade Civil contra Terceiros no Campo da Energia Nuclear (Paris, 1960) e a Convenção sobre Responsabilidade Civil por Danos Nucleares (Viena, 1963).

${ }^{108}$ Nesse contexto de disputas intrarregimes para hierarquizar ou descentralizar o tema ambiental, surgem propostas as mais diversas como a do estabelecimento de uma organização mundial do meio ambiente (ONUMA), a exemplo do que já ocorre em outras áreas, como a econômico-comercial (OMC), ou saúde (OMS). A proposta, capitaneada pelo governo francês, viria ao encontro da ideia de completar a arquitetura da regulação ambiental global, no entender do Primeiro-Ministro Lionel Jospin, naquilo que ela seria deficiente, ou seja, na busca de assegurar por meio de uma organização de caráter global o respeito aos compromissos internacionais 
na seara da segurança estatal, como as situações de desastres ambientais, em que, diferentemente dos problemas tradicionais da área ambiental, exigem respostas imediatas e retrativas de contenção de danos. A medida com que os Estados deverão pesar seus cálculos decisórios em tais situações ainda está por ser definida, mas tudo indica que será com o instrumento de que tradicionalmente se serviu: a soberania (e suas prerrogativas, entre elas o uso da força).

\subsection{Considerações finais}

Com o crescente destaque das questões ambientais na cena internacional, os atores vêm desenvolvendo mecanismos de proteção ao meio ambiente, pautada em valores e princípios que idealmente preconizam um futuro mais seguro e uma maior qualidade de vida para a humanidade, além de um equilíbrio sistêmico da ordem internacional. Conceitos vêm sendo refinados para que o "complexo de regimes" hoje existente se harmonize aos interesses de nações, dos indivíduos e das instituições, de modo a conformar uma opinião pública positiva sobre variados temas que afetam a ordem ambiental.

Esse processo não é fácil e seus desdobramentos influenciam as relações interestatais. Os Estados têm continuamente de fazer face a desafios mais "modernos" advindos da compressão espaço-temporal, que em larga medida tornou-se responsável por uma dinâmica mais assertiva da ordem global, propiciando por meio das tecnologias de informação mais avançadas um contato maior entre atores mais à margem da seara estatal. Essa proliferação de atores no âmbito transnacional impõe renovado ímpeto à atuação estatal, não mais decisor último dos temas afetos ao meio ambiente. Diante disso, os Estados têm buscado reorganizar-se para manter prerrogativas inerentes aos seus atributos soberanos também ameaçados. Pode-se creditar essa reorganização estatal diretamente às consequências da globalização? Consideramos que não.

Outras mudanças mais sistêmicas são responsáveis de forma similar pela composição da ordem global contemporânea. O final da Guerra Fria tem seu peso na história. A reordenação das alianças em adequação ao mundo uni-multipolar que se seguiu ao ocaso da bipolaridade permitiu que temas antes candentes voltassem às mesas de negociações dos atores estatais em diversas regiões do globo. A inovação sem 
precedentes desse período certamente revelou-se na revolução ontológica da concepção securitária da variável ambiental, em que instrumentos de análise mais refinados, a pautar a agenda dos Estados e dos atores não-estatais, foram postos, desvelando uma forma mais dinâmica de se pensar o meio ambiente e favorecendo uma participação mais efetiva de ambos os entes nos inúmeros foros que se tornaram propícios a partir da década de 1990, a contar pela CNUMAD.

A securitização do tema ambiental abriu caminho para se relacionar questões antes vistas eminentemente do ponto de vista humanitário, como desastres ambientais, a outras mais à vertente realista das políticas estatais, cujos líderes passaram a conceber o meio ambiente como fonte de conflitos e de solução para problemas mais prementes que afetavam suas unidades políticas, como poluição e degradação ambiental. Por um lado, a percepção do espectro holístico da variável ambiental, que permitiu a interconexão entre os diversos regimes que compõem a "burocracia" global, caso tenha favorecido a aproximação dos atores nas relações internacionais, por outro permaneceu como catalizador de conflitos inter e intraestatais e transnacionais, com consequências para a configuração da nova ordem, ainda por ser analisada por completo.

O terceiro capítulo da pesquisa, que encerra a Parte I, buscou conhecer esse processo de evolução da OAI, com o objetivo de fundamentar a "importação" dos princípios e práticas de áreas afins à temática ambiental, principalmente ao DIMA, que passou do materialismo-racional dos tratados para uma vertente mais humanista, para apresentar novos desafios e incorporar valores da contemporaneidade. Após essa parte introdutória da tese, em que a ordem global e seu subsistema, a OAI, foram trazidos ao escrutínio de modo a conhecer seu processo evolutivo e os aspectos da construção discursiva de seus diversos agentes, para conformar o quadro analítico-teórico e jurídico-institucional moderno pautado nas concepções de segurança ambiental global e desenvolvimento sustentável (RIBEIRO, 2001), avançaremos para o tema central do trabalho. A partir de então, a discussão alcança tons mais polêmicos e desafiadores, pela interseção das bases conceituais da SH, da R2P e das obrigações positivas.

As controvérsias temáticas e as divergências de opiniões caracterizam o debate das intervenções e do uso da força nas relações internacionais. Pretendemos, assim, 
avaliar e analisar nas próximas páginas a construção discursiva dos mecanismos voltados a prover de legitimidade e legalidade os instrumentos disponíveis no DI e na arena internacional, a respeito do uso da força e das intervenções mais soft, critérios, sem dúvida, definidores da política global. Nosso foco tenderá a privilegiar a variável ambiental, com atenção às intervenções verdes. 
CAPÍTULO IV

A INTERVENÇÃO: EVOLUÇÃO DO CONCEITO NAS RELAÇÕES INTERNACIONAIS 


\section{A Intervenção: evolução do conceito nas relações internacionais}

“(...) saying humanitarian intervention in a room full of philosophers, legal scholars, and political scientists is a little bit like crying 'fire' in a crowded theatre: it can create a clear and present danger to everyone within earshot."

\section{Robert Keohane, in Humanitarian Intervention (2004:1)}

\subsection{Considerações iniciais}

O tema da intervenção nas relações internacionais desperta paixões nos mais diversos círculos acadêmicos. Dos mais polêmicos, evoluiu conceitualmente nos últimos dois séculos para envolver denominações as mais amplas e ilimitadas possíveis, parte em razão das inúmeras situações em que não somente as Nações Unidas, mas também coalizões internacionais, recorreram à intervenção militar e econômica para enfrentar desrespeitos aos direitos humanos em diversas regiões do planeta. Das intervenções no período mais conturbado do Império Otomano, no século XIX (MANSFELD, 2003; RODOGNO, 2012; CLEVELAND \& BUNTON, 2013), às discussões mais avançadas a respeito dos temas da $\mathrm{SH}$, do direito/dever de ingerência à R2P, acadêmicos, políticos e internacionalistas vêm buscando responder ao paradigma da ação/inação diante de atrocidades cometidas por Estados, indivíduos e outras formas de coletividade contra os direitos humanos e o meio ambiente em nome, geralmente, da defesa da soberania estatal (BETTATI, 1996; ACHARYA, 2002; TRINDADE, 2002; HOLZGREFE \& KEOHANE, 2004; EVANS, 2008; AXWORTHY \& ROCK, 2009; COOPER \& KOHLER, 2009; WEISS, 2012). A questão das intervenções apresenta-se como uma caixa de pandora no SI pós-1945. É inegável que nas últimas décadas as relações internacionais passaram por avanços consideráveis nos direitos humanos, consubstanciados em inúmeras declarações de líderes e de organismos internacionais em prol do aprimoramento das técnicas e dos critérios de manutenção do direito e da preservação da vida humana. 
A discussão em torno da necessidade de a comunidade internacional intervir em nome de princípios superiores e universais é cada vez mais calorosa: "direito" e/ou “dever" de ingerência, SH, intervenção humanitária, R2P, são termos correntemente utilizados para buscar justificativas para eventuais intervenções externas para salvaguardar direitos humanos universais. Entre os casos recentes de intervenções e discussões sobre o tema podemos citar, entre outros, o da ex-Iugoslávia, República Democrática do Congo, Ruanda, Paquistão, Afeganistão, Síria, Líbia, e, mais recentemente, Iraque, contra o ISIL. São alguns que receberam especial atenção internacional, em razão da gravidade e violência dos fatos que os motivaram. Essa característica da ordem global, que passa a privilegiar intervenções, relaciona-se decerto com a natureza dos conflitos, que adquirem novos contornos e abordagens explicativas, em prol de uma evolução conceitual controversa de defesa de princípios declaradamente democráticos e universais, ainda por serem avaliados de modo mais crítico.

Como veremos no tópico sobre a $\mathrm{R} 2 \mathrm{P}$, adquire crescentemente força a tendência de se acreditar que, quando as soberanias falham em proteger a própria população, principalmente em guerras de caráter étnico, ou quando governantes são responsáveis diretos por crimes praticados contra quem deveria defender, a comunidade internacional deve chamar para si a responsabilidade e "ignorar" a soberania, por meio de intervenções pontuais. Em casos extremos, uma luz verde se acenderia para que outros Estados, motivados por princípios superiores de respeito aos direitos humanos, interviessem para pôr fim a uma agressão indevida contra indivíduos. Nye (2007: 161) aponta que a "intervenção" é um conceito confuso por não descrever somente o que está ocorrendo, mas também por ser carregado de valores morais. ${ }^{109}$

Nas Relações Internacionais, as abordagens explicativas com relação aos conflitos passam pelas diversas correntes de pensamento, desde a tradicional realista às mais contemporâneas liberais e construtivistas. O foco dicotômico cooperação-conflito

\footnotetext{
${ }^{109} \mathrm{Na}$ sua definição mais ampla, a "intervenção refere-se a ações externas que influenciam os assuntos domésticos de outro Estado soberano". Haveria necessariamente uma intervenção forçada na política doméstica de outro Estado. Mesmo um discurso de uma autoridade de um país contra a política de um outro pode ser considerada uma espécie de intervenção, do modo similar a assistência econômica de um Estado a outro em tempos de paz. O autor exemplifica com o auxílio econômico norte-americano para El Salvador, durante a Guerra Fria, assim como o soviético a Cuba, no mesmo período, e o apoio por meio de consultores militares a governos estrangeiros, com o fim de influenciar a política de segurança de outras nações.
} 
permanece válido, ainda que se alterem as premissas epistemológicas e ontológicas das escolas envolvidas em perscrutar as causas das intervenções como último ou necessário recurso para salvar vidas em situações inclusive emergenciais humanitárias, incluídas aí a assistência e a obrigação da comunidade internacional em situações de catástrofes ambientais.

Quando pensamos em desastres ambientais e na reação da comunidade internacional com relação à salvaguarda das populações neles envolvidas, com relativa perda de vidas humanas, não há como separar os temas da intervenção humanitária e da proteção internacional ambiental, sobretudo quando se acrescenta o componente humano às crises. É tradicionalmente aceito por parte da doutrina internacional que a responsabilidade primária da proteção das populações em situações de risco que afetem determinadas comunidades recai sobre o Estado-vítima, muito embora a evolução do tema aponte para o crescente desejo de alguns entes de intervirem em assuntos internos de outros quando estes estejam impossibilitados, ou mesmo impedindo deliberadamente, auxílio a populações afetadas. ${ }^{110}$

Afirmar que o Estado tem a responsabilidade primária de responder a situações emergenciais não significa que ele seja a única autoridade com um interesse em saber como a emergência será administrada. Podemos citar alguns casos concretos que engendram cooperação internacional: situações de desastres ambientais graves, como terremotos (China, 2014; Turquia, 2011; Japão, 2011; Haiti, 2010; Itália, 2009; Peru, 2007), tsunamis que assolaram o Oceano Índico, mais precisamente na ilha de Sumatra, na Indonésia, que deixou pelo menos 220.000 mortos (2004); a queda de aviões, como o da Air France (2009) e o da Malaysia Airlines (2014), a fome na Somália (2010-12), de razões ambientais, mais recentemente, e os de acidentes nucleares, como os das centrais de Chernobyl (1986) e Fukushima-Daiichi (2011), vistos oportunamente.

\footnotetext{
${ }^{110}$ Alguns casos recente que podem ser recordados dizem respeito às denúncias contra a Coréia do Norte (http://brasil.elpais.com/brasil/2014/02/17/internacional/1392643953_407244.html - Acesso em 10/01/2012) e a situação do Ciclone Nargis, em Myanmar, cujas autoridades recusaram inicialmente receber assistência humanitária (EVANS, 2009; RAFFELSEDER, 2011). Vale citar, ainda, o caso do submarino Kursk, em que as autoridades russas postergaram a aceitação de oferecimento de resgate pela comunidade internacional da tripulação sobrevivente no tempo necessário, levando todos a óbito (ao menos 23 indivíduos). Cf. "Eles estavam vivos" - In: http://veja.abril.com.br/011100/p_056.html 1/11/2000. Acesso em 15/04/2012
} 
Neste capítulo trataremos da evolução do conceito da "intervenção" no cenário internacional. Suas origens serão discutidas com uma imersão histórica, no intuito de avaliar a progressão político-sociológica e acadêmica do conceito, co-relacionando-se a intervenção no âmbito humanitário àquelas na área ambiental. Devido à forte oposição à transposição do conceito e de suas diretrizes hoje postas em prática pelo regime humanitário a outras áreas, como nos casos dos conflitos da década de 1990, nos Bálcãs e na África, e os mais recentes, não será uma tarefa simples. Gareth Evans (2009), exMinistro dos Negócios Estrangeiros da Austrália (1988-1996), um dos precursores do conceito de $\mathrm{R} 2 \mathrm{P}$, acena para os riscos da tentativa de transposição das intervenções para o meio ambiente.

\subsection{Uma breve história das intervenções}

Muito embora as intervenções humanitárias sejam concebidas no estudo das RI como um fenômeno do século XX, mais especificamente do final da primeira metade do século após a criação das Nações Unidas, a prática internacional das intervenções pode ser considerada como parte do século XIX, com o crescente envolvimento dos países europeus em territórios então ocupados pelo antigo Império Otomano (SIMMS \& TRIM, 2011; RODOGNO, 2012). Potências coloniais da época, como a Grã-Bretanha, a França e a Rússia, já exerciam papel considerável em intervenções nas fronteiras daquele império, sob o argumento de defesa das comunidades cristãs, do que viria a ser conhecida um século depois como "intervenções humanitárias". Obviamente tal terminologia era desconhecida à época, além do que se conhece nos dias atuais como crimes de guerra, crimes contra a humanidade, genocídio e limpeza étnica. ${ }^{11}$ Termos como "massacre", "atrocidade" e "extermínio" podem ser mais tempestivos e menos anacrônicos na literatura do século XIX. ${ }^{112}$

\footnotetext{
${ }^{111} \mathrm{O}$ artigo $5^{\mathrm{o}}$ do Estatuto de Roma do Tribunal Penal Internacional (TPI), estabelecido em 2002, com sede na Haia, tem jurisdição sobre os crimes de genocídio, os crimes contra a humanidade, os crimes de guerra e os crimes de agressão, definidos, respectivamente, em seus arts. 6, 7 e 8.

112 Para Davide Rodogno (2012:54), não é simples a discussão sobre as origens da intervenção humanitária, Rodogno discute a autenticidade do termo para as intervenções do século XIX fundamentadas na ideia de religião e questiona se não seria correto considerar as ações coercitivas como ato de imperialismo religioso, em razão de as intervenções humanitárias naquele período não terem sido baseadas - como as de hoje - em um "universalismo secular" e sistematicamente não transcendendo as fronteiras da religião. O autor traz à memória o fato de que quando as potências europeias lidavam com os massacres dentro do Império Otomano, ignoravam as violações aos direitos humanos que aconteciam dentro de suas colônias.
} 
Até o início do século XX, segundo o jurista Simon Chesterman (2001), o status da "intervenção humanitária" como doutrina legal não era claro e as diferenças fundamentais podem ser vistas em seu status normativo. Uns eram confiantes sobre o direito unilateral das "nações civilizadas" de intervenção, enquanto outros o rejeitavam veementemente. Havia também os que acreditavam que o DI não poderia imiscuir-se em tais questões, provavelmente relegando-as a outras áreas. Conforme observou Rodogno (2012), somente em um aspecto era possível consenso entre os policymakers no século XIX: o direito de intervenção não era uma opção com que os assuntos europeus estavam tão debruçados, especialmente quando atrocidades ocorriam nas fronteiras de outras "grandes nações".

No final do século XIX, embora a terminologia hoje utilizada para classificar intervenções, suas causas e consequências, ainda parecesse inexistente, seus princípios e parâmetros não eram (JAMES \& FRIEDMAN, 2006). À época, juristas argumentavam que a doutrina das intervenções humanitárias seria uma realidade no direito consuetudinário, argumento contestado por acadêmicos nos dias atuais. Os críticos ressaltam que a prática das nações mais poderosas naquele período era assaz contestável e sem conteúdo humanitário, por visar interesses próprios revestidos de caráter humanista.

Como apontou Chesterman (idem: 07), parte das análises históricas acerca da intervenção humanitária passa por uma lacuna de precisão sobre seu real significado. No início confundiam-se intervenções limitadas - com objetivos específicos - com "guerra total", ou então intervenções baseadas em uso da força ou ameaça com interferências diplomáticas. Nos textos clássicos, buscou-se um equilíbrio no reconhecimento da capacidade de um soberano de iniciar um conflito em nome de um povo injustamente oprimido por um outro.

Em suas origens, as intervenções como conhecidas nos dias atuais eram tributárias da doutrina da "guerra justa", desenvolvida pelos "escolásticos" e cujo máximo expoente foi o holandês Hugo Grotius (1583-1645). Em De jure belli ac pacis, Grotius sistematizou a prática da guerra sob as bases do jus belli. Justificava a 
intervenção na prática religiosa medieval, onde as diferenças eram frequentes e raramente toleradas. Na Europa dos séculos XVI e XVII, ao dissertar com base na vasta experiência de guerras religiosas europeias, prezou pela tolerância. Criticou a falta de limites aos conflitos de natureza religiosa e defendeu que guerras não poderiam ser justificadas pela interpretação do Cristianismo. Essa argumentação fundamentou a formulação dos princípios introduzidos na paz de Westphalia (1648) e a política de balança de poder europeia. ${ }^{113}$

Essa mudança de paradigma apresentada por Grotius respondeu pela emergência do positivismo no direito internacional. Embora a corrente positivista viesse a rejeitar a compreensão de "guerra justa" como aventada pelo jurista holandês, seus escritos fundamentaram a defesa do direito natural individual e o direito de se iniciar uma guerra em nome dos povos oprimidos (Chesterman, idem). Sobre o tema, a literatura, conquanto limitada, tem em Vindicae contra tyrannos, de Hubert Languet (1579), elaborado durante as guerras de religião na França, um exemplo de defesa do direito de intervenção em nome daqueles povos. Alberico Gentilli, De juri belli (1612), aparece também no rol dos autores que pensavam a soberania como uma responsabilidade. A ideia de que o Estado deve restringir-se de intervir ressurge com força em Thomas Hobbes (1588-1679). Nesse período, o positivismo "deslocou" o escolasticismo da teoria legalista internacional, quando também a religião parece ser afastada de vez da doutrina do direito internacional, para dar lugar à noção de soberania estatal como elemento crescentemente inviolável. ${ }^{114}$

\footnotetext{
${ }^{113}$ Para Chesterman (idem: 10), o tratado de Westphalia assegurou o direito aos soberanos de determinar a aliança confessional entre estados e súditos, trazendo dessa forma um fim às guerras religiosas. No entanto, afirma o autor, Grotius admitia um direito à guerra com propósitos punitivos, como necessário para a preservação da ordem social pela inexistência de uma autoridade supranacional para tanto. Grotius afirmava que "liberty to serve the interests of human society through punishments' derives not from the position of authority held by sovereigns but from the fact that, in the order of states, they themselves are subject to no one".

$114 \mathrm{O}$ primeiro autor a defender uma prescrição absoluta de intervenções parece ter sido o pensador alemão Christian Wolff (1679-1754), ao acreditar que uma guerra punitiva apenas seria legal se um Estado agisse em legítima defesa, após sofrer uma injúria irreparável, em que uma satisfação não pudesse ser obtida. Na mesma linha, o filósofo-jurista Emmrich de Vattel (1714-1767) adotou premissa semelhante ao defender a inviolabilidade da jurisdição doméstica, em The Law of Nations: Principles of the Law of Nature, Applied to the Conduct and Affairs of Nations and Sovereign (1758). Vattel critica Grotius na sua defesa da intervenção quando um soberano for responsável por uma transgressão das leis da natureza. (Chesterman, idem)
} 
Séculos depois, os princípios avançados pelos filósofos naturalistas encontraram eco nas revoluções que assolavam a Europa de forma irreversível, para trazer uma reconfiguração política e territorial que afetaria o modo de pensar dos povos daquela região. Surpreende que uma das primeiras declarações explícitas do princípio da nãointervenção tenha aparecido na Constituição Jacobina de 1793, que prevê em seus artigos 118 e 119, respectivamente, que o povo francês é "amigo e aliado natural dos povos livres" e "não se imiscui no governo de outras nações". Chesterman avalia que chega a ser irônico que a República francesa, que fez declaração do gênero no meio de uma atmosfera revolucionária, encontrasse estabilidade interna para partir rumo à missão napoleônica de conquistar o mundo. Essa missão, que não passaria despercebida para o mundo monárquico hegemônico europeu, viria a configurar aliança que se pautaria no direito de intervenção para proteger a ordem existente e manter a paz. ${ }^{115} \mathrm{~A}$ quádrupla aliança, que veio a se tornar uma pentarquia em breve com a admissão da França, em 1818, logo se tornou uma bem sucedida tríplice aliança, somente composta pela Áustria, a Prússia e a Rússia, em razão da oposição inglesa às expedições contrarevolucionárias de Nápoles, Grécia e Espanha (HOBSBAWM, 1989b; ROBERTS, 1990).

A expressão "intervenção humanitária" parece ter sido utilizada pela primeira vez, no âmbito do direito internacional, na obra Treatise on International Law (1884), de William Edward Hall, embora conceitos semelhantes já aparecessem na vasta literatura inglesa e francesa do século XIX. O lastro da ideia de intervenção pôde ser observado igualmente em Henry Wheaton, Elements of International Law (1836), citado por Richard Lillich (1973), quando o escritor utilizou-se do termo "interferência" para referir-se à ação dos países cristãos europeus em socorro aos insurgentes gregos contra o Império Otomano. No mesmo período, podem ser encontradas também

\footnotetext{
${ }^{115}$ Com a derrocada de Napoleão Bonaparte, a Áustria, Rússia, Prússia e Inglaterra buscaram restabelecer a paz e a estabilidade política na Europa. O Congresso de Viena tinha como objetivo reformular o mapa político europeu e reestabelecer a ordem na França, que deveria pagar uma indenização de guerra e formar um novo governo conservador. A Alemanha e a Itália tiveram de ceder parte de seus territórios para a Prússia e Áustria. Os resultados do Congresso de Viena foram vantajosos aos países dominantes, pela redefinição das fronteiras políticas e a relativa paz subsequente (SARAIVA, 2001).
} 
diferentes expressões como "intervenção com base na humanidade", "intervenção no interesse da humanidade", entre outras (CHESTERMAN, idem: 24). ${ }^{116}$

No século $\mathrm{XX}$, as primeiras restrições ao recurso às guerras foram avançadas no Pacto Briand-Kellog, de 1928. Também conhecido como Pacto de Paris, o acordo estipulava como instrumento de política nacional a renúncia à guerra. ${ }^{117}$ Ainda que sem alcançar plenamente seu propósito, as bases para a discussão estavam postas e viriam com força depois do advento da II Guerra Mundial. ${ }^{118}$ Com o término da II Grande Guerra e a criação da ONU, o tema das intervenções humanitárias ganhou mais proeminência. Embora duas décadas se passassem após a concepção da Liga das Nações e a breve evolução do DIH desde as Conferências da Haia, um pouco antes as intervenções como força normativa no DI e sua legitimação ganharam eficácia e forma, com a aceitação da Carta da ONU e o argumento legal nela prescrito. ${ }^{119}$ A Carta foi acordada entre os membros da então criada organização para buscar "corrigir" os erros de sua predecessora (a Liga das Nações) e trazer ao centro dos debates os motivos das duas guerras mundiais, que em tantas catástrofes e perdas de vidas humanas resultaram. $^{120}$

\footnotetext{
${ }^{116}$ Apesar de ser ponto usualmente pacífico de que o ápice do desenvolvimento conceitual da intervenção humanitária teve lugar a partir da Segunda-Guerra, com a Carta das Nações Unidas de 1945, já no século XIX alguns eventos podiam ser observados sob as lentes conceituais em apreço, caso se tomem como exemplos a intervenção conjunta inglesa-francesa-russa acima citada para auxílio aos insurgentes gregos, em 1827. Note-se também a ocupação francesa na Síria (1860) e a intervenção norte-america em Cuba, décadas depois (1898). Das intervenções não coercitivas, que envolviam tão somente a solução pacífica das controvérsias por meios diplomáticos, vale considerar a austro-húngara e russa contra o Império Otomano para salvaguardar o direito dos cristãos na Macedônia, no início do século XX, acompanhada da "intervenção" estadunidense também junto à Sublime Porta para proteção da comunidade armênia, entre 1905 e o final da Primeira-Guerra.

117 A Carta da Liga das Nações, apesar de apresentar princípios convincentes de que haveria o desenvolvimento conceitual das intervenções de caráter humanitário, nem proibia nem permitia expressamente quaisquer instrumentos nesse sentido. $\mathrm{O}$ uso da força foi proibido, mas questões humanitárias eram consideradas disputas e deveriam ser levadas a consideração da Liga. Da mesma forma, o Pacto Briand-Kellog condenava o recurso à guerra e estimulava seus integrantes a renunciá-lo como instrumento de política nacional.

118 Conforme estipulado já no preâmbulo do Pacto: "Persuadidos de que chegou o momento de se proceder a uma franca renúncia à guerra como instrumento de política nacional, a fim de que as relações pacíficas e amistosas atualmente existentes entre seus povos possam ser perpetuadas" Cf. http://pfdc.pgr.mpf.mp.br/

119 A Carta das Nações Unidas alterou os termos do debate, por duas razões. Passou a estabelecer as circunstâncias em que as intervenções são permitidas e passou a denominá-las "o uso ou ameaça de força".

${ }^{120}$ A primeira dificuldade que se encontrou foi aquela de especificar a natureza jurídica das Nações Unidas, além dos já claros objetivos políticos de seus membros. Não para menos, no silêncio da Carta sobre o estatuto jurídico, que deveria mais adiante servir de estrutura legal para justificar eventuais
} 
O período da Guerra Fria (1947-1991), em que as duas superpotências digladiavam-se em defesa de seus interesses pelo globo e utilizavam-se de duvidoso discurso dos direitos humanos para justificar intervenções realizadas, é convincente da retórica dos que defendem que as últimas intervenções, mesmo no seio das Nações Unidas, não passariam de disfarce, mas com outros nomes, da contínua busca de objetivos econômicos e estratégicos (ARRIGHI, 2003). Igualmente, Weiss (2012: 40) aponta que a retórica do humanitarismo tem sido usada em casos onde a motivação humanitária é a mais fraca possível, como na proteção dos próprios nacionais: "the use of ' $H$ ' adjective to mask other motivations indicates the scope for abuse'.

Em recorte histórico, o período da Guerra Fria é essencial quando se trata do tema da intervenção humanitária. Um primeiro ponto a se considerar refere-se à ambição central do SI pós-1945: a busca pela preservação da paz (VAISSE, 2004; McWILLIAMS \& PIOTROWSKI, 2005). Os anos sangrentos de guerra haviam deixado marcas em diversas regiões do planeta e a certeza de que a política expansionista de outrora ou de intervenções unilaterais, mesmo em defesa dos direitos dos povos, eram as responsáveis pelo sofrimento causado aos milhões de vítimas dos conflitos das duas grandes guerras que assolaram a primeira metade do século. Foi sob esse contexto que, em 1945, nações do mundo inteiro ratificaram uma carta retirando, de seus preceitos fundamentais, a prerrogativa do direito individual estatal de declaração de guerra. ${ }^{121}$

Michael Newman (2009:11) diz não ter dúvidas de que, em princípio, a exclusão do direito unilateral à guerra constituiu uma transformação no sistema internacional. No

intervenções em outros membros, várias consultas foram realizadas junto à Corte Internacional de Justiça no sentido de tornar precisa a natureza jurídica das Nações Unidas. Em consulta de 11/04/1949, sobre reparações a prejuízos ocorridos em nome das Nações Unidas, a Corte afirmou que: 'L'Organisation était destinée à exercer des fonctions et à jouir de droits qui ne peuvent s'expliquer que si l'Organisation possède une large mesure de personnalité internationale et la capacité d'agir sur le plan international. Elle (...) ne pourrait répondre aux intentions de ses fondateurs si elle était dépourvue de la personnalité internationale. On doit admettre que ses membres, en lui assignant certaines fonctions, avec les devoirs et les responsabilités qui les accompagnent, l'ont revêtue de la competence nécessaire pour lui permettre de s'acquitter effectivement de ces fonctions (REc. 1949, p.179)", citado por Emmanuel Decaux, em Droit internacional public, Dalloz, 6e édition, 2008.

${ }^{121}$ A prerrogativa de determinar a existência de ameaça à paz e as medidas para contê-la, nesse novo sistema de "segurança coletiva", passou ao órgão máximo das Nações Unidas, o Conselho de Segurança. Dos mais relevantes de todo o acordo, o Capítulo VII passou a ditar a política das intervenções a partir de então, com a única exceção o instituto de legítima defesa, ainda assim em casos específicos de preservar o direito individual ou coletivo de autodefesa em situação de um ataque armado contra um Estado-membro. 
entanto, não observa, na prática, uma diminuição dos conflitos no período entre 1945 e 1989 e ainda atribui às Nações Unidas certa inoperância diante de situações extremas, ao citar o caso singular da Guerra da Coréia, em que a ONU teria sido persuadida a apoiar militarmente a coalizão ocidental liderada pelos Estados Unidos. O autor dialoga com Hurrell (idem) e reconhece a centralidade do Estado na ordem global do pósguerra, fundada no modelo pluralista-minimalista em que prevalecia os princípios da soberania e da não-intervenção, mas avalia que seria errôneo sugerir os dois princípios como sendo as únicas diretrizes do sistema internacional normativo estabelecido naquele período. Se líderes políticos puderam ser considerados culpados de "crimes contra a humanidade", a exemplo do que ocorreu nos julgamentos de generais nazistas, fascistas e japoneses, haveria uma indicação de que a soberania não era uma proteção à responsabilidade internacional e que os Estados não seriam considerados invioláveis. Questões como essas não foram plenamente desconsideradas pela base legal do sistema internacional do pós-guerra.

Em uma análise mais direta do sistema normativo internacional estabelecido em 1945 pelas ONU, notamos que o preâmbulo da Carta estabelece que cabe aos "povos", em vez de aos "Estados", "preservar as gerações vindouras do flagelo da guerra", “unir as forças para manter a paz e a segurança internacionais e garantir, pela aceitação de princípios e a instituição dos métodos, que a força armada não será usada a não ser no interesse comum." 122 O preâmbulo, ao favorecer a pessoa humana e, consequentemente, estabelecer a base dos direitos humanos, serviria de pano de fundo

${ }^{122}$ Segundo o Preâmbulo, que transcrevemos abaixo: "NÓS, OS POVOS DAS NAÇÕES UNIDAS, RESOLVIDOS a preservar as gerações vindouras do flagelo da guerra, que por duas vezes, no espaço da nossa vida, trouxe sofrimentos indiziveis à humanidade, e a reafirmar a fé nos direitos fundamentais do homem, na dignidade e no valor do ser humano, na igualdade de direito dos homens e das mulheres, assim como das nações grandes e pequenas, e a estabelecer condições sob as quais a justiça e o respeito às obrigações decorrentes de tratados e de outras fontes do direito internacional possam ser mantidos, $e$ a promover o progresso social e melhores condições de vida dentro de uma liberdade ampla. E para tais fins praticar a tolerância e viver em paz, uns com os outros, como bons vizinhos, e unir as nossas forças para manter a paz e a segurança internacionais, e a garantir, pela aceitação de princípios e a instituição dos métodos, que a força armada não será usada a não ser no interesse comum, a empregar um mecanismo internacional para promover o progresso econômico e social de todos os ovos. Resolvemos conjugar nossos esforços para a consecução desses objetivos. Em vista disso, nossos respectivos Governos, por intermédio de representantes reunidos na cidade de São Francisco, depois de exibirem seus plenos poderes, que foram achados em boa e devida forma, concordaram com a presente Carta das Nações Unidas e estabelecem, por meio dela, uma organização internacional que será conhecida pelo nome de Nações Unidas." Cf. DECRETO $\mathrm{N}^{\circ}$ 19.841, DE 22 DE OUTUBRO DE 1945, em http://www.planalto.gov.br/ccivil_03/decreto/1930-1949/D19841.htm (acesso em 08/03/2014) 
para a Declaração Universal dos Direitos Humanos (1948), proclamado pela AGNU (A/RES/217). Serviria também de base para a Convenção Europeia de Direitos Humanos ("Convenção para a Proteção dos Direitos do Homem e das Liberdades Fundamentais"), de 1950, além de diversos outros mecanismos regionais e inúmeros protocolos invocando direitos sociais e econômicos (MAZZUOLI, 2006; PIOVESAN, 2013), alguns sob forte tensão interpretativa entre as duas superpotências do período e seus respectivos países-satélites (DUPUY, 2008: 251-256).

Outro quadro normativo que pautou a evolução dos conceitos relacionados aos direitos humanos e que, paulatinamente, veio apresentando um constante desafio ao princípio da não-intervenção pode ser encontrado na Convenção sobre Genocídio (Convenção para a Prevenção e a Repressão do Crime de Genocídio), de 1948, cujas negociações foram resultado direto das políticas de extermínio nazista, e na legislação derivada diretamente do Direito Internacional Humanitário (DIH), como as quatro convenções de Genebra, de 1949, e seus protocolos adicionais (1977).

Enquanto a Convenção sobre Genocídio passou a estabelecer limites à ação dos Estados e a representar um relevante passo para o tema da intervenção humanitária por estatuir em seus artigos a possibilidade de "punir" crimes daquela natureza, o DIH proibiu uma série de atos de violência contra beligerantes, aí incluídos assassinato, tortura, estupro, punições coletivas, entre outros. Mas todo o arcabouço normativoinstitucional estabelecido nas décadas que se seguiram às guerras, ao menos até os anos 1980, segundo Newman (2009), foi de apoio ao princípio da não-intervenção e, por consequência, de defesa da soberania como preceito basilar das relações internacionais. Esse período era de predominância da concepção pluralista-minimalista, que em breve cederia espaço maior para um consensualismo mais assertivo, embora de tendências políticas ainda realistas de valorização do minimalismo característico das décadas da Guerra Fria.

Ao menos até a década de 1990, não houve situação em que o CSNU autorizasse uma intervenção com bases humanitárias, ainda que ocasiões existissem em que justificativas fossem utilizadas considerando-se princípios do gênero, como prescrições de crimes contra a humanidade e violações sistemáticas de direitos humanos. O período 
da Guerra Fria pode ser apontado como aquele em que não se aceitava, em teoria ou em prática, os direitos humanos como derrogação da não-intervenção. Pode também ser visto como o período em que a realpolitik sobrepunha-se a questões humanitárias mais basilares (NEWMAN, idem: 37). O advento de uma nova ordem global unipolar nos anos 1990 traria mudanças substanciais na doutrina e na prática das intervenções, com uma situação completamente renovada e sua expansão conceitual.

Parte dessas mudanças relacionou-se diretamente com os novos aspectos dos conflitos que se descortinaram a partir do final da ordem bipolar. Grandes guerras, como as duas que ocorreram no século passado, cada vez tornam-se improváveis na política internacional, dada a dinâmica contemporânea das relações interestatais. Passaram a ser superadas por conflitos domésticos e regionais, com interferência crescente da comunidade internacional. Tomando em números, cerca de 110 conflitos ocorreram entre o final do período bipolar e o início do século XXI. Do total, mais de 90 foram guerras civis, enquanto os outros foram conflitos intraestatais com intervenções estrangeiras, sem contar a interferência de atores não-governamentais, cerca de 200 (NYE, 2007: 157).

As guerras inter- e intraestatais ocorridas nas últimas duas décadas são caracterizadas mais pelo caráter étnico do que pelos aspectos crescentemente inovadores das guerras oriundos da globalização e da difusão dos temas nas relações internacionais. Para Nye (idem), aqueles conflitos, chamados de "ethnic wars", têm como ponto comum o fato de que os beligerantes se definem geralmente em parte sob linhas culturais, dentro de uma concepção linguística, religiosa e racial comum, envolvendo o reconhecimento de um nome, de um passado histórico e a difusão de símbolos compartilhados. A maioria das guerras étnicas ocorre quando mecanismos anteriormente estabelecidos de mediação de conflitos dessa espécie entram em colapso, com a inabilidade de governos em mediar conflitos, a exemplo do que se passou em regiões como a África, os Bálcãs e o Cáucaso, com a derrocada dos impérios europeu, no passado distante, e soviético, mais recentemente.

Esses conflitos passaram a gerar problemas mais peculiares, como os deslocados internos (IDPs), seus impactos sobre os recursos naturais, sobre as nacionalidades e 
cidadanias, sobre a qualidade de vida das vítimas, entre outras agruras que atingiam cada vez maior número de vítimas civis, por ações bélicas de contendores difusos, nem sempre os Estados. Nesse contexto renovado de transposição de novas formas de se pensar os conflitos, de estabelecer critérios de proteção específicos que envolva outras dimensões para além das tradicionalmente reconhecidas pelos Estados, o indivíduo então é mais valorizado e sua dimensão "humana" crescentemente considerada, em detrimento dos paradigmas mais realistas e soberanistas. Parece prevalecer, nessa ordem global, uma sociedade consensual-maximalista, e com ela seus valores e normas, compartilhados em foros multilaterais, sob a noção inovadora (ou velhas práticas sob novos rótulos?) de se pensar holisticamente a proteção do ser humano em todas as suas dimensões, inclusive ambiental: a Segurança Humana.

Esse conceito, no cerne da reformulação das concepções realistas securitárias, perpassa a década de 1990 para ressurgir no novo século sob o epíteto de Responsabilidade de Proteger, a instrumentalização mais efetiva e controversa das intervenções, legitimada pela comunidade internacional, mas executada pelos atores de sempre. Essa realidade multifacetada das mudanças na forma de se pensar o instituto das intervenções, e com isso uma compreensão mais ampla da (in) efetividade e (i) legitimidade das intervenções verdes, é de especial relevância para a compreensão do dinamismo (ou falta de) do tema na atualidade.

\subsection{A Segurança Humana: conceitos e função prática}

O termo Segurança Humana (SH) apareceu pela primeira vez em 1994, nas páginas do Human Development Report, elaborado pelo Programa das Nações Unidas para o Desenvolvimento (PNUD). ${ }^{123} \mathrm{O}$ conceito representou uma inovadora forma de se pensar a segurança internacional, ao desafiar o tradicional sentido estatocêntrico de segurança prevalecente desde o final da II Grande Guerra e centralizar o ser humano nas

\footnotetext{
123 O termo human security serve para descrever um complexo de ameaças inter-relacionadas com guerras internacionais e civis, genocídios e deslocamento populacional. Significa, sobretudo, a liberdade do medo da violência. Um conceito mais amplo de SH baseia-se em dois pilares: a "liberdade de querer" (freedom from want) e a "liberdade do medo" (freedom from fear). A SH, nesse sentido, incluiria a segurança alimentar, a segurança da pobreza, habitacional, a luta contra a fome, as doenças, as guerras, e as consequências - não necessariamente nefastas caso haja o correto atendimento e políticas de segurança - dos desastres naturais. Cf. http://www.hsrgroup.org/human-security-reports/human-security-report.aspx (acesso em 15/01/2014).
} 
preocupações das políticas securitárias. ${ }^{124}$ Logo viria a ser saudado como uma abordagem no mesmo "compasso" da ordem mundial que se descortinava com o fim da bipolaridade na política internacional.

Tal foi sua relevância para as discussões no âmbito multilateral e para as políticas governamentais de alguns países como Japão e Canadá, que McRae \& Hubert (2001: 15-24) chegaram a descrever a SH como um "novo paradigma de característica revolucionária copernicana". Mas analisando agora, talvez tenha sido muito otimista e exagerado da parte deles. Wilson (2006), por sua vez, explicitou o novo paradigma como referindo-se simultaneamente a um conjunto de medidas e instrumentos de políticas, uma expressão de valores e de princípios, bem como uma nova forma de pensar e agir. Para o autor: "(...) it is involved in articulating the human condition in terms of the real, the (un) desirable, the (un) achievable, and the (in) intolerable. Those who employ the term seem keenly aware that human security, in addition to redefining security, involves a rethinking of the rights, responsibilities and role of the state, as well as of the system of states or international community of which it is a part".

Decerto os princípios que levaram à edificação discursiva da SH são genuínos e pautam a reconfiguração da ordem interestatal, mitigando a luta pelo poder no que tem de mais nefasta para comunidades envolvidas. As discussões em torno da $\mathrm{SH}$, nas suas origens, parecem demonstrar esse horizonte positivo (e otimista) em contraposição às agruras que assolaram o século XX e seu final, em decorrência das guerras étnicas. Um novo rumo político e normativo se apresentou, não como novidade, mas como uma busca pela instrumentalização necessária que desse alguma efetividade aos princípios a serem estabelecidos, no sentido de colocar o indivíduo no cerne do debate, mesmo, às vezes, em detrimento do seu próprio estado. Esse processo assinala uma transição ainda em curso, vale notar, e não um fato já realizado e indiscutível.

O contexto em que o conceito ganhou alento foi o de abertura temática no cenário internacional dos anos 1990. Uma revolução conceitual ocorria em paralelo às inúmeras reuniões multilaterais e o retorno do interesse geral por temas antes afetos

\footnotetext{
${ }^{124}$ A segurança na sua acepção tradicional permanece relevante, sendo a concepção de SH algo bem mais diluído, na ideia de que os conflitos têm origem na competição por recursos que, muitas vezes, nos países pobres, são escassos, como a água e terras agriculturáveis.
} 
quase que exclusivamente a questões relacionadas à segurança e à economia. Foi um período de expansão das agendas que envolviam a segurança, o que permitiu novas formas de pensar o "internacional" não mais sob as lentes exclusivamente estatais, provendo maior abertura para a inclusão do indivíduo na cena global e nas políticas de instituições as mais diversas. Passou-se a analisar questões securitárias com o entendimento de que a concepção de ameaças ultrapassa ataques violentos de Estados inimigos, para alcançar variados graus relacionados à pobreza, à discriminação, à degradação ambiental e à violação de direitos humanos básicos das populações. ${ }^{125} \mathrm{~A}$ figura (4.1) é ilustrativa dessa expansão temática ${ }^{126}$ :

\section{Fig. 4.1: Novas dimensões da Segurança Humana}

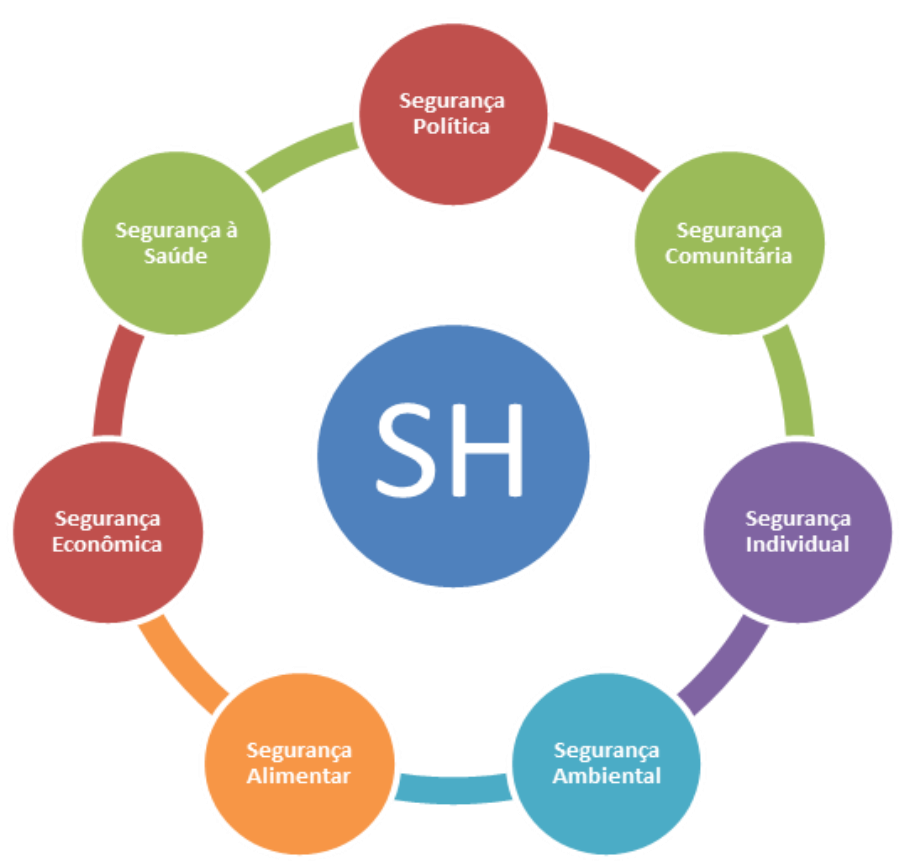

Fonte: Elaborado a partir de HDR (1994) - “New Dimensions of Human Security”

\footnotetext{
${ }^{125}$ McRae (Idem:19) entende "segurança" como um "conjunto de discursos e práticas por meio do que se define o significado de sentir-se seguro e por meio do qual se identifica e se gerencia aquilo que se acredita ameaçar a segurança individual. No caso do discurso da SH, (in) segurança é definida em relação a um conjunto de hipóteses sob o que segurança significa para o ser humano estar seguro, e a clamores de se saber como alcançar tal condição de "estar seguro" por meio da promoção daquilo que é visto como contribuindo para a segurança e abolindo o que contribui para a insegurança" (tradução livre do autor).

${ }^{126}$ O conceito de SH como originalmente concebido, conforme o Human Development Report (1994), divide o tema da segurança em sete áreas: econômica, alimentar, ambiental, de saúde, pessoal, comunitária e política. Por sua natureza ampla, a definição de SH, como inicialmente aventado por grupo de economistas desenvolvimentistas no âmbito das Nações Unidas, tem sido continuamente contestada por diversos segmentos.
} 
A natureza dos conflitos também se alterou. A partir de então, sem o aparato securitário das duas superpotências que por meio século garantiu relativo equilíbrio global, há um crescente problema de violência difusa e intraestatal, com minorias, separatistas e religiosos, de que são exemplos os movimentos secessionistas na antiga Iugoslávia, Chechênia, Ruanda, Darfur, entre outros (GURR \& HARFF, 1994; ESMAN \& TELHAMI, 1995). Logo, o contexto exigiu mudanças na abordagem político-jurídica do tema das intervenções, em razão de não se tratar mais de guerras declaradas interestatais ou de conquista de territórios.

Muito embora o conceito de SH tenha adquirido importante ímpeto nas discussões acadêmicas e nos fóruns internacionais com o fim da Guerra Fria, seria um equívoco considerar que a abordagem "humano-cêntrica" se tenha desenvolvido somente após esse período. A tradição teórica (neo) liberal das relações internacionais já se vinha desenvolvendo desde o final dos anos 1970, e temas como segurança ambiental e humana ganhavam adeptos cada vez mais ávidos. McRae (idem: 24-25) defende que as preocupações com a SH pré-existem ao discurso hoje bem delineado em torno do conceito. No entanto, o Relatório do PNUD, de 1994, foi quem atraiu maior atenção ante as iniciativas anteriores de aproximação dos temas de segurança, desenvolvimento e ser humano, ganhando a atenção global.

Com a evolução das discussões em torno do conceito, a SH rapidamente ganhou adeptos entre os que preconizavam sua definição mais ampla, para além da do Relatório do PNUD, e os que clamavam por um estreitamento de seus objetivos para torná-los “analiticamente mais propícios às realidades de policymaking” (WILSON, idem: 27).

A discussão sobre a necessidade de se estreitar o conceito da SH elaborada por Thomas \& Tow (2002) é interessante. Os autores redirecionam o foco do debate das ameaças aos seres humanos para o da violação das normas pelos Estados, em uma busca por "reestatocentrizar" a discussão. Baseiam-se na noção de que, já que indivíduos, grupos sociais e alguns Estados não podem assegurar apropriadamente sua segurança nem a de sua população (como os failed states), há uma necessidade de se prover uma resposta internacional para salvaguardar as normas internacionais (em especial relativa aos direitos humanos). Bellamy \& MacDonald (2002: 374-375) respondem criticamente 
a essa pressuposição, considerando-a "problemática" por várias razões, como a de que a tentativa de estreitar a segurança para torná-la mais "palpável" aos policymakers poderia levar à "reificação" das fontes de insegurança para os indivíduos, enquanto os Estados muitas vezes são os próprios responsáveis pela insegurança dos indivíduos. Os autores consideram a busca por tornar a agenda da SH "policy relevant". Thomas \& Tow acabam alterando seu escopo de modo a perder seu "potencial emancipatório". Segundo Bellamy \& MacDonald, "rather than furthering the human security agenda, they are essentially calling for its closure by forcing it to cohabit with the very political structures it is trying to interrogate."

Ainda das vozes contra a ampla definição e da necessidade do estreitamento do conceito, vale expor algumas considerações mais nuançadas do que aquelas de Thomas \& Tow (2002). Tadjbakhsh \& Chenoy (idem: 59-68) ${ }^{127}$ avaliam que, se as definições são abundantes, também o são as críticas baseadas em argumentos teóricos, analíticos e políticos. Essas críticas vão desde a de Roland Paris (2001: 87-102), para quem a SH seria uma espécie de rallying cry ou um hot air, às que insistem em que a securitização dos temas econômicos, sociais, políticos, ambientais e de direitos humanos fez com que o conceito perdesse em significação, sendo considerado um "movimento vago", sob forma de "jargão perigoso" e facilmente uma "presa" a manifestações políticas por governos, em nome da segurança.

Wilson (idem: 26), por sua vez, reconhece que a questão das normas internacionais, do papel e dos direitos dos Estados, além dos direitos humanos, são conceitos centrais que giram em torno da noção de $\mathrm{SH}$ e que, portanto, encaminhar o debate em torno dos que pretendem estreitar o conceito ou estendê-lo, parece mesmo “irreconciliável”. Autores como McRae (2001: 22), por sua vez, avaliam que a concepção tradicional de segurança, fundamentada na soberania estatal, e a SH não são conceitos excludentes e alternativos, pois a segurança seria um "single continuum”, que

127 Tadjbakhsh \& Chenoy consideram que as críticas à ampliação do conceito estariam dispostas da seguinte forma, em lista não exaustiva: (1) falta de precisão conceitual torna a definição de SH impossível; (2) definição vaga esconde relações causais; (3) conceito é demais amplo para focar em que agir contra ameaças; (4) natureza de "grande teoria" do conceito significa uma ausência de utilidade acadêmica; (5) conceito carece de uma agenda de pesquisa concisa; (6) conceito de Ciência Política não deveria ser uma postura ética; (7) interdisciplinaridade e intersetorialidade do conceito são impraticáveis. 
para ser protegida e avançada requer uma série de instrumentos e políticas públicas interconectadas.

Esse dilema entre as prerrogativas da $\mathrm{SH}$, sua aplicabilidade e a redefinição do papel do Estado (e de seu atributo tradicional de manutenção da paz e segurança internacional) tende a permear o debate durante toda a década de 1990, no âmbito das Nações Unidas, mas também em outras instâncias de discussão de temas relacionados à segurança, como os regimes internacionais e as organizações regionais. $\mathrm{O}$ foco do dilema gira novamente na questão da soberania estatal, de como conciliar uma visão política realista tradicional diante das novas diretrizes dessa ordem mundial que se conforma no pós-Guerra, trazendo consigo uma reavaliação das questões mais prementes voltadas a conflitos e o anseio dos Estados e dos indivíduos em alcançar o equilíbrio entre uma visão pluralista minimalista e o solidarismo consensual maximalista. À primeira vista, os trabalhos do ICISS parecem esforçar-se em conciliar essa tendência, dando um alento renovado ao debate. Por ora, voltemos à questão das dificuldades de se definir SH e de suas idiossincrasias, de modo a estabelecer o ponto de contato entre as concepções normativas mais imediatas e as lacunas quanto à efetividade de sua aplicação nos casos de desastres ambientais.

Tadjbakhsh \& Chenoy (2007) definem SH como a proteção de indivíduos dos riscos à sua segurança física e psicológica, dignidade e bem-estar. Segundo os autores, "an environment that is said to provide its members with human security is one which affords individuals the possibility to lead stable, self-determined lives." Antes mesmo da atual evolução discursiva dos direitos humanos, para sua aplicabilidade na noção de $\mathrm{R} 2 \mathrm{P}$, já expunham questões que nos levam a reavaliar a soberania dentro de um sistema teórico e prático, efetivo, da SH como conceito a ser melhor explorado. Buscam ultrapassar a noção estritamente nacional do conceito de segurança, ao apontar o ser humano como instância última, em sentido lato, da existência da comunidade de nações.

Mahbub ul Haq (1995), economista paquistanês que fez parte da comissão organizadora do Report, acredita que a SH não deveria se limitar a uma preocupação relativa a armas, e sim com a dignidade humana. Em última análise, seria necessário um olhar atento a "cada criança que não morre, uma doença que não se torna endêmica, 
uma tensão étnica que não explode, um dissidente que não silencia e um espírito humano que não é esmagado”. Para além da dificuldade de se conceituar SH, tal ideia, vista de maneira mais realista, apresenta-se como um paradigma para o entendimento das vulnerabilidades de forma a desafiar a noção tradicional de soberania, ao retirar do Estado e transferir para os indivíduos a referência quando se discute a necessidade de incrementar-se a segurança em determinada região. Pode-se afirmar que o discurso da SH começou a ganhar força pari passu ao final da guerra fria, quando começaram a ser desafiados os paradigmas (neo) realistas de segurança nacional como atributos primordiais da segurança global. Em análise mais ampla, mudaram também os atores nas relações internacionais, visto que o papel deles passou a se tornar parte do processo decisório em um mundo muito mais integrado.

Se essa edificação discursiva deverá pautar as novas formas de intervenção e mitigar os conflitos existentes no pós-Guerra Fria, talvez como elemento de "atos de fala" (os "atos de poder") das potências legitimadoras das normas internacionais e criadora das regras a serem impostas aos menos articulados, é uma questão a ser debatida entre acadêmicos e policymakers. Quanto às obrigações positivas, o que se pode depreender de todo esse aparato linguístico-discursivo é que a linguagem tradicional que ainda pauta o sistema jurídico-normativo interestatal permanece inadequada para prever situações de desastres ambientais e fornecer uma explicação mais direta às ações no âmbito das obrigações positivas.

A definição do PNUD $^{128}$ para SH buscou, decerto, influenciar a forma como antes era vista a necessidade de interferência estatal para se buscar sanar questões de direitos humanos, bem como os trabalhos da Cúpula Mundial das Nações Unidas sobre Desenvolvimento Social (Copenhague/1995), mas não alterou o debate em torno dos desastres ambientais, ainda percebidos por parte da academia e dos tomadores de

\footnotetext{
${ }^{128}$ No relatório, o conceito de SH, antes entendido como as "liberdades do medo e do querer", deveria ser estendido para incluir algumas ameaças adicionais, porém complementares. Dentre essas áreas, destaca-se a segurança econômica, que se refere à manutenção de uma renda básica para os indivíduos, de preferência de forma produtiva e remuneratória. O combate ao desemprego, tanto nos países em desenvolvimento quanto nos mais desenvolvidos, contribui para diminuir o fator de risco decorrente de problemas econômicos. A segurança alimentar, que requer tenham todos os indivíduos acesso à alimentação básica. Tal forma de segurança relaciona-se diretamente com a econômica. A segurança com relação à saúde também constitui relevante fator no combate à ameaça e à violência. Essa forma de segurança refere-se à garantia mínima dos indivíduos de proteção a doenças e outras causas maiores de mortalidade tradicionais (Cf. UNDP. Human Development Report, 1994)
} 
decisão sob o viés do assistencialismo e dos direitos humanos, quando tende a ser tratado mais do ponto de vista securitário tradicional. Diante de conceito tão amplo, com as múltiplas vertentes e variáveis para defini-lo, numerosos também têm sido seus críticos.

Uma crítica interessante das implicações políticas do conceito de $\mathrm{SH}$, que será vista com mais detalhes em outra ocasião por relacionar-se diretamente ao conceito de $\mathrm{R} 2 \mathrm{P}$, refere-se à gradual e contínua relação entre o conceito de segurança e responsabilidade. Não sem razão, os críticos da SH, a exemplo de Krause (2004), acreditam que relacionar as agruras por que passam certas populações em alguns países com a própria segurança nacional, como pretendem os adeptos dessa noção, tende a levar a um "wall-building”, ao invés de um "bridge-building”. O que críticos apontam é que o alargamento da definição de SH resultará em crescente utilização do uso da força uma "responsabilidade" da comunidade internacional. Mesmo defensores da SH reiteram que a securitização apregoada pelo conceito não pode significar intervenções militares em sua totalidade, porém uma responsabilidade da comunidade internacional para engajamento em outros níveis e estágios. Uma "Segurança Humana sustentável" envolveria a reestruturação normativa social e as instituições políticas, assim como a reconstrução econômica e a redefinição de normas sociais (HAMPSON, 2004, apud TADJBAKHSH \& CHENOY, idem: 65). Malgrado seu elevado valor moral, mas por ser um conceito altamente marginal e polêmico, bem como distante da realidade atual, ele não será aprofundado na presente pesquisa.

As implicações morais do conceito de SH são bem mais complexas, pois envolvem ao menos duas variáveis: a da universalidade e da individualidade. A SH reforçaria a divisão global? Seria ela individual ou universal? Os que defendem o reforço da divisão global aderem ao conhecido argumento de que a $\mathrm{SH}$ seria uma espécie de "cavalo de Tróia". Para os adeptos dessa corrente, o subdesenvolvimento econômico-social nos países do Sul estaria na origem da instabilidade política que "transbordaria" para o Norte desenvolvido (TADJBAKHSH \& CHENOY, idem). Essa instabilidade deve ser combatida em nome da R2P e por intermédio de sanções e ações preemptivas. Corolário da $\mathrm{SH}$, a R2P é vista com desconfiança pelos países em desenvolvimento, que denunciam eventual "etnocentrismo" e "double standard" do 
conceito em prol dos países mais poderosos. Para os defensores da doutrina da $\mathrm{SH}$, nada impediria que o Sul desenvolvesse seu próprio conceito de segurança.

Ainda com toda a dificuldade de definir, de estipular seus preceitos e articular suas delimitações, a SH continua a pautar os debates mais amplos nos foros multilaterais e em instâncias mais locais a respeito da expansão dos direitos sociais e humanos e a necessidade de proteção da segurança dos indivíduos, polo mais fraco nas relações internacionais, diante de estruturas estatais relutantemente preponderantes ou fragilizadas a serem influenciadas por entes externos com interesses por vezes obscuros. $\mathrm{O}$ conceito tem angariado força nas discussões das RI e não se podem analisar as intervenções sem recorrer às suas prerrogativas analítico-conceituais, vindas para transformar e redefinir o papel do Estado na ordem global.

Decerto que a SH carrega um forte conteúdo normativo-prescritivo, ao delimitar questões antes tratadas sob o ponto de vista puramente positivista e literal das obrigações de se prestar obediência a tratados e vontades nas relações interestatais. A SH redefiniu as responsabilidades do Estado relativas à proteção do ser humano. Com isso transbordou para áreas mais invasivas da soberania, trazendo consigo seus pressupostos temáticos, como os temas afetos ao meio ambiente, em um movimento de expansão das atribuições e diminuição de direitos nas relações internacionais.

Como os Estados vêm respondendo a esse processo é o desafio a ser pesquisado nas Ciências Sociais. Essa redefinição da soberania, diante da afirmação de prerrogativas da proteção da pessoa humana, torna-se central neste trabalho, no que concerne ao debate nos âmbitos jurídico e político sobre a proliferação também dos novos conceitos (intervenções humanitária e verde), que buscam responder às ameaças securitárias na ordem global, crescentemente questionada pelos Estados menos capazes e reafirmadas pelos entes interventores, sob interesses difusos baseados em cálculos estratégicos.

\subsection{Novos conceitos, novas roupagens}

A análise dos fatores que conduzem às intervenções nas relações internacionais, caso se pretenda legítima, começa pelo reconhecimento da excepcionalidade de sua 
prática, em respeito ao disposto na Carta das Nações Unidas, no tocante à proibição ao uso da força, autorizada somente em casos de legítima defesa, ainda assim sob o resguardo do Conselho de Segurança (art. 51). Não há de se falar de legitimidade fora dos mecanismos estabelecidos pela comunidade internacional, que facultam à coletividade as decisões sobre a necessidade de se realizar determinado ato que pressuponha agredir a integridade territorial e a soberania estatal. Apenas partindo de tal reconhecimento podemos acreditar que se esteja trilhando o caminho da razoabilidade e da coerência, além de contribuindo para o debate apresentado na maioria das vezes de forma polêmica, enviesada e obscura, onde interesses nacionais e individuais são postos constantemente à prova.

O ponto de onde se há de partir, seguindo a lógica da excepcionalidade da intervenção - aceitável apenas em casos de extrema necessidade e depois de esgotados todos os outros meios legais de solução das controvérsias - é o da primazia do princípio da "não-intervenção". Desde as origens, a Carta da ONU pretendeu sanar as falhas do Pacto Briand-Kellog (SARAIVA, 2001; BARROS-PLATIAU \& VIEIRA, 2006) e sustentar a ilegitimidade do jus ad bellum através da redação do princípio basilar de que "os membros da Organização, em suas relações internacionais, abster-se-ão de recorrer à ameaça ou ao uso da força contra a integridade territorial ou a independência política de qualquer Estado, ou de qualquer outra forma incompatível com os propósitos das Nações Unidas" (art. $\left.2^{\circ}, \$ 4^{\circ}\right)^{129}$. Este artigo aplica-se tanto aos membros da ONU quanto a toda a comunidade internacional. Pró́be também o recurso à força por seus integrantes contra quaisquer outros Estados que não façam parte da ONU, conforme se depreende no $\S 6^{\circ}$, do mesmo artigo, quando se afirma que a “Organização se compromete em assegurar que os Estados que não são seus membros ajam de acordo com os princípios erigidos na Carta, visando à manutenção da paz e da segurança internacionais." A guerra, antes considerada a continuação da política por outros meios (no dizer de Carl von Clausewitz - 1780/1831), tornou-se assim um ilícito internacional. Desse modo, de acordo com o mesmo artigo $2^{\circ}, \S 4^{\circ}$, "qualquer uso da

${ }^{129}$ Cf. BRASIL. Decreto $n^{\circ} 19.841$, de 22 de outubro de 1945. Presidência da República. Casa Civil Subchefia para Assuntos Jurídicos: Promulga a Carta das Nações Unidas, da qual faz parte integrante o anexo Estatuto da Corte Internacional de Justiça, assinada em São Francisco, a 26 de junho de 1945, por ocasião da Conferência de Organização Internacional das Nações Unidas. 
força no cenário internacional empreendido pelos Estados-membros, independente da razão, é vedado, a menos que expressamente permitido pela Carta".

O princípio da não-intervenção relaciona-se diretamente à proibição do uso da força. Argumenta-se, geralmente, como sendo uma conquista dos países do "Terceiro Mundo", alvo de constantes intervenções pelas grandes potências no século passado (MAGDOFF, 1979; TARLING, 1992; HOBSBAWM, 2001) ${ }^{130}$. Não sem motivo, as lutas independentistas em nome do princípio da "autodeterminação dos povos" elevaram a soberania plena e irrestrita ao patamar de fundamento supremo da existência do Estado (e da paz internacional). Positivados nos mais diversos acordos internacionais e na própria Carta da ONU, que dispõe da igualdade soberana de seus membros, os princípios da "soberania" e da "não-intervenção" já foram largamente reconhecidos até mesmo pela Corte Internacional de Justiça (CIJ), considerando-os pilares fundamentais do sistema internacional. Nos casos do Estreito do Corfu (Reino Unido e Irlanda vs. Albânia), de 1947, da Nicarágua (Atividades Militares e Paramilitares na e contra a Nicarágua - Estados Unidos vs. Nicarágua), de 1984, e, mais recentemente, de Atividades Armadas no Território do Congo (República Democrática do Congo vs. Uganda), por exemplo, a CIJ defendeu que o emprego de força de um Estado contra seus pares constitui um ilícito internacional em razão da violação territorial e dos princípios da não-intervenção e do não uso da força nas relações internacionais. ${ }^{131} \mathrm{~A}$

\footnotetext{
${ }^{130}$ É interessante notar a associação de países, conhecida como "Movimento dos Não-Alinhados", que surgiu na segunda metade do século passado, que buscava constituir uma terceira via à margem dos blocos liderados pelas superpotências da Guerra Fria. A origem do movimento - que congregava inicialmente em sua maioria países asiáticos e africanos, do chamado "Terceiro Mundo" pode ser determinada a partir da Conferência de Bandung, que teve lugar na Indonésia, em 1955. Do encontro resultou uma carta de princípios ("Dez Princípios de Bandung"), que conclamava os membros participantes a, entre outros preceitos, respeitar os direitos humanos e os princípios da Carta da ONU, bem como a soberania e integridade territorial de todas as nações. A abstenção ao uso de pactos de defesa coletiva a serviço de interesses particulares de quaisquer das grandes potências e de exercer pressões sobre outros países também pautava a carta de diretriz do movimento (TARLING, 1992; MAGNOLI, 2013).

${ }^{131}$ A decisão da Corte no caso do Estreito de Corfu foi um marco jurídico na defesa do princípio da nãointervenção e da soberania, e viria a pautar decisões futuras com relação ao uso da força. Na ocasião, a CIJ decidiu a favor da Albânia com relação a violações das águas territoriais do país pela Inglaterra, que alegava o critério da "necessidade" e da "self-protection" para obter provas da presença de minas no Estreito. No Nicaragua Case, a Corte considerou os EUA responsáveis, ao apoiar atividade paramilitares na Nicarágua, "in breach of its obligations under customary international law not to use force against another State", tendo exortado o país a "not to violate its sovereignty", tampouco "not to intervene in its affairs". No caso da República Democrática do Congo, a Corte decidiu que a Uganda violou os princípios do não uso da força nas relações internacionais e da não-intervenção, previstos na Carta das Nações
} 
Corte reconheceu, com aquela decisão, que mesmo pressões políticas, econômicas e diplomáticas (soft intervention) violam os princípios da Carta da ONU. ${ }^{132}$

Prescreve-se que o princípio da "não-intervenção" é regra geral que deve pautar a ação dos atores nas relações internacionais. Caso ocorram intervenções consideradas ilegais, os Estados devem ser responsabilizados de acordo com os institutos jurídicos punitivos e de reparação de danos a terceiros já existentes no DIP. Essa afirmação não exclui, no entanto, a existência de medidas excepcionais que, à luz do mesmo sistema jurídico, possam excluir a ilicitude da responsabilidade estatal. Podem-se considerar, pelo menos, duas situações em que o recurso à força tende a ser autorizado pela ONU: no já mencionado recurso da Legítima Defesa (art. 51) e nos mecanismos de Segurança Coletiva (Capítulo VII).

Já foi visto que o conceito de intervenção nas relações internacionais reveste-se de extrema dificuldade de definição, em razão da dupla característica inerente ao conceito: ação e inação. O sentido moderno, como se pode depreender da Carta da ONU, em seu artigo $2^{\circ}, \S 4^{\circ}$, onde se proíbe o uso da força, decerto relaciona-se com o segundo aspecto, a inação, quando estipula que "Todos os membros deverão evitar em suas relações internacionais a ameaça ou o uso da força contra a integridade territorial ou a independência política de qualquer Estado, ou qualquer outra ação incompatível com os propósitos das Nações Unidas", e acrescenta que "§7º Nenhum dispositivo da presente Carta autorizará as Nações Unidas a intervirem em assuntos que dependam essencialmente da jurisdição interna de qualquer Estado (...) este princípio, porém, não prejudicará a aplicação de medidas coercitivas constantes do Capítulo VII".

Apesar de estabelecer uma obrigação negativa de seus integrantes, a Carta trata das exceções à regra e indica a possibilidade de se intervir, porém com reservas. Segundo os artigos 42 e 51 (Capítulo VII) do mesmo texto legal:

Unidas e da Organização da Unidade Africana, violando assim obrigações internacionais (fonte: http://www.haguejusticeportal.net/).

${ }^{132}$ As exceções à proibição do uso da força se darão somente nas situações de exercício da legítima defesa (art. 51) e nas situações previstas no art. 39, quando o Conselho de Segurança autoriza o recurso da força para o efetivo cumprimento de seus propósitos. 
"Artigo 42. ${ }^{\circ}$ Se o Conselho de Segurança considerar que as medidas previstas no artigo 41 seriam ou demonstraram ser inadequadas, poderá levar a efeito, por meio de forças aéreas, navais ou terrestres, a ação que julgar necessária para manter ou restabelecer a paz e a segurança internacionais. Tal ação poderá compreender demonstrações, bloqueios e outras operações, por parte das forças áreas, navais ou terrestres dos membros das Nações Unidas."

Em seguida, como decorrência dos princípios de direito reconhecidos nas relações internacionais, o Artigo 51 indica situações em que o direito à legítima defesa pode ser invocado:

\begin{abstract}
"Artigo 51. ${ }^{\circ}$ Nada na presente Carta prejudicará o direito inerente de legítima defesa individual ou coletiva, no caso de ocorrer um ataque armado contra um membro das Nações Unidas, até que o Conselho de Segurança tenha tomado as medidas necessárias para a manutenção da paz e da segurança internacionais. As medidas tomadas pelos membros no exercício desse direito de legítima defesa serão comunicadas imediatamente ao Conselho de Segurança e não deverão, de modo algum, atingir a autoridade e a responsabilidade que a presente Carta atribui ao Conselho para levar a efeito, em qualquer momento, a ação que julgar necessária à manutenção ou ao restabelecimento da paz e da segurança internacionais."
\end{abstract}

Doyle \& Sambanis (2006) observam que, com a derrocada da ordem bipolar, os países-membros das Nações Unidas expandiram sua agenda para definir "a near revolution in the relation between what is in the legitimate realm of state sovereignty and what is subject to legitimate international intervention", endossada pela "expansão radical" no escopo da intervenção coletiva em razão da série de guerras intraestatais étnicas e civis que se anunciava, a notar pelos casos na Bósnia e na Somália. Na prática, as intervenções que tiveram lugar desde então aplicavam in loco o objetivo da segurança coletiva que estava no cerne das Nações Unidas, mas se encontrava paralisada por décadas com a falta de consenso no CSNU, também dividido em dois blocos de alinhamento às superpotências do período. ${ }^{133}$

133 As palavras do então-Secretário das Nações Unidas, Kofi Annan, a respeito do papel resgatado da ONU, são convincentes de um novo período que se abriu para as intervenções (DOYLE \& SAMBANIS, 2006). Em "Reflections on Intervention” (1999), Annan afirma “(...) our job is to intervene: to prevent conflict where we can, to put a stop to it when it has broken out, or - when neither of those things is possible - at least to contain it and prevent it from spreading. " Em números, esse dinamismo renovado das operações de paz a cabo das Nações Unidas significou, entre 1988 a 1994, um crescimento orçamentário para aquelas operações de US\$ 230 milhões para US\$ 3,6 bilhões (Cf. United Nations Peacekeeping from 1991 to 2000. Statistical Data and Charts. Departamento de Operações de Manutenção da Paz da ONU. Disponível em http://www.un.org/Depts/dpko/dpko/pub/pko.htm.) 
No início daqueles anos 1990, a agenda para paz e segurança das Nações Unidas cresceu em dinamismo e expandiu-se rapidamente. O Secretário-Geral Boutros BoutrosGhali (1992-1996), a pedido da Cúpula do CSNU, realizada em 1992, preparou o relatório conceitual que pautaria a agenda das intervenções pelos próximos anos: $A n$ Agenda for Peace: Preventive diplomacy, peacemaking and peacekeeping. ${ }^{134} \mathrm{O}$ documento resume as principais diretrizes que Boutrous-Ghali apontou para uma resposta aos desafios e conflitos no mundo pós-Guerra Fria. ${ }^{135}$ Reconhecendo os limites das operações de manutenção de paz de primeira geração (identificadas no Capítulo VI da Carta da ONU, o chamado Capítulo 6 e 1/2), os 15 membros do CSNU exortaram, ao final da Cúpula, o Secretário-Geral a propor futuras reformas para o sistema de segurança da Organização, reconhecendo na declaração final do encontro que a ausência de conflitos interestatais não assegura a paz e segurança internacionais e que as "fontes" não militares de instabilidade nas áreas econômica, social, humanitária e ecológica (destaque nosso) representariam as novas ameaças à paz e à segurança. ${ }^{136}$

Hehir (1998: 29-54) avalia que o interesse contemporâneo nas intervenções militares é dirigido em grande parte por preocupações normativas, para consternação da corrente realista, pois é focado no conflito de valores:

\begin{abstract}
“(...) that a multiplicity of internal conflicts within states pose for world politics in the 1990s. The debate of this decade about intervention challenges the norm of nonintervention, but it does so cautiously, remembering not only the realist's fear that intervention disrupts the order of states but also the liberal's fear that intervention forecloses the exercise of self-determination by individuals and groups within states. Those pressing the contemporary debate about ethics of military intervention do not have a secure theoretical home. Their proposals challenge both classic realist and liberal theory in world politics, and they seek to revise, reform, or overturn the prevailing norm of nonintervention in international law" (pg. 30)
\end{abstract}

\footnotetext{
${ }^{134}$ Cf. www.unrol.org/files/A_47_277.pdf (acesso em 12/10/2013)

135 Chamado de "Agenda para a Paz", o documento preconiza um papel mais assertivo para as operações de paz da ONU, passando por uma noção de peacebuilding, na qual a paz deve ser garantida por "indução categórica" (ALTEMANI \& LESSA, 2006: 25-26). A ONU toma como base o Capítulo VII, com a maior autoridade do CSNU, e passa a agir em duas diretrizes para além da peacekeeping: a peace enforcement e o statebuilding, pela reconstrução das sociedades após a intervenção.

${ }^{136}$ Cf. UN Department of Public Information, Yearbook of the United Nations, 1992, 34. Disponível em: unyearbook.un.org $(10 / 01 / 2013)$
} 
Hassner (1998: 9-28), de seu turno, aponta que o termo "humanitário", no conceito de "intervenção humanitária", é "em si mesmo" aberto a um variado leque de interpretações, a mais ampla a que inclui quaisquer formas de intervenção contra quaisquer formas de sofrimento, sejam causadas por desastres naturais, sejam por conflitos ou tiranias. A interpretação stricto sensu implica distanciar-se de razões políticas e militares. Para Hassner (idem: 16) uma intervenção deixa de ser humanitária caso seja incluída em seus cálculos interesses estratégicos ou econômicos, selecione beneficiários, seja enviesada, ou, até mesmo, "inflict suffering or death in the name of protection and peace”.

Os argumentos a favor ou contra intervenções passam, sobretudo, pela natureza do SI contemporâneo e da concepção da soberania como basilar para a formação do Estado-nação. Discutir o tema da intervenção significa adentrar no reino das controvérsias em torno dos aspectos legais da formação (e aceitação) das soberanias no DI e da moralidade e ética da interferência indevida na soberania alheia. Diversas correntes buscam estabelecer o debate e responder sobre a legalidade e legitimidade das intervenções. Smith (1998), por exemplo, parte das perspectivas realista e liberal na busca de compreender o fenômeno, enquanto Hehir (1979) dos argumentos moral e legal. O autor convida a refletir sobre a tensão das "duas tradições normativas" no seio da doutrina da "guerra justa", no que diz respeito ao tradicional entendimento moral religioso e a compreensão contemporânea dos conflitos no direito internacional moderno.

Para Holzgrefe (2003: 15-52), todas as taxonomias são recomendáveis, mas pecam em tentar capturar de forma dicotômica a diversidade do tema. Ao definir “intervenção humanitária” como “(...) the threat or use of force across state borders by a state (or group of states) aimed at preventing or ending widespread and grave violations of the fundamental human rights of individuals other than its own citizens, without the permission of the state within whose territory force is applied.”, o autor sistematiza o debate multifacetado sobre intervenção, criticamente explorando sua ética. Holzgrefe distingue, ainda, diversas teorias conforme a fonte, o objeto, o peso e a amplitude da moralidade envolvida. Em seu entender, as teorias da ética passariam, para se analisar a possibilidade ou não das intervenções humanitárias, por abordagens como 
a utilitária, do direito natural, do contrato social, do comunitarismo e do positivismo legal. $^{137}$

Tom Fare (2001), por sua vez, parte da mesma premissa definidora das intervenções humanitárias apresentada por Holzgrefe, mas expande o debate sobre as teorias das intervenções sob as lentes dos campos jurisprudenciais conhecidos como "classicistas" (ou "textualistas") e os "realistas-legais". Fare caracteriza os "classicistas" como conservadores, por assumirem a literalidade dos tratados. Para estes, o texto dos acordos tem intenções específicas e genuínas que, consistentes com as regras de direito, são cogentes enquanto o tratado viger. Os "classicistas" buscam conservar elementos de ordem em um sistema politicamente anárquico. Já os "realistas-legais" seguem a estratégia de alterar a carga sobre a literalidade e o significado do texto, contextualizando-o para a realidade presente. Com esse propósito, buscam melhor atender o objetivo da lei como instrumento de política pública e assim justificam as intervenções humanitárias.

$\mathrm{Na}$ defesa "classicista" das intervenções, encontram-se agentes que trabalham melhor, no entender de Fare (idem, ibidem), na busca de interpretar as ambiguidades dos textos legais. A hermenêutica dos "textualistas", elencada pelo autor, é interessante. Os "classicistas" tencionam, entre outras iniciativas: (1) interpretar o artigo 2 (4), da

${ }^{137}$ Diante de tantas teorias e controvérsias, Holzgrefe (idem, ibidem) sugere algumas formas para resolver a questão. A abordagem utilitarista, segundo o autor, referir-se-ia à doutrina naturalista, que prescreve que uma ação é "justa" se suas consequências forem mais favoráveis aos interessados. A teoria é naturalista na medida em que considera o bem-estar da pessoa humana um bem intrínseco. A versão utilitarista defende a intervenção humanitária se as consequências de um determinado ato forem favoráveis para o bem-estar social, ainda que danos colaterais estejam envolvidos. A doutrina do Direito Natural aponta para as obrigações morais dos indivíduos pelo simples fato de se conviver em uma só humanidade. Para os teóricos do direito natural, a natureza humana "gera" obrigações morais, como o direito à intervenção humanitária. Entre os jusnaturalistas, encontra-se Hugo Grotius (Jure Belli ac Pacis), ao considerar que, caso um tirano inflija aos seus súditos um tratamento negativo de que nenhum outro soberano seja capaz, outros Estados teriam o direito de exercer uma intervenção humanitária. Para a doutrina do contrato social, as normas morais derivam sua efetividade do consenso mútuo dos povos sujeitos a elas. Os adeptos dessa doutrina acreditam que as normas são moralmente mandatórias somente se livres e igualitárias e consentidas por atores racionais. Os comunitaristas, de seu turno, afirmam que as normas são moralmente efetivas se elas se encaixam nas crenças culturais e práticas de comunidades específicas. Um direito de intervenção humanitária seria justo, nessa situação, segundo Walzer (1983), pois se encaixa nas heranças culturais de comunidades políticas em todas as partes do globo. Já o positivismo legal, não menos controverso, sustenta que as normas são justas se válidas e legítimas, se são aplicáveis de acordo com procedimentos aceitos. Assim, o conteúdo da norma torna-se irrelevante para que ela seja eficaz, havendo uma obrigação moral de obedecê-la. Em outros termos, os positivistas defendem haver uma obrigação moral de obedecer as leis já previstas no caso da possibilidade ou não das intervenções humanitárias, que para o DIP contemporâneo se refere diretamente ao prescrito no artigo 38 (I) do Estatuto da Corte Internacional de Justiça. 
Carta da ONU, referente à proibição ao uso ou ameaça de força contra a independência política ou a integridade territorial de um país, como não cobrindo temporariamente a ocupação de um Estado se a finalidade da intervenção consistir ou for compatível com os princípios e propósito da Carta, tais como a promoção dos direitos humanos e das liberdades fundamentais da pessoa humana; (2) argumentar que a intervenção a pedido de um governo reconhecido, não expressamente explícito na Carta, confirma em vez de prejudicar o exercício da soberania protegido pelo artigo 2 (7); (3) insistir que os requerimentos previstos no artigo $53,{ }^{138}$ referentes à autorização para o uso da força pelo CSNU às entidades regionais, podem ser satisfeitos pela aprovação pósintervenção, quando houver falhas na condenação do ato; (4) insistir também que a assistência externa a oponentes de um governo, mesmo sem provisões de armamentos, constituem um ataque armado dentro do significado do artigo 51, justificando uma resposta armada.

De todas essas justificativas para intervenção, mesmo quando interpretadas pelos classicistas, que buscam maior literalidade do texto legal com o fim de sanar as ambiguidades mais prementes, parecem ser problemáticas e ultrapassar, em vez de limitar, o sentido original atribuído pelo legislador internacional. Tal insistência decerto corresponde a uma lógica de poder e apresenta uma dúvida de se saber como e quem poderá instrumentalizar as intervenções. Se tomarmos como exemplo de assistência externa a oponentes de um governo, como no caso de Nicarágua (Nicarágua vs. EUA), pode-se avaliar as dificuldades para que o governo nicaraguense fizesse frente às tentativas norte-americanas de derrubar o governo constituído do país, ainda mais enfrentando a superpotência da época sob a justificativa da legítima defesa - o que de fato foi o reverso, os EUA alegaram haver intervindo no país por razões de "necessidade" e "legítima defesa". Confrontado com as interpretações normativas e as atribuições morais, o analista das intervenções tende a considerar que o realismo

\footnotetext{
138 Conforme expresso no Artigo 53: “(1). O conselho de Segurança utilizará, quando for o caso, tais acordos e entidades regionais para uma ação coercitiva sob a sua própria autoridade. Nenhuma ação coercitiva será, no entanto, levada a efeito de conformidade com acordos ou entidades regionais sem autorização do Conselho de Segurança, com exceção das medidas contra um Estado inimigo como está definido no parágrafo 2 deste Artigo, que forem determinadas em consequência do Artigo 107 ou em acordos regionais destinados a impedir a renovação de uma política agressiva por parte de qualquer desses Estados, até o momento em que a Organização possa, a pedido dos Governos interessados, ser

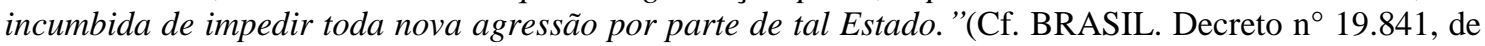
22 de outubro de 1945)
} 
político ainda pauta as atribuições estatais, em uma ordem global em que o pluralismo minimizador busca se renovar dentro das instituições que dão forma às prerrogativas dos atores nas relações internacionais. A defesa das intervenções passa por uma justificativa moral e legal, sob uma construção securitária que pretende transformar em "atos de poder" um discurso por vezes pautado na prática internacional de países comparativamente mais fortes.

Fernando Téson (2003: 93) defende que as intervenções humanitárias são justificáveis em algumas situações, sob o argumento filosófico político-liberal de que o principal objetivo dos Estados e governos é proteger e assegurar os direitos humanos. Assim, governos que seriamente violam direitos de seus cidadãos minam a razão que justifica seu poder político, não podendo, no entender do autor, serem protegidos pelo direito internacional. À diferença de Holzgrefe (2001) e Hassner (1998), Téson (idem: 94) define as intervenções humanitárias como o "the proportionate international use or threat of military force, undertaken in principle by a liberal government or alliance, aimed at ending tyranny or anarchy, welcomed by the victims, and consistent with the doctrine of "double effect.". ${ }^{139}$ Téson rejeita as objeções dos que se utilizam de argumentos relativistas, ou da inviolabilidade das fronteiras nacionais, da visão de que os governos devem evitar intervir em razão do respeito ao direito internacional ou, ainda, da visão de que intervenções humanitárias seriam uma ameaça à estabilidade global. Para o autor, dois componentes em defesa do argumento liberal estão postos: de um lado, o exercício de governos tirânicos e situações de extrema anarquia são sérias formas de injustiça contra o ser humano; de outro, a intervenção externa torna-se moralmente permitida para pôr fim a injustiças, mas com relevantes limites. ${ }^{140}$

\footnotetext{
139 A doutrina do "duplo efeito" tem origens da filosofia de Tomás de Aquino e relaciona-se com os princípios que regem a ideia da "legítima defesa". Em sua obra Suma Teológica (II-II, q.64,a.7,c), o filósofo questiona se é lícito a alguém matar a outrem se defendendo. Assim, o duplo efeito diz respeito à discussão sobre em quais condições uma ação seria ou não moralmente permissível diante dos resultados. Nas intervenções humanitárias, o duplo efeito referir-se-ia principalmente aos danos colaterais, geralmente em número de vítimas, ocasionado por quem deveria salvar as vidas ou livrá-las de jugo ds tiranias.

${ }^{140}$ Em sua defesa contra as objeções ao direito de intervenção, Téson condena o relativismo cultural como um argumento válido para se impedir intervenções humanitárias (em especial o pensamento de que o mundo seria ideológico e culturalmente bastante diverso para se aplicar uma filosofia específica- neste caso a político-liberal - em um problema que interessa a todo o mundo). $\mathrm{O}$ autor afirma não ver mérito no relativismo como visão filosófica geral e traz objeção - aponta para uma falácia - aos argumentos de que princípios liberais seriam comprometidos com uma visão ocidentalizada de mundo. No entender de
} 
Poucos autores defendem tão veementemente um "direito" a intervir quanto Téson, em sua concepção liberal moralista. Certas situações seriam moralmente tão repugnantes sob qualquer teoria ética plausível, a ponto de justificar intervenções humanitárias preconizadas por ele, que chega, inclusive, a criticar a percepção exagerada de inviolabilidade dos limites geográficos soberanos estatais. Embora reconheça considerações de ordem prática na configuração da integridade territorial e doméstica dos entes internacionais, pondera que as mesmas não excluem a legitimidade da intervenção humanitária. As situações que garantem a intervenção seriam de tal gravidade que não se pode simplesmente ignorá-las. Proteger as fronteiras nacionais significa preservar a "cola" que conecta a sociedade internacional, conquanto permitir atrocidades em seu nome seria muito pior do que dissolvê-las temporariamente.

O argumento de Téson, embora genuíno, parece não corresponder à realidade e torna-se discutível ao tomarmos em escrutínio os agentes dos valores das correntes filosóficas liberais, geralmente as democracias ocidentais. Caso houvesse instituições estáveis de governança global centrífuga, um ideal difícil de ser alcançado na ordem internacional contemporânea, caracterizada por aspectos contraditórios das sociedades pluralistas e maximalistas-consensuais, poder-se-ia minimizar o "relativismo" dos povos ou a intervenção para sanar situações de extrema anarquia, geralmente oriunda da própria dinâmica das relações internacionais e, por que não dizer, pelos mesmos interesses e iniciativas estatais daqueles que se pretendem os agentes da intervenção. Os Estados, tão desgastados em sua soberania, parecem ignorar essa alternativa e centramse continuamente na defesa de seus direitos e distanciamento de suas obrigações. Diante disso, defender uma ordem liberal "libertadora" dos oprimidos, sem os critérios claros e imparciais necessários, ainda parece algo inalcançável, e Téson parece não buscar responder aos questionamentos suscitados.

Buchanan (2003) também sai em defesa das intervenções de caráter humanitário, ainda que reconheça sua ilegalidade. ${ }^{141}$ Aponta para a percepção crescente de que os requerimentos do CSNU para preservação da paz e segurança tornaram-se, com o

Téson, certas situações são moralmente repugnantes sob qualquer teoria ética plausível, o que justificaria intervenções humanitárias sob a concepção política-liberal.

${ }^{141}$ Ao analisar casos emblemáticos como a crise humanitária no Kosovo, com a intervenção da OTAN (1999), as violações dos direitos humanos no Paquistão (1971), a guerra vietnamita contra o regime de Pol Pot, no Camboja (1978) e a deposição do governo de Idi Amin pela Tanzânia, em Uganda (1979). 
tempo, obstáculos para a proteção de direitos básicos dos seres humanos em situação de conflitos internos. Em razão de o mundo do pós-Guerra Fria estar presenciando, em maior parte, conflitos internos interestatais, seria o momento propício para a alteração ou abandono de regras tradicionais (da ONU) voltadas a intervenções humanitárias criadas para um mundo totalmente diferente. ${ }^{142}$

Nos mesmos moldes de Téson (idem: 5), Buchanan desconsidera argumentos de que o direito internacional é "inviolável", como defendem as correntes "classicistas" e "realistas-legais". ${ }^{143} \mathrm{O}$ autor desenvolve certos preceitos para guiar tentativas de reforma do direito internacional por intermédio de "atos ilegais". Ambos realizam, ao final, análises de cunho fortemente filosófico para aplicá-las ao tema das intervenções. Em tom mais radical, chegam a defender que o sistema normativo internacional deveria ser reformado para preencher valores de direitos humanos. Buchanan argumenta que os Estados que promovem direitos humanos com intervenções deveriam cumprir certos critérios e serem capazes de mostrar que as regras endossadas por eles são superiores a seus respectivos interesses nacionais (KEOHANE, idem: 5).

Em esforço de síntese das posições doutrinárias jurídicas e filosóficas dos autores que defendem as intervenções humanitárias, Stromseth (2003: 232-272) arriscase a condensar as correntes de pensamento na área das intervenções humanitárias, ao aplicá-las em situações mais práticas, como no caso de se buscar conhecer o status legal

\footnotetext{
142 Buchanan (2003130-173) apresenta as teorias da "Simple Moral Necessity Justification”; “Lawful Justification"; e a "Illegal Legal Reform Justification”, para fundamentar a necessidade de proteção dos direitos humanos. As duas primeiras, no seu entender, referem-se às justificativas morais pautadas em escolhas sobre o que priorizar, neste caso princípios universais básicos fundamentados na existência da pessoa humana e, em situações de violência, o bem maior representado pela vida humana. A terceira terminologia ("Illegal Legal Reform Justification"), na qual Buchanan se debruça com mais afinco, aduz ao fato de que as intervenções humanitárias acontecem tanto para responder a uma "emergência moral", quanto para contribuir ao desenvolvimento de uma nova e moralmente progressiva regra de direito internacional, na qual intervenções humanitárias sem o consentimento do CSNU são permitidas. O autor reafirma o prospecto de que atos ilegais são necessários para se alcançar uma evolução normativa, por conta da dificuldade de sua realização por meios puramente legais.

${ }^{143}$ Byers \& Chesterman (2003:177-203), tomando a ideia de uma "excepcional ilegalidade", acreditam até mesmo haver um fortalecimento do direito internacional com sua "quebra", com o reconhecimento da ilegalidade pelo Estado que intervém. Caso fosse adotada essa abordagem alternativa, o foco se alteraria não para o delito em si, mas para suas consequências, com argumentos de "legitimidade" mais propriamente passando a ser vistos como fundamentos de mitigação do dano. Sob tal abordagem, as violações de direitos humanos que resultaram na intervenção humanitária unilateral teriam de ser necessariamente consideradas e, de alguma forma, pesadas, ao se pensar em ações contra o Estado agressor, por exemplo quanto a situações de reparação dos danos causados.
} 
das intervenções humanitárias pós-Kosovo. ${ }^{144}$ Nesse esforço, realiza uma das mais interessantes análises sobre as justificativas das intervenções e suas consequências para o desenvolvimento normativo internacional. A autora considera que o status normativo das intervenções sem o consentimento do CSNU permanece incerto com a crise do Kosovo. Tal situação seria positiva e, até mesmo, um contraponto aos que tencionam intervir futuramente. A autora defende a tese de que essa ambiguidade torna-se um campo fértil para a emergência gradual de um consenso normativo, baseado na prática e nas decisões tomadas. Resumindo as posições dos autores supra sobre as eventuais justificativas para as intervenções, analisa quatro abordagens distintas: a "status quo"; a "excusable breach”; a "evolução do direito costumeiro relativo a uma justificativa legal" e o "direito à intervenção humanitária, por meio de codificação". ${ }^{145}$

\footnotetext{
${ }^{144} \mathrm{O}$ caso do Kosovo é considerado um dos mais controversos no direito e nas relações internacionais, e tem pautado ainda nos dias de hoje discussões relevantes na área dos estudos das intervenções humanitárias (FRANCK, 1999; SOFAER, 2000; BILDER, 2001; CHARNEY, 2001; WIPPMAN, 2001; ZACKLIN，2001; BELLAMY，2002; JOYNER，2002; TOMUSCHAT，2002; HOLZGREFE \& KEOHANE, 2003; STROMSETH, 2003). Em março de 1999, a OTAN iniciou um violento bombardeio contra a antiga-Iugoslávia, não autorizado pelo CSNU, sob o argumento de prevenção de alegada "limpeza étnica" na Sérvia, sendo conduzida pelo regime de Slobodan Milosevic. Kosovo era uma província da Iugoslávia com limitada autonomia e uma população de aproximadamente 1,8 milhões de albaneses étnicos. Em 1989, o governo pró-sérvio do país extinguiu a autonomia da região, resultando na formação de um movimento de resistência denominado Exército para Libertação do Kosovo (KLA, sigla em inglês). Era o final da Guerra Fria, e os movimentos secessionistas ganhavam força no leste europeu. $\mathrm{O}$ conflito pela independência do Kosovo evoluiu para uma situação sem precedentes às portas da Europa, levando os líderes das grandes potências a prestarem uma atenção peculiar aos seus desdobramentos. Uma série de iniciativas do CSNU, por meio de Resoluções do CSNU (1160; 1199; 1203), e negociações, como a de Rambouillet, todas frustradas, buscaram estabelecer a paz na região. O Capítulo VII (art. 42) da Carta das Nações Unidas foi invocado, para uma ação coletiva mais assertiva ("necessária para manutenção e restauração da paz e segurança internacional") de modo a interromper os massacres em andamento, mas continuamente vetado pela Rússia e pela China. Diante da inoperância e paralização do CSNU no conflito, uma coalização, liderada pelos Estados Unidos, a "Operação Forças Aliadas", sob o guarda-chuva da OTAN, iniciou uma campanha aérea com o objetivo de destruir a infraestrutura militar sérvia. Após dois meses de bombardeio e número crescente de vítimas civis, as partes chegam a um acordo para pôr fim no conflito no Kosovo, onde foi instituído um governo provisório sob a tutela da ONU. A intervenção da OTAN, à margem da autorização do CSNU, tem sido intensamente discutida nos foros multilaterais de segurança e no âmbito acadêmico. Suas consequências para o direito e política internacional ainda estão por ser melhor conhecidas, mas tendem a ser negativas, ao estimular iniciativas unilaterais ao arrepio da legislação internacional, a exemplo da recente discussão em torno da justificativa russa de apoio sob bases "humanitárias" aos dissidentes da Criméia, em alusão ao caso kosovar. (Cf. A Kosovo Chronology/War In Europe, acesso em : www.pbs.org/wgbh/pages/.../kosovo/etc/cron.html (15/07/2014); artigo: Intervention Lessons From Kosovo for Syria, por David L. Phillips (The Hunffington Post), acesso em: http://www.huffingtonpost.com/david-l-phillips/intervention-lessons-from_b_3858228.html.

(10/09/2012); BBC News/Kosovo/History, bloody history (cronologia do conflito), acesso em http://news.bbc.co.uk/2/hi/special_report/1998/kosovo/110492.stm (15/03/2013).

${ }^{145}$ Uma abordagem alternativa no âmbito da vertente normativa-legal do direito da intervenção humanitária também vale ser citada, em razão de seu interesse para o debate. Trata-se da noção "contrarestricionista" (counter-restrictionist) aventada por Bellamy \& Wheeler (2011: 510-523) e a discussão da
} 
A abordagem do "status quo" considera ilegítimas as intervenções sem a devida autorização do CSNU, por meio do procedimento usualmente aceito no direito internacional, codificado no artigo 2 (4) da Carta da ONU. Nessa categoria encontramse os "classicistas" e os "realistas-legais". Defensores dessa abordagem percebem uma lacuna na prática consistente de intervenção humanitária, que poderia sugerir um direito internacional costumeiro sobre a Carta. Avaliam que o objetivo do requerimento ao CSNU de autorização para intervir viria no sentido de minimizar o recurso à força como meio de solução de conflitos na arena internacional. O complexo procedimento requerido na Carta para autorização do uso da força foi planejado em seus primórdios para promover o consenso e a estabilidade nas relações internacionais e para proteger a soberania estatal e as populações de interferências externas violentas.

Com relação à abordagem da "excusable breach" do direito internacional, em análise aproximada daquela feita por Byers e Chesterman (2001) de "excepcional ilegalidade", Stromseth afirma que as intervenções seriam justificadas por razões de ordem política e moral em casos excepcionais, embora tecnicamente ilegais sem o mandato autorizativo do CSNU. Muito embora as intervenções do gênero violassem a Carta, os Estados dificilmente seriam punidos. Stromseth aponta alguns benefícios de tal abordagem, na medida em que a "excusable breach" é medida excepcional de intervenção humanitária legítima, sem contemplar novas regras tratando sobre o uso da força. A autora argumenta que "states intervening in such situations are unlikely to be condemned as law-breakers; but they act at their own risk in full awareness that they are violating the rules for a higher purpose”. Ainda que considere defensável tal abordagem, vê um problema principiológico com a teoria (idem):

“justificativa moral" para os Estados imiscuírem-se na soberania de outro ente quando os direitos humanos fundamentais violados assim o exigirem. O caso "contra-restricionista" para o direito de intervenção individual e coletiva subjaz em duas demandas. A primeira, na Carta das Nações Unidas, que prescreve a obrigação dos Estados em proteger os direitos humanos fundamentais. A segunda, no direito da intervenção humanitária, no âmbito do direito costumeiro internacional. Os defensores do argumento "contra-restricionista" elevam os direitos humanos ao mesmo patamar da segurança e da paz na Carta da ONU. Nesse sentido, o próprio preâmbulo, combinado com os artigos 1 (3), 55 e 56, dariam prevalência aos direitos humanos como razão principal da existência da Organização. Críticos dessa corrente alegam que os argumentos contra-restricionistas exageram na extensão do consenso sobre as regras que determinam o uso da força e que a leitura feita por eles das provisões da Carta das Nações Unidas seriam contrárias à maioria das opiniões legais a respeito e ao desejo dos formuladores da paz internacional no pós-Guerra, em 1945. 
"(....) For one thing, it is unsatisfying to label as "illegal" action that the majority of the UN Security Council views as morally and politically justified. If such situations were to recur, the tension between legality and legitimacy would yield problems over time. The legitimacy of the legal rules themselves would be called into question. Second, the justification offered by states - and the international responses to state action - are more nuanced that the "excusable breach" approach. NATO states did not argue "we are breaking the law but should be excused for doing so". Instead, NATO states, in sometimes differing ways, explained why they viewed their military action as "lawful" - as having a legal basis within the normative framework of international law (...)"

Para Stromseth, esta situação resulta na terceira abordagem: a evolução do direito costumeiro da justificativa legal para as intervenções humanitárias em casos raros. Tal visão perscruta se uma norma emergente de direito costumeiro com relação às intervenções humanitárias pode ultrapassar as considerações morais e políticas atualmente atribuídas, para enfim fazer parte do quadro normativo internacional do uso da força. No entender da autora, as vantagens dessa abordagem são consideráveis e parecem responder aos principais desafios com relação ao tema das intervenções.

Sua ambiguidade, no entanto, leva analistas a defender mais explicitamente uma quarta abordagem, a de formalização e codificação, por meio de uma emenda à Carta da ONU ou uma declaração da AGNU, do direito às intervenções humanitárias. Stromseth (idem: 245) considera que a ideia subjacente a essa abordagem seria criar uma base legal distinta quanto ao uso da força, que caminhe em paralelo ao direito de legítima defesa, com critérios e princípios pré-estabelecidos. ${ }^{146}$ Avalia também que "the case for codifying a right of humanitarian intervention rests on a normative attitude towards such interventions, a view about the impact of codification on the legitimacy of international law, a position concerning the role of formalization in curbing abuses (...)”. A autora reconhece a relevância do debate em torno de se codificar um "direito" à intervenção humanitária, mas considera o assunto "problemático" e "contraprodutivo" na atualidade. Melhor que se tentar "prematuramente" uma iniciativa nesse sentido,

\footnotetext{
146 Jane Stromseth entende que o direito internacional evolui para algo aproximado das abordagens da "quebra escusável" e o desenvolvimento de um direito costumeiro das intervenções humanitárias. Para a autora, a codificação seria uma "falsa esperança", em razão de sua difícil implementação. Ainda assim, as regras estabelecidas seriam criadas de modo vago e sem permitir uma flexibilização case-by-case (Keohane, idem: 8).
} 
seria avançar um processo gradual de evolução normativa sob os auspícios da Carta das Nações Unidas.

Se na doutrina jurídica observamos que há um forte embate entre aqueles que se preocupam prioritariamente com o bem-estar da pessoa humana, em uma concepção reformista mais recente (JENKS, 1958; AGGELEN, 1986; DUPUY, 1986; TRINDADE, 2002; MAZZUOLI, 2006), e os que priorizam a defesa de que o Estado e suas prerrogativas não devem ser desafiados de forma recorrente e "leviana", sob o risco de falência sistêmica, parece que a primeira corrente vem conquistando espaço nas OIs e outras arenas multilaterais. Ou seja, os próprios juristas contestam a validade das normas apenas pelo positivismo. Em política internacional as opiniões contra intervenções humanitárias parecem prevalecer.

Legalmente, os críticos defendem inexistir base jurídica que justifique uma intervenção ou o uso da força não autorizado pelo CSNU. Exceto pelo direito individual ou coletivo disposto no art. 51, não há exceções ao artigo 2 (4). Das vezes em que se utilizou unilateralmente das intervenções, as justificativas passavam geralmente pelo direito da autodefesa, a exemplo da intervenção indiana no Paquistão, em 1971, ou mais recentemente na intervenção norte-americana no Iraque e no Afeganistão, mais de três décadas depois. Para os realistas, os Estados quando intervêm dificilmente o fazem por objetivos nobres de sacrifício de seus militares em nome de valores universais, e sim por interesses individuais em jogo. Do ponto de vista das teorias realistas, intervenções imprudentes jamais servem ao "interesse nacional". Em eventual ausência de um mecanismo imparcial que determine a permissibilidade da intervenção humanitária, os Estados certamente deverão expor motivos humanitários em que na maioria das vezes somente seus próprios interesses estão em risco (BELLAMY \& WHEELER, 2008: 514).

O critério da "seletividade de resposta" também é apontado pelos defensores da não-intervenção. Os Estados geralmente tendem a aplicar princípios humanitários de forma seletiva, o que resultaria em iniciativas inconsistentes, em razão do comportamento estatal de "julgar" de acordo com o que seria um interesse próprio. Exemplo desse critério foi utilizado na intervenção da OTAN no Kosovo, quando ao 
mesmo tempo a crise em Darfur parecia, do ponto de vista humanitário, muito mais grave. Outras justificativas, mais pessimistas, simplesmente afirmam que intervenções de cunho humanitário não funcionam. "Outsiders" não teriam como impor direitos humanos a outros povos, por dificuldades inerentes das diferenças culturais e formas de governo estabelecidos. ${ }^{147}$ Há também quem aponte para a necessidade da preservação da ordem global, para uma estabilidade do "sistema de Estados" no longo prazo. Argumentam que intervenções humanitárias prejudicam a estabilidade internacional tanto pelo ato em si de interferir na soberania, quanto por criar um precedente que poderá levar a abusos. Governos bem-intencionados, ao se utilizarem das intervenções, contribuem para um "caos generalizado". 148

O debate acima tentou focar no instituto da intervenção em seu aspecto mais controverso, no que seria o uso da força visto como agressão militar contra um Estado soberano. Mas as intervenções são multifacetadas e se apresentam sobre variados "disfarces", desde pressões paraestatais até o auxílio econômico trasvestido de troca de apoio em foros multilaterais. Seitenfus (2002: 12-17) sintetiza magistralmente esse aspecto das intervenções e busca classificar sua prática de modo mais nítido. Para o autor, o instituto da intervenção pode ser apreendido quanto à sua modalidade, natureza e finalidade, pelo "extraordinário" alcance do fenômeno que, em seu entender, raramente encontra suporte legal. Dentre as modalidades expostas, elenca (1) pressões em Sentido Lato; (2) Rompimento de Relações Diplomáticas e Comerciais; (3) Embargo; (4) Intervenção Consentida; e (5) Intervenção Armada. Quanto à natureza da intervenção: (1) o uso da força ilegítima; (2) a consequência da interpenetração de interesses econômicos e (3) como consequência de um processo institucional. Quanto às

${ }^{147}$ Cf. WALTER, Michael. Arguing about War. New Haven: Yale University Press, 2004. pp. 67 apud BIERRENBACH, Ana Maria (2011). O autor situa a questão no contexto norte-americano, e afirma o seguinte para justificar sua opinião não-intervencionista: "We (on the left especially) have reasons for it, which derive from our opposition to imperial politics and our commitment to self-determination even when the process of self-determination is something less than peaceful and democratic (...). Still, nonintervention is not an absolute moral rule: sometimes, what is going on locally cannot be tolerated. Hence the practice of "humanitarian intervention" - much abused, no doubt, but morally necessary whenever cruelty and suffering are extreme and no local forces seem capable of putting an end to them." 148 Ao defender na ONU o conceito de "paz durável" e de "responsabilidade ao proteger" (RwP), o Governo brasileiro adota esta linha de que o uso da força não é e nunca foi a solução para defender o direito à vida das pessoas. Certo é que tal uso pode ser necessário em caso de conflitos que assumem dimensões graves e causam situações de urgência, porém a intervenção não pode ser vista apenas como o uso da força e o posterior abandono do território pelo interventor, sem a necessária reconstrução e reparação dos danos. Por isso as operações de paz evoluíram para compreender uma ideia mais avançada de state building. 
finalidades da intervenção, estão aquelas como (1) proteção aos estrangeiros residentes em território instável; (2) assistência humanitária; (3) imposição da paz; e (4) restauração da democracia.

Não nos preocupamos, neste tópico, em esclarecer conceitos como direito/dever de ingerência e direito de intervenção, além de outros atos de natureza militar que possam ou não ser cometidos em nome da proteção de pessoas em situação de vítimas. No pós-segunda Guerra, por exemplo, os EUA auxiliaram na reconstrução do sistema judiciário japonês. Na Alemanha vencida, a ingerência teria sido muito maior. Ao longo das décadas subsequentes houve casos de diversas naturezas, mas o cômputo geral foi de que a reconstrução do Estado não teria sido suficiente para assegurar a seus cidadãos algum tipo de proteção, especialmente em contextos como as intervenções no Iraque e no Afeganistão, exemplos "débeis" de state building. Alguns observadores mais ousados chegam a afirmar que o recente embate da aliança ocidental contra o Estado Islâmico seria resultado direto desta falha de reconstrução de sociedades fragilizadas na região.

\subsection{Considerações finais}

Demonstrou-se que a intervenção armada por razões humanitárias ainda é objeto de intermináveis querelas entre os defensores da proteção do Estado soberano no sistema internacional anárquico (no sentido de BULL, 1977) e aqueles que, ao contrário, sustentam o dever unilateral de agir da comunidade internacional ou dos Estados. A mesma clivagem é recorrente e encontrada nas áreas do DI e nas RI, com argumentos por vezes similares, entre a primazia estatal (em uma ordem política pluralista-minimalista) ou da pessoa humana (no PIPH), porém com argumentos próprios aos dois campos de estudo e suas respectivas agendas de pesquisa, que nem sempre dialogam.

Há consenso de forma geral de que os instrumentos internacionais analíticos e institucionais para responder às crises violentas dentro do território de um Estado soberano são insuficientes para garantir algum tipo de ordem. Ou seja, as intervenções tendem a ser decididas muito mais fora do sistema ONU ou em grupos informais (PRANTL, 2006; BADIE, 2011) do que na observância das normas e obrigações 
previstas em sua Carta. Além disso, alguns Estados são os principais intervencionistas: EUA, Reino Unido e França (uma ordem liberal ocidental?). Consequentemente, passamos por um período de transição, em que, muito embora haja consenso acerca da inadequação institucional, parece não haver no que concerne a suas possíveis soluções.

$\mathrm{O}$ conceito de $\mathrm{SH}$ ainda sobrevive e fundamenta a extensão dos direitos humanos e das intervenções humanitárias. As críticas que se manifestam passam pelos problemas antes referidos. Como conceito, o $\mathrm{SH}$ sem dúvida caracteriza um novo paradigma para se pensar as relações internacionais centralizadas na pessoa humana, em compasso com as diretrizes de um período em que os seres humanos são alçados ao protagonismo das decisões globais. A crise de confiança atualmente existente nos foros multilaterais tende a ofuscar as iniciativas em cumprimento às normas e obediência aos valores mais prementes. Essa percepção (temporária?) de que passamos por uma paralisação das instâncias decisórias estatais reflete em novos conceitos resultantes da evolução da doutrina intervencionista, como o R2P.

Reconhecemos que longo foi o alcance na busca de uma solução que conciliasse esse dilema entre intervenção e soberania. Outorgar menos direitos e mais obrigações foi um passo sem precedentes na história da humanidade, comparável aos resultados da ordem que se formou no imediato pós-Grande Guerra II e a aceitação da Carta da ONU como o apanágio para regular o uso da força entre os Estados membros da sociedade internacional da época. Ainda é cedo para afirmar se a R2P deverá tornar-se uma norma jurídica a pautar as diretrizes do uso da força nas relações internacionais, sobrepondo as prerrogativas securitárias tradicionais das nações na ordem global.

O diálogo sobre intervenção na soberania estatal conhece disputa acirrada. De um lado, estão aqueles a favor ou contra imiscuir-se em assuntos internos de outros entes nacionais, de outro os que concordam ou discordam da intervenção, mas em casos bastante específicos, como ameaças efetivas e em andamento, às populações, portanto de natureza humanitária (TADJBAKHSH \& CHENOY, 2007). Opiniões tão diversas resultaram em um emaranhado de posições divergentes que levaram Robert Keohane (2004: 01) a afirmar, de forma jocosa, que "saying humanitarian intervention in a room full of philosophers, legal scholars, and political scientists is a little bit like crying 'fire' 
in a crowded theatre: it can create a clear and present danger to everyone within earshot.".

No próximo capítulo, pretendemos tratar do conceito inovador e polêmico da $\mathrm{R} 2 \mathrm{P}$, direcionando o debate para esse núcleo duro das intervenções modernas. A relevância do conceito para a tese passa pelo reconhecimento de que a partir de sua afirmação nas relações internacionais, a soberania passa da inerência de direitos ao reconhecimento de responsabilidades individuais resguardadas pela coletividade em casos de incapacidades voluntárias ou sistêmicas. As obrigações positivas privilegiamse da fonte da "soberania como responsabilidade". O Estado tem o dever de proteger a própria população a partir de então, para além dos direitos que lhe eram conferidos plenamente na ordem global, como inerentes ao aspecto soberano de sua personalidade. Voltamos assim ao ponto inicial da pesquisa de se entender os desafios da globalização e de seus novos conceitos, que agora estão postos. 
CAPÍTULO V

A RESPONSABILIDADE DE PROTEGER:

CONCEITOS E LIMITES 


\title{
V. A Responsabilidade de Proteger: conceitos e limites
}

\begin{abstract}
"I recognize both the force and importance of these arguments. I also accept that the principles of sovereignty and non-interference offer vital protection to small and weak states. But to the critics I would pose this question: If humanitarian intervention is, indeed, an unacceptable assault on sovereignty, how should we respond to a Rwanda, to a Srebrenica - to gross and systematic violations of human rights that offend every precept of our common humanity? "
\end{abstract}

Kofi Annan, "We the Peoples" (A/54/2000)

\subsection{Considerações iniciais}

Longa foi a evolução da segurança humana $(\mathrm{SH})$ para sua concepção mais prática de "responsabilidade de proteger" (R2P). Na introdução de The Responsibility to Protect: Ending Mass Atrocity Crimes Once and For All (2008), Gareth Evans ressalta que a R2P teria sido a forma em que o mundo finalmente começou a responder às questões das reais causas dos genocídios e a tomar iniciativa no sentido de "nunca mais ter de dizer "nunca mais" aos crimes cometidos contra os seres humanos. Questionamentos sobre o tema vinham de longa data e preocupavam de forma crescente os líderes mundiais, que externavam seus desagrados em infindáveis discursos sobre atrocidades nos mais diversos foros multilaterais, em especial na ONU e nas conferências que tratavam de questões principalmente humanitárias. ${ }^{149}$

No relatório We the Peoples: The Role of the United Nations in the 21st Century (A/54/2000), apresentado à AGNU, em 2000, o então-Secretário-Geral Kofi Annan já apontava para o problema e demandava retórico e genuinamente respostas mais assertivas da comunidade internacional que não a inércia usualmente existente: "If humanitarian intervention is, indeed, an unacceptable assault on sovereignty, how

\footnotetext{
${ }^{149}$ Merece referência o discurso feito pelo então-Primeiro Ministro Britânico, Tony Blair, em abril de 1999, na esteira do conflito no Kosovo, em que oferece à comunidade internacional as bases para intervenção na soberania estatal quando a ameaças contra as populações vierem do próprio Estado que deveria protegê-las. Originalmente formulado como a "doutrina da comunidade internacional", ficou conhecido posteriormente como "Doutrina Blair". In: SLOBODA, John; ABBOTT, Chris. The Blair doctrine and after: five years of humanitarian intervention (artigo - 21/04/2004). Disponível em: https://www.opendemocracy.net (15/03/2013)
} 
should we respond to a Rwanda, to a Srebrenica - to gross and systematic violations of human rights that offend every precept of our common humanity? ",150

A pergunta de Kofi Annan era eloquente. As tragédias do século XX pela ação ou omissão de governantes em nome dos Estados, como os genocídios alemão e ruandês (1994), os assassinatos em massa no Camboja (1975), na Somália (1993) e em Srebrenica (1995), apenas para citar alguns, levaram os líderes de muitos países a repensar o tradicional conceito de soberania como atributo inerente à existência de uma coletividade em determinado território. A ONU, diante de suas responsabilidades institucionais bloqueadas por décadas de bipolaridade pelo confronto Norte-Sul, que impedia ações mais enérgicas para evitar ferir suscetibilidades dos representados, decidiu não mais restar inerte com os crimes cometidos contra seres humanos mundo afora. Em renovadas aspirações, relançou o debate sobre suas prerrogativas e, nas figuras de Boutros Boutros-Ghali e Kofi Annan, exortou as principais potências globais a assumirem responsabilidades de agir conforme as regras existentes. Novos desafios e questões levaram à criação de instituições e à emergência de novos atores no cenário internacional, responsáveis por lidar com situações de injustiça e desrespeito aos direitos humanos universais. ${ }^{151}$

A proliferação de instituições criadas para reunir os governos com o objetivo de trazer à discussão o tema dos direitos humanos fez-se acompanhar de crescente desentendimento por parte delas sobre o real alcance dos conceitos, princípios e métodos de solução das crises humanitárias e das demandas intervencionistas de blocos de países e atores individuais. Diante do dilema intervencionista e da relutância dos Estados em escolher alternativas para a proteção internacional dos direitos humanos, a ONU empreendeu esforços, por intermédio de seu Representante da Secretaria-Geral para Deslocados Internos, o diplomata sudanês Francis Deng, de trazer ao debate sobre direitos humanos a questão da soberania estatal, no âmbito da situação dos IDPs (que não gozavam, a exemplo dos refugiados, de proteção internacional, e já somavam à

${ }^{150} \mathrm{Cf}$. http://www.un.org/en/ga/search/view_doc.asp?symbol=A/54/2000 - tópicos 215-219 (Adressing the Dilemma of Intervention) - acesso em 10/03/2014

${ }^{151} \mathrm{Na}$ seara das instituições, tem-se destacado crescente número de atores e mecanismos como o AltoComissariado das Nações Unidas para os Direitos Humanos (1993), os Tribunais Penais Internacionais para a Antiga Iugoslávia (1993), para Ruanda (1994), Serra Leoa (2001), o Tribunal Penal Internacional (1998), entre outras. 
época de sua indicação para o cargo, em 1993, cerca de 23 milhões de indivíduos), visando redefini-la e adequá-la a novas realidades (BELLAMY, 2011; WEISS, 2012).

A noção de "soberania como responsabilidade" desenvolveu-se a partir dos trabalhos de Francis Deng e Roberta Cohen ${ }^{152}$ e seus esforços no sentido de ampliar o conceito de responsabilidade em situações de crises humanitárias relacionadas aos deslocados internos (IDPs) em conflitos civis e de confrontar o desafio de "persuadir" os governos a protegê-los e não recusarem assistência humanitária com argumentos de soberania (DENG, 2004: 20; 1996). Desse modo, buscavam avançar a ideia, abraçada rapidamente por acadêmicos, políticos e policymakers, principalmente nos centros de poder do norte desenvolvido (BELLAMY, idem, ibidem), de que os Estados deveriam proteger seus nacionais e facilitar a assistência humanitária, para ultrapassar os condicionamentos impostos pelos aspectos inerentes do princípio da soberania. ${ }^{153}$

A comunidade internacional passaria a ter uma obrigação de agir perante atrocidades cometidas por lideranças políticas e governos contra a própria população. Foi nessa esteira de evolução conceitual e normativa da soberania, para render-se à responsabilidade e distanciar-se do egoísmo pluralista minimalista de proteção indelével dos interesses estatais, distante do indivíduo como sujeito ativo das relações internacionais, que ganhou forma a Comissão Internacional sobre Intervenção e Soberania Estatal (ICISS). Criada em 2000, composta por especialistas e acadêmicos de diversos países, ${ }^{154}$ sob o patrocínio do Governo do Canadá, assumiu o objetivo de

\footnotetext{
${ }^{152}$ Deng e Cohen desenvolveram um extenso trabalho em prol da questão dos IDPs, em que expõem de forma coerente a questão da responsabilidade que deriva da soberania. Para tanto, desenvolveram um "Guia de Princípios" (Cf. COHEN, 2004), publicado em 1998, elaborado em conjunto com especialistas, com vistas a buscarem refinar o conceito de IDPs, identificar os instrumentos legais de direitos humanos para enfrentar o desafio soberanista, e estruturar os critérios a serem aplicados em casos concretos. Para outros estudos, vide Cohen (2004, 2006, 2006b) e Deng (1996, 2004, 2006 ).

${ }^{153}$ As críticas à noção de "soberania como responsabilidade" não se fizeram esperar, no sentido de que a ideia atentava contra os princípios da soberania e não-intervenção, além de constituir interferência nos assuntos externos dos Estados. Nesse sentido foi a argumentação de países como China e Cuba, nas reuniões que seguiram sobre IDPs na Comissão de Direitos Humanos da ONU. A clivagem Norte-Sul e a crítica ao ocidentalismo fizeram-se presentes novamente nos intensos debates que se seguiram. Como bem recordou Bellamy (idem), "sceptics worried that by advocating sovereignty as responsibility, the West was setting itself up as both judge and jury in relation to a doctrine that lent a veneer of legitimacy to self-interested coercive interference."

${ }^{154}$ Foram membros da Comissão: Gareth Evans (Australia), Co-Chair; Mohamed Sahnoun (Algeria), CoChair; Gisèle Côté-Harper (Canada); Lee Hamilton (United States); Michael Ignatieff (Canada); Vladimir Lukin (Russia); Klaus Naumann (Germany); Cyril Ramaphosa (South Africa); Fidel V. Ramos
} 
buscar responder ao desafio feito à comunidade internacional por Kofi Annan no relatório "We the Peoples" (supra). ${ }^{155}$

\section{O Relatório da SGNU da Sexagésima Sessão (2009), Implementando a} Responsabilidade de Proteger, avaliou que nenhuma preocupação sobre soberania ou entendimento de que tal conceito implica em responsabilidades estariam confinadas a uma parte do mundo, como poderia ser alegado por países potencialmente passíveis de intervenções humanitárias. A evolução do conceito de "soberania como responsabilidade" para a consagração do termo "Responsabilidade de Proteger" (bem como das variantes daí advindas, como a proposta brasileira de "Responsabilidade ao Proteger" - RwP) deu novo alento às aspirações humanitárias e reavivou as discussões sobre a redefinição da soberania como essencial para a existência dos Estados.

Este capítulo pretende discutir as origens conceituais da Responsabilidade de Proteger. De modo similar ao conceito de $\mathrm{SH}$, sua base principiológica que lhe confere legitimidade, a R2P vem sendo continuamente criticada em razão de sua inoperância conceitual, por não haver conseguido responder satisfatoriamente aos desafios impostos pela modernidade. Sua extensão para outras áreas, como a ambiental, ainda é recebida com muita cautela. Defensores do estrito significado atribuído a ela pela comunidade internacional parecem concordar que eventual alargamento conceitual tenderá a causar o esvaziamento e a elevar a desconfiança que caracteriza a sociedade internacional. A discussão que segue percorre esse caminho, além de buscar oferecer as bases do conceito, com seus aspectos e limites. Entender a evolução histórica da SH e R2P entra

(Philippines); Cornelio Sommaruga (Switzerland); Eduardo Stein Barillas (Guatemala); Ramesh Thakur (India).

${ }^{155}$ Kofi Annan foi dos maiores protagonistas da discussão do dilema da soberania, no período em que esteve à frente da ONU, principalmente na defesa dos direitos humanos e da noção de que soberania implica responsabilidade. Para além de "direitos", implicaria igualmente "deveres" e "obrigações" (no sentido de obrigações positivas e erga omnes, para citar Cançado Trindade (1993; 2020). Sua ideia inovadora de soberania para um mundo globalizado pós-Guerra Fria foi sintetizada em artigos de grande repercussão, como em Two Concepts of Sovereignty, escrito na esteira da crise do Kosovo, em 1999. No texto, o SG argumenta que: "State sovereignty, in its most basic sense, is being redefined - not least by the forces of globalisation and international co-operation. States are now widely understood to be instruments at the service of their peoples, and not vice versa. At the same time individual sovereignty by which I mean the fundamental freedom of each individual, enshrined in the charter of the UN and subsequent international treaties - has been enhanced by a renewed and spreading consciousness of individual rights. When we read the charter today, we are more than ever conscious that its aim is to protect individual human beings, not to protect those who abuse them." (Sept. 16, 1999/The Economist a convite). Disponível em: http://www.economist.com/node/324795 (10/01/2013) 
nesse contexto de reconhecimento da construção discursiva de seus significados, de modo a pautar a defesa da extensão dos princípios aplicados na proteção do ser humano em sua totalidade, incluída o meio ambiente e a OAI que lhe sustenta como ato de fala, uma ordem socialmente construída, mas pautada em interesses concretos de seus atores principais, os Estados.

\subsection{Origens, aplicabilidade conceitual e críticas}

O conceito de R2P foi apresentado pela primeira vez no Relatório final do ICISS $^{156}$ (2001), co-presidido pelo ex-Chanceler australiano Gareth Evans e o diplomata argelino Mohamed Sahnoun. As conclusões do estudo, intitulado Responsibility to Protect, foram louvadas pela comunidade internacional como serenas e equilibradas, por conciliar o tão criticado intervencionismo unilateral constantemente exercido em nome dos direitos humanos e da democracia e as aspirações genuínas dos que viam a inércia da comunidade internacional por paralisia de suas instituições diante de catástrofes humanitárias como algo a ser urgentemente revista. ${ }^{157}$ O SG Kofi Annan chegou a descrever o Relatório/ICISS como "the most comprehensive and carefully thought-out response we have seen to date". (UN press release SG/SM/8125, apud BELLAMY, 2011).

O documento alterou terminologias até então controversas de "intervenção humanitária" e "direito de ingerência" (ou "droit de regard"), confundidas como elementos de simples intervenções de nações mais bem capacitadas político e militarmente contra suas congêneres débeis e fragilizadas. De relevância primordial para a credibilidade da Comissão, as conclusões dos trabalhos foram no entendimento de que a intervenção coletiva em nome dos direitos humanos seria uma exceção (não,

156 Cf. ICISS. The Responsibility to Protect. Relatório. Publicado pelo International Development Research Centre. Dezembro, 2001. Disponível em: http://responsibilitytoprotect.org/ICISS\%20Report.pdf (50/11/2012).

157 Conforme visto supra, o contexto de criação da ICISS foi, entre outras situações, os resultados negativos advindos da paralisia do CSNU diante da crise humanitária do Kosovo e a contestada ação militar da OTAN no conflito sem devida autorização. 
em essência, contestação à soberania estatal) e também uma proteção das populações aos crimes contra a humanidade. ${ }^{158}$

Segundo o Relatório/ICISS, uma nova abordagem para a intervenção com bases humanitárias deveria pautar-se por quatro objetivos básicos: (1) estabelecer regras, procedimentos e critérios mais claros na determinação de "se", "quando" e "como" intervir; (2) estabelecer a legitimidade de intervenções militares quando necessárias e somente após o esgotamento de todos os recursos; (3) assegurar que a intervenção militar, ao ocorrer, seja executada somente em razão dos propósitos previamente definidos, efetiva e empreendida com preocupação apropriada de minimizar os custos humanos e os danos institucionais; e (4) ajudar a eliminar, onde possível, as causas do conflito, enquanto realça as perspectivas de uma paz duradoura e sustentável (tradução livre do autor). ${ }^{159}$

O conceito de R2P ganhou rápida repercussão política e acadêmica, culminada por sua adoção nos relatórios do Painel de Alto Nível da SGNU sobre Ameaças, Desafios e Mudanças: A More Secure World: Our Shared Responsibility (2004) e In Larger Freedom: Towards Development, Security and Human Rights for All (2005). A consagração veio, no entanto, em sua afirmação, por mais de 150 países, nos parágrafos 138 e 139 da Resolução 60/01 da Cúpula Mundial (High-level Plenary Meeting of the General Assembly), realizada em $2005^{160}$ :

\section{"Responsabilidade de Proteger populações contra genocídio, crimes de guerra, limpeza étnica e crimes contra a humanidade:}

\footnotetext{
${ }^{158}$ Fundamentando-se na R2P, a Comissão identificou as responsabilidades da comunidade internacional de (1) prevenir, (2) reagir e (3) reconstruir, como instrumentos de política gradual para o retorno à segurança e à paz necessárias para a correta proteção estatal aos seus nacionais (Fonte: Relatório/ICISS). Número considerável de recomendações da Comissão foi posteriormente incluído no relatório "In Larger Freedom: Towards Development, Security and Human Rights for All", de 2004, apresentado no Painel de Alto-Nível sobre Ameaças, Desafios e Mudanças, sob a liderança de Kofi Annan, como definem as provisões dos parágrafos 138 e 139 da Cúpula Mundial de 2005, realizada sob os auspícios da ONU. Esse tópico será explorado infra.

${ }^{159}$ No original: "2.3 Any new approach to intervention on human protection grounds needs to meet at least four basic objectives: to establish clearer rules, procedures and criteria for determining whether, when and how to intervene; to establish the legitimacy of military intervention when necessary and after all other approaches have failed; to ensure that military intervention, when it occurs, is carried out only for the purposes proposed, is effective, and is undertaken with proper concern to minimize the human costs and institutional damage that will result; and to help eliminate, where possible, the causes of conflict while enhancing the prospects for durable and sustainable peace”. (ICISS, idem: 11)

160 UNITED NATIONS. UN General Assembly. 2005 World Summit Outcome Document (UN A/RES/60/L.1)
} 
Parágrafo 138. Cada Estado, individualmente, tem a responsabilidade de proteger a sua população de genocídio, crimes de guerra, limpeza étnica e crimes contra a humanidade. A responsabilidade vai no sentido de prevenir tais crimes, incluindo o seu incentivo, através de meios necessários e apropriados. Aceitamos essa responsabilidade e agiremos de acordo com ela. A comunidade internacional deve, como convém, encorajar e apoiar os Estados a exercerem esta responsabilidade e ajudar as Nações Unidas a implementar um sistema de alertas antecipados.

Parágrafo 139. A comunidade internacional, por meio das Nações Unidas, também tem a responsabilidade de usar meios diplomáticos, humanitários e pacíficos apropriados, em conformidade com os Capítulos VI e VII da Carta, para auxiliar a proteção das populações contra genocídio, crimes de guerra, limpeza étnica e crimes contra a humanidade. Neste contexto, estamos preparados para empreender uma ação coletiva, de modo decisivo e oportuno, através do Conselho de Segurança, em conformidade com a Carta, inclusive com o Capítulo VII, de forma individual e em cooperação com relevantes organizações regionais, no caso de inadequação dos meios pacíficos e do fracasso manifesto das autoridades nacionais na proteção de suas populações contra genocídio, crimes de guerra, limpeza étnica e crimes contra a humanidade. Ressaltamos a necessidade de a Assembleia Geral continuar a refletir sobre a responsabilidade de proteger populações de genocídio, crimes de guerra, limpeza étnica e crimes contra a humanidade e suas implicações, levando em consideração os princípios da Carta das Nações Unidas e do direito internacional. Também pretendemos nos comprometer, quando necessário e apropriado, a ajudar a capacitar os Estados para protegerem suas populações de genocídio, crimes de guerra, limpeza étnica e crimes contra a humanidade e assistir aqueles em situações de tensão de iminência de crises e conflitos." (tradução livre do autor) ${ }^{161}$

${ }^{161}$ No original: "Responsibility to protect populations from genocide, war crimes, ethnic cleansing and crimes against humanity: 138. Each individual State has the responsibility to protect its populations from genocide, war crimes, ethnic cleansing and crimes against humanity. This responsibility entails the prevention of such crimes, including their incitement, through appropriate and necessary means. We accept that responsibility and will act in accordance with it. The international community should, as appropriate, encourage and help States to exercise this responsibility and support the United Nations in establishing an early warning capability. 139. The international community, through the United Nations, also has the responsibility to use appropriate diplomatic, humanitarian and other peaceful means, in accordance with Chapters VI and VIII of the Charter, to help to protect populations from genocide, war crimes, ethnic cleansing and crimes against humanity. In this context, we are prepared to take collective action, in a timely and decisive manner, through the Security Council, in accordance with the Charter, including Chapter VII, on a case-by-case basis and in cooperation with relevant regional organizations as appropriate, should peaceful means be inadequate and national authorities are manifestly failing to protect their populations from genocide, war crimes, ethnic cleansing and crimes against humanity. We stress the need for the General Assembly to continue consideration of the responsibility to protect populations from genocide, war crimes, ethnic cleansing and crimes against humanity and its implications, bearing in mind the principles of the Charter and international law. We also intend to commit ourselves, as necessary and appropriate, to helping States build capacity to protect their populations from genocide, war crimes, ethnic cleansing and crimes against humanity and to assisting those which are under stress before crises and conflicts break out". 
Tais provisões, de forma geral, avançam o entendimento da comunidade internacional de que a R2P é aliada da soberania, não adversária, pelos próprios fundamentos da existência dos Estados para com a coletividade. Ao auxiliar os Estados a agir corretamente, a R2P busca fortalecer a soberania estatal e proteger governos e populações do flagelo das guerras civis, do genocídio cometido por lideranças criminosas e de grupos políticos incapazes de preservar sua segurança interna. ${ }^{162}$

Não foi simples o caminho de reconhecimento da R2P como princípio normativo em construção. Ainda há quem duvide de sua efetividade na ordem global como uma norma realmente emergente a pautar o futuro das intervenções (principalmente após o caso líbio, na esteira da Primavera Árabe, e, recentemente, com a conflagração interna na Síria e na questão ucraniana). Foley (2013) avalia que as iniciativas para se alcançar consenso em torno do conceito acabaram por minar o conteúdo normativo da R2P. Para o autor, se a definição de uma norma consiste em um entendimento coletivo da devida conduta dos autores, como pretende Legro (1997), é difícil entender como a R2P se enquadraria nisso. $\mathrm{O}$ autor cita variadas situações em que autoridades teriam mencionado o conceito em discursos, como o PM Tony Blair durante a intervenção no Iraque, em 2003, o Chanceler russo, Sergei Lavrov, no caso da ação militar russa em apoio à Ossétia do Sul, e o Chanceler francês Bernard Kouchner, no caso de Myanmar. ${ }^{163}$ Para Foley, embora tais declarações possam ser tachadas de oportunismo político, não podemos desconsiderar a relevância de líderes da Grã-Bretanha, Rússia e

162 A Cúpula reconheceu também o instituto do "alarme prévio" (early warning) como meio necessário para a prevenção exitosa e ação protetora das nações, para lidar tempestivamente com os abusos aos direitos humanos perpetrados pelo Estado-alvo da intervenção. Nesse propósito, a comunidade internacional tem papel crucial no estabelecimento dos mecanismos de conformação da capacidade da ONU, por meio de seus integrantes, de responder como autoridade máxima na implementação dos princípios da R2P. Tais mecanismos de apoio passam pelo envio das informações que sejam relevantes e estejam disponíveis para fornecimento imediato às Nações Unidas, sobre preparação, incitamento de crimes, violações e agressões.

163 Diante da recusa da junta militar no poder de receber auxílio humanitário às vítimas do Ciclone Nargis, em 2008, considerado categoria 3 na classificação de gravidade para tempestades, e chegou a vitimar cerca de 130.000 pessoas, o Chanceler Kouchner declarou que a resposta dilatória do oferecimento da oferta de assistência da comunidade internacional justificava uma intervenção no Myanmar baseada no princípio da R2P, chegando a propor junto ao CSNU uma resolução para autorizar que a entrega de ajuda humanitária fosse mandatória. O PM britânico, Gordon Brown, aventou que o desastre natural em Myanmar tornara-se uma catástrofe de razões humanas, por conta da negligência e tratamento desumano contra seu próprio povo pela junta birmanesa. O caso gerou controvérsia imediata, em razão da eventual extensão do conceito da R2P para além dos casos previstos pela Resolução RES/60/01, aprovada pela AGNU. Para maiores detalhes sobre a discussão em torno do conceito, conferir BARBER (2009); COHEN (2009); EVANS (2009); AXWORTHY \& ROCK (2009); BELLAMY (2010b); RAFFELSEDER (2011). 
França, membros-permanentes do CSNU, quanto aos seus efeitos na prática das relações internacionais.

Malone (2009: 21) considera que, como um marco do direito internacional para o século XXI, cada termo dos $\S^{\circ}$ s 138-139 da Resolução 60/01 merece um "escrutínio cauteloso". Para a autora, o Relatório/ICISS não seria tão extraordinário como apontam alguns analistas, já que o documento ultrapassa a "rubrica" do permitido pelo direito internacional "to project where international law and the political realities of the global community are headed, formulating what should be the emerging overriding legal norm for the future in terms of resort to peaceful means of resolution, precautionary principles, national (preferably human) security, and the ultimate question of permissible use of force through the United Nations, collectively, and unilaterally. "164

$\mathrm{O}$ reconhecimento da $\mathrm{R} 2 \mathrm{P}$ na política internacional vem acompanhado não somente da imperiosa necessidade de aplicação prática de seus atributos, mas também da discussão de seu status no direito internacional. Algumas questões inevitavelmente se impõem ao pesquisador em saber se a R2P representa, do ponto de vista legal, uma norma costumeira de direito internacional ou se está em vias de tornar-se. Também em saber se o conceito reflete uma mudança na compreensão que se tem tradicionalmente da soberania, que em si resulte em significativas alterações legais (PAYANDEH, 2010: 480).

O High-Level Panel Report (“A more secure world”.../A/59/565, § 203) já aceitava a R2P como uma "emerging norm", ao prescrever "we endorse the emerging norm that there is a collective international responsibility to protect, exercisable by the Security Council (...)” (Parte III, IX, a), em opinião similar à do SG Kofi Annan, em In larger freedom (2005: 35). Annan é categórico ao concordar com o Relatório/ICISS, como se depreende do excerto a seguir: "While I am well aware of the sensitivities

\footnotetext{
${ }^{164}$ Malone sugere, ainda, que a perspectiva do relatório da R2P seria limitado por pelo menos dois fatores: é predominantemente "human centric", confinado a como deve ser formulada a intervenção humanitária em termos de prevenção de perdas humanas; e sofre por ter sido realizado antes dos eventos do dia 11 de setembro de 2001, com o ataque ao World Trade Center e de todas as consequências daí advindas, como os conflitos iraquiano e afegão. A autora sugere que o massacre de civis inocentes por atores não-estatais não constituiria um novo crime internacional, e que talvez a falta de sensibilidade dos co-autores do Relatório teria sido mais reflexo de suas preocupações humanitárias do que um limitação em suas conclusões legais.
} 
involved in this issue, I strongly agree with this approach. I believe that we must embrace the responsibility to protect and, when necessary, we must act on it (...)". Essa ousadia, no entanto, não foi acompanhada pelos membros da SGNU, no texto que reconheceu politicamente a R2P, o "2005 World Summit Outcome Document (UN A/RES/60/L.1).

Um dos obstáculos para se caracterizar a R2P como uma norma emergente salta de sua própria ambiguidade, alterada ainda durante sua formulação e com multidimensionalidade de significações incorporadas em si (PAYANDEH, idem: 481). Certos aspectos seus seriam formulados em termos que mais implicam uma obrigação do que uma norma de direito, enquanto outros componentes enumeram medidas potenciais ou exortam os atores a comportarem-se de determinado modo (uma espécie de guiding principles). Assim, a R2P incorporaria/combinaria um conjunto de linguagens normativas, política e moral, cujas noções estão longe de serem cobertas por uma simples norma.

Para Payandeh (2010), a R2P não poderia nem mesmo ser considerada uma norma emergente do direito costumeiro internacional, como pretendem autores como Evans (2006), Barbour \& Gorlick (2008) e Weiss (2012). O costume internacional, como fonte do direito, provém do fato de não haver, como bem salientou Mazzuoli (2006), "um centro integrado de produção de normas jurídicas", muito embora haja crescente tendência de codificação das normas internacionais consuetudinárias. Conforme o tradicional entendimento, expresso no artigo 38 (1) (b) do Estatuto da CIJ, dois são os requisitos para o consenso quanto à juridicidade das normas consuetudinárias, uma "prática geral” (repetida conduta) e sua aceitação como direito (opinio juris). Como conceito emergente nas relações internacionais, a R2P careceria dos elementos primordiais para já defini-la como uma norma consuetudinária. ${ }^{165}$

\footnotetext{
165 Essa corrente, geralmente, encontra guarida ou é influenciada pela doutrina legalista francesa da "teoria das fontes formais" do direito internacional, na acepção positivista voluntarista clássica da origem da sistematização da teoria das fontes do direito. Aplicada à ordem internacional, tal concepção tem o mérito de isolar o direito da política e permitir sua análise mais sistemática (DUPUY, 2008: 279-380). Na acepção clássica, a tipologia das fontes formais do direito internacional, de onde emanam as decisões e as obrigações, pode ser encontrada no artigo 38 do Estatuto da CIJ.
} 
No âmbito político, Quinton-Brown (2013: 62-72) reconhece que, apesar do progresso alcançado pelo R2P desde a Cúpula Mundial da ONU (2005), um número significativo de países ainda continua a fazer objeções contra o conceito, impedindo seu desenvolvimento normativo e o amplo reconhecimento do consenso alcançado sobre o termo. Ao "mapear" as categorias de objeções, o autor elenca seis desafios temáticos levantados por críticos do conceito, como a politização e uso indevido do instituto; a defesa de uma concepção tradicional de soberania e da não-interferência; a aversão ao uso da força; a ideologia pós-colonial; a falta de legitimidade do CSNU; e a falta de capacidade de alerta prévio.

Os Estados que criticam a formulação da doutrina da R2P acusam sua utilização por nações mais poderosas econômica e militarmente como seletiva e inapropriada, voltadas para a aferição de vantagens indevidas. Esse entendimento preconiza servir a R2P como instrumento de poder para agendas políticas de certos países. Críticos voltaram à tona, por exemplo, com o caso da intervenção líbia de 2011, quando teria havido abuso de poder e de prerrogativas dos interventores, em razão da mudança expressamente não-autorizada do regime de Ghadafi. ${ }^{166}$ Essa concepção crítica gira em torno da defesa da soberania tradicional, entendida como uma soberania não como "responsabilidade", e sim como um "direito", voltada para o fortalecimento da noção westfaliana, acordada há sessenta anos como preceito fundamental da Carta da ONU. Entre os países que defendem esse direito à soberania absoluta encontram-se a Argélia, a Rússia e a China.

Enfatizam a prevenção como pilar mais relevante da teoria da R2P os defensores do princípio da não-intervenção e da proibição ao uso da força nas relações internacionais, como reminiscência da teoria clássica da just war (jus ad bellum), que se baseia na utilização da força como último recurso e na prevalência da proporcionalidade

${ }^{166}$ De todos os casos em que o conceito de R2P foi aplicado, o da Líbia (2011) certamente é o mais proeminente e debatido nos foros multilaterais, não em razão da licitude ou legitimidade da intervenção, mas pela forma como foi implementada (BELLAMY, 2012). Com a intensificação do conflito interno e a disposição do regime de Ghadafi de recrudescer a violência contra os manifestantes, demonstrada por inúmeras declarações públicas de integrantes do governo, a ONU, por meio da Resolução 1973 do CSNU, autorizou a intervenção no país "por todos os meios necessários" para pôr fim ao conflito . A resolução autorizou os integrantes da coalizão a estabelecer uma zona de exclusão aérea para garantir a proteção dos civis. A percepção do $(\mathrm{ab})$ uso da intervenção tornou-se um importante revés, em razão da evidência do viés político consubstanciada pela mudança de regime, extrapolando-se as diretrizes da Resolução (BRAGA, 2013: 33). 
dos meios e da distinção dos combatentes. Os defensores dessa corrente afirmam que, caso a intervenção militar seja desnecessária, não deve agravar as tensões no terreno e causar mais danos aos civis (dentro da concepção de negação da doutrina do double effect). ${ }^{167}$

Quinton-Brown (idem: 68) avalia haver um "déficit de confiança", resultado da experiência negativa do passado com discursos intervencionistas com fortes interesses político-econômicos velados sob o manto dos direitos humanos universais. Outras críticas estão mais voltadas à estrutura do SI e a incapacidade do atual quadro institucional de enfrentar os desafios da globalização contemporânea, cujos reflexos diretos podem ser notados na percepção de países como a Índia, o Paquistão e a Argélia com relação à falta de representatividade do CSNU, que estaria perdendo legitimidade por sua composição anacrônica e poder de veto duvidoso e enviesado.

Indo além, Stahn (2007) ressalta que parte do problema com a R2P passa pelo desentendimento em relação a cinco proposições distintas e escalonadas: "(1) The Host State Has a Duty to Protect Citizens on Its Territory; (2) States Failing the Duty to Protect Have a Weak Sovereignty Defense; (3) Foreign Entities May Intervene Nonforcibly; (4) Foreign States May Intervene Forcibly; (5) Foreign Entities Have a Positive Duty to Act (destaque nosso). O autor ressalta, no entanto, que essa natureza multifacetada e diversificada de elementos, muito embora haja um núcleo conceitual

167 A defesa da diplomacia brasileira da ideia de "Responsabilidade ao Proteger" (Responsibility while Protecting - RwP) aponta para esse propósito. Os desafios em relação ao conceito vêm sendo tratados seriamente nos debates em torno das estratégias para efetiva aplicação do mesmo, adquirindo densidade após o conflito líbio, de 2011, que teria revelado fortes "deficiências, divisões e disjunções evidentes da arquitetura da segurança regional e global". Buscando dinamizar o conceito de R2P, no intuito de garantir sua credibilidade e eficácia, sem, contudo, contrapô-lo, foi como surgiu a variante brasileira, obtendo inicialmente ampla repercussão no meio político-diplomático e acadêmico. O discurso da Presidente Dilma Rousseff, na $66^{\text {a }}$ Sessão da AGNU, no mesmo ano, preconizou uma revisão dos métodos de aplicação da R2P, como forma de garantir maior legitimidade ao conceito, desgastado com a intervenção na Líbia em razão das críticas sobre sua utilização indevida e desproporcional e a mudança de regime que desestabilizou o país. Em pronunciamento posterior (fev/2012), o então-Ministro das Relações Exteriores brasileiro, Antonio de Aguiar Patriota, em debate sobre Responsabilidade ao Proteger na ONU, lançou as bases principiológicas do conceito da RwP. Segundo Aguiar Patriota, os conceitos da "responsabilidade de proteger" e da "responsabilidade ao proteger" deveriam evoluir lado a lado, com base em conjunto acordado de princípios fundamentais, parâmetros e procedimentos. Para consulta ao pronunciamento do Embaixador Antonio Patriota, realizada em Nova Iorque, em 21 de fevereiro de 2012, conferir o endereço eletrônico do Portal do Ministério das Relações Exteriores, Nota n. 38: http://www.itamaraty.gov.br/salade-imprensa/notas-a-imprensa/pronunciamento-do-ministro-das-relacoes-exteriores-antonio-de-aguiar-

patriota-em-debate-sobre-responsabilidade-ao-proteger-na-onu-2013-nova-york-21-de-fevereiro-de-2012. $(15 / 03 / 2014)$ 
aceito por todos de que a "sovereignty entails responsibility", justifica o êxito de sua aceitação por parte dos Estados, pois "it could be used by different bodies to promote different goals" (2007:118).

Quanto à proposição em destaque, Stahn compara os documentos que serviram de base para a legitimação do conceito de R2P (Relatório/ICISS; High Level Panel Report; Relatório do SGNU; e o Outcome Document 2005 da AGNU) e conclui que todos os instrumentos legais que justificaram politicamente a R2P alteram o foco de um "direito de intervenção" para uma "responsabilidade de proteção", portanto uma obrigação. Considera, no entanto, que o consenso se torna frágil quando se discute quem teria a obrigação positiva de intervir com base na R2P, em caso de incapacidade do Estado possuidor da responsabilidade primária. Se levarmos em conta que a obrigação primária pertence ao CSNU, detentor do direito legítimo de acordo com a Carta da ONU, o consenso alcançado foi nessa diretriz. Stahn adverte retoricamente com alguns questionamentos que são aqui pertinentes para a pesquisa (idem: 120): "What if the international community, through the Security Council, fails to exercice its responsibility to protect? Does the burden then shift back to individual states, groups of states, or regional organizations; and, if so, to which states and organizations?"

Ao considerarmos estas questões e atentarmos para o fato de que a doutrina da intervenção humanitária tende a ser substituída na prática discursiva como ato de fala pelo conceito de R2P, sua legitimidade política poderá ser enfraquecida e, mais preocupante, sua capacidade como emerging norm continuamente desvanecida. As obrigações positivas e outros sistemas também promissores, que poderiam se beneficiar das diretrizes já consagradas de soberania como responsabilidade, parecem tornar-se continuamente questionadas pela prática internacional negativa da R2P que the deveria servir de exemplo, haja vista o polêmico caso da Líbia, cujo precedente prejudica ainda hoje a aplicação mais assertiva do conceito, se tomarmos o deadlock da conflagração interna na Síria.

Como identificou Bellamy (2011), concordar sobre a necessidade e efetividade de princípios tão nobres como o de pronta defesa às vítimas de limpeza étnica e genocídios, sob argumentos da defesa dos princípios abstratos dos direitos humanos 
básicos, é uma coisa, traduzir os mesmos ideais em políticas eficazes levando em consideração os esforços locais, regionais e globais é outra totalmente diversa. A R2P tem sido utilizada em situações as mais diversas, contraditórias e inconsistentes possíveis, desde aquela para sanar a violência pós-eleitoral no Quênia (2008), como parte da diplomacia estratégica de Kofi Annan, até a invocação do princípio pela Rússia durante a intervenção militar unilateral na Geórgia (2008). ${ }^{168}$

É esse um dos fundamentos do debate sobre as intervenções (pautadas da R2P) que se apresentam para o pesquisador: saber aliar a legitimidade política à busca da normatização dos conceitos, para dar-lhe vida e maior aplicabilidade a situações reais, sem o qual são desconsiderados politicamente e se tornam "letra morta" de lei. O consenso em torno da R2P parece crescentemente distante. Seu exemplo não mais influencia outros institutos ora emergentes na ordem global, como a noção das obrigações positivas. Transpor conceitos de um sistema político-normativo, como a PIPH, que parece não responder com efetividade às suas predisposições analíticas e práticas, torna-se problemático. Nesse ponto a OAI deverá atentar-se para mitigar controvérsias no seio do SI e evitar um retorno excessivo à sociedade pluralistaminimalista de outrora. Pensamos que, em alguns temas específicos da agenda ambiental, como relativos a catástrofes, essa diretriz será naturalmente alcançada, tendo em vista a ineficácia dos instrumentos político-jurídicos então postos para enfrentar ameaças que cada vez mais afetam os Estados, em uma ordem de forças fragmentadas e quadro normativo ainda fragilizado.

\subsection{Responsabilidades de prevenir, reagir e reconstruir}

De modo simples, a ideia de que a soberania estatal implica responsabilidade primária na proteção de sua população encontra-se no próprio Estado, e é dos princípios basilares da R2P. Esse preceito pode ser facilmente extraído do Relatório/ICISS, quando cita ([b] XI): “onde uma população esteja a sofrer sérios danos, como resultado de um conflito interno, uma insurgência, repressão ou negligência estatal, e o Estado em questão esteja relutante ou incapaz de suspender ou evitar, o princípio da

\footnotetext{
${ }^{168}$ Na prática, nos últimos anos, além do Quênia e da Geórgia (2008), a R2P foi utilizada - ou ao menos aventada fortemente - em crises como em República Democrática do Congo (1995-), Darfur (2003-), Myanmar (2008), Gaza (2008-2009), Sri Lanka (2008-2009), Guiné (2009) e Norte Coreia (1995-).
} 
não-intervenção submete-se à responsabilidade de proteger internacional" (tradução livre do autor). ${ }^{169}$ As bases da R2P assentam-se nas obrigações inerentes do conceito de soberania; na responsabilidade do CSNU, com fundamento no artigo 24 da Carta; nas obrigações legais específicas dos direitos humanos e nas declarações de proteção de tais direitos, em tratados e outras convenções internacionais, no DIH e nas legislações nacionais; além de, no direito costumeiro, práticas em vias de consolidação (developing practice) dos Estados, das organizações regionais e do CSNU.

A responsabilidade internacional não é sem critérios, obedecendo a uma ordem tripartite de prerrogativas (Cf. Anexo IV - Sinopse/R2P). Conforme o Relatório/ICISS, a R2P abrange três responsabilidades "específicas": (1) a de prevenir (responsibility to prevent); (2) a de reagir (responsibility to react) e (3) a de reconstruir (responsibility to rebuild). A primeira das responsabilidades chama a atenção para a necessidade de se buscar as causas primárias e diretas dos conflitos internos e de outras crises que ponham em risco populações. A responsabilidade de reagir (responsibility to react) refere-se à necessidade de não se quedar inerte em determinadas situações de risco, por meio da execução de medidas apropriadas, inclusive coercitivas, mas non-enforcement, de que são exemplos as sanções jurídicas, e, em casos extremos, o uso da força por meio de intervenções militares. A terceira responsabilidade prevê o oferecimento de assistência, sobretudo após intervenções militares, para a recuperação, reconstrução e reconciliação das populações afetadas, buscando lidar com as causas do conflito que a intervenção almejou sanar. Dos elementos da tipologia de responsabilidades acima referidos, o ICISS priorizou a "prevenção" como a mais importante, uma vez que as opções relativas ao caráter preventivo devem sempre ser exauridas antes mesmo de a intervenção ter sido contemplada (Relatório/ICISS, idem: 19-27).

A R2P foi alçada a princípio norteador da ideia da legitimação da intervenção internacional no Relatório/ICISS como forma de se alcançar consenso na comunidade de nações sobre a legalidade do direito ou obrigação de intervir contra um Estado soberano nas relações internacionais. Na "responsabilidade de reagir" (aqui sinônimo de

\footnotetext{
${ }^{169}$ No original: "Where a population is suffering serious harm, as a result of internal war, insurgency, repression or state failure, and the state in question is unwilling or unable to halt or avert it, the principle of non-intervention yields to the international responsibility to protect”. In: Relatório/ICISS (idem: [b] $\mathrm{XI})$.
} 
intervenção) subjaz o aspecto mais controverso do conceito. O ICISS assumiu em suas conclusões que intervenções militares com fins humanitários são medidas “excepcionais" e "extraordinárias". ${ }^{170}$ Para serem legítimas (“warranted”), "deve haver sério e irreparável prejuízo (atual ou iminente) contra seres humanos" - uma larga escala de perda de vidas ou limpeza étnica (Relatório/ICISS, idem: 32-33). ${ }^{171}$

Não necessariamente militar (como se entende do capítulo VII da Carta), as ações coercitivas podem corresponder a meios pacíficos de solução de controvérsias (Capítulo VI) e à colaboração com mecanismos regionais e sub-regionais (Capítulo VIII). O processo de determinar o melhor modo de ação deve respeitar os princípios e diretrizes da segurança coletiva (autorização do CSNU), sem o que qualquer intervenção coletiva ou unilateral tende a ser considerada ilegal no DI. Esse é o entendimento do ICISS quando trata da autoridade legal com relação ao tema da intervenção militar. ${ }^{172}$

\footnotetext{
${ }^{170}$ Quatro são os princípios de precaução aventados pelo relatório/ICISS: "1) Correta intenção (right intention) - o objetivo primário da intervenção deve ser evitar o sofrimento humano; 2) Último recurso (last resort) - a intervenção militar apenas pode ser justificada quando todos os outros meios não-militares ou de resolução pacífica tiverem sido explorados; 3) Meios proporcionais (proportional means) - a escala, duração e intensidade da intervenção militar deve ser a mínima necessária para assegurar os objetivos da operação de proteção humanitária; 4) Perspectivas razoáveis (reasonable prospects) - deve haver uma chance razoável de eficácia da operação em realmente evitar o sofrimento humano - que justificou a intervenção - e os resultados da ação não podem ser piores do que eventual inação." (tradução livre do autor)

${ }^{171}$ Quanto a esse aspecto, o Relatório/ICISS (2001: 32) sinaliza que, para serem justificadas, as intervenções devem combater: "a) Large scale loss of life, actual or apprehended, with genocidal intent or not, which is the product either of deliberate state action, or state neglect or inability to act, or a failed state situation; or b) Large scale 'ethnic cleansing', actual or apprehended, whether carried out by killing, forced expulsion, acts of terror or rape."

${ }^{172}$ Segundo o Relatório (2001, XII): “A) There is no better or more appropriate body than the United Nations Security Council to authorize military intervention for human protection purposes. The task is not to find alternatives to the Security Council as a source of authority, but to make the Security Council work better than it has; B) Security Council authorization should in all cases be sought prior to any military intervention action being carried out. Those calling for an intervention should formally request such authorization, or have the Council raise the matter on its own initiative, or have the SecretaryGeneral raise it under article 99 of the UN Charter; C) The Security Council should deal promptly with any request for authority to intervene when there are allegations of large scale loss of human life or ethnic cleansing. It should in this context seek adequate verification of facts or conditions on the ground that might support a military intervention; D) The Permanent Five members of the Security Council should agree not to apply their veto power, in matters where their vital state interests are not involved, to obstruct the passage of resolutions authorizing military intervention for human protection purposes for which there is otherwise majority support; E) If the Security Council rejects a proposal or fail to deal with it in a reasonable time, alternatives options are: I. consideration of the matter by the General Assembly in Emergency Special Session under the "Uniting for Peace" procedure; and II. action within area of jurisdiction by regional or sub-regional organizations under Chapter VIII of the Charter, subject to their seeking subsequent authorization from the Security Council. F. The Security Council should take
} 
A "responsabilidade de reconstruir" (responsibility to rebuild) é consequência lógica da "responsabilidade de reagir", uma vez que as ações militares podem provocar destruição ao ponto de o Estado ter dificuldades para reerguer-se como instituição político-jurídica capaz de prover novamente a organização societária na área conflituosa. Em suas análises, o ICISS não desmereceu esse relevante aspecto da responsabilidade da comunidade internacional, caso seja convocada a cumprir com o seu dever de intervenção. O próprio Relatório prevê a responsabilidade de "provide, particularly after military intervention, full assistance with recovery, reconstruction and reconciliation, addressing the causes of the harm the intervention was designed to halt or avert."(idem: XI [3], c). Os princípios da obrigação de "reconstrução" pós-conflito vêm de longa data, podendo ser encontrados já na "Agenda for Peace" (1992), de Boutros Boutros-Ghali, que preconiza a necessidade de peacebulding/statebuilding por parte da ONU, em caso de operações de missão de paz com base no Cap. VII da Carta e sob o fundamento securitário do peace enforcement, (ALTEMANI \& LESSA, 2006: 2526). Uma das razões para facilitação do endosso das diretrizes do ICISS por Kofi Annan, por sua vez, vai nesse sentido. Em 1998, Annan já descrevia no Relatório "The Causes of Conflict and the Promotion of Durable Peace and Sustainable Development in Africa” (A/52/871- S/1998/318) as diretrizes e o entendimento do conceito e prática de post-conflict peace building, inaugurado por seu antecessor. Segundo o ICISS, a mensagem é "clara": “(...) There is no substitute for a clear and effective postintervention strategy.” (Relatório/ICISS, idem: 40)

A R2P, para ser eficaz e responder às aspirações dos países que a subscreveram, baseia-se em três pilares, inspirados nas provisões do Summit Outcome, de 2005, e desenvolvidos no relatório da AGNU, de 2009, sob o título "Implementing the responsibility to protect”" (A/63/677). Seriam eles (1) as responsabilidades de proteção do Estado; (2) a assistência internacional e a "capacity-building”; e (3) a resposta "tempestiva e decisiva" (timely and decisive response). O primeiro pilar aponta para a primazia da responsabilidade do Estado em proteger suas populações, nacionais ou não,

into account in all its deliberations that, if it fails to discharge its responsibility to protect in conscienceshocking situations crying out for action, concerned states may not rule out other means to meet the gravity and urgency of that situation - and that the stature and credibility of the United Nations may suffer thereby." 
dos crimes de genocídio, de guerra, limpeza étnica e contra a humanidade. O segundo, refere-se ao comprometimento da comunidade internacional na prestação de assistência aos Estados de modo a cumprir com aquelas obrigações. O último pilar, essência da R2P, aduz à responsabilidade dos Estados-membros da ONU de responderem coletivamente "de forma decisiva e tempestiva" a potencial ou efetivo risco às populações, quando o Estado apresentar-se manifestamente fragilizado para agir soberanamente ou é o próprio causador do dano.

\subsection{Por uma extensão do conceito da R2P?}

Até decisão em contrário dos Estados-membros das Nações Unidas, e aprovada no World Summit Outcome Document (2005/A/60/L.1 - 138), a R2P recai somente nos crimes e violações previstas, grosso modo, no Estatuto de Roma do TPI (art. $\left.5^{\circ}\right)^{173}$, com a exceção da "limpeza étnica", que não se afigura naquele instrumento legal do TPI ("138. Each state has the responsibility to protect its populations from genocide, war crimes, ethnic cleansing and crimes against humanity"). Posto isto, muito se tem discutido nos âmbitos político e acadêmico - mais contra do que a favor - a possibilidade de extensão da R2P para outras áreas de intervenções de caráter humanitário.

Evans (2009), um dos idealizadores do conceito e dos mais ávidos opositores de eventual extensão, defende a tese de que tentativas do gênero para abarcar situações que não as previstas no 2005 World Summit e no TPI, como combate a doenças, mudança climática, desastres naturais e/ou catástrofes ambientais, deverá "minar" o consenso já alcançado pela comunidade internacional em torno do tema, prejudicando sua utilidade operacional. Evans entende que a R2P se teria desenvolvido em contexto bastante específico, para lidar com necessidade igualmente específica. O contexto foi aquele de ausência de qualquer consenso internacional sobre como responder a crimes contra a humanidade dentro das fronteiras de um Estado. A diretriz das discussões propostas

173 Cf. BRASIL. Decreto no 4.388 (25/09/2002). “Artigo 5”: Crimes da Competência do Tribunal: 1. A competência do Tribunal restringir-se-á aos crimes mais graves, que afetam a comunidade internacional no seu conjunto. Nos termos do presente Estatuto, o Tribunal terá competência para julgar os seguintes crimes: a) $\mathrm{O}$ crime de genocídio; b) Crimes contra a humanidade; c) Crimes de guerra; d) $\mathrm{O}$ crime de agressão. 2. O Tribunal poderá exercer a sua competência em relação ao crime de agressão desde que, nos termos dos artigos 121 e 123, seja aprovada uma disposição em que se defina o crime e se enunciem as condições em que o Tribunal terá competência relativamente a este crime. Tal disposição deve ser compatível com as disposições pertinentes da Carta das Nações Unidas." 
inicialmente avançou no sentido do reconhecimento, pela comunidade internacional, de que crimes como os ocorridos no Camboja, Ruanda e Srebrenica, jamais deveriam ocorrer novamente pela inação e negligência dos Estados ("we have never again have to look back”). Pelo escopo potencialmente limitado do consenso sobre o R2P, Evans avalia que deveria haver cautela sobre quaisquer tentativas de se estender o alcance do conceito e dos mecanismos do R2P para outras situações de emergências, a exemplo das ambientais:

"A good deal also remains to be done, not least in the corridors and chambers of the United Nations itself, to ensure that the norm continues to enjoy the kind of unanimous support its articulation received in 2005. A number of states have subsequently expressed what has been described as "buyers' remorse" for their earlier vote, and there has been some anxiety that, in the context of a forthcoming debate in General Assembly on the subject (...) there would be a move to reopen and dilute the language of 2005 , rather than focusing on practical measures to ensure the more effective implementation of the principle in the future." (idem)

Mais apropriado para casos como os ambientais, segundo o autor, seria utilizarmos conceitos como "Segurança Humana" para situações que envolvessem outros temas que não os direitos humanos ("if one is looking for umbrella language to bring these issues and themes together, it is much more appropriate to use a concept like 'human security' than to say these are proper applications of the new international norm 'the responsibility to protect”). Evans apresenta como problema adicional da extensão do conceito para outras áreas o surgimento de possíveis críticas da R2P por parte dos países do Sul, que a taxariam como mera ação intervencionista do Norte desenvolvido (o que é recorrente), e reafirma citação do ex-Chanceler canadense Lloyd Axworthy de que, se a $\mathrm{R} 2 \mathrm{P}$ servir para proteger "todos de tudo, terminará não protegendo ninguém de nada" (tradução livre do autor). ${ }^{174}$ Evans aponta que a nova linguagem reproduzida pela R2P foi capaz de gerar um consenso efetivo entre os países, com relação à necessidade de dar respostas a casos extremos de atrocidades que choquem a humanidade, contrariamente daquilo que ocorria com o dissenso anterior em

${ }^{174}$ No original: “(...) if it is be about protecting everybody from everything, it will end up protecting nobody from anything. " Apud Evans (idem). 
torno do "direito à intervenção". ${ }^{175}$ Defende que se deve preservar o foco conceitual da R2P como um "grito de guerra" ("rallying cry") contra atrocidades em massa.

Edward Luck (2009), apontado em 2008 para o cargo de Special Advisor do SG Ban Ki-moon para temas voltados à R2P, no âmbito do Prevention of Genocide Office, ao preparar uma "genealogia" do processo decisório que levou à aceitação da "emerging norm" da R2P, destaca as diferenças entre as conclusões do relatório do ICISS (2001) e aquelas diretrizes aceitas no 2005 World Summit Outcome Document (parágrafos 138139, cf. supra). O autor avalia que as dificuldades em se alcançar consenso em temaschave, como desarmamento e não-proliferação nuclear, sempre polarizadores, apareceram também nas discussões sobre a R2P. O Relatório/ICISS teria sido muito amplo em suas premissas, no entender de Luck, ao não definir especificamente os crimes compreendidos pelo conceito de R2P (o ICISS citou vagamente, como visto acima, expressões como "large scale loss of life", "genocidal intent", "large scale ethnic cleasing”), enquanto os Estados negociadores buscaram delimitar ao máximo sua eventual aplicação. Diante disso, Luck (idem: 34) avalia que "going even an inch beyond would open up for some of them a Pandora's Box, as well as increasing the opportunities for other states to misapply the principle." Percebe que os Estados se tornam bastante desconfortáveis quando confrontados com o que consideram um "boundless concept". 176

Assim, diante da cultura burocrática da ONU, onde predominaria a síndrome do "everything is everything", no sentido de que tudo é holístico e inter-relacionado, afirma o Special Advisor, deve-se resistir à tentação de buscar expandir o conceito de R2P para outros temas que não os Direitos Humanos. Luck buscou evitar tal tendência no draft report do Implementing the Responsibility to Protect (A/63/677), apresentado

\footnotetext{
175 Com o conceito de "direito de intervenção" (Cf. Nota ${ }^{\circ} 24$ supra), mas também com suas variantes terminológicas, como o "direito/dever de ingerência", a "ingerência humanitária", a "intervention", entre outros. A literatura dos anos 1990 é riquíssima na utilização do termo “droit d'ingerénce” (desenvolvido principalmente por BETTATI, 1996), como se nota no título de obras de variados autores, a exemplo, não exaustivo, de "Le droit d'ingérence" (ZORGBIBE, 1994); "Le droit d'ingérence contre le principe de souveraineté" (BASSIR \& FRACHON, 1999; "Ingérence humanitaire et diplomatie” (BUJON, 1993).

176 Outras questões como negligência ou prevaricação (neglect/malfeasance), segundo Luck (idem, ibidem), estiveram bem além do alcance das discussões para se atingir o acordo com relação à R2P, e ainda hoje negociações envolvendo outros pontos, como intenções e capacidades, estão longe de alcançarem, principalmente entre países em desenvolvimento com déficits de capacidade operacional. Quanto ao critério da intenção, o autor vê uma dificuldade maior em determiná-la na área ambiental, sendo uma razão adicional por sua defesa pela impraticabilidade da extensão do conceito.
} 
ao Secretário-Geral. Sua resistência teria vindo, não somente por razões políticas, mas no entendimento de que um conceito demasiado elástico poderia enfrentar dificuldades em operacionalização. Argumenta que uma conceituação ampla demais da R2P tenderia a não ter conteúdo real e poder para além de seu apelo retórico, comparável ao conceito de SH: "an admirable way of thinking about security but one that has little operational content".

Ao defenderem a limitação do mecanismo de R2P, Evans e Luck utilizam-se da possibilidade de intervenção militar para coagir outro Estado no intuito de atuar de acordo com princípios estabelecidos pela sociedade internacional, na qualidade de membro da ONU. Do ponto de vista teleológico, não discutem a finalidade das intervenções, mas sim sua efetividade enquanto conceito, a ser aplicado na área ambiental. Evans (2009:32), em particular, faz uma crítica recorrente nas relações internacionais quanto à efetividade das normas, que perdem "valor" como instrumento de baliza para as ações dos atores no cenário internacional, sejam como incentivos compartilhados por seus pares, sejam coercitivamente cumpridas. Nesse sentido, o autor tece crítica contundente à extensão do conceito, sob uma argumentação convincente:

\footnotetext{
“(...) My bottom line, again, is simply that any widening of the application of "responsibility to protect" terminology, expressly or by implication, beyond its core business of addressing mass atrocity crimes is dangerous from the perspective of undermining the utility of "responsibility to protect" as a rallying cry. If anything else is bundled under the "responsibility to protect" banner - be it conflict generally, human rights generally, human security generally, environmental emergencies specifically, or anything else - we run a serious risk of diluting its capacity to mobilize international consensus in the cases where it is really needed. And that would be very bad news." (destaque nosso)
}

Axworthy \& Rock (2009: 64-65), de seu turno, contrapõem a defesa de Evans e Luck e argumentam que a R2P é "unbundled" (na linguagem mercadológica, o termo significa algo que é vendido separadamente, ao invés de parte de um pacote ${ }^{177}$ ) em seus "princípios fundacionais" (foundational principles), podendo ser aplicada, portanto, a outros problemas em que estejam presentes seres humanos. Recordam que a diretriz dos trabalhos do ICISS sobre R2P, nos idos dos anos 2000, foi justamente o conceito de SH,

${ }^{177}$ Cf. Oxford Dictionary: (online) www.oxforddictionaries.com - Acesso em: 03/02/2012. 
que privilegia os indivíduos, em vez de os Estados, no centro das relações internacionais ("promising a new emphasis on people rather than power"). Para os autores, os princípios que pautariam a extensão do conceito passam, assim, pelo "reconhecimento da primazia da soberania estatal como "first responder"; o dever da comunidade internacional de apoiar o Estado na consecução daquela responsabilidade; e a recusa da comunidade internacional em áreas de prioridade global de aceitar a mais simples falha do Estado ou de agir como última palavra" (tradução livre do autor). ${ }^{178}$

Sustentam, ainda, a atualidade do trabalho da ONU, considerado um unfinished business, como englobando uma versão mais alargada de tarefas, que incluiriam (a) a criação de um sistema de "early warning"; (b) alternativas para a intervenção militar; (c) a adoção de regras para o uso da força; (d) o aperfeiçoamento do sistema de sanções; (e) a montagem de um serviço emergencial permanente para a paz; (f) a criação de um plano de reforma do CSNU; (g) a incorporação do elemento de gênero, hoje negligenciado, nos trabalhos sobre o conceito de R2P; e (h) a intensificação da advocacy (AXWORTHY \& ROCK, idem: 57). Para os autores, enquanto permaneça uma prioridade focar na implementação da R2P, já seria tempo de se pensar em introduzir um apoio semelhante em outras questões de natureza global.

Em tom mais radical, Axworthy \& Rock chegam a defender a criação de uma nova comissão internacional, nos moldes da ICISS, para revisitar a iniciativa que inspirou a R2P "by examining how the principles inherent in the R2P concept represent one of the few ways of bridging the gap between the nation state system of political management and the global nature of risks and threats requiring cooperation and collaboration." Dentre os temas que poderiam utilizar-se da linguagem sobre segurança, como articulada pela R2P, no entender dos autores, seria o tema da mudança climática. Acreditam que, na área da segurança ambiental, as questões do impacto da mudança climática seriam das mais desafiadoras para a segurança no século XXI. Em exercício de como os princípios e diretrizes do conceito poderiam ser estendidos para a área da mudança climática, idealizam um sistema ambiental consensual sobre questões

\footnotetext{
${ }^{178}$ No original: “(...) the continued recognition of the primacy of the sovereign state as 'first responder'; the duty of the international community to support the state in meeting that responsibility; and the refusal of the international community in areas of global priority to accept the single state's failure or refusal to act as the last word."
} 
afetas ao clima; um consenso global que teria estabelecido relações de causa e feito, alvos e estratégias para lidar com o tema. Em tal cenário, os Estados estabeleceriam um acordo e criariam expectativas conjuntas para fazer face aos desafios. O consenso, enfim, seria alcançado pelo compromisso em torno de alguns princípios, tais como cada Estado estaria vigilante para cumprimento de suas obrigações, com apoio integral da comunidade internacional para tanto. Em caso de negligência ou recusa por parte de um Estado em cumprir com as obrigações previamente acordadas, as consequências seriam estabelecidas pela comunidade internacional de forma a resultar no fiel cumprimento das obrigações, sancionadas por um órgão superior de enforcement como o CSNU.

Por fim, a título de observação, vale considerar que a preocupação de Evans quanto à diluição do conceito é legítima e retira a qualidade de "emerging norm" da R2P. Como emerging norm, a R2P, em seu "ciclo de vida", na taxonomia de Finnemore \& Sikkink (1998: 895-905), ainda caminha para a "internalização", e sua extensão tenderia a prejudicar o processo e interromper seu ciclo normal de evolução normativa. O "ciclo de vida" proposto pelas autoras refere-se a um modelo trifásico interessante (figura 5.1), que busca compreender como as normas surgem, ganham densidade e aceitação, e depois são internalizadas pelos diversos atores, por seus mecanismos institucionais, em análise construtivista que merece consideração nesta tese.

\section{Fig. 5.1: Norm Cicle Life - Ciclo de vida normativo}

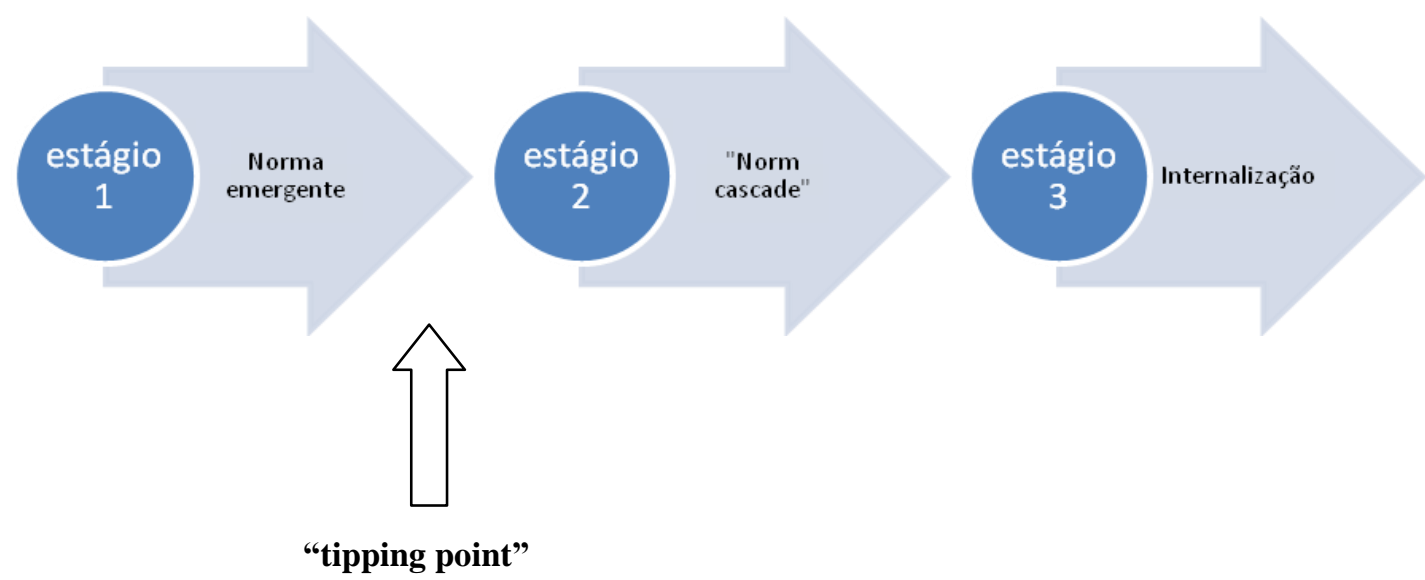

Fonte: Finnemore \& Sikkink (1998: 896) 
Segundo Finnemore \& Sikkink (idem: 895), a característica do primeiro estágio da emergência normativa seria a persuasão, por parte de seus promotores, para seu aceite, por intermédio do convencimento de uma massa crítica nos Estados (norm leaders) a adotar a nova norma (ou conceito, em nosso entender). A segunda fase, consequência da primeira e seu corolário, referir-se-ia mais a um processo de repetição autônoma dos norm leaders de, uma vez convencidos da eventual qualidade e efetividade da emerging norm, tentar convencer outros Estados, em um espiral em forma de cascata (norm cascade), a "socializar" o conteúdo normativo. A passagem do segundo estágio para o terceiro não seria inevitável, pois, recém-alcançado o segundo estágio, muitas normas falhariam em atingir o "ponto de inclinação" (tipping point) necessário, em que os atores se convenceriam sobre a efetividade das normas e sua adoção, passando a observá-las e internalizando-as. Nesse estágio final e desejável, segundo Finnemore \& Sikkink, "norms acquire a taken-for-granted quality and are no longer a matter of broad public debate".

Partindo da premissa de que a R2P é uma emerging norm, abraçada pelos Estados nos diversos instrumentos de legitimação política no âmbito da ONU, a contar pela ampla aceitação do conceito pelos Estados, nos § 138-139 do 2005 Outcome Document do World Summit, e em vias de operacionalização (Implementing the responsibility to protect/A/63/677), notamos que o conceito já atingira, na década de 2000, seu primeiro estágio no ciclo normativo e agora passa por momento crítico para firmar-se como norma plena a ser aceita e "internalizada" pelos Estados, com eventual risco até mesmo de falhar em alcançar o "tipping point" necessário após sua socialização.

Tal recorrente dissenso e crescente desconstrução conceitual, ou por sua extensão indevida, ou pelo descrédito de seus promotores quanto à sua efetividade em responder tempestivamente com meios operacionais realistas, vem resultando em sua aparente deslegitimação. Fica distante do otimismo uma vez presenciado pela comunidade internacional com relação ao conceito, como o apanágio para as mazelas que ainda assolavam a humanidade e como ponto de equilíbrio entre o aparente dicotômico e irreconciliável desafio da soberania estatal em face das exigências do mundo no século XXI. 


\subsection{Considerações finais}

A soberania cada vez mais é vista como uma condição na habilidade do Estado de prover segurança às suas populações. Sob essa ideia, desenvolveu-se todo um arcabouço teórico-normativo sobre segurança desde os anos 1990, pautado na extensão de seu conceito tradicionalmente apreendido do ponto de vista do paradigma da segurança nacional, para um viés mais humano, pela ideia então emergente da Segurança Humana. A construção discursiva do conceito, se por um período de euforia deu vazão às mais variadas iniciativas, por outro veio guarnecer uma lacuna prática das crises étnicas que assolavam aquela década e necessitavam, no âmbito multilateral, de uma justificativa mais sólida para fundamentar o retorno das intervenções, porém de modo menos intrusivo, nas soberanias mais frágeis. Exemplo desse processo foi a multiplicação das operações de peacekeeping a partir de então.

As Nações Unidas têm-se debruçado na questão das intervenções ao criar linhas de ação e diretrizes para conter abusos cometidos por Estados em nome das intervenções humanitárias, haja vista as últimas intervenções sob a égide da noção de "responsabilidade de proteger". As falhas nas intervenções passadas têm encorajado um dinamismo renovado com relação a iniciativas de prevenção e não-militares. Caso a agenda de SH fosse efetivamente adotada com foco na prevenção, no entender de Tadjbakhsh \& Chenoy (2007), a R2P seria bem menos tributária de "enforcement acts". Dessa forma, o conceito de $\mathrm{SH}$ seria visto como um apanágio para intervenções ilegítimas e um contrapeso ao imperialismo ocidental.

Consideramos que o conceito de SH é problemático. Aplicá-lo a situações de desastres ambientais, por meio de sua instrumentalização principal, o R2P, mais ainda, caso não haja uma crítica construtiva sobre o mecanismo. A definição de segurança humana carece de uma agenda concisa de pesquisa, sendo um campo tão vasto que se torna impraticável uma linha de ação específica. Há quem acredite que a "interdisciplinaridade" e "interssetorialidade" do conceito de SH torna-o unworkable (TADJBABKHSH \& CHENOY, 2007: 61). O mundo pós-Guerra Fria decerto apresenta ameaças sem precedentes que proveem razões urgentes para abordagens que assegurem uma praticidade das intervenções, mas as mesmas devem ser legitimadas e conter uma pauta genuína de proteção ao ser humano na sua integralidade, distante de 
fatores geoecômicos e enviesados. Nesse contexto, torna-se relevante investigar como intervenções em uma dada esfera pode gerar externalidades positivas ou negativas em uma outra e quais causalidades melhor delineiam as intervenções de natureza securitária humana. Nesse ponto há uma clivagem que pode beneficiar ou prejudicar definitivamente o conceito de R2P, crescentemente esvaziado como ideia, por não estar acompanhando a realidade do poder, ainda persistente, nas relações internacionais.

Essa cisão nos apresenta os dois polos intradebate sobre o conceito. Enquanto alguns promotores, como os supra citados, apostam no desenvolvimento conceitual como necessariamente estrito às questões humanitárias, no intuito de sua operacionalidade, outros defendem sua ampliação para responder aos mais variados problemas, sob o fundamento da amplitude oferecida por seus pressupostos basilares oferecidos pelo "guarda-chuva" da SH. Não se deve perder de vista que as intervenções representam tão somente uma das formas de intervenção no leque de possibilidades, de modo que a SH favoreceria amplamente soluções não-militares.

Quando retomamos ao debate inicial de nossa pesquisa, sobre as intervenções em casos de desastres ambientais, percebemos que o conceito de R2P não consegue alcançar os elementos que compõem um desastre, a não ser no ponto em que o Estadovítima deliberadamente esteja inerte ou então não proteja sua população. Ainda assim, é forte a oposição a que o conceito não se estenda para tais situações, e se comece a falar em assistência humanitária em sentido lato, pautado na segurança humana, a fim de desviar o foco do debate para um conceito mais limitado, aos crimes previstos tradicionalmente. Diante de toda essa cautela, como forçar um conceito que se estenda para cobrir casos de desastres ambientais transfronteiriços? Essa pergunta é eloquente e parece desafiar de modo contumaz os pressupostos que pautaram até o momento o debate sobre a R2P para casos ambientais. Não se pode esquecer que o êxito político do novo paradigma foi resultado da aceitação pela comunidade internacional do conceito para aqueles casos muito específicos, com a consciência de que o mesmo não teria um aval garantido para outras situações.

Todos os elementos do debate estão postos. A extensão do R2P para outras situações que não as previstas na Resolução 60/1 (2005/World Summit Outcome 
Document) prejudica a análise de outras mais prementes, como desastres transfronteiriços. Essa lacuna jurídico-política não deve ser limitada com sua inclusão entre os princípios que representam a SH, e sim ganhar força autônoma de modo mais eficaz, para preencher um espaço ainda não totalmente explorado na literatura acadêmica, adquirindo uma praticidade mais realista. A seguir discutiremos essa lacuna, seus aspectos e potencialidades, sob a proposta das Obrigações Positivas. 
CAPÍTULO VI

O DILEMA DAS INTERVENÇÕES VERDES

EM CATÁSTROFE AMBIENTAL 


\title{
VI. As Intervenções Verdes em Desastre Ambiental
}

\begin{abstract}
"It is often alleged, and apparently believed, that there is a great difference in character and content between an ethics of prohibitions and an ethics of positive injunctions, between moral rules that state what ought not to be done and moral rules that state what positively ought to be done. This belief frequently goes along with another, which is thought to be connected with it, that a "positive ethical code "is of greater value than one that is merely negative, that traditional morality has been basically and narrowly negative, and that what is needed is a set of precepts that will release the inherent and untapped potentialities of human nature, rather than a set of negative restrictions on impulses and desires (...)."
\end{abstract}

Marcus Singer (1965:97)

\subsection{Considerações iniciais}

As definições de direito de ingerência, intervenção humanitária e R2P remetem à ideia comum - ou tradicional - de interferência em assuntos internos de outros Estados sem consentimento do governo empossado. Em questões humanitárias, esse entendimento vem ganhando adeptos cada vez mais ávidos em desenvolver teorias em nome dos direitos humanos universais. Em temas ambientais, o debate ainda adquire contornos indefinidos, revestindo-se de características peculiares.

A emergência de uma consciência da necessidade da proteção do meio ambiente passa pela abordagem predominantemente nacional, em razão da inter-relação dos sistemas ecológicos "mantidos dentro das fronteiras". Quando se transpõe tal consciência para o ambiente jurídico internacional, percebe-se que um tratamento legal que almeje limitar a soberania dos Estados é não apenas silenciado, como também redigido de forma imprecisa e obscura. Tratar da força executória das convenções internacionais torna-se mais duvidoso ainda. Dentro desse panorama de incertezas e esvaziamento terminológico dos tradicionais conceitos, a noção de "obrigações positivas" tende a ter larga aplicação metodológica no DIMA e caminhar em paralelo às discussões mais atuais sobre SH e R2P. 
Em torno de tais questões, delinear seu conceito no PIMA, em paralelo aos já avançados estudos e pesquisas no campo dos Direitos Humanos, torna-se premente. O reconhecimento da importância do meio ambiente encontra-se legitimado nas relações internacionais contemporâneas e os Estados consagram variados mecanismos para internalizar suas regras e convenções (ou não fazê-lo). Muitas destas buscam intervir nas relações interestatais, seja pela tentativa de imposição de uma obrigação negativa (de "não-fazer") determinado ato que agrida o meio ambiente ou um direito alheio, seja pelas obrigações de fazer, como o cumprimento das metas obrigatórias em acordos ambientais (obrigação positiva). ${ }^{179}$

Uma situação que envolva desastres ambientais graves e direitos humanos básicos é propensa a angariar apoio dos defensores das intervenções dos mais diversos gêneros. Tomando-se como ponto de partida a Carta da ONU e a Declaração Universal dos Direitos Humanos (1948), percebe-se uma conexão lógica entre desastres e direitos humanos, como o direito à vida, à saúde e ao bem-estar. Ainda nessa lógica, a intervenção teria por finalidade interromper um processo irreversível de violência contra populações vulneráveis e sob a complacência (ou não) dos governos afetados. Tal ação, afirmam os defensores, seria justificável à medida que, além de corresponder aos propósitos amplamente difundidos pelas Nações Unidas, não seria direcionada contra a integridade territorial ou independência política do Estado-alvo. Ainda que moralmente válidos, esses argumentos são considerados controversos e ainda timidamente aceitos no direito internacional.

As diretrizes da Carta quanto ao tema não acompanharam as mudanças na ordem global contemporânea, ocorridas desde a aprovação do sistema de segurança coletiva. A Guerra Fria e o "travamento" do CSNU (PRANTL, 2005) e de sua habilidade em

\footnotetext{
${ }^{179}$ Em RI, a legitimação é importante, mas não é central. A história traz exemplos de intervenções que foram legitimadas a posteriori, como a da OTAN no Kosovo. No caso ambiental, no entanto, o problema é relativo ao déclenchement de um conflito armado ou consequências sérias, mesmo se sabendo que a comunidade internacional não tem sanções a impor de forma claramente positivada. Isto é, intervir para salvar vidas pode ser legitimável ou discutível. Intervir para salvar recursos naturais é mais discutível, como no caso da invasão do Iraque para "salvar" o petróleo do Kuwait. Ou intervir para salvar a Amazônia, que já foi objeto de debates acalorados, mas atualmente perdeu sua credibilidade em função do estabelecimento de mecanismos de cooperação internacional como o PPG7 e tantos outros menores. Ou intervir na China para frear a poluição industrial. Aqui caberia muito mais os mecanismos de "soft intervention" (pressões econômicas, financeiras e morais) que, como já mencionado, fogem ao escopo da pesquisa (ROTCHILD, 2006).
} 
garantir a segurança sob os auspícios do artigo 42, em razão do veto, e a "ingenuidade" com que os Estados passaram efetivamente a substituir a agressão indireta, tais como a exportação de insurgência e o apoio às guerras civis, pelo confronto militar tradicional, parecem ter contribuído para essa "adequação" indireta sem alterações específicas aprovadas por seus membros quanto ao texto legal. ${ }^{180}$

Chegando ao final da jornada, em que buscamos ao longo da pesquisa analisar a evolução da OAI, os desafios à segurança global e o tema das intervenções, cada vez mais presente nesse contexto, com suas múltiplas variáveis, é o momento de analisarmos o conceito proposto no estudo de tese: as obrigações positivas aplicadas a casos de desastres ambientais (naturais e tecnológicos).

Propomos discutir a natureza dos desastres e sua relação com as "intervenções verdes", assunto que ainda recebe limitada atenção acadêmica e que constitui lacuna a ser preenchida com o avanço das disciplinas de DI e RI. Desde 1945, o tema é considerado mais do ponto de vista humanitário do que de segurança. Tal constatação leva-nos a uma avaliação das tendências do DI, no sentido de compreendê-los dentro de perspectiva mais ampla, em que a evolução do direito avance no mesmo compasso das relações internacionais, ao se considerar o âmbito eminentemente político das reações pós-desastres.

Tratar das obrigações positivas nas RI exige um retorno às origens do tema nos Direitos Humanos (FREDMAN, 2006; RHARADE, 2014). Nas últimas décadas, o desenvolvimento crescente da OAI resultou em uma circulação conceitual dos mais diversos vetores, a ponto de levar o pesquisador ao questionamento não mais de "se" os princípios da PIPH poderiam ser avaliados de forma corrente na PIMA, mas "qual” a intensidade de sua transposição (TRINDADE, 1993). No plano das intervenções, abre-

180 É de se considerar, ainda, o desenvolvimento das tecnologias de armamentos, que resultou na obsolescência das provisões do artigo 51 da Carta, atinente ao direito "inerente" à legítima defesa. Com o advento de novas armas mais poderosas e de destruição em massa, tornou-se virtualmente impossível que um Estado aguardasse um ataque para responder, pois a própria existência é posta em xeque com a velocidade das tecnologias letais. De modo inevitável os governos passaram a responder a essas novas ameaças chamando para si um direito à "legítima defesa preemptiva", não apoiada ou prevista pela Carta (BARROS-PLATIAU \& VIEIRA: 2006). Outra mudança diz respeito à crescente consciência global dos temas afetos às liberdades individuais e às ameaças a paz, que levam alguns países a pensar nos direitos humanos - e na SA, como vimos anteriormente (Cap. IV) - como um "cavalo de Tróia" para justificar intervenções em seus assuntos domésticos (FRANCK, idem: 4; TADJBAKHSH \& CHENOY, 2007). 
se mais ainda uma polêmica há muito considerada nas discussões sobre o tema no âmbito dos foros multilaterais e acadêmico. ${ }^{181}$

Se buscamos até aqui desenvolver o processo histórico-conceitual do DI com relação ao uso da força, suas justificativas legais e inadequação conceitual para os desafios do mundo moderno, pretendemos agora analisar o impacto político e a praticabilidade sistêmica da noção das obrigações positivas nas arenas políticas internacionais. Para realizar esse objetivo, propomos dois fatos reais emblemáticos de desastres ambientais que "abrem portas" para reflexão, os acidentes ocorridos nas centrais nucleares de Chernobyl (Ucrânia/1986) e de Fukushima-Daiichi (Japão/2011). ${ }^{182}$ Sob as lentes das relações internacionais no século XX, com seu tradicionalismo pluralista-minimalista assentada na soberania, uma reflexão sobre os acidentes centrada nas obrigações positivas tenderia a ser de difícil compreensão, caso não houvesse o desdobramento conceitual e a expansão temática que englobasse outras dimensões analíticas como o tema ambiental. ${ }^{183}$

$\mathrm{Na}$ análise dos institutos atualmente existentes para justificar eventuais intervenções, priorizamos um estudo sobre a legítima defesa e o estado de necessidade (por serem os mais relevantes e usualmente invocados), a fim de conhecer suas nuances e verificar sua admissibilidade como justificativa para as intervenções "verdes". Demonstraremos neste Capítulo, em análise comparativa, que ambos os instrumentos parecem inadequados para serem alçados à justificativa viável de intervenções na área

\footnotetext{
181 Essas implicações possuem natureza bifacetada, razão pela qual analisaremos a transposição do tema das obrigações para as RI tanto do âmbito jurídico, quando compararmos os mecanismos das obrigações positivas, do estado de necessidade e da legítima defesa, como suas implicações políticas, vistas aqui de forma mais detalhada, com a atenção oportuna. Diante de tais considerações, propomos uma análise inicial da natureza dos desastres ambientais e das "intervenções verdes".

${ }^{182}$ Sem desmerecer outros acidentes e fatos marcantes, como tsunamis no Sudeste Asiático e a nuvem do vulcão islandês da geleira Eyjafjallajökull, que assolou o continente europeu em 2010, resultando em distúrbios ao tráfego aéreo da região e em prejuízos consideráveis para os países envolvidos. Quanto ao último caso, segundo se noticiou amplamente à época da erupção do vulcão islandês, havia o risco, não confirmado, de que o incidente gerasse igualmente, além da nuvem de fumaça expelida que atingiu largas partes da Europa, cancelando cerca de 20.000 voos em diversos países, uma inundação de expressivas em regiões no Sul da Islândia, devido à localização do vulcão, que se encontra entre as geleiras Eyjafjallajökull e Myrdaljökull.

${ }^{183}$ A razão para a escolha dos dois casos considerou a previsibilidade, a agressividade, a temporalidade e a realidade, critérios paras as obrigações positivas, presentes em Chernobyl e Fukushima-Daiichi, muito embora diversas outras situações pudessem ser descritas, em vista do potencial efeito conflituoso para as relações regionais ou bilaterais. A natureza dos desastres transfronteiriços e seus efeitos destrutivos para a população e território de outros países, além de seu potencial de perigo, foram considerados.
} 
ambiental em caso de desastres. O primeiro deles por priorizar o elemento constitutivo conceitual de "ataque armado", inexistente em catástrofes ambientais; e o segundo, por respaldar-se em situações de "iminência" do perigo, bem como tendencialmente cada vez mais aplicada como uma extensão "forçada" do sentido original e positivado da legítima defesa (art. 51 da Carta da ONU), que prevê aquele requisito de agressão por ataque armado.

A constatação supra dessa lacuna no DIMA a respeito dos desastres ambientais, a nosso ver prejudicial e premente, conduz-nos a questionar a própria ordem global pautada na sociedade consensualista-maximalista e a buscar conhecer respostas que ofereçam preencher esse "vazio" doutrinário e jurídico. A sociedade consensualista contemporânea, que caminha de seu solidarismo consensual para um solidarismo mais coercivo, deverá prover essas respostas em momento adequado e proporcionar "dentes" mais seguros para o efetivo cumprimento das normas que emanem das relações internacionais (HURRELL, 1999: 62). Uma característica dessa sociedade de Estados atual, no entanto, transparece na prevalência dos direitos humanos - e suas múltiplas facetas - nas discussões sobre segurança, com a inclusão de uma variável mais humanista que privilegie na totalidade não apenas o indivíduo, mas também seu meio. Nesse aspecto, a OAI parece ter sido alcançada e dessa forma é tomada nas análises mais elaboradas sobre $\mathrm{SH}$.

O Estado, por vezes resistente às diretrizes da nova ordem global, porém seguidor de seus preceitos, é impelido por razões de ordem humanitária e em consonância com prerrogativas mais avançadas de "soberania como responsabilidade" a intervir para salvaguardar a vida da própria população e integridade territorial, diante de ameaças as mais diversas (essa obrigação positiva encontra atualmente respaldo efetivo no DH, mas caminha ainda a passos lentos no DIMA). A ele pertence essa responsabilidade primária que o induz a agir (dever) e, em sua inação ou incapacidade para tanto, à comunidade internacional, respaldada pelos princípios de segurança coletiva autorizada pelo CSNU e fundamentada na noção basilar da proteção à pessoa humana, um dos avanços conceituais mais progressivos das Nações Unidas nas últimas décadas. 
Na ordem global contemporânea, de governança ambiental centrífuga e difusa, essa responsabilidade "retomada" pelo CSNU, no entanto, parece idealista e utópica. Em casos de desastres ambientais, a sociedade consensualista-maximalista cede espaço para o realismo político mais genuíno, em que prevalece o retorno ao minimalismopluralista da sociedade tradicional de Estados, pautado pela defesa da soberania e dos interesses imediatos, de sobrevivência e defesa territorial. Nessa realidade concreta ainda não positivada, os Estados tendem a preferir a "retração" ao princípio da nãointervenção - preconizada pelo consensualismo - mas em benefício próprio, de modo realista e tradicional, no intuito de justificar a inação de instâncias multilaterais, como o CSNU e mecanismos regionais, que usualmente não respondem aos anseios de seus membros com a celeridade necessária que situações catastróficas exigem. Soma-se a tal contexto a inexistência de mecanismos de cooperação adequados e mais assertivos no DIMA, que respaldem a tendência de se impor limites à soberania dos entes estatais (que não aceitem cooperar em um contexto transfronteiriço), refratários cada vez mais dessa ideia em razão de pressupostos geopolíticos inerentes.

\subsection{Desastres ambientais: conceitos e características}

Em um esforço inicial para conceituar "desastres", devemos analisar as características e elementos das crises modernas. Boin \& Rhinard (2008) descrevem a natureza das novas ameaças globais e os desafios impostos para seu gerenciamento pelas estruturas domésticas estatais e apontam de modo genérico ataques terroristas, secas, imigração, mudança climática e as pandemias, como as ameaças contemporâneas a serem enfrentadas pelos Estados. Quando uma dessas ameaças se torna manifestamente visível, passa-se então à existência de "crises", que impõem intricados desafios a líderes mundiais e burocracias estatais. Segundo os autores, uma crise é vista como "a threat to core values or life-sustaining systems, which requires an urgent response under conditions of deep uncertainty" (idem: 03). Crises seriam diferentes de “emergências rotineiras”, em razão de sua natureza efêmera e consequências limitadas.

As crises se diferenciam de desastres, segundo os autores. Os desastres podem ser vistos como "crisis with a bad ending”, o que envolve um julgamento normativo a respeito do resultado da crise. Quando uma crise é percebida pelos agentes como extremamente severa nos resultados, temos então uma "catástrofe". Boin \& Rhinard 
acreditam que a diferença entre "catástrofe" e "desastre" seria simplesmente semântica, portanto insignificante, uma vez que a percepção da intensidade negativa do fato depende de disposições culturais e da experiência de cada povo. Em linhas gerais, uma catástrofe se caracterizaria tanto por um dano sem precedentes (e irreversível), quanto por um evento de longa duração, que influenciasse as funções básicas de existência de um dado sistema social. É neste último sentido que vamos pautar como equivalentes o nosso entendimento sobre catástrofes e desastres, somando-se duas características: natural e tecnológico (antrópico). ${ }^{184}$

Do ponto de vista das RI e do DIP, a literatura sobre desastres evoluiu tradicionalmente em direção aos estudos sobre instrumentos de assistência e governança pós-desastres, onde se pode discutir mais livremente o tema das intervenções verdes. No DIMA, uma tendência forte consistiu na ideia de "antecipação", com a promoção de princípios tais como os da prevenção e precaução, com impacto direto nas práticas da política internacional (KISS, 2006; VARELLA \& BARROS-PLATIAU, 2004). No entender de David Fidler (2005), os tsunamis que assolaram o continente asiático na década passada incentivaram uma discussão mais intensa da comunidade internacional sobre como se organizar a assistência a desastres, conectando argumentos da Federação Internacional das Sociedades da Cruz Vermelha e do Crescente Vermelho (IFRC) de que uma assistência mais efetiva requer paralelamente o desenvolvimento efetivo do DIP.

Para Fidler (1999), uma das razões para que os desastres naturais tenham historicamente relação com o DIP de forma diferente dos conflitos bélicos, epidemias e acidentes tecnológicos, envolveria a diferença entre desastres e outros eventos em termos de dinâmica do SI:

\footnotetext{
${ }^{184}$ A classificação internacional de desastres pode ser encontrada no Banco de Dados Internacional de Desastres (EM-DAT) do Centro para Pesquisa sobre Epidemiologia de Desastres (CRED), no âmbito da Organização Mundial de Saúde (OMS/ONU). Segundo seus critérios, um desastre consiste em um "resultado de eventos adversos, naturais ou provocados pelo homem sobre um cenário vulnerável, causando grave perturbação ao funcionamento de uma comunidade ou sociedade, envolvendo extensivas perdas e danos humanos, materiais, econômicos ou ambientais, que excede a sua capacidade de lidar com o problema usando meios próprios", conceito este similar ao adotado pela perspectiva brasileira (IN/MIN/n ${ }^{\circ} .1$, de 24/08/2012, art. $1^{\circ}$ ). A Secretaria Nacional de Proteção e Defesa Civil, ao adotar a classificação do EM-DAT da CRED/OMS/ONU, aponta também, entre outras características, para os desastres "naturais" ou "tecnológicos", quanto à origem ou causa primária do agente causador. Contudo, a literatura especializada consultada utiliza mais os termos "catástrofes humanitárias" e "desastres ambientais", destacando as consequências das primeiras e a difícil previsibilidade dos segundos.
} 
“(...) The extensive use of international law in the contexts of war, epidemics and accidents reflects how these events, generally speaking, have systemic impact over time on the fundamental material interests that states have in international relations. International humanitarian law developed in response to warfare - a key instrument of state policy in a political system characterized by anarchy. State interests in international trade drove the evolution of international law on epidemic disease. Increasing industrialization and use of hazardous technologies in modern economies produced greater potential for transboundary pollution and friction between states affected by such pollution."

Duas distintas características tornam as crises transfronteiriças uma tendência para o futuro, tanto a natureza das novas ameaças que emergem ou riscos ambientais, para usar o termo de Ulrich Beck, em Risk Society (1992), quanto a vulnerabilidade da sociedade moderna a elas (BOIN, 2008). Uma série de ameaças enfrentadas pelos governos aumentou consideravelmente nas últimas décadas e tudo indica que deverá continuar a crescer. ${ }^{185}$ Embora os governos sempre tenham confrontado desastres ambientais, suas características apresentam-se como um desafio adicional aos padrões geográficos modernos. O conceito de transfronteiriço não se esgota na proximidade geográfica de vizinhos (que compartilham fronteiras), posto que se refere a danos causados por um Estado que afetam outro ou outros. Os riscos e as ameaças tendem cada vez mais a cruzar fronteiras imaginárias.

Três são os desdobramentos que deverão realçar o potencial catastrófico das próximas crises. Um deles é o avanço vertiginoso das novas tecnologias que, quando envoltas por tecnologias atuais, tornam virtualmente impossível aos governos que enfrentem suas imprevisíveis consequências (BECK, 1992; EGAN, 2007). Outro referese às formas inovadoras de terrorismo, sobretudo por agentes suicidas indiscriminados emergentes (LAQUEUR, 2003). ${ }^{186}$ Um terceiro diz respeito às futuras crises oriundas dos efeitos da mudança climática, com probabilidade de originar ameaças globais imprevisíveis, segundo os relatórios do IPCC. Tomados em conjunto, esses desdobramentos tornam os Estados crescentemente vulneráveis às manifestações

${ }^{185}$ Cf. Relatórios do International Panel on Climate Change (IPCC), disponíveis em: http://www.ipcc.ch/ 186 Nesse ponto, os próprios autores assumem, no que concordamos, que essa vertente "terrorista" é superestimada. O terrorismo gera crises localizadas, de acordo com seus alvos precisos. É um problema que deve ser tratado conforme suas características. Embora seja uma ameaça a ser combatida, está longe de ser global, tanto mais ainda "internacional", como se tem apreendido na literatura correspondente sobre o assunto. 
modernas de "old-fashioned threats", tendo em vista a interconexão existente nos níveis econômico, cultural, político e social (BECK, 1992; CASTELLS, 1996; FRIEDMAN, 2005).

Outra característica do fenômeno consiste em os Estados tornarem-se suscetíveis ao que anteriormente eram considerados problemas "locais" e/ou "estrangeiros". Uma crise emergencial em uma parte do globo pode ampliar suas externalidades para todo um continente, haja vista catástrofes já testemunhadas como o acidente nuclear em Chernobyl, o caso da doença da "vaca-louca", os conflitos interétnicos, a imigração ilegal, a gripe aviária, o ebola, entre outras. A ameaça de uma crise transfronteiriça não ultrapassa simplesmente os desafios tradicionais enfrentados pelos responsáveis em combatê-la, mas também pode prejudicar a efetividade dos instrumentos legais, políticos e organizacionais usualmente envolvidos, caso não exista uma cooperação eficiente entre os atores, a começar pelo acesso à informação adequada em tempo hábil.

É nesse ponto que vale retomar a discussão em torno dos desastres e sua relação com a soberania, tão cara aos internacionalistas. No caso das papeleras, ${ }^{187}$ contencioso entre Argentina e Uruguai devido à construção lindeira de usinas de celulose, a falta de entendimento entre as partes levou o caso à CIJ, em 2006. Diferentemente das guerras, os desastres têm costumeiramente sido episódicos e de curta duração, não afetando sistematicamente as interações estatais (FIDLER: 461). Essa característica parece levar ao entendimento de que os desastres seriam vistos mais como conectados ao "humanitarismo" e distantes das prerrogativas estatais de percepção dos interesses nacionais, sendo assim menos afetos à soberania, o que seria uma concepção equivocada, pois não é somente a natureza econômico-ambiental do problema que conta, mas sim a dificuldade de sua resolução não-litigiosa.

187 O problema de crises emergenciais parece adequar-se aos desafios de cooperação ambiental transfronteiriça atualmente enfrentados em regiões como a América Latina (LÓPEZ: 2002). Pode-se argumentar que a internacionalização do tratamento dos problemas ambientais e seus impactos nas estruturas domésticas influenciam profundamente a forma como os recursos naturais são geridos, e com isso como a cooperação é entendida e operacionalizada. Alguns fatores respondem por esse modo de cooperação e estão diretamente relacionados às perspectivas de como se apreende nos dias de hoje os problemas ambientais. Visto de maneira mais ampla, nota-se um novo entendimento do efeito internacional do processo de mudanças no meio ambiente, cujos problemas relacionam-se crescentemente ao processo econômico da região e de sua internacionalização, sobretudo em razão da existência de ecossistemas naturais integrados entre dois ou mais Estados-nações. López (idem) afirma que as "externalidades" transfronteiriças produzidas pela exploração dos recursos contribuem sobremaneira para aquela internacionalização dos problemas. 
Vistas com alto potencial de riscos, fronteiras levam à reflexão sobre segurança, ainda mais quando se tornam porosas aos crescentes fluxos de indivíduos, ideias, bens e investimentos. A partir de uma concepção de desastres ambientais, o conceito de segurança toma outro sentido. Ele evoluiu lentamente daquela noção tradicional geopolítica para englobar temas diversos, como o ambiental. Se nos dias atuais o avanço conceitual atingiu a segurança por meio da ideia de freedom from ${ }^{188}$ (liberdade da) degradação ambiental e da escassez de recursos, temos ainda uma concepção bastante materialista da segurança relativa ao meio ambiente. Desastres entram em um debate secundário quando se discute as origens dos novos conflitos para o século XXI, geralmente atribuídos a disputas entre Estados por recursos cada vez mais escassos (na noção de "segurança ambiental global" de RIBEIRO, 2001).

$\mathrm{Na}$ busca de avaliar a (in) segurança global resultante do meio ambiente, analistas recorrem inicialmente às preocupações de como a degradação ambiental pode levar à insegurança ao nível local e/ou regional em primeiro lugar. Muitos deles apontam para teorias clássicas, como a malthusiana, no intuito de explicar a relação entre escassez de alimentos, degradação florestal e meio ambiente, na busca dos antecedentes dos conflitos modernos. ${ }^{189}$ Outros, para a inequidade da distribuição dos recursos, que conduz a sérios estresses, como o stress hídrico bem conhecido no Brasil.

"Estresses ambientais" que resultam em desastres por razões naturais e tecnológicas fazem vítimas de diferentes formas. Embora de difícil estimativa, há indicações de que os desastres vitimam anualmente mais que conflitos convencionais. Sabe-se que a escassez de água potável ${ }^{190}$ e a fome em certas regiões, assim como a

${ }^{188}$ Cf. United Nations Development Programme (1994): Human Development Report.

189 Nils Gleditsch, em Environmental Change, Security and Conflict (2007), nota que uma extensa literatura emergiu para tratar desse problema conceitual de como definir segurança de modo a incluir a variável ambiental. Em suas análises, o autor separa três objetivos que estariam relacionados com (1) a prevenção da guerra e dos conflitos armados como um resultado da escassez de recursos e da degradação ambiental; (2) a prevenção de desastres que não resultantes de escassez e degradação; e (3) a prevenção da erosão da capacidade condutora da terra resultante na perda de sustentabilidade ambiental no futuro. Segundo Gleditsch, todos os três objetivos são de natureza antrópica. Outras análises, mais ao espectro "biocêntrico", tendem a radicalizar e prover direitos iguais a todos os componentes naturais como todos os seres vivos. O autor nota que, como nenhum daqueles entes pode "falar por si", cabe aos seres humanos formular direitos aos demais.

${ }^{190}$ Pode-se argumentar também o contrário, mas que não invalida o argumento de que a água potável represente um desafio à segurança humana. Ao tratar do tema da transferência de tecnologia e o comércio internacional, Carlos Silva (2011) traz à agenda um assunto que pode ser aplicado ao caso concreto da 
mudança climática global, tendem a representar os maiores problemas ambientais de nossa era, porém muitas outras formas de danos ambientais representam desafios à segurança humana (GLEDITSCH, 2007).

Segundo dados do World Disasters Report $(2013)^{191}$, editado pela IFRC, o CRED registrou, em 2013, a ocorrência de 364 desastres naturais e 188 desastres tecnológicos em todo o globo. Muito embora o número de desastres naquele ano tenha decrescido em relação a uma década anterior, quando ocorreram cerca de 242.000 mortes por tsunamis que assolaram o sudeste asiático em 2004, para somente 9.656 em 2013, não há motivos para otimismo, devido à imprevisibilidade dos acidentes daquela natureza. O número esteve fora da cadência em $90 \%$ da média da década analisada, tendo em vista que, em 2008, foram contabilizadas 235.272 mortes e, em 2010, 297.730. Acidentes tecnológicos usualmente fazem um número de vítimas menor do que os desastres naturais, porém não devem ser subestimados. Em 2013, o número de vítimas em desastres tecnológicos alcançou a cifra de 6.050, 28\% menor do que a média para a década analisada (2003-2013). O relatório do IFRC representa os acidentes tecnológicos de forma ampla, aí incluídos desde incêndios em estabelecimentos penitenciários até naufrágios de embarcações e acidentes fabris.

Em geral, o número de indivíduos afetados por desastres naturais em todo o planeta (cerca de 139 milhões) teria sido muito menor do que nos anos 2003, 2010 e 2011, quando se registraram alguns picos. Em 2012, por exemplo, as enchentes responderam por $53 \%$ do número de pessoas afetadas por desastres naturais, sendo a mais grave de todas a ocorrida entre abril e junho daquele ano na China, quando cerca de 30 milhões de pessoas foram afetadas gravemente. Para além das enchentes, as secas que assolaram o continente africano, no Quênia, Sudão e Etiópia, atingiram mais de 28 milhões de indivíduos. A figura (6.1) nos auxilia a compreender a dimensão geográfica

escassez de água potável. É de se considerar que uma das razões da escassez não é a falta da água, em si, mas sim os limites à transferência de tecnologia de dessalinização.

191 Para maiores informações, ver: www.ifrc.org/...and-reports/world-disasters-report/ (acesso em 19/07/2014). Buscamos utilizar na pesquisa informações do EM-DAT elaborado pelo CRED. Segundo dados da organização, o CRED foi estabelecido em 1973, na Bélgica, e passou a trabalhar em parceria com a OMS, a partir de 1980. Muito embora o foco do CRED seja o tema da saúde pública, pesquisa igualmente os efeitos socioeconômicos dos desastres de larga-escala. O CRED passou a atualizar o EMDAT e a ser uma referência na área, tendo já registrado mais de 20.000 desastres naturais e tecnológicos. O banco de dados da instituição é compilado de fontes diversas, que contam com a colaboração das diversas agências da ONU, de ONGss, empresas seguradoras, institutos de pesquisas, entre outros. 
desses desastres ambientais. Embora não seja atualizada, corresponde às regiões mais vulneráveis a desastres no passado recente, de acordo também com os relatórios do IPCC.

Os desastres tecnológicos, por sua vez, afetaram menos em proporção a outros anos. Ainda assim, cerca de 24.000 mil pessoas sofreram efeitos de acidentes tecnológicos, como o que ocorreu em uma explosão no depósito de munições na República do Congo (13.323), no vazamento de gás na República da Coréia (3.178) e no incêndio em uma vila no Nepal (2.067). ${ }^{192}$ A figura (6.2) a seguir, sobre o número de vítimas de desastres tecnológicos (1975-2012), e os mapas (figuras de 6.3 a 6.7) de localização geográfica dos desastres naturais por categoria (hidrológico, biológico, meteorológico, geofísico), conforme classificação internacional do EM-DAT - Centre for Research on the Epidemiology of Disasters (CRED) ${ }^{193}$, auxiliam igualmente nessa visualização da natureza dos desastres ambientais em todo o planeta.

192 Cf. Idem: 223.

${ }^{193}$ Cf. Nota n 191 supra. 
Fig. 6.1: Número de desastres ambientais por país (1976-2005)

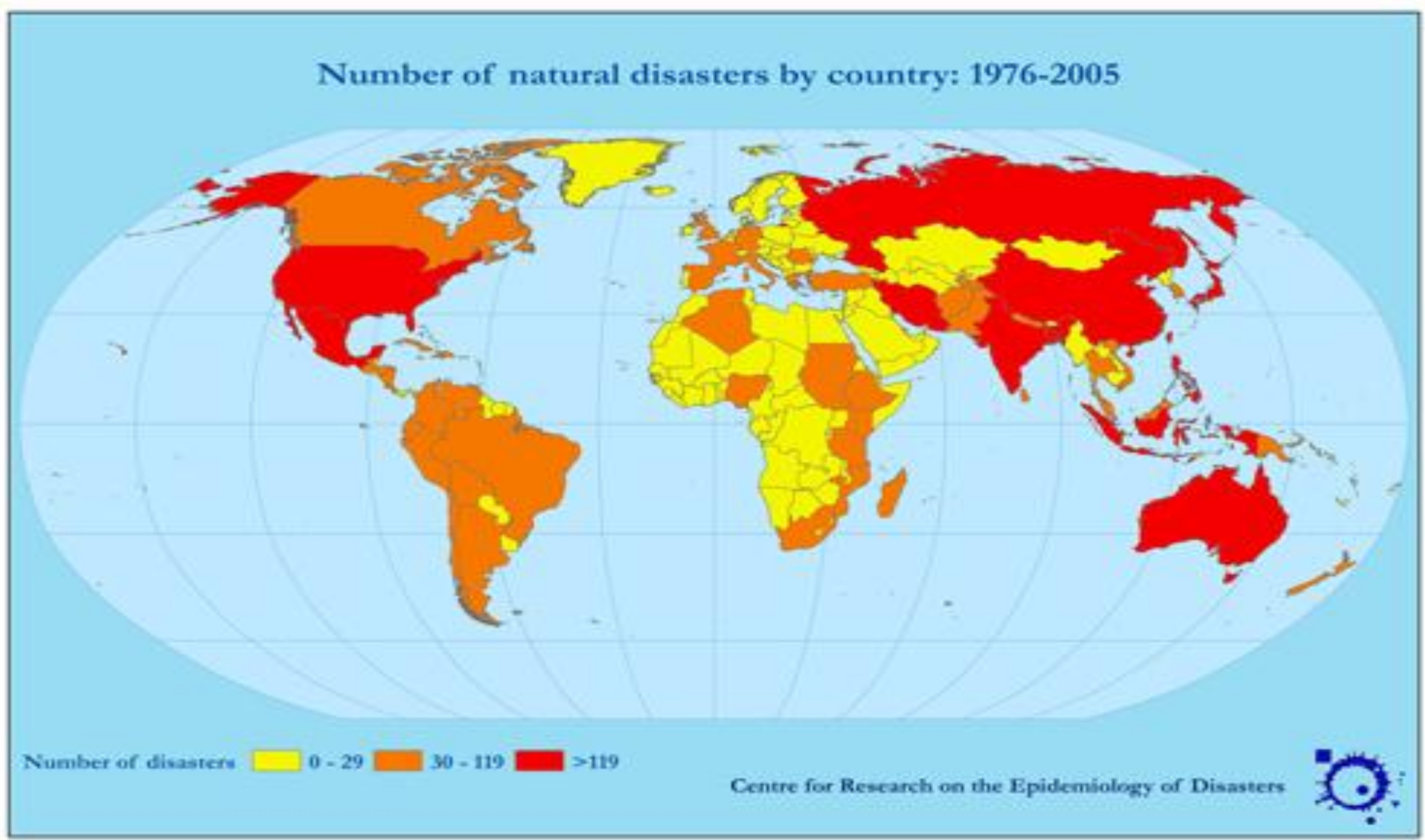

FONTE: EM-DAT-Centre for Research on the Epidemiology of Disasters (CRED) 
Fig. 6.2: Número de vítimas no mundo de desastres tecnológicos (1975-2012)

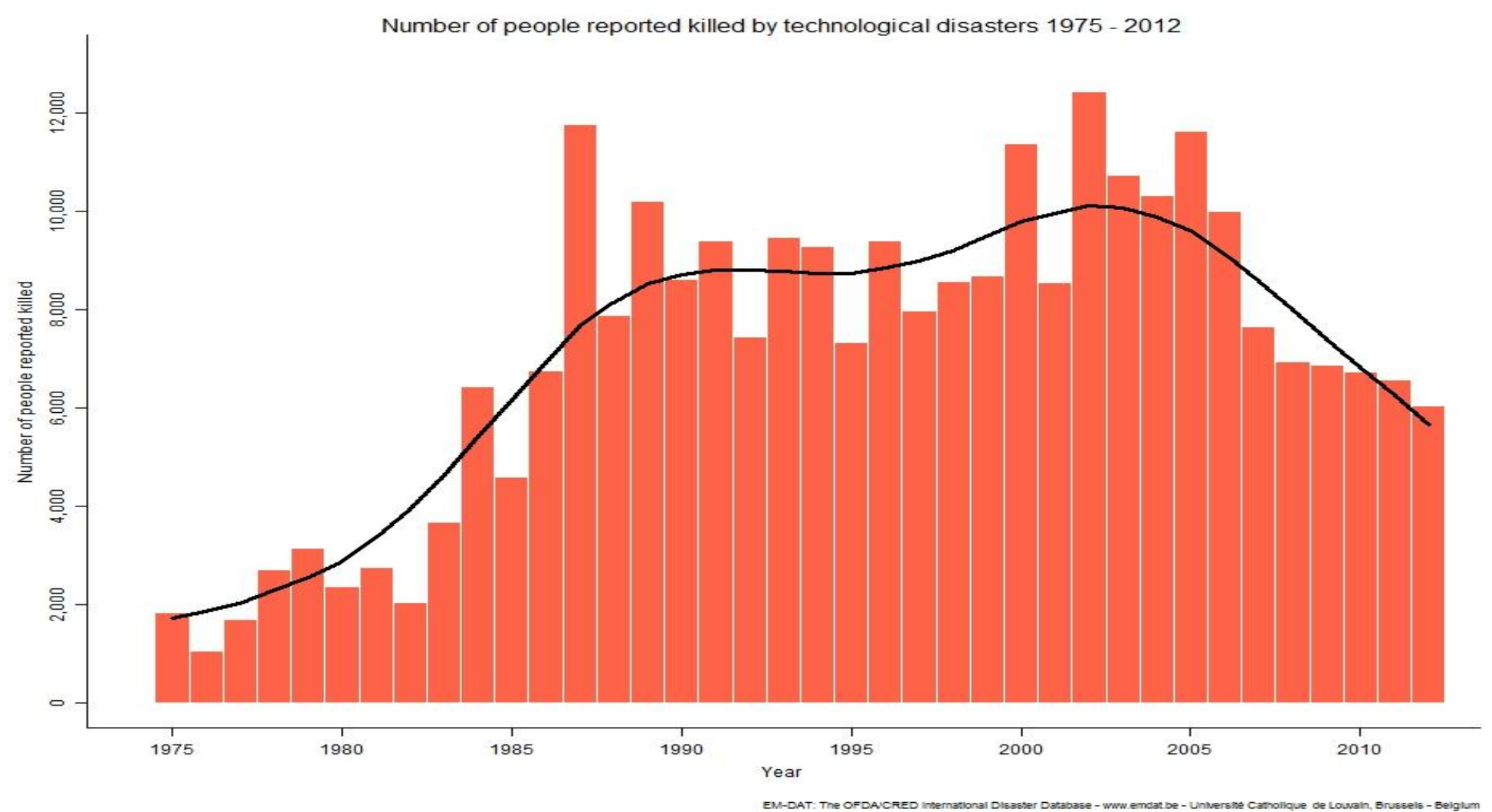


Fig. 6.3: Ocorrências de desastres por inundações (hidrológicos) por país (1974-2003)

Number of Occurrences of Flood Disasters by Country: 1974-2003
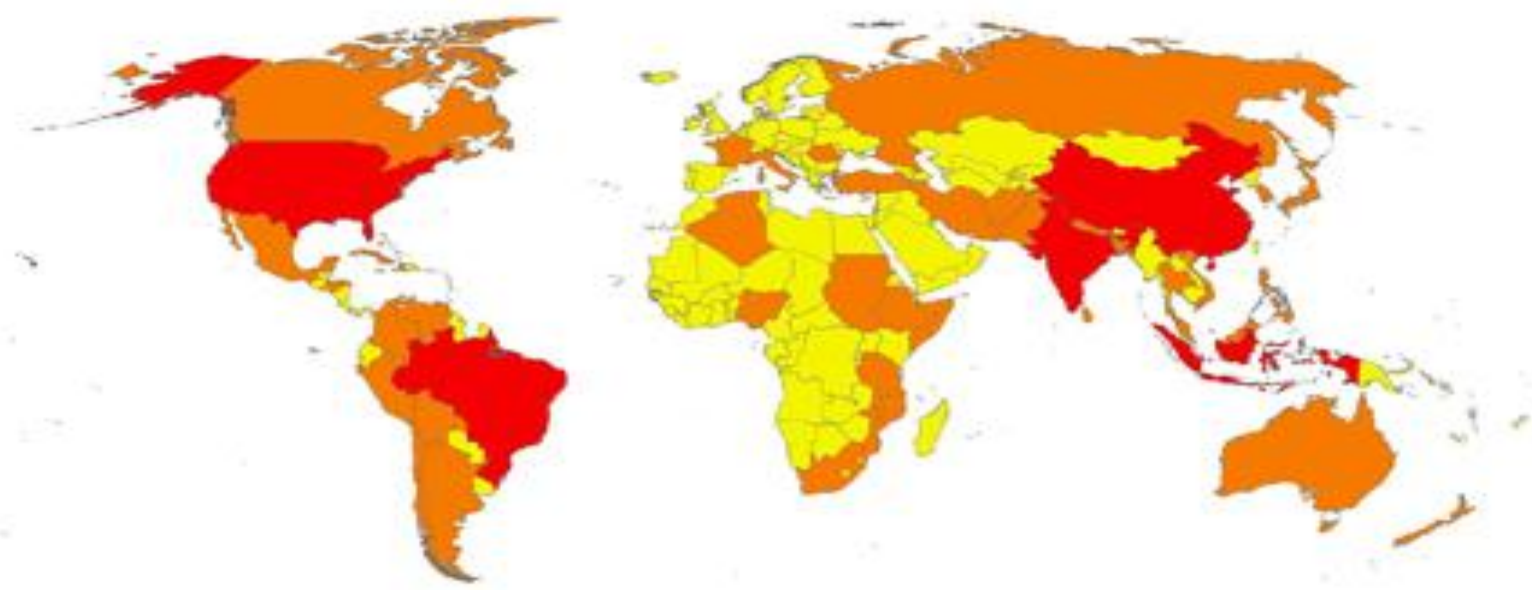

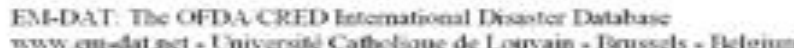

Number of Floods

Number of

FONTE: EM-DAT- Centre for Research on the Epidemiology of Disasters (CRED) 
Fig. 6.4: Ocorrências de desastres por epidemias (biológicos) no mundo: 1974-2003

\section{Worldwide epidemics occurrences: 1974-2003}

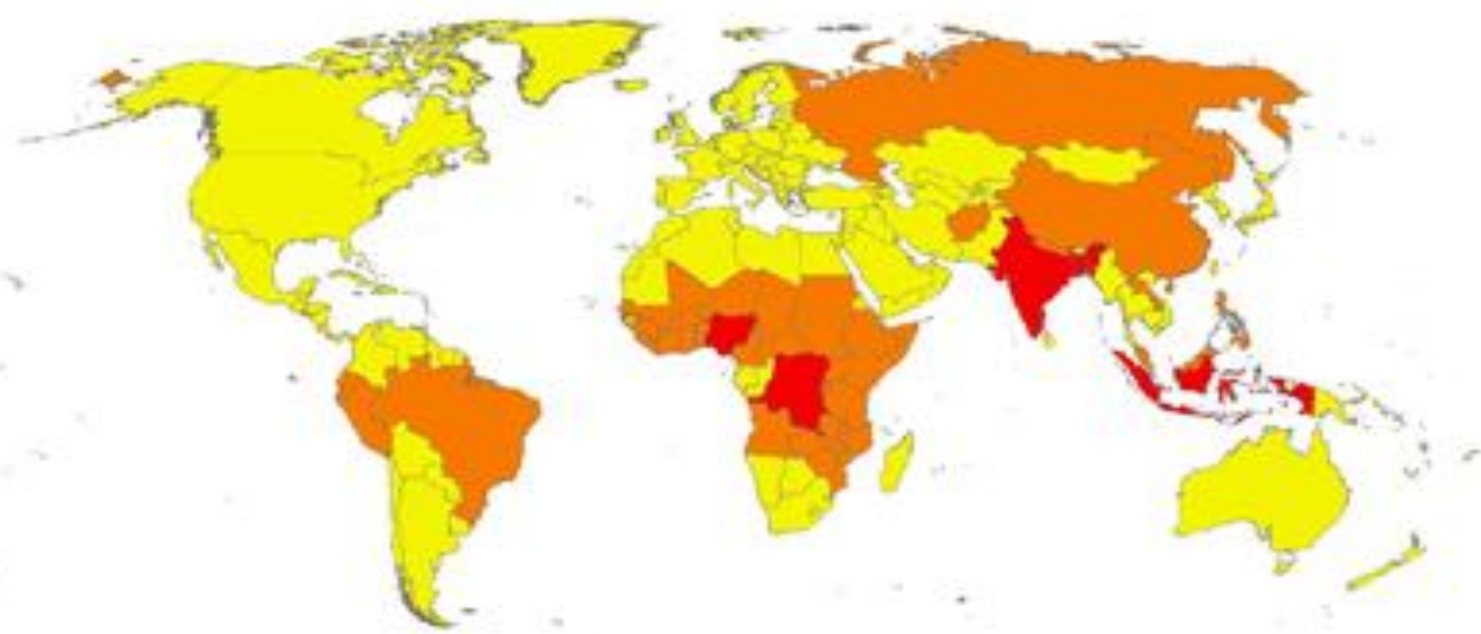

Number of Epidemics

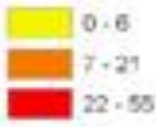

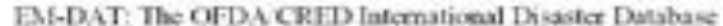

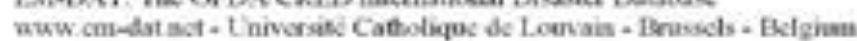

FONTE: EM-DAT-Centre for Research on the Epidemiology of Disasters (CRED) 
Fig. 6.5: Ocorrências de desastres vulcânicos (geofísicos) por país (1974-2003)

\section{Number of Occurrences of Volcano Disasters by Country: 1974-2003}
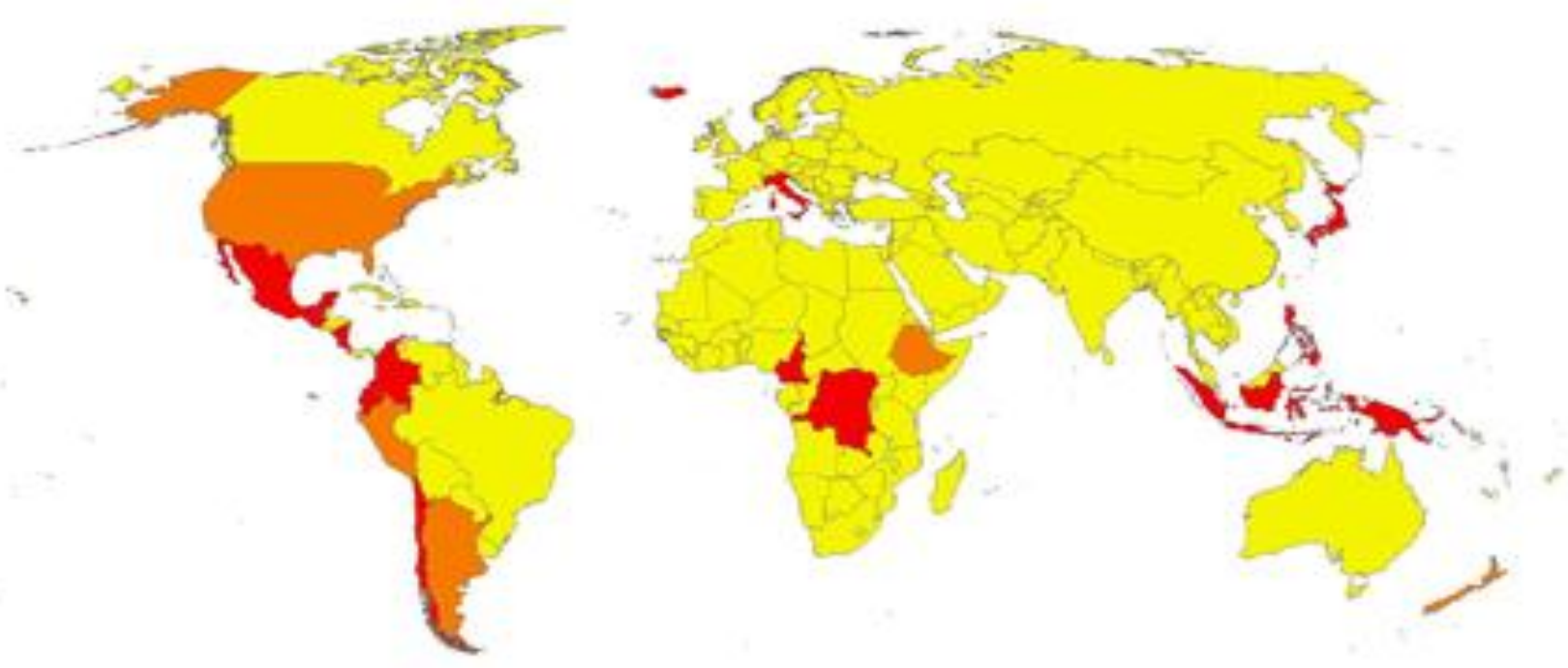

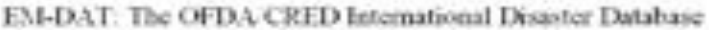

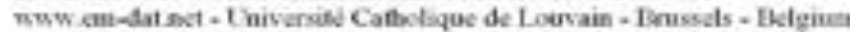

Number of Voleanos

$\square 0$

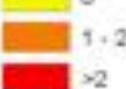

FONTE: EM-DAT- Centre for Research on the Epidemiology of Disasters (CRED) 
Fig. 6.6: Ocorrências de desastres por furacões (meteorológicos) por país (1974-2003)

\section{Number of Occurrences of Windstorm Disasters by Country:} $1974-2003$
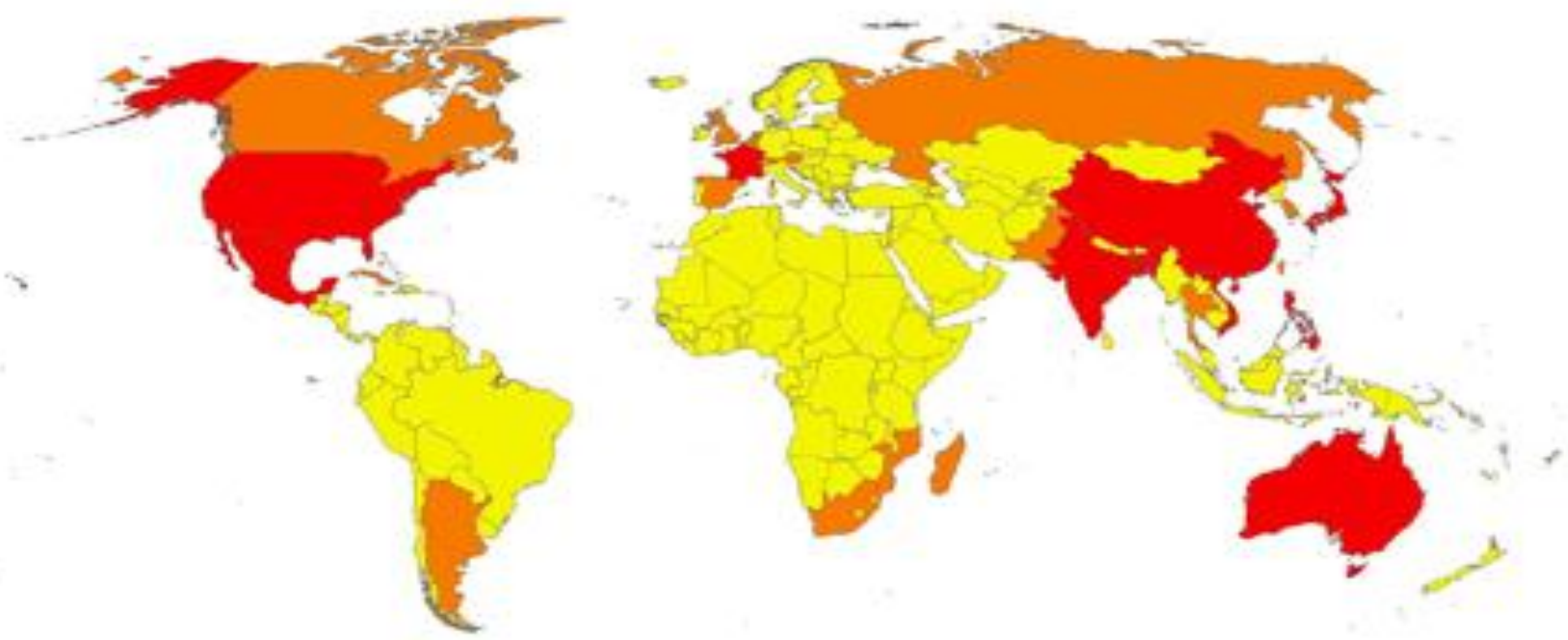

FMLDAT: TDE OFDA CRFD Enfenativenal Draster Datahus

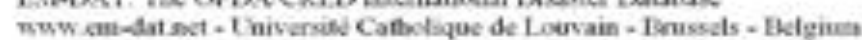

Number of Windstoems

D. $0-10$

C. $11-30$

FONTE: EM-DAT- Centre for Research on the Epidemiology of Disasters (CRED) 
Fig. 6.7: Ocorrências de desastres por terremotos (geofísicos) por país (1974-2003)

\section{Number of Occurrences of Earthquake Disasters by Country:} $1974-2003$
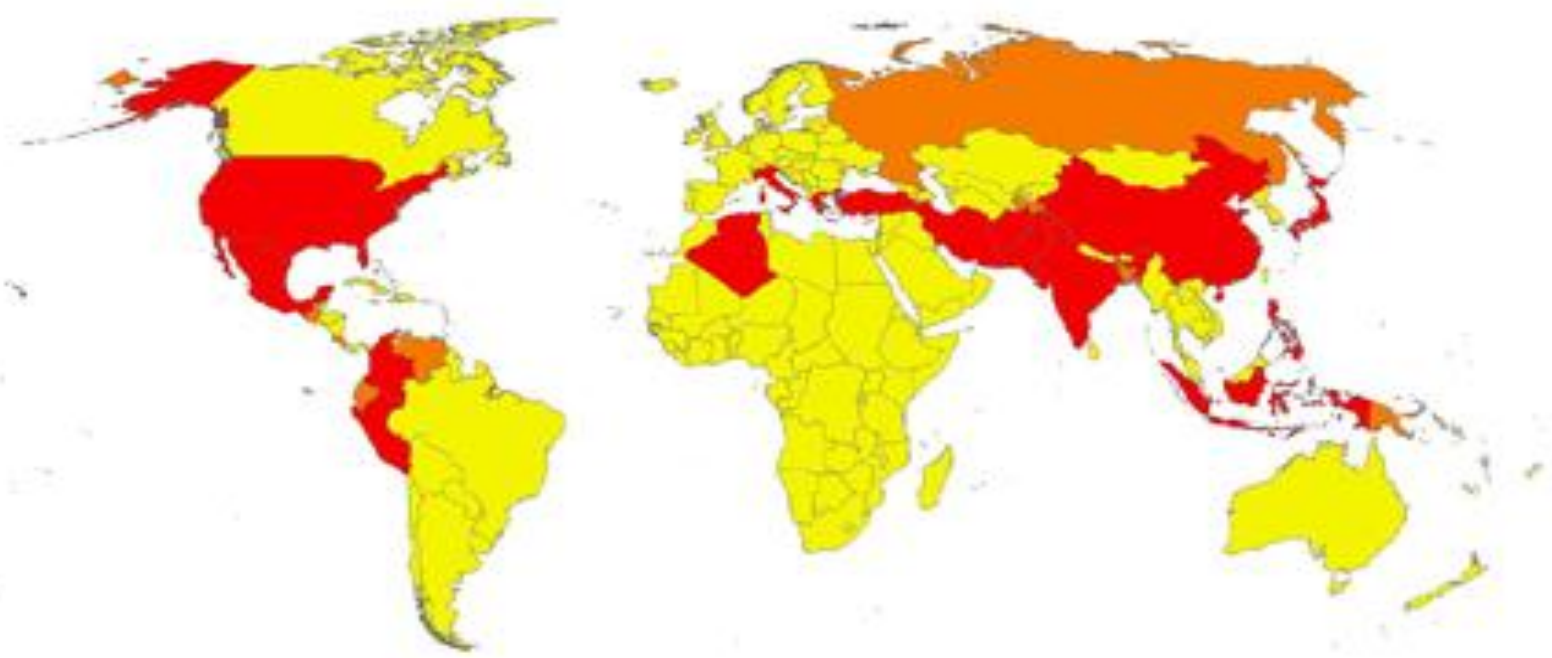

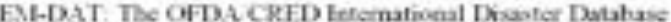
Number of Earthquakes

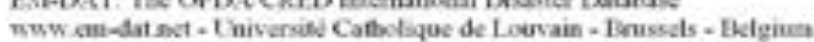

$$
\begin{aligned}
& 0.5 \\
& \square-10 \\
& \square=10
\end{aligned}
$$

FONTE: EM-DAT- Centre for Research on the Epidemiology of Disasters (CRED) 
Os custos envolvidos nos desastres naturais e tecnológicos, por sua vez, ajudam a compreender a dimensão dos incidentes para a política internacional (Figs. 6.8 e 6.9). Conforme análise do Relatório do IFRC (idem), os desastres naturais totalizaram, em 2012, prejuízos da ordem de US\$ 157,5 bilhões, o quinto maior orçamento da década. Consideram-se nessa soma os US\$ 50 bilhões gastos em recuperação dos estragos do furacão Sandy, que afetou os Estados Unidos, e os dois terremotos que assolaram o nordeste da Itália, e resultaram em US\$ 16 bilhões de gastos em assistência e reconstrução. Os desastres tecnológicos, por seu turno, somaram tão somente algo em torno de US\$ 30 milhões.

Os números do CRED são eloquentes pela natureza dos acontecimentos e de seus efeitos diretos para as populações envolvidas. Como observou Westing (1990), para além das vítimas diretas do desastre, os acidentes podem impactar as condições de vida futura dos indivíduos sobreviventes. Claramente, as tensões ambientais podem expor os seres humanos a sérios riscos, mesmo em casos que não resultam em situações de conflitos armados inter e intraestatais. 
Fig. 6.8: Dispêndio total em razão de acidentes naturais (1990-2012)

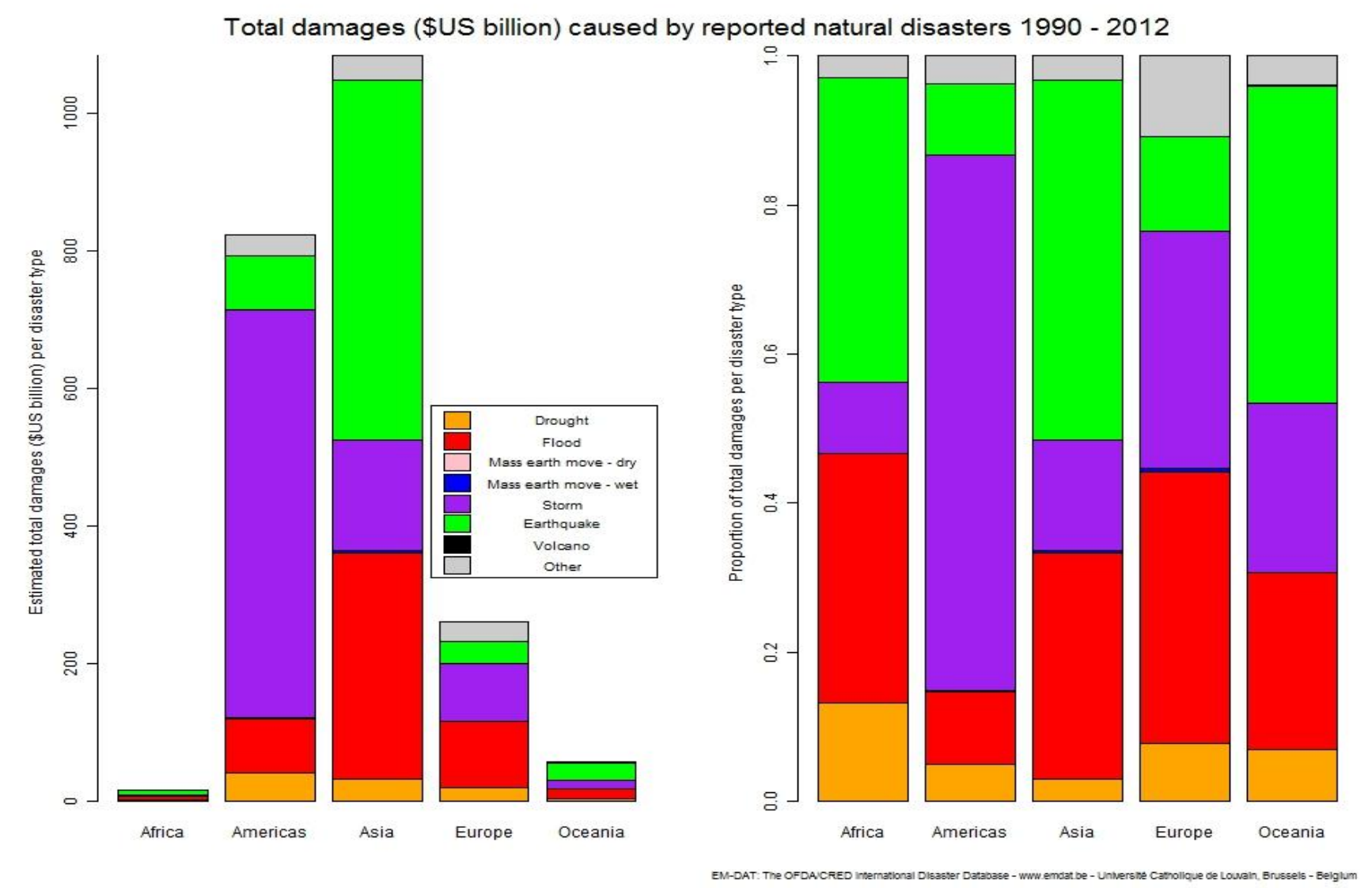

FONTE: EM-DAT- Centre for Research on the Epidemiology of Disasters (CRED) 
Fig. 6.9: Dispêndio total em razão de acidentes tecnológicos (1990-2011)

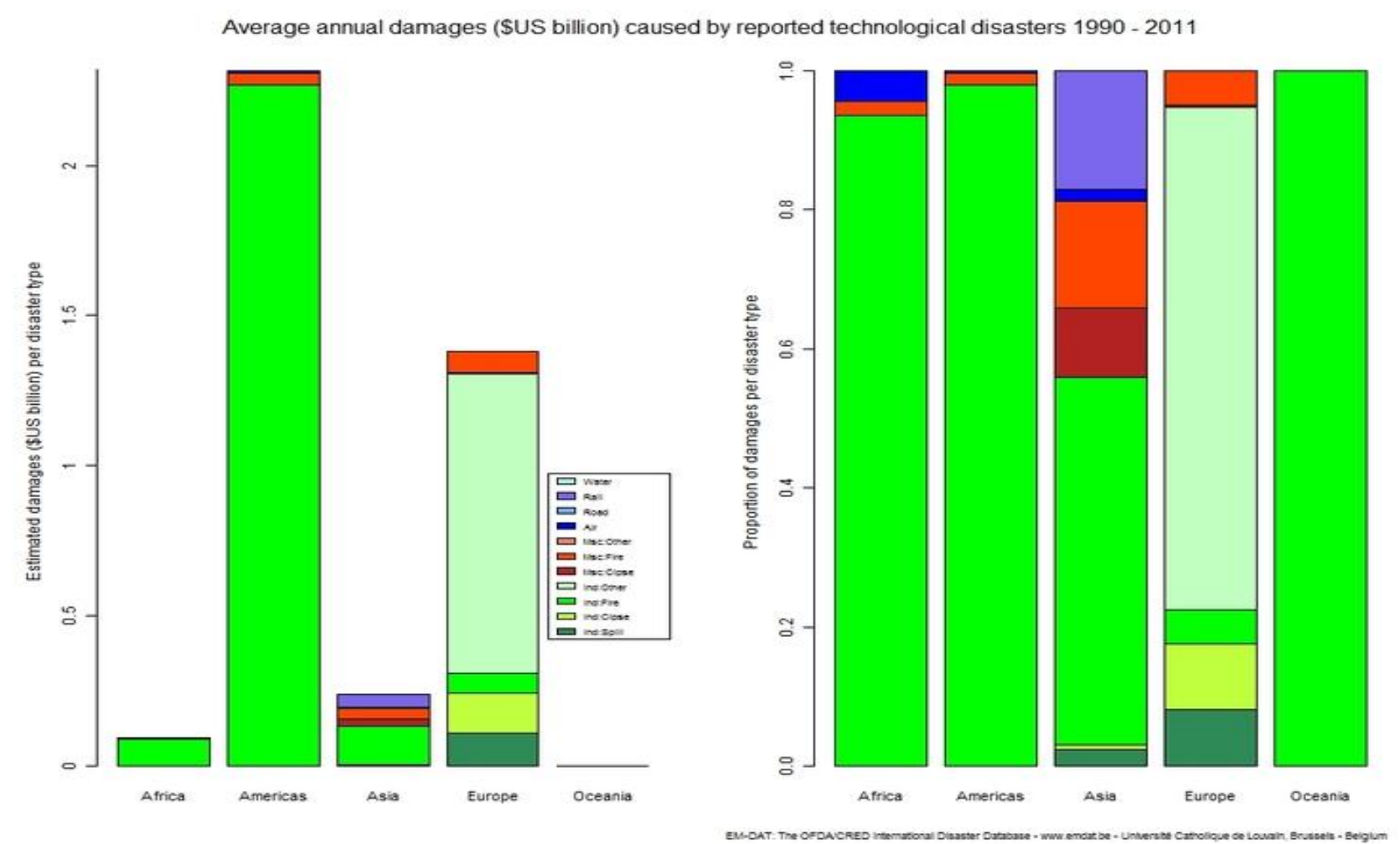

FONTE: EM-DAT- Centre for Research on the Epidemiology of Disasters (CRED) 


\subsection{O dilema das "intervenções verdes"}

Diante de tantas incertezas com relação às respostas aos desastres ambientais, que ceifam anualmente milhares de vítimas por todo o globo, surge o dilema intervencionista como um desafio às políticas estatais tradicionalmente consagradas de não-intervenção. As intervenções humanitárias são dilemas porque têm efeitos trágicos também. É impossível calcular seus impactos efetivos antes que ocorram. No caso das "verdes", mais ainda, por não haver precedentes. Parafraseando o Relatório/ICISS (que cita a expressão "The Intervention Dilemma"), o tema das intervenções, sejam humanitárias ou ambientais, é usualmente controverso, quando acontecem ou deixam de ocorrer. $^{195}$

Segundo o ICISS, as diretrizes básicas do debate internacional contemporâneo estão postas. Alguns consideram que a comunidade internacional não intervém como deveria, enquanto outros apontam demasiada intervenção. Ambos os lados divergem sobre a infinidade de aspectos que envolvem as intervenções e o debate se redireciona para questões como efetividade, legalidade e operacionalidade, todos contribuindo para fazer do tema da intervenção um perene dilema entre intervenção e soberania, já amplamente discutida em capítulos anteriores. Quando se trata de intervenções na área ambiental, o "desafio" é maior, tendo em vista a natureza complexa e interdependente dos problemas ambientais (HURRELL, 2007). ${ }^{196}$

Uma das discussões mais sofisticadas hoje no tema da eventual extensão dos preceitos da R2P relativa ao meio ambiente refere-se ao que alguns acadêmicos tendem a considerar, nas novas tendências da intervenção, a chamada "eco-intervenção" ou “intervenção ecológica”. Propomos denominar de "intervenções verdes" casos específicos de intervenções relativas predominantemente a catástrofes ambientais.

\footnotetext{
195 Tomando-se inicialmente como exemplo as tradicionais intervenções humanitárias da década de 1990, o caso Ruanda desvelou o "horror" da inação. Ainda que ciente da intenção genocida do governo ruandês, comunicada por oficiais das Nações Unidas presentes no país, o Conselho de Segurança recusou-se a tomar as ações necessárias para prevenir ou mitigar os efeitos de eventual conflito na região. Na Bósnia, do mesmo modo milhares de civis em Srebrenica pereceram, em 1995, vítimas da negligência da comunidade internacional. Soma-se aos casos acima a retirada precipitada das forças de operação de paz da ONU na Somália, anos antes, quando "an international intervention to save lives and restore order was destroyed by flawed planning, poor execution, and an excessive dependence on military force."

${ }^{196}$ Cf. Capítulo II, "A ordem global contemporânea", supra.
} 
Robin Eckersley, ao tratar do tema das intervenções ambientais, em Ecological Intervention: Prospects and Limits (2005), expõe algumas observações pertinentes para a pesquisa. A autora põe em questão a moralidade, legalidade e legitimidade das intervenções militares de caráter ambiental como extensão das intervenções humanitárias atualmente existentes. Eckersley questiona se a comunidade internacional deveria se preocupar com massacres perpetrados contra espécies animais hoje ameaçadas (a exemplo de massacre deliberado por caçadores contra populações sobreviventes de gorilas) de forma similar aos preceitos dos direitos humanos. ${ }^{197}$

Ao considerar tais cenários como de graves danos ambientais, a autora explora dois novos conceitos: "ecological intervention" e "ecological defense". Define intervenção ecológica como "the threat or use of force by a state or a coalition of states within the territory of another state and without the consent of that state in order to prevent grave environmental damage”. Por defesa ecológica, considera o uso preventivo de força em resposta a uma séria ameaça ambiental que "transborde" ao território do Estado-vítima.

Há decerto uma lacuna na literatura a respeito da questão da intervenção militar para assegurar a proteção ambiental no DI, em contraposição à farta literatura já produzida sobre SA e "ecological peacekeeping”. Um dos motivos reside em que, salvo melhor juízo, os problemas socioambientais raramente constituem um alto nível de ameaças constantes ou requerem a necessidade de uma resposta militar célere. Eckersley (idem: 295) cita o problema do aquecimento global, geralmente considerada uma arma de destruição em massa em razão de suas consequências, muito embora a ameaça não seja imediata nem militar e uma intervenção seja "inapropriada" para responder a problema tão complexo. A autora vai direto ao ponto do tema da R2P e defende um argumento controverso de que a responsabilidade estatal refere-se não

\footnotetext{
197 Aqui há dois pontos controversos, caso analisemos criticamente. Justificar intervenções ambientais unicamente porque as humanitárias foram por vezes justificadas e aceitas pela comunidade internacional não parece ser um argumento válido. Como uma construção discursiva, as "razões" das intervenções devem-se pautar por critérios objetivos que muitas das intervenções ditas "humanitárias" parecem não cumprir. Outro ponto discutível refere-se à comparação análoga entre seres humanos e gorilas. Eckersley passa do antropocêntrico ao biocêntrico como se fosse simples, todavia não é. É de se considerar que seres humanos são nacionais dos Estados e não seus recursos, portanto "inapropriáveis". Animais e plantas sim. Por isso o esforço (e fracassos) de iniciativas como a Convenção sobre o Comércio Internacional das Espécies da Fauna e da Flora Silvestres Ameaçadas de Extinção (CITES), de 1973, e outras relativas ao comércio ilegal de madeiras.
} 
somente ao controle e desenvolvimento do território, mas também a obrigatoriedade de protegê-lo além do tradicionalmente institucionalizado. ${ }^{198}$

Eckersley vai além do entendimento de haver ou não uma "responsabilidade de proteção ambiental" largamente aceita pela comunidade internacional e busca justificar as intervenções de caráter militar em questões ambientais (idem: 294). Em consonância com Fidler (1999), questiona as razões de haver uma literatura cada vez mais vasta sobre segurança ambiental e ecological peacekeeping, em contraposição a uma limitada atenção ao tema das intervenções para assegurar a proteção ambiental. Na sua análise das intervenções, três são as categorias de situações exploradas que merecem ser mencionadas. A primeira refere-se a (1) casos de emergências ambientais com efeitos transfronteiriços que ameacem a segurança pública em determinada região. A segunda diz respeito ao (2) "ecocídio" ou crimes contra a natureza que também envolvam genocídio ou sérias violações aos direitos humanos (independente de efeitos de transbordamento). Uma outra aduz a (3) crimes contra a natureza confinados a um determinado território e que não envolvam violações de direitos humanos.

A autora (idem: 296) considera ao menos duas razões para se explorar a lacuna existente no tema das intervenções ambientais. Enquanto a maioria dos problemas de natureza ambiental não é passível de qualquer necessidade de resposta militar, alguns ainda são típicos problemas e riscos que constituem uma emergência grave e iminente cuja solução depende de uma pronta e rápida resposta para ser evitada. Entende que o número de desastres ambientais e emergências do gênero deverão recrudescer futuramente, devido ao acréscimo na intensidade da conexão econômica global, consequência das pressões humanas - crescimento demográfico e avanço de tecnologias - sobre os recursos naturais e o ecossistema. Outra razão consiste no fato de que explorar o uso da força militar em situações ambientais permite um balanço útil da relação entre novas normas ecológicas e as normas jurídicas e os preceitos políticos fundamentais já existentes do tema da não-intervenção.

198 O possível alargamento do conceito de R2P para alcançar o meio ambiente já foi amplamente discutido neste estudo. Vale recordar, todavia, que o sentido estrito da R2P para abarcar tão somente os quatro crimes indicados pela AGNU ocorreu a contragosto da ICISS. O assunto não deixa de voltar à tona quando questões ambientais relevantes ficam à margem das discussões nos principais foros políticos internacionais. 
A classificação de Eckersley (idem: 298) desvela, ainda, o silêncio da Carta da ONU sobre as "intervenções verdes", em razão de os desastres ambientais não terem sido fonte direta das preocupações de seus elaboradores. Para sanar esse vazio, a AGNU e o PNUMA promoveram, com o passar dos anos e a emergência do meio ambiente como preocupação securitária nas relações internacionais, um regime ambiental pautado na proliferação de inúmeros instrumentos legais, como tratados e declarações, reconhecendo a "paz, o desenvolvimento e a proteção ambiental como interdependentes $e$ indivisíveis" (Princípio 25 da Declaração do Rio sobre Meio Ambiente e Desenvolvimento, 1992). Essa afirmação sinaliza uma mudança de paradigma iniciada há décadas, que busca reconhecer os danos ambientais como potenciais ameaças à paz e segurança globais. ${ }^{199}$

Quando se compara o tema dos desastres ambientais com outras áreas na política internacional, nota-se, ainda, uma considerável incipiência da questão e esforços vagos da comunidade internacional em buscar codificar parâmetros basilares que conformem eventuais diretrizes de ação para salvar vidas. Enquanto o DIP estabeleceu regras claras na área da PIDH, de que são exemplos Convenções de Genebra (1949) e seus protocolos adicionais (1977) em torno do tema de conflitos armados e proteção dos feridos e vítimas, ou então, mais recentemente, em assuntos ambientais como Direito do Mar $(1982)^{200}$, Movimento de Resíduos Tóxicos ${ }^{201}$, Mudança Climática ${ }^{202}$ (VIOLA,

\footnotetext{
${ }^{199}$ Essa seria uma prerrogativa do CSNU, que tem o poder de determinar o que representa ameaça à paz e de autorizar intervenções sob o argumento do capítulo VII, de modo a restaurar a ordem internacional. Algumas iniciativas sobre o tema das ameaças, apesar disso, adquirem corpo nas Nações Unidas, mas geralmente aquém de uma definição clara sobre o significado de "ameaça". O Painel de Alto Nível das Nações Unidas sobre Ameaças, Desafios e Mudanças, convocados em 2003, no período em que Kofi Annan esteve à frente da ONU, e responsável pelo Relatório "A More Secure World: Our Shared Responsibility”, limitou-se a indicar seis áreas como sendo as principais ameaças a serem enfrentadas neste século (ameaças de caráter econômico e social, pobreza, doenças infecciosas e degradação ambiental; conflitos entre Estados; conflitos internos, guerra civil, genocídio e outras atrocidades de larga escala; armas de destruição em massa; terrorismo; crime organizado transnacional), sem contudo apresentar uma definição de ameaça. Parece não haver, diante de tal quadro, um interesse por parte da comunidade internacional em organizar uma lista definida de ameaças, sob o risco de limitar a liberdade de ação dos países nas relações internacionais.

${ }^{200}$ Sobre o Direito do Mar, vale conferir a Convenção da ONU sobre o Direito do Mar (CNUDM), que constitui um tratado multilateral celebrado em Montego Bay, na Jamaica, em 1982.

${ }^{201}$ A Convenção de Basileia trata do Controle dos Movimentos Transfronteiriços de Resíduos Perigosos e seu Depósito, cujas negociações foram concluídas em 1989, na Suíça. A Convenção vem avançando protocolos que deem praticidade aos regulamentos pertinentes à responsabilidade estatal, a exemplo do Protocolo sobre Responsabilidade e Compensação, na Quinta Conferência das Partes, que busca dar uma resposta às demandas dos países em desenvolvimento sobre a falta de fundos e tecnologias para lidar com acidentes, despejos ilegais e outros infortúnios.
} 
2012, 2014; FRANCHINI \& LEMOS, 2013) e Biodiversidade ${ }^{203}$ (1992), outras áreas que representam também forte risco à espécie humana ainda estão à margem dos interesses de participantes de foros internacionais. Nestes espaços, discutem-se geralmente situações mais imediatistas. Temas com forte probabilidade de preocupação no futuro próximo, como os desastres ambientais, terminam por se sobressair e serem relegados para ocasiões menos propícias. ${ }^{204}$

\subsection{Das Implicações Políticas e Jurídicas das Obrigações Positivas}

Do ponto de vista político, cabe destacar, em primeiro lugar, a dificuldade de se estabelecer as "regras do jogo" quando se trata da justificativa de uso da força. Em Recourse to Force: State Action against Threats and Armed Attacks (2002), Thomas Franck elucida algumas questões pertinentes para se entender o atual estado da arte do instituto da legítima defesa desde seus primórdios. O autor afirma que a "drafting history” da Carta da ONU mostrou que o artigo 51 resultou de uma intensa negociação e um "uneasy" compromisso, tanto que falhou em buscar definições mínimas sobre o alcance do significado de termos como "direito inerente", "autodefesa" ou "ataque armado", relegados à interpretação de suas comissões, seus membros e agrupamentos regionais. Franck (idem: 51) considera que, em 55 anos de prática nas Nações Unidas, um padrão de justificativas emergiu, algumas explicitamente defendidas, outras implícitas no contexto.

\footnotetext{
${ }^{202}$ A exemplo da Convenção do Clima e do Protocolo de Quioto. A primeira é um tratado internacional acordado durante a Cúpula da Terra (1992). A proposta entre os signatários era de estabilizar a concentração de gases do efeito estufa (GEE) na atmosfera, para evitar interferências no sistema climático. A convenção entrou em vigor em 1994. Os países considerados historicamente como maiores emissores deveriam ter o maior índice de redução. O acordo foi firmado após a realização de 17 conferências. A partir das negociações, foram elaborados importantes documentos, como o Protocolo de Quioto, em 1997, que chegou a ficar mais conhecido do que a própria Convenção do Clima. O Protocolo abriga rígidas obrigações de países participantes quanto à redução da emissão dos gases que agravam o efeito estufa. Para maiores informações, acessar: http://www.mma.gov.br/.

203 A Convenção sobre Diversidade Biológica (CDB) foi assinada também na CNUMAD (1992). Seu objetivo era fazer cumprir o tratado elaborado, com disposições sobre a conservação da diversidade biológica, a utilização sustentável de seus componentes e a repartição justa dos benefícios dos recursos genéticos, estabelecendo assim normas e princípios para reger o uso e a proteção da diversidade biológica em cada país signatário. A convenção assegura a soberania dos países sobre seus recursos naturais, que devem ser explorados de forma racional. Para maiores informações, acessar: http://www.mma.gov.br/ .

${ }^{204}$ No caso de desastres ambientais, inexiste atualmente o dinamismo merecido, apesar dos avanços normativos em áreas que impactam populações civis. Escassas iniciativas limitam-se a projetos oriundos de organizações como a IFRC, de que é exemplo o programa International Disaster Response Law (IDRL), que buscam identificar princípios a serem aplicados em legislações nacionais de modo a facilitar a assistência humanitária em situações de desastres.
} 
Se tomarmos em consideração o exposto no artigo 51, que versa "Nada na presente Carta prejudicará o direito inerente de legítima defesa individual ou coletiva no caso de ocorrer um ataque armado contra um Membro das Nações Unidas (...)”, já se pode, em uma interpretação literal, desconsiderar o instituto da legítima defesa do rol das possíveis justificativas para se intervir em casos de desastres ambientais (pela inexistência da agressão armada). Visto em sentido lato, defensores das intervenções ambientais, no entanto, buscam descaracterizar o elemento "ataque armado", não existente na situação de catástrofes, e focar a atenção para o qualificativo "inerente".

O direito internacional atentou para esse fato que, às vezes, tem sido usado como argumento inicial para justificar intervenções, haja vista o projeto de acordo "Responsibility of States for Internationally Wrongful Acts" (2001), da International Law Commision, que exclui a ilicitude de um ato caso o mesmo constitua uma medida legal de autodefesa, em conformidade com a Carta da ONU (artigo 21). A existência desse princípio geral aceito como direito exime o Estado, ainda que potencialmente, de ter agido ilegalmente no exercício inerente de legítima defesa e de não-observância do artigo II $\left(\S^{\circ} 4\right) .^{205}$

Eckersley (idem: 299) força uma interpretação de que, no caso de inação do CSNU, em situações de emergências em razão do poder de veto por um ou mais de seus membros, organismos regionais ou Estados contíguos possam intervir como ato de legítima defesa com a finalidade de garantir a integridade física e a segurança de seus cidadãos. Para a autora:

“(...) Article 51 of the Charter explicitly preserves the right of states to use force in "self-defense" against an attack, and this has been interpreted to extend to the use of preemptive measures when a serious threat or attack is imminent and likely to be overwhelming and leave no room for choice. Direct and major incursions of pollution or hazardous substances into the territory of neighboring states are analogous to an "armed attack" with chemical, biological, or nuclear

\footnotetext{
${ }^{205}$ Nos comentários ao projeto (idem: 74), menciona-se que o direito internacional tradicional lida com tais situações de existência de um instituto como a legítima defesa prevendo legalmente um regime jurídico da guerra, definindo os direitos dos beligerantes e suspendendo os acordos em vigência entre as partes conflituosas. A própria Convenção de Viena sobre Direito dos Tratados, de 1969, prevê no artigo 73 que nada prejudicará "any question that may arise in regard to a treaty (...) from the outbreak of hostilities between States".
} 
weapons; they enter or threaten to enter the territory of the victim state without its consent and with equally grave consequences."

A discussão sobre essa interpretação mais extensiva do mecanismo da legítima defesa encontra suporte nas circunstâncias das relações internacionais e de sua evolução conceitual, afirmam seus defensores, que argumentam a favor de se desconsiderar a literalidade da codificação da Carta da ONU, escrita há mais de sessenta anos e em outro contexto. ${ }^{206}$ Esse entendimento tem sido, embora controverso e polêmico, cada vez mais defendido por juristas e acadêmicos.

Muito embora uma catástrofe ambiental (natural ou tecnológica) não corresponda a um ataque armado, no sentido tradicional do termo, os Estados podem desejar intervir para defender-se das consequências do desastre transfronteiriço no próprio território onde originariamente ocorreu, a fim de salvaguardar um eventual direito "inerente". Gavouneli (2001:637) aponta corretamente para o âmbito multilateral em desenvolvimento no DI, que estabelece preceitos no sentido de que os Estados cooperem para mitigar os efeitos dos danos transfronteiriços, ou mesmo a troca de informações a respeito do acidente e suas consequências (vide Convenção de Basiléia), mas não se aprofundam a ponto de discutir intervenções. Como forma de contornar essas limitações jurídicas, os Estados recorrem a outra argumentação: a "necessidade" de intervir em respeito ao princípio da autopreservação.

Para além da legítima defesa, com todas as suas incongruências conceituais como justificativa de intervenções em caso de desastres ambientais, seja por carência de elementos normativos, seja por inadequação lógica para casos iminentes e nãopreemptivos, outros cenários possíveis de justificativas de intervenções ocorrem, como

\footnotetext{
206 Uma outra discussão pertinente com relação à legítima defesa, que não interessa diretamente ao escopo da pesquisa, diz respeito à legítima defesa preemptiva (ou preventiva). A intervenção preventiva geralmente caracteriza-se pelo uso da força militar com antecedência ao uso da força pelo inimigo. Duas distinções podem ser feitas: uma ação militar antecipada e o uso preventivo da força. Enquanto o primeiro refere-se a um ataque iminente, o segundo sinaliza uma ameaça mais "remota". (GREENWOOD, 2003, apud BARROS-PLATIAU, 2006: 181). Bowett (1958) já apontava há cinco décadas essa ambiguidade de se preservar ou não o recurso de legítima defesa antecipatória em casos de extrema necessidade, distante do literalismo textual apregoado pela Carta. O autor conclui que "no state can be expected to await an initial attack which, in the present state of armaments, may well destroy the state's capacity for further resistance and so jeopardize its very existence". Diante da situação de ambiguidade que envolve o tema, Franck (idem:107) também avalia que: "The problem with recourse to anticipatory self-defense is its ambiguity. In the right circumstances, it can be a prescient measure that, at low cost, extinguishes the fuse of a powder-keg. In the wrong circumstances, it can cause the very calamity it anticipates.(...)"
} 
o que se convencionou chamar de "estado de necessidade", ou, simplesmente, "necessidade". Vamos priorizar a discussão em torno da necessidade, mais apropriada em situações já descritas neste trabalho por seus variados fatores, dentre eles a inexistência de ataque armado e pelo fato da iminência, gravidade e efetividade do perigo a ser avaliado. ${ }^{207}$

A justificativa do estado de necessidade, em substituição à legítima defesa, para casos de desastres ambientais poderia ocorrer quando o Estado onde se passou o acidente, como Chernobyl, na Ucrânia, houvesse sido tão afetado que não mais um governo constituído respondesse a critérios mínimos exigidos pela legislação internacional. Nessa situação hipotética, o Estado também se tornaria incapaz de solicitar assistência. Assim como nas legislações domésticas, o princípio da necessidade está largamente reconhecido no DI e tem sido utilizado em alguns casos para buscar legitimar entrega de assistência humanitária onde governos falham em fazê-lo.

O "estado de necessidade" encontra-se codificado no DI no supracitado projeto "Responsibility of States..." e é considerado um excludente de ilicitude do ato internacional. Em 2001, a AGNU, de acordo com o instituído pela Comissão, recomendou, por meio de Resolução, que os Estados recebessem o mecanismo do estado de necessidade sem prejuízo de sua futura adoção ou "outras ações apropriadas". Segundo o texto do projeto (art. 25):

\section{“Art. 25 Necessity}

1. Necessity may not be invoked by a State as a ground for precluding the wrongfulness of an act not in conformity with an international obligation of that State unless the act:

(a) is the only way for the state to safeguard an essential interest against a grave and imminent peril;

\footnotetext{
${ }^{207}$ Eburn (2007) cita um caso interessante que ilustra uma situação de "necessidade", o de um Estado que deseje defender-se dos efeitos de um desastre, um incêndio que possa estar avançando em um lado da fronteira e ameace seriamente ultrapassar as fronteiras nacionais e atingir um outro território, com sérias consequências para uma população estrangeira. Embora o incêndio não caracterize um "ataque armado", um Estado poderia, no entender do autor, argumentar em favor da "necessidade" de se cruzar a fronteira nacional para combater o incêndio, em vez de aguardar que o mesmo se prolifere para seu território. Recorda, ainda, que nos regimes multilaterais que tratam de poluição transfronteiriça e acidentes nucleares existem provisões que asseguram às nações de cooperarem para lidar com os efeitos de desastres, por exemplo trocando informações sobre sua natureza e possíveis efeitos, mas nada além, ou seja, ainda bem distante de prover um direito ao Estado afetado de resolver a situação in loco se o Estado causador do desastre não consentir.
} 
and

(b) does not seriously impair an essential interest of the State or States towards which the obligation exists, or of the international community as a whole.

2. In any case, necessity may not be invoked by a State as a ground for precluding wrongfulness if:

(a) the international obligation in question excludes the possibility of invoking necessity; or

(b) the State has contributed to the situation of necessity."

A noção de exclusão da ilegalidade de um ato sob a justificativa da "necessidade" sempre foi um ponto de controvérsia política e jurídica, não somente por ser considerado um conceito ambivalente e passível de variadas interpretações, mas também pelo receio de que a defesa dos interesses estatais pudesse justificar intervenções indevidas e desrespeitos a acordos entre os países. Autores como Ian Brownlie (1963) tendem a considerar a "necessidade" uma extensão do conceito da "legítima defesa", em casos idênticos de perigo aos Estados que não envolvam o critério do "ataque armado", como em áreas transfronteiriças e desastres ambientais.

Em seus primórdios, as duas excludentes (legítima defesa e necessidade) relacionavam-se diretamente com a noção de autopreservação, de onde emanava a ideia de que a um Estado não se pode exigir sacrifícios humanos ou sofrimento inaceitável, para cumprir obrigações internacionais. Esse entendimento não distinguia quaisquer critérios quanto aos conceitos de autopreservação, legítima defesa e necessidade, como se pode notar no caso Caroline, de 1837, entre a Grã-Bretanha e os Estados Unidos, envolvendo uma embarcação norte-americana atacada por forças britânicas. Na ocasião, o governo britânico invocou "necessidade", referindo-se à "necessity of self-defence and self-preservation", precursor também da legítima defesa preventiva (BARROSPLATIAU \& VIEIRA, 2006: 181-4). ${ }^{208}$

Segundo os commentaries ao projeto da ILC, submetido à AGNU, em 2001 (5 Sessão), o termo "necessidade" (état de nécessité) é utilizado para "denotar casos excepcionais onde o único meio de um Estado salvaguardar um interesse essencial ameaçado por um grave e iminente perigo é, naquele momento, não realizar uma outra

\footnotetext{
${ }^{208}$ Nesse sentido encontram-se as argumentações em variados casos nas cortes internacionais, como o Pacific Fur Seals Arbitration (1980), o Gabcikovo-Nagymaros Project (1997) e o Construction of a Wall (2004).
} 
obrigação internacional de menor peso ou urgência do que a ação que foi cometida." (tradução livre do autor). Conforme listou o documento, além de excepcional, a necessidade diferencia-se de outras situações em que haja o consentimento do país que sofreu a intervenção (art. 20), da legítima defesa (art. 21), das contramedidas (art. 22), por não ser dependente de conduta anterior daquele Estado. Diferentemente do instituto da "força maior" (art. 23), o estado de necessidade não envolve conduta involuntária ou coagida, e do "distress" (art. 24), na medida em que um agente, em nome do Estado, “(...) has no other reasonable way, in a situation of distress, of saving the author's life or the lives of other persons entrusted to the author's care".

Talvez o caso mais emblemático de intervenção ambiental recente com base no estado de necessidade tenha sido o do navio petroleiro liberiano Torrey Canyon (1967), bombardeado pela Grã-Bretanha por representar grave risco de contaminação de óleo nas costas britânicas. Após diversas tentativas de solução para a catástrofe que se anunciava, o governo britânico decidiu bombardear a embarcação no intuito de eliminar o petróleo remanescente no interior do navio. A Inglaterra não buscou justificar seu ato legalmente, porém apontou uma situação de perigo real e iminente extremo no intuito de conduzir a ação. O caso resultou no início das negociações para a assinatura de um acordo permissivo de intervenções do gênero em tais casos excepcionais (International Convention relating to Intervention on the High Seas in Cases of Oil Pollution Casualties). ${ }^{209}$

Analisando de forma mais detida o estado da necessidade, conclui-se que o princípio condiz com a prática estatal no que concerne a situações de desastres ambientais e à "necessidade" de intervenção em áreas transfronteiriças, embora, em paralelo a situações de legítima defesa, tenha sido utilizado pelos Estados para justificar variadas situações que não condizentes com o sentido genuíno oferecido pelo legislador internacional. Na literatura, a ideia de intervenção por necessidade tem, por essa razão, sido altamente controversa e submetida a condicionantes estritas. Desde o século XIX, quando a doutrina da necessidade ganhou mais visibilidade por sua associação com “direitos fundamentais dos Estados", passou a ser vista de forma negativa ao ser

${ }^{209}$ Cf. "The Torrey Canyon", “white paper” publicado pelo Governo do Reino Unido. 3246, London, H.M. Stationary Office, 1967. 
estendida ao direito internacional em razão dos abusos cometidos pelas nações imperialistas. $^{210}$

Por fim, surgem, ainda, dúvidas a respeito da aplicação da R2P em casos de desastres ambientais. Consideramos não ser viável falar em R2P em situações previstas por esta pesquisa para casos de catástrofes que envolvam as obrigações positivas. Se tomarmos o sentido original do conceito como base de justificativa para intervenções verdes por parte do Estado-vítima de dano originário em território contíguo ao seu, para salvaguarda populacional em desastres ambientais, incorremos em inadequação terminológica e epistemológica. A responsabilidade de proteger a população é do próprio Estado contra o qual a comunidade internacional requer para si, subsidiariamente, sua proteção, em seu território e por inação ou impossibilidade de protegê-la. Caberia falar em R2P se o Estado interventor não cumprisse sua obrigação positiva de proteger sua população. Ainda assim, a extensão da R2P para questões ambientais é um debate extremamente polêmico e controverso.

Tomemos eventual aplicabilidade do conceito nas consequências do ciclone Nargys, em Myanmar, para visualizar a situação, revestida de características interessantes que parecem não se adequar à análise em apreço do acidente nas centrais nucleares de Chernobyl e Fukushima-Daiichi. Naquele contexto específico, a invocação da R2P pela comunidade internacional teve origem na inabilidade da junta militar birmanesa (portanto o próprio Estado) de não aceitar a assistência oferecida, o que resultou na demanda do governo francês junto ao CSNU, para que interviesse em favor da entrega de auxílio humanitário sem o consentimento de Myanmar, portanto uma situação diversa dos institutos até aqui demonstrados.

Em um questionamento preliminar, deve-se considerar também que a R2P, conforme visto anteriormente, ainda não adquiriu consenso normativo expressivo na comunidade internacional, tanto em relação à sua aplicabilidade, quanto em sua prática

\footnotetext{
${ }^{210}$ Os elementos condicionantes do estado de necessidade são dignos de uma análise mais detida. O primeiro elemento, exposto no $\S 1^{\circ}$, diz respeito à essencialidade do interesse a ser resguardado e ao critério de gravidade e iminência do perigo. Segundo o Commentaries... (idem, pg. 83): "The extent to which a given interest is "essential" depends on all the circumstances, and cannot be prejudged. It extends to particular interests of the State and its people, as well as of the international community as a whole. Whatever the interest may be, however, it is only when it is threatened by a grave and imminent peril that this condition is satisfied. The peril has to be imminent in the sense of proximate."
} 
(RAFFELSEDER, 2011: 43-46). Sua aplicabilidade é posta em dúvidas por razões políticas. Enquanto em outros mecanismos codificados a dificuldade advém de uma eventual extrapolação do sentido inicialmente atribuído pelo DI, que lhe confere a legalidade (e legitimidade), questiona-se ainda a efetividade da R2P como uma "norma emergente". Uma das razões encontra-se na natureza do SI, largamente dividido entre as nações desenvolvidas, proprietária dos meios e recursos do uso da força, e as nações menos favorecidas e crescentemente dependentes daquelas para manutenção da própria segurança em um globo caracterizado por incertezas políticas e militares.

Haacke (2009:160) enfatiza que a implementação prática da R2P torna-se problemática na medida em que as nações em desenvolvimento receiam que as nações ocidentais intervenham sob a justificativa do humanitário somente "no papel". Se considerarmos a lacuna decisória que envolve países emergentes no processo de definição das decisões sobre quando e como intervir, tal receio torna-se mais forte. ${ }^{211} \mathrm{Se}$ considerarmos o mundo composto por países interventores e países alvos potenciais, esse receio torna-se compreensível.

Diante de tantas incertezas com relação à terminologia a ser empregada em situações de desastres ambientais e intervenção para defesa da própria população e território, propomos que, em eventos similares com característica peculiares de acidentes de efeitos transfronteiriços, melhor sejam aventados os princípios relacionados às obrigações positivas (e o próprio termo como empréstimo do $\mathrm{DH}$ ), de modo a justificar as intervenções verdes, para além de conceitos desgastados, como intervenção humanitária, e inadequados, como legítima defesa e necessidade. Em exercício de sistematização e reflexão, propomos a análise da tabela (6.1) abaixo, que buscou agrupar sequencialmente as características de cada conceito:

\footnotetext{
${ }^{211}$ Considerando-se especificamente a questão dos quatro crimes aprovados para a efetiva utilização da R2P, Edward Luck (2009) avalia que não se poderia extrapolar assim para outros eventos a R2P, enquanto o SG Ban Ki-moon exortou seus defensores a tratar o caso em tela como uma crise humanitária, o que corresponderia a se conceber desastres ambientais como tema relacionado aos limites conceituais da SH, sem ultrapassá-la no tocante à instrumentalização (leia-se, uso da força por meio da R2P). Ban Kimoon desvela, portanto, a discrepância de opiniões entre analistas e juristas sobre a real extensão do conceito e sugere uma digressão conceitual aos anos 1990, quando a securitização ambiental dava seus primeiros passos.
} 


\section{Tabela 6.1: Excludentes de Ilicitude - Modelo Comparativo}

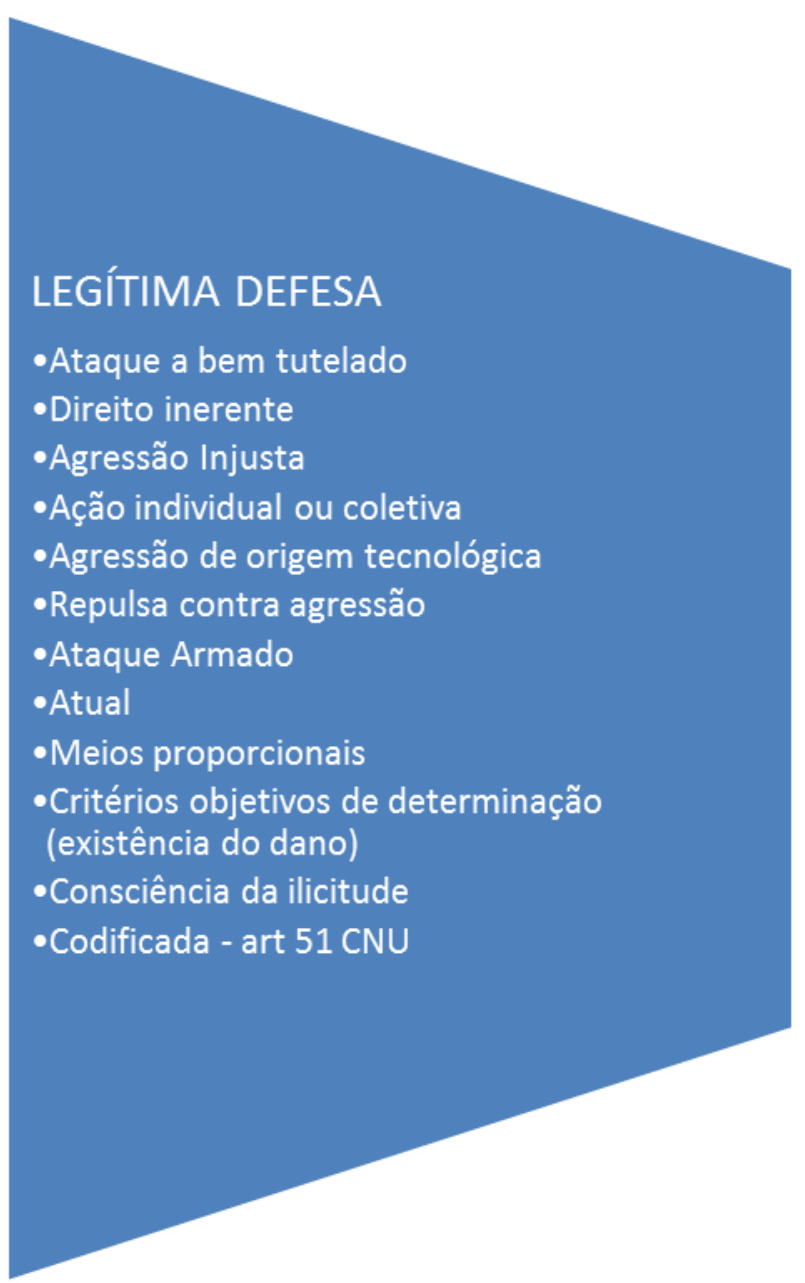

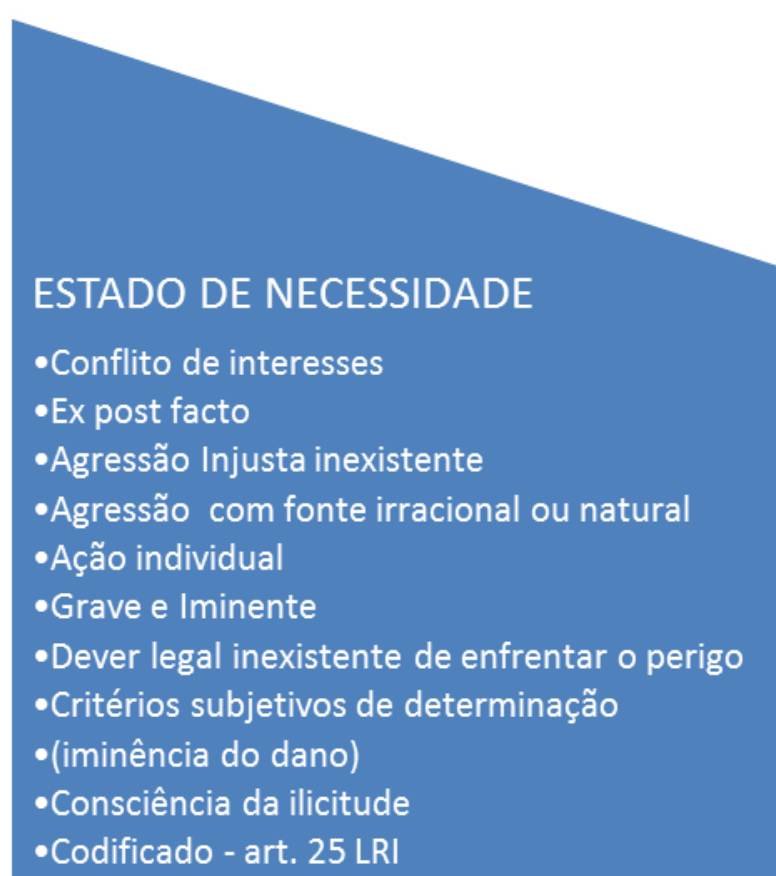

-Codificado - art. 25 LRI

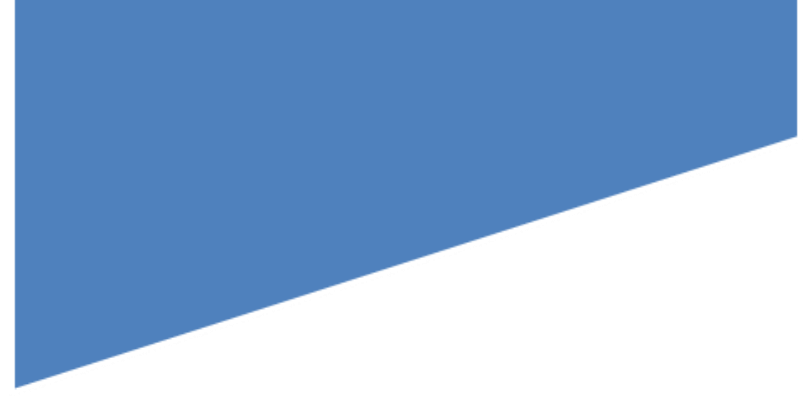

\section{OBRIGAÇÕES POSITIVAS}

-Ataque a bem tutelado

-Dever inerente

-Agressão Injusta inexistente

•Agressão de origem tecnológica ou natural

-Ação individual

-Atual ou Iminente

-Dever legítimo de enfrentar o perigo

-Critérios objetivos de determinação

(existência do dano)

-Consciência da ilicitude

•Não codificado 
As justificativas de intervenção na situação descrita foram divididas em três grupos, que contêm as características de cada instituto. A lista de características não é exaustiva, mas busca traduzir fielmente, de acordo com as observações que lhe são pertinentes na prática das intervenções e na doutrina jurídica, os mecanismos da legítima defesa, do estado de necessidade e uma proposta de transposição conceitual de “obrigações positivas” aplicadas aos casos específicos de desastres ambientais.

De modo geral, a legítima defesa e as obrigações positivas conjugam entre si a referência a um bem tutelado pelo Estado, nesse caso a integridade territorial e sua população. Enquanto na legítima defesa há um ataque voluntário ao bem, nas obrigações positivas há uma agressão sem dolo. No estado de necessidade, por sua vez, reconhece-se um conflito de interesses em jogo, pois a defesa de um corresponde à perda do bem de outro, portanto um jogo de soma zero.

Uma das diferenças fundamentais entre os mecanismos em análise refere-se à substância da agressão, ${ }^{212}$ pois define a reação do Estado-interventor. A legítima defesa se distancia da necessidade e das obrigações positivas por conter uma agressão injusta e consciente, nos moldes do artigo 51 da Carta da ONU (ataque armado). Os outros dois mecanismos não contêm agressão, e sim um fator natural ou um acidente tecnológico, cujas consequências seriam oriundas de um ato culposo, provavelmente jamais doloso, pelas próprias características do acidente. Caso doloso, poder-se-ia aventar um ato de agressão, distanciando-se, assim, da naturalidade dos desastres e constituindo um ato de guerra em ameaça à paz e à segurança internacional, justificando a intervenção pela legítima defesa.

Esta última observação traz à discussão a precedência do direito ou da obrigação dos três mecanismos. No ponto em que o próprio artigo 51 afirma que “(...) Nada na presente Carta prejudicará o direito inerente de legítima defesa individual ou coletiva no caso de ocorrer um ataque armado contra um Membro das Nações Unidas"

\footnotetext{
${ }^{212}$ Vale notar que, para os critérios da pesquisa, não diferenciamos "dano" de "agressão", pois são conceitos interconectados. Um dano advindo de um acidente nuclear com efeitos transfronteiriços constitui uma agressão, ainda que não seja um ataque armado. Todo ataque armado gera uma agressão ao território, mas nem toda agressão, que cause um dano, constitui um ataque armado. Na situação de desastres transfronteiriços por razões tecnológicas, como os acidentes nucleares, geram danos (uma agressão), mas não se apresenta como um ataque armado para caracterizar uma potencial invocação da legítima defesa, pautada no artigo 51 da Carta da ONU.
} 
(destaque nosso), tal ilação encerra em si um enunciado que antecede o próprio fato e que se relaciona ao direito à autopreservação dos Estados. Diferentemente da legítima defesa, o estado de necessidade deve ser considerado um direito adquirido ex post-facto, na medida em que inexiste um direito inerente à necessidade, devendo o fato que originou a reação do Estado ser analisado caso a caso, de acordo com critérios previamente estabelecidos. As obrigações positivas, para além de um direito inerente (legítima defesa) e um direito adquirido "ex post-facto" (necessidade), correspondem a um "dever inerente" próprio da soberania como responsabilidade, que recai sobre o Estado que sofre o dano e à comunidade internacional de forma subsidiária.

Um outro diferenciador diz respeito ao agente ou causa da agressão, se estatal, tecnológica, natural ou irracional. Podemos afirmar que a legítima defesa ocorre mediante agressões de natureza estatal e tecnológica, ${ }^{213}$ enquanto o estado de necessidade tem uma fonte irracional ou natural. As obrigações positivas referem-se a desastres naturais e tecnológicos, decorrentes da ação humana em regiões transfronteiriças ou suficientemente próximas para causar danos nos territórios de estados vizinhos.

Quanto ao aspecto temporal, o DI silencia com relação à legítima defesa. Sobre a necessidade, acrescenta ao perigo a ser combatido os adjetivos "grave" ou "iminente". Quando trata da legítima defesa, o projeto da CDI/ONU sobre Responsabilidade Internacional dos Estados, em seu artigo 21, remete-nos à Carta da ONU, que prolonga a ação de defesa até que "o Conselho de Segurança tenha tomado as medidas necessárias para a manutenção da paz e da segurança internacionais." Pode-se supor que a legítima defesa deve ser atual, apesar das crescentes divergências, já discutidas supra, com relação aos novos desafios internacionais que preconizam a existência de um direito à autodefesa "preemptiva". Nas obrigações positivas, propomos o critério da gravidade e atualidade, pois o desastre ambiental encontra-se em andamento e seus efeitos se fazem sentir na região transfronteiriça.

Os critérios de determinação da iniciativa obedecem a uma lógica dicotômica objetiva-subjetiva. Enquanto a legítima defesa e as obrigações positivas são

\footnotetext{
${ }^{213}$ A agressão na legítima defesa, para critério desta pesquisa, é considerada de forma restritiva, havendo assim uma repulsa do Estado interventor contra um ataque armado. Essa ação poderá ser individual e/ou coletiva, enquanto no estado de necessidade e nas obrigações positivas há de se falar em uma resposta individual a agressões ou ocorrências que não as armadas.
} 
determinadas de forma objetiva, pois devido à atualidade do perigo não há margem para decisões, no estado de necessidade, em virtude da iminência do fato, o processo decisório é apreendido de forma subjetiva, de acordo com a escolha e preferências do Estado-interventor. O critério de iminência é largamente criticado entre os autores que tratam do tema, devido à sua indefinição quanto à realidade objetiva e empírica. Como visto acima, a noção de "prevenção" ou "preemptividade" não é largamente aceita, quando se correlaciona ao instituto de legítima defesa. Um fato que ainda não ocorreu pode tornar-se uma realidade pela escolha equivocada do agente.

Um dos pontos não mencionados anteriormente relaciona-se ao "dever" de conter a agressão. Defendemos na proposta das obrigações positivas relativas a catástrofes que o Estado tem um dever legítimo de conter o dano, em razão dos preceitos da soberania como responsabilidade. Uma questão em aberto seria conhecer as consequências da inação do Estado, em eventual negligência de sua prerrogativa originária. Abre-se margem para uma extensão do conceito de R2P e para a comunidade internacional, subsidiariamente em nome do Estado-negligente, atuar no território de outro Estado onde ocorreu a catástrofe, pautado no preceito de segurança coletiva prescrito na Carta da ONU? Em outros termos, a comunidade internacional poderia intervir em um Estado-terceiro (fonte do dano) para salvaguardar vidas em um Estadoomisso (vítima do dano)? São questionamentos que ultrapassam o objetivo da pesquisa, mas que não merecem ser descartados, tendo em vista o avançar do direito internacional e das relações internacionais, considerando o tema da intervenção.

Em um plano mais prático da discussão relacionado diretamente ao escopo da pesquisa, a aplicação da doutrina da necessidade relacionada às intervenções merece especial consideração neste capítulo, por ser bastante próximo das obrigações positivas, mas sem com ela se confundir. Romano (1999) e Bradford (2004) vêm discutindo se a necessidade apresenta-se não somente nas discussões jurídicas e acadêmicas, mas também na jurisprudência a respeito, como um complemento ou uma "alternativa" ao instituto da legítima defesa. Tal dúvida viria em razão de sua inadequação como elemento explicativo do uso da força nas últimas décadas, com a "desatualização" do prescrito no artigo 51 da Carta da ONU e com os novos desafios que afetam a sociedade internacional, como terrorismo e desastres ambientais. 
Sobre esse aspecto, e considerando a questão das novas ameaças oriundas do terrorismo internacional, especificamente, Agius (2006: 55-56) considera que, à luz da existência do problema e do estado atual de incertezas, seria duvidoso se o Estado pudesse identificar o uso da força fora do âmbito da Carta da ONU, sem violar princípios de jus cogens de não utilizar meios não prescritos no DI. O mecanismo da necessidade como alternativa também parece indefensável em tais situações de silêncio da Carta quanto à extensão da legítima defesa. No entanto, há uma tendência de se considerar a "necessidade" como complemento ao instituto de legítima defesa naqueles casos como uma "válvula de escape" (safety valve), tendo em vista que a Carta não prevê medidas preventivas para conter situações difusas de perigo na ordem global contemporânea. $^{214}$

Para além das implicações jurídicas, as consequências políticas da extensão da ideia de obrigações positivas para o tema ambiental perpassam as análises mais realistas e conservadoras dos Direitos Humanos, por toda a evolução conceitual da temática da $\mathrm{SH}$, em suas múltiplas vertentes. Ao tratarmos do conceito genuíno de obrigações positivas, em paralelo aos mecanismos da legítima defesa e do estado de necessidade, devemos também analisar o tema de forma mais política, ultrapassando as meras justificativas legais positivadas das intervenções. Esse esforço analítico visa complementar a busca pelo entendimento de nuances mais práticas para nosso objeto de pesquisa, nem sempre em consonância com as prescrições reconhecidas pelo DI.

Ao traspassar os institutos da legítima defesa e do estado de necessidade no intuito de compreender conceitos não codificados, embora intrinsicamente relacionados e não menos legítimos de uso da força, as implicações políticas envolvem o nível

214 Essa situação de se utilizar o argumento da "necessidade" com o fim de traspassar argumentos baseados na legítima defesa, quando o elemento do mecanismo (ataque armado) não se fizer presente, não é tão recente, e ganhou força após decisão da CIJ, delimitando o sentido literal do instituto, no caso Nicarágua vs Estados Unidos, de 1986, a respeito de alegadas atividades paramilitares pelos norteamericanos contra o governo nicaraguense (1981-1984), cujo mérito da causa fundamentava-se em matéria concernente ao uso da força e da legítima defesa. A Corte fundamentou sua decisão no critério de que para tal justificativa seja viável, o Estado-vítima demonstre evidências de "ataque armado". Avaliou igualmente que os Estados, ao agirem sob legítima defesa conforme autorizado pelo artigo 51 da Carta da ONU, deveriam reportar imediatamente ao Conselho de Segurança, o que não havia sido feito até aquele momento pelo governo norte-americano. (FRANCK, 2002:60-63). Ao delimitar o sentido tradicional e costumeiro de ataque armado, a Corte abriu espaço para que a legítima defesa se tornasse "obsoleta" como fundamento para o uso da força em situações que não envolvam os critérios específicos do artigo 51, fazendo com que os Estados avaliassem utilizar-se de outras classificações, como o estado de necessidade, como tudo aquilo que não envolva "ataques armados", como os desastres ambientais. 
sistêmico das relações internacionais. Há de se reconhecer aqui um processo evolutivoconceitual de intervenção humanitária, sob os princípios basilares de SH, para alcançar a noção mais refinada e consensual de R2P. Na área ambiental, a exemplo dos Direitos Humanos, o avanço do debate sobre as intervenções (verdes) tem sido gradual e relativo, alcançou o arcabouço conceitual da área de forma tímida, mas não se encontra plenamente discutido.

\subsection{As Obrigações Positivas: de Chernobyl a Fukushima-Daiichi}

De modo a pautar a discussão que segue, de se saber se o acidente da central nuclear de Chernobyl pode ser analisado sob as lentes das obrigações positivas, propomos um exercício de reflexão sobre o acidente, que, em larga medida, terá similitudes com o acidente na central nuclear de Fukushima-Daiichi. Na análise, seguimos as orientações metodológicas da pesquisa e propugnamos as obrigações positivas como uma diretriz, um princípio e uma proposta conceitual viável (extensão da PIPH) de que emana uma justificativa para eventual intervenção estatal em casos específicos de desastres ambientais transfronteiriços com graves danos, como consequência da inadequação conceitual-terminológica da legítima defesa e do estado de necessidade. No âmbito político, a discussão adquire novos contornos, pelas peculiaridades do contexto internacional em que ocorreu o acidente da usina nuclear de Chernobyl.

Uma análise que considere tão somente aspectos de segurança e poder, descarta a priori qualquer esforço analítico mais efetivo de se conhecer a possibilidade de intervenções de Estados menos favorecidos sobre potências nucleares, pela própria natureza da lógica realista das relações internacionais. Em um contexto mais complexo, mesmo em situações onde a multiplicidade dos atores tenha favorecido o processo de regionalização, não há de se falar em intervenções contra Estados militarmente mais fortes, ou sob a proteção de uma potência, como no caso do Japão, protegido pelos EUA. Como este trabalho de tese se propõe a analisar as intervenções verdes em situações não-fictícias, um esforço para enquadrar eventual reação dos países limítrofes na classificação de obrigações positivas proposta faz-se necessário, sem considerar 
aqueles limitantes que na realidade empírica certamente impediriam a interferência do ente estrangeiro. $^{215}$

Neste capítulo da tese, mais analítico do ponto de vista das relações internacionais, será dada prioridade para um estudo das obrigações positivas com lentes da política internacional, buscando-se avaliar se o mecanismo poderia ser mais bem aceito para justificar intervenções em casos de desastres ambientais. Conforme apontado em outra oportunidade, a legítima defesa e o estado de necessidade, no âmbito jurídico, e a R2P, no político, tendem a ser inadequados como justificativas de intervenções nessas situações, além de extrapolar significativamente os sentidos tradicionais que lhes foram conferidos pelo DI. Pretende-se aplicar a seguir os conceitos e princípios basilares, longamente explorados no decorrer da pesquisa, para "reabrir" a discussão desse tópico polêmico e apaixonante.

O acidente na central nuclear de Chernobyl, em plena Guerra Fria, representa uma situação a primeira vista anacrônica que, em uma análise ou revisão literária sobre o período, não retrata genuinamente o moderno sistema securitário ambiental. Visto naquela época sob a ótica neorrealista, predominantes nas explicações sistêmicas da disciplina das RI, quando conceitos como SH ainda eram uma utopia (nem tão) distante nos âmbitos acadêmico e político, o acidente teria sido um caso clássico de aplicação das obrigações positivas, por enquadrar-se efetivamente no campo conceitual que retratamos.

Logo após a catástrofe, autoridades soviéticas buscaram encobrir informações sobre a real gravidade da crise e sobre a eventual vulnerabilidade de sua capacidade nuclear. ${ }^{216}$ Confrontada com estatísticas independentes sobre o nível de radioatividade

\footnotetext{
215 Aponto nesse sentido a reação da ex-União Soviética, no contexto da Guerra Fria, a uma intervenção por um dos países limítrofes à Ucrânia, para buscar conter os danos resultantes da catástrofe nuclear que se seguiu ao acidente em Chernobyl. Seria idealmente desproporcional a intervenção estrangeira em uma potência militar como a URSS da época. Não se pode descartar que, durante o acidente, as autoridades soviéticas chegaram a permitir, apesar de protestos, que somente representantes de organizações como a OMS, a AIEA e o CICV, além de poucos países satélites afetados, tivessem acesso às áreas mais críticas afetadas pela radiação nuclear.

216 Os créditos dos parágrafos sobre o acidente nuclear de Chernobyl pertencem à World Nuclear Association (http://www.world-nuclear.org/), relatório "Chernobyl Accident 1986", detalhado estudo sobre os fatos envolvendo o acidente. Website da Agência Internacional de Energia Atômica (AIEA) http://www.iaea.org/ e arquivo de "New York Times", com vasto material da época, http://topics.nytimes.com/ (acesso em 10/08/2013)
} 
na atmosfera, principalmente de institutos de países como a Suécia, as autoridades da URSS assumiram gradualmente a amplitude do acidente. Causou consternação à época o nível de desconhecimento sobre o acidente entre as populações afetadas na Europa (como França e Espanha), ainda semanas após o ocorrido. ${ }^{217}$

O acidente nuclear foi resultado da obsolescência dos reatores utilizados na planta da central nuclear e de sérios equívocos humanos praticados por seus operadores. Foi também consequência do isolamento da URSS no período da Guerra Fria e da ausência, no Leste Europeu, de padrões de segurança mais elaborados. O Complexo Nuclear de Chernobyl encontra-se a $130 \mathrm{~km}$ ao norte da capital ucraniana (Kiev) e a somente $20 \mathrm{~km}$ da fronteira com a Bielorrússia (fig. 6.10). A central nuclear consistia em quatro reatores modelo RBMK-1000 (fig. 6.11), produzidos com tecnologia soviética, utilizando-se de combustível de dióxido de urânio intensamente enriquecido (2\% U-235), e construídos entre os anos de 1970 e 1983. Duas unidades adicionais estavam em construção na época do acidente.

\footnotetext{
${ }^{217}$ A catástrofe levou a AIEA a promover projetos de acordos, antes fortemente repelidos pelas potências nucleares, entre eles uma convenção versando acerca da pronta notificação por parte dos Estados a AIEA e aos países diretamente afetados por um acidente nuclear. Outra convenção formulou diretrizes de auxílio e o limite temporal a que os Estados causadores e afetados pelo incidente deveriam seguir. Para Le Prestre (idem: 387), as consequências de Chernobyl afetaram também um outro aspecto da segurança nacional dos países detentores de armamentos nucleares, que chegaram a insistir, como os Estados Unidos, a que suas instalações nucleares não fossem alvo da convenção sobre notificação. O autor aponta para um desdobramento marcante, após o desmantelamento da ex-União Soviética com o final da Guerra Fria e à acessão da Ucrânia como nação independente, no que se refere à utilização do perigo potencial de possuir artefatos nucleares em seu território como um "trunfo" nas negociações multilaterais. Com esse propósito, o governo ucraniano buscou barganhar com os países ocidentais de modo a compensar os custos associados à necessidade de se reforçar a segurança e o fechamento da central nuclear de Chernobyl.
} 
Fig. 6.10: Área do entorno da central nuclear de Chernobyl

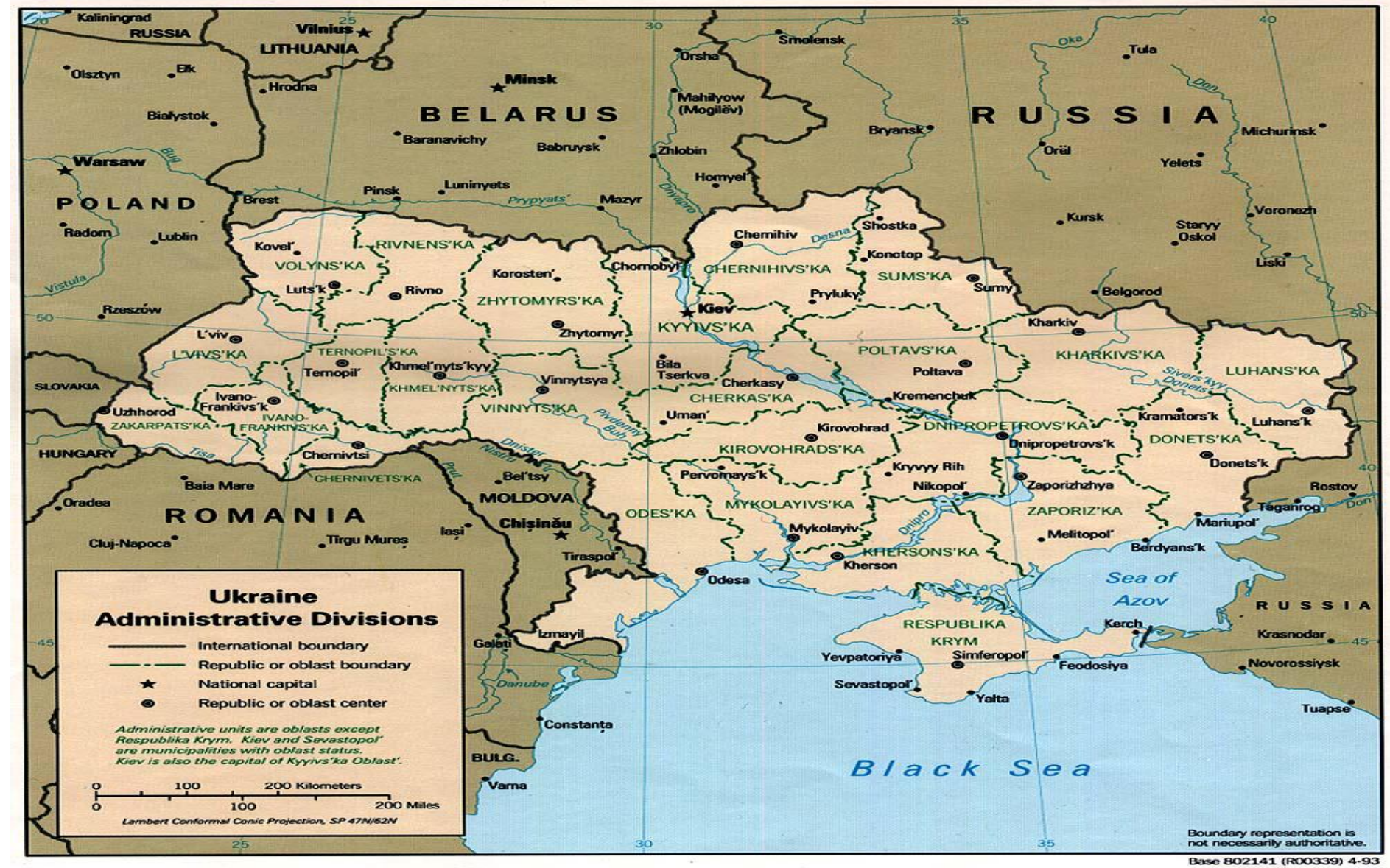

Fonte: http://www.lib.utexas.edu (acesso em 10/02/2014) 


\section{Fig. 6.11: Modelo de Reator na Usina de Chernobyl}

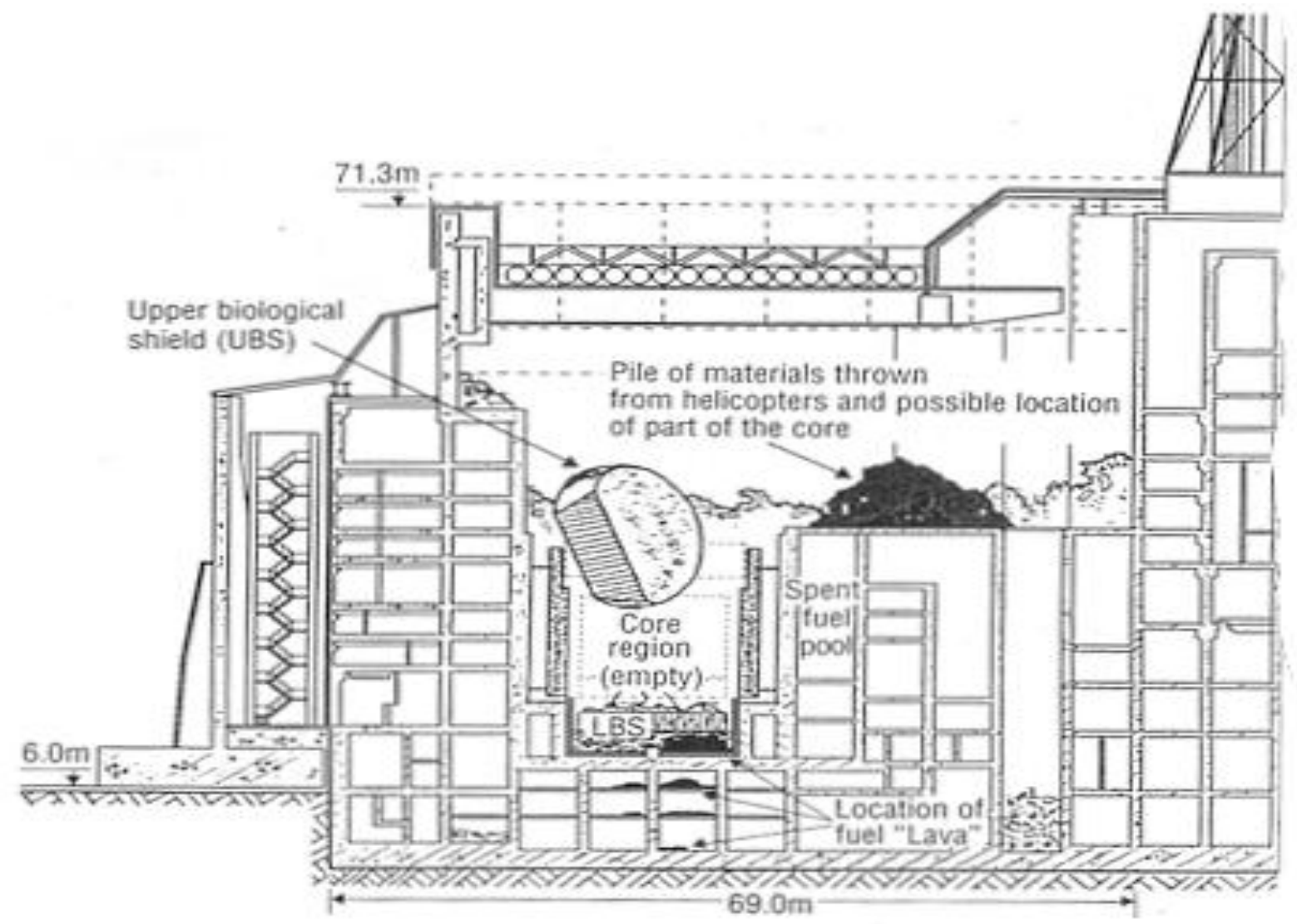

Fonte: www.world-nuclear.org (acesso em 10/02/2014)

$\mathrm{Na}$ região do Complexo, um lago artificial de $22 \mathrm{~km}^{2}$ havia sido edificado, próximo ao rio Pripyat, tributário do Dniepr, para fornecer água para resfriamento dos reatores (fig. 6.12). Na fronteira com a Bielorrússia, a área onde foi instalada a central nuclear se caracterizava pela baixa densidade populacional, mas na cidade de Pripyat habitavam cerca de 50 mil indivíduos e, na cidade de Chernobyl, a apenas $15 \mathrm{~km}$ do complexo, outros 12.500 habitantes. A população totalizava em torno de 130.000 habitantes em uma circunferência de $30 \mathrm{~km}^{2}$ radiano do Complexo Nuclear.

No fatídico dia 26 de abril de 1986, antes do desligamento rotineiro de um dos reatores, a equipe de operadores preparou um teste com o objetivo de determinar o tempo necessário para que as turbinas suprissem energia para as bombas principais de circulação, após uma queda no suprimento de energia elétrica. O teste já havia sido realizado anteriormente, com a finalidade de pesquisar a reação do reator diante de inovações tecnológicas. Durante as operações, a interação entre a energia de alta 
temperatura e os mecanismos de resfriamento levou a uma fragmentação energética e ao aumento incontrolável da pressão no interior das turbinas. A pressão excessiva danificou parcialmente a placa de 1000 toneladas que cobria o reator, rompendo a canalização de energia e deixando sem controle os aparelhos de ajuste. Duas explosões seguiram-se rapidamente e liberaram na atmosfera material radioativo oriundo do processo de fissão nuclear. Dois operadores morreram na hora em consequência da explosão. Cerca de 300 toneladas de grafite e energia causaram incêndios responsáveis por dispersar no meio ambiente uma alta concentração de material radioativo (um total de $14 \mathrm{EBq}$, um múltiplo de "becquerel", unidade radioativa, em linguagem técnica). Nos dias imediatos ao incidente, aproximadamente 5000 toneladas de boro, dolomita, areia e fagulhas foram despejadas de helicópteros no local, na tentativa de conter as chamas e limitar a quantidade de partículas radioativas ainda sob o risco de alcançar a atmosfera.

O acidente no Complexo Nuclear de Chernobyl resultou no maior despejo de material radioativo de que se tem notícia e durou cerca de 10 dias, a contar do momento da explosão do reator. Dois materiais altamente radioativos, em especial o iodo-131 e o césio-136, foram particularmente significantes para as doses de radioatividade despejadas no ar. O episódio constituiu um desastre social e econômico irreparável para parcelas consideráveis das populações da Bielorrússia, Rússia e Ucrânia. A nuvem radioativa pôde ser verificada na Escandinávia e em outras partes da Europa (PAINE, 1987). O número exato de mortes ainda hoje é desconhecido, mas imediatamente após o acidente, cerca de 30 agentes de equipes de segurança e bombeiros morreram em consequência da contaminação. Os efeitos demográficos foram notáveis. A cidade funcional de Pripyat, morada dos operadores da usina e seus familiares, teve de ser evacuada (45.000 residentes), e habitantes em um raio de $30 \mathrm{~km}$ do acidente realocados (120.000 indivíduos). 
Fig. 6.12: Imagem de satélite da área atingida pelo acidente

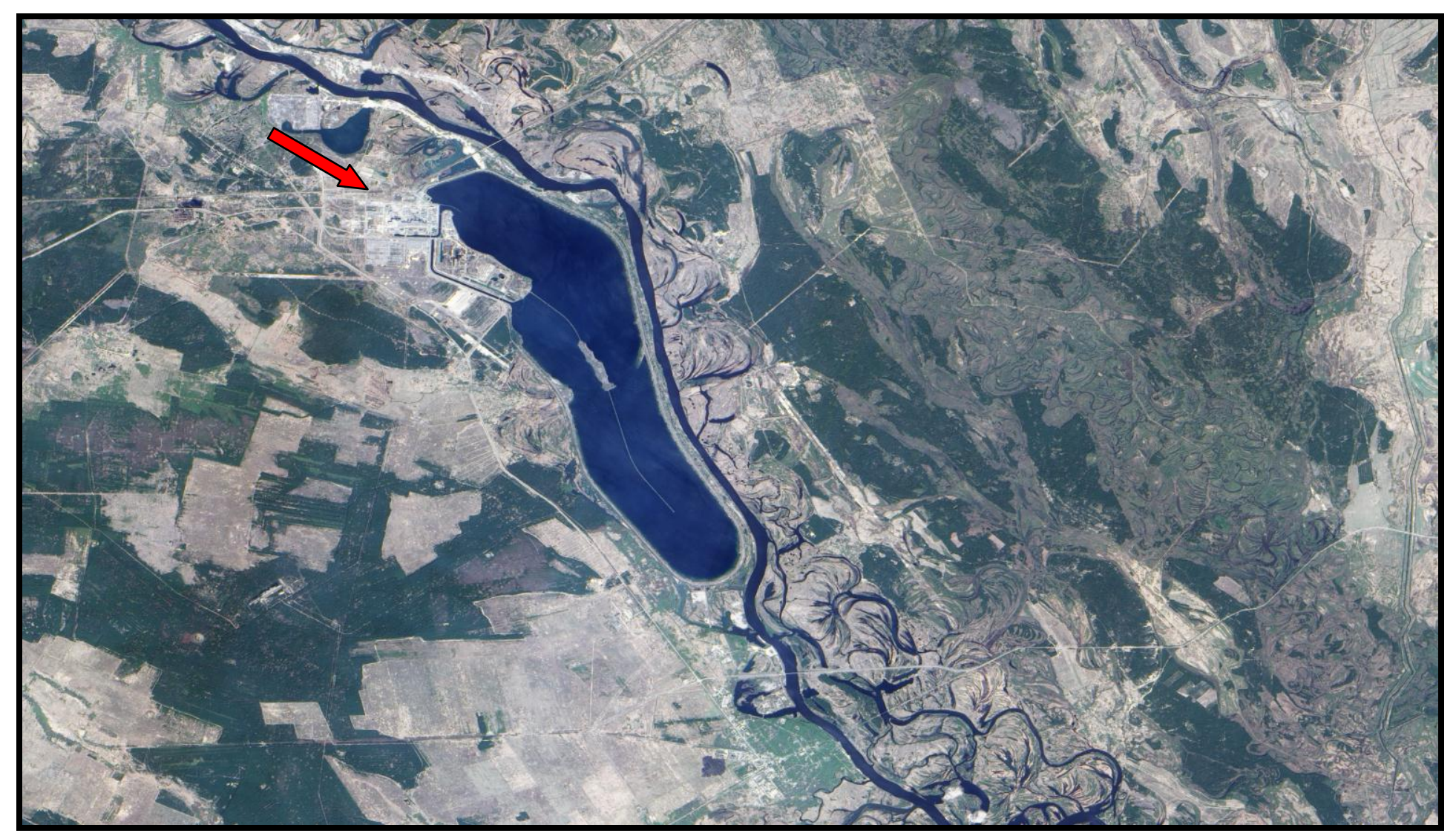

Fonte: NASA Earth Observatory (http://www.earthobservatory.nasa.gov/)

Acesso em 14/01/2014 
Fig. 6.13: Efeitos do acidente na central nuclear de Chernobyl

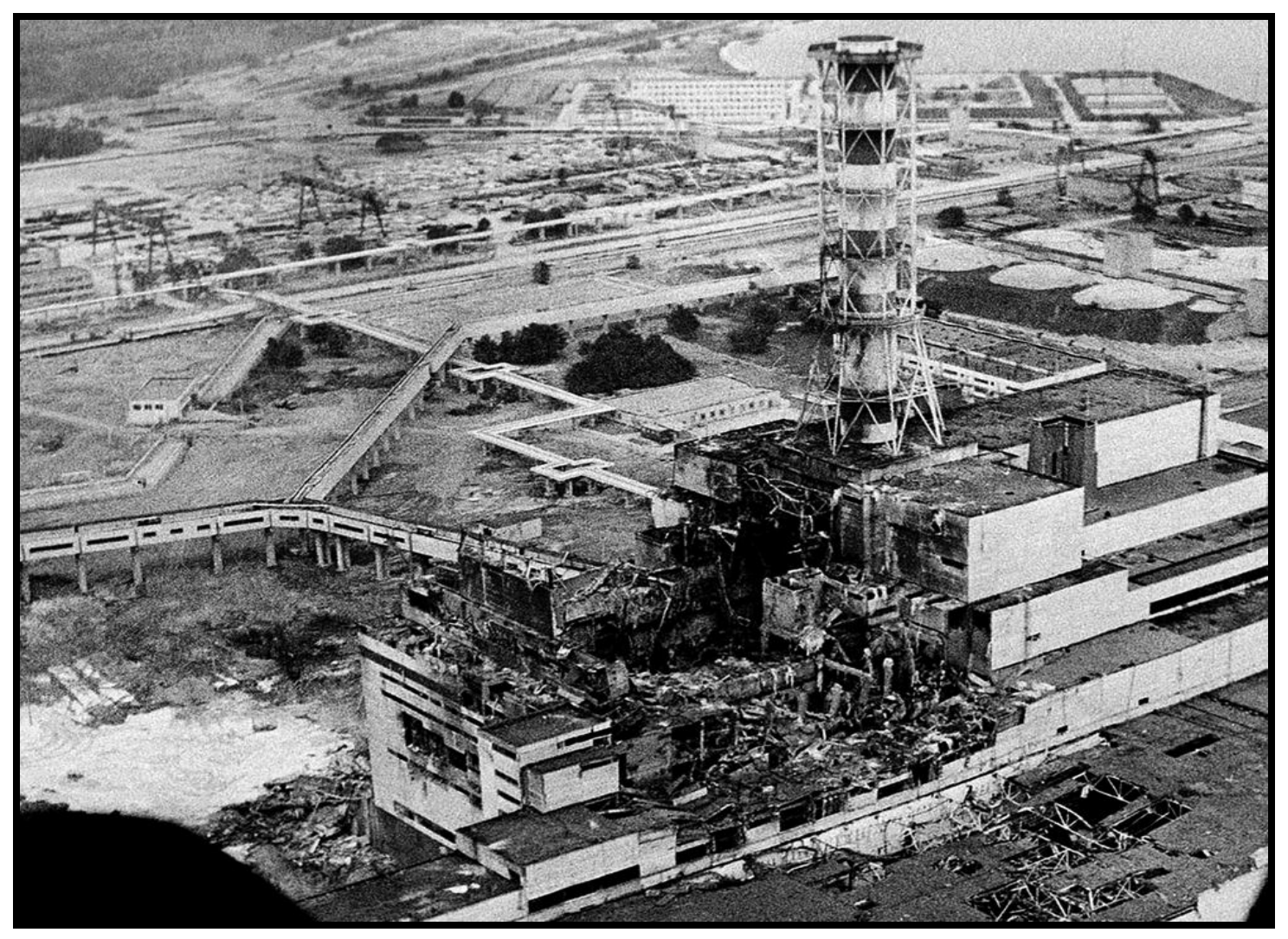

Fonte: www.ap.org/ (Associated Press)

Os efeitos do acidente de Chernobyl podem ser mais bem visualizados caso se considerem quatro fases do momento da explosão do reator. Em um primeiro estágio, o dia da explosão (26 de abril de 1986), houve uma descarga mecânica que liberou larga quantidade de energia radioativa. Os radionuclídeos liberados eram compostos, nessa fase, de produtos de fissão contidos na energia produzida, com nuclídeos enriquecidos de elementos voláteis como iodo, telúrio e césio.

Uma segunda fase, que durou cerca de cinco dias, entre 27 de abril e $1^{\circ}$ de maio, fase de diminuição da liberação inicial, correspondeu a 1/6 da média de descarga de material radioativo do dia "zero", momento da explosão. Ainda nesse período teve continuidade os trabalhos de deposição de material para conter a proliferação de gases decorrentes da explosão, cerca de 5.000 toneladas, composto basicamente de boro (40 tn), dolomita (800 tn), argila e areia (1.800tn), e chumbo (2.400 tn). A quantidade 
expressiva de chumbo depositado no reator, para evaporar posteriormente com o calor no núcleo, foi considerada o responsável por expressiva ocorrência de problemas médicos após o acidente, principalmente em crianças (GINZBURG \& REIS, 1991: 32$40)$.

Em um terceiro estágio, houve uma reativação das liberações de radiação na atmosfera, entre os dias 6 e 9 de maio, alcançando cerca de $70 \%$ do nível encontrado no estágio inicial do acidente. Especialistas soviéticos atribuíram o retorno da liberação do material radioativo a possível reignição de energia residual, por conta do calor liberado e ainda existente no núcleo do reator, assim como a carbonização de dióxido de urânio, facilitando a fuga de produtos resultantes da fissão nuclear. A quarta e última fase, a partir do dia 10 de maio, caracterizou-se por um acelerado decréscimo das taxas iniciais de liberação de material, em razão da introdução de nitrogênio líquido nas válvulas do reator e uma segunda leva de deposição de produtos para conter o vazamento.

Nos dez dias que seguiram a explosão inicial, formou-se um rastro de radioatividade em forma de nuvem que alcançou diversos países nas direções oeste e norte, conduzidos pela força do vento. Segundo dados do relatório NUREG-1250, de 1988, elaborado pela Comissão Regulatória Nuclear dos Estados Unidos (USNRC), níveis de radiação em direção ao norte da Ucrânia, nas proximidades da Bielorrússia e de partes da Escandinávia, em distâncias de 5 a 10 quilômetros e uma altitude de 200 metros, alcançaram cerca de $1.000 \mathrm{mR}$ por hora (unidade de radiação absorvida), no dia 27/04, e 500 mR, em 28/04. Áreas da Polônia passaram também a presenciar radioatividade, em uma dispersão progressiva que atingiu o Reino Unido, por volta do dia 02, e o sul da Europa, em países como Alemanha, Itália, Grécia e o Leste Europeu, até dispersar no oceano Atlântico, nos dias que seguiram. 
Tabela 6.2: Liberação total de material radioativo do acidente de Chernobyl (1986)

Porcentagem

Elemento Meia-vida (dias) $\quad$ Inventário (MCi) 1 liberada

\begin{tabular}{|c|c|c|c|}
\hline $\mathrm{Kr}-85 \ldots .$. & 3,930 & 0.89 & 100 \\
\hline Xe-1 $33 \ldots .$. & 5.27 & 46 & 100 \\
\hline $1-131 \ldots \ldots$. & 8.05 & 35 & 20 \\
\hline Te-132 ..... & 3.25 & 8.6 & 15 \\
\hline Cs-134 ..... & 750 & 5.1 & 10 \\
\hline Cs-137 ..... & $1.1 \times 104$ & 7.8 & 13 \\
\hline Mo-99 ...... & 2.8 & 130 & 2.3 \\
\hline $\mathrm{Zr}-95 \ldots . .$. & 65.5 & 119 & 3.2 \\
\hline $\mathrm{Ru}-103 \ldots .$. & 39.5 & 111 & 2.9 \\
\hline $\mathrm{Ru}-106 \ldots .$. & 368 & 54 & 2.9 \\
\hline Ba-140 ..... & 12.8 & 78 & 5.6 \\
\hline Ce-141 ..... & 32.5 & 119 & 2.3 \\
\hline Ce-144 ..... & 284 & 86 & 2.8 \\
\hline Sr-89 ....... & 53 & 54 & 4.0 \\
\hline Sr-90 ...... & $1.02 \times 104$ & 5.4 & 4.0 \\
\hline Np-239 ..... & 2.35 & 3.4 & 3 \\
\hline $\mathrm{Pu}-238 \ldots . .$. & $3.15 \times 104$ & 0.027 & 3 \\
\hline $\mathrm{Pu}-239$..... & $8.9 \times 106$ & 0.023 & 3 \\
\hline $\mathrm{Pu}-240 \ldots .$. & $2.4 \times 106$ & 0.032 & 3 \\
\hline $\mathrm{Pu}-241 \ldots .$. & 4,800 & 4.6 & 3 \\
\hline $\mathrm{Cm}-242 \ldots$. & 164 & 0.7 & 3 \\
\hline
\end{tabular}

1 Calculado conforme prescrito por especialistas soviéticos

Fonte: International Nuclear Safety Advisosy Group. Agosto, 1986, GLC (SPL.I)/3 AIEA in:Report NUREG-1250 rev. 1, U.S. Government Printing Office, Washington, DC, 1988. (tradução livre do autor)

Os efeitos do acidente de Chernobyl para a saúde das populações envolvidas e para o meio ambiente ainda são correntemente avaliados e objeto de grandes controvérsias (RAMANA, 2006:1743-4). Estima-se que ao menos 6000 indivíduos 
foram envolvidos diretamente como "liquidators" para conter a propagação do acidente e nos trabalhos de limpeza e ações de emergência, sendo os mais afetados (NEA, 2002). Diversas organizações intergovernamentais, pressionadas pelos países europeus, envolveram-se diretamente ou indiretamente no caso. Em 1989, a OMS expressou preocupação de que estudos científicos sobre o acidente poderiam estar equivocados, tendo em vista o acesso duvidoso da comunidade acadêmica a informações médicas préacidente, fornecidas por autoridades ucranianas à época. Por dois anos (1990-91), uma equipe multinacional composta de 200 especialistas, sob a coordenação da Agência Internacional de Energia Atômica (AIEA), realizou um estudo compreensivo sobre as consequências radiológicas e ambientais do acidente de Chernobyl.

Pesquisas subsequentes, baseadas em registros nacionais ucranianos, russos e bielorrussos, apontaram para um milhão o número de indivíduos direta e indiretamente afetados pela radiação nos anos seguintes, com larga detecção de câncer de tireóide. O Comitê Científico das Nações Unidas sobre os Efeitos da Radiação Atômica (UNSCEAR) informou que a dose de radiação média devido ao acidente, absorvida diretamente por indivíduos em áreas de controle estrito, entre 1986 e 2005, foi de 31 $\mathrm{mSv}$ (unidade usada para dar uma avaliação do impacto da radiação ionizante) sobre os seres humanos. Embora informações exageradas tenham sido publicadas nos últimos anos sobre estimativas do número real de mortes, a própria UNSCEAR reconheceu a imprecisão dos dados e uma carência de base científica. 
Fig. 6.14: Mapa de deposição de radionuclídeos

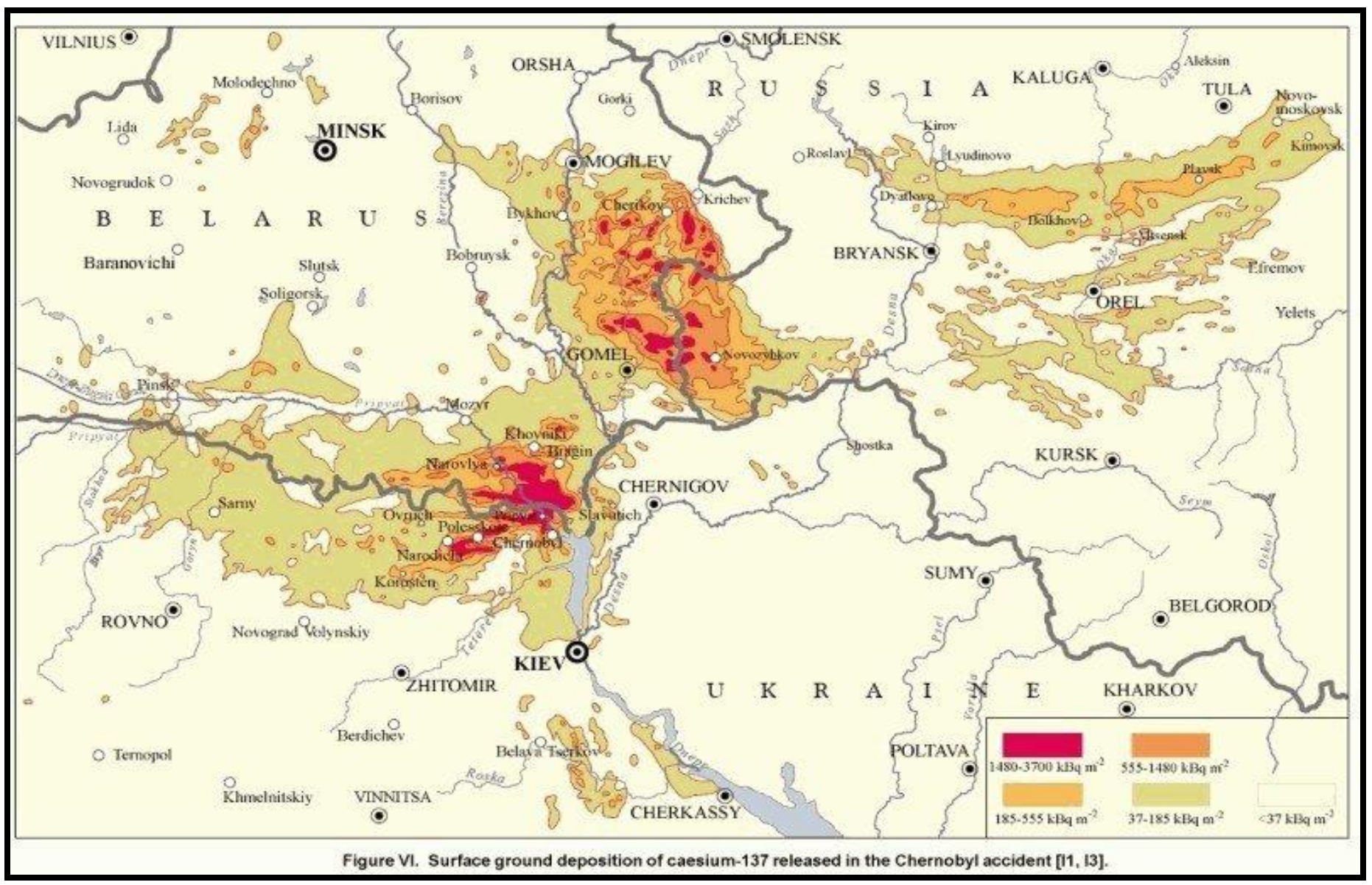

Fonte: UNSCEAR (acesso em 15/08/2013) 
Um trabalho progressivo foi realizado pela comunidade internacional com o objetivo de encerrar as atividades da central nuclear, o que ocorreu em dezembro de 2000, ao se desativar o último reator. Na década de 1990, cerca de US\$ 400 milhões foram despendidos no intuito de incrementar a segurança dos reatores remanescentes, após o encerramento das operações dos reatores 1 e 2. Os trabalhadores do complexo foram realocados para a cidade de Slavutich, a $30 \mathrm{~km}$ da planta, devido à evacuação completa de Pripyat. Após o anúncio, em 1995, do encerramento de dois outros reatores, assinou-se acordo entre Ucrânia e países do G7 para condução da operação. O reator 4, responsável pelo acidente, encontra-se hoje envolto em uma capa protetora de concreto. Um novo projeto, conhecido como "New Safe Confinement" (NSC), deverá ser concluído até 2016. A construção hermeticamente selada permitirá que engenheiros desmantelem a estrutura do Complexo remanescente de 1986 e capacitará a remoção de materiais radioativos com a menor utilização possível de recursos humanos.

Passados quase trinta anos da catástrofe, pode-se questionar o que se aprendeu com o acidente e quais suas consequências para as políticas públicas sobre energia nuclear, assim como o que foi feito para que gerações futuras não venham a conhecer de novo o flagelo de tragédias de natureza atômica. No plano tecnológico, as mudanças foram positivas para o incremento dos padrões de segurança dos reatores construídos pós-Chernobyl. Alterações foram realizadas de modo a superar deficiências nos atuais reatores ainda em operação. Uma maior cooperação entre cientistas e engenheiros europeus e russos pautou o contato bilateral, antes sob o mantra do distanciamento da Guerra Fria. Desde 1989, cerca de mil engenheiros nucleares da ex-URSS visitaram instalações nucleares ocidentais e multiplicaram-se os programas de intercâmbio entre profissionais da área.

Feitas essas considerações de caráter histórico-factual, podemos observar, do ponto de vista jurídico e político, que o acidente nuclear de Chernobyl parece ser uma situação clássica em que os princípios das obrigações positivas estariam presentes, pela adequação de suas características aos critérios previamente estabelecidos no decorrer da pesquisa. Deve-se considerar que acidentes nucleares como o da Ucrânia demonstram para a comunidade internacional a inadequação entre os ordenamentos jurídicos nacionais e os preceitos da PIMA. É correta nesse ponto a observação de Teclaff (1974), 
uma década antes do acidente na Ucrânia, de que qualquer recurso legal com relação aos danos causados por acidentes nucleares transfronteiriços deveriam vir primordialmente do DI. Com efeito, ressalte-se que, anos após o acidente nuclear, diversos tratados ambientais foram ratificados, assegurando maior acesso à informação e responsabilidade dos estados no movimento transfronteiriço de elementos perigosos, o que foi inclusive retomado no Protocolo de Cartagena relativo ao comércio e transporte de organismos vivos modificados de 2001. ${ }^{218}$ Falk (1975:403), por seu turno, questiona se decisões políticas como as que se relacionam a iniciativas que põem a comunidade internacional em risco, em especial que tratem de iniciativas de alcance transfronteiriço, podem ser deixados dentro da "province of national jurisdictional determination".

Malone (1987) faz parte do rol de autores que, à época do acidente, buscou entender a dinâmica do DI quanto à responsabilização das potências-nucleares em acidentes da mesma natureza. A autora argumenta para o que já foi tratado em outra parte da pesquisa: a existência de um vazio conceitual em relação a desastres ambientais de efeitos transfronteiriços e a legitimidade/legalidade de intervenções. Malone referiase, à época, à responsabilidade do Estado naquelas situações de desastres ambientais transfronteiriços envolvendo energia nuclear. A autora sugeriu fosse realizada então uma análise bifurcada a fim de saber qual a responsabilidade do governo soviético com o acidente, ou então de se conhecerem os avanços do DI quanto a um suposto "direito" ou "obrigação" de o causador da catástrofe aceitar assistência humanitária dos países afetados. ${ }^{219}$ E nesse ponto encontramos o paralelo com os desafios atuais, a respeito dos desastres ambientais e a aplicabilidade das obrigações positivas.

Tais casos considerados "clássicos" no DI por pautarem a criação do ordenamento jurídico e regimes relacionados aos princípios sobre a responsabilidade estatal, em situação de poluição transfronteiriça - já reconhecidos inclusive pelos preceitos da Conferência de Estocolmo (sobre a responsabilidade do Estado) e da

\footnotetext{
${ }^{218}$ Cf. Anexo I.

219 A autora apresenta um arrazoado jurídico interessante, que vale aqui mencionar: " 1 . A State has an absolute duty to protect against transational harm from ultrahazardous activity conduct within its territory and is strictly liable for any resultant damage. 2. A State has a duty to use reasonable care to protect States against extraterritorial harm from acts committed within its territory and failure to do so renders the State responsible for damage incurred as a result of negligence or intentional harm. 3. A State is liable if it permits transboundary pollution from within its territory to exceed that which its neighbors may be reasonably expected to endure." (1987: 214)
} 
CNUMAD (1992) -, tendem a oferecer respostas limitadas sobre casos de desastres ambientais que ponham em risco o território e a população de um Estado contíguo de onde se originou o dano. Diante dessa lacuna, ainda premente e atual, diversos mecanismos tentam suprir a justificativa das "intervenções verdes" em desastres ambientais.

Apesar dos preceitos codificados na Carta, diversas são as interpretações que buscam "brechas" para legitimar as intervenções. Se tomarmos a tabela de conceitos apresentada no tópico anterior e aplicarmos no caso de Chernobyl, notamos que cada um dos mecanismos possui uma ou várias inconsistências e buscam extrapolar o sentido conceitual que lhe fora originariamente atribuído, em dado período histórico, e por atores legítimos em foros bilaterais ou multilaterais adequados no período apreciado. Franck (2002) e Chesterman (2001) avaliam que as intervenções em socorro a vítimas de conflitos, por exemplo, não infringiriam a priori proibições legais substantivas, na medida em que se manteria uma coerência conceitual e principiológica com os ditames da Carta da ONU de não se utilizar do uso da força contra a "integridade territorial" de um Estado, tampouco sua "independência política". Embora os autores tenham tratado de intervenções humanitárias em conflitos, e não de intervenções em situações de desastres ambientais, pode-se forçar um paralelo na questão, porquanto intervenções do gênero buscariam, em última análise, salvaguardar o direito à vida, a integridade física do ser humano e demais direitos econômicos e sociais amplamente balizados pelo PIPH.

Do ponto de vista jurídico, tais argumentos não são aceitos pelo DI, atados ainda a um tradicionalismo exagerado. Eburn (2007) oferece uma interpretação extensiva das intervenções humanitárias para desastres ambientais, a nosso ver, também equivocada. O autor acredita que intervenções dessa natureza seriam mais defensáveis, em razão da ausência de conflitos armados na situação. Nesse caso hipotético, um Estado poderia escolher intervir em outro sem a utilização de forças armadas, com equipes de emergência desarmados, como organizações de defesa civil, o que não caracterizaria o "uso da força" proibido pela legislação internacional, no entendimento de que "armed force” estaria limitada à presença de pessoal armado. Vale observar que esse artifício já fora tentado ao longo da historia, porém Estados tendem a rejeitar até mesmo ONGs reputadas, como o Médecins Sans Frontières, Oxfam International, CICV, entre outras. 
Logo, não é o uso de armas o ponto problemático, e sim a presença alienígena sem o consentimento do Estado.

Em Chernobyl, todos os elementos de uma proposta das obrigações positivas parecem estar presentes, o que nos permite reavaliar as discussões sobre eventual legítima defesa e estado de necessidade e aplicar o mecanismo sobre uma situação hipotética de grave transbordamento do dano transfronteiriço oriundo da proliferação da radioatividade descontrolada. Entendemos que, na situação em apreço, não podemos classificar eventual reação interventiva do Estado atingido como de legítima defesa, por inexistir um "ataque armado", caracterizado por uma agressão injusta. Na defesa de desastres ambientais, não há inicialmente possibilidade de se prever o nível dos meios proporcionais a serem utilizados, pois não necessariamente o bem tutelado ameaçado pode resistir à ameaça. Outra diferença refere-se ao dever legal de enfrentar o perigo, inexistente na legítima defesa, porquanto há a escolha do agente de não defender-se e recorrer a instâncias multilaterais mais amplas na defesa de seus direitos.

No caso do acidente de Chernobyl, caso um Estado interviesse na Ucrânia a fim de salvaguardar sua população, buscando justificar a agressão territorial daquele país sob o instituto da "necessidade", haveria aí uma diferença sutil com relação às obrigações positivas. A terminologia, embora convincente, guarda em si algumas diferenças das obrigações positivas, que descartam aquele horizonte explicativo: o estado de necessidade não parece resguardar-se do aspecto temporal de atualidade do perigo, tão somente sua gravidade e iminência. Pode-se considerar como real a iminência de um dano onde há certeza de que deverá ocorrer, mas desvela-se um campo de pressuposição perigoso com tendência a prejudicar sobremaneira as relações bilaterais dos Estados envolvidos (nos mesmos moldes do controverso conceito de legítima defesa preventiva).

Nesse sentido, as obrigações positivas tendem a ser mais legítimas por serem um instituto de especial exceção, de maior intensidade que o estado de necessidade. A diferença entre a excepcionalidade nos dois casos encontra-se na dicotomia subjetividade/objetividade da determinação do agir em uma situação real, atual ou iminente. Muito se utilizou da necessidade como uma extensão da legítima defesa, uma complementação à doutrina da autodefesa, a fim de justificar violações à soberania de 
outros Estados, como no caso da ocupação de Luxemburgo e da Bélgica por forças alemãs, em 1914, onde a Alemanha aventou estado de necessidade para repelir eventual ataque de forças francesas pelo território daqueles dois países. ${ }^{220}$

Assim, em uma possível intervenção de países europeus, como França e Itália, ou mesmo a Grã-Bretanha, que chegou a ser afetada pela convulsão que abalou Chernobyl, seria melhor qualificar a ação como mais um caso a exigir a aplicação de princípios pautados nas obrigações positivas daqueles Estados para com seu dever de responsabilidade emanado de sua soberania.

Utilizar-se de critérios alienígenas de viabilidade jurídica duvidosa tende a prejudicar o debate e deslegitimar os institutos tradicionalmente aceitos no direito internacional de excludentes de ilicitude. As obrigações positivas, em casos de desastres ambientais, parecem uma proposta mais sensata e viável, tendo em vista suas características inovadoras e seus critérios mais específicos que pautam a atuação estatal, em situações cuja previsibilidade é dificultada.

Um estudo comparativo com outros acidentes ambientais contribui para sedimentar a análise em tela e efetivar uma discussão mais profícua. Propomos a seguir o caso do acidente nuclear na central de Fukushima-Daiichi, no Japão, ocorrido em 11 de março de 2011. Esse desastre reveste-se de especial peculiaridade, em razão de sua origem natural (tsunami), para depois desdobrar-se em uma situação de desastre tecnológico. Além disso, as obrigações positivas são aplicadas não na contiguidade geográfica transfronteiriça imediata, mas na ideia de transbordamento da crise para além de seu entorno (fronteira imaginária), incluindo um dos atores estatais mais sensíveis da atualidade, a China. ${ }^{221}$ Neste sentido, vale considerar, igualmente, avaliar a reação chinesa a respeito do acidente de Fukushima-Daiichi.

Ao contrário de Chernobyl, não haveria impedimentos mais efetivos, dada a supremacia militar chinesa na região, para contenção de uma intervenção em território japonês, caso houvesse uma proliferação incontrolável de material radioativo a atingir canais fluviais tradicionais, como o Mar da China Oriental, e pusesse em grave e atual perigo a população chinesa. O contexto era propício para que a China, utilizando-se do

\footnotetext{
${ }^{220}$ Cf. Report do CDI (1980), UN Doc. A/35/10, 91, fl. 126.

${ }^{221}$ Sobre um panorama a respeito das relações regionais e aspectos da diplomacia da República Popular da China, cf. Becard, Danielly Ramos (2014).
} 
argumento das "obrigações positivas", interviesse no Japão caso este demonstrasse negligência, incapacidade ou incompetência na gestão do acidente. Não discutiremos como se daria tal intervenção e nem sua proporcionalidade, apenas a decisão inicial chinesa. Se do ponto de vista teórico parece lógico que, diante da gravidade do acidente e dos danos contra seu território, a China deveria intervir, do ponto de vista da prática da política internacional, ao contrário, seria absolutamente proscrita e temerária tal decisão, por questões de geopolítica, haja vista que o Japão está sob proteção dos EUA desde o final da II Guerra, e a China é, manifestadamente, a maior ameaça da atualidade para os EUA.

Conforme os desdobramentos do acidente, o Grande Terremoto do Leste do Japão (designação oficial) ocorreu às 14h26m do dia 11 de março de 2011, quando um forte tremor de terra de magnitude 9.0 abalou o território japonês, com epicentro a 130 km da costa leste da península de Oshika, na reião de Tohoku. ${ }^{222}$ Ao terremoto seguiuse um tsunami que iria alterar sobremaneira a relação dos japoneses com a energia nuclear e seria considerada a pior catástrofe desde o acidente com a central de Chernobyl. O epicentro dos tremores ocorreu a $130 \mathrm{~km}$ ao leste da cidade costeira de Senday, em Miyagi, na ilha de Hoshu. O tsunami inundaria uma área de $560 \mathrm{~km} 2 \mathrm{e}$ resultaria na morte de quase 20.000 indivíduos. ${ }^{223}$

O acidente ocorreu após uma onda de quinze metros atingir a central elétrica nuclear e desativar o suprimento de energia para resfriamento de três reatores. No momento da catástrofe, 11 reatores em quatro plantas estavam em operação, sem apresentar danos após o encerramento automático das atividades (as unidades operacionais encerradas foram a Fukushima-Daiichi, 1, 2, 3 e Fukushima-Daini 1,2,3,4,

\footnotetext{
${ }^{222}$ Os créditos dos parágrafos sobre o acidente nuclear de Fukushima Daichii pertencem ao relatório "Fukushima Accident" (Agosto/2014), da World Nuclear Association, em http://www.worldnuclear.org/info/safety-and-security/safety-of-plants/fukushima-accident/ (acesso em 26/08/2014), complementados com informações extraídas de "Sismo e Tsunami de Tohoku de 2011", em pt.Wikipedia (com referências).

${ }^{223}$ A título de comparação, o sismo de Kobe, ocorrido em 1995, e o furacão Katrina, nos Estados Unidos, em 2005, causaram cerca de 6.400 e 1.800 mortes, respectivamente. Nada comparável, no entanto, ao terremoto que abalou o Haiti, em 2010, que resultou na morte de mais de 300.000 pessoas. (SCOCCIMARO, 2013: 439). O Relatório do IFRC traz dados aproximados, divergindo apenas no caso haitiano. Apresenta também outros, ao ressaltar como os desastres naturais mais severos, nos últimos anos, o tufão Bopha, ocorrido nas Filipinas, matou cerca de 1.900 pessoas (2013), enquanto o tsunami no Oceano Índico, em 2004, resultou em 226.408 vítimas.
} 
a Onagawa-Tohoku 1,2,3, e a Tokai-Japco). Alguns problemas passaram a ocorrer, no entanto, em reatores da Fukushima-Daiichi.

Apesar de operários da Tokyo Eletric Power (TEPCO) tentarem isolar o vazamento de água radioativa das usinas de Fukushima-Daiichi, despejos de radioatividade foram amplamente encontrados na região. A operadora da central nuclear chegou a informar que quase 12.000 toneladas de água radioativa contendo iodo-131 e césio-137 continuavam a ser despejadas no mar, em uma área somente $250 \mathrm{~km}$ de distância de Tóquio. Fez-se necessário o despejo de água radioativa em razão da necessidade de esvaziamento das piscinas de armazenamento, para preenchimento de outros líquidos radioativos acumulados nas instalações dos reatores 2 e 3. Como o resfriamento falhou nos primeiros dias, as autoridades japonesas ordenaram a evacuação em um perímetro que se estendia por $20 \mathrm{~km}$ da área afetada. Com a explosão de hidrogênio na unidade 1 , material radioativo foi detectado nas proximidades da planta nuclear, espalhada por via eólica. Em comunicado, as autoridades japonesas da Comissão para Segurança Nuclear determinaram a evacuação da população, e indivíduos abaixo dos 40 anos de idade tiveram de ingerir iodo como forma de precaução contra a ingestão indevida de iodo-131, provavelmente por meio de produtos lácteos. $^{224}$

\footnotetext{
${ }^{224}$ Idem, ibdem.
} 
Fig. 6.15: Mapeamento do Tsunami de março de 2011 - Japão

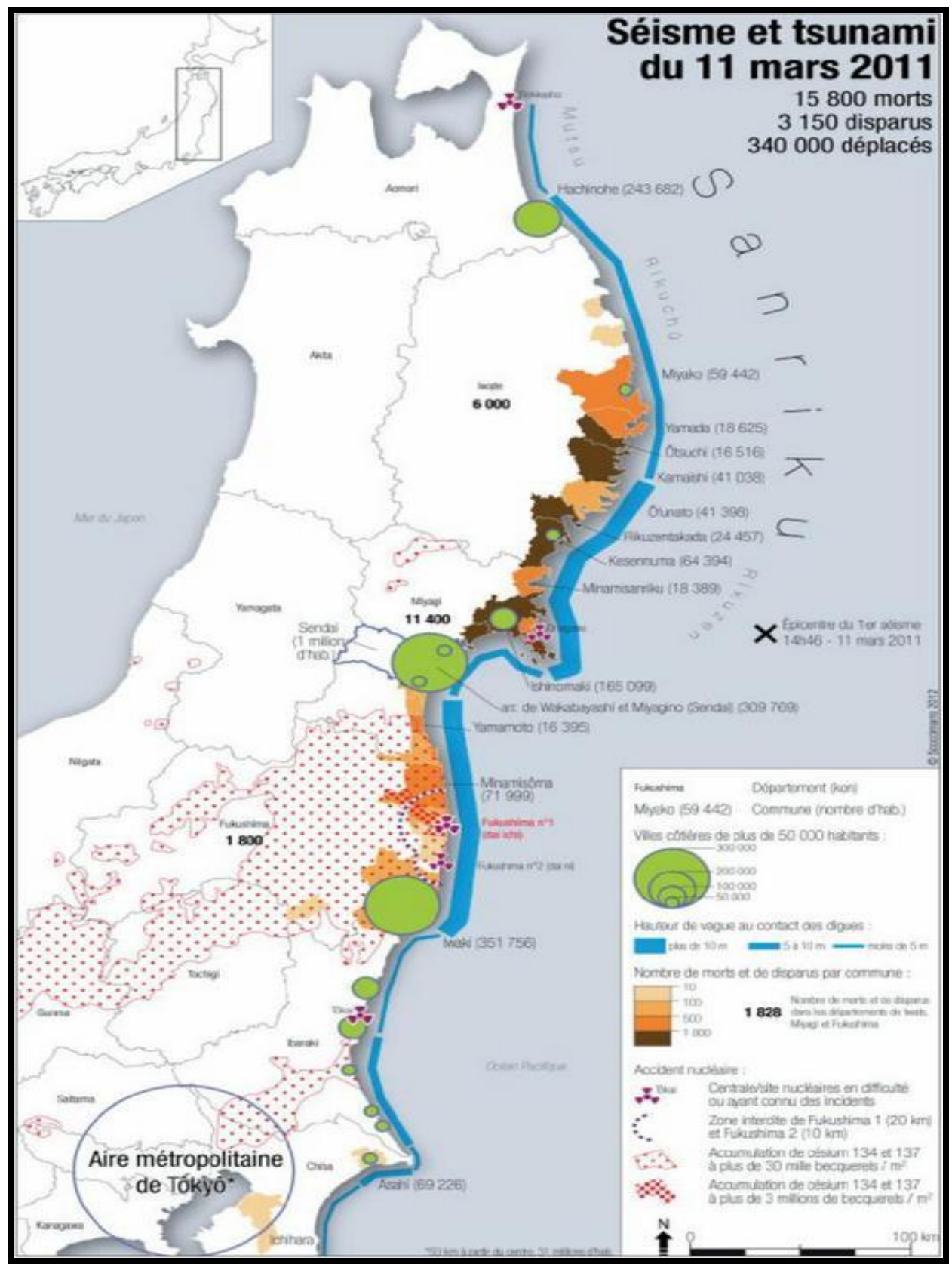

Fonte: SCOCCIMARRO (2013: 440)

Meses após o acidente começaram os trabalhos de recuperação da planta, com a construção de uma capa protetora em uma das unidades, a fim de evitar a liberação de mais material radioativo pela ação do vento. Uma equipe multinacional composta de integrantes da AIEA permaneceu por uma semana no local, para preparar relatório circunstanciado sobre a situação. A Dieta japonesa estabeleceu uma comissão de 
investigação para avaliar as causas do incidente e propor o reexame da organização administrativa e do quadro regulatório da segurança nuclear no país. No relatório oficial, publicado em julho de 2012, ${ }^{225}$ a comissão teceu fortes críticas ao governo e aos operadores da central nuclear, tendo apontado como causas do acidente sua negligência. O documento citou também que técnicos da TEPCO, desde 2006, eram cientes da (in) capacidade técnica da planta nuclear de Fukushima-Daiichi em caso de um blackout resultante de tsunamis. Afirmou que, na resposta inicial ao tsunami, a falta de preparo para conter o acidente somou-se à ausência de planejamento e treinamento no intuito de mitigar a severidade do desastre nuclear.

Fig. 6.16: Mapa da nuclearização do território japonês

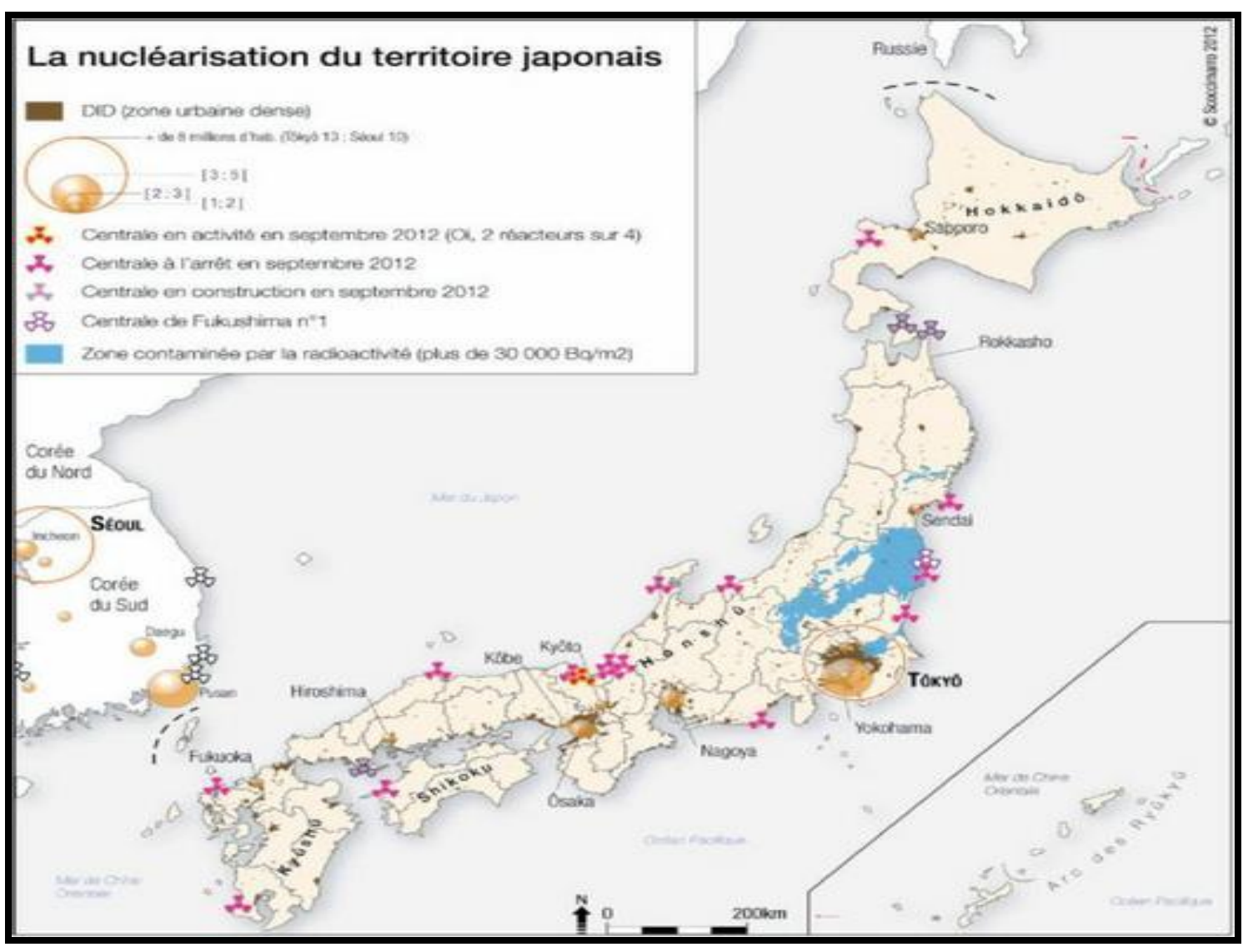

Fonte: SCOCCIMARRO (2013: 440)

O tsunami, seguido do acidente na central nuclear de Fukushima-Daiichi, revelou ao mundo a debilidade institucional do Japão em enfrentar catástrofes daquela

225 Cf. The National Diet of Japan. The Official Report of the Fukushima Nuclear Accident Independent Investigation Commission. Executive Summary, 2012. pp. 12-14. 
natureza (SCOCCIMARRO, 2013: 452). A Agência de Segurança Industrial e Nuclear (NISA) do país foi criticada por não ter instruído a companhia TEPCO a preparar-se para casos de desastres ambientais. O relatório informou que os técnicos se depararam com planos e manuais operativos de emergência defasados e com indícios de negligência no preparo da evacuação da população e compartilhamento de informação em situações de acidentes nucleares. Diversos outros documentos pautaram investigações independentes ou governamentais, com sugestões para a melhoria das práticas dos operadores dos complexos nucleares. Em junho de 2011, o governo japonês submeteu à AIEA texto compilado pela força-tarefa emergencial que atuou para conter o desastre, reconhecendo inadequações técnicas na utilização do reator. Logo depois, um relatório independente do Centro para o Avanço de Sistemas de Energia Nuclear do Massachussets Institute of Technology (MIT) levantou uma série de questões sobre a radiação despejada no meio ambiente. A TEPCO, por sua vez, publicou relatório interno apurando as causas do acidente.

O governo japonês admitiu, à época, por meio da NISA, seu despreparo para conter acidentes nas proporções do ocorrido em Fukushima-Daiichi. A Central de Resposta à Emergência Nuclear, no âmbito do Gabinete do Primeiro-Ministro, anunciou que os danos teriam sido maiores que os previstos. As informações iniciais que apontavam para o vazamento de 370 mil terabecquerels (unidade de medida de radioatividade) foram aditadas posteriormente com o acréscimo em quase $100 \%$ do valor inicial declarado (770 mil terabecquerels).

Das consequências do acidente de Fukushima-Daiichi para o contexto regional asiático talvez a psicológica tenha sido a mais notável. $\mathrm{O}$ acidente resultou em uma reformulação da política energética na Ásia, devido à pressão exercida pela opinião pública sobre seus líderes (KAWATO, 2013: 472). Alguns consideram que a reação inicial, e que uma possível moratória nos projetos que envolvam a energia nuclear na região, tenha sido um tanto exagerada. Ponderações de ordem mais econômica são vistas como responsáveis pela necessidade de mais energia elétrica produzida por usinas nucleares e outras fontes alternativas, parte da solução para o abastecimento das indústrias. Nesse contexto, Japão, China, Índia e Coréia do Sul reavaliaram seus programas e chegaram a conclusões distintas sobre a continuidade de seus programas 
nucleares. ${ }^{226}$ Vale notar que a região asiática é uma das mais propensas à ocorrência de desastres ambientais graves. Sua vulnerabilidade advém da localização geográfica desprivilegiada. Algumas áreas, como o arquipélago japonês, encontram-se mais expostas aos riscos de catástrofes por sua proximidade a vulcões ou falhas geológicas, adjacentes a zonas sísmicas. Conforme se observa na figura (6.17), a título de ilustração, podemos observar a ocorrência de desastres naquela região:

226 Apenas a título de informação, sem maiores interesses para a nossa pesquisa, vale notar que a Índia, que também mantém ambições nucleares, não somente pelas dificuldades em termos de gerar energia para uma população de mais de um bilhão de habitantes, mas pelas disputas político-militares com o seu rival vizinho, o Paquistão, dá mostras de não recuar em seus objetivos de fortalecimento da nuclearização. A catástrofe japonesa teve reflexos nas opiniões já alimentadas por céticos de que o território indiano, a exemplo do japonês, é fortemente vulnerável a desastres naturais como terremotos e tsunamis. Outra nação asiática que mantém firme as operações em busca da segurança energética nuclear é a Coréia do Sul. Uma das razões consiste na natural escassez energética territorial da península, cuja capacidade atual não acompanha a solidez da economia sul-coreana, pela indústria cada vez mais ávida por fontes de energia para lidar com o crescimento da produção voltada para o exterior. Por outro lado, a indústria sulcoreana de equipamentos da área, de que serve como exemplo a Korea Eletric Power, Samsung e Hyundai, começam a partir para novos mercados e competir com empresas já estabelecidas no mercado global como a Westinghouse e a General Eletric. Países do Oriente Médio, como os Emirados Árabes e a Jordânia, e um pouco além a Turquia são mercados promissores para os equipamentos da indústria sulcoreana de energia nuclear. Cf. Economist Intelligence Unit. Aftershocks: Nuclear Power in Asia after Fukushima. Pubished November, 2011. Disponível em: http://www.energyrealities.org (acesso em 10/03/2013) 
Fig. 6.17: Mapeamento da ocorrência de desastres naturais na Ásia

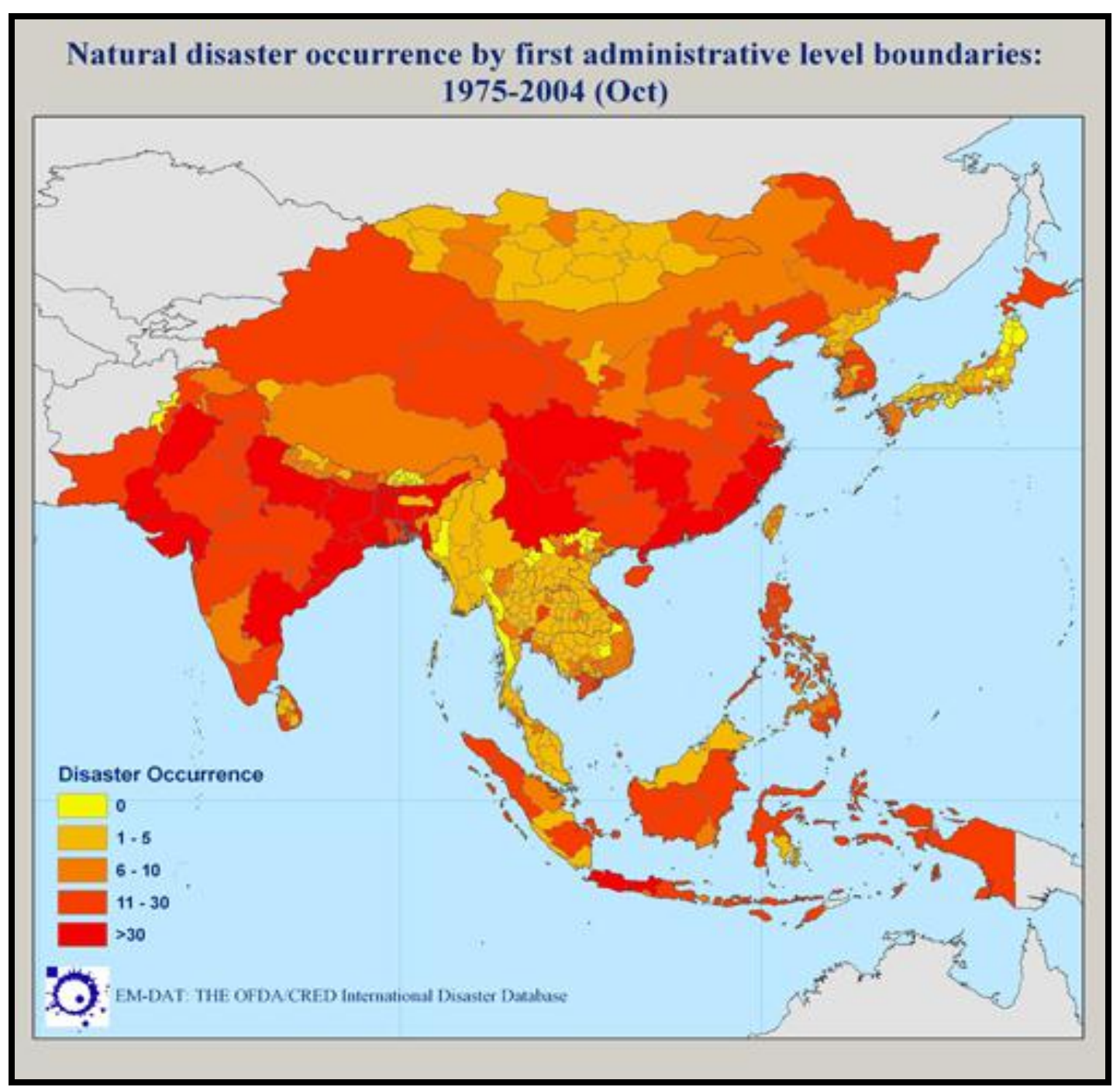

FONTE: EM-DAT- Centre for Research on the Epidemiology of Disasters (CRED)

No Japão, os danos causados pelo acidente de Fukushima-Daiichi não foram somente físicos, seus efeitos prolongam-se ainda hoje e o país teve de rever sua política nuclear, programada para gerar metade da energia ali produzida até o ano de 2020. Em setembro de 2011, o recém-empossado Primeiro-Ministro Yoshiniko Noda ainda tentou persuadir a opinião pública japonesa de que o crescimento econômico do país dependeria inexoravelmente da continuidade da produção de energia nuclear. Foi uma decisão arriscada, que ocorre em paralelo à rejeição crescente às diretrizes da TEPCO com relação aos padrões de segurança aplicáveis. Como demonstravam as pesquisas de opinião pública à época, quase $70 \%$ do eleitorado japonês exigiam o retorno à política 
do predecessor de Noda, Naoto Kan, que buscava eliminar de vez a energia nuclear do país por fontes alternativas. ${ }^{227}$

Nenhum outro país sentiu mais fortemente os efeitos do desastre ambiental japonês e seus reflexos do que a China. Segundo se noticiou amplamente, na época da catástrofe de Fukushima-Daiichi, o governo chinês interrompeu de imediato as obras em construção em seu território logo após o evento, tendo exigido um estudo compreensivo das situações de seus licenciamentos. A preocupação das autoridades chinesas era que a população buscasse questionar o programa nuclear do país e iniciasse demonstrações públicas de insatisfação com a política de segurança energética conduzida pelo Partido Comunista. ${ }^{228} \mathrm{O}$ então Primeiro-Ministro Wen Jibao criou, no mesmo período, um comitê especial ad hoc no intuito de reavaliar o programa de segurança energética nuclear chinesa, de forma a rever projetos em andamento na área. $^{229}$

Meses após o acidente, e diante da dificuldade do governo japonês em conter o derramamento de água contaminada no oceano, a China ainda demonstrava preocupação. Autoridades do país diziam-se "chocadas" em saber que a situação de Fukushima-Daiichi não aparentava estar sob controle. Em 2013, dois anos depois, o governo chinês ainda buscava, no âmbito das Nações Unidas, que o Japão fornecesse informações "acuradas" sobre os procedimentos adotados para lidar com a contínua liberação de materiais tóxicos e radioativos da central nuclear de Fukushima-Daiichi. O Vice-Representante da China na ONU, Wang Min, em reunião na AIEA, afirmou que seu governo seguia "de perto" as contramedidas adotadas pelo governo japonês para resolver a crise de Fukushima-Daiichi. ${ }^{230}$

\footnotetext{
${ }^{227}$ Idem.

${ }^{228}$ Cf. Gregory Kulacki, China project manager and senior analyst. "China Reacts to Fukushima" March/2011. http://allthingsnuclear.org/china-reacts-to-fukushima/ (acesso em 31/08/2014)

${ }^{229}$ No público, dias após a notícia do vazamento de material radioativo nas águas do pacífico na central nuclear de Fukushima, houve apreensão em áreas costeiras, eventuais alvos da radiação. O Escritório de Proteção Ambiental chinês publicava diariamente resultado de atividades de monitoramento pelo país, como forma de manter a população chinesa informada sobre o nível de radiação. (KULACKI, 2011).

${ }^{230} \mathrm{Cf}$. China demands 'accurate' nuclear account from Japan on Fukushima - Agence France-Presse at the United Nations - Wednesday, 06 November, 2013- Disponível em: www.scmp.com/ (acesso em 31/08/2014).
} 
Diferentemente de Chernobyl, o acidente de Fukushima-Daiichi pareceu distante da censura de informação inicial das autoridades soviéticas dos anos 1980. O avanço das tecnologias de informação uma geração depois do acidente de Chernobyl, tem levado os Estados a conhecer instantaneamente todos os contornos de catástrofes ambientais que assolam a modernidade, de que são exemplos os tsunamis no Sudeste Asiático e as tragédias humanas que atingem regiões distantes, da ilha de Tuvalu ao leste da costa japonesa. A preocupação das autoridades chinesas é genuína e vem ao encontro dos parâmetros que pautam nossa pesquisa. Alguns questionamentos contribuem para buscar conhecer a reação da China diante de um desastre ambiental que poderia ter atingido plenamente seu território e posto em risco a saúde física de sua população.

Em exercício de análise, surge a pergunta sobre se, na situação hipotética descrita, mas de forte probabilidade de ocorrência, a atitude da China de intervir em território japonês sem o consentimento daquele Estado poderia ser justificada com fundamento no princípio das obrigações positivas. Em outras palavras: há uma obrigação positiva da China de intervir no território japonês, no intuito de buscar conter efetivo e irreparável dano ambiental à própria população e território, diante da inação ou impossibilidade imediata de resposta curativa do governo japonês, que revelou à comunidade internacional sua inabilidade - institucional e técnica - de lidar com desastres ambientais da proporção e gravidade como o da central de Fukushima-Daiichi, segundo as próprias autoridades japonesas?

Os efeitos do tsunami que atingiu a costa japonesa despertaram de imediato o mundo novamente para o terror nuclear e levaram líderes a se questionarem da viabilidade de projetos dessa natureza. Na China, as consequências poderiam ter sido imprevisíveis, a exigir uma pronta resposta das autoridades no sentido de conter a grave e real catástrofe. A exemplo de Chernobyl, parece não haver um critério subjetivo de escolha entre intervir ou não, em razão da obrigação positiva das autoridades chinesas de conter o dano na costa chinesa.

Diante da inadequação terminológica de se utilizar conceitos como legítima defesa e estado de necessidade para fundamentar eventual intervenção da China no 
território japonês, para enfrentar um grave e atual perigo a ameaçar sua população e território, onde não houvesse outra alternativa razoável que não intervir para buscar conter a propagação do dano na fonte, as obrigações positivas parecem uma vez mais como um elemento explicativo válido para casos específicos de intervenções ambientais. Neste sentido, a resposta seria positiva, pois haveria sim uma obrigação positiva de Pequim de tomar as medidas necessárias para ajudar a conter o dano na fonte, com ou sem o consentimento de Tóquio. Seria esperado também que a comunidade apoiasse a decisão de intervenção e contribuísse para o sucesso da operação por meio de algum tipo de ajuda e monitoramento "neutro" para evitar eventuais atritos entre o interventor e o Estado-alvo da intervenção. Haveria a expectativa de que a comunidade internacional tomasse o caso como de segurança coletiva de "todos contra um"? Revela-se aí uma questão polêmica e complexa, que foge ao escopo desta pesquisa.

\subsection{Considerações finais}

Reclamar ou intervir? Qual a obrigação de um Estado que sofre danos oriundos de um desastre ambiental no território de seu vizinho? Foi esse problema que a presente tese buscou contextualizar, a partir da análise da Ordem Global descrita por Andrew Hurrell e da Ordem Ambiental Internacional, por Wagner Ribeiro. Navegando pelos quadrantes do direito e da política internacional, respondeu à pergunta com a proposta de "obrigações positivas" do Estado, fundamentadas na "soberania como responsabilidade", em face de outros conceitos como legítima defesa, estado de necessidade, segurança humana e responsabilidade de proteger, porém sem perder de vista que as querelas sobre intervenções alienígenas jamais atingiram algo semelhante a um consenso global, e que, sendo "verdes", são ainda mais controversas. Consequentemente, malgrado a gravidade do dano causado, apenas reclamar é o que se pode fazer no arcabouço político-normativo contemporâneo.

Os desafios enfrentados nas últimas décadas na ordem global, especificamente nos temas ambientais, têm tornado o debate profícuo e as análises mais refinadas tanto no direito como na política internacional. Em áreas mais específicas, como os Direitos Humanos, uma evolução conceitual inexorável ocorreu nos mais de sessenta anos que se passaram desde a criação das Nações Unidas. Um arcabouço político-institucional 
formou-se e um discurso em torno da proteção individual consolidou-se. Esse processo redefiniu o instituto da soberania para revelar uma obrigação do Estado relativa à segurança, mas ao mesmo tempo em consonância com a defesa intransigente dos seus respectivos interesses nacionais.

Nessa simbiose intrínseca às políticas estatais, reconhecemos que nossa percepção do meio ambiente é social, histórica e politicamente construída, aí incluídas as questões de segurança mais prementes que afetam as nações modernas.

A ordem global, cenário por excelência desses fenômenos, vem-se transformando compassadamente desde a derrocada da bipolaridade sistêmica, desvelando desafios à sua manutenção pacífica e construção consensuada. Os processos da globalização, que "comprimem" o tempo e a geografia, ao mesmo tempo em que favorecem a irrupção dos atores transnacionais e intergovernamentais, redefinem as ameaças tradicionais ao "securitizar" temas mais soft como as questões ambientais.

Neste sentido, Andrew Hurrell (1999) aponta que a "retração" da soberania absoluta e do princípio da não-intervenção terá sido dos mais relevantes desdobramentos da extensão da ideia tradicional de segurança e paz internacionais, consubstanciada nos princípios que regem o sistema de proteção dos direitos humanos, com seus respectivos progressos conceituais concernentes à Segurança Humana e à Responsabilidade de Proteger. Em seus corolários, como o meio ambiente, que é tributário igualmente dos preceitos que compõem essa ordem mais renovada e inclusiva, os desafios são mais amplos e têm-se privilegiado continuamente como unidade analítica a ser perscrutada nos âmbitos político e acadêmico.

A pesquisa buscou demonstrar, ainda, que a ordem global exorta a comunidade internacional a avançar rumo ao consensualismo de viés coercitivo, pautado no cumprimento efetivo do direito internacional e no respeito ao princípio do pacta sunt servanda. Alguns de seus subsistemas, como a OAI, muito embora avance paulatinamente, desde os anos 1990, para uma ordem mais global, parece carecer de preceitos básicos no DIMA, quando se trata principalmente dos desastres ambientais. Diante da inadequação daqueles mecanismos de justificativa para intervenções, como demonstrado nas situações dos desastres nucleares nas plantas de Chernobyl e 
Fukushima-Daiichi, revelando ameaças intransponíveis à integridade territorial e à vida das populações contíguas àqueles países, tende a prevalecer a ordem ambiental fundamentada na soberania do Estado e no realismo político.

Essa mudança de paradigma temático relativo à segurança alcançou a OAI, não sem deixar vazios a serem preenchidos, em um alcance incompleto ou enviesado, de acordo com os interesses de seus agentes de transformação, como os Estados que tradicionalmente direcionam os debates na seara da estrutura do "setor ambiental", para utilizarmos o conceito do Círculo de Copenhague.

A OAI vem sendo posta à prova pelas alterações sistêmicas intrínsecas à ordem global. Os instrumentos tradicionais coercitivos de cumprimento de normas e de cooperação parecem não vir acompanhando pari passu questões mais prementes das relações interestatais, como o desafio socioambiental envolvendo casos de desastres ambientais transfronteiriços, relegados nos foros multilaterais, muitas das vezes, ao debate em torno de situação mais imediatista de simples assistencialismo pós-desastres.

No tema das intervenções transparece uma natureza bicéfala. Por um lado, a questão referente às obrigações positivas possui um fundamento político-legal, moral e ético, pois se tende a aceitar a noção de que um Estado afetado por catástrofe ambiental tenha uma obrigação de proteger sua população e território. Por outro, ainda há um debate mais politizado e eloquente, ao tomarmos a realidade da política internacional, que corresponde a reanimar a perene clivagem Norte-Sul em geral, e o tema ambiental em particular. Ele ainda aponta para alvos precisos das intervenções por parte das grandes potências no intuito de se "salvar o Planeta" ou de um interesse geral em nome da humanidade. Nesse último ponto revela-se o debate atual com relação à gestão coletiva da biodiversidade, das florestas, das águas, cujos países em desenvolvimento e detentores de valiosos recursos naturais são seus principais refratários. Em outros termos, tratar de intervenções não é tarefa anódina porque a história mostra que os Estados fortes intervêm alhures, com ou sem justificativa plausível e legitimidade. Independentemente das ordens global e ambiental, os mesmos Estados podem intervir no futuro próximo em função de seus interesses particulares. 
É nesse ponto que se chega a um denominador polêmico e controverso, cuja aceitação passa pela relutância dos diversos atores que compõem a ordem global: a noção de "soberania como responsabilidade". Apesar de seus avanços na seara dos direitos humanos, o tema ainda revela uma inadequação dos mecanismos legais clássicos que instrumentalizam sua efetividade. Quando transpostos para situações de desastres ambientais transfronteiriços e eventual defesa territorial pelo instrumento interventivo, criam-se controvérsias de contornos diferenciados, conforme vimos no decorrer da pesquisa. Daí decorre o interesse da tese, qual seja, apontar critérios que permitam ao Estado responder à sua obrigação ao mesmo tempo limitando derrapagens que só o vazio político-institucional permite. Logo, é de interesse de todos os Estados estabelecerem regras mínimas em caso de desastre ambiental grave, como em situações de acidentes nucleares.

Esse vazio acadêmico e político-jurídico é indicativo dos novos desafios a serem enfrentados no contexto global do século XXI. Consideramos, assim, ter contribuído para uma maior compreensão dessa lacuna e para reviver o debate sobre as obrigações positivas relativas a desastres ambientais. Nossa proposta busca preenchê-lo, como uma abordagem viável para atuação estatal em casos específicos de desastres ambientais transfronteiriços com graves danos, haja vista a inviabilidade conceitualterminológica da legítima defesa e do estado de necessidade. As obrigações positivas respondem a um "dever" inerente próprio do entendimento da soberania como responsabilidade que recai sobre o Estado, tendo a comunidade internacional um direito de salvaguarda de valores humanitários "universais" de forma subsidiária.

Quanto a esse aspecto, embora supere o escopo deste trabalho, vale o questionamento: qual o papel futuro das Nações Unidas no resguardo de seu direito de proteção universal dos direitos humanos fundados em princípios aceitos por seus membros e instrumentalizados pelo CSNU? Essa responsabilidade marginal da comunidade internacional não pode desconsiderar a responsabilidade primária do Estado afetado, em respeito a sua soberania, nos casos ambientais, nem manter-se atrelada aos conceitos tradicionais de segurança construídos socialmente para um mundo totalmente diferente. As obrigações positivas não correspondem a uma intervenção "forçada", mas sim a uma situação que exige medidas curativas efetivas, à 
luz da extensão dos princípios humanitários, em casos bastante específicos de emergência ambiental e de graves consequências, quando o Estado gerador do dano não esteja apto a fazê-lo.

Nesse contexto, as intervenções verdes com fundamento nas obrigações positivas podem um dia adquirir proeminência na área ambiental, se levarmos em consideração que os conceitos são construídos socialmente e securitizados para acompanhar os fatos da realidade. Situações de desastres ambientais ocorrem com frequência e os Estados precisam estabelecer critérios e mecanismos claros de atuação na ordem global. O tema das intervenções verdes aqui proposto certamente não será ponto pacífico na política internacional, tampouco na estrutura normativa contemporânea, dada a complexidade inerente ao debate das intervenções. Entretanto, se pensarmos que há algumas décadas pautávamos nossas atuações pelos interesses nacionais clássicos e hoje avançamos no sentido de centralizar o indivíduo como objetivo das políticas estatais na ordem global contemporânea, há um horizonte ainda por ser desvendado, que estimula a continuidade de nossa pesquisa e traduz o otimismo pelo qual buscamos pautar o desenvolvimento deste estudo de tese. 
REFERÊnCIAS BIBLIOGRÁFICAS 


\section{Referências Bibliográficas}

ABBOT, Kenneth; SNIDAL, Duncan. Why States act through formal International Organizations. In The Journal of Conflict Resolution, Vol. 42, Issue 1 (Feb, 1998), pp 3-32.

ACCIOLY, Hildebrando. Manual de Direito Internacional Público. $14^{\circ}$ ed. São Paulo: Saraiva, 2000.

ACHARYA, Amitav. Redefining the Dilemmas of Humanitarian Intervention. Australian Journal of International Affairs. ${ }^{\circ}$ 56, 2002.

ADLER, E. Constructivism and International Relations. In: CARLSNAES, W.; RISSE, T.; SIMMONS, B. A. (eds), Handbook of International Relations. London: Sage, 2001, 95-118.

AGGELEN, J.G.C. Van. Le rôle des organisations internationales dans la protection du droit à la vie. Brussels: Story-Scientia, 1986. p. 23-38.

AGIUS, Maria. The Invocation of Necessity in International Law. Netherlands International Law Review / Volume 56 / Issue 02 / August 2006, pp 95-135.

AKANDJI-KOMBE, Jean-François. Les obligations positives en vertu de la Convention européenne des Droits de l'Homme. Précis sur les droits de l'homme, nº 7 - 2006.

ALEXANDER, Y; FRIEDLANDER, R. A. Self-Determination: National, Regional, and Global Dimensions. Boulder: Westview Press, 1980.

ALSTON, Philip; STEINER, Henry J. International Human Rights in Context. Oxford: Clarendon Press, 1996.

ALTEMANI, Henrique; LESSA, Antonio Carlos. Política Internacional: mundo em transformação (orgs.). São Paulo: Saraiva, 2006.

ALTER, Karen J.; MEUNIER, Sophie. The Politics of International Regime Complexity. Perspectives on Politics. v. 7, n. 1, p. 13-24, March, 2009.

ALVAREZ, Luis Ortega (org). Lecciones de Derecho del Meio Ambiente. Editorial Lex Nova. $4^{\mathrm{a}}$ edición, 2005.

ALVES, J. A. Lindgren. Relações Internacionais e Temas Sociais - A Década das Conferências. Brasilia: IBRI, 2001.

ANDREFF, Wladimir. Les multinationales globales. Paris: La Découverte, 1996. 
ANNAN, Kofi. Deux concepts de la souveraineté. In: Le Monde, 22 septembre 1999, pp. 20.

The Question of Intervention: statements by the Secretary-General.

New York: United Nations, 1999.

In Larger Freedom: Toward Development, Security and Human Rights for All. United Nations A/59/2005, 2005.

ARCHIBUGI, Daniele. Cosmopolitan Democracy, An Agenda for a New World Order.Cambridge, Polity Press, 1995.

ARMSTRONG, David. Law, Justice and the Idea of a World Society. International Affairs (1999), pp. 547-561.

ARON, Raymond. Paz e Guerra entre as Nações. Brasília: Editora Universidade de Brasília, 1986, 2ed.

ARRIGUI, Giovanni. O Longo século XX. Rio de Janeiro: Contraponto; São Paulo: Ed. Unesp, 1996.

ARTS, Bas. The political influence of global NGOs. Case Studies on the Climate an Biodiverty Conventions. International Books, 1998.

ART, Robert; JERVIS, Robert. International Politics: Enduring Concepts and Contemporary Issues. 7th edition, Pearson Education, Inc, 2005.

ATTAR, Frank. Le droit international entre ordre et chaos. Paris: Hachette, 1994.

AXWORTHY, Lloyd; ROCK, Alan. R2P: A New and Unfinished Agenda, Global Responsibility to Protect, 1, 2009.

AZEVEDO, Álvaro Villaça . Teoria geral das obrigações e responsabilidade civil. 11. ed. São Paulo: Atlas, 2008. v. 1. 331 p.

BACHELET, Michel. Ingerência ecológica: direito ambiental em questão. Rio de Janeiro : Instituto Piaget, 1995.

Le souverain. In : Pouvoirs, $n^{\circ}$ 67, PUF, 1993.

BADESCU, Cristina. Humanitarian Intervention and the Responsibility to Protect: Security and Human Rights. Routledge: 2010.

BADIE, Bertrand. L'État importé: Essai sur l'occidentalisation de l'ordre politique. Paris: Fayard, 1992.

.La fin des territoires, essai sur le désordre international et sur l'utilité sociale du respect. Paris: Fayard, 1995. 
Un monde sans souveraineté: Les États entre ruse et responsabilité. Paris, Presses de Sciences Po, 1999.

SMOUTS, Marie-Claude. Le Retournement du Monde. Paris: Presses de Sciences Po, 1999.

La diplomatie de connivence. Les dérives oligarchiques du système international, Paris, La Découverte, 2011, pp 274

BAN, Ki-moon. Report of the Secretary General - Implementing the Responsibility to Protect (UN A/63/677, 12 January/2009)

. Report of the Secretary General - Early warning, assessment and the Responsibility to Protect (UN A/64/864, 14 July 2011)

Report of the Secretary General - the Role of Regional and Subregional Arrangements in Implementing the Responsibility to Protect (UN A/65/877, 27 June 2011)

BANNON, Alicia. The Responsibility to Protect: The U.N. World Summit and The Question of Unilateralism. Yale Law Journal. N 115, 2006: 1157-1164.

BARBER, Rebecca. The Responsibility to Protect the Survivors of Natural Disasters: Cyclone Nargis, a case study. In: Journal of Conflict \& Security Law. Oxford University Press, 2009.

BARBOUR, Brian; GORLICK, Brian Gorlick. Embracing the Responsibility To Protect: A Repertoire of Measures Including Asylum for Potential Victims. International Law Journal/Refugee Law. 533, 535, 2008.

BARKIN, Samuel. Realist Constructivism. International Studies Review. Vol. 5, $\mathrm{n}^{\mathrm{o}}$ 3, 2003. pp. 325-342.

BARNETT, Jon et alli. Global Environmental Change and Human Security. Cambridge: MIT, 2010.

BARNETT, Michael. Social Constructivism. In: BAYLIS, John; SMITH, Steve; OWENS, Patricia (org). The Globalization of World Politics: an Introduction to International Relations. Fifth Edition. Oxford University Press, 2008. 680 pp.

BASSIR, Afsane; FRACHON, Alain. Le droit d'ingérence contre le principe de souveraineté. In: Le Monde, 21 octobre, 1999.

BAYLIS, John; STEVE, Smith. The Globalization of World Politics. An Introduction to International Relations. Third Edition. Oxford University Press, 2004. 
Oxford University Press. Fifth Edition. 2011.

et al. An introduction to international relations.

BARROS-PLATIAU, A. F.; VARELLA, Marcelo. “A percepção da soberania brasileira face a questões emergentes na agenda internacional". Carta Internacional, USP, n 96, ano 09, 2001, p.7-10, São Paulo.

; GOES, Ancelmo. Direito Internacional e Globalização face às Questões de Direitos Humanos. In: Ribeiro, M. de F. e Valério de Oliveira Mazzuoli (coords) Direito Internacional dos Direitos Humanos: estudos em homenagem à professora Flávia Piovesan coordenadores, Curitiba: Juruá, 2004, 432p, pg. 57 a 71.

; VARELLA, Marcelo; SCHLEICHER, Rafael. Meio

Ambiente e relações Internacionais: perspectivas teóricas, respostas institucionais e novas dimensões do debate. In: Revista Brasileira de Política Internacional, n. 47 (2) 2-32, 2004b.

A Legitimidade da Governança Global Ambiental e o Princípio da Precaução. In: Varella; Barros Platiau. (Org.). Princípio da Precaução. 1 ed. Belo Horizonte: Del Rey, 2004c, v. 1, p. 401-415.

Scientific Expertise and International Environmental Law: Does Legitimacy Matter? In: Conference on Global Environmental Governance, 2004d, Paris.

VARELLA, Marcelo. Ciência, Direito e Politica: Acordo Global de Governança? Revista Focus Eurolatino, Santiago, v. 2, p. 19-28, 2004e.

Política Externa Ambiental: do Desenvolvimentismo ao Desenvolvimento Sustentável? In ALTEMANI, H. e LESSA, A.C. Relações Internacionais do Brasil, Temas e Agendas. São Paulo: Saraiva, 2006, vol. 2, pg. 251 a 282 .

; VIEIRA, Priscilla Brito Silva. A legalidade da intervenção preventiva e a Carta das Nações Unidas. In: Revista Brasileira de Política Internacional. Brasília, v. 49, n. 1, 2006.

A Mudança Global do Clima no Direito Internacional para o Desenvolvimento Sustentável e o Papel do Brasil. In: SILVA, Solange Teles da; CUREAU, Sandra; LEUZINGER, Márcia. (Org.). Mudança do Clima - Desafios jurídicos, econômicos e socioambientais. 2ed.São Paulo: Fiuza, 2011, v. 2, p.

; Fernanda Viana de CARVALHO; SILVA, C. H. R. T. . A dissonância do quadro institucional brasileiro e os desafios para a Rio+20. Revista de Direito Internacional, v. 9, p. 159, 2012. 
; ORSINI, Amandine. "Emerging Countries". In:

Essential Concepts of Global Environmental Governance. Jean-Frédéric Morin e Amandine Orsini (eds.). Londres: Routledge, 2014.

BAUMAN, Zygmunt. Globalização - as conseqüências humanas. Rio de Janeiro: Jorge Zahar, 2005.

Entrevista: "Unwinnable War: an interview with Zygmunt Bauman"http://www.opendemocracy.net/debates/article.jsp?id=6\&debateId=27\&article $\mathrm{Id}=3082$. Acesso em: 02/09/2006.

BEAUD, Michel. História do capitalismo. De 1500 aos nossos dias. 2 ed. São Paulo: Brasiliense, 1989.

BECARD, D. S. R. (Org.); LACERDA, Gustavo Biscaia (Org.) ; PEREIRA, Alexsandro Eugenio (Org.) . Dossiê Relações Internacionais: Novos Cenários e Agendas. 37. ed. Curitiba: Revista de Sociologia Política, 2010.

; CASTRO, A. C. As relações China - Asean e a construção da liderança sub-regional chinesa: economia e diplomacia (1997-2010). Carta Internacional (USP), v. 8, p. 22-47, 2014.

BECK, Ulrich. Risk Society: Towards a New Modernity. SAGE Publications, 1992.

BELLAMY, Alex. Kosovo and International Society. New York: Palgrave, 2002. ; McDONALD, Matt. The Utility of Human Security: Which Humans? What Security? A Reply to Thomas \& Tow. Security Dialogue, 2002.

; WHEELER, Nicholas J.. Humanitarian Intervention and World Politics. In BAYLIS, John; SMITH, Steve; OWENS, Patricia (org). The Globalization of World Politics: an Introduction to International Relations. Fifth Edition. Oxford University Press, 2008. 680 pp.

Atrocities. Polity, 2009.

Responsibility to Protect: The Global Effort to End Mass . The Responsibility to Protect: Five Years On. Ethics and International Affairs, vol. 24, no. 2, 2010. pp. 143-169.

. Should Nations Force Aid on Others? In: Natural Hazards Observer. Vol. XXXIV, $n^{\circ}$ 3, 2010 b.

Global Politics and the Responsibility to Protect. From words to deeds. New York. Routledge ed., 2011. 
BERTHIER Serge. L'avenir de la Chine éternelle- Entretien avec Jiang Zemin. In Politique internationale - interview exclusive de Jiang Zemin, ${ }^{\circ} 75$ - printemps 1997 , 21 pgs.

BERTRAND, Maurice. A ONU. Petrópolis: Vozes, 1995.

BETTATI, Mario. Le droit d'ingérence - Mutations de l'ordre international. Paris: Editions Odile Jacob, 1996.

; KOUCHNER, Bernard. Le devoir d'ingérence: peut-on les laisser mourir? Paris: Noël, 1997.

BIERRENBACH, Ana Maria. O conceito de responsabilidade de proteger e o direito internacional humanitário. Brasília. Fundação Alexandre de Gusmão, 2011. Tese apresentada no Curso de Altos Estudos do Ministério das Relações Exteriores/Instituto Rio Branco.

BILDER, Richard. Kosovo and the 'New Interventionism': Promise or Peril? Journal of Transitional Law \& Policy. $N^{\circ}$ 9/153, 2001.

BISWAS, Ranjan Niloy. Is the Environment a Security Threat? Environmental Security beyond Securitization. International Affairs Review. Vol. XX, No. 1: Winter 2011.

BITENCOURT, Cezar Roberto. Tratado de Direito Penal - Parte Geral. 10 Edição, Editora Saraiva Código Penal Brasileiro, RT, 2009.

BOBBIO, Norberto et al. Dicionário de Política. $2^{\mathrm{a}}$ ed. Brasília: Ed. Universidade de Brasília, 1986.

ed. Brasília: UNB, 1997.

A teoria das formas de governo. Tradução de Sérgio Bath. 10.

BODANSKY, Daniel. "The Legitimacy of International Governance: a coming challenge for international environmental law?", in: American Journal of International Law, vol. 93:3, 1999, pp. 596-624.

University Press: 2007.

et al. Handbook of Environmental International Law. Oxford

The Art and Craft of International Environmental Law.

Harvard University Press, 2010.

BOED, R., 'State of Necessity as Justification for Internationally Wrongful Conduct', Yale Hum. Rts \& Development L. J. (2000) 1-43.

BOIN, Arjen; Rhinard Mark. Managing Transboundary Crises: What Role for the European Union? International Studies Review (2008) 10, 1-26. 
BOLI, John; LECHNER, Frank J. The Globalization Reader. 2nd ed. Blackwell Publishing. United Kingdom, 2004.

BOUCHER, David. Political Theories of International Relations. Oxford: Oxford University Press, 1998.

BOUTIN, Christine. De la mondialisation à l'universalisation: une ambition sociale. Collection des rapports offciciels. Rapport intermédiaire au Président de la République. Mission présidée par Christine Boutin, ancien Ministre. Décembre 2010.

BOWET, Derek. Self Defense in International Law. Publicado originalmente: New York: Praeger, 1958.

Treaties and State Responsibility. In: Mélange M. Virally: Le Droit international au service de la paix, de la justice et du développement (Éditions A. Pedone, 1991) 137-45.

BRADFORD, William. The Duty to Defend Them: A Natural Law Justification for the Bush Doctrine of Preventive War. Notre Dame L. Rev. (2004).

BRAGA, C. C. Vianna. A Manutenção da Paz, a R2P/RwP e a Questão do Uso da Força (artigo). In: HAMANN, Eduarda P.; MUGGAH, Robert (orgs.). A Implementação da Responsabilidade de Proteger: novos rumos para a paz e segurança internacional?. Brasília. Instituto Igarapé: 2013.

BROWN-WEISS, Edith. The Changing Strucuture of International Law. In: PRIEUR, M. \& LAMBRECHTS, C. (orgs.) Les Hommes et l'environnement. Quel droit pour le vingt-et-unième siècle? (Mankind and the Environment. What Rights for the TwentyFirst Century?). En Hommage à Alexandre Kiss, Paris: éditions Frison-Roche, 1998, 691 p., pp. 3-15.

BROWNLIE, Ian. Principles of Public International Law. Sixth Edition. Oxford University Press: 2003.

University Press: 1963.

International Law and the Use of Force by States. Oxford

BRUNDTLAND, Gro Halem. Nosso Futuro Comum. Rio de Janeiro: Fundação Getúlio Vargas, 1988.

BUCHANAN, Allen. Reforming the international law of humanitarian intervention. In: HOLZGREFE, J. L.; KEOHANE, Robert O. Humanitarian Intervention. Ethical, Legal, and Political Dilemmas. Cambridge University Press. 2003. pp. 130-174.

BUJON de L'ESTANG, François. Ingérence humanitaire et diplomatie. In: Revue des Deux Mondes, juin 1993, pp.113-128. 
BULL, Hedley. The Anarchical Society: A Study of Order in World Politics. London: MacMillan Press, 1977.

; WATSON, Adam (eds). The Expansion of International Society. Oxford: Clarendon Press, 1984.

BURSZTYN, Marcel; PERSEGONA, Marcelo. A grande transformação ambiental: uma cronologia da dialética do homem-natureza. Rio de Janeiro: Garamond, 2008.

BUZAN, Barry. People, States and fear: an agenda for international security in the post-Cold War era. Chapel Hill: University of North Caroline, 1983.

. Peace, Power and Security: Contending Concepts in the Study of International Relations". Journal of Peace Research, vol. 21, n 2, 1984.

- The Case for a Comprehensive Definition of Security and the Institutional Consequences of Accepting It. Working Paper COPRI, nº 4, 1990.

et al. The Logic of Anarchy. Neorealism to Structural Realism. Columbia University Press: New York, 1993.

; LITTLE, Richard; JONES, C. The logic of anarchy: neorealism to structural realism. New York: Columbia University Press, 1993.

Rethinking Security after the Cold War. In: Cooperation and Conflict.1 (1997). vol. 32 no.1, 5-28

; WÆVER, Ole; WILDE, Jaap de. Security: a new framework for analysis. Boulder and London: Lynne Rienner Publishers, 1998.

The United Nations and the Great Powers: World Politics in the Twenty-First Century. Cambridge: Polity Press, 2004.

BYERS, Michael; CHESTERMAN, Simon. Changing the rules about rules? Unilateral humanitarian intervention and the future of international law. In: HOLZGREFE, J. L.; KEOHANE, Robert O. Humanitarian Intervention. Ethical, Legal, and Political Dilemmas. Cambridge University Press. 2003. pp. 177-203.

CARENS, Joseph. Rights and Duties in an Egalitarian Society. Political Theory, vol. 14, nº1, 1986. pp. 31-49.

CARLSNAES, Walter et al. Handbook of International Relations. Sage Publications: London, 2007.

CARR, Edward H. Vinte Anos de Crise, 1919-1939. Brasília: Editora UnB/Imprensa Oficial do Estado/IPRI, 2001. 
CARVALHO NETO, Inacio de. Curso de direito civil brasileiro: teoria geral das obrigações. Curitiba: Juruá, v. 2.

CASSESSE, Antonio. Le droit international dans un monde divisé. Paris: BergerLevrault, Coll. Monde en devenir, Série Manuels B.-L., mars 1986, 375 pages.

CASTELLS, Manuel. A sociedade em rede. São Paulo: Paz e Terra, 1999. v. 1 Fim de Milênio. São Paulo: Paz e Terra, 1999.

The Rise of the Network Society. Cambridge: Blackwell, 1996.

A Era da Informação - o poder da identidade. Vol.2, $3^{\text {a }}$ edição.

São Paulo: Paz e Terra, 2002.

CERVO, A. L. Globalização, integração e Estado Nacional no mundo contemporâneo. Meridiano 47, vol. 8, No 84 (2007).

História da política exterior do Brasil. 4. ed. Brasília: Editora Universidade de Brasília, 2011.

Relações Internacionais da América Latina: de 1930 aos nossos dias.

3. ed. São Paulo: Saraiva, 2013. v. 1. 276p.

CHALECKI, Elizabeth. Environmental Security: A Case Study of Climate Change. In: Pacific institute for Studies in Development, Environment, and Security (2009).

CHARNEY, Jonathan. Self-determination: Chechnya, Kosovo, and East Timor. Vanderbilt Journal of International Law. 34(2) 455, 2001.

CHASEK, Pamela S. et al. Global Environmental Politics. Sixth Edition. Colorado: Westview Press, 2014.

CHESTERMAN, Simon. Just War or Just Peace? Humanitarian Intervention and International Law. Oxford: Oxford University Press, 2001.

CHOUCRI, Nazli (org). Global Accord Environmental Challenges and International Responses. MIT Press, Cambridge, 1995

CLARK, Ann Marie. Non-gouvernmental organizations and their influence on international society. Journal of International Affairs, n. 48, 2, 1995

et al. The sovereign limits of global civil society. A comparison on the NGO participation in UN World Conferences on the Environment, Human Rights, and Women. In: World Politics 51 (october 1998), number 01.

CLARK, Ian. Globalization and Fragmentation. International Relations in the Twentieth Century. Oxford, Oxford University Press, 1997. 220p. 
Press, 1999.

Globalization and International Relations Theory. Oxford University

Classical Theories of International. London: Macmillan Press, 1999b.

CLEVEland, William; BUnTON, Matin. A History of the Modern Middle East. Fifth Edition. University of Victoria. Westview Press, 2013.

CMMAD - Comissão Mundial sobre Meio Ambiente e Desenvolvimento. Nosso Futuro Comum. Rio de Janeiro: Fundação Getúlio Vargas, 1998.

COELHO, Teresa. O Direito Internacional e a Ingerência Humanitária: O poder/dever da intervenção armada. In. Nação e Defesa, verão 2003, n. 105, pp. 103-119.

COHEN, Roberta. The Guiding Principles on Internal Displacement: An Innovation in International Standard Setting. Global Governance, 10 (3), 2004.

Strengthening Protection of IDPs; The UN's Role. Georgetown Journal of International Affairs. $N^{\circ}$ 7, 2006: 101-110.

Developing an International System for Internally Displaced Persons.

International Studies Perspectives, 7 (1), 2006b.

The Burma conflict and the Responsibility to Protect. In: Global Responsibility to Protect 1, 2009. pp. 253-257.

; DENG, Francis M. Masses in Flight: The Global Crisis of Internal

Displacement. Washington: Brookings Institution, 1998.

COLARD, Daniel. Les Relations Internationales de 1945 à nos jours. Paris : Armand Colin, 1999.

COMTOIS-DINEL, Eve-Lyne. La fragmentation du droit international: vers un changement de paradigme? Lex Electronica, vol. $11 \mathrm{n}^{\circ} 2$ (Automne / Fall 2006). Disponível em: http://www.lex-electronica.org/articles/v11-2/comtoisdinel.pdf

COOPER, Richard; KOHLER, Juliette. Responsibility to Protect: The Global Moral Compact for the 21st Century. New York: Macmillan, 2009.

COURBEVILLE, Clélia. La longue marche des dissidents chinois - Entretien avec Liu Qing. In: Politique internationale, $\mathrm{n}^{\circ} 75$ - printemps 1997, pp.387-400 (entrevista).

COWIE, J. Climate Change: Biological and Human Aspects. Cambridge University Press, 2007.

CRAWFORD, James. The International Law Commission's Articles on State Responsibility - Introduction, Text and Commentaries. Cambridge University Press, 2002 . 
DALBY, Simon. Security and Environmental Change. Cambridge: Polity, 2009.

DANISH, Kyle W. International Relations Theory.

DAVIES, Sara; GLANVILlE, Luke (Eds.). Protecting the Displaced: Deepening the Responsibility to Protect. Martinus Nijhoff, 2010.

DAY, Graham. FREEMAN, Christopher. Operationalizing the Responsibility to Protect - The Policekeeping Approach. Global Governance, nº 11, 2005: 139-147.

DECAUX, Emmanuel. Droit international public. 6e édition.Paris: Dalloz. 2008.

DELMAS-MARTY, Mirelle. Trois défis pour un droit mondial. Le Seuil, 1998.

DENG, Francis M. et al. Sovereignty as Responsibility: Conflict Management in Africa. Washington: The Brookings Institution, 1996.

Quarterly. Fall 2004.

The Impact of State Failure on Migration. Mediterranean

Divided Nations: The Paradox of National Protection. The Annals of the American Academy of Political and Social Science. No 603, 2006.

DEUDNEY, Daniel. Environmental and Security: Muddled Thinking. Bulletin of the Atomic Scientists,v. 47, n. 03 (1991): 22-28.

DEUTSCH, Karl. Análise das relações internacionais. Brasília: Editora da Universidade de Brasília, 2002.

DEVIES, Richard. The Effects of the Accident at Chernobyl upon the Nuclear Community. Science, Technology \& Human Values, vol. 11, nº 4, 1986. Pp 59-63.

DEVIN, Guillaume. Sociologie des Relations Internationales, Paris, La Découverte, 2002.

DINH, Nguyen Quoc; DAILLIER, Patrick; PELLET, Alain. Droit International

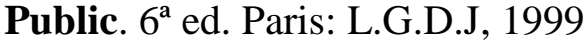

DOBB, Maurice. A evolução do capitalismo. 9ª ed. Rio de Janeiro: Zahar, 1983.

DOYLE, Michael; SAMBANIS, Nicholas. Making war and building peace: United Nations peace operations. Princeton University Press: 2006.

DRAGO, Roland (dir.). Souveraineté de l'Etat et interventions internationales. Paris: Dalloz, 1996.

DREZNER, Daniel. The Power and the peril of International Regime Complexity. Perspectives on Politics. v. 7, n. 1, p. 65-70, 2009. 
DUPONT, Alan. The Environmental and Security in Pacific Area. ADELPHI Paper 319 (1998).

DUPUY, Pierre-Marie. Droit international public. 9e Edition. Paris: Dalloz, 2008.

DUPUY, R. J. La communauté internationale entre le mythe et l'histoire. Paris: Economica, UNESCO, 1986.

DURAND, Marie-Françoise; MARTIN, Benoit; PLACIDI, Delphine; TÖRNQUISTCHESNIER, Marie. Atlas de la mondialisation: Comprendre l'espace mondial contemporain. Paris: Presses de Sciences Po, 2007.

DUROSELLE, J.B. A Europa de 1815 aos Nossos Dias. Liv. Pioneira, S.Paulo, 1985.

EASTON, Geoff. Marketing: A critical realist approach. Journal of Business Research, 55 (2), 103-109.

EBURN, Michael. The Responsibility to Protect Populations from Natural Disasters: an Extension of International Humanitarian law. School of Law Staff Seminar, University of Glamorgan (Pontyprydd, Wales). Jan/2007 e McCoubrey Centre for International Law, 2006/2007. International Law Seminar Series, University of Hull (Kingston-upon-Hull, England). Feb 2007. Disponível em: http://law.anu.edu.au/staff/michael-eburn?tb=5 (acesso em 18/01/2012)

ECKERSLEY, Robin. Ecological Intervention: Prospects and Limits (2005). Segundo informações da autora, o artigo foi apresentado como seminar paper para $\mathrm{o}$ Departamento de Relações Internacionais - Centro de Pesquisa de Estudos sobre Ásia e Pacífico - da Universidade Nacional da Austrália.

EGAN, Matthew Jude. Anticipating Future Vulnerability: Defining Characteristics of Increasingly Critical Infrastructure-Like Systems. Journal of Contingencies and Crisis Management (2007).

EMMERS, Ralf. The Threat of Transnational crime in Southeast Asia: Drug Trafficking, Human Smuggling and Trafficking, and Sea Piracy. UNISCI Discussion Papers, 2003.

ESMAN, Milton; TELHAMI, Shibley. International Organizations and Ethnic Conflict. Cornell University Press, 1995.

EVANS, Gareth. From Humanitarian Intervention to the Responsibility to Protect. Wisconsin International Law Journal. 703, 704, 2006.

The Responsibility to Protect: ending mass atrocity crimes once and for all. Brookings Institution. 2008. 
The Responsibility to Protect in Environmental Emergencies.

Presentation by Gareth Evans. American Society of International Law (ASIL) 103 rd Annual Meeting. Washington DC, 2009.

EVANS, Malcolm. International Law. Second Edition. Oxford University Press: 2006.

FALK, Richard. A Study of Future Worlds. New York: Fress Press, 1975.

FAUSTO, Boris. História do Brasil. São Paulo: USP, 1995.

FERIS, Elizabeth. The Politics of Prevention: The Limits of Humanitarian Action. Brookings Institution Press, 2011.

FIENSTEIN, Lee. Darfur and Beyond: What is Needed to Prevent Mass Atrocities. Council on Foreign Relations. $\mathrm{N}^{\circ} 22,2007$.

FIDLER, David. International Law and Infectious Diseases. Oxford University Press, USA, 1999.

FINNEMORE, Martha. National Interests in International Society. Ithaca and London: Cornell University Press, 1996.

; SIKKINK, Kathryn. International Norm Dynamics and Political Change. International Organization. 52 , 4, Autumn, 1998. pp. 887-917

FLOYD, Rita. Security and the Environment: Securitization theory and US environmental security policy. Cambridge: Cambridge University Press, 2010.

FOLEY, Conor. Avanços Normativos sobre a Proteção de Civis em Conflitos Armados (artigo). In: HAMANN, Eduarda P.; MUGGAH, Robert (orgs.). A Implementação da Responsabilidade de Proteger: novos rumos para a paz e segurança internacional?. Brasília. Instituto Igarapé: 2013.

FONSECA, Fúlvio Eduardo. As Organizações Não-Governamentais e a Implementação dos Acordos Ambientais Multilaterais: entre a Participação Formal e a Influência Real. Tese de Doutorado. UnB/IREL. Orientador: Prof. Antônio Augusto Cançado Trindade. Ano 2006.

FOUCAULT, M. Power/Knowledge: Selected Interviews and Other Writings. Nova York: Pantheon Books, 1980.

FRANCK, Thomas. Lessons of Kosovo. American Journal of International Law. 93/857, 1999.

Recourse to Force: State Action Against Threats and Armed Attacks. Cambridge University Press, 2002. 
Interpretation and change in the law of humanitarian intervention.

In: HOLZGREFE, J. L.; KEOHANE, Robert O. Humanitarian Intervention. Ethical, Legal, and Political Dilemmas. Cambridge University Press. 2003. pp. 204-231.

FREDMAN, Sandra. Human Rights Transformed: Positive Duties and Positive Rights. University of Oxford Faculty of Law. In Oxford Legal Studies Research Paper n. 38/2006.pp 498-520

FRIEDMAN, Thomas. The World Is Flat. New York: Farrar, Straus, Giroux, 2005.

FUKUYAMA, Francis. O fim da História e o último homem. Rio de Janeiro: Rocco, 1992.

GADDIS, John. We now know. Rethinking Cold War history. Oxford:Oxford University Press, 1998.

GAGLIANO, Pablo Stolze; PAMPLONA FILHO, Rodolfo. Novo Curso de Direito Civil: obrigações. São Paulo: Saraiva, v. 2. 15ª Ed. 2014

GARDNER, Royal C. Respecting Sovereignty. in: Fordham Environmental Law Review. Vol. 8, issue 1, art. 7. 2011.

GAVOUNELI, Maria. Responsibility for Catastrophes: New Concepts in Their Conventional Application. In: David D. Caron and Charles Leben (eds), The International Aspects of Natural and Industrial Catastrophes (Martinus Nijhoff, The Hague, 2001).

GIDDENS, Anthony. The Constitution of Society. Berkeley: University of California Press, 1984.

A Política da Mudança Climática. Rio de Janeiro: Zahar, 2010.

Sociology. Cambridge Polity Press. 1993, $2^{\text {nd }}$ ed. P. 528.

GILPIN, Alan. Environmental Impact Assessment (EIA): Cutting Edge Impact for the Twenty-First Century, Cambridge University Press, 2006.

GILPIN, Robert. War and Change in World Politics. Princenton: Princeton University Press, 1993.

Princenton University Press, 1987.

Global Political Economy. Understanding the International Economic Order. Princeton University Press: 2001.

GINZBURG, Harold; REIS, Eric. Health Consequences of the Nuclear Power Plant Accident at Chernobyl. Public Health Reports (1974-). Vol. 106, No. 1 (Jan. - Feb., 1991), pp. 32-40. 
GRAYSON, Kyle. Human Security in The Global Era. In: D. Drache (ed.). The Market or the Public Domain: Global Governance and the Asymmetry of Power. New York: Routledge, 2001 pp229-52.

GRECO, Rogério. Curso de Direito Penal - Parte Geral. Volume I. 11 a Edição, Editora Impetus, São Paulo/SP, 2014.

GREENE, Owen. Environmental issues. In: BAYLIS, John; STEVE, Smith. The Globalization of World Politics. An Introduction to International Relations. . Third Edition. Oxford University Press, 2004.

GUILLAUME Gilbert. Inventaire du droit positif. In: Revue des Deux Mondes, juin 1993, pp.100-112.

GURR, Robert; HARFF, Barbara. Ethnic Conflict in World Politics. Westview Press, 1994.

HAAKE, Jürgen. Myanmar, the Responsibility to Protect and the Need for Practical Assistance. In:Global Responsbility to Protect (2009). Pg. 156-184

HAAS, Ernst. Beyond the Nation-State: Functionalism and International Organization. Stanford: Stanford University Press, 1964.

HAAS (2), Peter M. Introduction: Epistemic Communities and International Policy Coordination. In: International Organization, 26, 1 (Winter, 1992).

; SUNDGREN, Jan. Evolving International Law: changing practices of national sovereignty. In: CHOUCRI (N), Global Accord: Environmental Challenges and International Responses. Cambrigde and Londres, MIT Press, 1993, p. 401-429.

HAMPSON, Fen Osler. A Concept in Need of a Global Policy Response. Security Dialogue. September (2004) 35: 349-350.

HAQ, Mahbub ul. Reflections on Human Development. Oxford University Press, 1995, p. 288.

HAGETTE, T. M. F.. Metodologias Qualitativas na Sociologia. 10. Ed. Petrópolis: Vozes, 2003.

HALLIDAY, Fred. Repensando as Relações Internacionais. Porto Alegre: Editora UFRGS, 1999.

HAMANN, Eduarda P.; MUGGAH, Robert (orgs.). A Implementação da Responsabilidade de Proteger: novos rumos para a paz e segurança internacional?. Brasília. Instituto Igarapé: 2013. 
HAMILTON, Rebecca. The Responsibility to Protect, from Document to Doctrine -But what of Implementation?. Harvard Human Rights Journal. N 19, 2006: 289-297.

HAMMER, Craig; NAGAN, Winston. The Changing Character of Sovereignty in International Law and International Relations. In: Journal of Transnational Law. Columbia, Volume 43, Number 1. University of Asmara (2003).

HASSAN, Shaukat. Environmental Issues and Security in South Asia. ADELPHI Paper, nº 262, 1991.

HASSNER, Pierre. From War and Peace to Violence and Intervention: Permanent Moral Dilemmas under Changing Political and Technological Conditions. In: MOORE, Jonathan. Hard Choices: Moral Dilemmas in Humanitarian Intervention. Rowman \& Littlefield Publishers. Boston: 1998, pp. 9-28.

HARVEY, David. Condição pós-moderna: uma pesquisa sobre as origens da mudança cultural. São Paulo: Ed. Loyola, 2003, $12^{\mathrm{a}}$ ed.

HAY, C. Comtemporary Capitalism, Globalization, Regionalization and the Persistence of National Variation. Review of International Studies, 26 (4). 2000. Pg 509-32.

HEIBERG, Marianne (ed). Subduing Sovereignty. London, Pinter, 1994.

HEHIR, Bryan J. The Ethics of Non-Intervention: Two traditions. In: Peter Brown and Douglas Maclean eds. Human Rignts and US Foreign Policy: Principles and Applications. Lexington, 1979. pp. 121-39.

Military Intervention and National Sovereignty: Recasting the Relationship. In: MOORE, Jonathan. Hard Choices: Moral Dilemmas in Humanitarian Intervention. Rowman \& Littlefield Publishers. Boston: 1998, pp. 29-54.

HELD, David. Democracy and the Global Order, from the Modern State to Cosmopolitan Governance. Cambridge: Polity Press, 1995.

J. Zahar, 2001.

; MCGREW, Anthony. Pros e contras da globalização. Rio de Janeiro:

"The Changing Structure of International Law: Sovereignty

Transformed? (2003) acesso em: https://www.polity.co.uk/global

et al. Global Transformations. Politics, Economics and Culture.

Stanford, CA, Stanford University Press, 1999.

HENSON, Robert. The Rough Guide to Climate Change. The Symptoms. The Science. The Solutions, Rough Guides, 2006.

HERZ, John. Political Realism and Political Idealism: A Study in Theories and Realities. Chicago: The University of Chicago Press, 1951. 
HERZ, Mônica; HOFFMANN, Andréa R. Organizações Internacionais: histórias e práticas. RJ: Elsevier, 2004.

HEYWOOD, V.H., WATSON., R.T. (eds.). Global Biodiversity Assessment. Cambridge: Cambridge University Press, 1995.

KHONG, Y. Foong. Human security: A shotgun approach to alleviating human misery? Global Governance. Nº ${ }^{\circ}$, Jul-Sep 2001. pp. 231-236.

HINSLEY, F. H. Sovereignty. 2nd ed. Cambridge: Cambridge University Press, 1986.

HINTON, Alex (ed.). Transitional Justice: Global Mechanisms and Local Realities after Genocide ad Mass Violence. Rutgers University Press, 2010.

HIRST P.; THOMPSON, G. Globalization in Question. $3^{\text {rd }}$ Edition. Cambridge.: Polity Press. 2009.

HOBSBAWM, Eric. A era das revoluções. São Paulo: Paz e Terra, 1989, $7^{\circ}$ ed..

A era do capital. São Paulo: Paz e Terra, $1989 b, 7^{\circ}$ ed.

Era dos extremos: o breve século XX: 1914-1991. 2. ed. São

Paulo: Companhia das Letras, 2001

HOFFMANN, Stanley. Janus and Minerva: essays in the theory and practice of international politics. Westview Press, 1987.

HOLANDA, Sérgio Buarque de \& CAMPOS, Pedro Moacir. As etapas dos descobrimentos portugueses. In: HOLANDA, Sérgio Buarque de (Org.). História Geral da Civilização Brasileira. 7 ed. São Paulo: DIFEL,1985, Tomo 1, Vol. 1, p. 2634.

HOLZGREFE, J. L.; KEOHANE, Robert O. Humanitarian Intervention. Ethical, Legal, and Political Dilemmas. Cambridge University Press. 2003.

HOOGVELT, A. Globalization and the Post-Colonial World. Basingstoke: Palgrave. 2001.

HOPF, Ted. The Promise of Constructivism in International Relations Theory. International Security. Vol. 23, $\mathrm{n}^{\circ} 1$ (summer, 1998), pp. 171-200.

HUBERMAN, Leo. História da riqueza do homem. 20 ed. Rio de Janeiro: Zahar, 1985.

HUNTINGTON, Samuel. O choque das civilizações e a recomposição da nova ordem mundial. Rio de janeiro: Objetiva, 1997. 
HURRELl, Andrew. On Global Order, Power, Values, and the Constitution of International Society. Oxford University Press, 2007. Sociedade Civil e Governança Global. In: Lua Nova nº 46, 1999.

IMBER, Mark. Environment, Security and UN Reform. New York: St. Martin's Press, 1994.

INOUE, C. Y. A.; SCHLEICHER, R. Conhecimento Científico e Formação de Regimes Internacionais Ambientais: O Caso do Regime de Biossegurança. Cena Internacional (UnB), Internet, v. Ano 6, n.Número 1, p. 13-35, 2004.

Regime global de biodiversidade: o caso Mamirauá. Brasília: Editora Universidade de Brasília, 2007.

Governance of global climate change in the Brazilian Amazon: the case of Amazonian municipalities of Brazil. In: Revista Brasileira de Política Internacional. v. 55, p. 170-189, 2012.

JAMES, Paul; FRIEDMAN, Jonathan. Globalization and Violence, Vol. 3: Globalizing War and Intervention. London: Sage Publications, 2006.

JACKSON, Patrick Thaddeus et al. Brinding the Gap: Toward a Realist-Constructivist Dialogue. International Studies Review, vol. 6, n² 2, 2004. pp. 337-352.

JACKSON, R.; G. SORENSEN. Introdução às relações internacionais. Rio de Janeiro: Zahar, 2003.

JENKS, C.W. The Common Law of Mankind. London: Stevens, 1958.

JOYNER, Daniel. The Kosovo Intervention: Legal Analysis and a More Persuasive Paradigm. European Journal of International Law. 13(3)/597, 2002.

JORGENSEN, K. Erik. Four Levels and a Discipline. Constructing International Relations: the next generation. Londres: M. E. Sharpe, 2001, p. 36-53.

KATZENSTEIN, P. Cultural Norms and National Security. Ithaca and London: Cornell University Press, 1996.

KAWATO, Yuko. Sécurité nucléaire et avenir de l'énergie : le débat japonais. OutreTerre. 1/ $2013\left(\mathrm{n}^{\circ} 35-36\right)$. p. 471-480

KAY, David; JACOBSON, Harold, eds. Environmental Protection: The International Dimension. Totowa, NJ: Allanheld, Osmun \& Co, 1983.

KEMP, Walter; POPOVSKI, Vesselin; THAKUR, Ramesh. Blood and Borders: The Responsibility to Protect and the Problem of the Kin-State. United Nations University Press, 2011. 
KECK, Margaret E \& SIKKINK, Kathryn. Activists Beyond Borders. Advocacy Networks in International Politics. Ithaca and London: Cornel University Press: 1992.

KEOHANE, Robert. Neorealism and its critics. Columbia University Press. New York: 1986.

International Institutions: Two Approaches. International Studies Quartely, v. 32, n. 4, p. 379-396, 1988.

; NYE JR., Joseph S. Transnational relations and world politics. Boston: Harvard University, 1972.

Politics in Transition. Boston: Little, Brown and Company, 1977. ; VICTOR, David. The Regime Complex for Climate Change. Discussion Paper 10-33. The Harvard Project on International Climate Agreements, January 2010.

KERBRAT, Y.; MALJEAN-DUBOIS, S. The Transformation of International Environmental Law. Pedone, Paris / Hart, Oxford, 2011.

KISS, Alexandre. Introduction au droit international de l'environnement. 2a édition, 2006. In: Programme de Droit de l'Environnement: UNITAR.

; SHELTON, Dinah. Manual of European Environmental Law. 2nd edition. Cambridge: Cambridge University Press, 1997.

Martinus Nijhoff, 2004.

International Environmental Law. 3 ed.

KNUTSEN, Torbjron. A history of international relations theory. Manchester \& New York: Manchester University Press, 1997.

KORINMAN, Michel. Puissance écologie. Outre-Terre. 1/ 2013 (n³ 35-36). p. 9-9

KOSKENIEMI, Martti. Global Legal Pluralism: Multiple Regimes and Multiple Modes of Thought. Harvard, March 2005.

; LEINO, Päivi. Fragmentation of International Law?

Postmodern Anxieties. Leiden Journal of International Law, 2002. pp. 553 -579.

KRASNER, D. Stephen. Problematic Sovereignty. Contested rules and political possibilities. New York: Columbia University Press, 2001.

University Press, 1999.

Sovereignty: organized hipocrisy. New Jersey: Princeton 
1983.

International Regimes. London: Cornell University Press,

- Abiding Sovereignty. International Political Science

Review. Vol. 22, n. 3. Transformation of International Relations: Between Change and Continuity. 2001. pp. 229-251.

2010. Environmental Transborder Cooperation in Latin America: Challenges to the Westphalia Order. Pgs. 291-304. In MATTHEW, Richard; BARNETT, Jon; MCDONALD, Bryan; O'BRIEN, Karen. Global Environmental Change and Human Security. MIT press. 2010.

KRATOCHWIL, Friedrich. Rules, Norms and Decisions. Cambridge, Cambridge University Press, 1989.

KRAUSE, Keith. The key to a powerful agenda, if properly delimited. Security Dialogue. 2004, 35(3):367. Acesso em:sdi.sagepub.com/content/35/3/367.full.pdf+html $(08 / 04 / 2012)$

KULACKI, Gregory. China Reacts to Fukushima. China project manager and senior analyst. March/2011. (artigo). In: http://allthingsnuclear.org/china-reacts-to-fukushima/

LAGO, A. C. do. "Estocolmo, Rio de Janeiro, Joanesburgo: A Evolução do Discurso Brasileiro nas Conferências Ambientais das Nações Unidas.", Trabalho apresentado no XLVI CAE do Instituto Rio Branco/MRE, Brasília, 2004.

LAIDI, Zaki. Un monde privé de sens. Librairie Arthème Fayard. Hachette Littératures, 1994.

LAKE, David. The New Sovereignty in International Relations. International Studies Review v. 5, pp. 303-323, 2003.

LAPID, Yossef. The Third Debate: On the Prospects of International Theory in a PostPositivist Era. International Studies Quartely, v. 33, n. 3, p. 235-254, 1989.

LAQUEUR, Walter. No End to War: Terrorism in the Twenty-First Century. New York: Continuum, 2003.

LAROCHE, Josepha. Politique internationale. LGGJ. 2e ed, Paris: 2000.

LE BILLON, Philippe; WAIZENEGGER, Arno. "Peace in the Wake of Disaster? Secessionist Conflicts and the 2004 Indian Ocean Tsunami." Transactions of the Institute of British Geographers. New Series, Vol. 32, No. 3 (Sep., 2007), pp. 411427

LECHNER, Frank; BOLI, John. The Globalization Reader. Blackwell Publishing: 2004. 
LEFEBVRE, Maxime. Leu jeu du droit et de la puissance. Précis de relations internationales. 2e édition. Paris: Presses Universitaires de France, 2000.

LEFORT, Claude. "Nação e Soberania". In: NOVAES, A. (org.). A crise do Estadonação. Rio de Janeiro: Civilização Brasileira, 2003.

LE PRESTRE, Philippe. Ecopolítica Internacional. São Paulo: Senac, 2000.

Paris : Armand Colin, 2005.

Protection de l'environnement et relations internationales.

LESSA, Antonio Carlos. A construção da Europa: a última utopia das relações internacionais. Brasília: IBRI, 2003.

História das relações internacionais - a Pax Britannica e o mundo do século XIX. Petrópolis: Vozes, 2005.

LEVITT, Jeremy. The Responsibility to Protect: A Beaver Without A Dam?. Michigan Journal of International Law. No 25, 2003: 153-177.

LEZAUM, Javier. Limiting the Social: Constructivism and Social Knowledge in International Relations. International Studies Review. Vol. 4, no 3 (Autumn, 2002), pp. 229-234.

LINKLATER, Andrew. The Transformation of Political Community. Cambridge: Polity Press, 1998.

; SUGANAMI, H. The English School of International

Relations: A Contemporary Reassessment. Cambridge: Cambridge University Press 2006.

Reflections on Western and non-Western Perspectives. Ritsumeikan Annual Review of International Studies. Vol. 9, 2010. pp 1-13.

Globalization and the transformation of political community.

In: BAYLIS, John et al. An introduction to international relations. Oxford University Press. Fifth Edition. 2011, pp. 530-558.

LIJPHART, Arend. Comparative Politics and the Comparative Method. APSR, 65, n. ${ }^{\text {o }}$ 3, September, 1971.

LITFIN, Karen T (org.). The Greening of Sovereignty in World Politics. MIT: Massachusetts Institute of Technology, 1998.

LOPES, Alexander. 2002. Environmental change and social conflicts in the Brazilian Amazon: Exploring the links. Ph.D. dissertation. University os Oslo, Norway. 
LUCILE, Maertens. Environmental Securitization within the United Nations: a Political Ecology Perspective. Paris: Institut de Recherche Stratégique de l'École Militaire, 2003.

LUCK, Edward. Environmental Emergencies and the Responsibility to Protect: a Bridge Too Far? In: MALONE, Linda. Green Helmets: Eco-Intervention in the Twenty-First Century. College of William \& Mary Law School. Faculty Publications. 2009.

The Responsibility to Protect: Growing Pains or Early Promise?.

Ethics and International Affairs, Volume 24. $N^{\circ}$ 4. Winter, 2010.

MACFARLENE, Neil, KHONG, Yuen. Human Security and the UN: A Critical History. Indiana University Press, 2006.

MACK, Andrew. Human Security Centre. Human Security Report 2005: War and Peace in the 21st Century. New York: Oxford University Press, 2005. Acesso em: http://www.hsrgroup.org/human-security-reports/2005/text.aspx

MACQUEEN, Norrie. Humanitarian Intervention and the UN. Edinburgh University Press, 2011.

MAGDOFF, H. Imperialismo: da Era Colonial ao Presente. Rio de Janiero: Zahar, 1979.

MAGNOLI, Demétrio (org.). História das Guerras. São Paulo: Contexto, 2008.

História da Paz. São Paulo: Contexto, 2008.

O Mundo Contemporâneo. $3^{\circ}$ ed. São Paulo: Atual, 2013.

MALANCCZUK, Akehurst's Peter. Modern Introduction to International Rights. New York, Routledge, 1997.

MLJEAN-DUBOIS, Sandrine; RAJAMANI, L. La mise en oeuvre du droit international de l'environnement/Implementation of International Environmental Law. Martinus Nijhoff: London, 2011.

MALONE, Linda. The Chernobyl Accident: A Case Study in International Law Regulating State Responsibility for Transboundary Nuclear Pollution. Faculty Publications. Paper 590, 1987.

Green Helmets: Eco-Intervention in the Twenty-First Century. College of William \& Mary Law School. Faculty Publications. 2009.

MANSFELD, Peter. A History of the Middle East. Second Edition. Peguin Books, 2003. 
MARTIN Pierre-Marie. Les échecs du droit international. Paris: PUF, Coll. Que saisje?, Septembre 1996.

MATTHEW, Richard et al. Global Environmental Change and Human Security. MIT press, 2010.

MAYO, Bernard. Negative and Positive Duties: A Reply. The Philosophical Quarterly, vol. 16, n 63, 1996. pp. 159-164.

MAZZUOLI, Valério. Curso de Direito Internacional Público. São Paulo: Editora Revista dos Tribunais, 2006.

McRAE, Rob; HUBERT, Don. Human Security and the New Diplomacy: Protecting People, Promoting Peace. Montreal and Kingston: McGill-Queen's University Press, 2001.

McCORMICK, John. Rumo ao paraíso: a história do movimento ambientalista. Rio de Janeiro: Relume-Dumará, 1992.

1995.

The Global Environmental Movement. London: John Wiley,

McWILliAMS, Wayne; PIOTROWSKI, Harry. The World Since 1945: a History of International Relations. Boulder: Lynne Rienner Publishers, 2005.

MEPHAM, David; RAMSBOTHAM, Alexander. Safeguarding Civilians: Delivering on the Responsibility to Protect in Africa. Institute for Public Policy Research. Maio, 2007.

MEARSHEIMER, John. The Tragedy of Great Power Politics. New York: W. Norton \& Company, 2001.

MERLE, Marcel. Bilan des Relations Internationales Contemporaines. Paris: Economica, 1995.

MILWARD, Alan (ed). The frontier of national sovereignty. History and Theory, 1945-1992. London and New York, Routledge, 1993.

MONTEIRO, Washington de Barros. Curso de Direito Civil: direito das obrigações. São Paulo: Saraiva, v. 4. $41^{\mathrm{a}}$ Ed. 2014

MOORE, Jonathan. Hard Choices: Moral Dilemmas in Humanitarian Intervention. Rowman \& Littlefield Publishers. Boston: 1998.

MORADA, Noel. R2P Roadmap In Southeast Asia: Challenges and Prospects. UNISCI Discussion Papers. N 11, 2006: 59-70. 
MOREAU-DEFARGES. Un monde d'ingérences. 2. ed. Paris: Presses de Sciences Po, 2000.

MORGENTHAU, Hans. Politics among Nations. The struggle for power and peace. 6th ed. New York: Mcgraw Hill, 1993.

MOURA, Gerson. A legitimidade e outras questões internacionais. São Paulo: Paz e Terra, 1998.

MOWBRAY, Alastair. The Development of Positive Obligations under the European Convention on Human Rights by the European Court of Human Rights. Oxford, 2004.

NAGAN, Winston; FRSA; HAMMER, Craig. The Changing Charater of Sovereignty in International Law and International Relations. University of Florida - Levin College of Law. Artigo preparado para conferência na Universidade de Asmara, Eritréia, 2003.

NAU, Jean-Yves. Le prix Nobel de la paix a été attribué à 'Médecins sans frontières. In: Le Monde, 16 octobre 1999, p34.

NEIVA, Ricardo. As Organizações Não-Governamentais nas Nações Unidas. Brasília: Instituto Rio Branco; Fundação Alexandre Gusmão; CEE, 1999.

NEVES, Gilda Motta Santos. Comissão das Nações Unidas para Consolidação da Paz: perspectiva brasileira. Brasília : FUNAG, 2009.

NEWMAN, Michael. Humanitarian Intervention: confronting the contradictions. Columbia University Press. New York, 2009.

NOGUEIRA, João Pontes; MESSARI, Nizar. Teoria das Relações Internacionais: correntes e debates. Rio de Janeiro: Elsevier, 2005.

NOORANI, A. G. State's Duty to Protect Dissent. Economic and Political Weekly. vol. $23, \mathrm{n}^{\circ} 34,1988$.

NYE, Joseph S. Understanding International Conflicts: an introduction to theory and history. $6^{\text {th }}$ edition. Longman, 2007.

OLIVEIRA, Carina Costa de. Solução de conflitos ambientais no direito internacional. Porto Alegre: Núria Fabris ed., 2010.

; SAMPAIO, Rômulo Silveira (orgs). A economia verde no contexto do desenvolvimento sustentável: a governança dos autores públicos e privados. Rio de Janeiro: FGV, Direito Rio, 2011. 
O Direito Internacional Ambiental: a busca pela mitigação dos efeitos das catástrofes no plano internacional. In: AHMED, Flávio; COUTINHO, Ronaldo (Orgs.). Curso de Direito Ambiental. Rio de Janeiro: Lumen Juris, 2012.

ONUF, Nicholas. World of Our Making - Rules and Rule in Social Theory and International Relations. Columbia: University of South Carolina Press, 1989.

The Constitution of International Society. In: European Journal of International Law, vol 5, 1994, pp 1-19.

ORFORD, Anne. International Authority and the Responsibility to Protect. Cambridge University Press, 2011.

ORSINI, Amandine. Multi-Forum Non-State Actors: Navigating the Regime Complexes for Forestry and Genetic Resources. Global Environmental Politics. MIT. 13.3, 2003.

OST, F. La nature hors la loi. L'écologie à l'épreuve du droit. Paris, La Découverte, 1996.

OWEN, Taylor. Human Security - Conflict, Critique and Consensus: Colloquium Remarks and a Proposal for a Threshold-Based Definition. International Peace Research Institute, Oslo, Norway. In: Security Dialogue, 2004, vol. 35 (sept.), pg. 37387.

PACE, William; DELLER, Nicole. Preventing Future Genocide: A Responsibility To Protect. World Order. N 36, 2006: 15-30.

PAINE, Robert. Ideologies and Routines: Chernobyl over Norway. Anthropology Today. Vol. 3, nº 4, 1987.pp 7-10.

PARIS, Rolland. Human Security. Paradigm Shift or Hot Air? International Security, Vol. 26, No. 2 (Fall 2001), pp. 87-102. Acesso em: http://aix1.uottawa.ca/ rparis/Paris.2001.IS.Human\%20Security.pdf. (15/01/2012)

PATTINSON, James. Humanitarian Intervention and the Responsibility to Protect: Who Should Intervene?. Oxford University Press, 2010.

PAYANDEH, Mehrdad. With Great Power Comes Great Responsibility? The concept of the Responsibility to Protect within the Process of International Lawmaking. Yale Law School. 2010.

PELLETIER, Philippe. De la guerre totale (1941) à la guerre de Fukushima (2011). Outre-Terre. 1/ 2013 ( $\left.\mathrm{n}^{\circ} 35-36\right)$, p. 399-438

PIOVESAN, F. (Org.); FACHIN, M. G. (Org.). Direitos Humanos na Ordem contemporânea: Proteção Nacional, Regional e Global. 1. ed. Curitiba: Juruá Editora, 2012. v. V. 608p. 
.Direitos Humanos e o Direito Constitucional Internacional. 14 ${ }^{\mathrm{a}}$. ed. São Paulo: Saraiva, 2013. v. 1. 704p .

PONTING, Clive. A Green History of the World: The Environment and the Collapse of Great Civilizations. Penguing Books, 1993.

PORTER, G.; BROWN, J. Global Environmental Politics. Westview Press, Boulder, 1996.

POTTER, William; KERNER, Lucy. The Soviet Military's Performance at Chernobyl. Soviet Studies. Vol. 43, nº 6, 1991. Pp. 1027-1047.

POWELL, Kristiana; BARANY, Stephen. Delivering on the Responsibility to Protect in Africa. North-South Institute Policy Briefing Paper, 2005.

PRANTL, Jochen. Informal Groups of States and the UN Security Council. International Organization, 59, 2005. pp 559-592.

.The UN Security Council and Informal Groups of States: Complementing or Competing for Governance?. Oxford University Press, 2006. pp 296.

Taming U.S. hegemony: informal institutions and the challenge to Western global order. Chinese Journal of International Politics (online), 2014.

PRINCEN, Thomas; FINGER, Mathias. Environmental NGOs in World Politics. Linking the local and the global. London and New York: Routledge, 1994.

PULEY, Greg. The Responsibility to Protect: East, West and Southern African Perspectives on Preventing and Responding to Humanitarian Crises. Project Ploughshares, 2005.

PUTNAM, Robert. Diplomacy and Domestic Politics: The Logic of Two Level Games. International Organization. 1988. v. 42.

QUEIROZ, Fábio Albergaria de. Hidropolítica e Segurança: as Bacias Platina e Amazônica em perspectiva comparada. 374 p. (UnB/IREL, Política Internacional e Comparada, 2011). Tese de Doutorado

QUINTON-BROWN, Patrick. A Responsabilidade ao Proteger: Elemento de Ligação ou Cavalo de Tróia para a R2p? (artigo) In: HAMANN, Eduarda P.; MUGGAH, Robert (orgs.). A Implementação da Responsabilidade de Proteger: novos rumos para a paz e segurança internacional?. Brasília. Instituto Igarapé: 2013. pp. 66-72.

RAFFELSEDER, Judith. The challenges and limitations of R2P's applicability in the aftermath of the natural disaster in Myanmar. Master Thesis. International and European Public Law. University of Tiburg. Junho, 2011. 
RAMANA, M. V. Twenty Years after Chernobyl: Debates and Lessons. Economic and Political Weekly, vol. 41, no 18, 2006. pp 1743-1747.

RANJEVA, Raymond. Les organisations non gouvernamentales et la mise en ouvre du Droit International. Recueil des cours de l'Académie de la Haye, The Hague, Boston, London, Martinus Nijhoff, v. 270, 1994.

RAUSTIALA, Kal; VICTOR, David G. The Regime Complex for Plant Genetic Resources. International Organization, 58, 2004 pp 277-309.

REDEKER, Robert. L'humanitaire et la guerre à la place du politique. In: Les Temps Modernes, mai-juin 1999, n604, pp.13-17.

REISMAN, W. Michael. Report, Tenth Commision: Present Problems of the Use of Armed Force in International Law, Sub-group on Humanitarian Intervention, 72 Annuaire de l'Institut de Droit International, 237, 244 (2007)

REVEL Jean-François. Le devoir d'ingérence est en train de devenir un droit. In: Le Monde, 26 novembre (supplément), propos recueillis par Jean-Pierre Langellier.

RHARADE, Leïla. Les obligations positives des États parties a la convention europeene des droits de l'homme. European Court of Human Rights. Rapport de recherche : avril 2014.

RIBEIRO, W. C. Relações internacionais: cenários para o século XXI. 1. ed. São Paulo: Scipione, 2000. v. 1.

A Ordem Ambiental internacional. São Paulo: Contexto, 2001.

Desenvolvimento sustentável e segurança ambiental global. Biblio 3W, Revista Bibliográfica de Geografía y Ciencias Sociales, Barcelona, v.VI, n.312, p.1- 10, 2001b. Disponível em: <http://www.ub.es/geocrit/b3w-312.htm>. (acesso em $15 / 02 / 2013)$

Ecologia política: ativismo com rigor acadêmico. Biblio 3W, Revista Bibliográfica de Geografía y Ciencias Sociales, Barcelona, v.VII, n.364, p.1-20, 2002.

International environmental order and the emergence of new powers.

Fudan Journal of the Humanities and Social Sciences, v. 4, p. 79-92, 2011.

(Org.). Governança da ordem ambiental internacional e inclusão

social. 1. ed. São Paulo: Annablume, 2012. v. 1.278p

ROBERTS, J. M. History of the World. New edition. London: Penguin, 1990.

ROCHA, Antonio Jorge Ramalho. Por Uma Compreensão Crítica das Teorias das Relações Internacionais. Cena Internacional. 03 [1]: 76-116, 2001. 
RODOGNO, Davide. Against Massacre: Humanitarian Interventions in the Ottoman Empire, 1815-1914. Princenton University Press, 2012.

ROMANO, John-Alexi.Combating Terrorism and Weapons of Mass Destruction: Reviving the Doctrine of a State of Necessity. Georgetown L. J. (1999) 1023-57.

ROTBERG, R. (ed.). Mass Atrocity Crimes: Preventing Future Outrages. Washington, DC: World Peace Foundation, 2010.

ROTCHILD, Donald. The Logic of a Soft Intervention Strategy: The United States and Conflict Conciliation in Africa. Brill, 2006.

RISSE-KAPPEN, Thomas (ed). Bringing Transnational Relations Back In. NonState Actors. Domestic Structures and International Institutions. Cambridge, New York, Melborn: Cambridge University Press, 1999.

Between a New World Order and None: Explaining the Reemergence of the United Nations in World Politics. In: Krause, Keith; Williams, Michael (Orgs). Critical Security Studies. Minneapolis: Minnesota University Press, 1997.

ROSENAU, James N. Governance without Government: Order and Change in World Politics. Cambrige: Cambridge University Press, 1992.

RUGGIE, J. G.. Constructing the World Polity: Essays on International Institutionalization. London: Routledge, 1998.

RYAN, Stephen. The United Nations and international politics. New York: St. Martins' Press, 2000.

SALAME, Ghassan. Appels d'empire: Ingérences et résistances à l'âge de la mondialisation (Essais). Paris: Fayard, 1996.

SARAIVA, José Flávio S. (org.). Relações internacionais contemporâneas. Da construção do mundo liberal à globalização. Brasília: Editora da UnB, 2002.

Relações Internacionais - Dois Séculos de História: entre

a preponderância europeia e a emergência americano-soviética (1815-1947).Brasília: FUNAG/IBRI, 2001.

SARAIVA, José Hermano. História concisa de Portugal. 23 ed. Lisboa: Publicações Europa-América, 2005.

SARFATI, Gilberto. Teoria de Relações Internacionais. Editora Saraiva. São Paulo. 2005.

SCHABAS, William. Preventing Genocide and Mass Killing: The Challenge for the United Nations. Minority Rights Group International, 2005. 
SCHRIJVER, Nico. The Evolution of Sustainable Development in International Law: Inception, Meaning and Status. The Hague: Martinus Nijhoff Publishers, 2008.

SCHWARTZ, Peter; RANDALL, Doug. An Abrupt Climate Change Scenario and Its Implications for United States National Security, 2003.

SCOCCIMARRO, Rémi. L'archipel disloqué. Le Japon après le 11 mars 2011. OutreTerre 1/ 2013 (n³5-36), pp. 439-455.

SEITENFUS, Ricardo. A. S. Manual das Organizações Internacionais. 2. ed. Porto Alegre: Livraria do Advogado, 2000.

Ingerência ou Solidariedade? Dilemas da Ordem Internacional

Contemporânea. São Paulo em Perspectiva, 16 (2): 12-26, 2002.

SEMELIN, Jacques (Ed.). Resisting Genocide: The Multiple Forms of Rescue. Columbia University Press, 2011.

SENARCLENS, Pierre de. Mondialisation, souveraineté et théories des relations internationales. Paris: Armand Colin. 1998.

SHUE, Henry. Mediating Duties. Ethics. vol. 98 , n 4, 1988. pp. 687-704

SIMMS, Brendan, TRIM, D. Humanitarian Intervention: A History. Cambridge University Press, 2011.

SINGER, Marcus. Negative and Positive Duties. The Phisolophical Quarter, vol. 15, $\mathrm{n}^{\circ}$ 59, Moral Philosophy Number, 1965. pp. 97-103.

SLAUGHTER, Anne-Marie. The Grand Themes of UN Reform. The American Journal of International Law. № 99, 2005: 619-631.

SLOBODA, John; ABBOTT, Chris. The Blair doctrine and after: five years of humanitarian intervention. (artigo). Disponível em: https://www.opendemocracy.net $(15 / 03 / 2013)$

SMITH, Michael. Humanitarian Intervention: An Overview of the Ethical Issues. Ethics \& International Affairs. Vol. 12 (1998).

SMITH, Steve; BOOTH, Ken. International Relations Theory Today. Cambridge: Polity Press, 1995.

SMOUTS, Marie-Caude (org.). Les nouvelles relations internacionales: pratiques et théories. Paris: Presses de Sciences Po, 1998.

SOFAER, Abraham. International Law and Kosovo. Stanford Journal of International Law. 36/1, 2000. 
SOUTO MAIOR, Luiz A. P. A ordem mundial e o Brasil. Revista Brasileira de política Internacional, vol. 46, $\mathrm{n}^{\circ} 1,2003$.

SPRUYT, Hendrik. The Sovereign State and its Competitors. Princeton, Princeton University Press, 1994. 288p.

STAHN, Carsten. Responsibility to Protect: Political Rhetoric or Emerging Legal Norm?. The American Journal of International Law. Vol. 101, No. 1, 2007. pp 99120.

STEINBERGER, Peter J. Political Obligations and Derivative Duties. The University of Chicago Press. The Journal of Politics, vol. 64, nº. 2, 2002. pp. 449-465.

STEWART, Davis et al. International Human Rights. Third Edition. West Group, 2004.

STROMSETH, Jane. Rethinking humanitarian intervention: the case for incremental change. In: HOLZGREFE, J. L.; KEOHANE, Robert O. Humanitarian Intervention. Ethical, Legal, and Political Dilemmas. Cambridge University Press. 2003. pp. 232-272.

SUKIENNICKI, Wictor. La Souveraineté des États en Droit International Moderne.Paris, Pedone, 1927.423p.

TANNO, Grace. A Contribuição da Escola de Copenhague aos Estudos de Segurança Internacional. Contexto Internacional. Rio de Janeiro, vol. 25, n.1, jan./jun.2003, p.4780 .

THAKUR, Ramesh. Iraq and the Responsibility to Protect. Behind the Headlines. $\mathrm{N}^{\mathrm{o}}$ 62, 2004: 1-16.

Security to the Responsibility to Protect. Cambridge University Press, 2006.

The Responsibility to Protect: Norms, Laws and the use of Force in International Politics. Routledge, 2011.

TADJBAKHSH, Shahrbanou; CHENOY, Anuradha M. Human Security. Concepts and implications. New York: Routledge, 2007.

TARLING, N. Britain and the Bandung Conference of 1955. Cambridge: Cambridge University, 1992.

TECLAFF, Ludwik. International environmental law. New York: Praeger, 1974.

TESON, Fernando. Humanitarian Intervention: An Inquiry into Law and Morality. $2^{\text {nd }}$ ed. Transnational Publishers, Dobbs Ferry, 1997. 
The Liberal Case for Humanitarian Intervention. In: HOLZGREFE, J. L.; KEOHANE, Robert O. Humanitarian Intervention. Ethical, Legal, and Political Dilemmas. Cambridge University Press. 2003. pp .93-129

THEODORSON, G.A. A modern dictionary of sociology. New York: Crowell, 1970.

THOMAS, Nicholas; TOW, William T. The Utility of Human Security: Sovereignty and International Intervention. Security Dialogue, vol. 33, n. 2 (2002): 177-192.

THUAN, Cao-Huy, FENET, Alain (dir.). Mutations internationales et évolution des normes. Amiens, PUF, 1994.

TRINDADE, Antônio Augusto Cançado. Direitos humanos e meio ambiente: paralelo dos sistemas de proteção internacional. Porto Alegre: S.A. Fabris Ed., 1993, p. 89-112.

. O Direito Internacional em um Mundo em

Transformação. Editora Renovar. Rio de Janeiro - São Paulo, 2002.

Environment and Development : Formulation and Implementation of the right to Development as a Human Right. In: Asian Yearbook of International Law, v. 3. pp. 15-45.

Direito das Organizações Internacionais.

$3^{\text {a }}$ edição revista, atualizada e ampliada. Editora Del Rey. Belo Horizonte, 2003.

TOMUSCHAT, Christian. Kosovo and the International Community: A Legal Assessment. New York: Kluwer Law International, 2002.

ULLMAN, Richard. Redefining Security. International Security, v. 8. N. 01 (1983) pp 129-145.

VAISSE, Maurice. Les Relations Internationales Depuis 1945. Paris: Armand Collin, 2004.

VARELlA, Marcelo; BARROS-PlatiaU, A. (orgs.) O Princípio de Precaução. Coleção de Direito e Política Ambiental, Belo Horizonte: Del Rey, 2004.

; BARROS-PLATIAU, Ana Flávia (orgs). Proteção internacional do meio ambiente. Brasília: UNITAR, UniCEUB, UnB. 2009. 302p.

Direito Internacional Público. 4 ed. São Paulo, Ed. Saraiva,

2012.

Internacionalização do Direito: direito internacional, globalização e complexidade. Brasília: UniCEUB, 2013.

VARGAS, João Augusto Costa. Um mundo que também é nosso: o pensamento e a trajetória diplomática de Araujo Castro. Brasília : FUNAG, 2013. 
VIEIRA, Ronaldo. Foucault em casa: aspectos discursivos da construção da comunidade sul-americana de nações (2004-2006). Fundação Alexandre de Gusmão: Brasília, 2010.

VILLA, Rafael A. Duarte. Formas de influência das ONGs na política internacional contemporânea. In: Revista de Sociologia e Política, no 12 :21-33, Curitiba, junho1999.

. "Agenda ecológica global e os regimes internacionais de meio ambiente: um estudo de caso difícil". In : A agenda social das relações internacionais. Belo Horizonte: Ed. Puc Minas, 2005 org. Matilde de Souza.

VINCENT, R. J. Non-Intervention and International Order. Princeton: Princeton University Press, 1974.

VIOLA, Eduardo; FERREIRA, L. (orgs.) Incertezas de sustentabilidade na globalização. Campinas: Unicamp, 1996.

A Dinâmica das Potências Climáticas e as Perspectivas de Transição ao Baixo Carbono. In: José Eli da Veiga. (Org.). Mudanças Climáticas: Perspectivas para o País. 1ed.São Paulo: Instituto Artecidadania, 2012, v. , p. 32-75.

; LESSA, A. C. Global climate governance and transition to a lowcarbon economy: a special issue of RBPI. Revista Brasileira de Política Internacional, v. 55, p. 5-8, 2012.

VIOLA, Eduardo; FRANCHINI, Matías; LEMOS, Tahis. Sistema Internacional de Hegemonia Conservadora: Governança Global e Democracia na Era da Crise Climática. Annablume Editora, 2013.

Impasse na Governança da Mudança Climática. In: Luis Moita. (Org.). Janus 2014. Metamorfoses da Violencia (1914-2014). 1ed. Lisboa: Universidade Autonoma de Lisboa, 2014, v. 16, p. 14-16.

VIZENTINI, Paulo. A Guerra Fria. In: REIS Filho, Daniel Aarão; FERREIRA, Jorge; ZENHA, Celeste. (Org.). O século XX. Rio de Janeiro: Civilização Brasileira, 2000

WAEVER, Ole; BROCK, L. The Environment and Security: Conceptual and Theoretical Issues. In: Nils Gleditsch, ed. Conflict and the Environment - NAT ASI Series, Kluwer Academic Publishers, 1997.

Securitization and Desecuritization. In: RONIE, D. Lipschultz (ed.). On Security. New York: Columbia University Press, 1994.

WALTER, Michael. Arguing about War. New Haven: Yale University Press, 2004.

WALTZ, Kenneth. Man, the State and War. A Theoretical Analysis. Columbia University Press: 2001. 
Lisboa. 2002.

Teoria das Relações Internacionais. Gradiva Publicações.

WALZER, Michael. Spheres of Justice: a Defense of Pluralism and Equality. Basil Blackwell, Oxford, 1983.

WATSON, Adam. A Evolução da Sociedade Internacional: uma análise histórica comparativa. Brasília: Editora UnB, 2004.

WAPNER, Paul. Global Civil Society. In: YOUNG, Oran R. Global Governance. Drawing Insights from the Environmental Experience. MIT Press. 1997, pp. 65-84.

WHEELER, J; BELLAMY, Alex. Humanitarian Intervention in World Politics. In: BAYLIS, John; SMITH, Steve. $3^{\text {rd }}$ ed. The Globalization of World Politics. Oxford University Press, 2005. pp. 555-578.

Saving Strangers: Humanitarian Intervention in International

Society. Oxford: Oxford University Press, 2000.

WEISS, Thomas. Military-Civilian Interactions: Humanitarian Crises and the Responsibility to Protect. Second Edition. New Millennium Books in International Studies (Rowman \& Littlefield Publishers, 2004).

; THAKUR, Ramesh. Global governance and the UN: an unfinished journey. Bloomington: Indiana University Press. 2010.

Press, 2012.

Humanitarian Intervention. Second Edition. London: Polity

WENDT, Alexander. The agent-structure problem in international relations theory. International Organization, v.41, n.3, 1987.

Anarchy is what States make of it: the social construction of power politics. International Organizations, v.46, n.2, 1992.

Collective identity formation and the international state. American Political Science Review, v.88, n.2, 1994.

20(1), 1995.

. Constructing International Politics. International Security, University Press, 1999.

Social Theory of International Politics. Cambridge: Cambridge

WESTING, Arthur. Environmental Hazards of War: Releasing Dangerous Forces in an Industrialized World. London: Sage, 1990.

WIGHT, Martin. Systems of States. Leicester: Leicester University Press, 1979. 
University Press, 1991.

International Theory - The Three Traditions. Leicester: Leicester

WILSON, Rhéa Nadine. Securing the Human: A Critique of Human Security and The Responsibility to Protect. Thesis. Master of Arts. Carleton University, 2006.

WILSON, Thomas M., DONNAN, Hastings. Border Identities. Nation and state at International frontiers. Cambridge University Press: 1998.

WIPPMAN, David. Kosovo and the Limits of International Law. Fordham International Law Journal. 25(1)/129, 2001.

WOJCIECHOWSKI, Paola Bianchi; ALTHAUS, Ingrid Giachini. O esvaziamento do conceito tradicional de soberania em face do sistema internacional de proteção dos direitos humanos. Revista Eletrônica Direito e Política, Programa de Pós-Graduação Stricto Sensu em Ciência Jurídica da UNIVAL, Itajaí, v.6, n.2, 2º quadrimestre de 2011.

WOLFERS, Arnold. The Actors in World Politics. In: WOLFERS, Arnorld (ed.) Discord and Collaboration: Essays on International Politics. Baltimore, Md: John Hopkins Press, 1962.

WOODS, Ngaire. Explaining International Relations since 1945. Oxford: Oxford University Press, 1996.

WORSTER, Donald. The Wealth of Nature. Environmental History and the Ecological Imagination. Oxford: Oxford University Press, 1993.

XENOS, Dimitris. The Positive Obligations of the State Under the European Convention of Human Rights. Routledge, 2012.

YOUNG, Oran R. International Governance: Protecting the Environment in a Stateless Society. Ithaca, NY: Cornell University Press, 1994, pp. 19-26.

Global Governance. Drawing Insights from the Environmental Experience. MIT Press. 1997.

ZACKLIN, Ralph. Beyond Kosovo: The United Nations and Humanitarian Intervention. Virginia Journal of International Law. 41(4)/923, 2001.

ZORGBIBE, Charles. Le droit d'ingérence. PUF, Coll. Que Sais-Je? 1994. 


\section{Documentos e Relatórios}

BRASIL. Decreto n 19.841, de 22 de outubro de 1945. Presidência da República. Casa Civil. Subchefia para Assuntos Jurídicos: Promulga a Carta das Nações Unidas, da qual faz parte integrante o anexo Estatuto da Corte Internacional de Justiça, assinada em São Francisco, a 26 de junho de 1945, por ocasião da Conferência de Organização Internacional das Nações Unidas.

BRASIL. Decreto-lei no 2.848, de 7 de dezembro de 1940. Casa Civil. Subchefia para Assuntos Jurídicos. Código Penal Brasileiro.

BRASIL. Decreto $n^{\circ}$ 4.388, de 25 de setembro de 2002. Presidência da República. Casa Civil. Subchefia para Assuntos Jurídicos: Promulga o Estatuto de Roma do Tribunal Penal Internacional.

INTERNACIONAL LAW COMMISSION. Draft articles on Responsibility of States for Internationally Wrongful Acts, with commentaries. Texto adotado pela Comissão de Direito Internacional, na 53 ${ }^{\text {a }}$ Sessão, 2001, e submetido à AGNU como parte do Relatório da ILC (A/56/10).

Report of the Study Group of the International Law Commission on Fragmentation of international law: difficulties arising from the diversification and expansion of international law. Fifty-eighth session. A/CN.4/L.702 18 July 2006.

BRASIL. Instrução Normativa $n^{\circ}$ 01, de 24 de agosto de 2012, do Ministério da Integração Nacional: Estabelece procedimentos e critérios para a decretação de situação de emergência ou estado de calamidade pública pelos Municípios, Estados e pelo Distrito Federal, e para o reconhecimento federal das situações de anormalidade decretadas pelos entes federativos e dá outras providências.

INTERNATIONAL COMISSION ON INTERVENTION AND STATE SOVEREIGNTY. The Responsibility to Protect. Relatório. Publicado pelo International Development Research Centre. Gareth Evans, co-Chair; Mohamed Sahnoun, co-Chair. Dezembro, 2001.

INTERNATIONAL CRIMINAL COURT. Rome Statute of the International Criminal Court (2011).

NATIONAL DIET OF JAPAN. The Official Report of the Fukushima Nuclear Accident Independent Investigation Commssion. Executive Summary, 2012. pp. 1214. 
NUCLEAR ENERGY AGENCY. Chernobyl: Assessment of Radiological and Health Impacts (2002 Update of Chernobyl: Ten Years On): OECD, 2002.

US DEPARTMENT OF DEFENSE (DoD). Climate Change Adaptation Roadmap. (2014)

UNITED NATIONS DEVELOPMENT PROGRAMME. Human Development Report. (1994)

UNITED NATIONS ENVIRONMENT PROGRAMME. Convention on Biological Diversity: Text and Annexes. Genebra (1994b)

UNITED NATIONS. UN General Assembly. The causes of conflict and the promotion of durable peace and sustainable development in Africa ( $A / 52 / 871$ S/1998/318).

UNITED NATIONS. High Level Panel on Threats, Challenges, and Change: A More Secure World: Our Shared Responsibility. (2004)

UNITED NATIONS. UN General Assembly. 2005 - World Summit Outcome Document (UN A/RES/60/L.1)

UNITED NATINS. Report of the Secretary-General of United Nations. Implementing the Responsibility to Protect. Sixty-Third Session. (2009)

WORLD CONSERVATION MONITORING CENTRE. Guidelines for National reporting in the context of the Convention on Biological Diversity. Cambridge, (1997).

\section{$\underline{\text { Sítios eletrônicos visitados }}$}

www.ap.org/ - Associated Press

www.asean.org/ - Association of Southeast Asian Nations

www.cred.be - Centre for Research on the Epidemiology of Disasters

www.emdat.be - EM-DAT-International Disaster Database 
www.hsrgroup.org/ - Human Security Report Project

www.iaea.org/ - International Atomic Energy Agency

www.icc-cpi.int - International Criminal Court

www.icj-cij.org/ - International Court of Justice

www.idrc.ca - International Development Research Centre

www.ifrc.org/ - International Federation of Red Cross and Red Crescent Societies

www.iidh.ed.cr - Inter-American Institute of Human Rights

www.imf.org/ - International Monetary Fund

www.ipcc.ch/ - International Panel on Climate Change

www.itamaraty.gov.br - Ministério das Relações Exteriores - Brasil

www.nato.int/ - North Atlantic Treaty Organization

www.planalto.gov.br/ - Portal da Legislação - Presidência da República

Www.responsibilitytoprotect.org/ - International Coalition for the RtoP

www.scmp.com/ - South China Morning Post: International Edition

www.un.org/ - United Nations

www.un.org/law/ilc/ - International Law Commission

www.undp.org/- United Nations Development Programme

www.unece.org/ - United Nations Economic Commission for Europe

www.unep.org/ - United Nations Environment Programme

www.unrol.org/ - United Nations Rule of Law

www.unscear.org/ - UN Scientific Committee on the Effects of Atomic Radiation

www.world-nuclear.org/ - World Nuclear Association

www.worldbank.org - World Bank 
Anexos 


\section{$\underline{\text { Anexo I }}$}

\section{ORDEM CRONOLÓGICA DOS TRATADOS E CONVENCÕES INTERNACIONAIS MULTILATERAIS SOBRE MEIO AMBIENTE, REGISTRADOS NA ONU}

\section{PARTE I}

- Convenção de Berna entre Baden (República Federal da Alemanha) e Suíça para o Estabelecimento de Regulamentações Uniformes concernentes à Pesca no Reno entre Constança e Basiléia, 9/11/1869;

- Convenção de Basiléia entre Baden (id.), França e Suíça, para o Estabelecimento de Regulamentações Uniformes Concernentes à Pesca no Reno e nos seus Tributários, Inclusive o Lago de Constança, 25/03/1875;

- Convenções da Haia de 1899, sobre codificação de costumes de guerra, nomeadamente: a Convenção I (relativa às Leis da Guerra Terrestre, art. 56), Convenção IV (relativa às Leis e Usos da Guera Terrestre, Anexo) e Convenção IX (relativa ao Bombardeamento por Forças Navais, em Tempos de Guerra, art. $5^{\circ}$ );

- Convenção de Londres para a Proteção de Animais Selvagens, Pássaros e Peixes na África, 19/03/1900;

- Convenção relativa à Utilização de Chumbo Branco em Pintura, Genebra, OIT, 1921, (T);

- Convenção para a Regulamentação da Pesca da Baleia, Genebra, (Liga das Nações), 1931 (F). Promulgada pelo Decreto no 23.456 de 14/11/1933;

- Convenção relativa à Preservação da Fauna e Flora em seu Estado Natural, Londres, 1933;

- Tratado para a Proteção das Instituições Científicas e Artísticas e Monumentos Históricos, (Pacto Roerich), Washington (União Panamericana, antecessora da OEA), 1935, (N), (P);

- Convenções de Genebra de 1949, Convenção IV (relativa à Proteção dos Civis em Tempo de Guerra, art. 53) e Protocolo Adicional I (art. 53);

- Convenção para a Proteção da Fauna e da Flora e das Belezas Cênicas Naturais dos Países da América, Washington, 1940, UPA (União Panamericana, antecessora da atual OEA),(F), (P). Promulgada pelo Decreto $n^{\circ} 58.054$ de 23/08/1966;

- Convenção para a Regulamentação da Pesca da Baleia (com emendas), Washington, 1946 (F). Promulgada pelo Decreto n 28.524 de 18/08/1950;

- Convenção para o Estabelecimento de Uma Comissão Interamericana do Atum ]Tropical, Washington, 1949;

- Acordo para o Estabelecimento de um Conselho Geral de Pesca para o Mediterrâneo (com emendas), Roma, 1949;

- Convenção Internacional de Paris para a Proteção das Aves, Paris, 1950 (F); 
- Convenção para o Estabelecimento de uma Organização para a Proteção de Vegetais na Europa e no Mediterrâneo (com emendas), Paris, 1952;

- Convenção Internacional para a Proteção dos Vegetais, Roma (FAO), 1951 (F). Promulgada pelo Decreto $\mathrm{n}^{\circ} 51.342$ de 28/10/1961;

- Acordo Relativo a Medidas para a Proteção das Reservas de Camarão de Fundo do Mar ("pandalus borealis"), Lagosta Européia ("homarus vulgaris"), Lagosta Norueguesa ("nephrops norvegicus") e o Caranguejo ("cancer pagurus"), (com emendas), Oslo, 1952 ;

- Convenção Internacional sobre a Pesca em Alto Mar no Oceano Pacífico Norte (com emendas), Toquio, 1952;

- BIS-Protocolo de Emenda à Convenção Internacional sobre Pesca em Alto Mar no Oceano Pacífico Norte, Tóquio, 1978;

- Convenção da UNESCO para a Proteção de Bens Culturais em Caso de Conflito Armado, Haia, 1954; aprovada no Brasil com o Decreto Legislativo $n^{\circ} 32$ de 14/08/1956;

- Convenção Internacional para a Prevenção da Poluição do Mar por Óleo (com emendas em 11 de abril de 1962 e 21 de outubro de 1969, e 1971), Londres (OMCI, antecessora da atual OMI), 1954, (M);

- Emendas à Convenção Internacional para a Preservação da Poluição do Mar por Óleo de 1954, Relativa à Colocação de Tanques e à Limitação do Tamanho dos Tanques, Londres (OMCI) 1971;

- Emendas à Convenção Internacional para a Preservação do Mar de 1954, Relativa à Proteção dos “Great Barrier Reef” na Austrália, Londres (OMCI) 1971;

- Acordo de Proteção dos Vegetais para o Sudeste da Asia e a Região do Pacífico (com emendas), Roma (FAO), 1956;

- Convenção Provisória sobre Conservação das Focas de Pele no Pacífico Norte (com emendas), Washington, 1957;

- Convenção Relativa à Pesca nas Águas do Danúbio, Bucareste, 1958;

- Convenção sobre a Plataforma Continental, Genebra, 1958, (M). Autorizada a Adesão pelo Decreto ${ }^{\circ} 45 / 68$;

- Convenção sobre Pesca e Conservação de Recursos Vivos do Alto Mar, Genebra, 1958, (M), (F). Autorizada a Adesão pelo Decreto Legislativo no 45/68;

- Convenção sobre o Alto Mar, Genebra, 1958 (M). Autorizada a Adesão pelo Decreto Legislativo $n^{\circ} 45 / 68$;

- Convenção sobre Pesca no Atlântico Nordeste, Londres, 1959;

- Convenção Relativa à Pesca no Mar Negro, (com emendas), Varna, 1959;

- Tratado da Antártica, Washington, 1959,(GE). Promulgado pelo Decreto no 75.963 de 11/07/1975;

- BIS- Protocolo ao Tratado da Antártica sobre Proteção ao Meio Ambiente da Antártica, Madri, 1991. Remetida à aprovação do Congresso Nacional com a Mensagem no 231 de 30/IV/1993.

- Acordo Relativo à Cooperação na Quarentena de Vegetais, e Sua Proteção contra Pestes e Doenças, Sofia, 1959;

- Convenção Relativa à Proteção dos Trabalhadores contra Radiações Ionizantes, Genebra, OIT, 1960. Promulgada pelo Decreto ${ }^{\circ}$ 62.151 de 19/01/1968;

- Convenção de Steckborn sobre a Proteção do Lago Constança contra Poluição, 27/10/1960; 
- Convenção sobre Responsabilidade Civil contra Terceiros no Campo da Energia Nuclear (com emendas descritas adiante), Paris, denominada "Convenção de Paris", 1960;

- Convenção sobre Responsabilidade dos Operadores de Navios Nucleares, Bruxelas, 1962;

- Convenção Suplementar à Convenção sobre Responsabilidade Civil contra Terceiros no Campo da Energia Nuclear, (com emendas descritas além), Bruxelas, 1963, (impropriamente denominada "Convenção EURATOM");

- Protocolo Relativo à Constituição de uma Comissão Internacional para a Proteção do Mosela contra a Poluição, Paris, 1961;

- Convenção Internacional para a Proteção das Obtenções Vegetais, Paris, 1961, (criação da União Internacional para a Proteção de Obtenções Vegetais, UPOV, sediada em Genebra) [posteriormente modificada em 1972, 1978 e 1991, pelos denominados: Ato Adicional de 1972, Ato de 1978 e Ato de 1991];

- Convenção sobre o Gafanhoto Migratório Africano, Kano, 1962;

- Convenção Relativa à Cooperação na Pesca Marítima, Varsóvia, 1962;

- Acordo Relativo à Comissão Internacional para a Proteção do Reno contra a Poluição (com emendas), Berna, 1963;

- Convenção de Viena sobre Responsabilidade Civil por Danos Nucleares, Viena, 1963, sob a égide da AIEA. Promulgada pelo Decreto n ${ }^{\circ} 911$ de 03/09/1993;

- Protocolo Opcional Relativo à Solução Compulsória de Controvérsias, Viena, 1963;

- Protocolo Adicional à Convenção de Paris sobre Responsabilidade Civil contra Terceiros no Campo da Energia Nuclear, Paris, 1964;

- Protocolo Adicional à Convenção EURATOM (Convenção de 31 de janeiro de 1963, Suplementar à Convenção de Paris de 29 de julho de 1960, sobre Responsabilidade Civil contra Terceiros no Campo da Energia Nuclear), Paris a 1964;

- Tratado de Proscrição das Experiências com Armas Nucleares na Atmosfera, no Espaço Cósmico e sob a Água, Moscou, 1963. Promulgado pelo Decreto $\mathrm{n}^{\mathrm{o}} 58.256 \mathrm{de}$ 26/06/1966 (conhecido por "Partial Test Ban");

- Acordo para o Estabelecimento de uma Comissão de Controle do Gafanhoto do Deserto na Região Ocidental de Sua Área de Distribuição no Sudeste da Ásia, (com emendas), Roma, 1963, FAO;

- Acordo Nórdico de Assistência Mútua de Emergência, no caso de Acidentes Radiológicos, 17/10/1963;

- Convenção e Estatuto Relativos ao Desenvolvimento da Bacia do Tchad, (com emendas), Fort Lamy (N’Djamína), 1964;

- Convenção sobre o Conselho Internacional para a Exploração do Mar (com emendas), Copenhague, 1964;

- Acordo para o Estabelecimento da Comissão de Controle do Gafanhoto do Deserto no Oriente Médio (com emendas), Roma, FAO, 1965;

- Convenção Internacional para a Conservação do Atum e Afins, do Atlântico, Rio de Janeiro, 1966. Promulgada pelo Decreto no 412 de 09/01/1969;

- Tratado para a Proscrição de Armas Nucleares na América Latina (Tratado de Tlatelolco), Cidade do México, 1967. Aprovado pelo Decreto Legislativo no 50/1967, e ainda pelo Decreto Legislativo $\mathrm{n}^{\mathrm{o}} 169$ de 15/05/1994 e promulgado pelo Decreto $\mathrm{n}^{\mathrm{o}}$ 1246 de 16/09/94 (DO de 19/09/94), p. 14093; 
- Tratado sobre Princípios Reguladores das Atividades dos Estados na Exploração e Uso do Espaço Cósmico, Inclusive a Lua e Demais Corpos Celestes, Londres, Moscou, Washington, 1967. Promulgado pelo Decreto n ${ }^{\circ} 64.362$ de 17/04/1969;

- Convenção Fito-Sanitária para a África, Kinshasa, 1967;

- Convenção Africana sobre a Conservação da Natureza e Recursos Naturais, Argel, 1968;

- Convenção Européia sobre a Restrição do Uso de Certos Detergentes em Produtos de Lavagem e de Limpeza, Estrasburgo, 1968;

- Tratado da Bacia do Prata, Brasília, 1969 (GE), (R). Promulgado pelo Decreto no 81.351 de 17/02/1978;

- Convenção Européia para a Proteção de Animais durante Transporte Internacional, Paris, 1968;

- Convenção Européia para a Proteção da Herança Arqueológica, Londres, 1969;

- Acordo para a Cooperação no Trato com a Poluição do Mar do Norte por Óleo, Bonn, 1969 ;

- Convenção sobre Conservação dos Recursos Vivos do Atlântico Sudeste, Roma, 1969;

- Convenção Internacional sobre Responsabilidade Civil por Danos Causados por Poluição por Óleo, Bruxelas, 1969, (conhecida por “CLC”, "civil liability convention”), complementada por 2 protocolos, adiante referidos) Promulgada pelo Decreto $\mathrm{n}^{\circ} 79.437$ de 28/03/1977;

- Convenção Internacional relativa à Intervenção em Alto Mar nos Casos de Baixas por Poluição por Óleo, Bruxelas, 1969;

- Protocolo relativo à Intervenção em Alto Mar nos Casos de Poluição Marinha por Substâncias alem do Óleo, Londres, OMI, 1973;

- Convenção sobre Medidas a Serem Adotadas para Proibir e Impedir a Importação, Exportação e Transferência de Propriedade Ilícita de Bens Culturais, Paris, (UNESCO) 1970. Promulgada pela Decreto $n^{\circ} 72.312$ de 31/05/1973;

- Convenção BENELUX sobre Caça e Proteção de Pássaros, (com emendas), Bruxelas, 1970;

- Acordo para o Estabelecimento de uma Comissão para o Controle do Gafanhoto do Deserto no Noroeste da África (com emendas), Roma, FAO, 1970;

- Convenção relativa a Zonas Úmidas de Importância Internacional, Particularmente como Hábitat das Aves Aquáticas, Ramsar (Irã), 1971, (F)(GE). Autorizada sua adesão pelo Decreto Legislativo no 33 de 16/06/1992;

- Protocolo de Emenda à Convenção relativa a Zonas Úmidas de Importância Internacional, Particularmente como Hábitat das Aves Aquáticas, Paris, 1982. Aprovada sua adesão pelo Congresso Nacional, nas mesmas condições que a Convenção de Ramsar;

- Tratado sobre a Proibição da Colocação de Armas Nucleares e Outras Armas de Destruição em Massa no Leito do Mar, e no Fundo do Oceano e em Seu Subsolo, Londres, Moscou, Washington, 1971. Promulgado pelo Decreto $\mathrm{n}^{\circ} 97.211$ de 12/12/1988, com reservas;

- Convenção relativa á Responsabilidade Civil no Campo do Transporte Marítimo de Material Nuclear, Bruxelas, 1971;

- Convenção Internacional relativa ao Estabelecimento de um Fundo Internacional para Reparação de Danos por Poluição por Óleo, (com emendas descritas mais abaixo), Bruxelas, 1971, conhecida como "Fund Convention"; 
- Convenção sobre Responsabilidade Internacional por Danos Causados por Objetos Espaciais, Londres, Moscou e Washington, 22 de março de 1972. Promulgada pelo Decreto $n^{\circ} 71.981$ de 22/03/1972;

- Convenção relativa á Proteção contra Riscos de Envenenamento Causado por Benzeno, Genebra, 1971;

- Convenção para a Prevenção de Poluição Marítima por Alijamentos de Navios e Aeronaves, (com emendas), Oslo, 1972;

- Convenção relativa ao "Status" do Rio Senegal e Convenção que Estabelece a Organização de Desenvolvimento do Rio Senegal (com emendas), Nouakchott, 1972;

- Convenção para a Conservação das Focas Antárticas, Londres, 1972. Promulgada pelo Decreto n 66 de 18/03/1991;

- Convenção sobre a Proibição do Desenvolvimento, Produção e Armazenamento de Armas Bacteriológicas (Biológicas) e de Toxinas, e Sua Destruição, Londres, Moscou, Washington, 1972. Promulgada pelo Decreto n 77.374 de 01/04/1976 (conhecido como BWC);

- Convenção relativa à Proteção do Patrimônio Mundial, Cultural e Natural, Paris, UNESCO, 1972. Promulgada pelo Decreto no 80.978 de 12/12/1977;

- Convenção sobre Prevenção de Poluição Marinha por Alijamento de Resíduos e Outras Matérias (com emendas), Londres, Cidade do México, Moscou, Washington, 1972. Promulgada pelo Decreto no 87.566 de 16/09/1082;

- Convenção sobre Comércio Internacional das Espécies da Flora e da Fauna Selvagens em Perigo de Extinção, Washington, 1973, com emendas. Promulgada pelo Decreto $\mathrm{n}^{\circ}$ 76.623 de 17/11/1975. Com as emendas votadas em Gaborone, em 1983, promulgadas pelo Decreto $\mathrm{n}^{\circ}$ 92.446/86 e as emendas votadas em Bonn, em 1979, promulgadas pelo Decreto ${ }^{\circ} 133$ de 24/05/1991;

- Convenção para o Estabelecimento de um Comitê Permanente Interestatal para o Controle da Seca para o Sahel, Uagadugu, 1972;

- Convenção sobre Pesca e Conservação dos Recursos Vivos no Mar Báltico e Estreitos, Gdansk, 1973;

- Convenção Internacional para a Prevenção da Poluição Causada por Navios, MARPOL, Londres (OMI), 1973, (M). Aprovada pelo Decreto Legislativo $\mathrm{n}^{\circ}$ 4/87; promulgada pelo Decreto n ${ }^{\circ} 2.508$ DE 04/V/1998, inclusive com a adoção dos Protocolos e de todos os Anexos; (vide observações no item \#70 a seguir);

- Protocolo de 1978 relativo à Convenção Internacional para a Prevenção da Poluição Causada por Navios, MARPOL, Londres (OMI), 1973, (M). Promulgado pelo Decreto $\mathrm{n}^{\mathrm{o}}$ 2.508/98, da mesma forma que o mencionado no item anterior. Este Protocolo e a Convenção mencionada no item anterior sob \# 69, são conhecidos como "Convenção MARPOL 73/78" ou simplesmente, "Convenção MARPOL";

- Acordo relativo à Conservação dos Ursos Polares, Oslo, 1973;

- Convenção relativa á Proteção do Meio Ambiente entre a Dinamarca, Finlândia, Noruega e Suécia, Estocolmo, 1974;

- Convenção relativa à Proteção do Meio Ambiente Marinho da Área do Mar Báltico, Helsinki, 1974;

- Convenção relativa à Poluição Marinha de Origem Telúrica, Paris, 1974;

- Convenção relativa à Prevenção e Controle de Riscos Profissionais Causados por Substâncias e Agentes Carcinogênicos, Genebra, OIT, 1974;

- Acordo sobre um Programa Internacional de Energia, Paris, 1974; 
- Convenção para a Proteção do Mar Mediterrâneo contra Poluição, Barcelona, 1976;

- Protocolo para a Prevenção da Poluição do Mar Mediterrâneo por Alijamento de Navios e Aeronaves, Barcelona, 1976;

- Protocolo relativo à Cooperação no Combate à Poluição do Mar Mediterrâneo por Óleo e Outras Substâncias Perigosas em Casos de Emergência, Barcelona, 1976;

- Protocolo à Convenção Internacional sobre Responsabilidade Civil por Danos Causados por Poluição por Óleo, adotado em Londres, a 1976, (conhecido por "1976 CLC Protocol");

- Protocolo à Convenção para o Estabelecimento de um Fundo Internacional para Compensações por Danos de Poluição por Óleo, adotado em Londres, a 1976 (conhecido por "1976 Fund Protocol");

- Protocolo Adicional I à Convenção de Genebra concernente à Proteção de Vítimas de Conflitos Armados Internacionais (Arts. 35[3], 53, 55, 56), 08/06/1977 (texto in 16 ILM 977 (1977);

- Protocolo Adicional II à Convenção de Genebra concernente à Proteção de Vítimas de Conflitos Armados Internacionais (Arts. 14-16), 08/06/1977 (texto in 16 ILM 1442 (1977);

- Protocolo para a Proteção do Mar Mediterrâneo contra a Poluição de Origem Telúrica, Atenas, 1980;

- Protocolo relativo a Áreas do Mediterrâneo Especialmente Protegidas, Genebra, 1982;

- Protocolo de Emenda à Convenção de Paris (sobre Responsabilidade Civil contra Terceiros no Campo da Energia Nuclear de 29 de julho de 1960), com as Emendas do Protocolo Adicional de 19 de janeiro de 1964, Paris, 1982;

- Protocolo de Emenda à Convenção EURATOM (Convenção de 31 de janeiro de 1963, Suplementar ä Convenção de Paris de 29 de julho de 1960, sobre Responsabilidade Civil contra Terceiros no Campo da Energia Nuclear, conforme Emendas do Protocolo Adicional de 28 de janeiro de 1964), Paris, a 1982;

- Convenção Européia para a Proteção de Animais Capturados para Fins Agrícolas, Estrasburgo, 1976;

- BIS - Protocolo de Emenda à Convenção Européia para a Proteção de Animais Capturados para Fins Agrícolas, Estrasburgo, 1992;

- Acordo relativo à Proteção das Águas das Praias do Mediterrâneo, Mônaco, 1976;

- Convenção sobre a Conservação da Natureza no Pacífico Sul, Apia, 1976;

- Convenção sobre a Proteção da Herança Arqueológica, Histórica e Artística das Nações Americanas (Convenção de San Salvador), Santiago, 1976;

- Convenção sobre a Proteção do Reno contra Poluição Química, Bonn, 1976;

- Convenção sobre a Proteção do Reno contra Poluição por Cloretos, Bonn, 1976;

- Convenção sobre a Proibição do Uso Militar ou Hostil de Técnicas de Modificação Ambiental, Nova York (ONU), 1976. Promulgada pelo Decreto n 225 de 07/10/1991 (conhecida como ENMOD Convention);

- Convenção sobre Responsabilidade Civil por Dano Decorrente de Poluição por Óleo, Resultante de Exploração e Explotação de Recursos Minerais do Subsolo Marinho, Londres (Governo do Reino Unido), 1977;

- Convenção sobre a Proteção dos Trabalhadores contra Riscos Profissionais devidos à Contaminação do Ar, ao Ruído e às Vibrações no Local de Trabalho, Genebra, OIT 1977, (T). Promulgada pelo Decreto ${ }^{\circ} 93.413$ de 15/10/1986; 
- Convenção Regional do Kuwait para a Cooperação na Proteção do Meio Marinho contra a Poluição, Kuwait, 1978;

- Protocolo relativo à Cooperação Regional no Combate à Poluição por Óleo e Outras Substâncias Perigosas em Casos de Emergência, Kuwait, 1978;

- Tratado de Cooperação Amazônica, Brasília, 1978. Promulgado pelo Decreto $\mathrm{n}^{\circ} 85.050$ de 18/08/1990;

- Convenção sobre Cooperação Multilateral Futura na Pesca no Atlântico Noroeste, Ottawa, 1978;

- Convenção sobre a Conservação de Espécies Migratórias Pertencentes à Fauna Selvagem, Bonn, 1979;

- Convenção Européia para a Proteção de Animais para Abate, Estrasburgo, 1979;

- Convenção Européia sobre a Conservação da Vida Selvagem e Hábitats Naturais, (Conselho da Europa) Berna, 1979;

- Convenção sobre Proteção Física de Material Nuclear, Viena, AIEA, 1979. Promulgada pelo Decreto $n^{\circ} 95$ de 16/04/1991;

- Convenção sobre Poluições Atmosféricas Transfronteiriças de Longa Distância, Genebra, 1979;

- Protocolo à Convenção sobre Poluições Atmosféricas Transfronteiriças de Longa Distância, relativo ao Financiamento a Longo Prazo de um Programa de Cooperação para o Controle e Avaliação da Transmissão de Poluentes Atmosféricos a Longa Distância na Europa (EMEP), Genebra, 1984;

- Protocolo à Convenção Internacional sobre Responsabilidade Civil por Danos Causados por Poluição por Óleo, adotado em Londres, a 1984 (M) (GE) (T) (RR), (conhecido por "1984 CLC Protocol");

- Protocolo à Convenção para o Estabelecimento de um Fundo Internacional para Compensações por Danos de Poluição por Óleo, adotado em Londres, a 1984 (conhecido por "1984 Fund Protocol");

- Protocolo à Convenção de 1979 sobre Poluições Atmosféricas Transfronteiriças de Longa Distância, sobre a Redução de Emissões de Enxofre ou Seus Fluxos Transfronteiriços, ao Nível de Pelo Menos 30\%, Helsinki, 1985;

- Protocolo à Convenção de 1979 sobre Poluição Atmosférica Transfronteiriça de Longa Distância, relativo ao Controle de Emissões de Óxido de Azoto ou Seus Fluxos Transfronteiriços, Sofia, 1988;

- BIS - Protocolo à Convenção de 1979 sobre Poluição Atmosférica Transfronteiriça de Longa Distância, relativo ao Controle de Emissões de Compostos Orgânicos Voláteis e seus Fluxos Transfronteiriços, Genebra, 1991;

- Convenção para a Conservação e Gestão da Vicunha, Lima, 1979;

- Convenção sobre a Conservação de Recursos Vivos Marinhos Antárticos, Canberra, 1980. Promulgada pelo Decreto no 93.935 de 15/01/1987;

- Convenção Modelo Européia sobre Cooperação Transfronteiriça entre Comunidades ou Autoridades Territoriais, Madri, 1980;

- Convenção sobre Cooperação Multilateral Futura na Pesca do Atlântico Nordeste, Londres, 1980;

- Convenção para a Criação da Autoridade da Bacia do Niger e Protocolo relativo ao Fundo de Desenvolvimento da Bacia do Niger, Faranah, 1980;

- Convenção para a Cooperação na Proteção de Desenvolvimento do Meio Ambiente Marítimo e Costeiro da Região Central e Ocidental da África, Abidjan, 1981; 
- Protocolo relativo à Cooperação no Combate à Poluição em Casos de Emergência, Abidjan, 1981;

- Convenção para a Proteção do Meio Ambiente Marítimo e da Área Costeira do Pacífico Sudeste, Lima, 1981;

- Acordo sobre Cooperação Regional no Combate à Poluição do Pacífico Sudeste por Óleo e Outras Substâncias Perigosas em Casos de Emergência, Lima, 1981;

- Protocolo Suplementar ao Acordo sobre Cooperação Regional no Combate à Poluição do Pacífico Sudeste por Óleo e Outras Substâncias Perigosas em Casos de Emergência, Quito, 1983;

- Protocolo para a Proteção do Pacífico Sudeste contra Poluição Telúrica, Quito, 1983;

- Protocolo para Conservação e Gestão de Áreas Protegidas, Marítimas e Costeiras do Pacífico Sudeste, Paipa, 1989;

- Protocolo para a Proteção do Pacífico Sudeste contra Contaminação Radioativa, Paipa;

- Convenção relativa à Segurança e Saúde nas Atividades Ocupacionais e no Ambiente do Trabalho, Genebra, OIT, 1981, (T);

- Convenção Regional para a Conservação do Meio Ambiente e do Mar Vermelho e do Golfo de Aden, Jiddah, 1982;

- Protocolo relativo à Cooperação Regional no Combate à Poluição por Óleo e Outras Substâncias Perigosas em Casos de Emergência, Jiddah, 1982;

- Convenção para a Conservação do Salmão no Oceano Atlântico Norte, Reykjavik, 1982;

- Convenção BENELUX sobre a Conservação da Natureza e a Proteção da Paisagem, Bruxelas, 1982;

- Convenção das Nações Unidas sobre o Direito do Mar, Montego Bay, 1982; assinada pelo Brasil, promulgada pelo Decreto $\mathrm{n}^{\circ} 99.165$ de 12 de março de 1990, e declarada em vigor no Brasil pelo Decreto n ${ }^{\circ} 1530$ de 22 de junho de 1995;

- Convenção para a Proteção de Desenvolvimento do Meio Ambiente Marinho da Região das Grandes Caraíbas, Cartagena, 1983;

- Protocolo relativo à Cooperação no Combate aos Derramamentos de Óleo na Região das Grandes Caraíbas, Cartagena, 1983;

- Protocolo relativo a Áreas Especialmente Protegidas e à Vida Selvagem, à Conservação para a Proteção e Desenvolvimento do Meio Ambiente Marinho da Região das Grandes Caraíbas, Kingston, 1990;

- Acordo para a Cooperação no Trato com a Poluição do Mar do Norte por Óleo e Outras Substâncias Perigosas, Bonn, 1983;

- Acordo Internacional sobre Madeiras Tropicais, Genebra, UNCTAD, (Conferência das Nações Unidas sobre Comércio e Desenvolvimento), 1983. Segundo consta do documento da UNEP, o Brasil é parte da mesma, com a data de 01/04/1985, para a entrada em vigor da Convenção, constando ainda a nota de que o País declarou sua aplicação provisória. Este acordo expirou em 1994 e foi substituído pelo Acordo Internacional sobre Madeiras Tropicais, Genebra, 1995, tendo este último texto sido subscrito pelo Brasil e já se acha promulgado pelo Decreto no 2.707 de 04 de agosto de 1998;

- Convenção de Viena para a Proteção da Camada de Ozônio, Viena, 1985. Promulgada pelo Decreto n ${ }^{\circ}$ 99.280 de 06/06/1990;

- Protocolo de Montreal sobre Substâncias que Destroem a Camada de Ozônio, Montreal, 1987. Promulgado pelo Decreto ${ }^{\circ} 99.280$ de 06/06/1990; 
- Ajustes do Protocolo de Montreal sobre Substâncias que Destroem a Camada de Ozônio, adotados em Helsinki a 29/06/1990. Promulgados pelo Decreto $\mathrm{n}^{\circ} 181 \mathrm{de}$ 25/07/1991;

- Emenda ao Protocolo de Montreal sobre Substâncias que Destroem a Camada de Ozônio, Londres, 1990. Submetida à Aprovação do Congresso Nacional, com a Mensagem Presidencial no 537 de 08/10/1991;

- Convenção para a Proteção, Gestão e Desenvolvimento do Meio Marinho e Costeiro da Região da África Oriental, Nairobi, 1985;

- Protocolo relativo a Áreas Protegidas e à Flora e Fauna Selvagens na Região da África Oriental, Nairobi, 1985;

- Protocolo relativo à Cooperação no Combate à Poluição Marinha em casos de Emergência, na Região da África Oriental, Nairobi, 1985;

- Convenção relativa a Serviços de Saúde no Trabalho, Genebra, OIT, 1985;

- Tratado de Desnuclearização do Pacífico Sul, ("South Pacific Nuclear Free Zone Treaty"), Raratonga, 1985;

- Acordo ASEAN sobre Conservação da Natureza e dos Recursos Naturais, Kuala Lumpur, 1985;

- Convenção relativa a Segurança na Utilização de Asbestos, Genebra, OIT, 1986;

- Convenção sobre Pronta Notificação de Acidentes Nucleares, Viena, AIEA, 1986. Promulgada pelo Decreto $\mathrm{n}^{\circ} 9$ de 15/01/1991;

- Convenção sobre Assistência no caso de Acidente Nuclear ou Emergência Radiológica, Viena, AIEA, 1986. Promulgada pelo Decreto $n^{\circ} 9$ de 15/01/1991;

- Convenção das Nações Unidas sobre as Condições para o Registro de Navios, Genebra, 1986;

- Convenção relativa à Preservação da Confidencialidade de Dados Relativos a Áreas do Solo do Alto Mar, Moscou, 1986;

- Convenção para a Proteção dos Recursos Naturais e do Meio Ambiente da Região do Pacífico Sul, Noumea, 1986;

- Protocolo para a Prevenção de Poluição da Região do Pacífico Sul por Alijamento, Noumea, 1986;

- - Protocolo relativo a Cooperação no Combate às Emergências Poluidoras na Região do Pacífico Sul, Noumea, 1986;

- Convenção Européia para a Proteção de Vertebrados Usados para Experiências e Outros fins Científicos, Estrasburgo, 1986;

- Acordo sobre um Plano de Ação para uma Gestão Ambiental Correta do Sistema Comum do Rio Zambeze, Harare, 1987;

- Convenção Européia para a Proteção de Animais de Estimação, Estrasburgo, 1987;

- Convenção sobre o Regime Jurídico das Atividades Relativas aos Recursos Minerais da Antártica, Wellington, 1988;

- Protocolo Conjunto relativo à Aplicação das Convenções de Viena e de Paris (sobre responsabilidade civil por danos nucleares), Viena, AIEA, 1988;

- Acordo sobre uma Rede de Centros de Aqüicultura na Ásia e no Pacífico, Bangkok, 1988 ;

- Convenção da Basiléia sobre Movimentos Transfronteiriços de Resíduos Perigosos e Seu Depósito, Basiléia, 1989. Promulgada pelo Decreto no 875 de 19/07/1993; 
- Convênio entre Brasil, Argentina, Chile, Paraguai e Uruguai, para a Constituição do Comitê Regional de Sanidade Vegetal, COSAVE, Montevidéu, 09/03/1989 (F). Promulgado pelo Decreto no 161 de 02/07/1991;

- Convenção sobre a Proibição da Pesca com Grandes Redes de Arrastão Flutuantes ("Long Drift Nets") no Pacífico Sul, Wellington, 1989;

- Convenções Internacionais sobre o Salvamento, Londres, OMI, 1989;

- Protocolo relativo à Luta contra Emissões de Óxido de Azoto ou Seus Fluxos Transfronteiriços, Sofia, 1988;

- Convenção sobre Responsabilidade Civil por Danos Causados durante o Transporte de Produtos Perigosos por Rodovias, Ferrovias ou por Barcos de Navegação Interior, conhecida por CRTD (do acrônimo de sua denominação de francês: Convention, Responsabilité, Transport, Dangereuses), Genebra, 1989;

- Convenção relativa à Segurança no Uso de Produtos Químicos no Trabalho, Genebra, OIT, 1990;

- Convenção sobre a Conservação de Focas no Mar de Wadden, Bonn, 1990;

- Convenção Internacional sobre o Preparo, a Prevenção, Resposta e Cooperação em Caso de Poluição por Óleo, Londres (OMI), 30 de novembro de 1990. Conhecida como Convenção OPRC. Assinada pelo Brasil a 3 de abril de 1991; promulgada pelo Decreto no 2.870 de 10/12/1998;

- Convenção de Bamako sobre o Banimento de Importação para a África e o Controle de Movimentos Transfronteiriços e o Manejo de Resíduos Perigosos dentro da África, Bamako, 20 de janeiro de 1991;

- Convenção das Nações Unidas sobre Avaliação de Impacto Ambiental em um Contexto Transfronteiriço, Espoo (Finlândia), 25 de fevereiro de 1991;

- Tratado que estabelece a Comunidade Econômica Africana, Abuja, 1991;

- Acordo sobre a Conservação de Morcegos na Europa, Londres, 1991;

- Acordo sobre a Conservação de Pequenos Cetáceos dos Mares Báltico e do Norte, Nova York, 1992;

- Convenção sobre Efeitos Transfronteiriços de Acidentes Industriais, Helsinki, 17 de março de 1992;

- Convenção sobre a Proteção e Utilização de Cursos d'Água Transfronteiriços e Lagos Internacionais, Helsinki, 17 de março de 1992;

- Convenção sobre a Proteção do Mar Negro contra a Poluição, Bucareste, 21 de abril de 1992;

- Convenção-Quadro das Nações Unidas sobre Modificação do Clima, Rio de Janeiro, 1992. Assinada pelo Brasil, durante a ECO-92, tendo seu texto sido aprovado pelo Decreto-Legislativo $\mathrm{n}^{\circ} 1$ de 03/02/1994; (depósito de 25 ratificação junto à ONU em 28/02/1994); promulgada pelo Decreto $\mathrm{n}^{\circ} 2.652$ de 01/07/1998;

- Convenção sobre a Diversidade Biológica, Rio de Janeiro, 5 de junho de 1992, assinada pelo Brasil durante a ECO-92. Seu texto foi aprovado pelo Decreto Legislativo $\mathrm{n}^{\circ} 2$ de 03/02/1994; (depósito de ratificação junto à ONU em 28/02/1994); promulgada pelo Decreto no 2.519 de 16/III/1998. 


\section{PARTE}

\section{ATUALIZAÇÕES}

I - Convenção para a Proteção do Meio Ambiente Marinho do Atlântico Nordeste, Paris, 22 de setembro de 1992; (Texto e informações, apud 32 ILM 1069 (1993); deverá substituir a Convenção relativa à Poluição Marinha de Origem Telúrica, Paris, 1974 (\# 75) e seu Protocolo de 1986, bem como a Convenção para a Prevenção de Poluição Marítima por Alijamentos de Navios e Aeronaves, (com emendas), Oslo, 1972, (\# 60);

II - Convenção para a Proteção do Mar Negro contra a Poluição, Protocolo sobre Proteção do Mar Negro contra Poluição Telúrica, Protocolo sobre Proteção do Mar Negro contra Poluição por Óleo e outra Substâncias e em Situação de Emergência, e Protocolo sobre Proteção do Mar Negro contra Poluição por Alijamentos, Bucareste, 21 de abril de 1992. (M). (Texto e informações apud 32 ILM 1101 (1993);

III - Convenção "Europeia" sobre Responsabilidade Civil por Danos Resultantes de Atividades Perigosas ao Meio Ambiente, Lugano, 21 de junho de 1993.Elaborada sob a égide do Conselho da Europa (Texto e informações apud 32 ILM 1228 (1993);

IV - Convenção sobre a Proibição do Desenvolvimento, Produção, Estocagem e Uso das Armas Químicas e sobre a Destruição das Armas Químicas Existentes no Mundo, negociada em Genebra (Comissão de Desarmamento) e adotada em Paris, a 13/I/1993. Aprovada no Brasil pelo Decreto Legislativo no 9 de 29/II/1996;

V - Acordo Norte-Americano sobre Cooperação Ambiental, entre EUA, Canadá e México, assinado em Washington, Ottawa e Cidade do México, em 1993 (GE). (Texto e informações apud 32 ILM 1480 (1993);

VI - Acordo para Redução da Mortalidade dos Golfinhos no Oceano Pacífico Oriental, junho de 1992, em La Jolla (EUA). (Texto e informações apud 33 ILM 936 (1994);

VII - Acordo para Promover Conformidade às Medidas de Conservação e Administração por Barcos Pesqueiros em Alto Mar, Roma, FAO, 24 de novembro de 1993. (Texto e informações apud 33 ILM 968 (1994);

VIII - Instrumento de Estabelecimento do "Global Environmental Facility" Reestruturado, Genebra, 16 de março de 1994. (Texto e informações apud 33 ILM 1273 (1994);

IX - Acordo relativo à Implementação da Parte XI da Convenção das Nações Unidas sobre o Direito do Mar de 10 de Dezembro de 1982, Nova York (ONU), 28 de julho de 1994. (Texto e informações apud 33 ILM 1309 (1994);

X - Acordo Internacional sobre Madeiras Tropicais, Genebra, UNCTAD, (abertura à assinatura em Nova York, a 01 de abril de 1994), promulgado no Brasil pelo Decreto 2.797 de 04/08/1998 (F);

XI - Convenção das Nações Unidas para o Combate à Desertificação Naqueles Países que Experimentam Sérias Secas e/ou Desertificação, Particularmente na África, 17 de julho de 1994, Nova York. Assinada pelo Brasil na mesma data, tendo seu texto já sido encaminhado à aprovação do Congresso Nacional com a Mensagem 697 de 15/01/1996. (Texto e informações apud 33 ILM 1328 (1994); 
XII - Acordo para a Implementação das Provisões da Convenção das Nações Unidas sobre o Direito do Mar de 10 de Dezembro de 1982, Relativas à Conservação e Gerenciamento de Espécies de Peixes Altamente Migratórios e Tranzonais; Nova York, (ONU) a 04 de agosto de 1995. (Texto e informações apud 34 ILM 1542 (1995);

XIII - Tratado sobre a Zona Livre de Armas Nucleares do Sudeste da Ásia ("Treaty on the Southeast Asia Nuclear Weapon-Free Zone"), Bangkok, 15/12/1995;

XIV - Tratado sobre a Zona Livre de Armas Nucleares da África ("African NuclearWeapon-Free Zone Treaty”), (Tratado de Pelindaba), Cairo, 11/IV/1996;

XV - Convenção sobre Responsabilidade e Reparação por Danos Relacionados com o Transporte de Substâncias Perigosas e Nocivas por Mar, Londres, IMO, 1996, dita "Convenção HNS" (sigla de: "High", "Noxious", "Substances", a partir de sua denominação em inglês: "Convention on Liability and Compensation for Damage in Connection with the Carriage of Hazardous and Noxious Substances by Sea"). Texto e informações apud 35 ILM: 1406 de novembro de 1996.

XVI- Tratado de Proibição Completa dos Testes Nucleares (conhecido pela sigla de sua denominação em inglês, CTBT, "Comprehensive Test-Ban Treaty"), adotado por ocasião da LI Assembléia Geral da ONU, em Nova York, em setembro de 1996 e assinado pelo Brasil a 24/IX/1996.

XVII- Convenção da UNIDROIT sobre o Retorno dos Bens Culturais Furtados ou Ilicitamente Exportados, (PC), Roma, 1995.

XVIII- Convenção das Nações Unidas sobre o Direito das Utilizações dos Cursos d'Água Internacionais para Fins Distintos da Navegação, Nova York (AG da ONU), aberta à assinatura na sede da ONU, a 21 de maio de 1997, texto apud 36 ILM 700 (1997).

XIX- Protocolo de 1996 à Convenção sobre Prevenção de Poluição Marinha por Alijamento e Outras Matérias, Londres, novembro de 1996 (M) (T), texto apud 36 ILM 1 (1997).

XX- Protocolo de Kyoto à Convenção-Quadro das Nações Unidas sobre Modificação do Clima, Kyoto, 10 de dezembro de 1997, texto apud 37 ILM 22 (1998).

XXI- Protocolo de Basiléia sobre Responsabilidade e Compensação por Danos Resultantes de Movimentos Transfronteiriços de Resíduos Perigosos e Seu Depósito, Basiléia, junho de 1999.

XXII- Protocolo de Cartagena sobre Bio-Segurança, à Convenção sobre Diversidade Biológica, Montreal, 20/01/2000.

Fonte (adaptado): Guido Soares (compilador)

Disponível em: http://www.unep.org

UNEP - Registro dos Tratados e outros Acordos na Área Ambiental (1993) tradução livre do compilador. 


\section{Complemento - Atualização (em inglês)}

Disponível em: International Environmental Agreements (IEA) - Database Project www.iea.uoregon.edu/

- Amendment To The Montreal Protocol On Substances That Deplete The Ozone Layer. 03.12.1999. Ozone Secretariat.

- Protocol On Liability And Compensation For Damage Resulting From Transboundary Movements Of Hazardous Wastes And Their Disposal. 10.12.1999. Secretariat of the Basel Convention.

- Protocol To Amend The 1971 International Convention On The Establishment Of An International Fund For Compensation For Oil Pollution Damage. 27.09.2000. IOPC Funds Secretariat.

- Agreement on cooperation in the field of training for Radioecology, radiation safety, radiobiology and related sciences. 30.11.2000. Secretariat of the Commonwealth of Independent States.

- International Convention On Civil Liability For Bunker Oil Pollution Damage. 23.03.2001. International Maritime Organization (IMO).

- Amendments To Annex I (Condition Assessment Scheme) of The International Convention For The Prevention Of Pollution From Ships. 27.04.2001. International Maritime Organization (IMO).

- ASEAN Agreement On Transboundary Haze Pollution. 10.06.2002. Association of South-East Asian Countries (ASEAN) Secretariat.

- Agreement on cooperation of the CIS member-states in the field energy efficiency and energy saving. 07.10.2002. Secretaria t of the Commonwealth of Independent States.

- Protocol on Civil Liability and Compensation for Damage Caused by the Transboundary Effects of Industrial Accidents on Transboundary Waters to the 1992 Convention on the Protection and Use of Transboundary Watercourses and International Lakes and to the 1992 Convention on the Transboundary Effects of Industrial Accidents. 21.05.2003. UN Economic Commission for Europe (UNECE).

- Protocol on Pollutant Release and Transfer Registers to the Convention on Access to Information, Public Participation in Decision-Making and Access to Justice in Environmental Matters. 21.05.2003. UN Economic Commission for Europe (UNECE).

- Protocol on Strategic Environmental Assessment to the Convention on Environmental Impact Assessment in a Transboundary Context. 21.05.2003. UN Economic Commission for Europe (UNECE).

- Agreement on exchange of information on emergency situations of natural and man-made, on information exchange with mitigation and assistance to the affected population. 18.09.2003. Secretariat of the Commonwealth of Independent States 
- Protocol To Amend The Convention Supplementary To The Convention On Third Party Liability In The Field Of Nuclear Energy. 12.02.2004. Organization for Economic Cooperation and Development.

- Additional Protocol on Cooperation and Assistance in Environmental Emergencies to the Agreement On An Environmental Framework Of Mercosur. 07.07.2004. Mercosur Secretariat.

- Cooperative agreement among the United States, Canada and Mexico supplementary to the North American plant protection agreement. 17.10.2004. North America Plant Protection Organization.

- Agreement among the governments of Costa Rica, the Dominican Republic, El Salvador, Guatemala, Honduras, Nicaragua, and the United States of America on environmental cooperation. 18.02.2005. CAFTA-DR Environmental Cooperation

- Treaty betweeen Mali, Mauritania, and Senegal and Guinea Relative to the Adhesion of Guinea to the Senegal River Development Organization. 17.03.2006. Organization pour La Mise En Valeur Du Fleuve Senegal.

- Protocol on Environment and Natural Resources Management to the Treaty for the Establishment of the East African Community. 03.04.2006. East African Community.

- Agreement Establishing a Secretariat for Environmental Matters Under the Dominican Republic - Central America - United States Free Trade Agreement. 27.07.2006. CAFTA-DR Environmental Cooperation.

- International Convention on the Removal of Wrecks. 18.05.2007. International Maritime Organization (IMO)

- Protocol on Integrated Coastal Zone Management in the Mediterranean. 21.01.2008. UNEP Mediterranean Action Plan.

- Additional Protocol to the Cooperation Agreement For The Protection Of The Coasts And Waters Of The North-East Atlantic Against Pollution. 20.05.2008. Centro Internacional de Luta contra a Poluição marítima no Atlântico Nordeste (International Center for pollution combat in the Northeast Atlantic).

- International Convention for the Safe and Environmentally Sound Recycling of Ships. 15.05.2009. International Maritime Organization (IMO)

- Agreement on the Central Asian and Caucasus Regional Fisheries and Aquaculture Commission. 02.10.2009. Central Asian and Caucasus Regional Fisheries and Aquaculture Commission.

- Protocol No. 3 concerning Euroregional Co-operation Goupings to the European Outline Convention On Transfrontier Cooperation Between Territorial Communities Or Authorities. 16.11.2009. Council of Europe.

- Protocol for the Protection of the Coastal and Marine Environment of the Western Indian Ocean from Land-based Sources and Activities to the Convention For The Protection, Management And Development Of The Marine And Coastal Environment Of The Eastern African Region. 01.04.2010. UNEP 
Regional Coordinating Unit for the Eastern African Action Plan (EAF/RCU)

- Protocol to the International Convention On Liability And Compensation For Damage In Connection With The Carriage Of Hazardous And Noxious Substances By Sea. 30.04.2010. International Maritime Organization (IMO)

- Agreement between the Government of the Republic of Latvia, the Government of the Republic of Estonia and the Government of the Republic of Lithuania on cooperation in the field of environment. 04.06.2010.

- Nagoya-Kuala Lumpur Supplementary Protocol on Liability and Redress to the Cartagena Protocol on Biosafety to the Convention On Biological Diversity. 15.10.2010. Secretariat for the Convention on Biological Diversity.

- Nagoya Protocol on Access to Genetic Resources and the Fair and Equitable Sharing of Benefits Arising from their Utilization to the Convention on Biological Diversity. 29.10.2010. Secretariat for the Convention on Biological Diversity.

- Protocol concerning Regional Preparedness, Response and Co-Operation in combating Oil Pollution Incidents to the Framework Convention on the Protection of the Marine Environment of the Caspian Sea. 12.08.2011. Caspian Environment Programme.

- Agreement on the Regional Contingency Plan for Preparedness for and Response to major Marine Pollution Incidents in the Western Indian Ocean. 06.09.2011. UNEP Regional Coordinating Unit for the Eastern African Action Plan (EAF/RCU)

- Protocol on Amendments and Additions to the Agreement on cooperation in the field of industrial safety of hazardous production facilities. 18.10.2011. Secretariat of the Commonwealth of Independent States.

- Agreement on the establishment of the Global Green Growth Institute, 20.06.2012. Global Green Growth Institute

- Agreement For The Establishment Of The African Risk Capacity (ARC) Agency, 23.11.2014. Secretariat of the ARC Agency

- Protocol for the Protection of the Caspian Sea against Pollution from Land based Sources and Activities to the Framework Convention on the Protection of the Marine Environment of the Caspian Sea. 12.12.2012. Caspian Environment Programme.

- Agreement on Cooperation on Marine Oil Pollution, Preparedness and Response in the Arctic, in 15.05.2013. Artic Council

- Minamata Convention on Mercury, signed on 31.05.2013

- Agreement on cooperation in the field of environmental protection among the member-states of the Commonwealth of Independent States 31.05.2013 
Tabela dos dez mais importantes acidentes naturais por categoria (1985-2014)

Classificação do Centre for Research on the Epidemiology of Disasters (CRED) -

\section{Desastre Geofísico}

\begin{tabular}{|l|r|r|}
\hline \multicolumn{1}{|c|}{ Desastre (Terremoto) } & \multicolumn{1}{c|}{ Data } & \multicolumn{1}{c|}{ Vítimas } \\
\hline Haiti & $12 / 01 / 2010$ & 222.570 \\
\hline Indonésia & $26 / 12 / 2004$ & 165.708 \\
\hline China & $12 / 05 / 2008$ & 87.476 \\
\hline Paquistão & $08 / 10 / 2005$ & 73.338 \\
\hline Irã & $21 / 06 / 1990$ & 40.000 \\
\hline Sri Lanka & $26 / 12 / 2004$ & 35.399 \\
\hline Irã & $26 / 12 / 2003$ & 26.796 \\
\hline Ex-União Soviética & $07 / 12 / 1988$ & 25.000 \\
\hline Colômbia (vulcão) & $13 / 11 / 1985$ & 21.800 \\
\hline Índia & $26 / 01 / 2001$ & 20.005 \\
\hline
\end{tabular}

Desastre Hidrológico

\begin{tabular}{|l|r|r|}
\hline \multicolumn{1}{|c|}{ Desastre (Enchentes) } & \multicolumn{1}{c|}{ Data } & \multicolumn{1}{c|}{ Vítimas } \\
\hline Venezuela & $15 / 12 / 1999$ & 30.000 \\
\hline Índia & $12 / 06 / 2013$ & 6.054 \\
\hline China & $01 / 07 / 1998$ & 3.656 \\
\hline China & $30 / 06 / 1996$ & 2.775 \\
\hline Haiti & $23 / 05 / 2004$ & 2.665 \\
\hline Bangladesh & jun/88 & 2.379 \\
\hline Somália & $19 / 10 / 1997$ & 2.311 \\
\hline Bangladesh & $22 / 07 / 1987$ & 2.055 \\
\hline Índia & $\mathrm{mai} / 94$ & 2.001 \\
\hline China & $14 / 07 / 1989$ & 2.000 \\
\hline
\end{tabular}

Fonte: EM-DAT: The OFDA/CRED International Disaster Database

\begin{tabular}{|l|c|r|}
\hline \multicolumn{1}{|c|}{ Desastre (terremoto) } & \multicolumn{1}{c|}{ Data } & \multicolumn{1}{c|}{ Afetados } \\
\hline China & $12 / 05 / 2008$ & 45.976 .596 \\
\hline Índia & $21 / 08 / 1988$ & 20.003 .766 \\
\hline Índia & $26 / 01 / 2001$ & 6.321 .812 \\
\hline Paquistão & $08 / 10 / 2005$ & 5.128 .309 \\
\hline China & $03 / 02 / 1996$ & 5.077 .795 \\
\hline Guatemala & $04 / 02 / 1976$ & 4.993 .000 \\
\hline Haiti & $12 / 01 / 2010$ & 3.700 .000 \\
\hline Filipinas & $15 / 10 / 2013$ & 3.222 .224 \\
\hline Peru & $31 / 05 / 1970$ & 3.216 .240 \\
\hline Indonésia & $27 / 05 / 2006$ & 3.177 .923 \\
\hline
\end{tabular}

\begin{tabular}{|l|c|r|}
\hline \multicolumn{1}{|c|}{ Desastre (enchentes) } & Data & \multicolumn{1}{c|}{ Afetados } \\
\hline China & $01 / 07 / 1998$ & 238.973 .000 \\
\hline China & $01 / 06 / 1991$ & 210.232 .227 \\
\hline China & $30 / 06 / 1996$ & 154.634 .000 \\
\hline China & $23 / 06 / 2003$ & 150.146 .000 \\
\hline China & $29 / 05 / 2010$ & 134.000 .000 \\
\hline Índia & $08 / 07 / 1993$ & 128.000 .000 \\
\hline China & $15 / 05 / 1995$ & 114.470 .249 \\
\hline China & $15 / 06 / 2007$ & 105.004 .000 \\
\hline China & $23 / 06 / 1999$ & 101.024 .000 \\
\hline China & $14 / 07 / 1989$ & 100.010 .000 \\
\hline
\end{tabular}


Tabela dos dez mais importantes acidentes naturais por categoria (1985-2014)

Classificação do Centre for Research on the Epidemiology of Disasters (CRED) -

Desastre Climatológico

\begin{tabular}{|l|r|r|}
\hline \multicolumn{1}{|c|}{ Desastre (Furacão) } & Data & \multicolumn{1}{c|}{ Vítimas } \\
\hline Bangladesh & $29 / 04 / 1991$ & 138.866 \\
\hline Myanmar & $02 / 05 / 2008$ & 138.366 \\
\hline Bangladesh & $24 / 05 / 1985$ & 15.000 \\
\hline Honduras & $25 / 10 / 1998$ & 14.600 \\
\hline Índia & $28 / 10 / 1999$ & 9.843 \\
\hline Filipinas & $08 / 11 / 2013$ & 7.986 \\
\hline Filipinas & $05 / 11 / 1991$ & 5.956 \\
\hline Bangladesh & $15 / 11 / 2007$ & 4.234 \\
\hline Vietnã & $02 / 11 / 1997$ & 3.682 \\
\hline Nicarágua & $25 / 10 / 1998$ & 3.332 \\
\hline
\end{tabular}

\begin{tabular}{|l|l|r|}
\hline \multicolumn{1}{|c|}{ Desastre (Furacão) } & \multicolumn{1}{c|}{ Data } & \multicolumn{1}{c|}{ Afetados } \\
\hline China & $14 / 03 / 2002$ & 100.000 .000 \\
\hline China & $20 / 04 / 1989$ & 30.007 .500 \\
\hline China & $16 / 07 / 2006$ & 29.622 .000 \\
\hline China & $17 / 04 / 2011$ & 22.000 .150 \\
\hline China & $01 / 09 / 2005$ & 19.624 .000 \\
\hline Filipinas & $08 / 11 / 2013$ & 16.106 .807 \\
\hline Bangladesh & $29 / 04 / 1991$ & 15.438 .849 \\
\hline China & $08 / 09 / 1996$ & 15.005 .000 \\
\hline China & $01 / 07 / 2001$ & 14.998 .298 \\
\hline Índia & $12 / 10 / 2013$ & 13.230 .000 \\
\hline
\end{tabular}

\section{Desastre Biológico}

\begin{tabular}{|l|r|r|}
\hline Desastre (Epidemia) & \multicolumn{1}{c|}{ Data } & \multicolumn{1}{c|}{ Vítimas } \\
\hline Peru & $18 / 08 / 1991$ & 8.000 \\
\hline Etiópia & set/88 & 7.385 \\
\hline Nigéria & $06 / 05 / 1991$ & 7.289 \\
\hline Haiti & $22 / 10 / 2010$ & 6.908 \\
\hline Nigéria & $\mathrm{fev} / 96$ & 4.346 \\
\hline Zimbábue & $15 / 08 / 2008$ & 4.276 \\
\hline Burkina Faso & $07 / 02 / 1996$ & 4.071 \\
\hline Níger & $03 / 03 / 1995$ & 3.022 \\
\hline Índia & nov/88 & 3.000 \\
\hline Sudão & 1988 & 2.770 \\
\hline
\end{tabular}

\begin{tabular}{|l|r|r|}
\hline \multicolumn{1}{|c|}{ Desastre (Epidemia) } & \multicolumn{1}{c|}{ Data } & \multicolumn{1}{c|}{ Afetados } \\
\hline Quênia & jan/94 & 6.500 .000 \\
\hline Bangladesh & abr/91 & 1.500 .000 \\
\hline Brasil & jan/11 & 942.153 \\
\hline Burundi & out/00 & 722.591 \\
\hline Burundi & jan/99 & 616.034 \\
\hline Bangladesh & $27 / 09 / 1987$ & 600.000 \\
\hline Haiti & $22 / 10 / 2010$ & 513.997 \\
\hline Indonésia & $01 / 01 / 1986$ & 500.000 \\
\hline Zimbábue & $23 / 05 / 1996$ & 500.000 \\
\hline Zaire/Congo & dez/02 & 500.000 \\
\hline
\end{tabular}

Fonte: EM-DAT: The OFDA/CRED International Disaster Database 
Tabela dos acidentes industriais (tecnológicos) por continente (1985-2014)

Classificação do Centre for Research on the Epidemiology of Disasters (CRED) - ANEXO III

\begin{tabular}{|c|c|c|c|c|c|}
\hline Região & \begin{tabular}{|c} 
Tipo de \\
Acidente \\
\end{tabular} & \begin{tabular}{|l} 
Quantidade \\
de eventos
\end{tabular} & \begin{tabular}{|l} 
Número de \\
Vítimas \\
\end{tabular} & $\begin{array}{l}\text { Total de } \\
\text { afetados }\end{array}$ & \begin{tabular}{|l|}
$\begin{array}{l}\text { Prejuízos } \\
\text { financeiros } \\
\text { (em US\$) }\end{array}$ \\
\end{tabular} \\
\hline \multirow[t]{5}{*}{ África } & $\begin{array}{l}\text { Derramamento } \\
\text { Químico }\end{array}$ & 4 & 105 & 1.430 & - \\
\hline & Colapso & 43 & 1.502 & 227 & - \\
\hline & Explosão & 41 & 3.063 & 7.612 & $8.964,00$ \\
\hline & Incêndio & 13 & 407 & 549 & 12.100 \\
\hline & Contaminação & 5 & 425 & 20.423 & - \\
\hline \multirow[t]{8}{*}{ Américas } & $\begin{array}{l}\text { Derramamento } \\
\text { Químico }\end{array}$ & 24 & 21 & 67.494 & 15.000 \\
\hline & Colapso & 8 & 231 & 30 & - \\
\hline & Explosão & 58 & 1.478 & 44.531 & $227.909,00$ \\
\hline & Incêndio & 19 & 95 & 50.298 & 77.000 \\
\hline & $\begin{array}{l}\text { Vazamento de } \\
\text { Gás }\end{array}$ & 8 & 26 & 22.014 & - \\
\hline & $\begin{array}{l}\text { Derramamento } \\
\text { de Óleo }\end{array}$ & 2 & 1 & 120 & - \\
\hline & Contaminação & 6 & 103 & 552.432 & - \\
\hline & Radiação & 1 & 17 & 488 & - \\
\hline \multirow[t]{8}{*}{ Ásia } & $\begin{array}{l}\text { Derramamento } \\
\text { Químico }\end{array}$ & 19 & 29 & 125.938 & 57.554 \\
\hline & Colapso & 54 & 2.861 & 1.753 & 15.000 \\
\hline & Explosão & 429 & 14.072 & 152.063 & $5.713,74$ \\
\hline & Incêndio & 104 & 2.884 & 132.442 & $6.984,00$ \\
\hline & $\begin{array}{l}\text { Vazamento de } \\
\text { Gás }\end{array}$ & 26 & 212 & 161706 & 30.000 \\
\hline & $\begin{array}{l}\text { Derramamento } \\
\text { de Óleo }\end{array}$ & 2 & - & 17.000 & - \\
\hline & Contaminação & 41 & 1.464 & 38.171 & - \\
\hline & Radiação & 4 & 28 & 327.729 & - \\
\hline \multirow[t]{8}{*}{ Europa } & $\begin{array}{l}\text { Derramamento } \\
\text { Químico } \\
\end{array}$ & 20 & 15 & 62.937 & $10.900,00$ \\
\hline & Colapso & 5 & 142 & 41 & $13.200,00$ \\
\hline & Explosão & 67 & 2.495 & 25.445 & $2.187,00$ \\
\hline & Incêndio & 31 & 419 & 5.006 & $17.225,00$ \\
\hline & $\begin{array}{l}\text { Vazamento de } \\
\text { Gás }\end{array}$ & 7 & 13 & 787 & - \\
\hline & $\begin{array}{l}\begin{array}{l}\text { Derramamento } \\
\text { de Óleo }\end{array} \\
\end{array}$ & 1 & - & - & 30.000 \\
\hline & Contaminação & 8 & 64 & 1.399 & - \\
\hline & Radiação & 2 & 41 & 135.000 & $28.000,00$ \\
\hline Oceania & Explosão & 4 & 51 & 2.062 & 12.000 \\
\hline
\end{tabular}

Fonte: EM-DAT: The OFDA/CRED International Disaster Database 


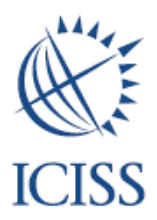

\section{THE RESPONSIBILITY TO PROTECT}

DECEMBER 2001

REPORT OF THE

INTERNATIONAL COMMISSION ON INTERVENTION

AND STATE SOVEREIGNTY 


\section{SYNOPSIS}

\section{THE RESPONSIBILITY TO PROTECT: CORE PRINCIPLES}

\section{(1) BASIC PRINCIPLES}

A. State sovereignty implies responsibility, and the primary responsibility for the protection of its people lies with the state itself.

B. Where a population is suffering serious harm, as a result of internal war, insurgency, repression or state failure, and the state in question is unwilling or unable to halt or avert it, the principle of non-intervention yields to the international responsibility to protect.

\section{(2) FOUNDATIONS}

The foundations of the responsibility to protect, as a guiding principle for the international community of states, lie in:

A. obligations inherent in the concept of sovereignty;

B. the responsibility of the Security Council, under Article 24 of the UN Charter, for the maintenance of international peace and security;

C. specific legal obligations under human rights and human protection declarations, covenants and treaties, international humanitarian law and national law;

D. the developing practice of states, regional organizations and the Security Council itself.

\section{(3) ELEMENTS}

The responsibility to protect embraces three specific responsibilities:

A. The responsibility to prevent: to address both the root causes and direct causes of internal conflict and other man-made crises putting populations at risk.

B. The responsibility to react: to respond to situations of compelling human need with appropriate measures, which may include coercive measures like sanctions and international prosecution, and in extreme cases military intervention.

C. The responsibility to rebuild: to provide, particularly after a military intervention, full assistance with recovery, reconstruction and reconciliation, addressing the causes of the harm the intervention was designed to halt or avert.

\section{(4) PRIORITIES}

A. Prevention is the single most important dimension of the responsibility to protect: prevention options should always be exhausted before intervention is contemplated, and more commitment and resources must be devoted to it.

B. The exercise of the responsibility to both prevent and react should always involve less intrusive and coercive measures being considered before more coercive and intrusive ones are applied. 


\section{THE RESPONSIBILITY TO PROTECT: PRINCIPLES FOR MILITARY INTERVENTION}

\section{(1) THE JUST CAUSE THRESHOLD}

Military intervention for human protection purposes is an exceptional and extraordinary measure. To be warranted, there must be serious and irreparable harm occurring to human beings, or imminently likely to occur, of the following kind:

A. large scale loss of life, actual or apprehended, with genocidal intent or not, which is the product either of deliberate state action, or state neglect or inability to act, or a failed state situation; or

B. large scale 'ethnic cleansing', actual or apprehended, whether carried out by killing, forced expulsion, acts of terror or rape.

\section{(2) THE PRECAUTIONARY PRINCIPLES}

A. Right intention: The primary purpose of the intervention, whatever other motives intervening states may have, must be to halt or avert human suffering. Right intention is better assured with multilateral operations, clearly supported by regional opinion and the victims concerned.

B. Last resort: Military intervention can only be justified when every non-military option for the prevention or peaceful resolution of the crisis has been explored, with reasonable grounds for believing lesser measures would not have succeeded.

C. Proportional means: The scale, duration and intensity of the planned military intervention should be the minimum necessary to secure the defined human protection objective.

D. Reasonable prospects: There must be a reasonable chance of success in halting or averting the suffering which has justified the intervention, with the consequences of action not likely to be worse than the consequences of inaction.

\section{(3) RIGHT AUTHORITY}

A. There is no better or more appropriate body than the United Nations Security Council to authorize military intervention for human protection purposes. The task is not to find alternatives to the Security Council as a source of authority, but to make the Security Council work better than it has.

B. Security Council authorization should in all cases be sought prior to any military intervention action being carried out. Those calling for an intervention should formally request such authorization, or have the Council raise the matter on its own initiative, or have the Secretary-General raise it under Article 99 of the UN Charter.

C. The Security Council should deal promptly with any request for authority to intervene where there are allegations of large scale loss of human life or ethnic cleansing. It should in this context seek adequate verification of facts or conditions on the ground that might support a military intervention. 
D. The Permanent Five members of the Security Council should agree not to apply their veto power, in matters where their vital state interests are not involved, to obstruct the passage of resolutions authorizing military intervention for human protection purposes for which there is otherwise majority support.

E. If the Security Council rejects a proposal or fails to deal with it in a reasonable time, alternative options are:

I. consideration of the matter by the General Assembly in Emergency Special Session under the "Uniting for Peace" procedure; and

II. action within area of jurisdiction by regional or sub-regional organizations under Chapter VIII of the Charter, subject to their seeking subsequent authorization from the Security Council.

F. The Security Council should take into account in all its deliberations that, if it fails to discharge its responsibility to protect in conscience-shocking situations crying out for action, concerned states may not rule out other means to meet the gravity and urgency of that situation - and that the stature and credibility of the United Nations may suffer thereby.

\section{(4) OPERATIONAL PRINCIPLES}

A. Clear objectives; clear and unambiguous mandate at all times; and resources to match.

B. Common military approach among involved partners; unity of command; clear and unequivocal communications and chain of command.

C. Acceptance of limitations, incrementalism and gradualism in the application of force, the objective being protection of a population, not defeat of a state.

D. Rules of engagement which fit the operational concept; are precise; reflect the principle of proportionality; and involve total adherence to international humanitarian law.

E. Acceptance that force protection cannot become the principal objective.

F. Maximum possible coordination with humanitarian organizations. 